THE BRITISI WLECRICAL

$$
1875-1914
$$

by

I.C.R. BYATY

[MT 1962]

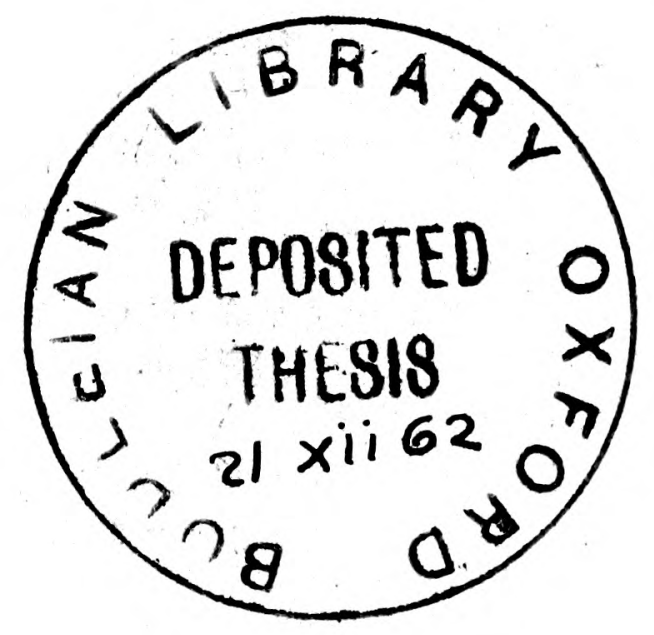


CONTENIS

page

Wist of Tables
iist of Flgures
Abbreviations used

Abstract

Cisap. 1.

Electric Iighting; the Early Days Appendirs: The rolative cost oi gas and electric lighting in the U.S.A. and Britain

iii

vii

vii:

ix

2

48

58

2. The Genesis of Public Supply

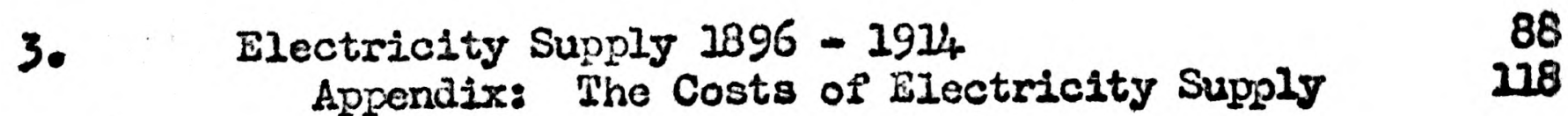

4. The Power Companies 127

5. Electric Traction 162

6. Electric Power 246

7.' The Marmfacturers of Electrical Machinery $1875-1396$

308

8. The lanufacturers of Eloctrical Hachinery $1896-1914$

355

9. The Public Control of Electricity Supply and Trantays

418

440

10. The Pricing Policy of Electrical Utilities

464

11. Some further comients

485

512

518

Díliography. 


\section{List of Tablos.}

page

1. Costs of Jablochlopf arc lighting and gas lighting

2. Costs of various arc lighting systems

3. Sales of Brush concessions 2881 and 1882

4. Capital called up by companics formed in 2882 to exploit clectrical inventions

5. Electricity supply. Provisional Ordors and Llcences eranted by the Board of Trade 1382 - 1912

6. Provisional Orders granted in 1882

7. Hastings, Brichton and Eastbourme. Number of lichts supplied $1882-86$

8. Cost of gas and arc lighting in the City of London 188239

9. Costs per hour of 16 c.p. gas and olectrio lamps. pence 40

10. Gas prices

42

11. The early Iondon electricity supply companies

60

12. Early electricity supply undertakings, 1.e. those which begen supply before the end of 1893.

13. Ageregate gross investmant in electricity supply $1839-95$

64

14. Iondan, Notropolitan and Westminster Cos., Lamps connected at the becinning of each year

15. Iondon Companies. Capital expendituro per lamp 82

16. Gross investnent in Electricity supply $1896-1913 \quad 89$

17. Average size of supply undertakings measured by KN capacity of generating plant

13. Connections to public supply mains

92

19. Price of elcctricity for lighting $1893-1912$ 
page

20. Prime movers installed in British central stations 1888 - 1902. Percentages

21. Electricity supply. Average size of gonerators installed in British central stations $1888-1913$

22. Electricity supply. Snles. Militon KWh.

III

23. Electricity Supply. Porcentage of capacity in the largest ten undertasings

215

24. Blectricity supply. Narimu load as a percentage of central station capacity

25. The use of electricity 1907 and 1912. Jillion Kroh.

26. Electricity supply. \& per III addod

27. Eloctricity supply. Capital expenditure. Percentages on various items

28. Generating sets. \& per $\mathrm{KW}$

29. Cost per KWW of varlous sizes of generating station $1909 \quad 124$

30. List of Electric power companies

31. Scme other big supply undertakings in 1912

32. The Power companies in 1905

33. Newcastle Electric Supply Co. Seles, Million KMh.

34. Electric Tranway litleage

35. Gross investment on electric tramays 164

36. Capacity utilisation in Tranays 166

37. British Tramways. Million passengers p.a. 175

38. Tramays. Capital utilisation and investment 179

39. Tramways. Costs and reveruse per car mile 280

40. Ilectricity used per car mile 181

41. Tramray operating expenses 1900. 
pago

42. Utilisation of Tramways 183

43. Migration to the Torns 2851 - 1921

44. Trannays. Average recelpts per passenger. d. 288

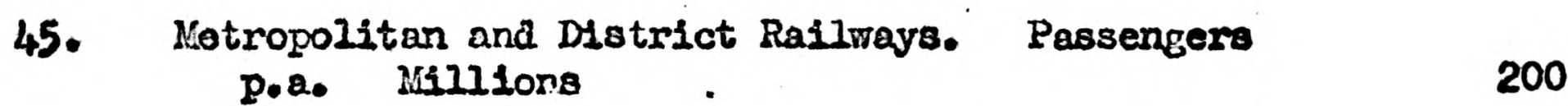

46. London underground railmays gross investment 204

47. The Crorth of the Underground. Passengers p.a. unll1000 205

43. London undercround. Capital expendíture per mile open 207

49. Iondor Electric Railways. Density of Trassio. . 208

50. The profitability of the Underground 210

51. London Transport. Pacsengers p.a. Lillition 227

52. Source of Electricity used by electric trams and
electric Eailwoys

53. Sales of electrioity for power from publis supply stations 260

54. Notor power in manufacturing and mining 263

55. Spead variations in textile machinery 286

56. Electrical k. p. used in British coal mines in $2912 \quad 289$

57. Value of "lachinery" returned for hame use 306

58. Bnush sales of are and incandescent lighting equipment 317

59. Gross output of electrical machinery. Major Pirms, 325
2880s.

60. Shares of the market for incandescent lighting
dymamos, early 1886 - end 1837

61. Sicuens Bros. The Ilectric Iight Dept. Net propit
as a percentage of sales and stock

62. Sanufacturers of electrical machinery 2882 - $2895 \quad 332$

63. Dynamos installed by the 5 principal firns in
central stations up to the end of 1892 
64. Gross output of the major Sima $1888-96$

65. Brush assots 2837 - 1395

66. Brush propits $2890-95$

67. Siemens Bros. Profits on electrical machinery

68. Siemens Bros. Assets 1997 - 1895

69. Sales of electrical machinery 1896 - 1913

70. Electrical machinery manufacturers. The expanston of assets $1896-1904$

71. Electrical machinery mamifacturers. The source of funds $1896-1904$

372

72. British production of electrical machinery $1903-1913 \quad 374$

73. Tenders for generators for the I.C.C. tramays 2901376

74. The Profitability of electrical machinery mamfacturing 380

75. Rurchases of tramears by Tramsay Undertakings in Dritain 1904 - 11

381

76. B.T-II. Bdiness secured. $1906-I 1$

77. Electrical machinery manufacturers. The expansion assets $1904-10$.

78. Electrical machinery manufacturers. The source of funds $1904-10$.

79. Gross output of various firns $1900-\mathbf{U}_{4}$

80. Percentages of central station Eenerators installed by various fims

81. Market for central station generators - concentration

82. Electrical plant and machinery sold to utilities numbor of ijross tendering

83. Rotating plant for central stations. Firms tandering for, and supplying, plant

84. Tender variances for different product groups 2894 - 1913 
65. Profitability of cable manuecturing 420

86. Eleotrical machinery manufacturing. The source of furad $1910-14$

87. Electrical machinsry manufacturers. The source of funds $1910-1_{4}$

83. Non-traction $\pi$. sold by the Corporations of Hanchester and Glasgom

89. Brightor Ioad factor

90. The effect of pricing on the load fretor of a lighting stailion

91. Gross investweni in Pixed capital in the Electrical Iralustry $1897-1913$

92. Edraundsoni Electricity Corporation. Investinents

93. Wotor power in mining and manufacturing by industries

\section{Ilst of Pigures}

1. Tramiay pażongers and passengers p.Q. per milo $1886-1902$

2. The labour cost of conl

3. Electrical ana mechanical methods of transmission of power - discontinuities

Wap of Iondon Under round Railiways between 2908 and $19 U_{4}$ (Reprochuced by permission of London Iransport) 
Abbreviations used.

T.T. Telegranhic Tournal

E.R. Elecirion? Rovien

Elect. Elecinicion

$\frac{\text { Garlo's }}{\text { Ilonual }}$ Garke's homal of Electrical Undertakings

E.T.D. Electrical Mrades Directory

B.P.P. Eritish Parliamentary Payers

E.J. Economic Jourmal 
Abstract.

This is a study in the beginnings of an industry. Tho electrical incustry was chosen for two ressons. Firstly its story is that of the beginings of the substantial econonic applicat1on of a new technology. Secondly it was an important industry in the British oconomy at the time. It has sometimes been argued that the slow growth of this industry is one of the reasons for the slow growth of the econory. Thus the material has becn principally organised arouns two matters, innovation and technical procress, and the allegedly slow growth of this industry in Britain beforo 19u4.

Tho electrical industry has been widely defined. I have taken the three principal uses of electricity at the time, lighting, traction ora (non traction) motor power, and looked at the introduction and early growth of electrical methods. Thus the industry is defined within technological bounderies. I have included electricity supply, eleotric traction and the manufacture of electricel machinery - all of which could be treated as separaio industries. Thus I have dealt with heavy electrical enginecring, and have ifnored the light electrical endineering of the time, which was connected with the use of electricity for telegraphs and telophones. Electo cheristiry has also been ignored as the scarcity of cheap water yoncr in Britain mado it unlikely that it would develop to any considerablo extent in Britain.

Roughly speaking, elec'ric lighting, traction and power were new methods of proviaing existing proulucts, lifeht, rail transport (by 1. Principaly factory motors. For convenienco electrio power 18 gonerally used to refer to non traction electric motor porrer. 
train or tram) and factory tum Ther. Therefore in Chapters 1, 5 and 6 I have looked at the cost of the new electrical mothods compared with oxisting methods, or nore sulucately have tried to see what resources rould be saved by using electriciti.

IIonever che caunot oxject the oniy reason why new technical developments were (or were not) adoptod, or adopted quickly or slowly to be that they did (or did not) savo resources. Thus I have 10 kcd at other valiables, like the rate of rowth of the economy, the timing of cyclical fluctuations, logislation wid relations between business and technology. Attempts have been ia to illuminate the English experience by contrasting it with the situation in the United States. In Chapter 1 I have argued that the principal reason for the a parant failure of the atiempt to cutablish electric lighting in this country in the carly 2800 s was the low price of gas. As the price of electricity rolativo to gas fell during the 10303 and 1890 s electrio Iighting becane moro wilely used. Itowever it does not scen to have been until the introduction of the matal filanent lomp in tine yoars $19 c 8$ - 10 that electric lighting had the samo advantage, relative to gas that it seans to have had in the Uizited Statos as early as the midile 2330s. Also the slower raie of uribanisation in Britain compared with tho Uaited States, and lise tiwing of the cycle affected the rate of aioption of electido lightiag. Chapters 2 und 3 deal with the use of olectrlc Ilghting whon electricity was provided from a central station.

In Chapter 5, Section I I have argued that eleotrio trams saved resources, but that their adoption was dolayed in the early and midalo 
nineties'by the effect of the Iramiay Act, tize unprofitability of horse trams, the lack of interest of howe electrical manufacturers, the attitude of the munfoipalities and their relations with joint stock enterporise. I have argued that the boom in electric traction $1897-1903$ was stlmulated by the building cycle, the rising derand for transport, and the entry of Americon fims. After 1903 the boom died array as demand had been satisfled. Demand rose only slowly as trammays do not appear to have stimulated suburiban builaing in the short run. In Section $\overline{I I}$ I have disoussed urban electric railiraj3, particuioriy the Iondon Underground. I have stressed the inporiance oi American engineering and onterprise in promoting resource saving innovations. I have also argued, although the matter is complicated by questions of loy out and fares, that the low profitability of urion electric railways showed that dewand was

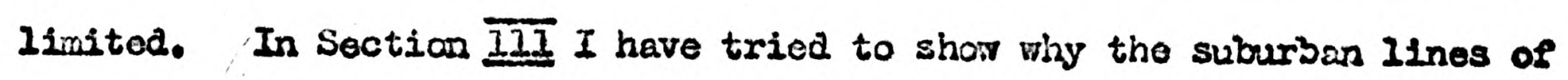
main line steam railways were only slowly electrified. I have argued that electric traction would have only boen actopted had it been capital saving. Whore transy competition made capacity redunciant, electrification was not worth while.

In Chapter 6 I have examined featory electrification. My tentative conclusions are that while electric transmission of power was probably on balance fuel saving, its capital costs were greater than those of mechanical transmission before 1901 - 05, although after that they fore, on balance, as 10w. However the evidence suggests that substantial resource saving would only have accrued from electrification if, it had takon place in confunction with other changes in the technigues of production flowevor 
there are enormous difference between industries and an importont reason for tho apparently slow rate of factory electrification in England is that 1is advantages were purhaps least in two of the great power using Industries, toxilles and riring.

In adition Electricity supply and the manifacturo of electrlcal machinery havo been dealt with in some detail. Thoir combinod influence on the cost of electrical methods ras very great. Costs in these scetore foll regularly as the process of innovation continued. The prices of other inputs of eloctrie lighting, power and tracilon generally foll less than thoss of the products of those two sectors. Also they held a central position in the procoss of innovation. Most innovations wero adopted on their Initiative, and they vere responsible for melcine adeptions to other machinery and to buildings.

Tho electricity surply sector is dealt with in Chapters 2, 3, 4, 9 and 20. In Chapters 2 and 3 I have Iocled at the general dovelopwont of electrlcity supply laresly by discussing the major innovations and trying to seo how their adoption tilight have reducca, or did reduce, costs. I have also trica to put the story of the beginnings of eloctricity supply an a oound stutistical basis by consiructing time series of investment in electricity supply and sales of eleciricity for lighting porror and traction. Chapter 4 deals with the attenpts substantially to increase the area of supply and shows how the only successful attenpt involved somo important innovations. Particular attention has been given to dovolopments in eloctricai machinery. This is partly becauss the makers of electrical wichinery have also been dealt with in detail. 
Chapters 9 and 10 are on the mirol of electrical utilities ond their pricinis policy. It has often ben said that legislation delayod the dovolopment of the industry and Chapter 9 is an attompt to oxemins the inadequacies of the publio utility control at the tims. It is sirown both that it worised very crudely, and that it had a tendenoy to keop profits lor by keening costs hich. In Chapter 10 it is shown that tho usual pricing system of elcctricity supply undertakings was based on a theoretical misconcepision, and that it could lead to distortion of resources. Tho pricing policy of electric traction undertakings is whom to be rezvorse because of the attampt to holp worken to live in better houses.

The makers of electrical machinery are constidered in Chapters 7 and 8. Three important iscues have been dealt with, the process of innovation, the question of new entry into this new industry, and the workings of competition. The three are intimately connected. Innovations in machinery often involved the entry of new firms. The workings of competition taken together with the nature of the cyclical Pluctuations in the demand for eloctrical machinery, reacted on innovation. The spoed of irnovation affectca the way competition rorked. I have also discussed tho effect which the British capital market had on the electrical manufacturers. Chapter il contains two sections. One is a summary of tho 1. Jeess of Innovation in the whole electrical industry. The other is a sketch of the financing of investinent in electricity. I suggest that borroming was only alficult in sane scetors.

The thethods of calculating some of the Tables are in an Appondix. There is also a Technical appondix explaining some of the enginoering matters. 
Chapter 1.

Electric Lighting: the carly days.

\section{1}

One of the earliest ways in which it was thought electrical energy could be used was in electric lighting. As early as 2808 Sir Humphrey Davy demonstrated that it could be used for are lighting. Ile produced an arc of intense brilliance by touching and separating two carbon rods connected to a huge primary battery. He also shewed that various materials could be heated to incandescence by the passing of electrical currents and concluaed that carbon and platinum wires could probably be used in this way to make a light. From these tro forms of light were developed the are and incandescent Iams respoctively, which were used up to 1944 for lamps of large and small intensity. Tho arc lamp has subsequently been replaced for all but a few uses, but the incandescent lamp is still used for such interior lighting. In Davy's time there was no chance of electric lighting being used comercially. Tho incendescent lamp had still to be invented, and while the only source of electricity was tise primary battery, the cost of electrio If hating was prohibitive. The solution to this problem was the Invention of a dynaro, but many years passed ofter the discovery of electro-magnetio induction by Faraday in 1831, before such a source of

1. H.C. Passer. The Electrical Manufacturers 2875 - 1900. Carabridgo, Hass. 1953. P.21.

2. Inid. P.75. 
of energy could bo used to produce electricity at a cost which mado electrio lighting compercially possible. A small generator was constructed by PIxil a year after Faradoy's discovery, and largor ones followed at intervals. But the important developisnts were made in the sixties and early seventics. In 1860 paccinotti developed a ring wound armeture, but this important develorasent was largely ovorlooked. In 1866 - 7 Wernor Siemens, Wheatstone, Vorley and Wilde, working from an Idea of Wilde's, constructed generators which operated on the principle of self excitation. This meant that they could generate the current for their orn fields and made the construction of powerful - but relativels small - dynamos possiblo. This very important stop forward was consolidated by Grame who in 1870 rediscovered ring winding and cambined 1t with the priviciple of self excitation in the construction of a dynamo which was the first to have good coinercial prospects. Three years later von Hefner Alteneck redesigned the Siemens aynamo willoh had the same economic advantage as that of Gramne.

The question of providing cheap current having boen solved, the other leg of the basic technical problem, the construction of good lamps, could proceed without dolay. Some rosk had boen done before the 2870 s on arc and incandescent lomps but it had not been very successful, nor had it been pursued with such energy as was to go into developments In the late seventies. Davy had used soft pieces of charcoal for his

1. J.A. Pleming. Fifty years of Electricity. London 1921 PP 47 \& 109-110 2. Ibja. 
lamp and these were rapidly co: Wore suitablo electrodes had $t$. also somo method of maintainin a by the passage of the current. devised which burnt more slowly and are of the same lencth when the electrodes were consumed. In 15 J.B.I. Foucault had produced a self regulating aro lamp and in the $2860 \mathrm{~s}$ thls had been improved by the solenold controlled clockwork mechanism of V.L.M. Sermin. In 1876 a Frenchman, Carre, produced carbon electrodes which lasted for a reasonable time. In the late seventies a large muber of regulating mechenisms were also dovised.

Incandescent lighting became comercially feasiblo at a slight later date. In the 1840 s the invention of the Danielli, Grove and Bunsen primary batteries eroused a burst of activity airected towards producing an incandescent lamp. But tho inventors were handicapped by thedr inability to produce a good vacuum. Without it the incandoscent element rused and the activity of the 40 s subsided without having achleved anything. But in 2865 Sprengel invonted the mercury vacuum pump and in 1875 Sir William Crookes obtained an almost perfect vacuun with it. 4 This togethor with the new dynamos of the early 7Cs induced another, this time succeisful, burst of inventive activity. J.W. Swan, who had dane same Fork on the incandescent lamp in tho 40s, returned to it, roiking in conjunction with C.H. Stearn, who had been making experimonts with a vacuum purap and by December 1878 had shoin a practical incandescent Iang

2. J.A. Fleming op.cite, P 150

2. J.A. Flewing. op.cit, P 150

3. A.A. Bright Jns. The Electric Irmp Industry. New York $2949 . P P 36-40$. 
to tho Howcastlompon-ryn Chowtonl Soctety. 1979 bo gent Lmproving the flicwent axd tho eribustion procoss on: by oar2y 1830 he was cominced that tho insup was a caxorolel proposition. Falaon had

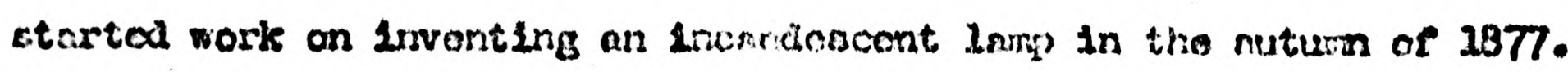
At firat ho attconticd to uso a platinum Plinnent but this lamp, brought out in 0otower 1073 , was not a sucsoss. Flowover, ono year lator ho

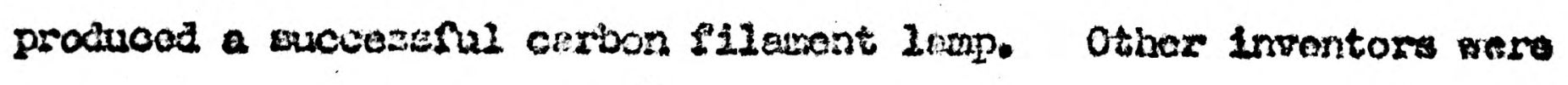
workin; on an incaratoscent lams at the sawe tho; in England St. Coorte

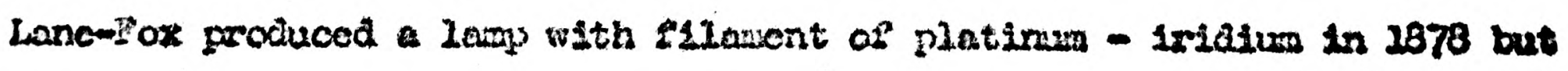
two years later folierex achion and Swan vith a carbon fillament. In

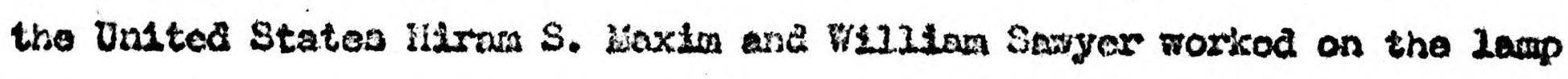
and by the end of 1090 bisitin had groduced a succosasud ono.

These dovelopartits ard invertions had brought olootrio 1ighting so tho throshola of controrelal develorment. Fon wo can consider this. Are lightirig was usod pumst. It had even boen used at South Faro and Liflathouss as carly as 1358, but it had been both cxpensive and tochnioally unsatiafactory. Howover in 1877 Irinity House morle

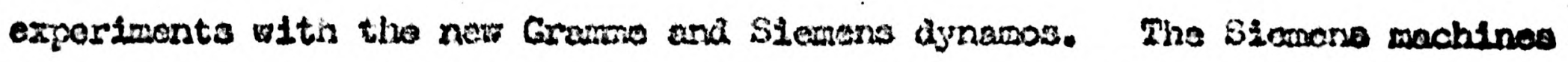
worked particularly, rol1; they cost lese than a firth of the cost of the South Borelana typo anamoo and gavo 3.6 - 4.4 timos tho 21 ght. 3. Eleotrio

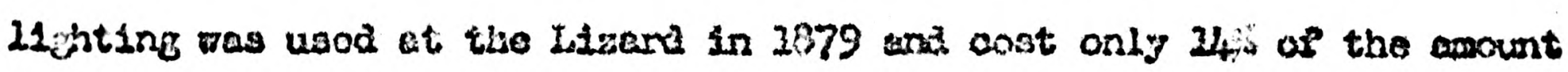

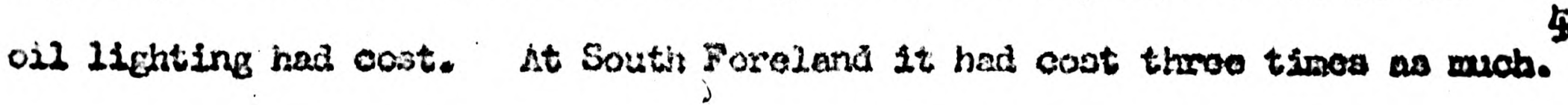

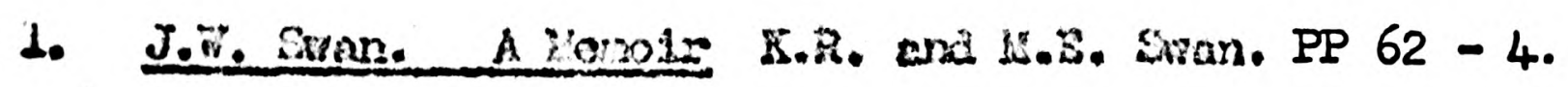

2. Ibia. P 70 .

3. Royort on tho Irinsty Iouse Tests. Telegraphic Journal. Vol. 5 PP 257 - 64 . 4. Report of tho Soloct Camitite on Lifhting by Eleotriolty. B.2.2.2878 - 79. Vol. 2. 683457 - 69. 
If chingusios provided the most favourable conditions for are 11quting. Conpared with other sources of lirhting, oil and gas, aro livits provided a relativcly chenp light fif vory great intensity was required. Buti for small powered lamps gas nas cheaper.

Apart from rsther special. crees like lighthouses, the obvious uses lor arc loma wes for 11 ghting; streets, open spaces, factories and lare public buildings. In the second half of the 1870 it was more exjenizive then gas fur those gurposes. A high candle power aro lamp, cay above 1000 candle porrer, was cheaper than a gas lamp of the same power. But as the power of the are was reduced costs fell very litile. Illuratiation, however, is not simply a cuestion of the canale power of 2auspo. The 1llusination given out by a lamp diminishes by the squaro of the aistance between the larap and the object 1it. A few high candle yower arcs would give pools of light with semi darkeness in between. A Iarge number of low powered lights giving the saure average illumination would give a wuch wore even distribution of light. If arc lamps were to replace gas lams and give the same minimum illumination, the average 1lumination over tise whole area lit would be much greater. It follows that the grcater the average illumination required the more advantageous it would be to are lighting.

In the 2870s lighting standards were still fairly 20\%. The otreets in the centrs of toms were lit by low porrered (often 26 candle 
power) gas burmers. Lighting was being inproved by the introduction of new, higher ponered gas burners made by Brws and Sieg, giving 150 250 c.p.' But al though towns were at the tino prepared to pay more for some wore lighi, the jung to the asount of ligiat which fairly oven aro lighting rould entail was considerable.

For interior illumination the situation was more favourablo to exo lighting, because more light was reguirod and because tho inside walls by providing some rerlection helped high poifered ligits. In lacturies it could, in sorno caves, reduce cosis by increasing the productivity of other resourees. Better Ifghtine could ingreve the quality of work or speed up tasiss. Overhead lights out of the way of the wachinory reduced the risk of accidents. In theatrea and indoor places of assembly arc lighting aid not raise the temperature. In any building where there was a fire risk aro lamps were sofer than gas. Tho quality oi the lifht jiven by are lanns bas oper to somo objoction. It washarsh, bluish in colour, and thres deep shahows. Its colour gavo, human conplexions an unpleasant appearance. It also flickered in an unpleasant fashion. ${ }^{3}$ on the other hand it gave a whitor ligit than the yellow gos lanks. Thus it was particularly usaful in

1. The incandescent gas mantle was not introduced until 2885 and scaucely used until the late ninetios. The 16 c.p. Eas bumer would give approciably less light tinan the modern 25 watt bulb.

2. Sugg marleted the Siemens rogenerative gas burner.

3. "Twinkle, twinkle, little Aro

Sickily, bluo, uncertain iparik;"

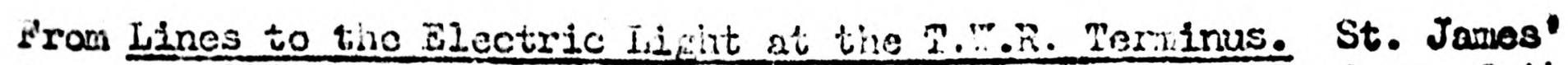
Gazette 1883 - quoted in fuli by R.H. Passons. The Early days of the Power Station Industry. Carbriage 1939. P 42. 
establishments where colours had to bo distinguished, for example in cioth factories and drapers'shops.

Even artor the inprovements in dymamos in the 1870 s are lighting was much too costiy to bo used, excopt for gpocial functions, 11i:o 11 ghthouse 10ipo. Tils is cicar from an examination of the cost of Sicmens are 11.jiting. Siemens Bros. were one of tho pioneers and their dynamos rere perhaps the best and the dieajest on the markot. They coula draw. on tive entinecring resources of Sienens and llalske of Berlin, with whom they were very closely associated. Sir William Siewen was a very ablo encineer indeed, ana in the Iato seventies ho made several inportant ingroverents to are lanps. Ho saw that the ef gnificance of arc lighting was that it could produce a light of great intensity more cineaply than gas. To give the best results aro lumps were placed on posts, 60 - $80 \mathrm{ft}$. high. 3 Although in 3879 and 2830 siemens are laxps wore installed in a number of places, thoy wore, allowing for all the dificiculties of isessureinent, very wuch more expensive than gas lacips. The reason for this was that, like most of the carly are lifiting pioneers Sienens used a dynamo for each aro Ianp. Fad this continued are lamps rould nave been very ravely usod. Eventually arc lifiting costs wo o suistantially rocuced when oeveral lampis were rin from each dyarko. This was successfully achiovod

1. For details of the relations between Siemens Bros and Siemens \& Halske see J.J. Scott. Siewenis Bros. 2350 - 1926 . Lositors 1958.

2. T. Pole. Hite of Sir W. Siemens. Ionian 1893. P 247.

3. Ibid: P 236. H. Cscw. Ensingerirs 16 spril \& 19 November 1880. 
by the uso of high voltage dymaros. Sut thoy had to bo doveloped, and control dovicos inproved so that inojo could rogulato themelves individualig whon all wore on the earo clroult. Tro syitens of aro 11giting which attempica to roduco costs by prooding aynam costa over oovoral lnsps pero Introluoed Into Britain in the years 1373 - 1830, Ono cerato from Prance; ono Irow the Unito Stateo; ono was a fallure; one was very ouccosalul.

Tho former. and the sret to cono to this country was tho are

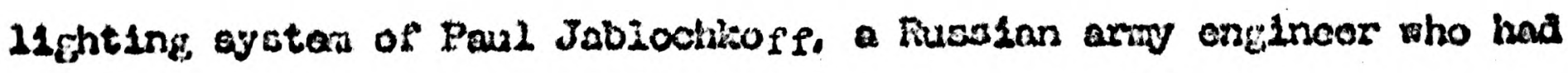
setiled in iranos. I3ls aystera was olmpio, robust and Inexpensivo to manuraoturo. In tho place of the usual lasp with 1ta expersive alocico work mechankism ho odopted a "comalo" type lamp. It worked at $20 \%$ roltage and ax "candlos" wore connocted to oach elroust. He used a Gramo alternator mound so that it could pood aovoral clroutto. Thum Jablochleof f was ablo to uso an oxistini typo of dynawo and aysoad the heavy aymoso and priwo mover costs over mang 1kghto. Tho candic porer of the "cardilez" was $100-150-200$ o.p. Thts was usoful. for the laproved gas lamps oosalng in at tinls time were of

1. Soo Tochnical Apperdix 1511 Sor dotails, ard an explanation of the elootrical torms used.

2. The "candie" consisted of tro rods of carbon placed paraljol and soparated by an insuleting atrip of kaolin. Tho oro started at the top and travollod comwarito as tigo carbons wore burnt and the moited.

3. "It was offoctivoly a polgphaso machlno, o1x "canales" boing connoctod to oach phase. See rechnical apponaix. 
this porer. But unfortunately tho uas of fare lanizs of auch low powor

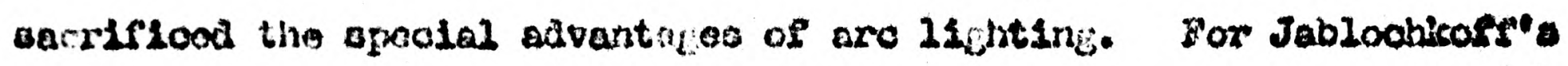
"condies" vero arore oxpansive than the now cas burners.

\section{Table 1.}

Costs of Joblocilose gro 1 ighting and gas 11 ahting.

1. Cost of Jablonhicopp are lighting

Total cost excopt for carbons, per lamo hour d.

$3600 \quad 1740$

Coste on the Exisanimont

actual rumine $c$ estinited capital oosts

3.8

4.4

ditto plus ostinato of cxtra

cost to mako 1notoliation porsanont

4.3

5.4

is estionates con a 60 light etation,

the bigiest ano built

2.0

2.2

2.

Corbon costs par lamp bour

1877. 4.70.: 10to 1879, 2.02. 12to 1880. 1.3a.

3.

Cost of Suge gas bumers.

Total cost por lasp hour a. asouraing price of gas was

3/6a per 1050 cuble seet.

Ilown Iigting per anmon

$\begin{array}{ccc} & 3600 & 2740 \\ 255 \text { c.p. bumers } & 2.2 & 2.5 \\ 265 \text { c.p. bumers } & 3.7 & 4.0\end{array}$

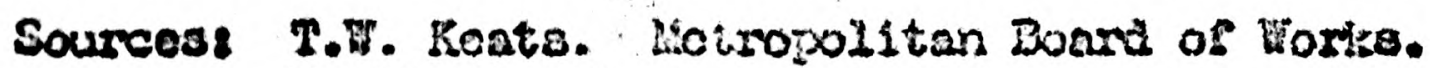

W. Chers. Hlecirpou gas eneineor.

Sucs in ovidence to tho 21579 Seloct Candittoe. 
As Table I shows cirion costs alone wero Iltite leas than tho cost of egues paiter gess burners, thus althugh cagltal costo waro oproed vidoly and kept dom by altay lo aparulus, thers was only a umall gerp

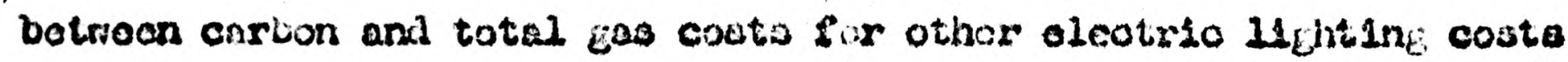

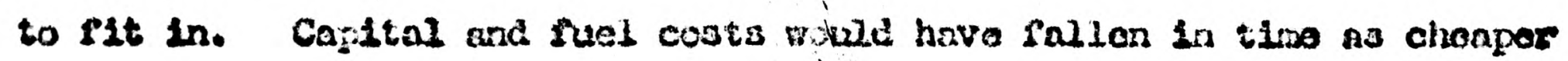
and more ofiliciont dynesos wero made. But it is unlikely that oarbon coots could have boen further reciucol, or that more than 60 jangs oould be conreoted to one gonerstor.

Jablochlor? are lighting was a failure because it ald not use the comparartvo advartage of aro 14kting - the bility to produoe an intenso

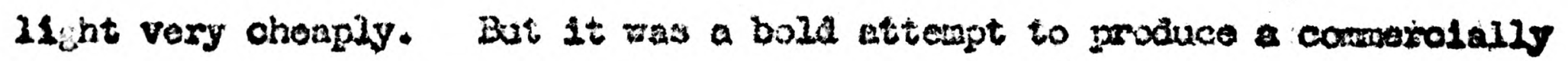
viabla eystem. Ecanario considorations more cleariy to the Poro. Deing

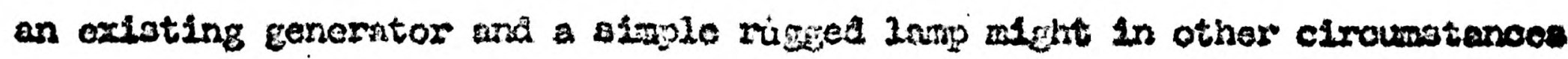
have been a great auccess. As it wes, it was too crulo to bo further developed to the polnt where it usliht becono cheap cnough. Using a Gramm

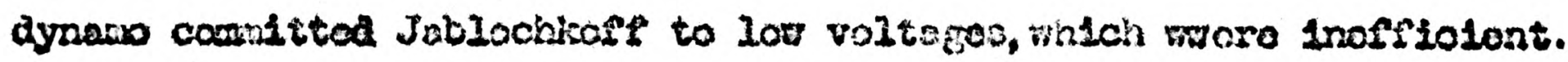

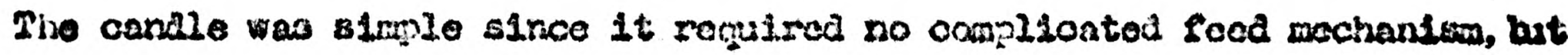
It noeded a.c. phich was then wore costiy than d.c. Because of poar insulation, wizicin coula noi bo ingrovod, it was vasterul of curront. 1 Jablochlso aro 21 ghting was czhioitod at the Newt India Docks In 1877. Howevor tho flrist importent inctallation was in Fariss tho Avonuo do L'Opora was $21 \mathrm{t}$ by Jablockltorf "candlcs" cano time bofuro a pormanemt installation was mode in this country, and many Englishom wont

2. Tw. Vol. 5 T250.July 1877. 
to Paris to study 1t. In 1878 the Société Généralo do l'Electricité, the manufacturers of the "candles", was able to percuade the Conmisaloners of Sewers of the City of London to try the ner lighting for a period of threo months on Holborn Viakuct. The experiment was not successful; thero wero many brealedorns and ii was vexy expensive. At the ond of three months an offer to conilinue the lichting at half the experimental price was refused. However in Deceniber 1878 the Netropolitan Board of Works also decided to try the light and 20 lamps wore put on the Embantment. This installation vas more successful. It lasted for several years end the numiver of lights was increased to 40 in March $2879 .{ }^{2}$

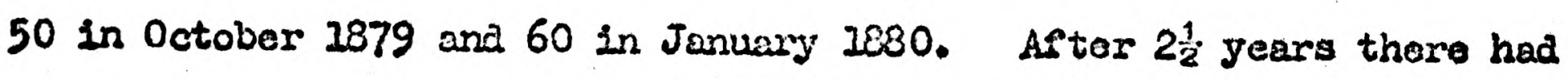
not been a single breakdowm. In 1879 several small Jablochkoff Installations wero made, and at the end of the year it was ootinated that 165 Jablochkoif lanps were in use nightly in England.

The second, and successful attempt to reduce costs by tho use of multi-aro dynemos was that of C.P. Brush. He saw that the key to the problem was the dynamo and developed a high voltage machine which would servo soveral arc lamps in series. For his lamps he chose a porrer of 2000 c.po This was in between the very high power of Siemens lamps

1. Evidence of Colonel Iaymard to the Select Committee on Lighting by Electricity. B.P.P. 1878 - 9. Vol. 2. QQs $2074-95$.

2. 'R.t. Parsons, op.cit. P 5.

3. For a detalled account of Brush's work see H.C. Passer. op.cit. Chap. 2.

4. Soe Technical Appenäix.

5. Theg wore 2000 momiral c.p. Actual candle power was about half the nominal value as nominal candle power was obtained by putting the carbons in an abnormal position. 
(3000 c.p.) and the small power Jablochkoff "condles." Thus the relat1ve advantages of are lighting were kopt, but it wes more suitable for general 1ichting purposes than the Siesens lomp. The Brush lanps were sinply regulated and robust. Ihe light was not as regular as that of somo other lamps with moro conplex regulating meckanfomo, but Brush inuroved metters by manufacturing his own carbons, which were said to be the best on the market. By using a double carbon lamp which burned for 16 hours labour costs wero reduced as carbons no longer had to be changed during the night. Brush's dynamo was also wore economical than most. An aditional advantage of using high voltages was that cablo costs could be very mach reauced.

As Fable 2 shows Bruah"s imovations reduced the cost of aro lighting to a point for below that achieved by Siemens. In January 2880 the Anglo-American Brush Electric Lighting Corporation was formod. The comercial story of are lighting in Britain dates largely from then. Incandescent lighting wąs used comnorcially very soon after aro 11:hting. Unlilse are lighting the porser of the lamp was small, the same as that of the existing ordinary gas burnors. This was intentional. Although Swan's first lamps were about 25 c.p. he soon reduced them to 16 o.p. Thus incondescent lanps fitted directly into the existing Iighting market and the costs of gas and electric incandescent lights were directly comparable in a way that gas and erc lighting costs wore

1. R.E.B. Crompton. The Electric Iight for Incustrelal Pusposes, 2880,

2. Hoscelorth referred to as Brusia. 
Table 2.

Costs of various arc lighting ststans.

2. Intial cost per lamp (excluding erection costs)

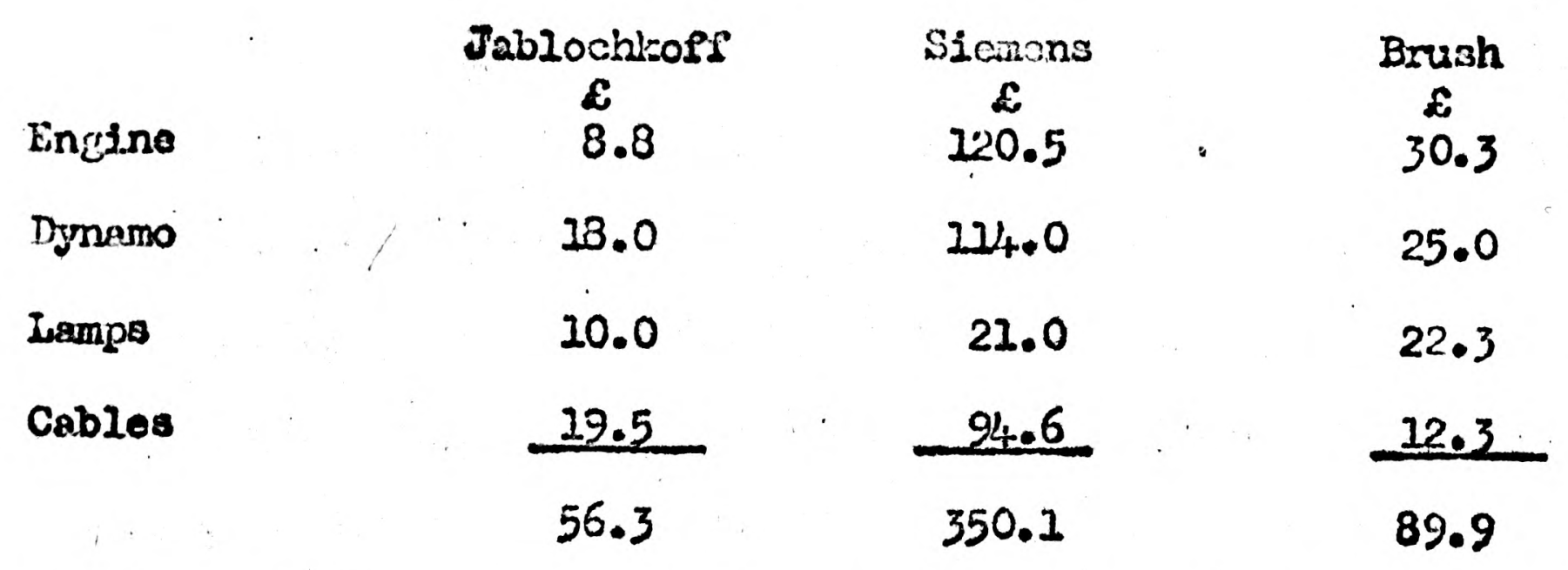

2. Running costs per lamp hour a. (labour is excluded. If Included Brush results would become even more favourablo.)

\begin{tabular}{|c|c|c|c|c|c|c|}
\hline & Jablochkoff & & Stemens & & Brush & \\
\hline & $1878-9$ & 3879 & 2880 & 1882 & 1881 & 2882 \\
\hline Fuel & 0.69 & 2.65 & 3.27 & 3.78 & 0.69 & 0.50 \\
\hline Carbons & 1.33 & 5.5 & 2.73 & 2.27 & & \\
\hline & 2.02 & 8.15 & 6.00 & 6.05 & & \\
\hline $\begin{array}{c}\text { Number of lamps } \\
\text { per dynamo }\end{array}$ & 20 & 1 & 1 & 1 & 16 & 32 \\
\hline $\begin{array}{c}\text { Cabale porier } \\
\text { of lamps }\end{array}$ & 150 & & 3000 & & & 0 \\
\hline
\end{tabular}

Co2l prices vary, but this makes little alfference.

Sources: Jablocbloff. T.W. Keats. Lvidence to the Select Comittoe on Iighting by ilectricity 2879, corrected to allow for full employment of capacity.

Sienens.

Brush Crompton. ilectric Lightind for Industrial Purposes Chow. Engineoring 1980. Ilect. Vol. 9, P 355. 26 August 1882. Electric Iight 28 June 1886. 
not. But the question of whether poople were going to use gas or electrio lighting was not entirely a quostion of their relative costs. Electrical incandoscent 11 ght had quality auvantages. It gave a steady light compared with the ravering $2 i_{\text {ght }}$ of the gas jet. It did not produce as much heat for a given quantity of light - rell lit gas lit rooms becamo unbearably hot at times. Also gas producod fumes which were unpleasant, and as it burned it vitiated the atmosphere and blackened decorations. An important advantage was that ciectrio incandescent iighting was the oniy form of light which was not a flame light and thus had a lower fire risk than any other type of Iight. In buildings with a large fire risk only electric incandescent light could bo used. The higher quality of incandescent lighting affected the degree of substitution botween inoandescent and gas lighting. It was not perfectly elastic because people with aifferent incanes would change from gas to electrio Iighting at afferent levels of the price cap (eloctricity excoeding gas) betwoan them. If the two foris of lighting cost almost the same amount there was 114 llo doubt that olectricity would bo chosen. When Edison made a survey in New York ho found that at "gas price" noarly all consumers prefered electrio lighting. Tho amount by which electrio lighting costs would exceed gas costs and yet prosper, depended on the excess which peoplo were prepared to pay for this luxaury light. But olearly whon the prices of gas and olectrio lighting were not dissinilax there would be high elasticity of substitution between the two. If such a price parity could bo achleved for electric lighting it woula lnevitably spread into a wido market. Without achieving this it would satisfy only a small luxury noed. 
Inventing the lamp was only one step in the introduc. on of incandescent electric lighting. Existing arc lighting dynamos designed to operate at a constant current were unsultable, as incandescent lamps roquired a constant voltago.

Also the typo of distribution system used for are lighting, was unsuitable. On a series circuit lights had to be switched on and off together. For street lamps and factory lighting this was not a majer disadvantage, but it clearly rould have bean for Incandescent lamps whor many more would have to be connected to each dynamo for the 11 ght to be sufficiently cheap, and where intermittent use was more clearly desirablo. Being able to control lights individually would economise on both capiter and runing costs.

Tho only way to do this was to connect lamps in parallel. Parallel connection could however involve very high conductor costs, if the operating voltege was low. The construction of a lamp for a high voltage cirouit was more dificicult than one for a low voltage. The first lamips ran at $50 \mathrm{v}$. but lighting costs were much reduced when lamps for $100 \mathrm{v}$. clrcuits were developed.

1. Gapital costs because the probability that all would be switcheo on togetiser was very small.

2. See Tecinical Appendix... 
Tho bogimings of the introduction of arc 11 ghting in tinto asuntry cowo in 3079. It was a yenr of 21,hting exhibitions, and in the conirse of the yoar nearly all large towrs hac exhloltions or aro 11enting.

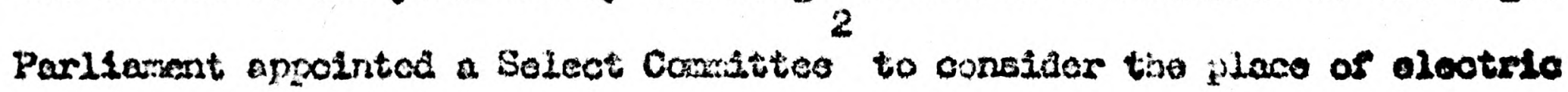
12ghting in the econowy. But alchough the intorost was great, vary 2ittlo had been dono and the coirsitteo did not feel that the tiros was ripo to give an general purrors to electro lighting comantes to undertake pubijo and peivato 11ghting.

In 2990 eloctric 14 ghting started to apear on wor than minute scale. Tho year togan, gropheticelly onough with tho formation of Brush. At fixst the compary wos only andeo agunoy for tho Amorion parcnt but sales of Drush oguiment wero sudiolentiy largo for it to

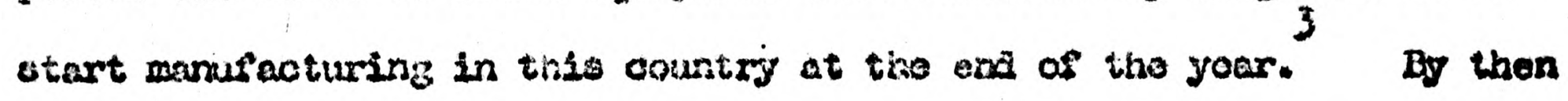
2t had cono to sharo wth Siaveno and Jablocblori" the rirst place in the aro 21ghting barkot.

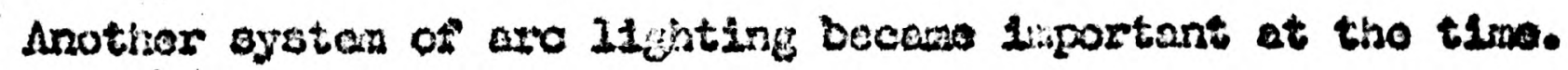

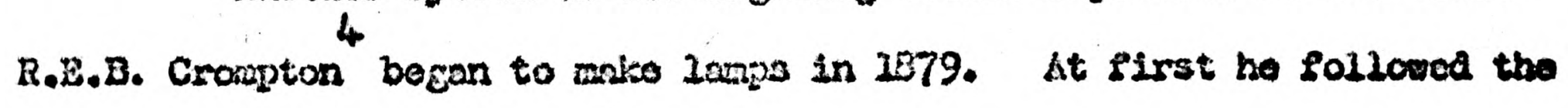

1. Eloot. Vol. 4 280. 3 January 2800.

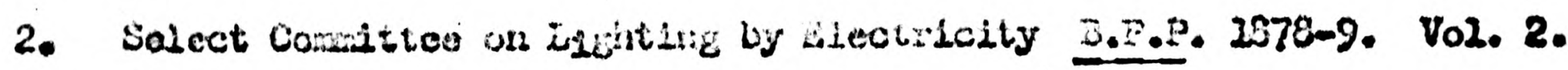

3. Elect. Val. 6 P 31. 4 Deccinbor 1500.

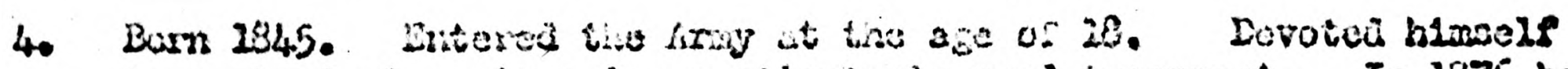

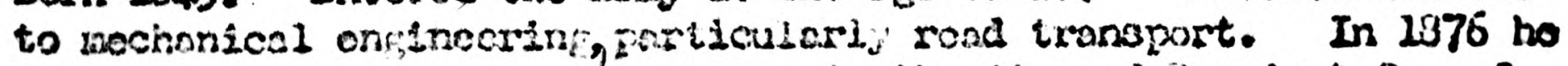

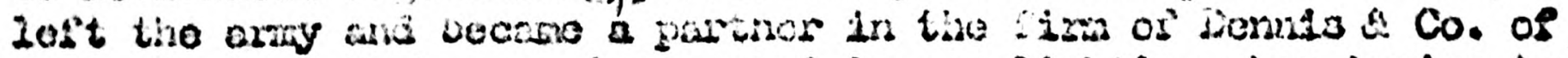

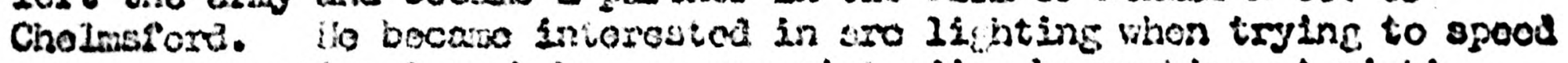
sows constructional wosk he was superinitondirg by worting at nigite.

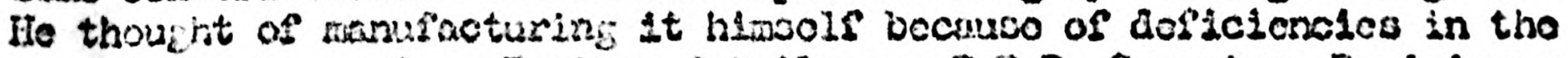
are 2ighto he usoc. Further dotails soo R.E.B. Crompton. Raminiscences 
usual practico of using a dynamo for each lamp, but following the succoss of Brush he began in 1380 to make mult1 arc dymamos. In 1879 hts lamp was used in only six pleces; in 1830 he had at least 24 inetallations and was said to be unable to produce equipment fast enough. But ho had only a small works.

Throughout 1881 the progress continued. Brush seans to have takers the lead. Siemens expanded, but at a slower rate. Jaulochkoif Ilghting was declining in importance and Crompton joined B2tisin and Siemens in the first place. Eut Jablochiori sales rere probably rising.

A smaller company, the British Slectric Light Co., formed as early as Decenber 1878 to import Grame dynamos, and which ind subsequently brought the patents for the Brockie arc lamp, was also very busy and doubled its office accomodation during 1832 . New companies were formed, notably the Electric Light and Pover Generator Co., to market the Iontin lamp in England, which had become notable in 1350.2881 was noterorthy for the electric lighting in the City of Lordon whicis was sponsored by the Comissioners of Sewers. Tnis was a good opportunity to demonstrate the virtues of electric lighting promineritly and on a large scale. The major companies, Brush, Biencons, Cromption and the Electric and Lagnetic Co, sont in tenders. Contracts were arrarded to

1. Elect. V0I. 6 P 908, January 1831.

2. Elect. Vol. 8 P I227. January 1882.

3. Elect...Vol. 8 P 212.

4. Elect...Vol. 8 P 122. 


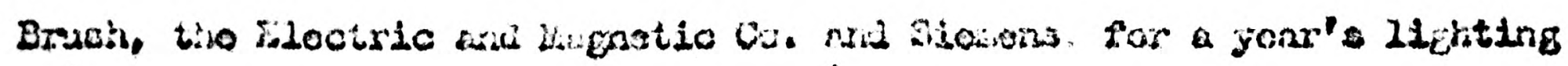

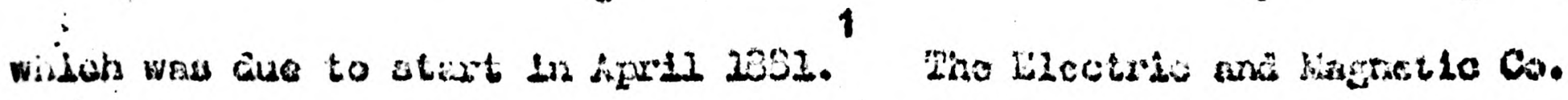

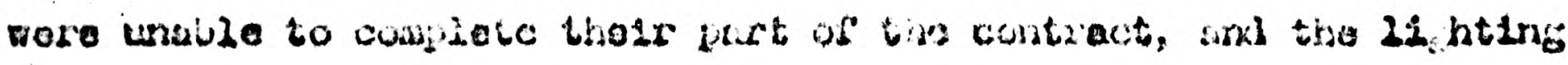

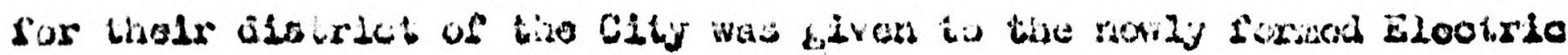

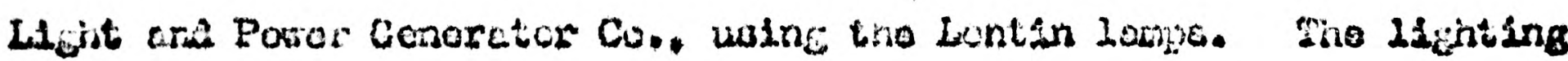

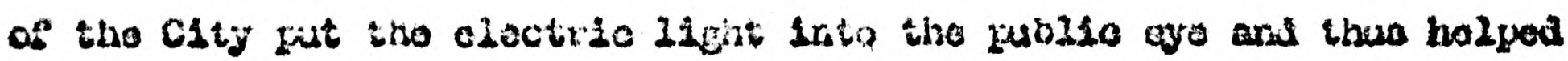
to create the corrations for the bowas of 1332.

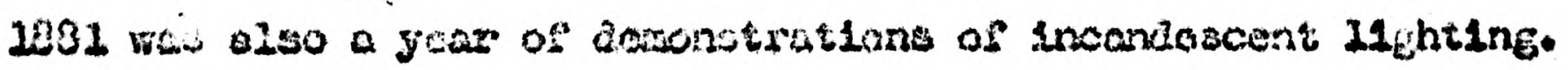

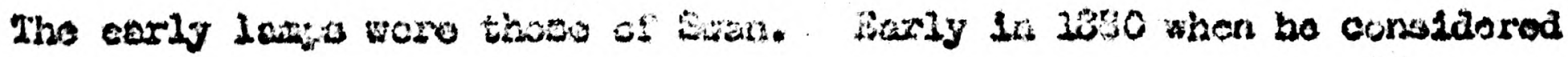

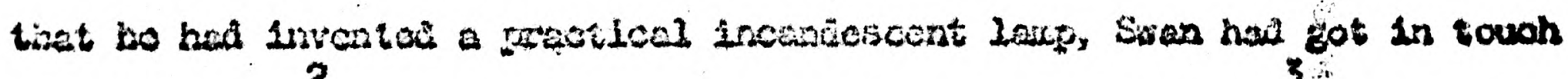

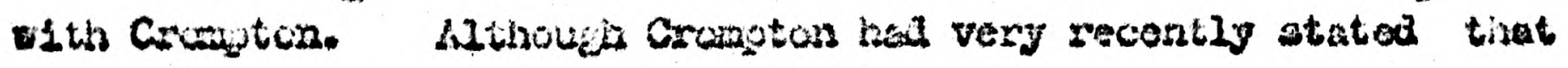

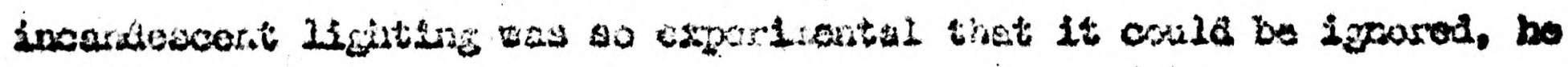

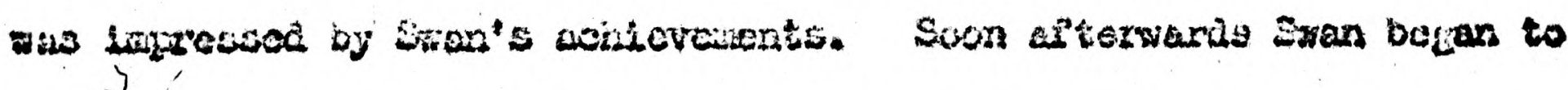

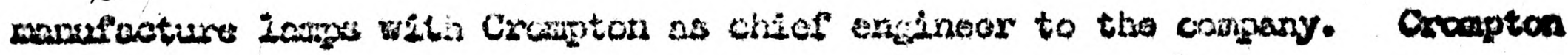

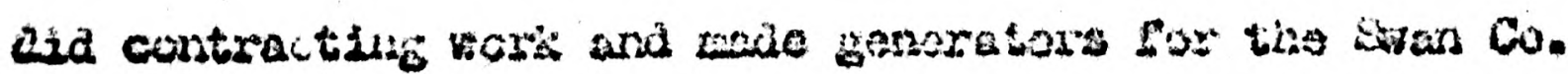

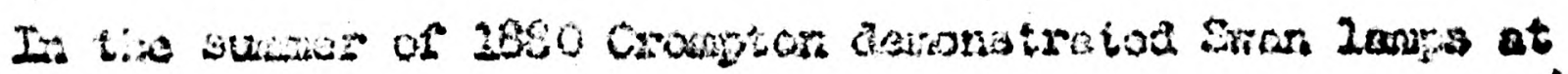

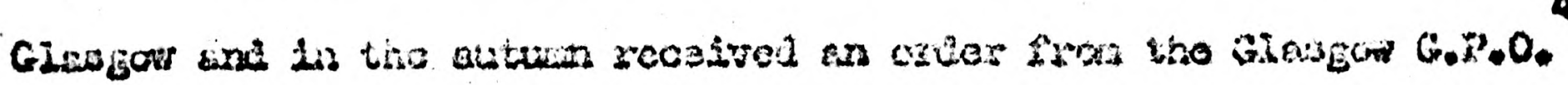

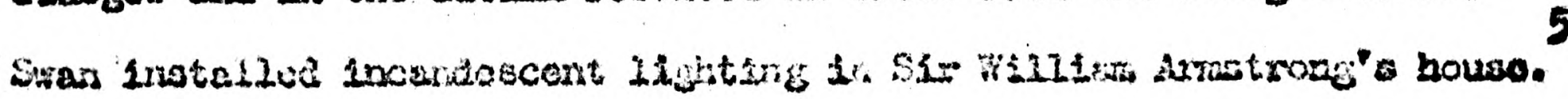

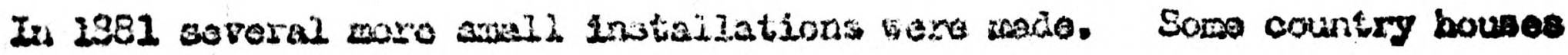

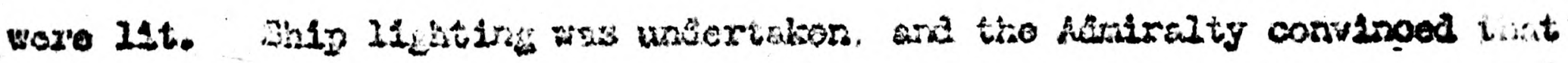

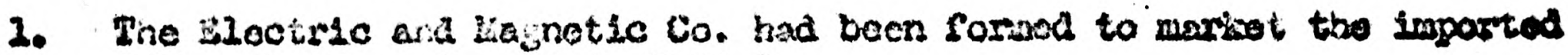
Jeblociliort oqusigent in Bustriln.

2. M.B. E H.R. Sran. devidies P 70.

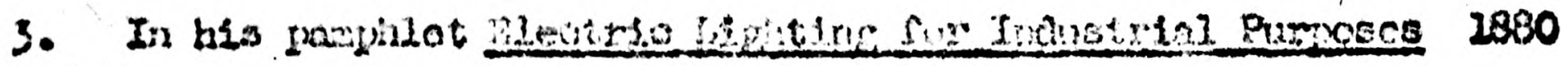

4. R.B. Crompton. Berintsecones Lonton 1923. P 94.

5. Uason swan Elcctrical Co. Pareant of tho Lasp. 
that Incandescont bulbs pould be sate enough and tough onou h for a man of war. Dut 1892 was chlaf2y epent in bringlng incandoscent 21 ght ing Into the fuiblic oye. It car tho Parlo oxhibition and tizlo gave Shan

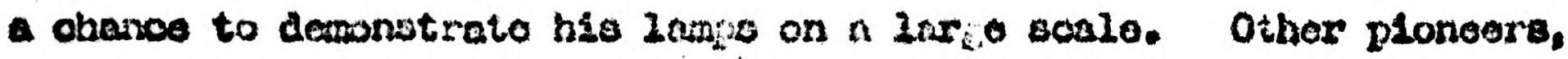
Balson, Marion and Lanomgrox aloo exhiblted at Pario.

In tise firet half of 1982 a conaluerablo boca acened to bo dovoloping in olectrio lichting. It was primarily a boa in aro lighting. very Larjoly becauso of tive success of tho Brush system. But Incandescont

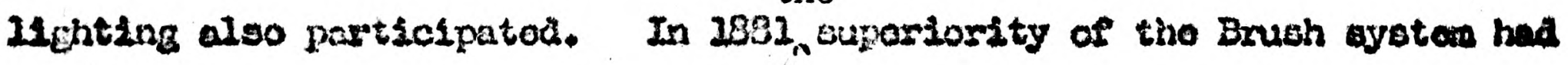
bocowo obvious. Illtherto Brush hod both andactured and nold aro IIghting equipmont to einal consumers. But in 1831 it decided to concentrate on romufacturing. It bogan to soll concossions to compantes Eiving thew the exclusive right to oell Brush equipont in a particular area. The dirst concession was oold in Juno iE81. Campanies wore rormod to buy concosulons for othor areas, and for your thoso odou continuod at nich pricos.

Once foriod these concosalonary companies bought Buthe equigmont and began to damonstrate it to stimilate sales. Confianoo in the futuro

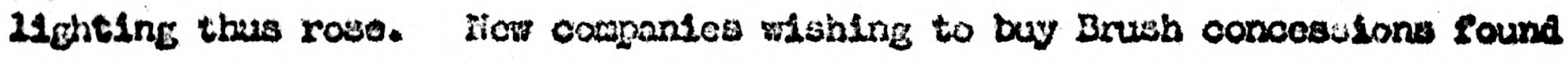
1t oesy to borror troney and the process c.ntimed.

At tho samo the the manclpalities becars interestad in the po ofblo uso of aro lamps for streot 2ighting. In tho early daje, it was alfficult to find out about the desirability or costs of oloctrio 11ghting 1. H.E. \& K.R. Swan. op.eit. PP $76-7$. 
Table 3.

Brush Sales of Concessions 1881 and 1882.

1881 .

Dublin E.L. Co.

Hamrond Co.

Scott1sh Brush

Poreign Companies

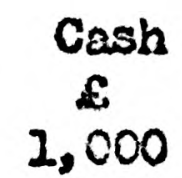

20,500

20,000

34,000

Total less expenses
Shares

$\mathcal{L}$

9,000

$-$

20,000

20,000

1882

Hammond Co. 7,000

G.W. Eloctric Llght and Power Co.

S.I. Brush

Brush lifaland

Metropolitan Brush

Provincial Brush

Irish licence

Isle of lian Licence

Poreign Companies

$\begin{array}{rc}23,750 & 15,000 \\ 10,000 & - \\ 14,000 & 16,000 \\ 150,000 & - \\ 25,000 & \\ 2,000 & \\ 250 & \\ 62,505 & 64,000\end{array}$

Total less expenses
54,000 99,500

7,000

Total $\varepsilon$ 10,000 20,500 30,000 28,750 10,000 30,000 250,000 25,000 2,000 250 226,505 407,296

Source: Brush accounts for 1882.

whout putting down a trial installation. There were muexous publishod estimates of costs, but most of these vere deficient (for axample capltal costs were forgotten) or biased. Some local authorities were cantent 
with a roport, but some, like tho London authorities, the Comnissioners of Sewars and the Hetropolitan Boand of Works, dotermined to seo it in use. Among provincial corporailions, Liverpool showed the oarliest interest. They installed trial lighting to explore the possibilities of the arc lamp as early as 1879. In late 1881 and early 1882 a large muber of looel authorities tried arc lighting, awong them important boroughs 11ke Blrmingham, Blackburm and Leeds. 'These local authorities samotimes Invited tenders for a temporary lighting installations and scmetimes bought plant.

All these exhibitions and experiments greatly stimusiated sales of aro lighting equipment. The amount of plant they required was largo relative to the small output of equiprent in 1881. In 1881 Brush sales were about $\$ 80,000$. In 1882 they rose to $\$ 200,000$. Calculations suggest that the concessionary companies may have spent as much as $\$ 100,000$ on Brush plant in 1882 alone. Brush had to expand manufacturing feclisties extensively and to mect the sharply rising demand they had to import some equigment from the American Brush Co.

There was naturaliy also an increase in dernand for tho arc If ghting equipment of other firms. Sales of Siemens are lighting equipment rose from $\$ 35,840$ in 2831 to $\$ 33,780$ in 1882 . Crompton was clearly extremely busy although manufacturing facilities do not seem to have boen expanded.

1. See the evidence of municipal representatives before the Select Comitte of the House of Iords on the Eleotrio Lighting Blils of 1886. B.P.R. 2886 Vol. 7. 
In 2892 incandescent liginting became known. In that year Crompton made the first large installation of incandescent lamps in England - at the Lar Courti. The Raison lamp also mado its appearance in England. An agreement was made with the Comiosioners of Sewers in January 1832 to light Holborn Viaduat free for 3 months and subsequentiy at "gas price" if electricity could vo supplied to private customers. In Merch 1832 an English Edison Company was formed to sell Eaison incandescent Iighting equipment in England.

Jany of the arc lighting companies became interested in incandescent 1igiting. Siemens Bros. used Sran lamps in conjunction with their own are lamps at Godalming in 1881. The British Electrio Iight Co. bought the Lanowox incandescent lamp patents. Howover it did not make much use of them and Lane-Fox repurchased them. He then sold thom to Brush, but the latter at least up to 1883 - 4 shored only marginal Interest in Incardescent 11ghting. The Electric Light and Power Generator Co. punchased the incandescent lamp patents of Hiram S . Haxim in 2882. Crompton had been involved with both are and incandescent lighting since 1880. Together arc and incandescent lighting could provido electrio Iighting of almost any intensity, and thus for any purpose.

\author{
1. R.E.B. Crompton. Reminiscences 107. \\ 2. R.IL. Earsons. op.cit. P I0. \\ 3. R.H. Parsons. op.cit. P 12. \\ 4. Necting of Naxim - Woston Electrical Co. EeRe Vol. 10 P 325. \\ 6 May 1832.
}


In tho first balf of 1832, there was groat entholasen over oloctric 11giting particulariy are 11 chting. Thero had been rapla and axolting technicel devolopmenti, and wary pooplo folt they were at the cawn of the eleotrical age. At tho titro there was aloo a weak boom in othor soctions of the econcry. Tho acprosition of the late sevantles was very coep, and in the short revival of confiance from 1930 to 1882 tho

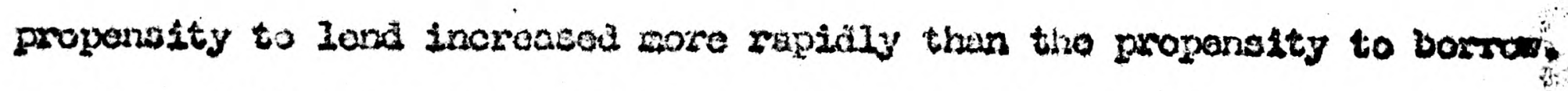

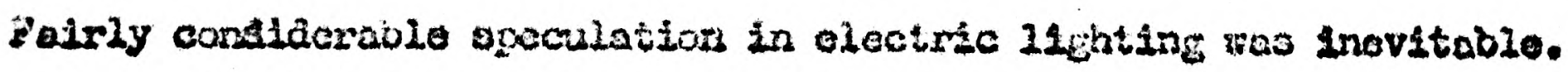

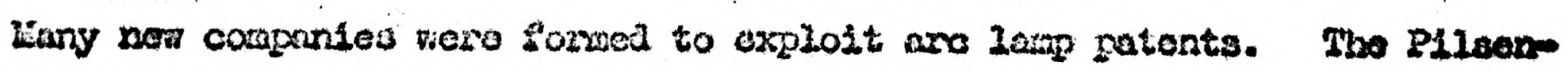
Joel wis forwal to aell Pilsen are lamp, and the Guleher Co. to soll

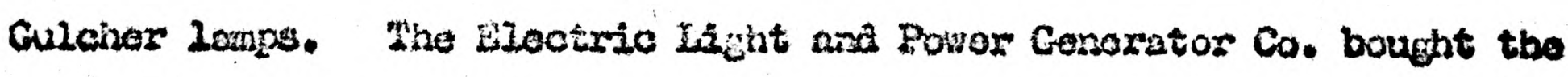

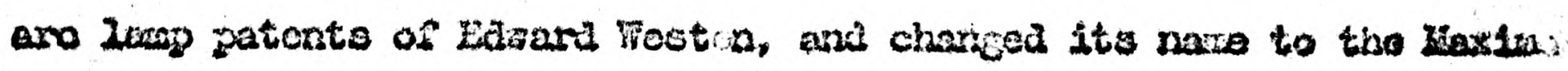

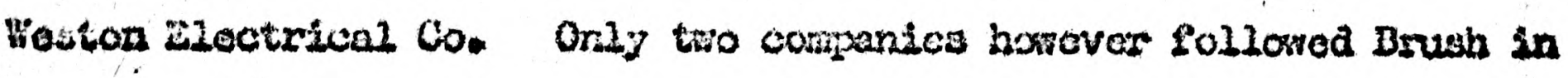

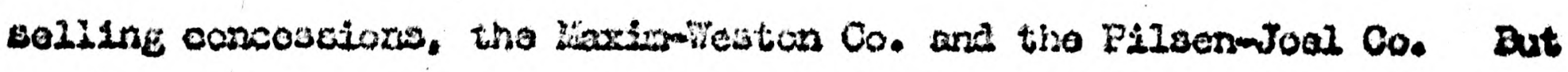
thay oniy sola ono concesision excis.

There wes coraldenaib stock exchango apeculation in Bruab shares.

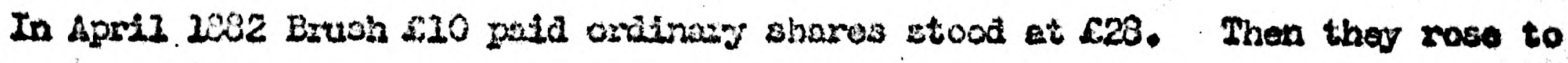
- peais of 868 in liay ard thereaficr foil agats. Dut as lato as Soptenbor 2082 they wowe whil ais hith as set.

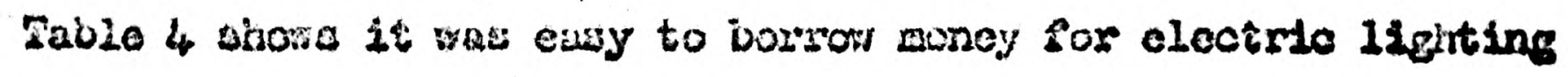

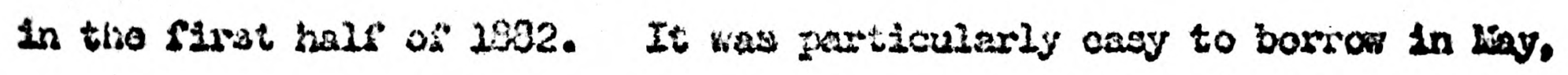

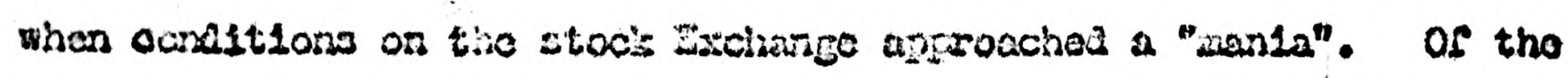
$2.3,053,575$ bordered by the iesue of shared in $2832,22,703,850$ oan bo allosated to jart lcular months. \$1,924,000 was barroned in tho 2na quartor, $\mathcal{E} 1,530,000$ in $\mathrm{Xey}$ olone.

1. Economist. $20 \mathrm{kray}$ 2882. Elect. Sejtenbor 2982. Vol. 9. PP 407, 430, 455 , 
Table 4.

Capital called up by companies formed in 3882 to exploit clectrical invention.

1. Menufecturing companies or companies intending to manufacture

737.000

2. Supply conpanies or companies intonding to supply

$1,150,000$

3. Electrical Contractors

4. Companies formed to warket miscellaneous elcctrical inventions (not always eloctric lighting)

965.475

5. Companies intending to operate abroad

646,500

3.053 .573

I have allocated companies into these groups on the basis of the name of the compony. But this is not an infallible guide. Somotimes tho name is fisleading. Sometimes companies intended both to manufecture equipment and supily electricity. These companies have been put under manufacturers.

Source: Electrical Trades Directory. 1883.

There was thus a general feeling in 1882, particularly in the second quarter, that arc lighting would soon be used to a considerable extent, and that the widespread use of incandescent lighting would soon follow. In this situation people naturally thought of contral station 11ghting. Whother there should be central station supply or not depended on whether there were suff'icient economics of scale to fustify it.

It is possible to have electric lighting without central station supply

1. The contemporary word central station has been used in this work rather than the modern word power station, in order to avoid confusion with the electricity stations specifically or mainly built to supply electricity for motive power. 
but if there had been a considerable demand for electric llghting there almost certainly would have been sufficiont economies of scale.

The arc lighting companies were vory anxious to devolop atreet 11ghting. In an already urban England, with streets lit by gas, there was a large market for street lighting. And lighting the stroets was a good first step to general contral station supply. Onco wires had been lold It would not be difficult to give a supply to customers whose demand for IIght was too small for it to be worth while for them to have an isolated installation. Are lighting by itself did not lend itself to extensive central station supply. In 1882 thinty two Iamps were about the maximum which could be supplied by one dynamo, and most makers made dynamos for only 10 - 15 lomps. The small dynaros - they were not more than $30 \mathrm{KM}$ at the outside - were best driven by portable or seni-portable engines. Distribution costs soon offset any advantage of grouping more than a small number of generators together. But incandescent lighting pronised much greater economies of scale in generation. It was pessible to Increase the output of a constant voltage dynarco much more easily than $1 t$ was to increase the output of an arc lighting dynamo. Easson sam this and in 1982 opened the large Pearl Stroet central station in the Wall Street area of Nev York City. For it he designed his famous Jumbo dynamos built to serve 1200 lanps (approximately $75 \mathrm{KW}$ ) and over four times the size of the largest incandescent lighting generators previously made. In London the Edison installation on Holborn Viaduct ras a central station, boing to somo extent a pilot scheme for Pearl Street. EdIson sent over E.H. Johnson, one of his chief assistants, to begin the Iondon Station. 
When 2t opened in April 2382 it had 938 lamps connected to its mains. Aro. lighting companies hoped to run both arc and ircandescent lights from the sawe central station, although as the electrical circuits had at the time to be separate, the advantages of doing so were limited. Before central station lighting co:ld develop sane permissive legislation was necessary. Thecrucial question was the opening of the streets to lay underground mains. Mhch of the early arc lighting simply used overhead wires, but it was clear that any substantial central staticn would involve underground mains. Who had the right to cpen up the strects was not at all clear. Even the local authorities were uncertain of their r1ghts. Iiverpool Corporation held that they had no powers to break up the streets of the city to lay elcctric lighting mains and sponsorad a Bill in 2879 to givo such powers. The 1879 Select Cominitteo doubted this contention but roported that if local authorities did not have such powers under existing statutes. (0.g. the Public Health Acts) ample porrers should be given thare. But the Comittee felt that the time was not yet ripo to give general powers to companies to break the strots excopt by consent of the local authorities. By the first half of 1882 it was clear that some ceneral permissive act was necessary, and one was introduced. covering any electricity supply undertaking laying cables under the stroot. General conditions roro laid down. Intending suppliers could then apply to the Board of Trade either for a Provisional order or a Licence, a much cheaper procedure than a private $\Lambda$ ct of Parliament. A licence, which ran for sevon years, requirod the consent of the local althority. However an 1. R.H. Parsons, on.cit. P 11 . 2. Report of the Selec't Comnittee on lighting by electricity B.P.P. 1878 - 79. 
application for a rovisional order would not be refused even if the local authority concerned opposed it, unless the Board of Trade was o onvinced that the local authority intended to start its own electricity supply. A very important provision under a Provisional order was that the local authority should be able compulsorily to acquire an undortaling aftor 21 yoars from the granting of the Order at the then market value of the physical assets of the Company.

The boom was in essence a fairly large scale trial of an important innovation. There was only a small rise in the permanent demand for electrio lighting. The result of the trial was that eleotrie Iighting was considered too expensive for widespread use. As a result the boom quickly broke, and having over stimulated productive capacity. all sections of the Industry entered a long period of depression. It was real and not financial conditions which were responsible. Tho considerable stock exchange speculation of early kay quickly disappearea, but Brush shores did not fall below the pre-bubble price. Enough had been borrowcd in May to install a great deal of electric lighting, and the number of applications for provisional orders aftor August shows that confidence remained high. But the events of the 4 th guarter of 1882 and 2883 showed that such confidence was excessive.

Central stations depended on a considerable use of eleotrio lighting in a small geographical area. It was beceuse events showed that tho demand for electric lighting was small and that tho attempt to begin thom was doomed. But companies who expected oxtensivo isolated lighting were equally disappointed. 
Table 5.

Electricity supply. Provisional Orders and Iicences seanted by the Board of irade. 1232 - 1912 .

Year

2882

3

4

6

7

8

9

2890

1

2

3

4

5

7

8

9

2900

1

2

3

4

5

7

8

9

1920

21

12
Provisional orders

69

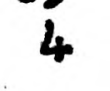

1

2

13

59

25

15

24

23

31

50

67

90

99

97

64.

53

65

56

4.9

23

22

11.

19

25

31

38
Lleences

1

2.

1

1

5

4

2

3

3

2

1

The rumber applied for was always greater. Somo applications competed for the sarno area and some proposed schemes wero unscund.

Sources B.P.P. Returns made annually by the Board of Trade. 
Table 6.

Provisional Orders granted in 1382.

Iocal Authorities Companies Othors.

Brush concessianaries

Iondion

Provinces

$$
\begin{gathered}
1 \\
13
\end{gathered}
$$

28

The Electric Iighting Act received the Royal Assent in August 1882. The eagerness to begin a public supply of electricity can bo gauged by the fact that one month later 83 applications had been made 1 for Provisional Orders of which 55 had been granted by the Board of Trade.

The Brush concessionaries Fere well in the fore of the attempt to found central stations. Thoir applications for provisional ordors wore $48 \%$ of the total. Yot they all soon collapsed. The Brush Company of Scotland was the Ilrst to go but the Metropolitan Co. which had applied for as many as 26 provisional orders, followed it quickly. Before proceeding with its Provisional orders it decided to mun a pilot soheme at Holborn. Estimates of cost and demand were made and it was thought that electricity would be supplied at "gas price" fiving a return of $8 \frac{1}{2} \%$. The stockholders however took a different viow about the scheme and a compltee of investigation set up by then reported that the demand estimates were excessive. Virtually only the shops would take the eleotrio 11ght and would use it only luring business hours. Finmond (Chaiman of the Ilanmond Electric II Iht and Power Co.) who was a lorge sharoholdex

1. Report of the Board of Trade B.P.P. 1883. Vo1. 64. 
endorsed the report but gave as a reason for the probable fallure of the schems that the scalo of oporation was tuo small. He of ierod to purchase tho compary so that a largo scale station coild bo oponed. But the ahareholders, who were alasued at the way the company was run, esm pecially at the flotation of a subsiaiary cordpany, the Cit $y$ and suburban Co.p which they whought was a clear case of company mongering, wero not Impressed by Haminon's offer and decialed to cut their losises by voting tho company into Iiquialation.

The Great Western Co. Was wore wodest in Its aims but no moro successful. It had small establishweris at 3ristol and Caniff comprising 62 aro 2ights and 398 incandosccnt lightis in all and it also hiro out portablo and exhibition plant. Recoipts were veiv stall, $1832-3$ \$520, $2383-4 \& 1,433$ and the lossfor the latter Jear was \&I,067 despite a drastio reauction of expenalisure. In December 2884 tize company was purchasod by Anglo-Ararican Biush. The experionce of Brush Wialand was much tho same. They staried with exinibition lighting in various parts of thoir torritory - in Boston, Chester, Grivsby, Gainsborough and Reading, and had also scme contiacts to light various works whero they aimod at a proitt. After 30 bontils' operation their total losses amounted to $85,298$. And there was littio hope that business would, in the foresoeablo futuro, ingaro. Tisey did not go into Central Station work and tho general trado ciepreasion kept down demand for isolated iwstellations. An attompt was made to keep down expenses by pooling oficicials wich the Great Wostern 1. Nieoting of Wetropolitan Brush E.L ..\& P. Co. Elect. 23 February 1884. 2. Report of Brush hialand t.I.. \& P. Co. Elect. 18 Novembir 1832. Vol. 10. PP $22-3$. 
Co. but when Anglo-American Brush offered to purchazo the Company in Decomber $1884_{4}$ their offer wos gladiy nccopted.

The South Eastern Brush Co. accomplished a little more. One technical problem that the Brush compenies faced was that they wished to uso incandescent as well as arc lighting and did not possess a complete incandescent system. They had bougint the Lane-Fox patents which covered only the lanp, and the parent Brush Co. at the time had not a dymamo out tablo for incandescent lighting. Tho Motropolitan Brush Co. tried, as they put 1t, "to adopt the Brush aynamo to low tension", but ald not have the technical ability to succeed. The South Eastern Brush Co. tried to overcome this by developing a system of their oim, in which accumulators were charged in sories at a high voltage and discharged in parallel at a low roltage. This was an interesicing system teahnically but was very expensivo to perfect. Accuraulators, a new invention, bad to be developed and to do this S.E. Brush, joined by Provincial Brush, had to subsidiso a company - the Consolidated Electric Co. - they had set up. This exhausted their cash reserves and when they finally opened a station at Colchester it ran for the first jear at a loss, revenue covering only $32 \%$ of expenses. The Company was short of cash and was urable to ralse any more. The shareholders wiched to liquidate the company and in the

1. Elect. Vol. 12 PP 21 - 2. 1 December 1884.

2. Report of Wetropolttan Brush. Elect. Vol. 12 P 43.22 December 1884 .

3. See R.H. Parsons. Op.cit.e FP $52-55$.

4. Weeting of S.E. Brush. Elect. Vol. $u_{4}$, P $300 . u_{4}$ Pebruary 1885. 
infalle of 1885 the Station was closcd down and the company wound up. The Station had cost 27,338 to build, preliminary expenditure, on estimating demand and obtaining Provisional orders, had been $\$ 3,981$, and $\$ 7,000$ had been advanced to the Consolidated Co. This excludes the purchase moner for the Brush concession. The Installation was sold for 1345 . The Frovincial Brush Co. had also been interested in tho installation. They had coniributea $\$ 3,000$ to the Consolidated Co. and intended to use tho accumulator system should it prove successful. They had also started with small installations on which they had lost $\$ 6,824$ in 15 months to November $1883^{3}$ Then they suspended many of their operations to wait for the success of S.I. Brush. When the Colchester Station failed, Provinolal Brush also went into liquidation.

The most important Brush subsialary was however the Harmond Co. When It was liquidated in 1885 it did leave some legacy behind it. The Company had firet concentrated on selling and fitting "isolated" Brush sets for factories - Robert liamond clained to have chosen the Brush 11 ght because it was the most suitable for factories. In 2882 it made installations of arc lights in the strects of several towns. The operations of 1882 wero successful ana profits for Feb. - Dec. 2882 wore \$8,086 after $12 \%$ depreciation of plant and $\$ 5,000$ had been witten off the good wili account. In addition $\$ 52,162$ in shares of subsidiary companies

1. Accounts to June 1884, of S.E. Brush. Elcot. Vol. It P 300. U4 Pobruary

2. R.H. Parsons. op.cit. P 55. 2885.

3. Provincial Brusin meoting. Nlect. Vol. 12 PP 70 - 71. 1 December 1883.

4. See mectings of Provincial Brusi Co. Elect. Vol. 12 FP 398 - 9. 3 Ulay 1834, Vol. 14 PP 137 - 8. 27 Docember 1834 . 


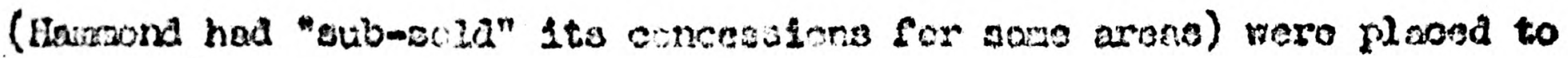
1

reservo. The flarsionl Co. solved the problew cougen by the lecis of a

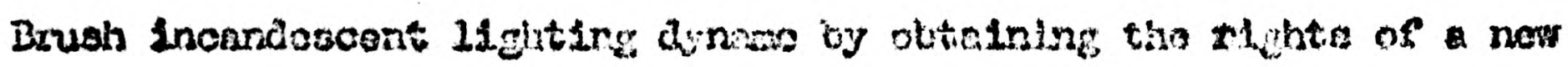

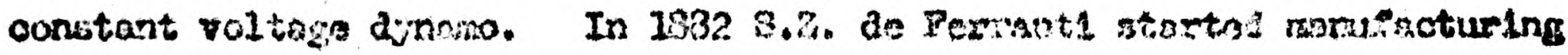

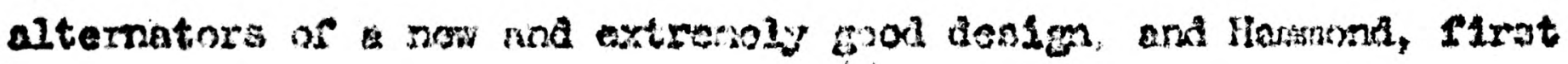

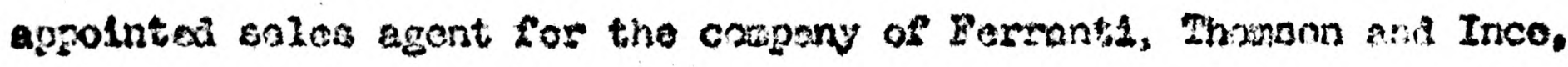

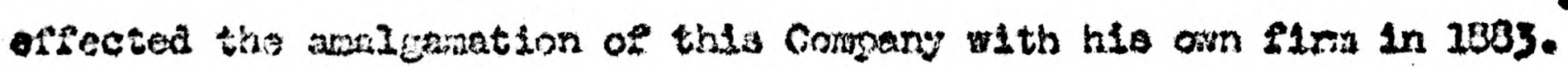

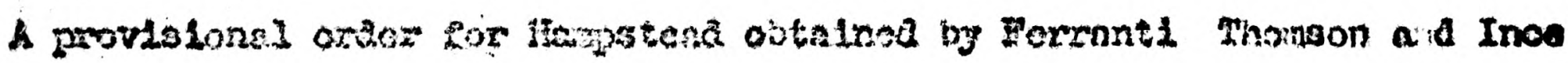

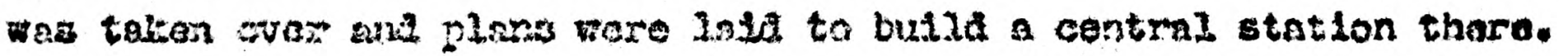

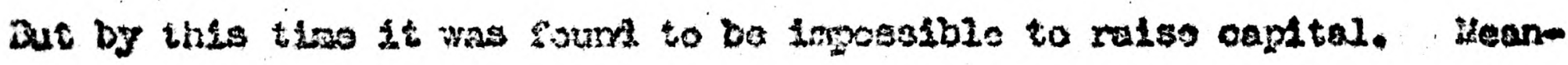

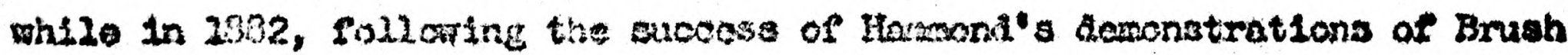
aro 21chting at Erlghton, Ifatingo and Enstbourne, subaldiary ccoparlos had ben ato up in the latior tro places. In the boun they found 1t ossy

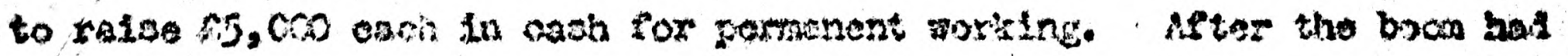

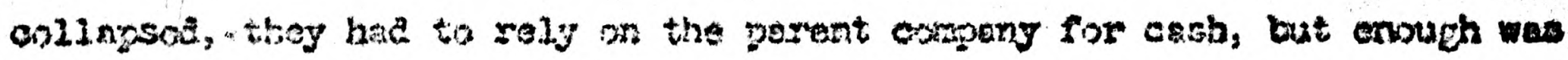

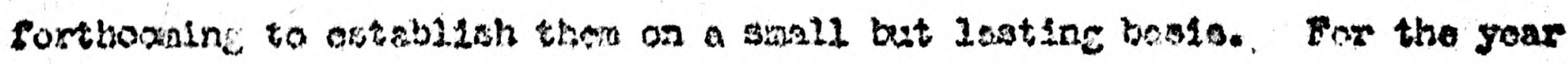

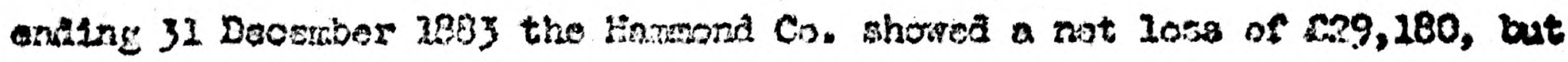

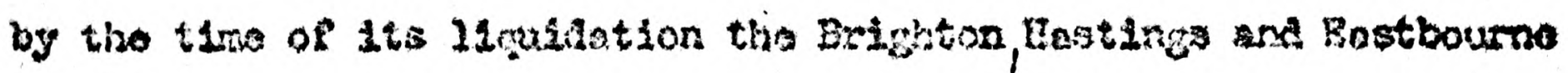

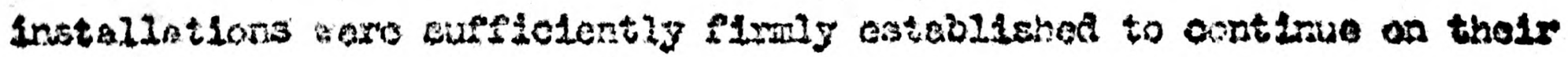
orn.

The exponierce of other comperise wos simtlar to that of the Brush concesizionaxtes. Tho Plisen-Joel Co. which hod omiled for

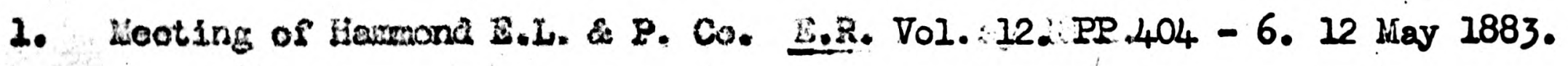
2. Meeting of Laviond Co. 12 Axriz 1804, Elect. Vol. 12 PP 22 - 4. 


\section{Table 7.}

Hastings, Brighton end Restbourne, Number of Ligrhts supplied.

\begin{tabular}{|c|c|c|c|c|c|}
\hline & \multicolumn{2}{|c|}{ Hastings } & \multicolumn{2}{|c|}{ Brighton } & \\
\hline & arco & incandescent & are & noandescent & \\
\hline 1882 & & & 16 & & $\begin{array}{l}\text { No figures are } \\
\text { ovetlablo for }\end{array}$ \\
\hline 1883 & & & 40 & 8 & $\begin{array}{l}\text { the Eastbourne } \\
\text { Co. unt i] } 1888\end{array}$ \\
\hline 2884 & 27 & 96 & $?$ & $?$ & $\begin{array}{l}\text { when it had } \\
1,700 \text { lamps }\end{array}$ \\
\hline 1885 & 29 & 4.56 & 34 & 516 & \\
\hline .1886 & 27 & 576 & 27 & 875 & \\
\hline
\end{tabular}

Sources: Reports of Brighton, Hastings and Eastbourne Eloctric Sup ly Cos, and R.H. Parsons. op.cit.

3 provisional orders in 1882 , combined, like many of the companies, supply and manfacturing. But it became by the lato eighties chiefly concernod with supply, 2ighting small groups of buildings. The installations were scarcely profitable. Up to $1885-6$ losses were heavy. In the two following years small profits were made and at the end of 1888 - 9 it was Just breaking even over its installations. An adverse report by a comittee of shareholders sent the company into Iiquidation in December 1889. Another company doing some supply work, the liaxim-Heston Co. did very little business and went into liquidation in 1888.

The Edison and Stan Companies applied for 5 provisional orders botween them in 1882, and started a number of small installations where

1. Pizsen-Joel meetings. various years.

2. Maxim-iveston meetings. various years. 


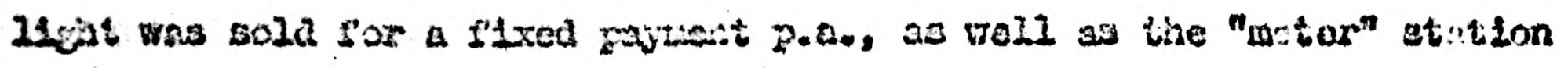

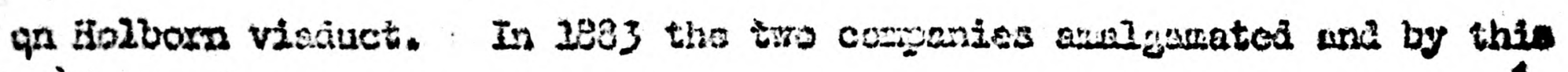

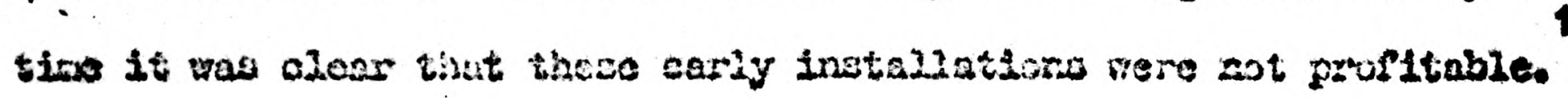

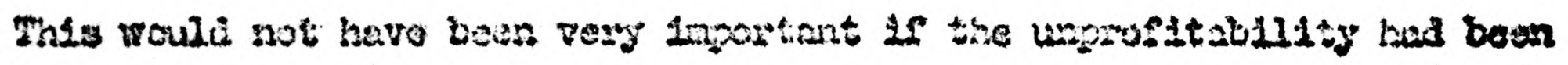

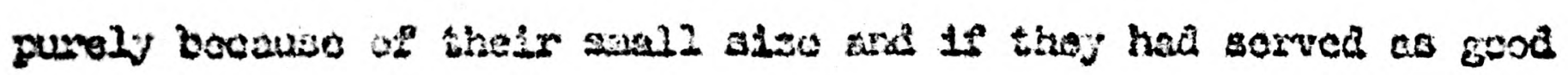

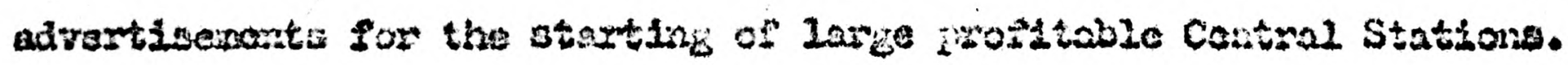
But by then it wa cloar that tho expectad latge doman wat not golng to

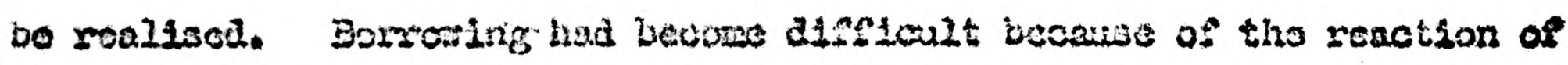

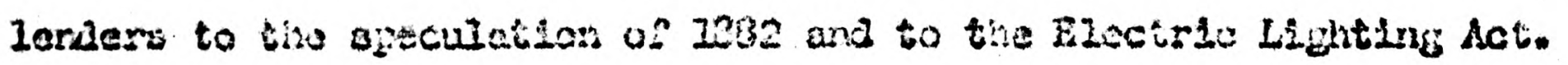

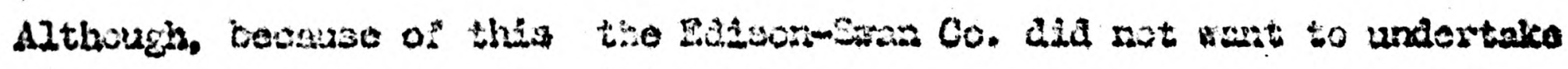

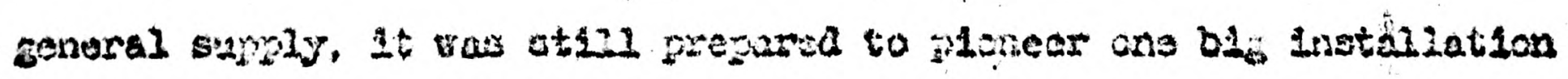

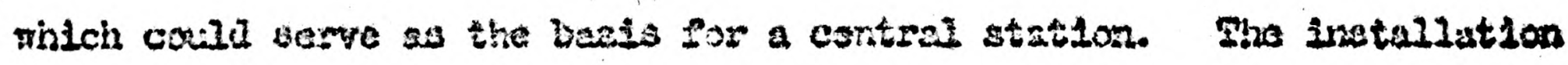
In queation was of Vietorita Station.

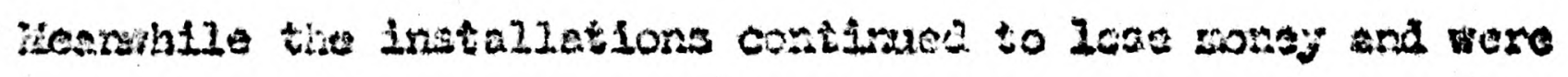

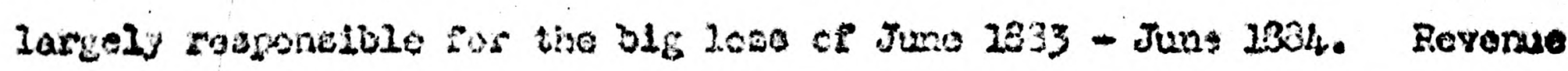

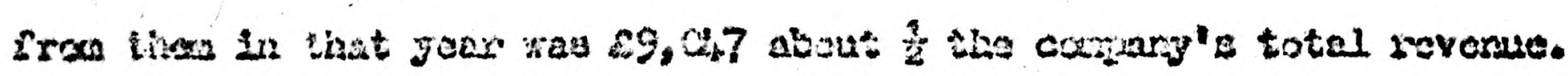

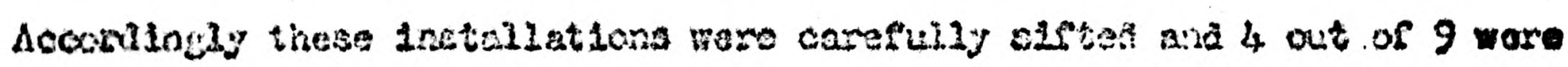

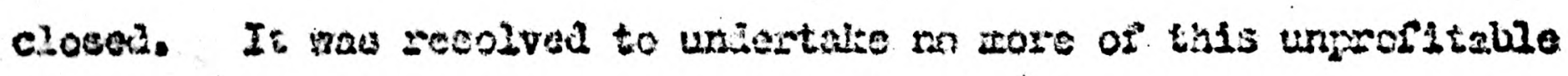

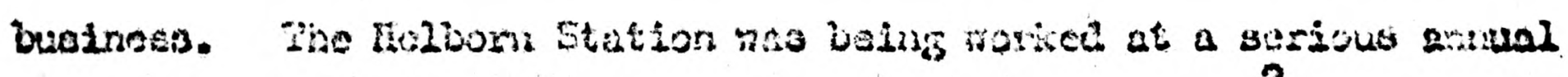
losa but noverthelege nav kopt hon for the tine belng. Dut tho polioy

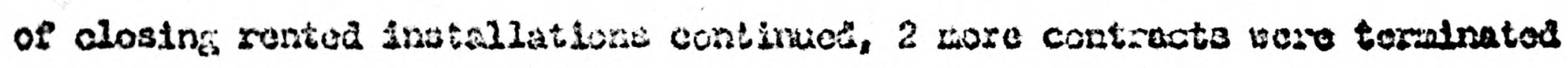

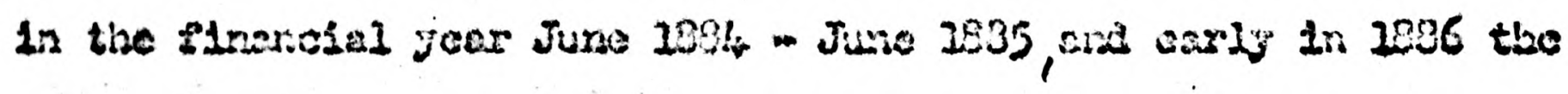

1. Uectin of Siran United Co. E.R. Vol. 13. PP 470 - 2. 13 December 1883. 2. Koting of taisonmitran. E.R. Vor. 15. PP 396-8. 15 November 1884. 
Holborn Station was closed. Notice was given that supply from tho remaining installations was to be terminated in September 1886. Thus only the Victoria Station instaliation resained. The lighting of Victoria Station had been completed by tho ond of 1884 at a cost of $\$ 16,000-\$ 17,000,{ }^{2}$ but the original intention to extiend it into a central station was abandoned and the installation was not profitable. This was the only result of a large expenditure on lighting installations which by Noveriber 1884 stood at $\$ 77,251$.

\section{1}

Thus the attempt to begin large scale electricity supply for 11ghting failed. Sorne electric lighting remained and fran 1883 anvards the amount of plant sola for electrio ligiting rose fairly steadily. Until the late eighties it was all for isolated installations. Arc Ifuhting vas used in factories, docks, railway stations, etcs incandescent lighting in large private houses, clubs and ships. Ships were important, for the advantiago of electricity ovor oil was considerable,

1. Edison-Svan. accounts. E.R. Vol. 17, P 210. I August 1885.

2. Ldison-Swan meeting. E.R. Vol. 15, PP 395 - 8, 15 November 1884, and Siclect Comritiec of the House of Iords 1336. Evidence of J.S. Forbes and Crompton. B.P.P. 1886 Vol. 7.

3. Reetine of Idison-Swan November 1884. Elect. Vol. I4 P 19. 15 November 1834. This was a substantial sin easily onough to establish a central station. By the end of 1895 out of the 37 central stations outside London witich had boen running fur at least two ycars, 31 had spent less than $\$ 77,000$ on capital account. 
and gas was impracticable. In 2383 for exaraple the adison-Stran Campang supplied equipaent for 32 ships and 23 land installations.

The principal reason for the Sailure of electric lighting to be used mach in the eighties was its cost relative to that of gas lighting. The pioneers had thought that electric lighting woild onis sind a market if it could be supplied at the gas price. Iot it was inpossible to do this prositably.

As was seen earlier in this chapter, are lighting costi cannot be compared with the costs of gas lighting without considering the lighting purpose. In factories are lichting was sometines cheaper. This was partly because of the need for cood illunination and partly because arc lighting costs were often particuloriy low in factorius. Some had spare engins power and cynumos could be connectcd to extating exgines and run for very little extra cust. Ordinary employees of the factory could periodically change the carbons with the loss of very littlo tirie. Ihis sunetines meant that direct costs could bo reduood to carbon costs alone. Hight shift working kept capital costs low. On the otherhand while it is difficult with very scanty evidence to core to a balanced judgment on the watier it is likely that for the vast wajority of pactories arc lighiting was jore extendive than gas lighting at icosi up to 1900. But where litile iight was reguired, as In the streeti, the aro lanp was nearly always inore oxpensive than eas Lightine. Naturaily it gave wore lleht sut this was often not wanted at the astira cost. Finere inrroved strect Iijhtine was required 
It could be more cheaply done with better gas burners. One can quote Beveral examples of the high cost of arc lighting compared with gas.

In 188160 Brockio Iamps replaced 245 gas jots in Liverpool. But the runnine costs alone, without allowance for interest or dopreciation, were $\$ 2,600$ per arnum while the old gas lighting cost only E1,288. Abordeen exporimented with a Brush 26 arc system in 2883. The Iights costs f222. 9s. 3a. p.a. for running expenses alono. Gas had previously beon used at on annual cost of \&65. 10s. 3 Table 8 shows how much more expensive than gas was the experimental are I1ghting In the City of Londion in 1881. As both Siemens and Brush were working below costs the Table undorstates the difference.

Those costs refor to the early eighties. Costs foll rapidy afterwaras. But it was not until the late ninoties that aro lighting was much used in the streets. Even at the end of 1890 there were only 700 aro lomps in the streots of English toms. 4 Then olectrioity for stroet lamps cost about $2 d$ per IFh. while in the early eighties it cost about 9-10a. Carbon costs also fell dramatically over this period.

1. Beiter lighting was being installed at tho tine. The Slemons regeneration burners on Holborn Viacuct cost $3-8$ timos the amount of the old gas ifghting. The very bad lighting in Waterloo Place London was replaced by improved gas lighting costing 21.3 times as ruch. Eut this desand was linsited.

2. Elect. Vol. 7, P 35. 4 June 1381.

3. Eleot. Vol. 10. P 579. 5 May 1833.

4. Elect. Vol. 26. 2 275. 2 Jonuary 1891 
Table 8.

Cost of cas and arc lighting in the City of Jondon 2881.

\begin{tabular}{|c|c|c|c|c|c|c|c|}
\hline \multirow{2}{*}{\multicolumn{2}{|c|}{$\begin{array}{l}\text { Dis- System } \\
\text { trict }\end{array}$}} & $\begin{array}{l}\text { Cost of } \\
\text { working } \\
\text { for } 12 \\
\text { months }\end{array}$ & $\begin{array}{l}\text { Cost of } \\
\text { fixing \& } \\
\text { removing }\end{array}$ & $\begin{array}{l}\text { Iotal } \\
\text { cost }\end{array}$ & $\begin{array}{l}\text { Cost of } \\
\text { gas l1ght- } \\
\text { ing hither } \\
\text { to used }\end{array}$ & $\begin{array}{l}\text { No. of } \\
\text { arc lamps } \\
\text { proposed }\end{array}$ & $\begin{array}{l}\text { No. of gas } \\
\text { lamps to } \\
\text { bo } \\
\text { roplaced. }\end{array}$ \\
\hline & & $\mathcal{E}$ & $\mathcal{E}$ & $\mathcal{L}$ & $\varepsilon$ & & \\
\hline \multirow[t]{4}{*}{2.} & Brush & 660 & 750 & $1,4,10$ & & 32 & 250 \\
\hline & Crampton & 2,007 & 500 & 2,507 & 690 & 17 & 152 \\
\hline & Sienens & 2,050 & 1,650 & 3.700 & & 29 & 344 \\
\hline & Jablochlooff & 1,500 & 1,550 & 3,050 & & 48 & Ut \\
\hline \multirow[t]{3}{*}{2.} & Crompton & 2,167 & 560 & 2,727 & & 26 & 276 \\
\hline & Jablochlooff & 1,530 & 2,350 & 2,930 & 700 & $?$ & 161 \\
\hline & Siemens & 1,850 & 980 & 2,830 & & 32 & 164 \\
\hline \multirow[t]{2}{*}{3.} & Crompton & 2,475 & 650 & 3,125 & 612 & 18 & 232 \\
\hline & Slanens & 2,270 & $1,4.55$ & 3.725 & & 32 & 238 \\
\hline
\end{tabular}

Sounces: Engineering Nov. 19, 1880 and Electrician 27 Way 1882.

In 2880 carbons cost about 9d. per f'oot. By 1894 they cost slightly over 1a. Thus very substantial cost reductions were necessary before it became economical to use arc lighting in the streets.

1. In 1893 Professor L.B. Mariks invented the enclnsed aro lamp. This reducea carbon consumption to betrieon a filth and a quarter of that of the open arc. Eut the efficiency of the lamp was less that that of the open aro lamp and it used 60, nore current. At English price ratios it would anly have been worth aropting the enclosed aro if the cost of changing carbons was very substantialiy reduced. 
Because incandescent lomps were of the same power as gas burners the costs of gas and electric incandescent lighting can be simply compared. This can be done from Tablo 9 onee the costs of gas and electricity aro known.

\section{Table 9.}

Costs per hour of 16 c.pe gas and electric lamps. pence.

1. Gas.

\begin{tabular}{|c|c|c|c|c|c|c|}
\hline $\begin{array}{r}\text { Gas prices per } \begin{array}{r}1000 \\
\text { shil] }\end{array} \\
\end{array}$ & l.ft. & $2 / 6$ & $3 /=$ & $3 / 6$ & $4 / 0$ & $4 / 6$ \\
\hline \multirow{2}{*}{$\begin{array}{l}\text { Consumption of gas, } \\
\text { in cu. ft. per hour }\end{array}$} & 5 & 0.15 & 0.13 & 0.21 & 0.24 & 0.27 \\
\hline & 6 & 0.18 & 0.22 & 0.25 & 0.28 & 0.32 \\
\hline
\end{tabular}

2. Incandescent elechrio.

Niectricity prices

$\begin{array}{lllllllll}\text { per KTh pence. } & 4 & 5 & 6 & 7 & 8 & 9 & 10\end{array}$

$\begin{array}{lllllllll} & \text { Efflotency of } 4.5 & 0.29 & 0.36 & 0.43 & 0.50 & 0.58 & 0.65 & 0.72\end{array}$

lamps in

$\begin{array}{lllllllll}\text { watts per } & 4.0 & 0.26 & 0.32 & 0.38 & 0.45 & 0.51 & 0.58 & 0.64\end{array}$

C.po

$\begin{array}{llllllll}3.5 & 0.22 & 0.28 & 0.34 & 0.39 & 0.45 & 0.50 & 0.56 \\ 3.0 & 0.29 & 0.24 & 0.29 & 0.34 & 0.38 & 0.43 & 0.48 \\ 2.5 & 0.26 & 0.20 & 0.24 & 0.28 & 0.32 & 0.36 & 0.40\end{array}$

There are no overall statistics of gas prices before 1887. Bit in 1881 gas cost about 3/- per cu. it. In Iondon, about 2/6 in the big northern torns (Manchester, Ieeds, Liverpool, Blrmingham and Shorfleld) and about $3 / 6$ to $4 /$ in the country as a wholo. 16 cande power gas lamps used $5-6$ cu. ft. por hour. 
Table 10.

Gas prices. All undertakings.

Average Revenue.

Shillings por $1000 \mathrm{cos}$. ft.

1897

3.58

1890

3.66

2895

3.4 .9

2900 .

3.81

1905

3.38

1910

3.42

Source: Annual returns of the Gas Undertakings. B.P.P.

Electric Incandescent lamps used about 4.5 vatts por 0.p. in 1880 - 2. Efficiencics then rose to about $3.5 \mathrm{w}$. er c.p. by the end of the elghtles. Although some manufacturers sold lanps of officienoles up to 2.5 w. per c.p. the princlpal ones aid not and efficiencies dia not further inprove until the introduction of metal filoment lamps in the years 1908 - 10. However by then the incandescent gas mantlo was widely used and thus there is no point in comparing metal-filament lamps with simple gas burmers.

In 2882 electricity cost at least 9- 10d. per ikh. Evidericens rather soanty. In 188\% the Brichton Company charged $1 /-$ per Nih. S.R. Brush charged 6a. but only covered $30 ;$ of expenses. In 1838 the Cadogan Eloctric Supply company and the Chelsea Company charged 7a. and 8d. 
per $\mathrm{kWh}$ respectively. In the early ninoties more is lonom as there wero more electricity supply companies. In January 1893 the unweighted avorage price charged by 35 unlortakings was 7.20 and in January 28946.98 for 54 undertakings.

However in the early eighties electricity generated in isolated installations was often cheapor than central station supply. This was because there were few oconomies of scale in genoration to set off against the cost of primary mains. The distribution network could easily account for half the initial costs of a contral station supply systern. In 1882 Brush dynamos operating at the usual lighting load factor wore generating electricity at $8-8.5 \mathrm{a}$ per $\mathrm{krmh}$. Same engineers olaimed in somo installations to bo ablo to supply electricity for loss than this. 0. Coope, ormer of Beerchurch Hall, where Crompton installed eloctrio lighting in 1883 estimated that clectricity cost as 1ittle as $3.5 \mathrm{a}$ per KWho This sounds very optimistic.

In most cases in 1882, electric incendescent lighting cost three times as much as gas. By the ond of the elghties improvements in the efficiency of lamps and recuctions in the cost of current brought Incandescent Iighting down to about twice the gas price. By the late nineties the average revenue of a random sample of twenty contral stations solling olectricity solely for lighting was $4.7 \mathrm{~d}$ per Krin. At that prios thore was very little difference botmeen tho cost of gas and electrdo 11ghting.

2. In 1898. 


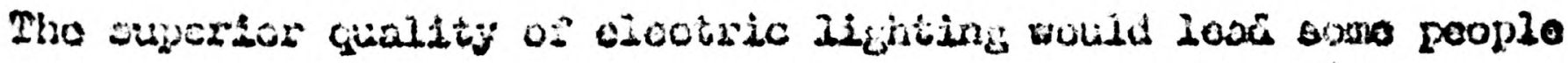

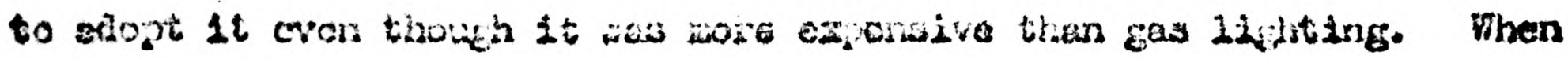

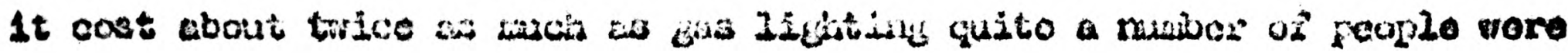

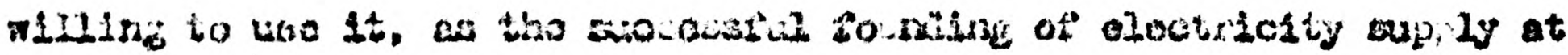
the and of the effitica, and the zate nhinoties shows. But at three thas

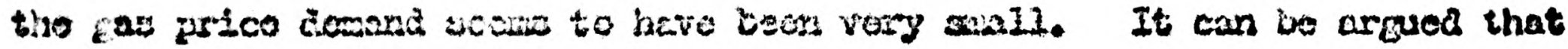

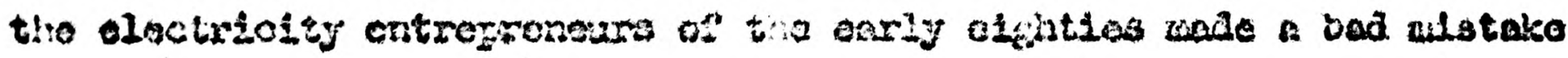

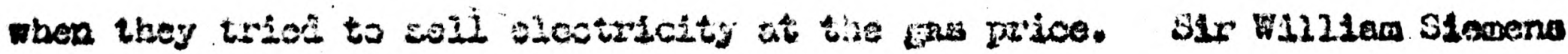

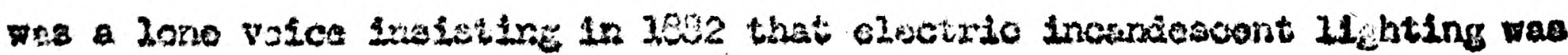

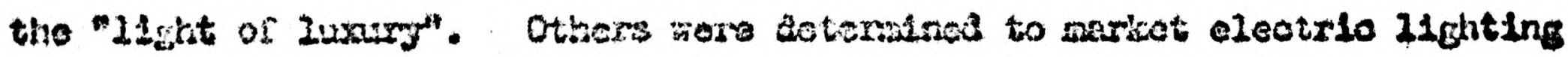
on the erowita that it was as cheap, of cheagor than gas. The long controversy in the tochnics press on the colativo chospress of dov or

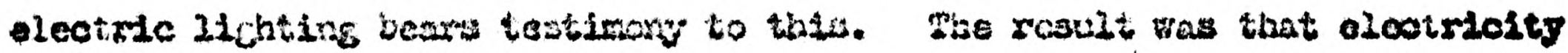

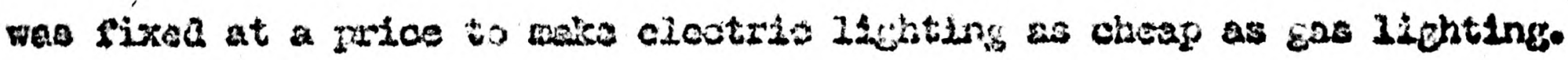

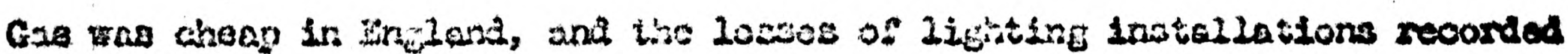

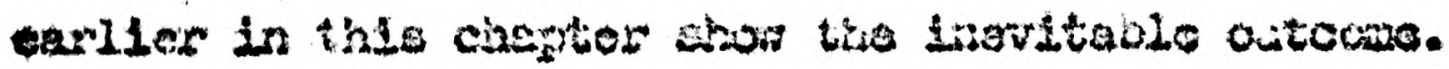

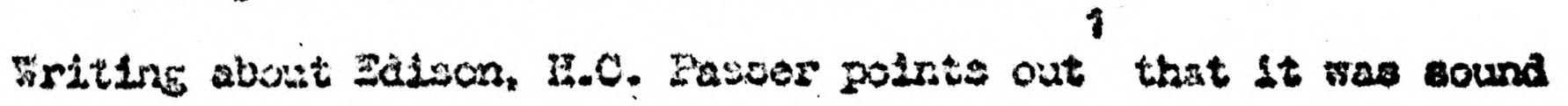

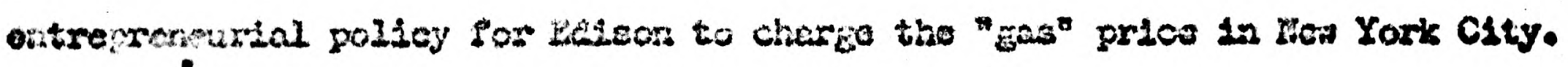

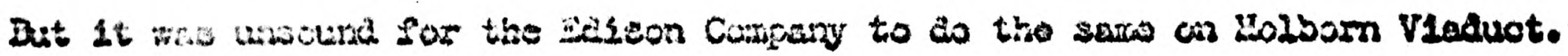

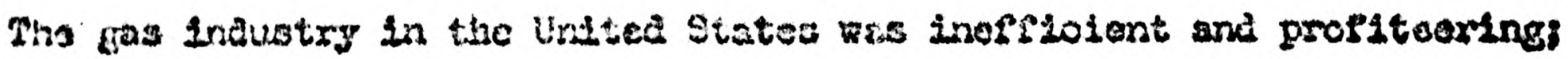

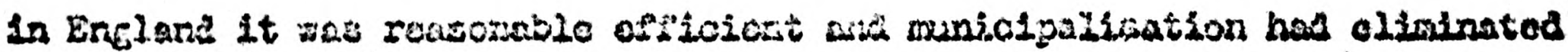
monopolis prorts.

1. H.C. Passer. co.cit. Chapters 7 and 8.

2. Thlo queotion 1 discuosed in detail in tho appesidx to this chapter. 
If intondinc sup $21 \mathrm{ca}$ in $\mathrm{Bn}$ isnd had odontod a diferent pricing pollcy tiog wi hi hnve had a modeot auocoss. Iut it would havo bean modest, cortainiy not onicugh to justify tire expoctaitona of 1842.

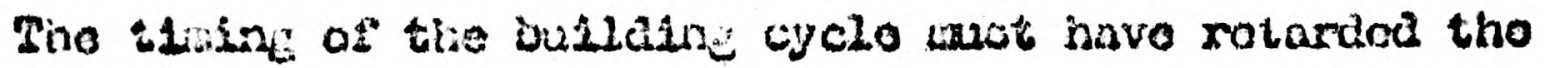

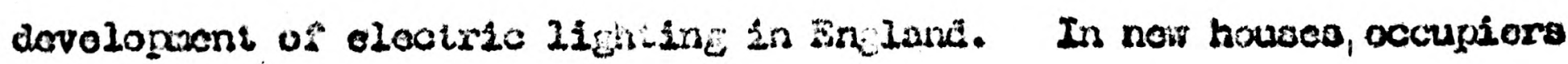

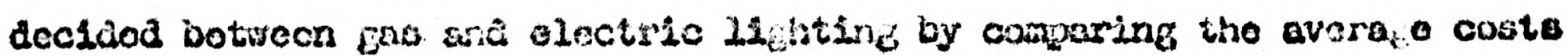
of both and wolghing tho alporenco acainst alfesonos in util1ty. But In axlating houses already crosised for gas tho conaunor had alvo to tako

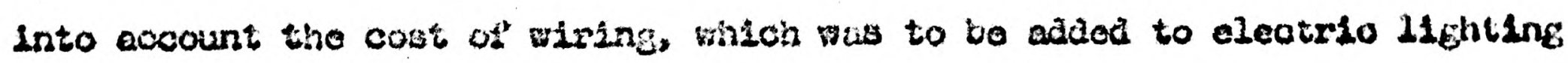
costs. Also even if rationolly juatified, wirling for olectricity would tond to bo delayed beceuse it could be a laree initial experso. Dullaing boced in beitatn during the 1370 ard a vory larye nutwer o' now houses were built. Consequentis throughout the oighties and oxtonding into tho,

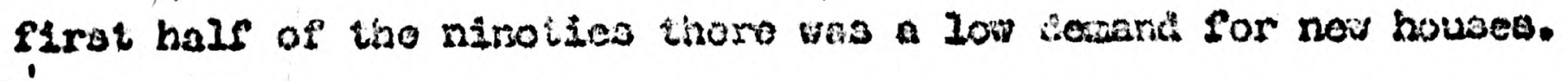
Where olectric lighilos migt havo been acoptod by fluws and not

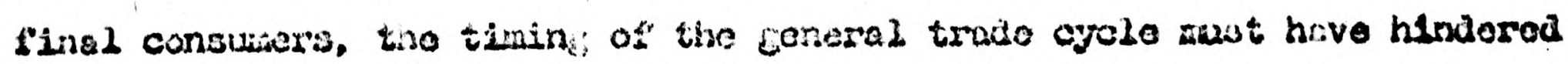
its adoption in the elghtios. Axtce o strong boas in the seventies, tho

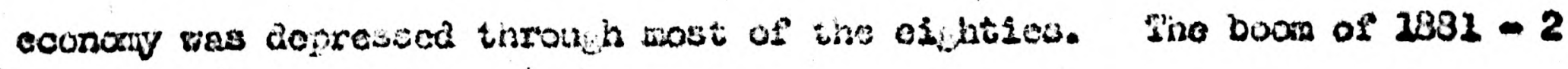

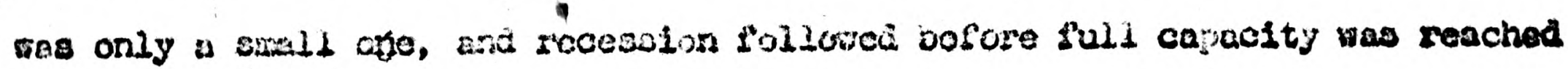
In all industries. Ono rotarding factor I have avoidod discuostng so far,

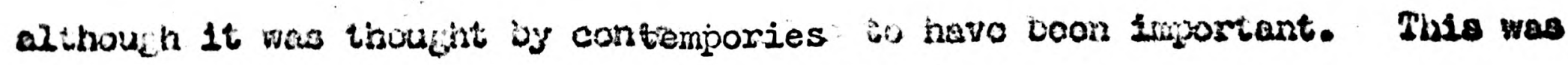
the offect of the comprilsory purchase cianso on the 3332 Act on the oupply or capital.

In 1834 ine Sialist doclored what "tio oloctr'ical Infent was

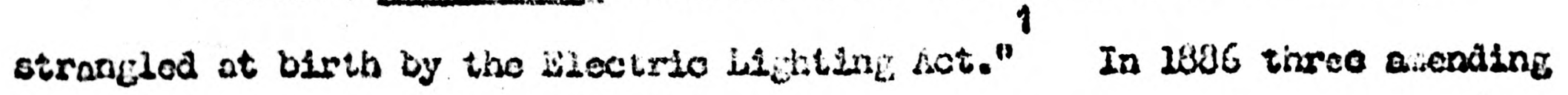

1. Cuoted by H.II. Dailin. Ins or onisation of Electricity Sugnly in Great Britain. London 1945. P 11. 
Bills wore pxesented to Parlioment, and the House of Lords appointed a comitteo to hear evidence for and against them and it also reviemed the effect of the Act of 1882. Bafore this comnittee the representatives of the electrical industry, Crompton and J.S. Borbes, the Chairman of Edison-Swan, argued that thoy were ready for central station oupply in 1882, but having started on it were unable to complete their plans because the Electric Iight Act made innance impassible to obtain. In this they were supported by evidence frorn jouls Cohen at one time a stockbroker who said that the Act was "almost prohibitory to the finding of capdtal" and J.JK. MacDonald, a partner in the firm of Messrs. Matheson and Co., of Iombard Strect, who said, more moderately, that the purchase clauses "deterred investors". There is no doubt that this was 80 \% even Sir G. Lorrison, the Town Clerk of Ieeds admitted that "after the very strong evidence which has been given by somo gantleman that It is so, I do not like to say that the Act may not have had some remoto connection with it" (the failure of the supply companies), but he went on to question the importance of this explanation. Certainly the emphasis placed on the deterrent effect of legislation by J.S. Forbes before the comnittee is not the sare as the emphasis placed on the unprofitbility of electric lighting in his speeches to the shareholders of Edison-Swan. The ropresentatives of the municipalities, who appeared before the carmsttee

1. Select Committee of the House of Iords on the Electrio Ilghting Bills of 1836. Q 7 .

2. Ihia, QQs $1888-9$.

3. ibian 1652 . 
to oppose the repeal of the purchase clauso - although tiney agreed tho years of operation allowed to the companies might be increased - placed great emphasis on the high cost of electric lighting, "Hy orm view and the view of many of those connected with corporations with whom I have oonversed is that the real cause of the failure of the electrio lighting companies has been the impossibility at present from a cormercial point of viow, for them to compete successfully with gas as an 11luminant" contimued the Town Clerk of Ioeds. The municipalities of Liverpool, Birmingham, Blackburm and Loeds supported their contentions with accounts of their own experience of the costs of electric lighting in 2882.

Host of the evidence supports the contentions of the municipalities. Quite enough capital mas raised in 1832 to have supplied the small demand for electric lighting if it had been properly used. After the initial mistakes it is arguable that if wore capital could have been raised it would have been possible for intending suppliers to carry on-at higher priceso until they established tiemselves. However, after all the protestations of electric lighting adrocates as to its cheapness it is not olear that higher pricos would have led to higher profits. Raising prices, would probably have driven away customers, even those who would have used electric Iight if they had been charged tho cost price in the beginning. Hlgher pricos wore not generally tried; the Edison station at Holborm for example was closed before there was any resort to higher charges.

\section{Ibidi.., Q 1652 .}




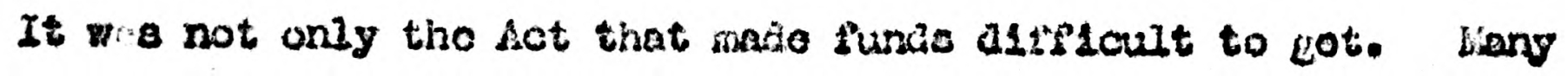
ordinary ohares wore speculative in the oightiess they could only bo aold In tivos of bocw. Eleotrio 11 chting clusos were wore spoculative than most. The collayse of the boos wes guito sufflckent to make the further sale of ebares extremely aifincult.

Tho industry gound in leg1slation a convoniont scaregont. for its allegedly poor porforranco. It is a scapegont vihioh appoared acain and agaln. Dat periags tho best way to sum up the experience of the olghtios is to quote the conouderod oplntor of Alexander Sicrens in hio Dresidontial adoress to the r.Institution of Electrical Engtroens in 2894.

"lowover rasch othax causes any have ontributed to delay the

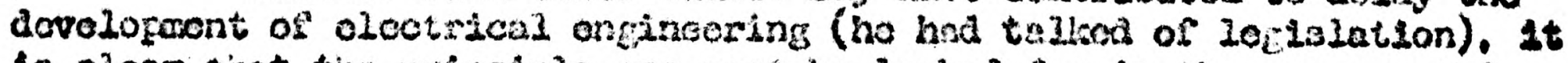
is clear that the prineipio one zatit be looliod for in the exaceorrted oxpectations that were rnised, oliber by 1 frovence or dost $n$, when the general publio first ceriousiy thought of regrarding alootrielty as a comodity for everyciay use .... 2hero wns a short titno of oxcltanent to the public and os prosit to the prowoters; thon the conplatonos of the public in electricity fas alnost destroyod and could only be regalnod by years of pationt work" 2

1. J.B. Joftrojs. Irends in Dusiness omantation since 7356. Unpublished Loncon Hh.D. thosts 1938.

2. Elect. 19 Jnmary 3334. Vol. 32, P 300. 


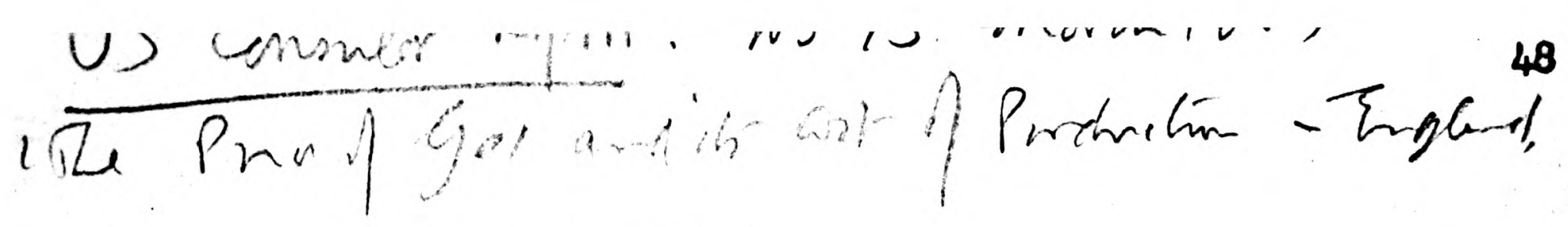

Appendix.

The rolative costs of gas and electric lighting

in the United States and Britain.

In the United States the experiments with electric lighting were anccessful, and for the rest of the decade the adoption of - lootrlo lighting procecded rapidly. The question arises os to whother this was due to the bigh cost of electric lighting in this country. Tho data in this appendix tends to show that the difference in the two countries was due rather to the high cost of gas in the United States and reinforcing this, the high rate of urban expansion.

Relative prices of gas ard electricity have been calculated, and so have the prices of some of their factor imputs. From prices per physical unit in $\&$ and $\not f$ an exchange rate in $\not \delta$ per $\&$ has been computed for each comodity. To see what was relatively expensive and relatively cheap in both couniries these exchange rates averaged over several years (usually 5), have been expressed as a percentage of the gold standard exchange rate $-\$ 4.85=81$. High figures suggest high relative U.S. prices.

\section{Gas prices.}

$$
\text { Big towns All towns. }
$$

1878 316

2881 318

$2888-9$

224

$2889-90$

159

Big towns: Britain. 1378 London only. Othervice London, Biminghom, Liverpool, lianchester, Sheffield, Leeds. United States. New York, Philadelphia, Baltimore, Cleveland, Cincannati, Richmond. 
The 2881 U.S. Sigure has been estimated by interpolating between 2878 and 1888 prices. A constant rate of fall has been aisured.

Sources: U.S. H.C. Passer, op.cit. PP 197 and 2 C2.

Britain. B.P.P. Return of lietropolitan and other gas compenlos.

\section{Electricity prices}

Iondon and Hew Ioris average revemue por unit.

$$
2895-8 \quad 215 \text {. }
$$

For New York the figures are those of the Edison

For Iondon an avetage of 6 undertakings.

There are no satisfactory earlier figures.

Belor are given the principal inputs of gas and electricity undertakings.

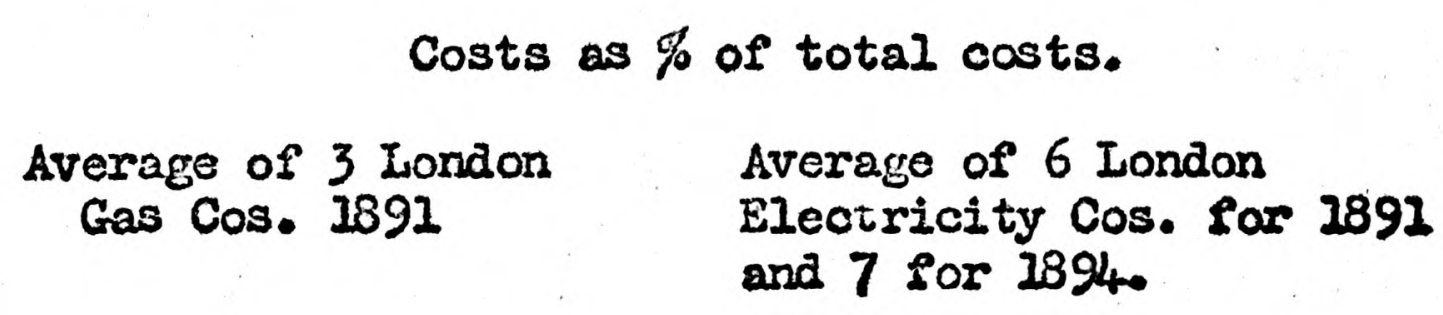

\section{Coal}

Iabour

Capital
47

13

20

Capital costs were calculated at $15 \%$ on the capital stock used for output. The calculation of the latter wes difficult as gas companies figres included expenditure on superseded works and electricity companies wore rorking bolow full capacity. 
The result is crudo but unlikoly to be far enough out to affect the conclusions. It ma, be argued that capital costs for gas should be less than $15 \%$ as the rate of depreciation was lower than for electriclty. But a lower rate would strengthen my argument.

Below are the relative costs of some of the imputs of gas and electricity.

Coal (export value) Pig Iron Coppor

$\begin{array}{ll}\text { U.S. average of No. I Foundry } & \text { U.S. smelter fob } \\ \text { Gray forge (after j83I) } & \text { works } \\ \text { Gray lake forge, Bossemer } & \text { average value } \\ \text { (arter 1885) } & \text { U.R. avorage value } \\ \text { U.K. average of Cleveland, } & \text { of exports and } \\ \text { Cumberland, North and South } & \text { imports of } \\ \text { Staffs, and Scots pig. } & \text { unirrought copper. }\end{array}$

$\begin{array}{llll}1880-4 & 156 & 171 & 122 \\ 1884-9 & 134 & 146 & 129 \\ 1890-4 & 110 & 117 & 108 \\ 1894-9 & 95 & 103 & 106\end{array}$

By-products of gas morits.

Colse

U.S. average value fob oven

U.S. average values of exports of coke and cinders
122

119

108

206

$\begin{array}{lll}1880-4 & 56 & \\ 1885-9 & 53 & 42 \\ 1890-4 & 43 & 31 \\ 2895-9 & 48 & \end{array}$


Notes

Prices vary quite considerably in dif'fercnt locations. For exam le in the U.K. In $1890 \mathrm{coal}$ at the pit head had on average value of 8.25 shillings per ton, while the declared value oi exports was 12.39 shilings per ton and the London price (at the Royal Grecririch hospital) was 18.42 shillines per ton. This is oring to quality as well as location. Care has been taken to make the prico time series uscd in compiling the above table as comparable as possible, but the results are approxinately racher than exactly correct. Ono source of error should be noted; for copper, coke and tar English export values are used and cornared with internal U.S. figures. In general this will overestimate the internal English value and make the rigures in the table a little too low.

Sources: D.S. Historical Statistics

Statistical abstract 1903.

Bulletin of the department of Labour No. 39.

U.K. Board of Trade Report on Retail and Wholesale prices 1902 Parliamentary Papers, Annual Abstract of irade.

Costs of coal and capital were significantly different percentages of costs of gas and electricity (at the lio level).

These are olearly the categories to investigate to see whother relative prices were different in the two countries. Unfortunately there is insufficient information about capital costs. All we can do is to note the interesting but inconclusive point that iron, which was used much more extensively in gas works than in electricity stations was relatively expensive in the United States in the 1330s. On the coal side the picture is mach clearer. Cool was relatively expensive in the United States in the $183 \mathrm{Cs}$. Also in the eighties and ninoties by-products of gas works were much more valuable in Britain. Cake and tar accounted for about $75 \%$ of the value of these by-products. The sales of residuals in Ingland were a high proportion of the value of coal used $-56 \%$ in 1878 and $72 \%$ in 1889. 
The difference of coal and by-product prices could substantially affect the price of gas in the two countries, as can be shown by the following arithmetic. Let us assume fixed physical inputs and an appropriate exchange rate so that tho samo monetary unit can be used in both countries. Let the cost of gas and residuals in England equal 100 units of money. Coal costs are then about 45 and other costs 55. If residual sales amount to $60 \%$ of coal costis, total costs net of residual are $45-(60 \%$ of 45$)+55=122$.

If in the United States coal costs 50\% more than in England, but the prido of al: other factors is the same, gas plus resicuals costs $(150 \%$ of 45$)+55=122$.

Rendered prices are half that in England so the not cost of gas is $67-(30 \%$ of 45$)+55=108$.

$$
\frac{109}{73}=248
$$

This calculation ignores mach but it does give same indication of the effect of full and by-product prices.

Thus while factor prices explain some of the difference between American and British gas prices a large gap is left. The main explanation for the remaining difference is the differenci between the wastoful monopolistic American gas industry and the controlled and partly munioipalised English industry.

The British gas industry was controlled by maximum prices, dividend limitation (the two wore often combined by a sliding scale which pormitted highor dividends if prices wero lowered) and devices to make the 
watering of capital difilcult. Such control, however, was not oufioient to provent all abuse of the monopoly position.

As a result tho municipalities had begun purchasing gas works in the 1870 s and running then more efficiontly. When this happened prices mere usually reduced, and the quality of managenent usually rose. "Gas and Water" a London tochical journal, sajs that in almost every instance where corporations took possession of the worics the price of gas was 10wered. The "Times" coimenting on this stated "In all the boroughs to which roference has been made, a spirit - an intelligent spirit - of progross is to be found actuating the corporations."

As carly as 1891 the ranicipalities had a $29 \%$ share of tho total sales of gas. Noreover it was the big towns which toak the lead. Gas was thus often municipalised and cheap where elcctricity was most likely to be used for lighting.

In the United States the complaints about the gas companies were often prefixed with a rhatorical question asking why gas should be very much more expensive than in England. The companies wero said to be technologically backward, wasterul and unconcermed with the value of by-products. James quotes the address of the President of the American Gas Association to the Association in 2833 in which he estimated that gas rould bo supplied in New York - by efficient worles - at $65 \not 5$ per 1,000 cubic feet. In 1878 gas

1. Seo J.A. Cusining, "A further plea to Conereos with prayer for such investigation into tho sitains of tho lieshington Gas Iirht Company as will leed to an ocuitavle adjustent of price, aulity and measurement of sas and a proper protection of consum.s. Vashington D.C. 1871 .

2. E.J. James, The Relation of the Nodern Iunicipality to the Gas Supply. New York. 1886. 
onst 82.25 p $:$ i,000 cublo Lect, and \$2.25 in 3833. This may bo optimictio but the city works at Whocling, West Vircinia charged only 90,5 por 1,000 cublo fect while aono companies charied as mach as 75.00 . The wasto of gas was hilh, bolng $25 ;$ in Mor Forle againct $9, ;$ in Fngland. Tho Northem Ifberties Conpany in Philadelphin aizored valuable amontacal zlocuor to

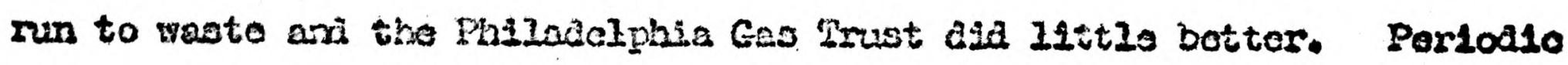
corrotition secen to havo had the long run rosilt of incroosing th" prow as posce wars wore sollowed by acrocuents, and the only lasting rosult of

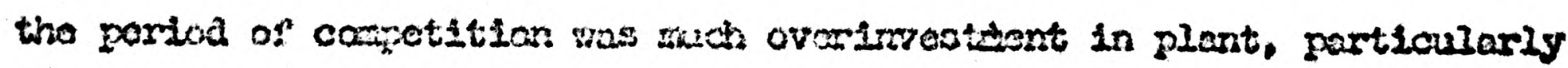

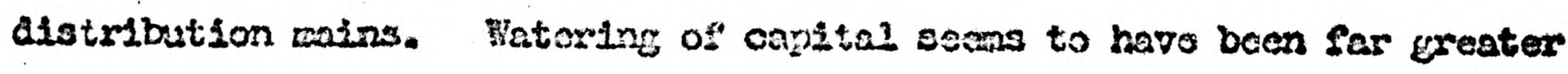
than in Ingland. Tho Now York companies captalszed at 326 milliang

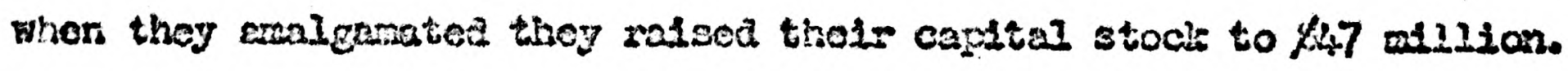
Capitalization varice frox betweon $\$ 5.25$ to $\$ 15.00$ per 1.000 oublo peot bola,

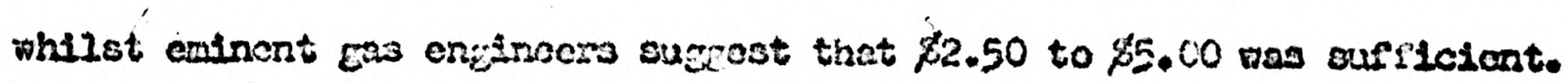
In Ioncon, capital bes $\$ 2.77$ per 2, c00 cubio eeet oold. Somo citios had otartod to win their on gas voxis and hed reduced pricos oubstantialzy but those were very auch amallow proportion than in Ingland.

The Dehaviciroi eas prices in the tro countrics in the 1890

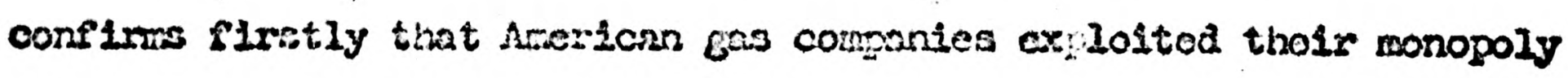
position by short run proflt meximisation, and sccondly that tho rolatively high costs of cloctrlc 31 ghing in Bngland resultad in a rolatively moh lower cross clastlotey of dowand between gas and elrotrio lighting.

Cas pricos foll nech woro in tiso Unitod States, auch moro than could to accourted for by the fector fall. of conl poicos. Iraditional

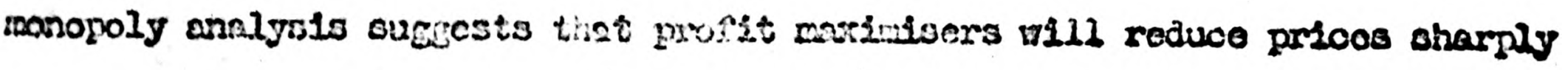
1. Those escamplos cono 8xon E.J. Jardos, DD.c5t. 
when domand becomes moro elastic. The introduction of eleotrio 11 ght ing In the Unjted Statos at the ger price Inaroosed the elastioity of domand for gas at the rolevant prico rango vory consicorably. It could not have

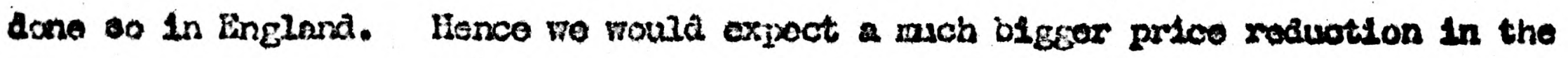
U.8. This is what happendi.

\section{D.S. nos porkes}

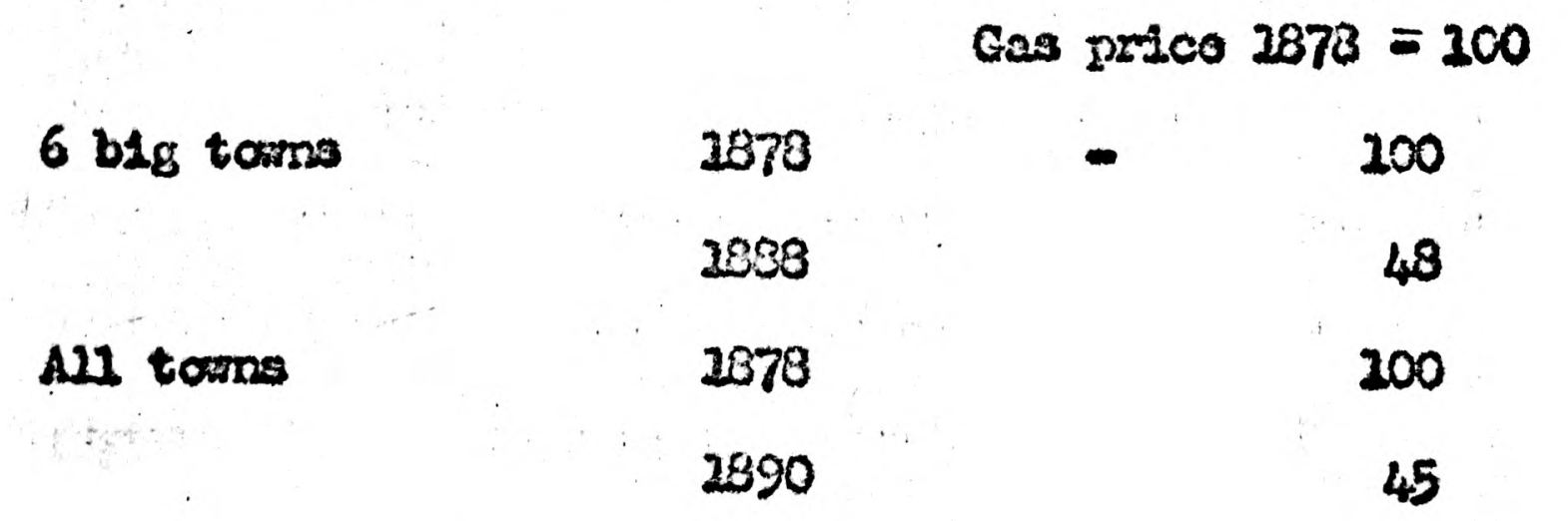

Encland Reles

Iandan

$(2870$ 200 )

3878

100

2931

89

1989

63

111 companies

$(1031=100)$

(Somp20)

1891

100

1839

92

Inondon and

5 major citiea (2831 = 100)

3383

200

2599

85

Source: U.S. H.C. Passor, 09.04t. IT 397 and 202

U.I. Rotums of the Gas Companios and tho Board of trado Parilarantary papors. 
The market for contral station lishting (supplied by elcotrioity of gas) grew at a mach fastor rate in the United Statos than in Great Britain. It is posotblo to measure 11 ght consunption, albeit arudely, and the results are below, in millians of 16 candle power light hours.

\begin{tabular}{|c|c|c|c|c|c|c|}
\hline \multirow[t]{2}{*}{ Year } & \multirow[b]{2}{*}{$\begin{array}{l}\text { Supplied by } \\
\text { gas lighting }\end{array}$} & \multicolumn{2}{|l|}{ United States } & \multicolumn{2}{|c|}{ England \& Wales } & \multirow[b]{2}{*}{ Total } \\
\hline & & $\begin{array}{l}\text { Sup olied by } \\
\text { electric lighting }\end{array}$ & Total & $\begin{array}{l}\text { Supplied by } \\
\text { gas lighting }\end{array}$ & $\begin{array}{l}\text { Supplicd } \\
\text { oy eleco } \\
\text { trio } \\
\text { lighting }\end{array}$ & \\
\hline 1869 & 1840 & nil & 1840 & & & \\
\hline 1882 & & & & 13,320 & $\begin{array}{l}\text { negligo } \\
\text { 1bie }\end{array}$ & 23,320 \\
\hline $\begin{array}{l}1890 \\
1891\end{array}$ & 8,880 & 4,240 & 13,120 & 19,974 & 66 & 20,040 \\
\hline $\begin{array}{l}1899 \\
1900\end{array}$ & 20,050 & 14,500 & 24,550 & 28,084 & 2,550 & 30,634 \\
\hline
\end{tabular}

This partly accounted for by the faster urban growth rate in the U.S. (measured by the growth in the population in towns of more than 25,000 people, as can be seen in the following figures.
(1) Central station light growth rate per onram.
(2) Urban population (2) - (2) Growth rate per annum

United States

1869-(1889-90)

o 8

England \& Fares
$(1381-1882)-(1890-1)$
$4 \cdot 6$
2.1
$2.59 \%$

United States

2890-(1899-1900)

7.2

3.6

$3.65 \%$

U.K.

$(1890-1-(1900-7)$

4.8

2.2

$2.80 \%$

2. First sales of gas and electricity wore taken. U.S. gas gales are given in H.C. Passer op.cit. P 202 \& 199. U.S. olectricity.sales. 
Tro conclusions emerge. One is that eloctricity was at a relative disadvantage in Britain where it had to replace gas, while in the United States there was so little central station lighting in 2880 that it was a quostion of now consumers choosing gas or electricity. Socondy the continued growth of gas sales in Britain, while almost the whole Erowth segment in the United States was I"illed by electricity sales, confirms the relative high cost of electrio lighting in Britain.

are (a) for 1890 based on the number of aro and incandescent lamps in operation (Passer op.cit. PP 70 \& 206). It was assumed arc lamps were used $5 \frac{1}{2}$ hours per night. For incandescent lamps the Iondon number of lamps: KWM assumed ratio for 1891 was used (34.7 KWh p.a. 90\% confidence interval 28.4 - 4.1.0). Central station supply is estimatod to bo $80 \%$ of this figure (b) 1899. 1902 figure given in J.M. Gould. Output and productivity in the Electric and Gas Utilitics $1899-1242$ N.B.E.R. 2946. 1899 figures estimated by assuming a constont rate of growth between 1890 and 1902.

British sales of gas are given in the Board of Irace kotums (B.P.P. various years.) No allowance has been made for the use of gas ior other than lighting purposes.

Electricity sales in 1891 are those of the Londion Compnnies. Other sales vere very small indeca. For 1900 the figure is taken from Table 22. To convert tho a light hour basis I have assumed a 16 c.p. lamp hour toak 5 c.ft. gas, 64 watts in $1889-1$, and 60 watts in $2899-2900$. 


\section{Chapter 2.}

\section{The Gonesis os Public Supoly.}

The boan of 1882 was prinarily an unsuccessful trial and the public supply of electricity dates srom the earily 1890s. Tho first power stations were established in London in the years $1889-92$, and In the early and middie 2890 s electricity supply spread to the provinces. However aggregate capital expenditure on power stations was at first fairly small; the peak period in power station construction before $194_{4}$ came in the years $1898-1904$.

There are several reasons why electric supply startod in London. The London undertakings were private companies, while many of the big provincial stations were owned by the manicipalities, who wero anxious to avoid too speculative ventures and wanted to soe what yould happen in Iondon. Also the pioneers were anxious to start electric supply in an area whore it would be most noticed. But perhaps most inportant is the nature of the market. Electricity supply was for electric ligiting. Electric trams were starting in the U.S. In the late $1830 \mathrm{~s}$ but were scarcely thought of at the tine in England, and electric porrer was undorstood to bo a development of the future. Electric lighting in this country was something for the wealthy individual rather than for businesses. For, by the midalo eighties, most people had corse round to Sir William Slemens's view that electric lighting was the "light of lwxury". Iondon provided a high income mariset sufficientiy closely grouped spatially

1. For detailed encineering histories of the early Iondon Companies soo R.H. Parsons, op.cit., Chapter 5. 
for the powor stations serving a small area to bo profitable whilo charging high prices for onergy, which made olectric lighting 2 to 3 times as expensive as gas lighting. The West Ind of London by the midale of the elghtios boasted many "isolated" installations, not only in theatres ard clubs but in large private houses. In some cases the wealthy gentlomen of, for example, Grosvenor Square clubbed together to provide plant to light several houses. Several of the early supply undertakings in fact grew out of such."isolated" instaliations. In 2883 Sir Coutts Indsay installed oloctric lighting in the Grosvenor Gallery, a picture gallery in Bond Strect, and the demand for light from neighbouring residents and shopkeepers led him to begin a larger and more permanent Installation in the Gallery in Decerber 1838. Iis success Ied In 1887 to the forration of the London Electric Supply Corporation with a subscribed capital of over 4500,000 , and plans to extend operations over a very largo part of Iondon, whose large station at Deptfora and 10,000 zolts transmission lines foreshadoned modern electrioity supply practico. Another cass is the lighting of Kensington Court, which Colonel Crompton, one of the residents, started in 1086. This grew into the Kensington and Knightsbridge Electric Iighting Conpany, which was in the 18908 one of the large and successful supply companics. The Vietropolitan Electr10 Supply Co. started by acquiring the Whitehall Electric Supply Co. whioh had been forred to light Whitehall Court and neighbouring buildings, and the Rathbone Place power station, a private undertaking. The company rapldy expanded supply and in a fen years of starting had added two largo power stations to those two. Clubs, theatres, and fashionable shops were also roady to take a supply of electricity for lighting and there wero successful 
power stations established from the beginning on a foiriy large (at the time) scalo. The first company with a provisional order which boro frust was the Chelsea Electric light Company, which connenced oporations in 1889, its order having becn granted in 1835. The St. James and Pall Mall Electric Lifht Company found the London club area very profitable. The Kestrninster Electric Supply Co. began supply in 1890 and soon had canstructed three power stations. By the end of 1891 over 82 million had been spent ori power stations and their distribution notworks in Contral Iondon.

Table. II.

The Early London Electricity Supply Companies.

$\begin{array}{lll}\text { Company } & \text { Comencement Capital } & \text { Revenue Unts sold } \\ \text { of supply } & \begin{array}{l}1 \\ \text { cxpended to the end } \\ \text { of } 1891 .\end{array}\end{array}$

\begin{tabular}{|c|c|c|c|c|c|}
\hline London E.S. Co. & & 1835 & $753,4.28$ & $\stackrel{\&}{25,561}$ & 457.300 \\
\hline Wetropolitan E.S. & Oct. & 1838 & 485,926 & 43.747 & $2,250,233$ \\
\hline Westrninster E.S. & Nov. & 1890 & 297,640 & 19,455 & 573.385 \\
\hline $\begin{array}{l}\text { Kensington and } \\
\text { Knightsbridge Co. }\end{array}$ & Jan. & 2837 & $y_{+} 0,6 a_{r}$ & 13,288 & 385,050 \\
\hline $\begin{array}{l}\text { St. James and } \\
\text { Pall Hall Co: }\end{array}$ & April & 1389 & 139,458 & 31,898 & $2,067,990$ \\
\hline Chelsea Co: & Sept. & 1889 & 74,720 & 10,172 & 290,458 \\
\hline Notting Hill Co: & June & 2891 & 67,845 & 1,623 & 30,000 \\
\hline $\begin{array}{l}\text { House to House } \\
\text { (Brompton and } \\
\text { Kensington) }\end{array}$ & Jar. & 1889 & 58,376 & 8,328 & 230,242 \\
\hline Total & & & 18,997 & $\Psi_{4} 3.972$ & $4,284,658$ \\
\hline
\end{tabular}


Source: Returns of the compenies to the Board of Trade, The Electrician. January 1892.

1. Estimated by the Elcctrician from revenue and price data. No figures are given for tho Charing Cross Co. (supily commenced 1890) and St. Fancres Vestry municipal undertaking (supply commonced 1891).

Capital exponditure on electricity supply outside London was very small. The only company of a size approaching the London companies was that at Iiverpool. Although founded in 2883 it had remained tiny until 1888 when 1t had started to grow more rapialy. Even then at the beginning of 1891 it had no more lamps connected to Its mains than the Westminster Company, which had only started supplying electricity in 1890. The London Electrio Supply Corporetion and the Metropolitan Bleotric Supply Co. had respectively 3 and 4 times as many IIghts connected. Otherwise in the provinces at the beginning of 1892 there wore the small companios e.t Brighton, Fastbourne and Hastings, which were left over from the boon of 1882. In the West country Beveral atations wore started in the late eighties largely through the enterprise of one man, H.G. Massingham in 1886. He bought ThamsonHouston aro lighting equipment and used it in Taunton. The station was a success and was sold to a local company early in 1887. 2 Under Uassingham's auspices are lighting spread to Bath and Exeter and by the end of 2891 Bath had 200, Taunton had 90 and Exeter had 60 arc 1 amps.
2. Electrician, Vol. 26 P 525. 27 February 1891.
2. Electrician, Vol. 22 P $385 \quad 1$ February 1839
3. Electrician, Vol. 26 P $275 \quad 2$ January 1891 
A small rumber of incandescent lamps were also uscd in theso installations. They grew subsequently but even by the ond of 1895 thoir combinod capital expenaiture was only $\$ .70,000$.

A more inportant developrent was the be inning of publio supply in the large provincial towns. Here the manicipal corporations pleyed a large part, although the tempo of muicipal enterprises was slower than that of the conparies. Wany corporations had applied for provistonal orlers in the 18805 but the first municipal power station was a contem porary of the Iandon ones. It was built at Bradford and cane into operation in 1889. But in general the municipalities wero not anxious to rush into electricity supply. They did, however, build powor stations very soon after their success had bcen demonstrated in Landon. In 1891 Brighton Corporation started suply in competition with the Brighton Compans, in 1892 Dublin Corporation opened their porror station, and in 1893 Blackpool, Bristol, Burnley, Derby, Dindee, Glasgor, Huddersfield, Iull, Kingston-on-Thames, Hanchester, Witehaven and Woolwich followed. Heanwhile public supply hac been started in other large torns by companies, usually in advance of supply in the towns which were to have maicipal electricity. Thus two power stations were built in Newcastle upon Tyne in 1889 and 1090, Cambridge, 0xford, Preston and Sheffield in 1892 and Leeds and Norwich in 1893. Often where tho corporations had been a Iittle slow but nevertheless interested in publio supply, and a company had started operations, the corporation bought it out. This happanod in Bath, Iiverpool and Southampton in 1896, Sheffield and Leeds in 1898 and Birmingham in 1900 . By 1900 the general pattern in the provinces 
was established: tho large towns had minicipal supply, while the small toms were in the hands of companies.

The ond of 2895 is quite a good statistical vantage point frow which to viow the very beginnings of electricity supply in this country. For the first time there are good overall statistics. These are sumed up in Table 12.

\section{Table 12.}

Early Electricity supply undertakings 1.e. those which bersen supply before the end of 1893.

Position as at the end of 2895.

Capital Expenditure. $\quad 8000$ (Number of companies)

$$
\text { Companies Motal. }
$$

\begin{tabular}{lllll}
\hline Londian & $4,016(10)$ & $124(2)$ & $4,140 \quad(12)$ \\
\hline Provinces & $1,303(24)$ & $1,060(14)$ & $2,363(38)$ \\
\hline Total & $5,319(34)$ & $1,184(16)$ & $6,503 \quad(50)$ \\
\hline
\end{tabular}

Source: Garice's Mienual.

Tho figures include some of my estimates.

The Inportance of Jondon stands out clearly in the above table, as does the large size of the Iondon companies. Although the quantitative importance of Iondon declined later, nevertheless the Irondon companies remained among the big undertakings. The other major 
point to notice is that the provincial companies' undertaking was signtficantly amaller than the municipal undertaking: while the capital expenditure of the average provincial manicipal electric supply undertaking was \$75,700, that of the average company undortaking was only 654,400 . This gap was to widen with time, as the big provincial towns wore further developed by the municipalities leaving the smaller towns for the compant No good figurcs of capital expenditure are available until the end of 1895. However the "silectrician" made conternorary estimates and I have combined them with estinates of my own Pram Garke's Manual. The resulting figures contain a certain amount of glesswork, and can bo only an approximation to the truth. The margin of exror could be as high as 20.5 million, but is probably less.

Table 13.

Aggregate Gross Investment Electricity Sunoly.

$\begin{array}{cc}\text { Year } & 0.7 \\ 1889 & 0.8 \\ 90 & 1.2 \\ 91 & 1.3-2.5 \\ 92 & 1.3-1.5 \\ 93 & 0.6-1.6 \\ 94 & 1.4 \\ 95 & \end{array}$

1. See Appendix P 4855 . 
One of the most inportant variables in eloctricity supply Is the size of area served by one porrer station. This area has continuously exponded, the rato of expansion being closely allied to tochnical progress, and this expansion has caused many of the organ1sational difficulties in the industry. As we are discussing the beginrings of electricity supgly it is worth asking why it should be economicaily desirable to have public supply at all, as opposed to the mumerous "isolated" installations of the late 1880s. Not that these "isolated" plarits disappeared - somo dij, but they were replaced by others, and by 1907 toore electricity jas zenerated by users than was generated in public supply power stations. There are two principal reasons for having a public supiy of electricity. One is that big generating plant up to a certain size, is cheaper, both in capital and running cosi than small plant. The limit of the economio s1re of generating plant has lincreasiod over tirce, as technical improvements have been maclo. The second reason is that the divorsity of poak loads will increase the larger the numbor of appliances connected, even if these appliances are all the sane kind - for example lights. Because electricity cannot be stored, the size of generating plant required is a function of the peak denand for the appliances connected. But as electrical appliances are nearly almays usea intermittently tho probability tirat they will all be witched on together is a decroasing Sunotion of the mumer of appliances. That this latter factor is of as wido and continuing a general spipication as the former can be seen ircul the great saving of generating plant which was made possible by 
tho construotion of tho natianal grid in tho 1930a. Horsevor against these savings dus to centralised generntion thoro 13 the cost of tho diotribution notworis. A distribution notworis is vory exponolvet of the capital expenditure of electrio curply systcras about 40,\% was spent on tho colns during tho wholo period up to 194. Iransalosion and alotribution costs could bo reduced in three ways. Firatiy the transmisalon voltage could bo raised, thwo reduoing the cross-soctional area of the conductor. Secondiy botter insulating materials could bo used. Tairdly cabios could ba modo ousier to lay. Aleo a distribution notrorts involvas a croet deal of arritohgon. This bocanes woro atfficult to decisn, and nore oxpensive the greater the voltage, but also the creater the total perrer tranarattied, bocause faults on a systen carrying a lot of powor will cause asomous mochanical atratiss un witches. Inolequate oriztch gear mono that gaulto can causo consideraile danage to sachinery and mains, and breatrdoms aro proportionatcly more expenalva with biefer plant. Iloving rasce these general corrents we can go on to discuss these variables in the years around 1390 . The cost per $x$ of enorating plant sell wi the size of plant Increasod, up to a sise of about $160 \mathrm{zW}$. Even this aizo was relatively big for the timo. Sase of the carly vdison dyramos had ranced up to this size and on the Continont Cronyton hod Installed $125 \mathrm{~kJ}$ macinines.' J.E.H. Gordon

1. R.E.3. Crospgton. Reminssconces. Lonaton 2928. P 117 . 
had bullt $350 \mathrm{KW}$ altcrnators for the G.W.R. In the midale $1880 \mathrm{~s}$ but these machines were not successful and disillusioned even Gordon hinself. 1 S.z. de Ferranti was using bigger machines, of about $450 \mathrm{KW}$, at the Grosvenor Gallery in 1887, but his preailection for using the largest machines possible was not commercially very succossful, partly because of thoir high initial cost. Most dymamos were smaller than $100 \mathrm{IN}$, and many of the early London companies started on aymamos of $50-100 \mathrm{kT}$. Bigger units seem to have been slightiy sore expensive to build and because of the much Ereater mechanical strains involved, moro liable to broak doun. Brenkdowns meant intermuption of supply which was undesirable partly because of the expense of repair, but more because it was the best way to lase customers. Also heavy machinery was unsuitable for power stations in contral residential districts. Largo reciprocating ongines mado considerable vibration and noise and neighbours attempted, in soveral cases ouccessiully, to get injunctions aguinst a campany causing a misance in this way. To build stations outside the residential areas would have demanded a revolution in technique. Ferrants attempted ouch a revolution which is better discussed later. It was not however

2. R.H. Parsons, op.cit., PP $42-51$.

2. R.H. Parsons, op.cit., P 24. 
oconomically succossful.

There was little point in having more than 8 - 10 gonerating units in each power station. If 14 was a d.o. station and all tho plant would be operated connected in parallel, fuel cconomios could be achieved if about 8 units were Installed, but no further economies could be realised with more. In the case of a.c. plants where mahines could not at first bo coupled together there was less scope for saving fuel by using several generators fram the same boilers. There wore economies of scale in buildings and boilers, but again not where there were moro than about 8 - 10 units.

Then of course there was the question of the cost of alstribution. An $800 \mathrm{~kW}$ power station would serve about 26,0008 o.p. 21ghts. In tho provinces in the very early days one could not hope to got more than this connected in the central area. On the outskirts the cost of distribution raised electrio lighting to a lovel well abovo that which could be achieved in quite and isolated plants. In Iondon demand was much greater but it was clearly cheaper to duplicato power stations after the limit of generating economies had boen reached.

But to make even the small stations of the early $1890 \mathrm{~s}$ oconomically feasible required attention to the dribution notwork. Electric lighting in this country was prinarily by incandescent lamps. It was at the time impossible to manufacture one to run on a clroust of more than $100 \mathrm{v}$. But the cost of $100 \mathrm{v}$. mains was excessive. The Edison 3 wire system was one technique of substantially reducing the cost of mains by permitting a doubling of tho transmission voltage and 
a further refinement on this was the more complicated, but evon cheaper, Siemens 5 wire system. With such voltaces it was not cconomical to have transmission mains moro than a mile long. It was difficult to raise the transmission voltage surther on a a.c. network, although this was attempted. There wore two main techniques. One was to use accurmulators as roltage transformers. They wore placed in sub-stations, charged at a high voltage and discharged at low voltages. Crompton used this aystom at Kensington Court, and it was also used by the Chelsea Elocttio Supply Co. These battery systems enabled voltages of up to $500 \mathrm{v}$. to be used In the trunk mins, and also enabled electricity to be stored. The other technique was to use continuous current transformers, which wero a generator and a motor coupled together. Tho motor was driven by cursent Irom the mains at up to $2000 \mathrm{v}$. and this drove a lon voltage generator for the lighting suppIy. This was the woll known "Oxford" system, pionecrea by Thomas Paricer, then chief electrical engineer of the Electric Construction Corporation.

A mach better system of voltage transforsation was the use of alternating current and the static transformer. Although tho principle. of the a.c. transformer goes back to Faraday's aiscovery of electro magnetic induction, the realisation of its cconomic value in permitting high tranomission.voliages and a simple change to low voltages for use was of very recenti discovery. Caulard and Gibbs had patented a transformer in 1832 which was intended to be used as a device for maintaining a constant cument for arc lamps irrespective of the number in the circuit.

1. J.A. Fleming, Alternating Current Stations, Electrician Vol.27 PP $582-8$ 25 September 1891 
They do not secm to have appreciated its value to change voltages and pelmit high voltage transmission. The first people to do this were Zipermatalst, Deri and Blatiny, the enginecrs of Ganz \& Co. In Budapest. By 1885 they had a system of transfomers connected in parallol used to transforn voltages. In the United States George Mestinghouse sar that Gaulard and Gibbs transfomors could be developed in this way and by the spring of 1836 Stanley. Westinghouse's electrical engineer, had a practical system of parallel connected trassformers in operation. In England S.Z. de Forranti sar exactly tho same polnt. Sir Coutts Iindsay had installed Gaulard and Gibbs transformers in the Grosvenor Gallery in 1885 when putting his terporary installation on a permanent footing. Eut the systern was unworkable and Forranti, who at the age of 21 had already made a name in alternator design, pointed out to Lindsay the superiority of the Zipernowski transfomer. Ho was comissioned to change the system and in 1886 complotely redesigned it, and roplaced the oxisting dynamos with his orm altermators. Generation was at 2400 v. and the current was transfomed down to $100 \mathrm{~V}$. for use.

Thus a.c. hat considerable advantages for transmission and distribution. Kains cost less, static transformers were rouch cheaper and depreciation due to wear and tear was less than for rotatine d.o. transformers or batteries. Also their operating efficiency was highers this not only saved fuel, but more importantly, reduced the anount of generating machinery required per IIf of noxinum demand. But to offset this a.c. generating plant was very markedly inferior to d.c. plant. 1. H.C. Passer, op.cit. Chapter 9.

2:- Iotter from G.I. Addenbrooke to Urs. Ferranti, 20 October 1932. Forranti private files m.s. 
Farly aloutrical onzinoering has concontatod on direot curront. It was betton for aio lams and this the are lanp pioneers had used it. In the

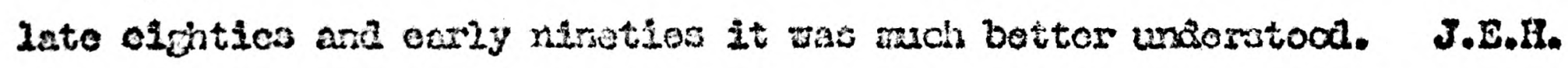

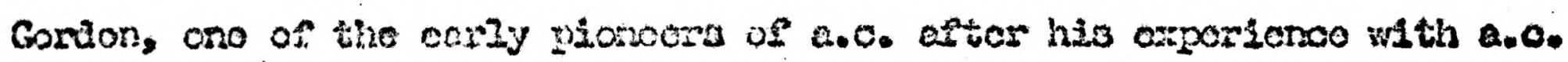

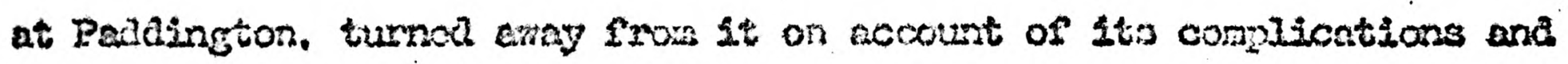
arvocated a.c. for tij mitchall porer atation of tive letropolitan Blectrio supty Co. D.C. plant was consteorably cheapor; a.0. plant

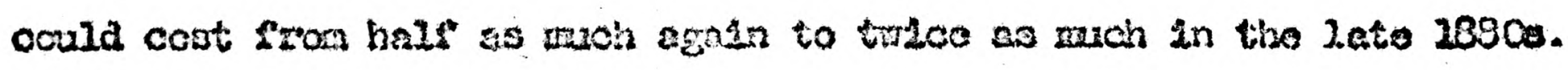
The efficiongy of altomators whs lower than thet of a.c. goneratora and

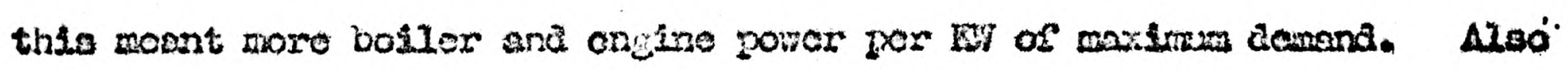

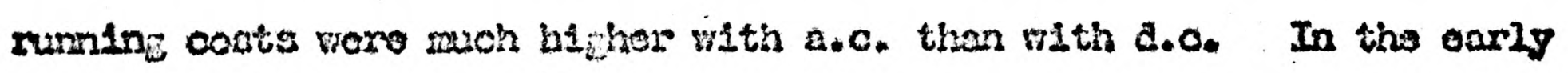
days altomating curront stations could consune $2-3$ thes as auch coal nor unit generated. In 1592 tho Rlectnicel Revlery stated that the averago coax comoungtion of a.c. atations wes $20-25$ 2bs. por xhb compared vith 10 100. For tho a.c. otatins. In $120 \%$ whon a.c. onglneering hei beon intonistroly cultivated for somo years Crompton cotinated the averngo thermal expolency of 7 a.c. etations at $2.31 \%$

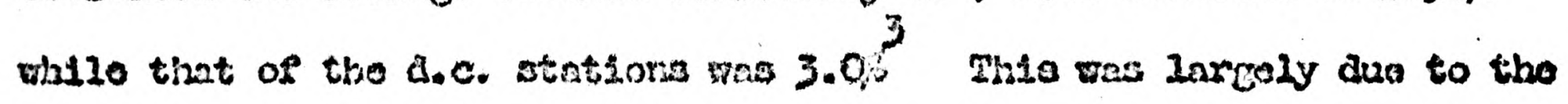

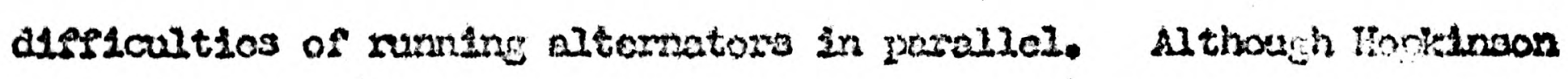
had shom in 1894 that parallel ruinghig was theorotically possiblo, it was raroly dono until the madilo and late 1990 and then onmtinos with wamo raluctenco. A rumbor of canly stations zan alternators in pamallol

1. R.II. Parsous, 0.0.0ten, P 72 .

2. Quotol by R.h. Earson, On,0it, P 133

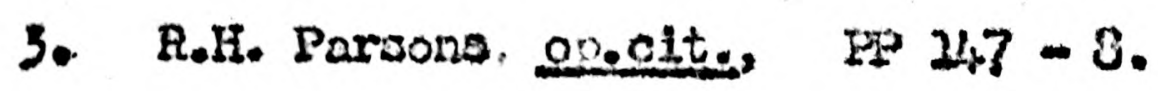


occasionally, a nurcber had no provision for doing it at all, each machine being connected to a section of the distribution netrorik. As a lighting load has a sharp pook in the early evening, but is otherwise very low this meant that each engine and alternator was running light mosit of the time. Whis was very extravacant wich coal. Often to moke parallelling easier a rope drive was used, which again incroased the coal cost. D.C. machines were usually directly. coupled to engines ond could be easily worked together. Thus oach engine could be kept on nearly. full load, extra ongines being brought Into operation and shut down as the load rose and fell. Crampton reckoned that 8 mecinines per power station could give tho best fael results.

In the carly $1890^{\circ} \mathrm{s}$ engineers engaged in a great a.o. - d.o. controversy knom as the "Battle of the Systems". In areas of 10 m supply density it was agreed that a.c. was better. Crompton himself the great a.c. protaronist - Iut down a.c. plant for the lighting of Chelmsford in 2890. But in the areas moro populated with customers the question was unresolved in the ninoties. It is however probablo that d.c. was slightly to be preferred. The major reason for this was that there were not enough econonies of scale in goneration for $1 t$ to bo economical to think in terms of a big distribution network. Only with very big stations is high voltage a.c. transmission a great advantage. The early a.c. stations used about 2000 v. in the primary 
mains compared with d.c. voltages of $500-1500 \mathrm{v}$. When there was no point in building stations above 1000,2000 and $3000 \mathrm{~kW}$, which was about the minimum efficiont size in the late eifhties, early nineties and midale nineties respectively, and the area of supply was densely populated with customers, the length of mains which one would have evon at 2000 v. was relatively short. The possibility of using accurmlators with d.c. supply but not with a.c. perhaps turmed the balance in favour of the former. It is not likely that they reduced costs, probably the reverse. Few people seemed to know about the costs of accumilators, efther their initial costs or the cost of saintenance, or about their efficiency and reliability. Somo people put great faith in them, some disliked them intensely. of all cost estimates those concerning accunulators vary most and are most disputed. Some people advocated using them to mect the stations' peak demand, thus economising on othor plant, but their high first cost and high rate of depreciation meant that capital costs per KW maximun demand were as hich with accumalators as with generating machinery or even higher. Sorne stations used them at night when the generating machincry was shut down, but this was probably only thought profitable becauso inadequate capital charges were calculated. Accumulators declined with the rise of big stations in the early 20th Century, partly because they continually failed to fulfil the reiterated promise that sanguine engineers made on their beholf and partly because other plant became mach more reliable. But in the early days they asd ensure regularity of supply by providing a standby when the other machinory broke down. Early plant could be very unreliablo and ang accounts of the 
operations of early power stations siress the endless faults and makeshift devices ane had to use to keep the plant going. As one can soe bolow from the case of the London Electric Supply Corporation, interruption of supply caused customers to melt array. In the event most of the Iondon companies and most of the undertakings in the big toms adopted d.c. leaving a.c. for the areas with 100 consurner density. Naturally there were exceptions like the Newcastle Electrio Supply Co. and the Metropolitan Electric Supply Co.

Had it been profitabie to suply over a wide area, a.c. would have been the better systen to choose. There was only one attemot to do this, that of the London Electric Supply Corporation, but this is a ploneer attempt, which is in itself sufficiently important to merit discussion, and provides an illuminating contrast with contemporary practice. Ferranti's first achievement was the remodelling of the Grosvenor Gallery plant. He constructed for the first time in this country an a.c. transforser system using 2400 v. in conjunction with his own $450 \mathrm{Km}$ alternators, with a generous overload capacity. These dynamos scom to have been the bigfrest in the courntry at the timo. This in itself put Ferranti in the forefront of the pioneers, but ho was not content to rest there. He argued that there were still very considerable economies of scalo to be gained from ruch larger generating plant. The otiner pioneer advocates of a.c., Westingiouse and Stanley in the U.S., the Ganz ongineers on the Continent, and Gisbert Kapp in England were cantent 1. See R.H. Parsons, op.cit., 
with 2000 v. transmission but Ferranti wanted to go much further. He argued that big plant was cheaper in first cost and running cost than small plant, that facilities for handing fuel and oil were very bad in the centre of the crowded hetropolis, that expansion of the small stations then in favour was impossible and even that they might bo closed dow as a nusance. Savory \& Hoore did in fact in 1389 obtain an injunction to prevent the running of heavy machinery at the Grosvenor Gallery. Ferrant1 was moreover impressed by the action of the gas companies in moving their works out to Beckton and Rotherhide. He decided on Deptfora as the best place to put his power station. But as this vas some miles out of Iondon the transmission pressure had to bo very high and Ferranti proposod to use tho then fantastic prosure of $10,000 \mathrm{v}$. , at a time when many authoritios considered that insulation for more than 2000 v. was impossible. The conception of the scheme was of breathtaking originality, and earned for Ferranti the title of "the Edison of England". It involvod a complete doparture from existing practice; nearly everything had to be designed completely from scratch. First there was the question of generating plant. This hod to bo big and Ferranti proposed five glant alternators of $7500 \mathrm{KIN}$ capacity, well over ten times the size of anything constructed at the time and about sevonty times the size of the usual generating unit. While they were being built he constructed $800 \mathrm{KW}$ alternators which themselves were very big for the timo. The $7500 \mathrm{KW}$ machines were to be enormous, although they were never finishod. The massivo reciprocating engines were to be made by liessrs. H1ak, Hargreaves \& Co. Itd., of Bolton, who had built the smaller ensines for Deptford. 
Their crankshafts were forged from steel ingots peighing 75 tons each, these boing the heaviest ingots cast in Great Britain at that timo. Tho fly wheel altemators were to weigh 575 tons each and were to stand 45 feet high. Their casting was such a large job that Krupps of Essen voro unable to promise delivery in less than 3 years, and so the work was undortaken in Fingland with specially constructed tools. Apart from the casting the alternators were being made entirely at Deptford under Ferranti's supervision with special lathes and other tools. The building also had to be on a rassive scale as opposed to the other power stations of the timo, with light machinery which could be housed simply, in somo cases, in existing buildings. It was not only the electrical machinery that Forrant had to supervise, he also designed a multiple steam pipe for the boller plant while working at Deptford, which was an improvement on existing steam practice. Ferranti's transmission system was if anything more original st111. No one had evor designed a transforwer to deal with 10,000 v., and so Ferranti built one himself and had to devise his orm way of testing It as no adequate tosting instruments were available at tho timo. For his cables Perranti chose jutio insulated concentric cables manufactured by the recently formed Foviler-Wrarin Company. The cables from Deptford wore laid along the railway track which was simpler than getting authority to put theun underground and probably much cheaper. But although the

1. B.R. V01.28 P.591- 4.May 1891.

2. P.V. Hunter \& J.T. Hazoll, Develonment of Power Cables, Iondon 1956. Chap. 7. 
Forlormarin: cables were olectrlcally satiafactory, thoy vere vory ouscoptible to catching fire fros tho sparies and cinderwa of pasising oncinos. So Porranti can to the conclusion that ho must deaten and conotruct his own molns. Iio choso a concentric cable insulatod with papar. The use of paper as a dicicotric for forter cables was a notable Inrovation and was cxirecoly valuoblo for high voltage mains, The revolutionery dosign of his cables was ayosed by the Borat of Trade, and to convinos thers of thrix safely Ferranti devisod a test forereby ons of his aselatants hale a chisol which was than ariven throuch tho woins.

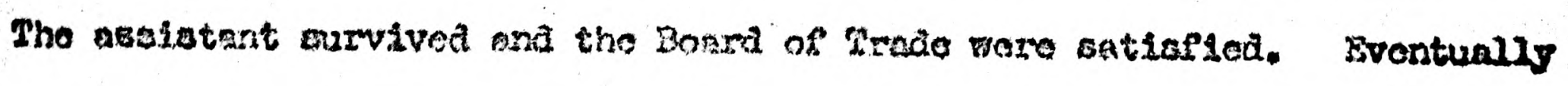
Pexranti overeno ell the ondineoring afficultied, ooloing the host of amall problens which always arise whon inchovations of this magnituco are bolne carrica out. Br barch 2891 bo was able to roport to his Direotore that "no engineoring or elsctrical disticulties whatever hove arisen which I have not been ablo to ovoreano, ard at the present moonent I know of no weak points in your systern" " Jy this tiso Grosvenor Gallery ans a oubo - station and all current wes gonerated at Dertrord.

The Deptiond echecio vas a vorit of gentus. It was a megnificant engineering achiovencut, but was also more than that. For It was the Pirat cabolinent of the modarn gysten of electrical supply with largo cenerating otations and high voltage trangwinstan. The titilo of the "Jisison of Encland" wal a docorved ono. Bor Ferrant1 had combinod tho samo gualst; of vision with the saxo gualsty of engineering ablitty that bason

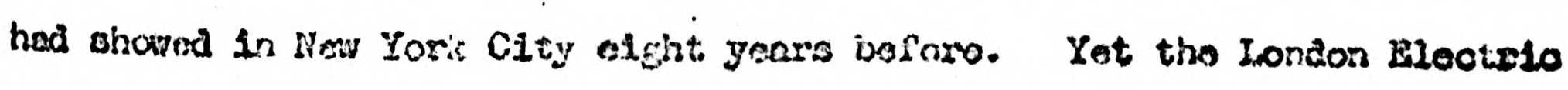

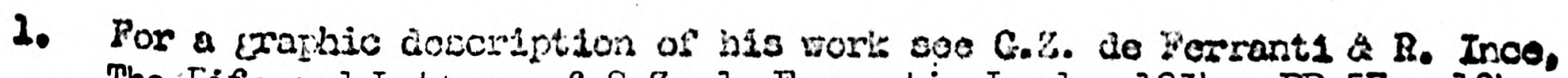
The Life and Letiers of S.Z de Ferranti, London 1934. PP 57 - 104.

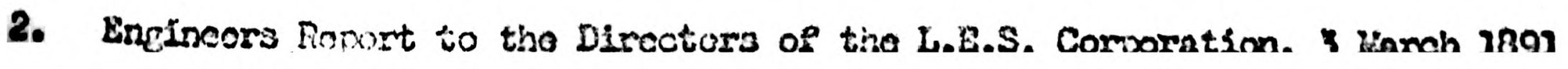


Supply ochesso mas coiniercially a fallure. By 2324 it was in the hands of the Recolvez, in 2395 its capital was reduced by a thita, and deapito this no dividonds wore paid on tide oritinary captial until 2905, by which

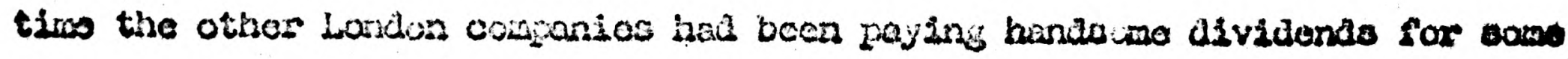
- time. Tinis was not becouse of the engincoring of the oystem. Fexpant1

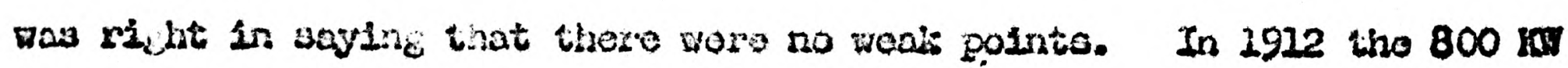

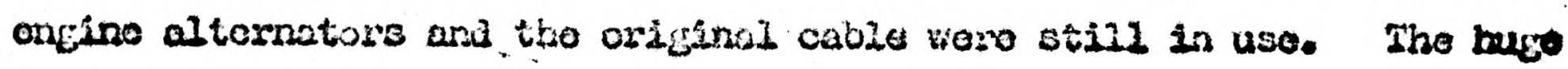
$7510 \mathrm{EI}$ wachinos were nover built but in 2825 the conpany aboncd 1 to

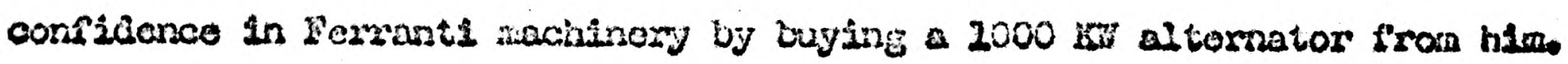

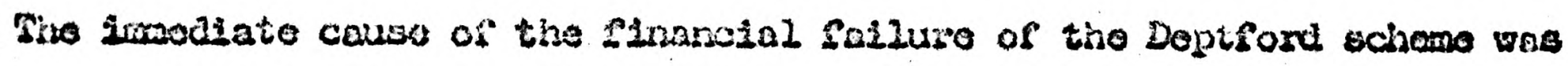

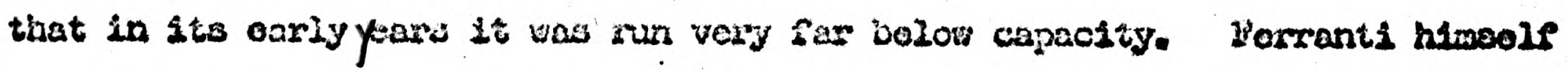
later." atiributed the lailure of Daptioni to the action of the Board of Irade in carving up Londion for olcctricity supply jurposos into anall aroos." The Board of Trois had hela an Inquiry Into olectricity supgly in London in 2099, when all theso schace for gublic aup 25 were about to be put into

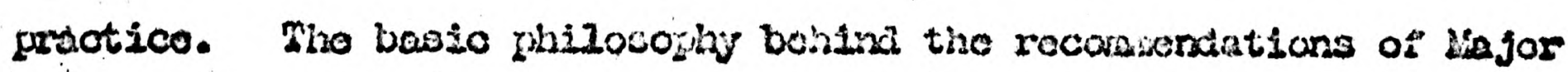
Larindin who concucted tiso Iroquiry cocis to have been firsily that any lareo

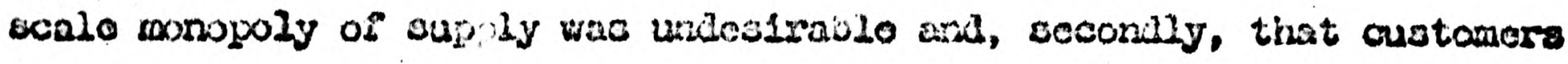
oudut to have sara choico of supgller. Wajor larindin socas to havo been

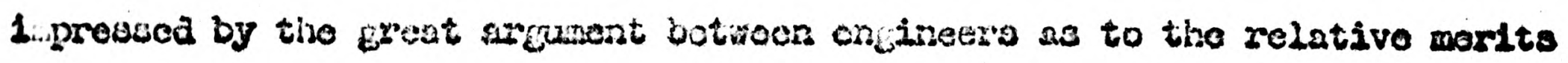

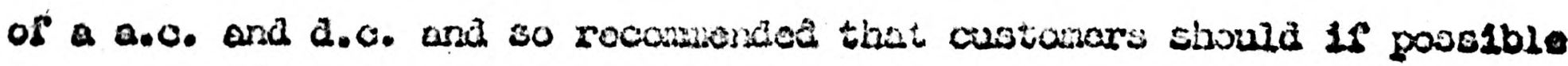
have a chuice botweon the tro. This aficcict the Lonion Supply Carporation

2. Lottor to the Lininecr. Deccriber 1929. Berranti privato Piles. 
on both countis. The area of supply granted to then by the Board of Trade was much less than they applied for and in the area north of the Thames, where most of the demand existed, provistional orders were also granted to competing a.c. companies. As might be expectod the Deptford scherse had bad tecthing troubles. Thero wes a fire at the Grosvenor Gallery sub station in Novezber 1890, which caused a dijirtdown for three months, just when people vanted lighting most. On the eve of the fire there were 38000 lamps on the ccinpany'a mains; when supply restarted in February 1891 only 9000 rerained. Fe following autum the systom went over to the full $10000 \mathrm{v}$. transmission and this caused numerous faults and interruptions of supply on many occasions. In November 1891 supply was interrupted for four days. By the end of the year there were only 36000 lamps connected. After this tho plant becamo more reliable, but the damage was done; onco the competing a.c. companios had distribution networks in most of the strect of the area, it was very difficulit to break in. Table shows how slow the Erowtin of the London Electric Supply Corporation was compared with tro of its oig rivals. Whe Westminster Co. operated as a conpetitor in some areas. The teething troubles of tho system seem, to have lost Ferranti the confidence of the directors. of tine original subscribed capital in 1887 of $\$ 535,000, £ 220,000$ was pert up by Sir Coutts Linasay, another $148,885 \mathrm{by}$ Lora Wantage and noarly the

1. Report of I.E.S. Corporation Sor 1891. Electrician Vol. 28, IP $587-8$ IApril 2892.

2. Report of P.W. D'Alton, enginear of the L.E.S. Corporation, March 2892. He was Ferranti's successor. Electrician Vol. 28, 25 Larch 1892. 
whole of the rest by 26 other sharcholders. Ferranti had obviously captured the inagination of Lindsay and Tantage for at first they backed him acninst nearly all cngineering opinion at tize tiwe, which regarded Ferranti's scherne as quite mad. But by 1891 their financial rosources were becoming exhausted. The shares stool at such a discount that they could not raise moncy on debentures, and their Groat gamble did not seen to be coning of Grosveror Gallery fire. In Aligust 1891 Ferranti was dimissed and it was decided not to proceed with the $7500^{\circ} \mathrm{kn}$ alternators.

Table 14.

Lamps connected at the beginning of each year in 000 s. $\begin{array}{llllllll}1891 & 1892 & 1893 & 1894 & 1895 & 1896 & 1897 & 1898\end{array}$

\begin{tabular}{lllllllllll}
\hline $\begin{array}{l}\text { Lonion Elec } \\
\text { trio Supply }\end{array}$ & 38 & 36 & 66 & 66 & 74 & 100 & 120 & 124 \\
\hline $\begin{array}{l}\text { Isctropolitan } \\
\text { Electrio } \\
\text { Supij Co. }\end{array}$ & 48.5 & 86 & 128 & 164 & 204 & 256 & 310 & 354 \\
\hline $\begin{array}{l}\text { Westminster } \\
\text { Co. }\end{array}$ & 12 & 64 & 100 & 132 & 168 & 210 & 250 & 270 \\
\hline
\end{tabular}

- Novemer 1890.

Source: Electrical Traces Directory 1998.

1. F. Bailey. The Life and Work of S.zi. de Ferronti, $1964-1930$ Address to the Electrical Power Enginecrs Association 1931. Privately printed by Forranti Lta. Holliniood. 
Government policy and lack of financo is then sufficient reason for the failure of the scheme. but it is worth trying to see whother it would otherwise have succeeded. There aro two matters to discuss. One is whether, had the schene been coraploted, supply would have been cheaper than from the small stations which provided olectricity for most Londoners. Tho other is whather even if electricity fram Deptford had boen only a littlo moro expensive than it could havo been fram elsewhere, much of the choos which quito quickly developed in Iondon's electricity suply might have been avolded.

It is difficult to do much more than approach an answer to the first as there are not oven estimates of hom mach a completed Deptford would have cost. Also to make matters vorse no figures of capital expenditure from 1891 to 1898 exist. The actual Doptford had a very high capital oxpenditure per lamp connocted. In 1890 it was \&17.2. By 1898 1t had fallen to $\$ 7.1$ but in the interim the capital had boen reduced by $1 / 3$ and fixed assets woro probably written dom by a similar amount. In 1891 capacity was about 90,000 lamps, al though to supply them properly more money would have had to have been spent. Hupothotical capital cost per light would thus be at loast $\$ 8.5-\$ 9$, probably more alloning for connecting consumors to the mains. But a large sum of money must already have been spent on the two $7500 \mathrm{KJ}$ alternators, which would have brought capacity at the porror station up to about 340,000 1amps. How mah more would have had to be spent on them, and how much on conneoting the lamps to the mains cannot be knom but it is scarcely cancelvabio that the total could amount to less than $\&_{4}-5$ per lamp. Even then it was only

1. Probably about another $\$ 50,000$. 
approaching the actual cost per lanp of the other companios as can be seen from Table.

Table 15.

London Companies lapital Expenditure per lamp.

Company

Numbor of lamps

Capital

Capital

Expenditure

Expendit ire per lamp

Iondon E.S.

$\$ 000$

6

Corporation

1890 actual

1891 estimate

38

653

27.2

90

768

$8.5-9$

Chelsea

1891 actual

26

75

2.9

House to House

1891 actual

20

58

2.9

Kensington and

Knightsbridge

1891 actual

36

140

3.9

Tostminster

1891 actual

64.

297

4.6

St. James and

$\mathrm{Pall} \mathrm{Mall}$

1891 actual

38

139

3.7

Notropolitan

2891 actual

86

487

5.7

- Iater fell.

For the years $1894-6$ inclusive for 10 London undertakings excluding the London L.S. Corporation the urweighted average cost per lamp connected was $\& 3.4$. 
Had the orlginal scheme becn adhered to and all five of the $7500 \mathrm{KW}$ alternators been constructed capital costs might have boon snaller, but probably not by much. It is more likely that they would have been moro expensive por KW than amaller plant. Reciprocating engine altemators of this size were never built. In 1905 Manchester Corporation bought two $4000 \mathrm{~km}$ reciprocating engine alternators, which were sald to be the largest in any power station in Europe. But this was the lirit and all bigger subsequent units were turoino driven. IIIgh capital costs could bo justified by much lower running costs. But running costs with this plant were unfortunately high and would have been even higher with the very large machines proposed. Berranti wanted to build his large station partly because large angines would use less coal per Km generated than small onos. But on the other hand engines Iunning on a light lood were very wasterul of fuel. The combination of the sharp short peak of the lightirg loed ard the difficulty of running the alternators in parallel meant that the engtnes wore on a light load much of the time. A fortiort the $7500 \mathrm{~km}$ machines would have been nore wasteful. As opposed to this what Crompton had learnt from his experience of the running of the early power stations was that the way to reduce coal costs pas to divide the station load between about eight machines and so Iun tham as mach as possible on full 20ad. This question of fuel economy and the fluctuation of the Ilghting load scems to have been neglected by Ferranti. The problem of coal costs rould have been solved if the London Electric Supply Corporation had had a sufficiently high rate of growth. Also 
capital costs would have been lower if the full station had been built because the costs of innovation would be more widely spread. Even then It is not IIkely that the latter would be even as low as thoso of other stations. On this point, however, Eerranti seoms to have over-estimated the rate of growth of demand. Deptford was planned for one milition lampa and by 1898 the number of lamps in London had topped this mark. The Iondon Electric Supoly Corporation accounted for only $10 \%$ of these, but even given more liberal treatment by the Board of Trade could not have hoped for much more than balf of them. It is difficult to imagine that Deptford rould have had one million lamps before 1900. And as it would probably not have sold electricity any more chaaply, the rato of growth of supply would not have becn higher than it was.

Ferranti's scheme foreshadowed future electricity supply practice. Could it then be argued that it would have been bettor to esteblish electricity supply on his lines even though in the $1390 \mathrm{~s}$ this was perhaps more expensive than the methods used? There are three points to be consiciered here. The first concerns future technical progress. Later bitcer generating sets were developed which wero cheaper than the amall ones of the early 1890s. Iransmission pressures wore raised, and the cost of supply fell. If Ferranti's scheme had been tolorably successhul it might have stimulated electricity supply engineors and electrical manufacturers to devote more effort to increasing the size of gencrators. English encineers do seem to have been excessively conservative in the later 1890s, and by 1900 inglish electrical engineering was very backward. There was particular backwandness on the a.c. side. 
There are however other factors which contribute to this.

Secondly if a supply syster is coibnitted to small stations and d.c. networks this might be more expensive some years later, than if 0.0 . and bif plant had both been adopted froin the beginning. This would be the case while the costs of wholesale conversion were above the present value of expected future cost savings. But this could only bo Important with fairly slow tecinical progress, and the losses to the comunty would be srall. Also as demand was groring it was more a question of expansion than scrapping. New, efficient machinery could bo Installed and old machinery used for meeting the peak load. When there vas no more space in existing power stations big ones could be built outside the town, and the old ones used as sub stations. The trunk mains could be a.c. and convertine plant put in the old porrer stations, thereby using the same old distribution network.

The third question is organisational. The continual Erowth of the optinal supply area meant some amalgamation or supersession of companies was desirable. In the event this was difficult. This problem really erose, however, only because of the inadequate public utility control of the time. It wiIl be later argued that a good case could be mado out for large private nonopolies in electricity supply. But it is olearly not the only vay the problem could havo beon dealt with.

All told the late eighties and early ninetios wero a period of much exciting innovation in British electricity supply. Although public supply started late in this country there was little gciseral experience of large scale supply anywhere in the rorla. In the U.S. 
where olectric lighting had developed most rapidly, wost power stations were very small. By 1891 the average U.S. undertaking had $2-4000$ lamps connected. Only in New York, Chicago, and Boston in the late elghties were there stations comparable in size with the ones being planned in Britaln. The quality of English enginecrs was high; there were many exciting inprovements in machinery anc mains. The irdustry was in the hands of engineers and they were able at this tine to find enough capital to carry out their schemes. The general cyclical upswing in the economy fron 1887 made borroving easier. This was reinforced by the electric Iighting Act of 1888 but even without this Act the abundant general supoly of funds relative to demand made it easy to get capital. Thoy had learnt from their mistakes in the early 1980 s and put electricity supply in a sensible economic position - one where the factor endowments of the British economy were properly undorstood. There was considerable co-operation between electrical supply undertakings and the electrical manufacturers; in many cases the same people were involved in both. Crompton planned the Kensington and Knichtsbridge Conpany and was also manufacturing scoe iof tho plant ho was to use there. Perranti ran a small manufacturing business a.1 through the time ho was rorking at DeptPord. The kiectric Construction Corporation headed by Thomas Parkar designed the oxford plant and also constructed the electrical machinery for 1t. The Brush Company designed and manufactured the plant for the City of Iondon Electric Supply Co. and was responsible for putting the

1. See H.C. Passer, op.cit., PP 30, 121 and 150.

2. Seo R.H. Parsons, op.cit., and R.V. Hunter and J.T. Hazell, op.olt.. 
system on ita feet. Technical change had proceeded rapidy in lowering costs and it was clear that more prosress would take place.

Thus in the enrly 1890 s one could be really quite optinistio about the future. 
Chapter 3.

Electricity Supply $1896-1214$.

By 1896 electricity supply was firmly established in this country. The experience of those places which had pioneer stations showed that the demand existed at prices which were profitable. Sevoral munioipal corporations had bullt power station, and encouraged by their success many others follored. Capital expenaiture by the municipalities rose from 1893 at an increasing tempo. The damonstration of the practical success of electric supply coincided with the rise of the muicipal trading movement which reached its peak around 1900. Company pronoters sav the success of the Iondon and provincial companies and as soon as the cyclical upswing of the late 1890 s mado finance easier to get, company power stations began to be constructed all over the country. The pattern was typical of the one noted more widely by Schampeter; first there was the pioneer innovation in the late eighties and early nineties and then with the next trade cyclo camo widespread imitation innovation. The volume of consiruction makes the investmont of the very early days look very small indeed. In the three years 2897 - 99 inclusive as much was spont on public supply as in all the years before 1897 : by the end of 1903, when the boon in electric supply construction was breaking, five times as mach had been invested as before 1897. Thereafter the rate fell off, but continued throughout the period at an annual rato higher than any in the early days. Tables 16 \& 17 give same relevant data; the latter shows the large number of new undertakings established and also shows that exlsting undertakings were growing ravidly enough for the average 8120 to moro than double itself. 
Table 16.

Gross Investment in British Electricity Sunply 1896 - 1223.

\begin{tabular}{|c|c|c|}
\hline Year & $\begin{array}{l}\text { Gross Investracnt } \\
\quad \& 000\end{array}$ & $\begin{array}{l}\text { Additions to capacity of } \\
\text { generating stations. } \\
\text { KW }\end{array}$ \\
\hline 1896 & 1,972 & \\
\hline 7 & $\therefore 2,472$ & 20,236 \\
\hline 8 & 3,285 & $33,4,46$ \\
\hline 9 & 4,822 & 60,175 \\
\hline 1900 & 6,260 & 79,608 \\
\hline 2 & 6,502 & 107,099 \\
\hline 2 & 7,3499 & 92,352 \\
\hline 3 & 7,602 . & 80,352 \\
\hline 4 & 5,241 & 93,607 \\
\hline 5 & 5,361 & 206,667 \\
\hline 6 & 4,582 & 83,119 \\
\hline 7 & 2,892 & 102,121 \\
\hline 8 & 2,734 & 38,527 \\
\hline 9 & 2,603 & 54,910 \\
\hline 1910 & 2,722 & 70,350 \\
\hline 11 & 2,805 & 97,019 \\
\hline 12 & 1,633 & 134,487 \\
\hline 13 & 3,335 & 117,332 \\
\hline
\end{tabular}

Sourco: Calculations fron Garise's Lanual of Ilectrical Undertakings. 1907 and 1925 . For mothods of computation and estimation sco Appendix P 486. 
Taolo 17.

Avcrage sizo of Supply Undertakings measured by $\mathrm{KW}$ capacity of generating plant.

\begin{tabular}{|c|c|c|c|c|}
\hline Year & $\begin{array}{l}\text { Approzimate } \\
\text { liumber of } \\
\text { Supply } \\
\text { Undartakings }\end{array}$ & $\begin{array}{l}\text { Number } \\
\text { with } \\
\text { roliablo } \\
\text { statistios }\end{array}$ & $\begin{array}{l}\text { Averaje } \\
\text { size of } \\
\text { undertakings } \\
\text { in Col. } 2 . \\
\mathrm{KW}\end{array}$ & $\begin{array}{l}\text { Number of very large } \\
\text { undertakings } \\
10,000 \mathrm{~kW} \text { and above }\end{array}$ \\
\hline 2896 & 124 & 107 & 870 & 1 \\
\hline 2900 & 210 & 133 & 1510 & 4 \\
\hline 1903 & 332 & 275 & 1890 & 9 \\
\hline 1907 & 380 & 297 & 3000 & 19 \\
\hline 1912 & 391 & 295 & 4460 & 34 \\
\hline
\end{tabular}

- Figures as at 3lst Decernber or 3lst Harch the following year.

* A few very small undertakings may be missing.

Source: Garise's Línual.

By the ond of 1903 all the wiger torns had electricity supply, although only a very small proportion of their populations had electrio 11ghting. Before 191: only a fringe had electricity in their houses. In $1910 \mathrm{I}$. Crouch colculated that in 80 inland torns electricity consumers were 2.5\% of the population. As oach house had only one consumer but

I. L. Crouch. Electrical Develonment in Industrial Areas. E.R. Vol. 70 . PP 75 - 6 \& $117-9.12 \& 19$ Jamiary 1912. 
several users tho porcentage of the population using eloctricity was mach higher: in industrial torns in 1911 the number of persons per house 1

raried between 4.0 and 4.5 and this would make the numbor of persons using electricity in the big towns range from $6.1 \%$ to $6.8 \%$ of the population, excluding domesitic servants. In 2903 the percentage was very mach lower. Electricity was still very largely for lighting, olthough from 1900 on; Iublic supply stations started selling electricity to the ner electric tranways.

The minicipalities played a very important part in this. Wany municipalities had built new central stations in the late ninetios and in the early years of the new century, whilo existing ones had been raptaly expanded. By the end of 1901, 61\% of the connections to public supply mains (measured in Kir) verre to municipal mains, and by the end of 1903 the figure had risen to $68 \%$. This wos a peak figure but the percentage eell off only slightly in the folloring jears before 1914 .

Table 28.

Comections to Public Supnly Malns.

$\begin{array}{cccc}\text { Yoar } & \text { Municipal Supply } & \text { Coxpany Supply } & \text { Total } \\ 1896 & \mathrm{~N} / \mathrm{A} & \mathrm{N} / \mathrm{A} & 115,000 \\ 1901 & 247,300 & 153,100 & 394,400 \\ 1903 & 448,34.1 & 207,626 & 655,767 \\ 1907 & 823,550 & 426,516 & 1,250,066 \\ 1912 & 1,218,585 & 630,424 & 1,849,009\end{array}$

Source: The Flectrical Trades Directory. N.I.S. Co. Historical Stat1stics.

1. J.H. Clapham. An Economic History of Modern Britain. Vol. 3 Cambridge 1951. P 459 
Increases in demand for electrio lighting seem to have becn the main motive force behind the boon. There is no rcal ovidence of supply stations being built ahead of demand. On the other hand, there is evidence that in sone places at least the denand for electrio lighting was consistently underestimated. Edinburgh Corporation found in 1897 that 1ts estinate of revenue for tirat year was only $80 \%$ of tine octual figure. In September 1897 Shefileld Corporation, having the year before bought the electric supply company gave notice that it could accept no more customers. The imrediate cause was said to be the nan-delivery of plant owing to the great engineering strike of that year, but their having no reservo capacity indicates the pull of denand. Rarly in 1898 Sunderland estirated its demand for 1898,1899 and $1900{ }^{3}$ the estimates were $98 \%, 83 \%$ and 69,0 of the ectual totals. But perhaps the best example of this is Nanchester. Initially the system was built for 40,000 lamps and opened in July 2893 by Sarch 1894, 40,000 wore on the mains. Plant was put down for another 16,000 Iann3; by Varch 1895, 66,914 lamps were connected. Thus a big increase was planned to bring total capacity up to 120,000 lamps by the time the plant was ready to come into operation $\psi_{4} 3,398$ lamps were connected. Then there was a rushed job to provide another 50,000 lamps capacity. Thoro was no time to build a new station so some of the rachines installed anly

1. I.R. Vol. 40. P 783. 4 June 1897.

2. E.R. Vol. 4I, P 409. 24 September 1397.

3. E,R, Vol. 42, P 550. 22 April 1898. 


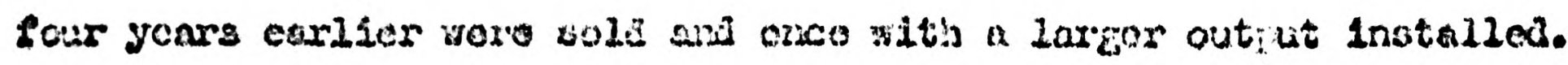

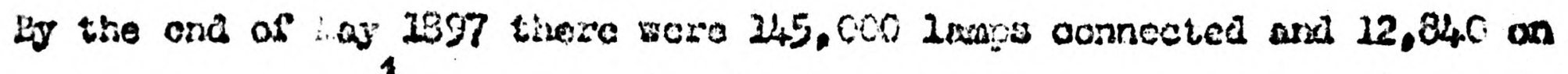

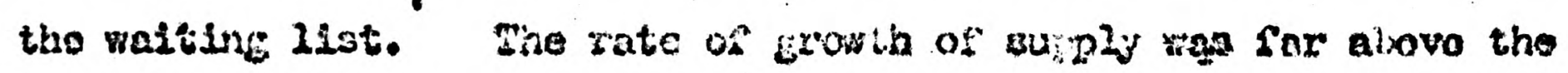
Corporation's expectationa, ajuling as lit wis aver. year. It hed boen cripecied that tino original plant would loot for throe Jcara, but Ansticad there were those basty adlitiono, ard aevare overloading of plant. Not

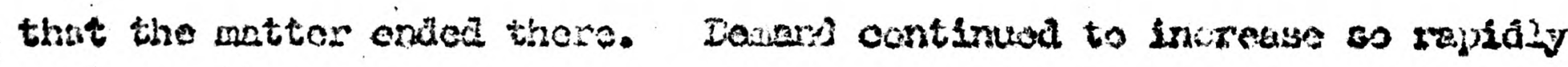
that in the enoly part of 1901 the elootrio liwhing combittan was at

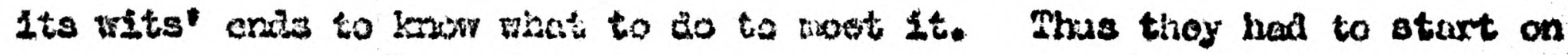
the extensions to the nent Stuart street contral station beforo tho firbt part was opers. Not really wail2 Liarch 1903 was there thought to be

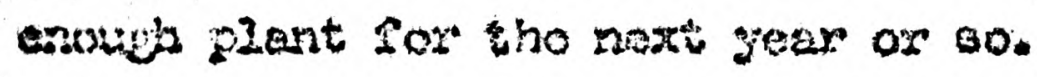

Anothor picco of evidence to support the vien tint it was tho pwll of demand which dotexulued the tiring of centrol station canstruction is the attitude of tho mulcipalities. Fory ready to trade, yoi carotul.

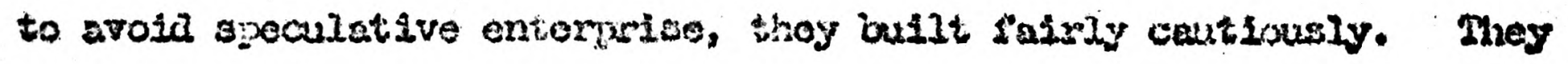
did not seo tine oreation of deniand ss one of thoir functions at ald. Tho hif denand for eleotrichty for lighting sn the late niroties seans prixcipally to have boen due to the enowing arreosation of the advantages of clectric liuhting and to reatuctions in the price of electricity.

1. 2.R. VoI. 4.0. 2. 74.3. 23 hay 2557.

2. 2.1.. Vol. 33 P. 237. 21. Feomuary 1896.

3. En Voi. 50 \&.896. 30 May 1902.

4. E.s. Vol. 52, PP. $391-2.6$ varcin 2903. 


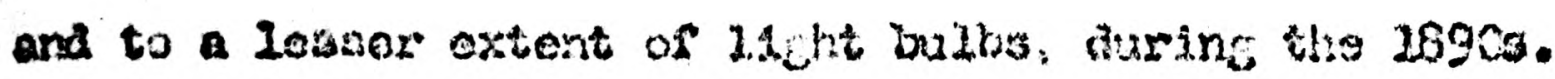

Taule 29.

The artes of cloctriosty for 1 inding $2823-3212$

\begin{tabular}{|c|c|c|c|}
\hline Yoar & $\begin{array}{l}\text { Munbar of } \\
\text { undontakings } \\
\text { in exrolo }\end{array}$ & 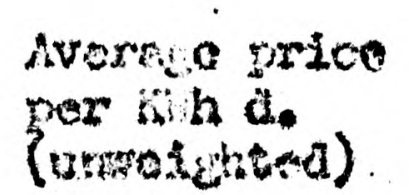 & Vartarsos. \\
\hline 3893 & .35 & 7.27 & \\
\hline 1394 & 54 & 6.90 & \\
\hline 2393 & 20 & $4.7 \%$ & 1.21 \\
\hline 1912 & 20 & 3.63 & 3.27 \\
\hline
\end{tabular}

Calculations frow tho Bloctrictan end Gorioto inaral.

It my have been stimulated by the bullding bacm which begins around 1395, and the goncral industrial bow of the late $139 \mathrm{Co}$,

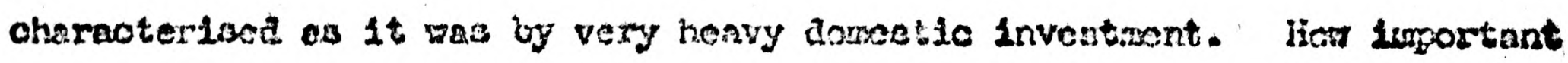

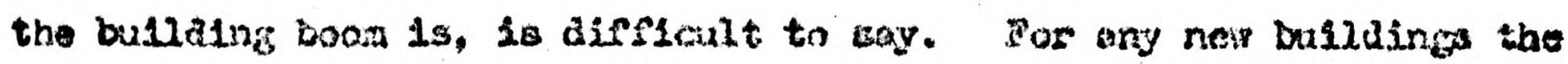

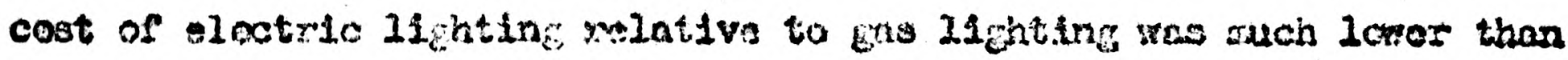
for old ones, which woro arready carcassed for gas. Also the Inteial onst of wixing old houses, es it hal to wo ano by tho conewnor, could woll

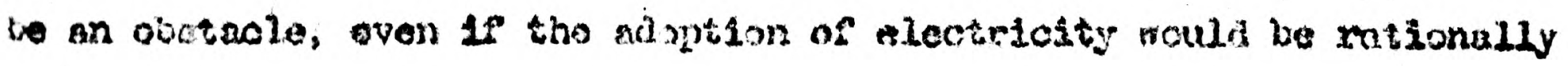
Justiflat. Eloctric zut 2y mains were only lald in the midalo of town,

1. B. Webar A Now Irdex of Fosiclontlaz Consiruotion and Lon, Cyoles in Inves Dullaing in Groat iritain 1070 - 2950. Goottish Journal of Political kon vig. Vol. 2 IT $3 \mathrm{C}_{4}-132$.

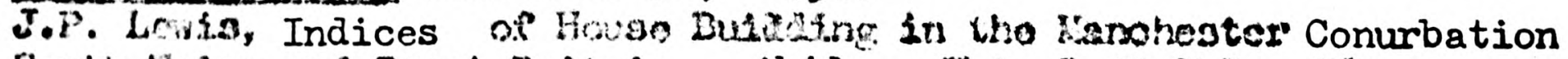
South Walce and Great Dritaln. ibid... Vol. 8 pP $U_{4} 8-56$. 
and thas all new building on the outskirts is irrelevant. But there was a considerable arnouis of reconstruction all over the country in the housing boom of the late nincties.

A large proportion of electricity wes sola to shops and offices, and they rould be stiraluted by the uptum of the business cycle. Better business conditions would stimulete the rewodelling of the bigger shops and they wolld be libely to instail electric lighting as part of their modernisation scheres.

In this situation it was not in general to be expected that lare scale plant, fully exploiting all possible economies of size should be laid down. Power stations had now plant fit piecomeal into buildings designed for snaller plant: there was often ro tine to plon the whole gystem in an ideal marner. What makes this important is that the possible economies of scale were onjy potential. Planning and building bigger incividual pieces of tachinery was the responsibility of the encine, dynamo and boiler makers.but the planing of the system as a whole wos in the hunds of the clcctricity sup liers. Also they were the onos who had to decicie so iry new types of plant, whose delivery dates were longer than iried units. For by the midale nineties the design of power stations had passed out of the hands of the manuficturers of plant into those of consulting engincers, who were appointed to build and cxtend supply systems. Witid raro excepions they were coraletely independent of the manufacturers.

1. A.K. Caimcross. Home and Foreirn Investruent $1870-1913$.

Cambriage 1953. P27. 
The municipalities were used to employing consulting engineers for other works like buildings and santtary scheines and noturally extended this to electricity supply. The optimum size of gonerating machinery was extended during the $189 \mathrm{Cs}$, as manufacturero were able to design larger units satisfactorily, reducing the cost per $\mathrm{KW}$ at the same time. But partly because of the factors mentioned above, the size of generating unst Installed pas a good deal smaller in general by the late 1890 s than wao the case in the United States or on the Continent of Europe. By Soptember 1900, when American and Continental influence was becaming important, the Plectrical Roview comnented that only in the last few years had British manufacturers had a demand for dynamos abovo $300 \mathrm{KN}$. But apart from demand there was one factor on the mamfacturing side which reinforced this tendency torrards small units. This was the success of the high speed engine. Its development and use for driving dynamos was extremely valuable, and peculiarly British Innovation. The utility of a high speed engine for driving dynamos was apparant from the very early days. The desirable speed of rotation of dynamos was high relative to that of most stean engines, 400 - 900 r.p.m; as against under 200. At first rope driving was adopted to provide the necessary gearing but the consequent loss of power made direct driving attractive. Direct driwing with high speed engines springs from the co-operation between Crompton and Peter Willans

1. Born 1851. Apprenticed at the age of 16 to lessrs. Carret and Marshall at Leeds. Then he worked with J. Penn and Sons of Greenwich and liessrs. Hunter and English of Bow on marine engines. In 1880 he went into partnership with hark Robinson to develop his high speed engine. 
Table 20.

Prime movers installed in British central stations. 1883 - 1902. Percentares.

Year

Up to and

including

1892

93

94.

95

96

97

98

99

2900

01
All high speed reciprocating engines 1
Willans engines

フ 
in $1879-80$. Willans was developing high opeed engines for launches and yachts. Crompton was a mechanical engineer who had just became interested in electric lighting. Together they camo to the conclusion that tho generating sot of the future would be a high speed engine coupled direct to a dymamo. They made their first central station installation using six $125 \mathrm{KW}$ Willans-Crampton generating sets in Vienna in $2883-6$. $^{2}$ Such was the success of the Willans engine that all the London d.0. central stations of 1888 - 92 used direct coupled Willans engines. Thoso high speed generating sets were initially cheaper than slower ones, and their fuel consuraption was very low. As a result high speed direct coupled units becane standard a.c. practice for the 1390s. Willans engines retained their pre-eminence although othcr manufacturers also made high spoed engines. These engines were admirable when small i.e., below $200 \mathrm{~km}$. But it was dificult to build bigcer ones, and they did not work so woll. Even the big supply undertakings with more than $10,000 \mathrm{~kW}$ generating capacity had small generating sets. Lhanj of them had a number of central stations. Several of the Iondon companies had had several otations from the very eerly days. Perhaps the most extremo examples of the duplication of small plant are the Ifiverpool Corporation posver station which as late as 1904 had 78 generating units aggregating $24,825 \mathrm{~km}$ and

1. R.E.B. Crompton. Reminiscences. P 89.

2. Ibid. 105.

3. R.H. Parsons, op.cit. PP 72, 75, 78, 84, 97, 203, 107.

4. R.H. Parsons. op.cit. P 164 . 
the Festminster Company which in 1903 had 49 units aggregating 9,330 $\mathrm{kN}$ in threo power stations. But there were soino big power stations which atterpted to extend the fronition of scale economies. It 18 usefur to consider thom under tro headings, first the biE power stations of existing undertakings, and second those of the porrex companies, nost of which were founded in 1900 and 1901. Discussion of the latter is best aeferred to the next chapter.

As the load on the early stations in tho centre of town Exer, and irprovewents in electrical machinery continued it began to be economically sensible for a supply undertaking to build a big new station some distance away from the centre of its supply area and transmit at high voltages. This was frecilitated by three very important innovations, all products of the 1890s. The first was the introduction of polyphose aiternating current. Tho second was the use of paper insulated cablos. The third was the developrient of the Parsons stean turbine.

The initiators of polyohase a.c. were Profossor G. Ferraris, 2 Nikola Tesla and Von Dovilo Dobrowolsky. It was intensively developed In the United States, particularly by Westinghouse, who omployed Tesla, but also by General Blcctric, and in Europe particularly by A.E.G.,

1. Sec Tecinnicai Appendix .

2. J.A. Flening: op.cit., P $U_{4} 6$.

3. H.C. Passer On.cit., Chapiers $18 \& 29$.

4. Allgaracino Bleitzizitäts Gosellschart, originally the German Edison Co. 
who cmployea Dobrowolsky, and the Oerlikon Comparv. fuite apart from its use of a 3 phose ${ }^{1} 8.0$. transmission Iine could recuce the copper cost of the nains by 15\%. 3 phase alternetors vere cheaper than ordinary a.0. (sinelo phaso) rachines. Also it was easy to convert 3 phase a.c. to d.c. and thus hich voltace transmission could be linked to the existing d.c. distribution systen arla the new a.c. porer station run in parallel with the old d.c. cne. This was not possible with single phase a.c. C.I.I. Brown of the Derlition Company and Dobrowolsky demonstrated a 3 phase a.c. transmission syster at $30,000 \mathrm{v}$. over 110 miles Prom Franlefurt to Lauffen as part of the Electrical Exhibition at Franidurt in 1892 . Cver 300 bo p. was transmittcd, 74\% of the pover being received at the other end. This gave a powerfui impulse to the Niataxa Scherre of 1835 when 10,000 h.p. was generated at Niagara and transmitted at 71,000 V. 2 phase.

Very fen Inglish electrical engineers ware in the 18903 at all interested in polrphase a.c., and Finglish manufacturing firms could seo no point in it at all. Flectricity supply engineers were hovever nore progreesive and one of the best, C.iH. Wordingham, Nanchester Corporation's Chief Electrical Engineer, who hnd workea witi Ferranii at Deptford, pointed out to the Northern Society of Electrical ingineers in November $1897^{5}$ that

7. 2 phaso a.c. was also used in the early days. It was intially aimpler than 3 phese but ultimately inferior.

2. H.C. Passer. on.cit., P 282.

3. See Technical Appendix,

4. J.A. Flcming, op.eit., ?.239

5. E.R. Vol. 4I, PP 733 - 6. 19 Novembor 1897. 
conditions rere now very diffcrent front those in the envy years. Then, he argued, it was a question either of a cluster of chibuters taling a fairly larce amount of energy, cathered in a compnct ares, or of a number of 1solated consumers scettered over an extented Area. Hence the "battle of the aysters". How, howeres, he angied, both supply density is rioing

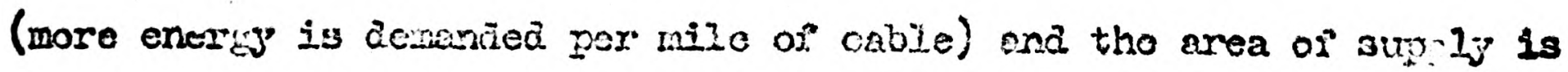
being extended. Ho preferred d.c. dietribution; it was botter for motors and arc lains, and accumulators could be used. Pach distribution notwork would be fed by d.c. or yolyphase a.c. transmission lines, elther from one large station or from several. small ones according to local circunstances. Before he Iart Nanchester Corporation in 1901 he had designed and built a 10,500 $\mathrm{KT}$ d.c. station and a 19,000 Kh 3 phsse a.0. station with high voltage transmission. The tondon companios by tho late nineties had outgrom their smoll stations and they also bul.lt vig stations sone distance frou tincir supuly aroas. In 1897 the lictropolitan Electric Supply Comnany decided to build a new station at willesden; three 1,500 KNI 2 phase alternators built by Westinghuse vere installed and transmission was at 10,000 . The Kensington and Knightsbridge Company and the Notting Hill Conpany combined to build a joint generatine station which was opened in 1900. This worked 3 phase at $5000 \mathrm{v}$., tho first high voltago 3 phase system in this country. A furthor step was taken by tho Charing Cross Conpany wich oponcd its now power station at Bor in 1902. This worked at $21,000 \mathrm{v}$. With $1,600 \mathrm{KH}$ genarating units, built significantly by tho

\section{Soe Chapter 6.}


Iahmeyer Company of Cologno. It is worth noting that although Britioh electricity supply was adoptine Ferranti's transmission pressure it made no attempt to build plant of the size he proposed. Thus the big power stations began to be established, but there is little doubt that this country was slow to edopt American and Continental innovations.

Paper insulated cables were first used for mains by Ferrant1 at Depford. They vere the culnination of severl attempts maile in the eighties to inprove cables. Telegraph and telephone cables wero not suitaole for electric lighting. Several alternatives wore tried. Somotimes the improvements were in insulating material like the use of vulcanised Bitumen or jute. Sometines the improvenents were in the general design of the mains, like the use of bare wires or rods suspended on insulators In an underground tunnel. But generally they all had the disadvantage either that the insulation was not satisiactory for high voltage operation or that they were rigid and this expensive to lay. Then in 1838 Ferrants patented paper insulated cables. Paper was a cheap material, and cheap to apply. The Depford cables, the pirst porfer cavles to use papor as a dielectric, were however rigid tubes. Tho paper insulation ras rolled on in shoets 20 feet long. However Ferranti's patent also covered use of paper applied helically in strips. This method had also been used in the United States for telegraph cables. Waile on a visit to Americe

1. P.V. Hunter and J. Temple Hazell. Develonment of Power Cables. London 1956. They give a detailed account of attempts to improve distribution mains. 
In 1839 J.B. Atherton noticed paper insulated telephone cables. He bought the British rights in 1890, and on his return to England in 1891 he formed the British Insulated Wire Company to manufacture paper insulated mains cables. In the same year Ferrant left Depford, and possessing the British patent of 1838 for paper winding was invited to Join the board of B.I. Wire. In 2893 the company made same $11,000 \mathrm{v}$. concentric paper insulated cables for the London Electric Supply Corporation. They wero sinilar to Perranti's Depford cables with the additional advantage of flexibility. This meant that they were almost entirely manufactured at the factory, and could be simply and cheaply laid. Very fer joints wore needed. Thus the cost of high voltage mains was very substantially reduced, and thus the economies of scole in generation could be further used.

The third major innovation in electricity supply was the steam turbine. Here the attitude of the English power station onginoers was samewhat arabiguous. It was the wost important British innovation In electricity supply machinery made in this country bofore 194. Ofton the successful idoas came from abroad, but this wes entirely home produced, through the ability and determination of Charles Parsons.

1. 6th son of the third Earl of Rosso, who was an engincer and an astronower, beconing a Prosilent of the Royal Socioty. Born 1854, educated at home by Robert (later Sir Robcrit) Ball the astromer. at Trinit; College Dublin and St. Join's College Cambridge. Ito eraduated from Canbridge in 1877 as Aleventi Vrangler. Ho was annrenticed for four years at the Elswick Works of Sir William Amstrong \& Co. Fron 1881 1833 he worked with Wessrs. Kitson \& Co. of Loeds. In 2834 he becamo a junior partner in Clarke Chapman \& Co. and took charge of the newly created electrical departinent. In 2839 he founded his own works in Newcastle-upon-Tyne. He was a great inventor and we aro only concerned with some of his work. See R. Appleyard, Charles Parsons, Londan. 1933. R.H. Parsons, The Stcam Turbine and othor Invontions 
The basic idea of the steam turbine is very ancient and goes back to the machine built by Hero of Alexandria to open the doors of the temple. Several attempts were made to build steam turbine engines in the 19th centry. But oll failed because such engines only worked efficiently at enornous speeds. In 1834 Parsons patented the idea which was a complete solution to this problem, and built a turbine engine to his patent specification. His idea was to place a serles of turbino wheels along a shaft. Stear passed through the blades of auccessive wheels losing a small amount of its pressure at each wheel. Because the energy in the steam was not instantly converted into rotating motion, but ras used gradually, the speed of the turbine engine could be vastly roduced without loss of efficiency. The Parsons turbine of 1884 used, however, considerably more steam than a conventional steam encino for a given power, 129 Ibs. steam per KWh while as efficient reciprocating steam engine would use about 20. By 1392 Parsons had inproved the turbine until steam consumption was down to 27 IDs. per KWh, which although somewhat above that of the best reciprocating engines proved that the turbine was not necessarily wasteful. It seens to have been relatively less wasteful at smoll loads, which was particularly useful for electricity generation. But the steam turbine was primarily a capital saving innovation. Its first cost was slightly lower than that of reciprocating engines when bullt in large sizes above about $500-100 \mathrm{Km}$. It pas mach smaller and

of Sir Charles Parsons, 0.M. Scie co in Britain seiles published by the British Council. A iurstall, 2ho Place of Sir Charles Parsons in the In the History of Mechanical ingin ering Lecture to the Stophenson Ezineering Society, King's College, Newcastle-upon-Tyno. 1954. Published by the Heaton Worles Joumal Sumer 1954. C.A. Parsons, The Steam Turbine, Cambridee. 1911. 
Lighter than large reciprocating engines. It is instructive, although rather extreme, to compare the $7500 \mathrm{KN}$ turbo alternators which were instajled at Deptford in 1912 with Forranti's projected rcciprocating engines. The latter would have been 3.7 times as wide, over 5 times as high and 0.9 times as long. As a result the cost of foundations and buildings was mach reduced; it was about half that involved in installing large reciprocating engines. It was a rach faster engine, which mach reduced the cost of the dyramos driven by it: instead of the enormous fly wheel altemators ariven by slow speed engines, compact machines could bo used with only a fraction of the size and witight of the former. Also the turbine had a particularly useful characteristic for electricity supply; it would run for a short timo at extremely high overloads. Thus the sharp peak of the electricity load could be net with plant whose normal capacity was perhaps oniy three quarters of the peak demand, very substantially reducing tive cost per KW of maximum demand. Turbines would thus have been capital saving even at the same cost per KH of narmal capacity as reciprocating engines.

During the $1890 \mathrm{~s}$ stean turbines were used only in this country. This was partly beceuse Parsons was an Finglishrnen. The first turbo altermators were installed at the Forth Banks power station at Newcastioupon-Tyme in 1839; the company was however forwed by Parsons and his frtends and the fonver was the managing director. In 1892 they wore put into the nowly formod Cambridge Company's station; again Pansons 
was the managing director, the corupany boing formed by Parsons and Cambriage university friends. Other sinall turbines were installed but the most important turbine plant of the midale $1890 \mathrm{~s}$ was that at tho lletropolitar Electrio Supply Company'a Manchester Squaro Station in London. Here the Willans engines caused a great deal of vibration, which a whole series of expedients were porrerless to eliminate. Neighbours complained of the nutsance and In 1894 obtained an Injunction ogainst the Company. But the Btation was saved by the installation of 350 KW Parsons turbomalternatore more than twice the slize of any hitherto built. These were however somewhat special circumstances, for in general the turbine alsplayed no very great advantages over the high speed engine when it was built in small sizes. Its superiority was over the big low speed ongine and thus one would not expect the turbine to be widely installed until big generating units, were used. English power stations were slow in installing big plant and thus it is not surprising that from 1900 - 1905 the pioneer big turbine installations were in the United States and on the Cantinent. The first big Parsons machines were built for tho Corporation of siberfield in Gerny in 1900, with a capacity of $1000 \mathrm{KW}$. The Westinghouse Nachino Company acquired tho Parsons patents in 1896 and rapidiy developed them;

1. A.C. Ewing, Prosessor of Enginecring at Canbridge conducted important tests on iarsons turbines in 1892, dispelling their carly roputation of being "stean eaters". It is amsing to seo that in eleotrio lighting systems, as in other natters, Oxford should by comparison be the bome of lost couses.

2. R.H. Parsons, op.cit. P 381 . 
1

Brom-Boveri bought a licence inwediately after the succe.s of the Elberfeld machines, and again developea them rapidily. They wero quickly followed by Gencral Llectric in the United Statics and A.F.G. and Slenons \& Halsko in Germany with different types of turbino. In both places big generating units were widely used and thus thare was a bicger demand for large prime mover's. It is horgever rather surprising to flnd that when English eleotricity supply eninoers did build big plant, they used large reciprocating vachinery, usually of foreign manufacture. The Lotropolitan Electrio Supoly Company, despite 1ts Kanchester Square turbinos, chose Westinghouse plant for its Willesden station. Wordingham at llanchester is an odder case. The speciflcations for tho huge stuart Street plant were issued in 1901. Turoines would almost certainly havo been better, although their advantages in large sizes had only just been demonstrated. But as late as 1905 Wordinghom, although extremely able and still under 40, told a House of Lords Cornitteo that he thought turbinos were a passing fashion. An exarple of really antiquated practice is provided by the Greenrich tranary porter station of the I.C.C. opened in 1906. Four $3500 \mathrm{Im}$ engine altermators were installed; $6 \frac{1}{2}$ yoars later it was realised that they wero obsolete and tro $8000 \mathrm{KW}$ turbo alternators instailed in the samo space.

1. Foundod in 1892 by C.E.I. Bromn. The works were in Baden.

2. Proceedings before the Select Comnittee of the House of Iords on the Aaninistrative County of Iondion Company and District Electrio Porrer Bill 1905. Q 5601 .

3. E.R. Vol. 71, P 943. 13 December 1912. 
1

As R.H. Parsons has pointed out there was no real excuse for this as the Nercastle Electric Supply Company had had very successful $3500 \mathrm{KW}$ turboalternators running at Carville in 1904. Profossor A.T.B. Konnedy, the consulting engineer to the L.C.C., had become an export in designing successful small stations in the 2890 s but by 1905 he seems to have lost his touch. Charles Merz's brilliant achievement at Carville is a pleasing contrast, and his plans for Iondon, if allowed to bo put Into operation, wight have revolutionised English power station pract10e. After the success of Carville, however, turbines did come to be used consiajerably for big plant. There was still considerable controversy about the merits of steam turbines, but it soon became generally accepted that turibines were better than reciprocating engines in sizes above $1000 \mathrm{KW}$. Below $500 \mathrm{~kW}$ reciprocating engines were sald to be better. There is rather inadequate information about the switch from reciprocating engines to turibines. By the end of 1903 at least $2500 \mathrm{KW}$ of Parsons turbines had been installed in British central stations. This was only 2.6\% of total capacity. $25000 \mathrm{kF}$ is no doubt an underestimate but it is not likely that the actual pigure was more than twice this. Between the end of 1903 and the end of 1907, 408,000 KT of capacity

1. P 169.

2. This is confimed by his evidence before the House of Lords Commttee, on the Adninistrative County of Iondon \& District Electric Power Bill. There he said that 3 phase supply Eould, he felt certain, have ceased to exist in 15 years time. Q 4578 .

3. E.R. Vols. 53 \& 54 for a long controversy in the correspondence columns. Table on P 54 of V01. 54 and Vol. 55 PP 2009 - 1010. 
was installed in British central stations. By then there pere $250,000 \mathrm{KW}$ powered by steam turbines. This $53-58 \%$ of the canacity added in the years 1904 - 07 was driven by turbines. Table 21 shows that not until 2904 did the averago size of gencrator rise above $500 \mathrm{KW}$. Thus turbines were largely not were not used.

By the end of 1903 electricity supply undertakings existed in nearly all big towns. All tows but tro with a population of more than 100,000 had electricity supply. Blectricity was sold mainly for lighting. Supply stations were smali on the average and distribution mains did not extend very far. As a means of lighting electricity was much less used than ges. When converted to a cormon bosis, electricity seens to have provided 6,057 million 16 c.p. light hours in 1904 , against 28,300 million supplied by gas. This was only $18 \%$ of the total but was considerably wore than the $4 ; 3$ supplied by electricity in 1896. Iet during the yeors 1396 - 1904, the light hours suonlied by electricity rose only by 5,185 million p.2. while those supplied by gas rose by

1. Census figure minus 4\%,000 k/ at Iots Road. The Census figure also includes any turbines in municipal tramway power houses. But there wero very lew turbines in ranicipal trauvay power houses in 1907.

2. Deperding on whether we take $15,000 \mathrm{kw}$ or $30,000 \mathrm{KW}$ as the capacity of turbines installed at the end of 1903.

3. Inaugural adiress of R.G. Gray. President of the I.2.D. Novemiber 1903. E.R. Vol. 53, PP 84.1 - 2,880-3.

4. Assuming a 16 c.p. electric lamp took 60 watts ( 3.75 w. per o.p.) and a $16 \mathrm{c.p}$. ges burmer took $5.5 \mathrm{cu}$. Peet of gas per hour. Tho calculator is very crude. 
Table 21.

Averago sine of gerofators inwlailea in British centrals stations $18893-1213$.

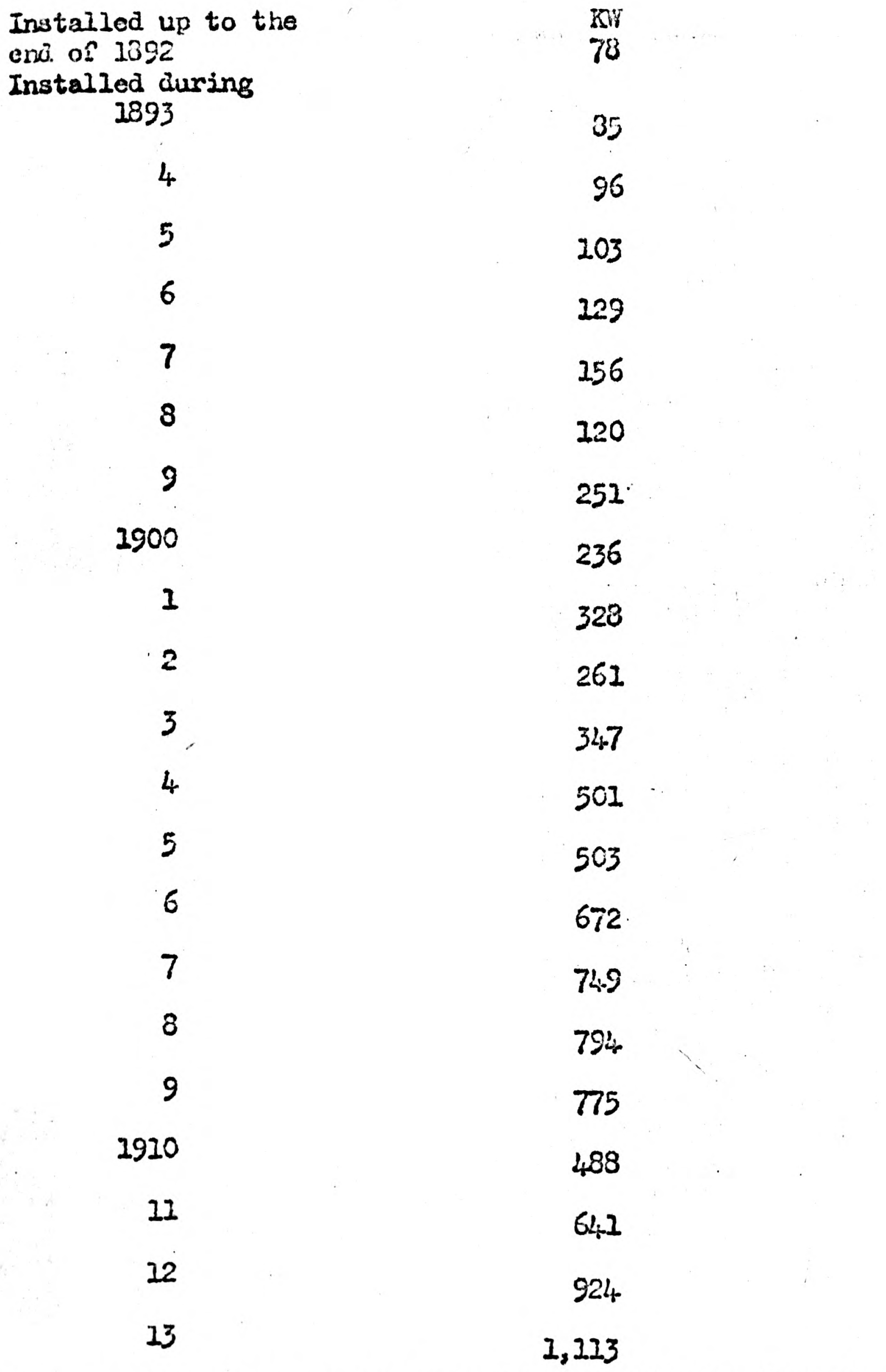

Source: Calculations from the Electrical Trades Directory: For details see Aprendix P. 510. 
makie 22.

Rlectricity Suply. Sales, dillion Fih.

In the sirst three columas fleures are for the accounting year which most overlaps the relevant calcndar year. In the fourth colum figures havo bean corrected to a calendar yoar basis.

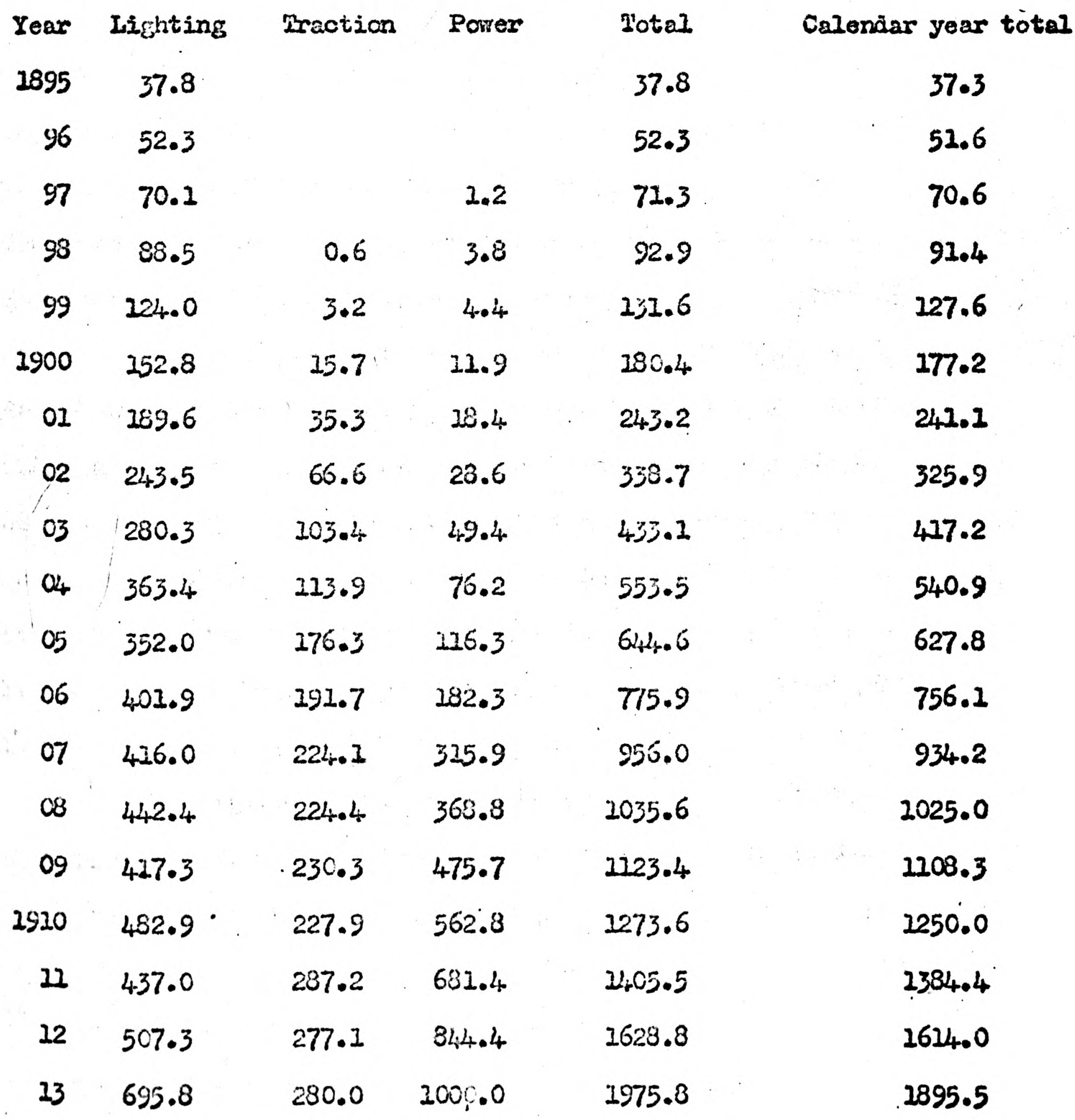

For details of calculations see Appendix. P 489. 
7,000 million. The incrense in gas ligiting may howover bo ovorestimated .

Eleciric lighting was unfortunate in that by the tine the cost of oloctrio incandoscent lighting had cone dom alnost to that of gas bumers, the incandescent gas mantle had peen developed, which substantially reauced the cost of gas lighting. This nay woll account for the decline in the rate of increcse of tho consurption of electricity for lifhtine. As lablac2 shows the salo of electricity for lighting rose by $247 \%$ botween 1897 and 1902 but only by $71 \%$ between 1902 and 1907. The invention of the retal silament lomp, which began to be usea in larg nuabers frow 1907 omrards redressod the balance again. The metal filoment laing used about a third as mach electricity for a given light as did the carbon filanent lang. After 1907 the use of the metal filawent lamp, the incandescent gas lowp and tho use of gas for heating maize measurements of the amount of 1 ight proviäed by gas and electricity quite imposible. Sales of electricity for lighting dia not riso much (the rise nay vell be overeutinated in fable 22). Dut the amount of lignting rose rapidly, and probabiy more than trebled between 1907 and 1912.

The figures for the sale of electricity for lighting include both incandescent and arc lighting. Lost syas for incandescont lighting. In 2907 incomplete figures were given of the sale of electricity for

1. No allowance has been made for as sales for heating and power, which wore amall yot rising aster than sales of. Eas for lighting, or for the effect of the adoption of the incandescent gas lamp. Theso two erfects would work in apposite directions. 
lighting, soparate figures being given for public lighting (chieily are lights in tho street) arid puivato iichting (chichy incandescent lighting). 17: of the recorded total of saies for lichting went for public lighting.

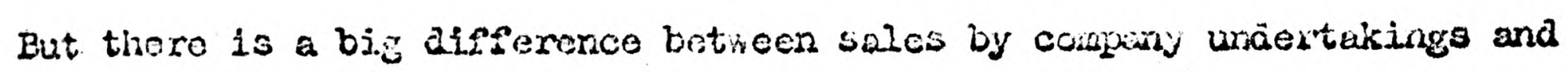
by municipal undertaings. Onjy $3 \%$ of the sales of compaizies for lighting went for public lights, acainst $25 \%$ for tricipaltics. Municipal corporations were willing to uso are lighting in the strects wiben they operated the tom's central station but were not anzious to buy electricity In large quantities srom private central stations. Aftor 2907 street: lighting dia not ircrease very inch. Dather incoxplete figuzes suggest that the amount cf electricity sold for pibile likgting rose by only 17\% between 1907 and 1912. By then ure Iighting was at the end of its useful 1ife. Just before the $29 y_{6}$ war the "hale wait" incancescent lamp ap eared. It was equal in output to tire are lawp, but used only half as ruch electricity. Also there was no need to change carbons. After tho $19 y^{-}$- 30 war it soon supersoded the are lanp. As Table 2? shows sales of elociricity for traction rose rapidy up to 1907, but then flationed as tranyay constmiction fell of. "3. Sales for power began to be inportanit from abulit 194. onwards. Most electricity for power was generated by users, public supply stations in

1. Which is $88 \%$ of iny estiwate for all sales for lighting.

2. 0.5 watts per dandle power efriciency.

3. See Chapter 5.

4. Seo Chapter 6. 
general supplying small users who wed motors intermittently. In this most central stations built originally for lighting supply one different from the power companies. The power companies sold a largo proportion of their electricity to a fow big usors.

The pattcrn of the use of eleciricity bought from central stations to a large extent explains tho fail in central station investinent after 1903. In the late nineties capacity was a function of the 11ghting peak. After 1907 these two loads ceased to frow. The rising power load soems to have had a peak which did not in general coincido with the lighting and traction peaks. Thus relatively littlo extra capacity was needed to meet rising power sales. However from 1911 owwards the rising power load did require considerable additions to capacity. The lighting lood ras also beglnning to rise again. Several comittees sat during the $294_{4}-18$ war to consider the state of the electricity supply industry. By then its deficiencies were glaring; too many snall units, too much variety of practice. But many of the faults were already appearing in the boom of $1896-2903$. After 1903 matters got worse because, 23 is shown in Table 23, there was no increase in concentration. Even by 1903 there nere unexploited economies of scale. After that existing underiakings simply expanded plocenoal. Except on the North East Coast there was no tendency to

1. Coal Consorvation Comittee. Copa.. 9004, 1918.

Electrical frades Comittee. Cf .. 9072, 1918. Williamson Comsitre. Cid. 9062, 1918. Birchenough Comittee. Cxis. 93, 1919. 
centralisation. The power companies, who might heve achieved this, wero not. 1 a success. Existing suppliers could or would not comoperate with each other. This lack of co-operation was very wasteful. The extent of economies of scale will be aiscussed in the next chapter. However one of the major disadvantaces of non-co-operation was the very largo amount of resorve plant needed. Table 24, shows that anly 60,0 of plant was necded on tho average to meet the peak denand. Sorse plant wos clearly intended to meet increases of demand, but not as much as the reraining $40 \%$

\section{Tablo 23.}

Electricity Supply. Percentage of capacity in the largest ten undertakings.

$\begin{array}{ll}1896 & 48.5 \\ 1398 & 38.1 \\ 1900 & 33.5 \\ 1902 & 31.2 \\ 1904 & 28.0 \\ 1906 & 27.5 \\ 1908 & 29.9 \\ 1910 & 29.8 \\ 1912 & 28.9\end{array}$

Sourco: Calculations from Garke's Lamal.

1. See Chapter 4 .

2. Soe Chapter 9. 
Table 24.

Maximum load as a percentare of central station capacity.

\begin{tabular}{|c|c|c|}
\hline Year. & $\begin{array}{l}\text { Number of undertaking } \\
\text { in sample. }\end{array}$ & $\begin{array}{l}\text { Ageregato maximum load as } \\
\text { percentage of aggregate capacity. }\end{array}$ \\
\hline 1907 & 277 & 57.5 \\
\hline 1909 & 276 & 60.9 \\
\hline 1911. & 283 & 63.6 \\
\hline 2913 & 284 & 61.8 \\
\hline
\end{tabular}

Source: Garice's llanuel.

It is important not to overestimate the importance of central station supply. Table 24 suggests that in 1907 and 1912 only 40, of the electricity used for traction lighting and powor came from central stations. 
Table 25.

The use of electrictty 1907 and 1212 . m. Thih.

1907

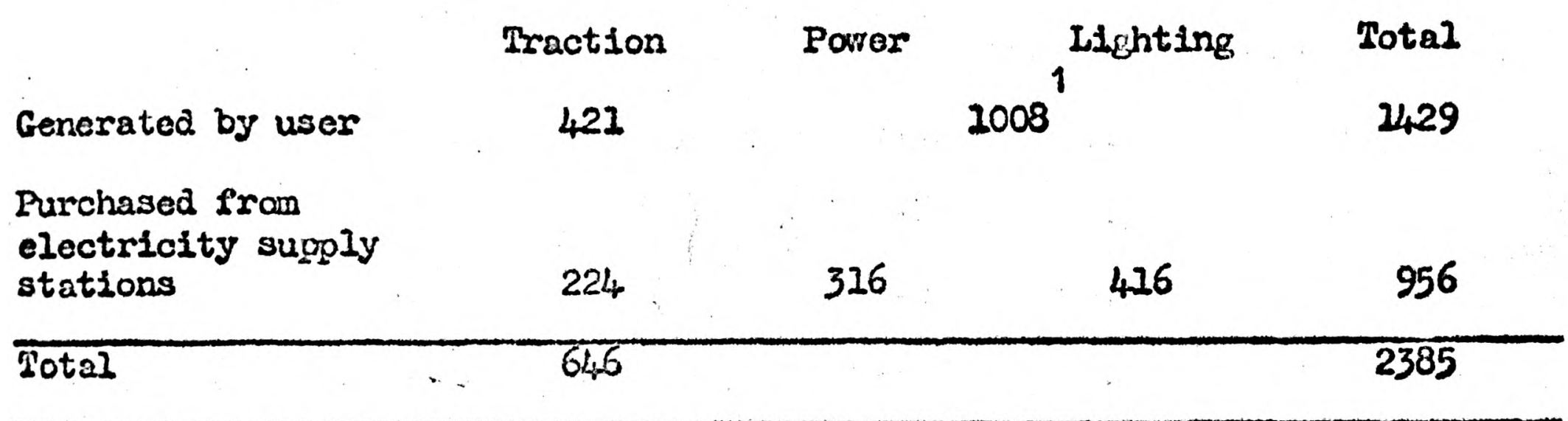

1912

\begin{tabular}{lcccc} 
& Traction & Power & $1^{\text {Iighting }}$ & Total \\
Generated by user & 562 & $1950^{1}$ & 2512 \\
$\begin{array}{l}\text { Purchased from } \\
\text { olectricity supply } \\
\text { stations }\end{array}$ & 277 & 844 & 507 & 2629 \\
\hline Total & 839 & & 4740 \\
\hline
\end{tabular}

1. Power was alnost certainly more than $3 / 4$ of this total. Electric lighting was not used as mach industrially as in shops, offices and houscs, which bought electricity fron public supply stations.

For details of calculations see Appendix. 496 . ifures have been rounded after calculations.

Sources: Census of Productions 1907 and 1912. Board of Trade Feturns relating to tranrays. Aerke's Wanual. 
Avaraix.

The Costo of Eloctricity Sumlta

A larco nount of inforsation was publiohoc about to costs of eloctricity apply during this periok. Infortunately wost of it is elthor deriolent or nislending. Gool sigures of capital covis, a larco

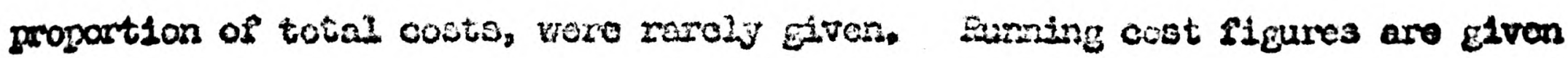
as costs por unit sola (or gonoratod). Bccauso dingy rmaning costs, labour magenent, and oven sono coni costo, vere detenindel by tho sise of tho oontral station rativer than by tho number of units genorated avorago cost IIguros have litile conamio value.

So aralyso prectsoiy tho costs os electricity suphiy and point to changes in cost oves tho period rould bo a very lareo task and has not

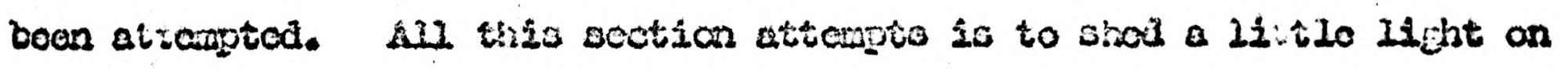
the natter.

Iho costo of elcotricity suply are of three typos. Sirutiy tharo aro costs incurred by mesting the parat cemaral i.o. the coists of cential atation copacisy. and noot of the coit of tre distribution notrarie. Socondiy thore are tho costs inaxred by jarticulas conauners, in particular locations, part of tho distribution notroxis. Thindy there aro tho cooto Incurred by suplyize of perts vinite. Dhene is no information on tho costo lncurred by the goografideal positidon oi particular contumero. Thus wo are Init with capacity costs ens ort pool cenoratine conto; Iong rus and shout run bareme costs resioctivoly.

The mojor comisonent of Iong run mancinizl cost seems to have been

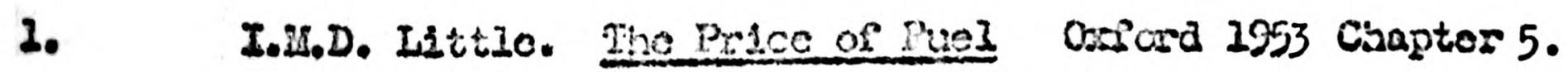


capital cost. To arrive at capital cost we rust first try and get figures o. initial cost per $\mathrm{KWT}$ of capacity and secondly rates of interest and depreciation. There are two sources for initial cost peis kit; engireering estinates and tise marginal cost per hr added pigure which can be derived from ny estinates of gross investment in, and capacity added to, British Central stations. Both are subject to dirficulites. The first, which applies paricularly to enginecring estinates is that there was no accepted desinition of capacity. Capacity of generating sets was the measure of capacity usually adopted, but as I. H. Hobart pointed out generatine capacity figures were vague because there was no widely adopted standard of temperature rise and overload. Indineering estimates clearly had a wide variance, but there are not enough of them for one to be able to estirate, and thus allow Por, this variance. The marinai cost per XII added figure has the advantace that it refers to average.practice. The main disadvantage is that it pluctuates considerably from year to year. This is portly because of inadequacies in tho capital expenditure and capacity fizgures, partily bccause the varianco of the $\&$ per INI statistic was high in practice. To try ard deal with this, three year moving averages were taisen of the investwent and acilitions to capacity series and the \& per In figure derived froin these noving averages. The results aro shown in Table 26.

The gencrating station was only part of ihis cost. often undertakings gave details of capital czpenditure on various parts of tho

1. H.M. Hobart. The Rating and Cost of Stean Pleat je Generating Stations I.R. V01. 64, $17781-2,821-3,359-60,7,4$ and 21 Wha 1909. 
Table 26.

\section{Electricity suonly. \& per HW added.}

$\begin{array}{rr}1853 & 93.0 \\ 99 & 77.4 \\ 1900 & 71.2 \\ 01 & 72.0 \\ 02 & 76.6 \\ 03 & 75.8 \\ 04 & 73.9 \\ 05 & 53.6 \\ 06 & 43.9 \\ 07 & 45.6 \\ 08 & 42.2 \\ 09 & 48.4 \\ 1910 & 36.7 \\ 11 & 20.6 \\ 12 & 19.8\end{array}$

supply system. Randon sarples of 20 were taken for each year, and Table 27 constructed.

Hore is knom about the cost of generatine stations, particularly about the costs of generating sets. A certain arount of prico data is available on gencrating sets, but it is dilficult to interpret. The cost per KN Sell both with bigger machinery, and over time. The generator cost 
Table 27.

Eloctricity Supply. Capital Expenditure. Percentares on various itens.

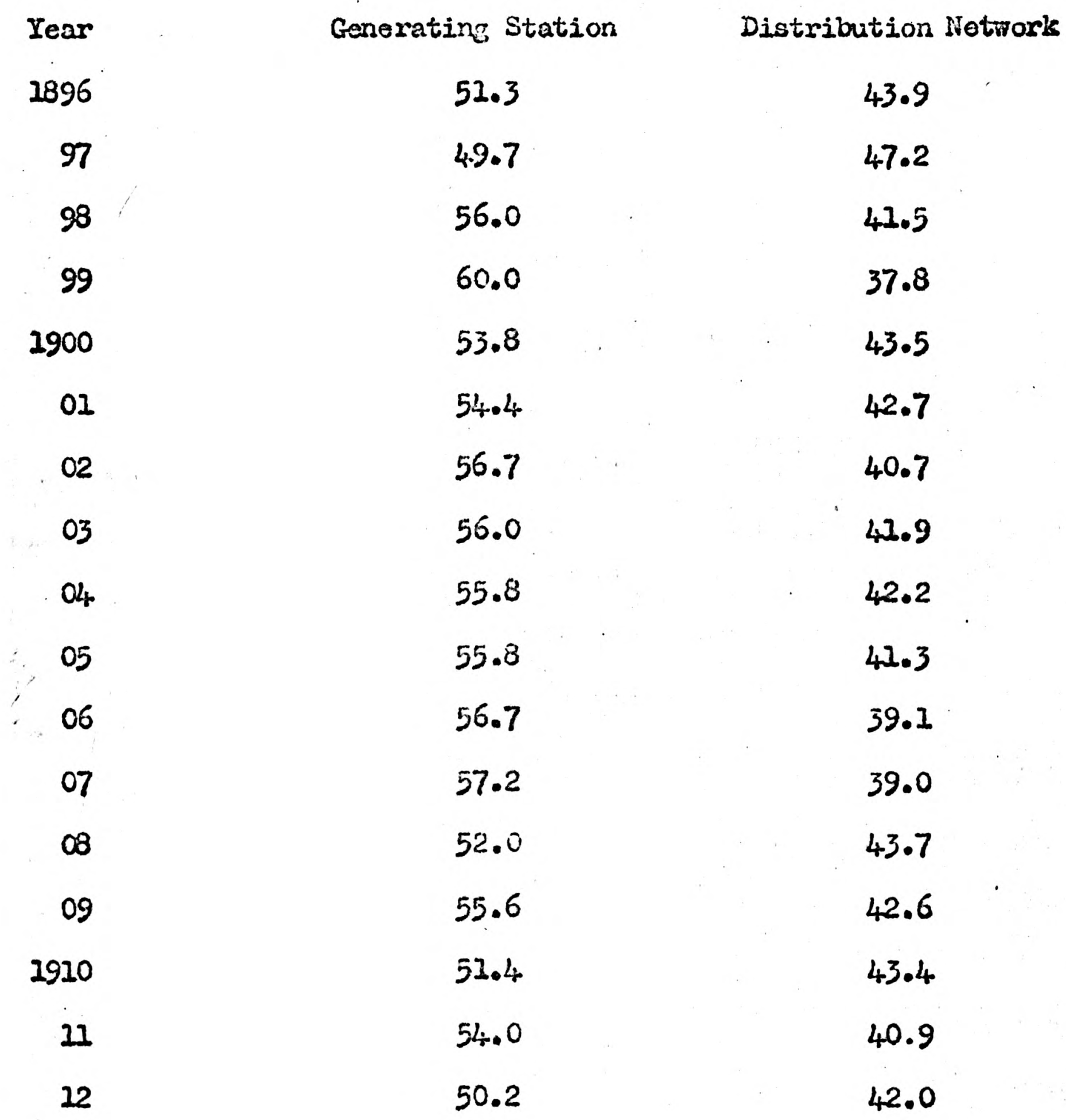

The remaining percentage was spent on legal charges, Provisional Orders and other miscellaneous matters.

Source: Sampling from accounts in Garke's lianual. 
curve seems to have been of the pollowing shape.

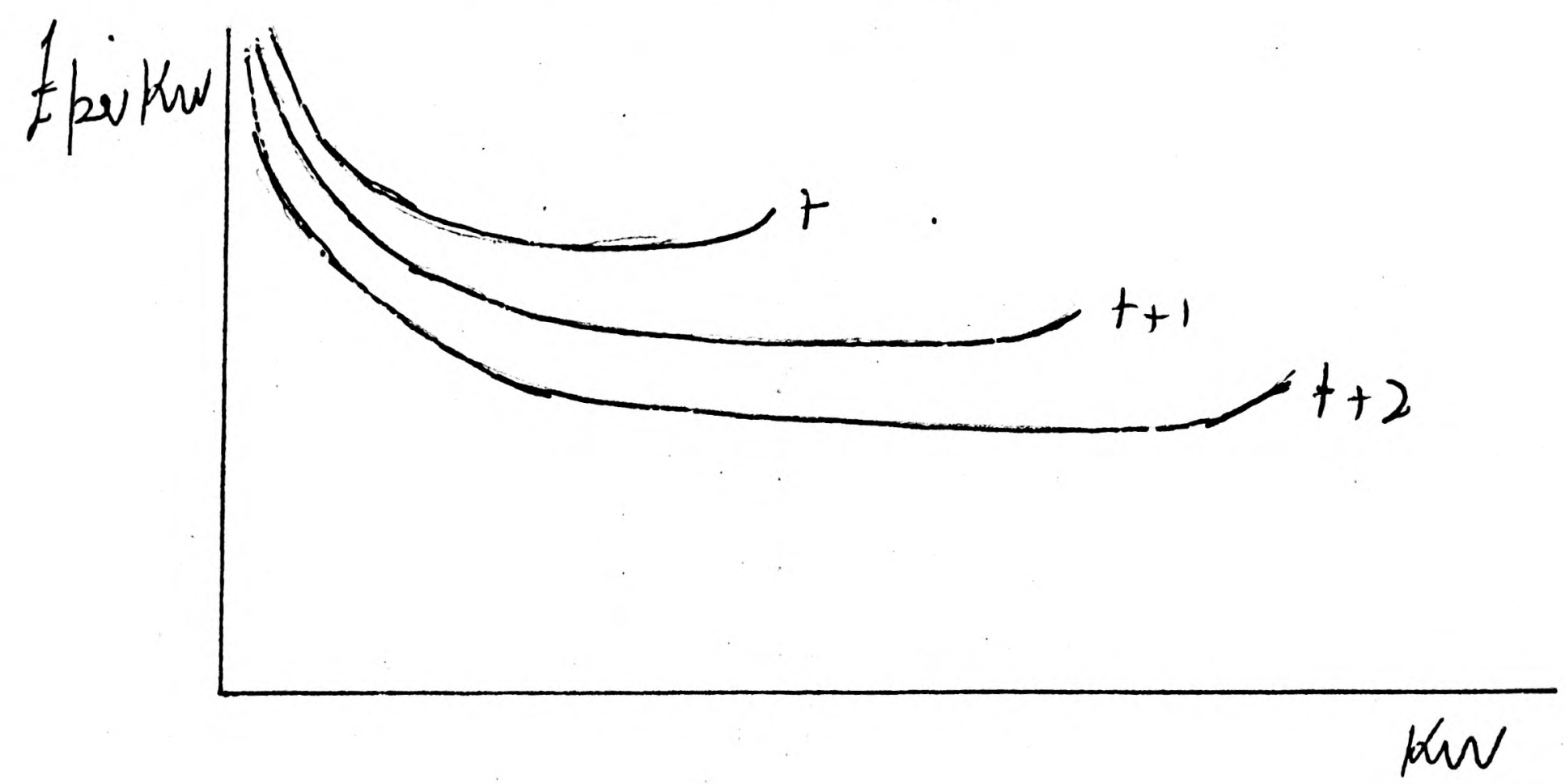

Supply stations would tend only to buy plant of optimun sizo - i.e. somerhere roughly along the horizontal part of the cost curve for any year. Ir so far as they did tris yo can use toridcr price information to indicate yrice chanses over time, as is done in Table 28. But the figures only show the trend crudels.

Perhaps the best indicators of the general shape of part of the cost curve of generating stations ore data given by two eninant engineers in 1909. Their figures are shom in Table 29.

There were long disputes about what rate to take on initiol cost for capital charges, jarticularly about tho depreciation zate. Writing in the Electrical Reviow in 1903 a consulting onginear lajd down the following percentaises for doprociation.

$\begin{array}{lc}\text { Buildings } & 1 \\ \text { Plant ard nachinem } & 7 \frac{1}{2} \\ \text { Naino } & 7 \frac{1}{2} \\ \text { Weters } & 10\end{array}$

Instruments 
Table 28.

Generating Sets. \& per KWV

$\begin{array}{lrrr}\text { Year } & \text { L per Kt } & \text { Average sizo of set } & \text { Number of contracts } \\ 1899 & 11.6 & 380 & 2 \\ 1902 & 7.1 & 575 & 2 \\ 03 & 9.1 & 367 & 3 \\ 04 & 8.8 & 1,513 & 5 \\ 05 & 5.5 & 933 & 3 \\ 06 & 8.5 & 1,250 & 2 \\ 07 & 6.2 & 1,250 & 3 \\ 08 & 3.0 & 4,000 & 2 \\ 09 & 4.3 & 1,167 & 3 \\ 1910 & 3.9 & 3,000 & 1 \\ 11 & 2.3 & 1,675 & 2 \\ 13 & 2.7 & 4,833 & 3\end{array}$

On the whole undertaking he reckoned 5.94\%. The actual depreciation provision was nearly always at a lwwer rate. However $6, ;$ is alnost certainly the mintmu, real rate of depreciation. Interest rates varied. $4 \%$ is probably. a reosonable average. Thus capital changes should be at least $20 \%$ on initial cost (if the straight line nethod of depreciation is to be usea)

There does not seom to be anj satisfactory information on labour and management costs. It could be extracted froin accounts, but only with very considerable labour. 
'Tsble 29.

Cost per in of various sizes of scingrating station. 1909.

H.M. Hobart $\quad$ G.I. Addenbrooke 2

$\begin{array}{ccc}\text { Size of station } & \mathcal{S} & \mathcal{E} \\ 2501 & 25 & \\ 1500 & 21 & 24 \\ 2500 & & \\ 3000 & 18 & 20 \\ 5000 & & 17 \\ 6000 & 16 & 15 \\ 10000 & & \\ 12000 & 15 & 14 \\ 20000 & & \\ 24000 & 14 & \\ 40000 & & \\ 48000 & & \end{array}$

1. H.13. Hobart. Ine Fating and Cost of Stecn Eleciric Generating Stations E.P. Vol. 64 PP 781-2, 821-3,859-60, 7, 14. and 21 Has 1909 .

2. G.I. Aüanbrocke. The 2ublic Suvgy of Power Cantor Irectures to the - Society of Arts 11, 16 and 29 January 1909. E.R. VOL. Q4, IP $236-7,278,325-6$. 
Coal costs are tho principal elencnt in short run marginal costs. But it was soon noticed that coal costs varied inverscly with the load 1

fration and thus one cannot take the averago coal cost por unit generated as on aproximation to short run warinal cost: Unfortunately horaly any useful records of coal consumption wore publishod. Howover in a paper given to the I.E.E. in 1907 on Sentral Station Econonics, their study and What it promios in the way of cheasen supply. H. is. Taylor gave coal consurption rigures for various amounts of electricity generated in a $3000 \mathrm{knt}$ station in a perioa of 500 hows. His figures show that fuel consumpition is a linear sunction of the quantity of electricity generated. For a 500 hour period the following equation can be calculated -

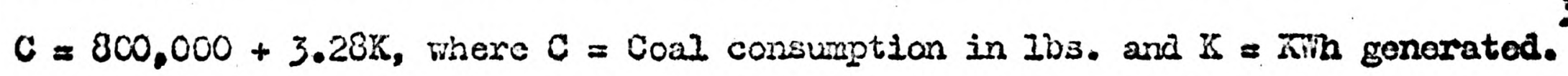
Thus in a 500 hour period the cost of 800,000 1b3. 02 coal can be regarded as being conjectod with the size of the genurating station rathor than the quantity of electricity generated. Taylor's figures were based on the use of coal and slack at $7 / 6$ a ton. At this price tho cujacity cost of coal is 10.73 p.a. per IWW, and the short man mercinal (coal) cost 0.132d. per KMm. Unfortunately sirailax f'igures for other yeurs are not available. We knoir that juel costs were higher bofore 1907 and lower afterwards. But ge carmot say by how inech.

1. Finst by J. Hopkinson in a paper to the Junior Englneering Society in 2892.

2. E.R. Vul. 60, PP $410-13$.

3. For a later period l. I. Parsone crirosiod coal consunption as a linear function of electricity Eeneration. His time period was the shift and his equation $C=5000+1.2 j \%$. (R.H. Parsons, onecit. Anpondix 1.) 
As the uninown management and labour costs were very largely capacity costs, at least this appendix vill have given some inaication of the very great dificrence between land and short run marginal costs. 
Chapter 4

ho Power Conponios.

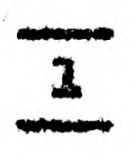

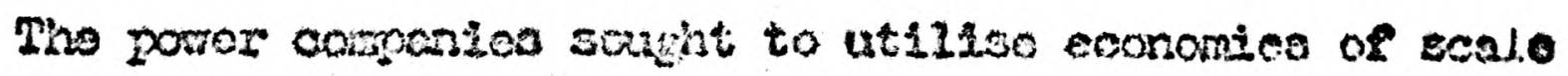
in oloctricity Eeneration for two purposes to suply olectricity in bulk to extsting oloctrictity euphilers, and new onse, espectaily In the emaller tome, and to suply eleotricty sor power, both for cloctric traction and for sectorics. Whe converoien of tramseys to electric traction had beon orpected during most of tho nineties, although 2t ata not start in conett un:il 1997 , ond electric pormer had begun to bo used in the United Stated from tho nidile ninotios, athough the olcctrisseation of english factorios was vory rare until 2900.

The firct pryor scheme mas thet of the Ceneral Parer

Distribution Company, mornted oy a syrisicate of laree tanufacturers In the Chesterficid aroa. Powers vere condet by sot of Parlianent for

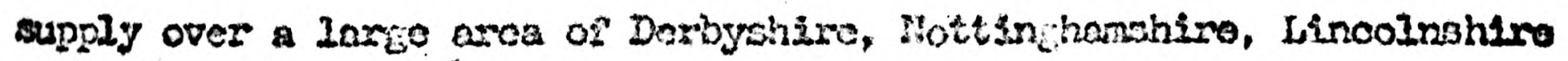
and the Wect Riding. Over drost of tho area no cne hod authority to

1. Soo Chaptor 5.

2. Sec Chayter 6.

3. Sit Henyy de Self.E.M. Jation, Blectricity Supriy in Creat Britain.

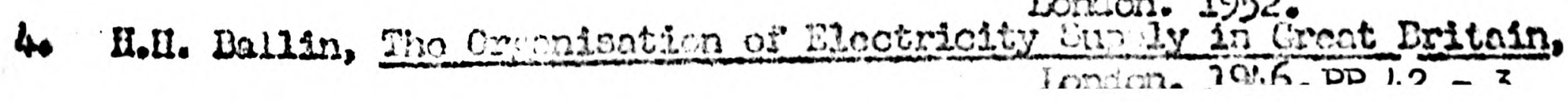


supply electricity but it inclucied the fowns oi Shefíeld and rottingham, both with municipal supply. The Company wanced to bo able to ccapete with exlsting suppliers, and principally because of this it was strongly opposed in 2898 by affected minicipalities. This caused the Bill to be held over to tho next Parliamentary session and in 1899 it was opposed by the Uunicipal Corporations on bloc, and thus railed at the second reading on the grounds that it upset the prosent lam and was "prejudiolal to the privileges of the great municipalities". As a resuit the Cross Committee mas appointed in 1898, which recowiended that technical changes had created conditions afferent from those envisaged by the draibers of the eariler Acts and that it was dosirable to give powor to undertakings who were to use plant of exceptional dimensions and high voltages, to supply over a large area which ineluded existing suppliers. This report formed the basis for tise Electric Parer Bills of 1900, 1901 and 1902. In 1900 Bills vere passed for power companies in South Wales, Durham, Lencashire (south of the Ribble) and tho North Letropolitan area (from Hertford and St. Nibans south to Willosden and Stoke Nowington.) The Durhan and North Metropolitan schenes woro for supply to authorised distrioutors only, and passed without difficulty. The Loncoshire and South Wales Bills were very strongly opposed by the big municipalities. They disliked the regrests for powers to give power supply to big customers within their areas. As a result the big municipalities were excluded from both schemes, thus cutting out much

2. H.H. Ballin, op.cit.2 P 43. 
of tho most profitable areas of supply. This set a precedent and in future Acts the municipalities managed to get themselves excluded if they could show that they were already giving a cheal supply for power. Tavie 30.

Iist of Electric Power Companins.

\begin{tabular}{|c|c|c|c|}
\hline Company & $\begin{array}{l}\text { Date of } \\
\text { initial } \\
\text { Set of } \\
\text { Parliament }\end{array}$ & $\begin{array}{l}\text { Date of } \\
\text { commencement } \\
\text { of suprisy }\end{array}$ & $\begin{array}{l}\text { Capacity of } \\
\text { ganerating } \\
\text { stations } \\
1912\end{array}$ \\
\hline Nencastio & 1902 & 1900 & 90660 \\
\hline North Letropolitan & 1900 & 1901 & 25990 \\
\hline County of Durham & 2900 & 1902 & $0^{\prime}$ \\
\hline ufialend & None & 1902 & 20600 \\
\hline $\begin{array}{c}\text { Derbyshire \& Nottingham- } \\
\text { shire }\end{array}$ & 1901 & 2903 & 5080 \\
\hline South Wales & 1900 & 2903 : & 27450 \\
\hline Cleveland and Durisam & 1901 & 1904 & 6000 \\
\hline Clyde Valley & 2901 & 1905 & 27300 \\
\hline Iancashire & 1900 & 1905 & $18500_{3}$ \\
\hline Yorkshire & 2901 & 1905 & $10000^{\circ}$ \\
\hline Scottish Central & 1903 & 1905 & 3600 \\
\hline Fife & 1903 & 1905 & $7000^{4}$ \\
\hline North Wales & 1904 & 1906 & 6000 \\
\hline Kent & 1903 & 2907 & 3500 \\
\hline Cormwall & 1902 & $\begin{array}{r}1911 \\
2\end{array}$ & 2800 \\
\hline \multirow[t]{2}{*}{$\begin{array}{l}\text { Shropshire, Staffordshire } \\
\text { and Worcestershire }\end{array}$} & 1903 & - & \\
\hline & & Total & 224,480 \\
\hline
\end{tabular}


Table 30 continued:

1. The Midand Electric Coporation for Power Distribution operated uncier a nuiber of Provioional Orders only.

2. Powers transferred to the Bimingham \& Vidland Tramays, who already had a power station, in 1908.

3. 1910, later figures not available but 1912 figure wouid certainiy be hicher.

4. $\quad 1913$

5. Included in ivewcastle - the two companies were fully integrated.

Sources: Electrical Trades Directory and Garke's Lanual. 
Table 30 tells its ow story. The power campanies wero not quic: oft the mark and a courarison with tho bigcest ten other undertakings (Table 31) shows that by the end of 1912 they had not become very large. There is one exception: the Newcastlo Electric Supply Company was extremely successul, ran a unificd system together with the County of Durham Power Company, and from 1912 onwards the Cleveland and Durhar Conpany. This Jocal grid extendins from the Northumberland coalfield to the Cleveland irontield had wat more generating capacty than any other undertaking. In 1912 it had about $42 \%$ of the total capacity of all tho British power comanies.

Table 31.

Some other big undertakings in 1912.

Undertaking

Manchester Corporation

Glasgow Corporation

Birminghan Corporation

Liverpool Corporation

Shefilela Corgoration

London E.S. Corporation

City of I.ondon R.S. Co.

lietropolitan E.S. Co.

Ireas Corporation

County of London Company

1. Estimated.

$$
\begin{aligned}
& \text { Capacity of } \\
& \text { genorators } \\
& \hline 59,300 \\
& 47,030^{1} \\
& 37,465 \\
& 37,000 \\
& 28,500 \\
& 27,250 \\
& 25,000 \\
& 23,250 \\
& 22,940 \\
& 20,300 \\
& 322,035
\end{aligned}
$$

\section{Source: Garke's Lanual.}


If we exclude the North East Coast Companies, the average poirer company in 1912 had only about $10700 \mathrm{KR}$ capacity. As the standard large turbo alternator bsing instalied ras about $5000 \mathrm{Kir}$, many of them could claim fer of the economies of scale rinich wero to justify their existence. Escept in the North East the power companies becano suppliers to the smaller settlenents outside the areas of the large manicipalities. Sorn, like the Clyde Valley, Lancashire and Yorkshire schemes specialised in power supply, sone line the North hetropolitan and the lizaland were genoral all round sup liers.

Except for Newcastlo those specialising in power were not financially successful. The worst case is that of the South Wales Company. By 1904 it had built four power stations, only one of them being large, but was unable to raise further capital. By June 1906 the situation hed becone so bad that the Company had to make arrangements with its consuwers to provide capital to continue oporations. The two snaller genereting staticiss wore sold to the relevant local authorities. The Treporest Ilectrical Consumers Company was formed to work one area anä provided 230,000 por generaing plant. The power company was reconstructed and continued to work one part of its area.

There are a number of reasons for the poor shoting of the power conpanies. Excopt for Nowcastle, the big torns sere cut out from the bevining. Glasgow the heart of Clydaside wos in the hands of Glasgow Corporation, tho Lancashire und roxisuitre power companies threaded thelr trunk mans between the big fowns. Lighting loads outsice tho big toms trero expensive to supily as, outsile areas of hich pogulation donsity 
cable costs per lamp were hidh. Irawnas were chiefly located in the big tom and where they took public supply they generally bought it from the tom prior strition. Power supply for industry was slow to develop This was partiy because the electrificiation of Ectories did not really start on hore than a very small scale until about 1905. Electric driving for texilles cane late largely for technical reasons, and the colliery cwnere were conservative; the Lancashire, Yorkshire, Clyce Valley and S. Wales Companies were in textile and mining ereas. It was also parily oecause it was opten better to put down an "1soloted" installation rather than take priblic supply. Again many potential power consumers were inside the big toms.

The power conpanies found it very aifizicult. țo borrow, especially for their big schames. The Eestation period of invostment was long and big schemes rould naturally operate at a loss in the early years. Costs wore often undorestimated. The down fum of the trade cycle came boforo enough had been raised, end the heavg foreign investrient from 1904 onwaris made the raising of money for hoite investment difficult. The costs of a private Act of Prxilanent vere higin and severly handicapped the companies in their early days. The netters mentioned in the last paragraph naturally made borroving more difricust.

Apart from demand and finareing difficulties, there is reason to suppdse that the encincering of some of the schemes was not very good. And engineering ability of a high orier was necessary to make them a success. 
Iaije 32.

The Power Comparies in 1905.

\begin{tabular}{|c|c|c|c|}
\hline Compariy & $\begin{array}{l}\text { Number of } \\
\text { power } \\
\text { stations } \\
\text { initially } \\
\text { planred }\end{array}$ & 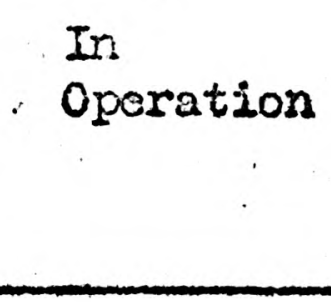 & $\begin{array}{l}\text { Ageregate } \\
\text { cajacity in } \\
\text { operation. }\end{array}$ \\
\hline Cleveland and Duriban & 7 & 3 & 4,750 \\
\hline Clyae Valley & 3 & 2 & 8,000 \\
\hline $\begin{array}{c}\text { Derbyshire \& Nottingham- } \\
\text { shire }\end{array}$ & 4 & 1 & 720 \\
\hline Lancashire & 4 & 1 & 6,000 \\
\hline Mizaland & $\cdot$ & 2 & 3,200 \\
\hline Iifo & & 1 & 800 \\
\hline S. Trales & 3 & 4 & 7,640 \\
\hline Yorkslaire & 4 & $I$ & 6,000 \\
\hline
\end{tabular}

- This was a pilot schero, opened in 1905. But 1905 was extremely late for a pilot scheme.

The Erardisll and IIarris schemes, the Cleveland and Durham, the South Wales and tino Derbyshire and Notinghamshire were poorly engineered, with small stations and small plant. The Lancashire, Yorkshire and North Netropolitan were also planned with several small stations. al though the former tro vere replanned under H.F. Parshall, an American who had cone to England in the late 1890 s to deal with the B.T.-H. tremray building. The big munioipalities

1. The Consulting Ingineers. 
usually opposed the power companies partly on the geounds that they. could supply at least as cheaply thenselves. In the years $1900-05$ when theso power schemes were planned, the ovidence is very largely on their sido, their enginearing soens to have beon at loast es good, and their costs lower than those of the power companies, because of their more fovourable geographical position.

\section{1}

The Newcastle scheme had none of these disadvantages. It grew out of an existing undertaking which made financing easter; there was no initial long waiting period before dividends were paid. Once successful it could continue to raise money. The local goverment situation on Myneside was very Savourable. Newcastle Corporation had not been interested in electricity supoly, and the rest of the north bank of the Tyne rias compossed of small local government areas. There was a dense industrial area to ve served, with very progressive enginoering factories. Even before the Newcastle power schemo Tymeside had been noted for its factory electrification. Shipbuilaing was booning and procressive and there were close links between important industrialists and the Newcastle Fiectric Supply Co. In 2904 the North Eastern Railway opened the first electrified suburban 2

lines in this country. To start tho scheme thero was Charles

1. Henceforth reperred to as N.E.S. Co.

2. The Lancashire and Yorkshire Railway oponed its electrified Iiverpool-Southport line in the same year and thus shares the North Eastern's position as a pioneer of main line railway electrification. 
2.

Werz, who had exactly the right combination of vision, optimiam and technical skill. From the beginning his engineering was admirable and the construction of Carville power station, opened in 1904, was one of the big lendrarks in electricity supply.

$$
2
$$

The Newcastle pover scheme started with the plans of

J. Wighara Richordson, The Tyne shipbuilder. Ho was Inpressed by tho use of electric porrer in shipbuilding as were other Tynoside marino and other onginecis. He was also a director of tho follsend and Walker Gos Compony, which had been a pionoer in the use of gas for industrial purposes. He persuaded the gas campany to begin electric supply and in 2893 a schenie was in preparation. Wisham Richardson's brother-in-law and fellon Guaker was J.T. Vierz, a director of N.B.S. Co.

2. Lorz's Private Notes have been an important source of information $20 \%$ tise rost of this chapter. Herz was born in 1874. Lidicated at Dootham School, York. In 1891 ho spent a year at the Durhan Collego of Scienco. In 1892 ho joined N.L.S. Co. as an apprentice. In 1894 he joinod B.T.H. In 1899 he became a consulting engineer, forming the partnerizip of liferz \& Velelian. See J. Rowland, Prencess in Paver privately printed 1960 for the story of Lexz \& íclellan.

2. P.B. Henderson, The develoment of statutory powexs relating

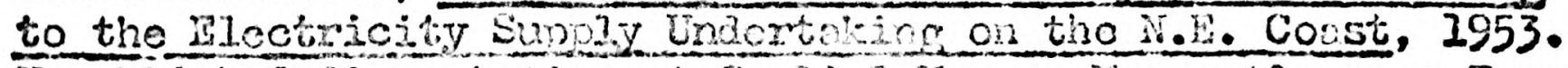
Unpubisshed disscrtation at Cardiol fouse, Wewcastle upan Tyno. This is the best dotailed history of the company.

3. The North Eastem harine Co. had decided to clectrify in 1897 seo remarles of Sir Surners Hunter in the Discussion on R.P. Sloan's paper Develonnents in the Uso of Electricity. Transactions of N.E. Coast Constitution of Lingineers and Shipbuildors, Vo1. 45 PP. 345 - 72, 1928 - 9 . 
They had also had business associations in the years aroung 1870. In 1898 Charles, Merz's son, who had at tho age of 24 quite considernble engineering experienco both in power stations and with the British Thomson-Houston Company, was asked to help with the proparation of the Act of Parliament for the Vialker and Wallsend 3cheme. Ile was very critical of the gas company's consulting ongineer and made him nodify the schare. With Iferz's holp the Bill soon passed. Then ho was appointed coneulting engineer to the company. The foundation of his scherro was the 3 phase motor, virtually unknown in the country at the time. Merz knew of its value through his associations viti the Amcricans at B.T.-HI, and had mado his own experiments with it. He vas deternined to use it as ho was suro it was the best motor for the shipyards. He also visualised electrio traction and wanted to bo able to supply lighting as well. At tho time it was technically difitcult to amalgamate the three because Igiting and powcr worked best at different frequencies. No English manufacturers wore interested in 3 phase wachinery and herz discuesed

1. Merz had very successfully managed tho Bloydon Chemical Works for Richardson who had investcd a considerable amount of monoy In them. Richardson felt indebted to lierz and this sceme to have been one reason why he thought of heiping Charles Kerz by aking him to investigate the Walrer and wallsend electric power scheme. The latter was only a very youns man al though he must have shomed sirns or ureat ability. (See Private Notes of C.H. Kerz, unpublished; Nowoirs or J. Wishan Richarden, privately printed, Glasgon I91I).

2. Rotary convertore for converting 3 phase a.c. to d.c. for traction were usually run at 25.n. Iights Plickered noticeably at as 10 w a Irequency as this. 
1

the matter with Gencral Electric and Brom-Boveri. There was no obvious solution but eventually it was decided to adopt 40 cycles per socona as a compromiso. It worked very well. This was an important capital saving innovation, as less power station plant and also much less transmission and distribution plant was needed.

II.E.S. Co. were also interested in poirer supply and in 1898 they had installed two $500 \mathrm{~kW} \mathrm{d.c.} \mathrm{Eenerators} \mathrm{in} \mathrm{addition} \mathrm{to} \mathrm{their}$ lighting altemators for supplying rotive power in Newcastle. Merz when planning the Valker and Wallsend scheme had devoted a good deal of effort to getting custorers. He had had long discussions with various engineers and shipbuilders about the velue and cost of electrio power. Thus both the Lerzs's and Vigham Richarison decided to promote a portor Act to Iink up N.E.S. Co. with tho Walker and Wallsond schense and to sell poner along most of the north bank of the isyne. At the same time Parsons, Campbell Swinton and others were promoting a rival power Act for the whole of Pyneside. Parsons was a director of the Newcastle and District Ilectric Supply $\mathrm{Co}$. which supplied tho westorn half of Newcastle. This latier was a larger scheme and had vory Influential prosnotors but the Nerze and Richardson had the advantage of havine already started on their scheme and could point to their partially constructed power station at Neptune Bank adjacent to the

1. The Ancricans usce 25 upor traction and 60 for lighting and power. The Wriss used $40 \mathrm{r}$ and $5 \mathrm{~cm}$.

2. Other parts of tise country later standardised at 50 cycles and after the 1926 Ilectricity Supply Act the North East system was converted to that frequency. 
ble whigarjo. Thoy won. In tune 1901 Lord keivin operod Noptuno

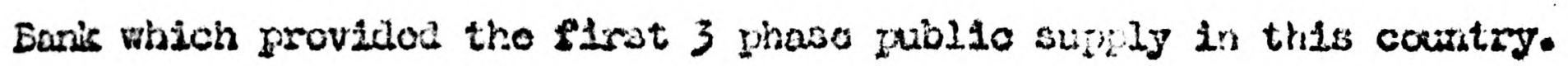
At first it caterea for a fer big shiparso, int tho auccess of olootrio

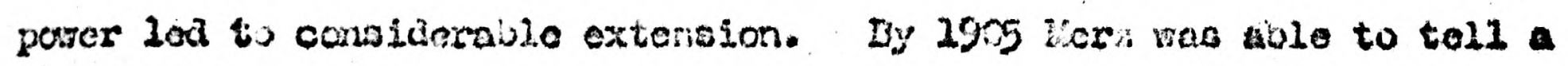
Seleot Comitives of tiso Eolito of Laras both thet "all tho priva:e plants on the Hortin Bank of the Tyrie have chtior becn done aray whth, or are boing done aray with" and thet on Fynosico in tho N.E.S.CO. aread ono-bals to tro-thinds of the total poror used is sulollod by N.B.s. Co."

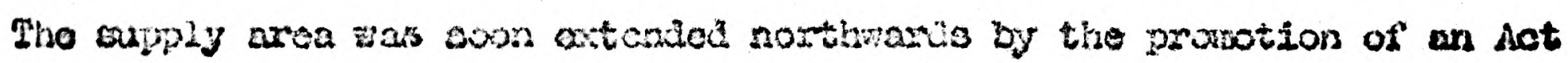
in 3902 to srolucio the Northunbelard conflald. Fis wes alto oppored.

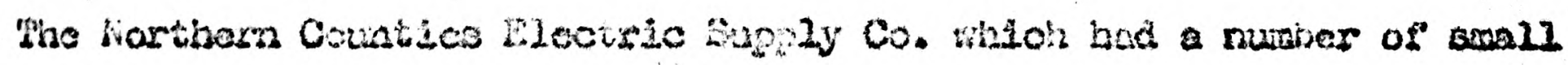

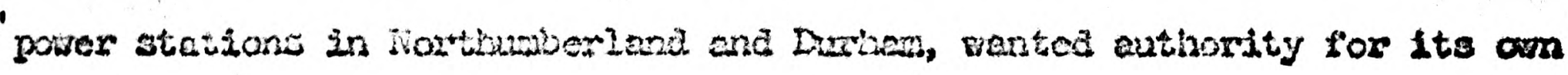

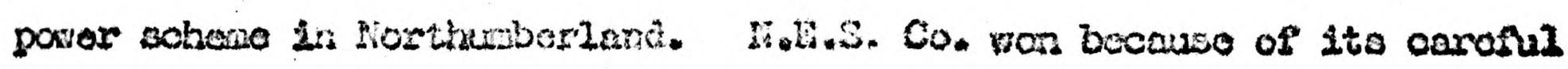
cotimition of domard, Its excollent fecord of technical skill and good manarewont rovealod in its very lon costa. ard tho vay in which it

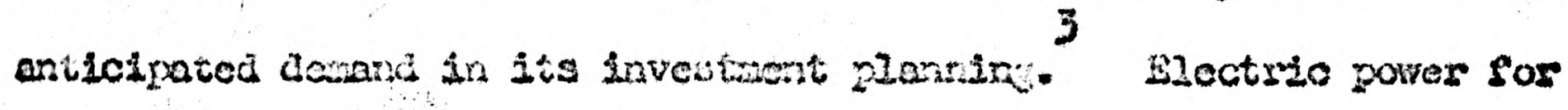
colllortes was, howover, slow to develop and nore infortont for tho

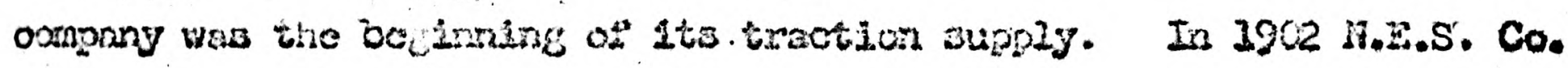

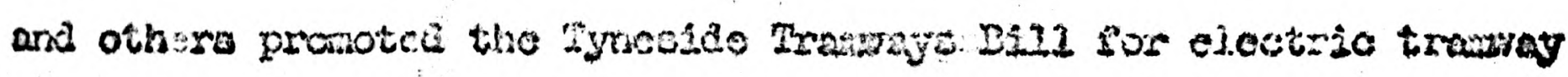

1. Seloct Comittee of the Ilouse of Lows on the Mariniotrativo

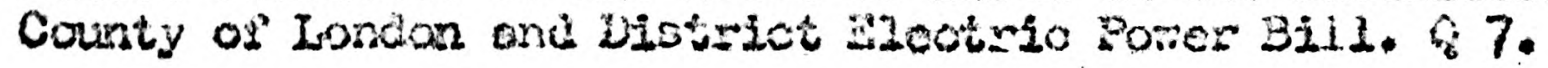

2. ibid. $=1210$.

3. Minutes of tine procectirge beforo ind Solect Comiztea op

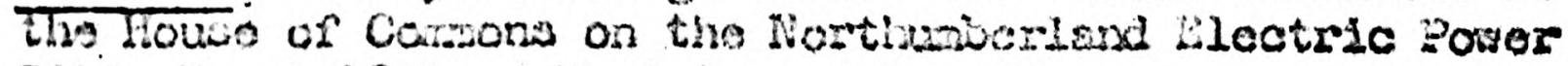
B111. Harch 1962. Decision of Coustice. 


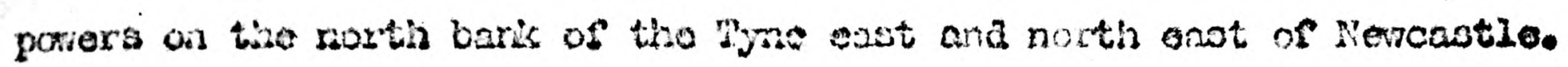

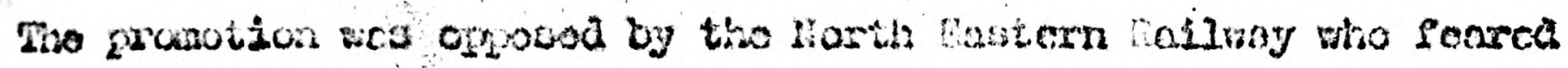

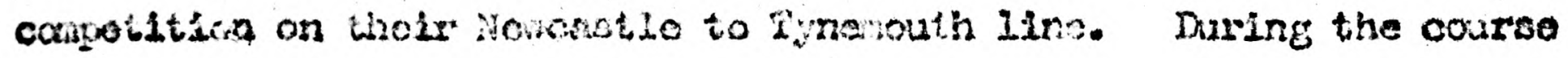

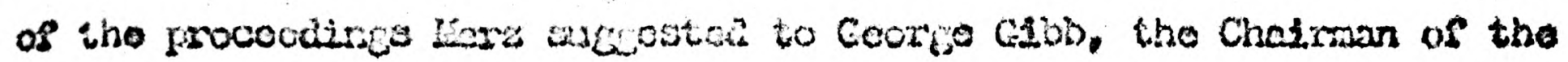

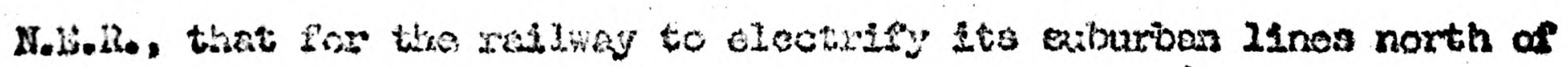

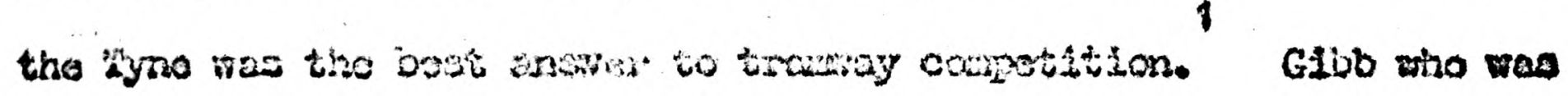

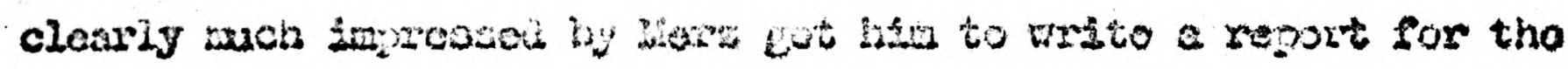

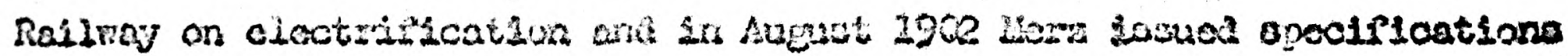

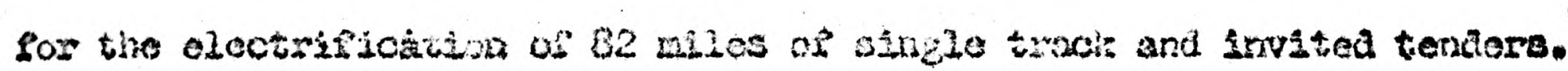

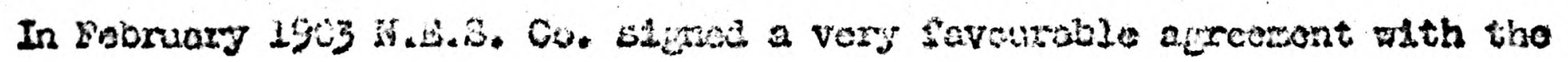

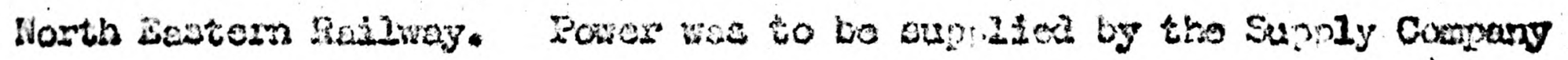

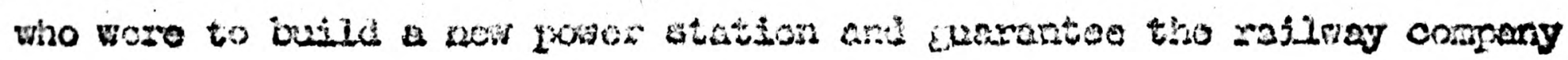

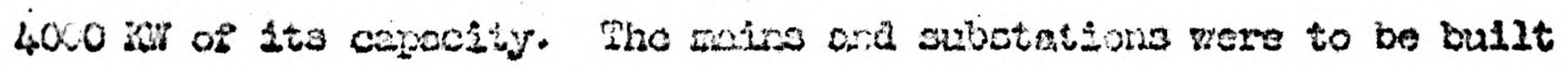

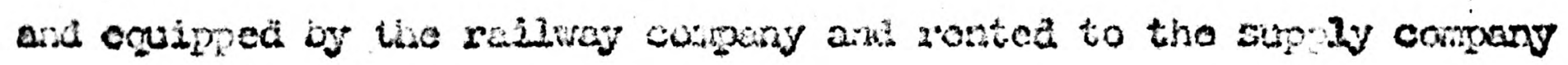

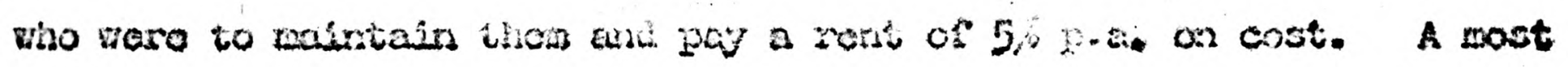

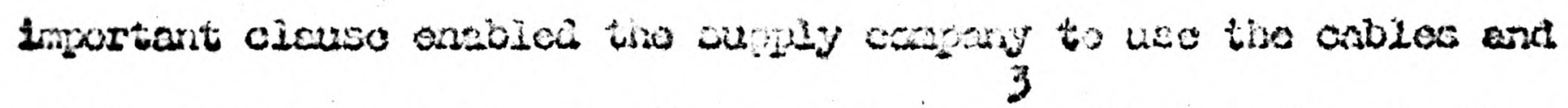

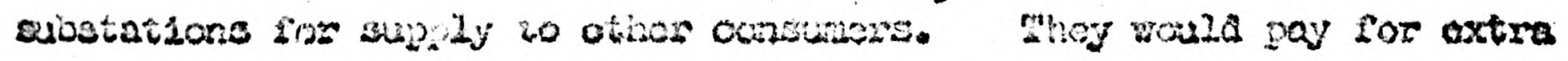

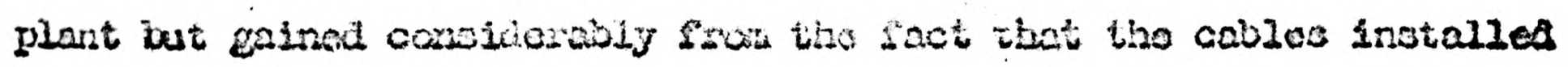

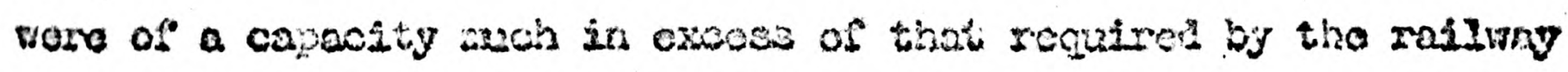

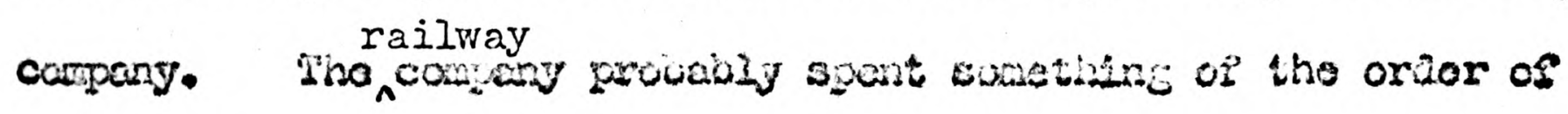

1. There is a stovy etill. In cinculation that the reweastlo riectrio

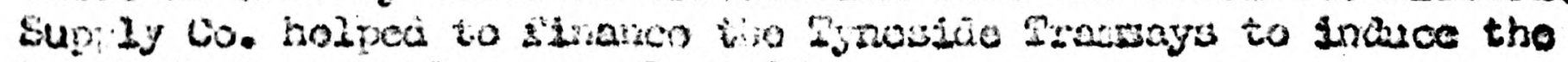

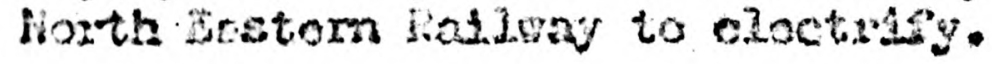

2. E.R. Vol. $51, \mathrm{PP} 25$ ? - 8. 25 Akust 1902.

3. Agroment botween the Nowowsthe Elcotrio Suply Co. and tho North

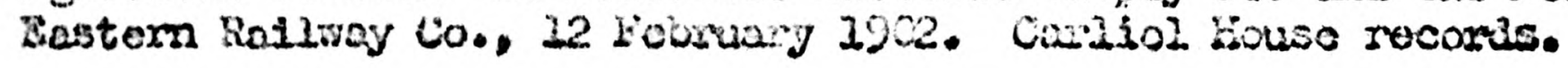


$\$ 90,000$ on this distribution system. It is not knom how mich of this was necessary simply for supplying the rallway but the magnitude of the money raised in this way through the railway company can bo seen by the Pact that by December 19d, the supply company had spent 1256,000 on high tension cables and sub stations, and $\& 1,229,000$ on everthing excluding the Newcastle city installation dating from 1890. The agreement with the North Eastem Railway Co. Thus contributed to N.E.S. Co.'s very rapid expansion at the time on both the demand and the supply sides. Meaminile N.E.S. Co. had storted to give a bulk supply to the County of Durisem Electric Power Company. The latter had powers for supply to authorised distributors in tho Northern hals of County Durham, incluaing the south bank of the Tyne. It was orned by the British Electrio Traction Corpany, who had used it only for supply to their trams in Gateshead, Jarrow, and Durhan City where they also held provisional orders. In 1904 the Durhan Company was taken over by N.I.S. Co. and the area began to be developed. 'The latter was determined to supply to the county generally, especially the collieries,

1. If the railway company reverted to steas the supply company was to purchase tine cables etc. at cost, not exceeding 290,000 less 4\% p.a. depreciation - or at the option of the railway to pay 5\%. rent in perpetuity.

2. Parliamentary powers were obtained in 2902 .

3. The County or Durham Electric Power Company, which held the Parliamentary powers was cwned by the County of Durham ilectric Power Distribution Company which hold the provisional order.

4. N.I.S. Co. and the Durhan Companies vere run as one unit from 1 January 1905. 
and not merely the larcer towns.

In 1904 traction supply made up the bulk of sales. The combined sales of the Newcastle and Durhern Companies wero approximately 17.4 million Jwh; 9.8 million went for txaction, 5 million to manufacturers chiefly on the Pyne and the rest for lighting. This concentration in traction was typical of big undertakings: Lanchester in 1904 sold 33.7 million $\mathrm{kmh}$ of which 18.9 million vere for the Corporation Tramays. The rapid rise in output from under a million Kmn in 1899 to over 17 million in 194. was more than the Neptuno Bank power station could deal with and in 190, the new Carville power station, which had boen started when the electriffeation of the North Eastern Railway was planned, was opened. Carvilie, desifpea by lierz, was a major break through in power station design, the beginning of what eventually become standard practice. What lerz arrived at was a big improvement in the reliability of plant and a big reduction in costs. And costs could beat be reduced by reducing the initial cost of the power station. Both were to bo achioved by a radical reorganisation ond dirplification and the use of plant incorporating the best engineering practice.

1. The biegest tom in the area, Sunderland, had a very progressive and eflicient manicinal supply, managed at the time by J.F.C. (later Sir John) SneIl, and would have boen extremely unlikely to take a bulk supply.

2. In Newcastle, the traways were eventualiy electrified and mun oy the Corporation from their orm porter station.

3. See C.H. Iforz and W. LaLcllan, Porrer Station Design. Paper read to the I.E.I., $28 \mathrm{Aps}$ il $19 \%$. This papor was yoars in advance of other contenporary writing on power stations. It is thus all the more remarikable that lierz vas simply preaching what ho had already practised at Carville. 
- "The comercial success of such an undertaking (for portex supply) is absolutely dopentent upon the chcapness and reliobility of supply. It may be argucd that this is no now phase of the supply problem; but the argument, though possibly correct in principle, is so wide of the rark in degree that is a station for pover supply wero designed on similar lines to many existing power stations for traction 1 and lighting purposes connercial failure would almost certainly result."

Capital costs, Werz argued, were much too high; when boiler plant was obtainable for $22-3$ per $\mathrm{KW}$ and generating machinery for $\$ 10$ per IW at the outside, it was surprising to find power stations coming out with a total cost of 24.0 or even more per KNI. To reduce capital costs was of overwhelming inportance, and wits good initial design this could easily be done. Iike the principles behind all major innovations, this now seeins obviously correct. But Merz's principles cut right acrosi current power station practice. Perusal of the technical interature of the tine does reveal very much nore concern with running costs, particularly cosl costs, than with capital costs, although capital costs accounted for at least half of the total costs of supply and coal costs for less than a quarter. In the design of plant simplicity had been sacrificed to elaborate complications to avoid an interruption of supply. Herz had to stress the principle that no complications should be introduced co facilitate the repair of a breakdom should the complications increase naterially the risk of breakdom.

"That all tho earliex station engineers should consistently disregard this axion was perfectly natural, as in vicw of tho comparatively unreliable apyaratus at their aisposal they were more impressed by the necessity of specay repair than by the importance of avoiding a breakdown altogether. In lact they came to regerd brcaledowns as inevitable, devoting their attention to minimising their effect tather than to reducint the anount of apparatus in which a breakdown could occur.

1. Merz and MaLellan, op.cit., 
This line of procedure, while possibly justifiable in the earifer staces of the industry, has in rang cases becn pushed too fiar. In some stations the designers have aporently sot themsolves tire task of rendering possible overy conceivable conbination of boiler and enitine, cneine and exciter, purne and boiler, etc."1

They recomisended the "unit" sjstem of construction, whoreby the plant was divided into sovoral independent units - cach consisting of boilers, engines, dynaroos and switchgear. This was essential to reliability.

"If trouble was to be hod with anything it would be obtained by crowding together all kinds of water and stean pipes; 19 troublo was to bo had with switgigseor it would le obtained by fixing many cables or comections for different purposes either on one panel, or in one partition, or in one cable trench ...."

Power Stations must be designed so that they could be Inoxpensively extonded.

"It is possible in laying out a station to avoid placing chimneys, flues, offices and claborately built brick ends so as to interfere with extensions to cither boiler houses or encine rooms, although it is to te feared that this is not always dono"l

They advocated a steel framed building, where the filling betreen the columns was merely a weatherproor screen wall, a contrast to the solid brick structures of current practice. This type of construction represented an innovation in building. As Merz told a Select Conntiteo of the House of Lords in 1905, "You look on the boiler house of a modern electric station in much the same way as you look on the boiler house of a ship, where the structural part and the machinery are very mach

1. Herz \& Veirellan, op.cit.,

2. Nerz \& Maisellan, op.cit., 
Intermingled and form part the one of the other." Steel frame buildings were raro in those days althouch same had been built in Chicago from tho 1 288Cs.

Carvilile uscd only steam turbines, the first big English power station to do so. Ono $1500 \mathrm{Km}$ Parsons turbine had been installed at Neptune Bank, at Wichas Richardson's sugeestion, and had worked very well. The turoine, as stated earlier, was capital saving; the cost of buildings was ruch roduced by using it, and it had a high overload capacity. Morr pointed out what was isually neglected, that it was economically desirable to use this overioad capacity to neet the nornal peak, and not just for sudden emergencies, that higher muning costs would be considerably over coinpensated by reauced capital costs. He considered that capital costs could be reduced by $20-40 \%$ by a careful consideration of the shape of the load, overload capacitios and spare plant.

In $19 \alpha_{1}$. Verz was 30 , but 211 this is not sirnipy a young; man's criticisa of current practice. The average power station at the time cost a littie over $\$ 40 \mathrm{per} \mathrm{Im}$. 'Big stations were cheaper. lienchester's Stuart Street station, opened in 1902, cost $\$ 24.5$ per KN excluding land, West Ilam's station, which was a conternporary of Carville, \$25.6 incluaing 4 Engineers estimates of proposcd large power stations in $1900-03$

1. N. Pevsner, An Outline of European Architccture, Penquin 5th Ed. 1957

2. Sec Appendix on Power station costs.

3. Select Comittec on Administrative County of Iondon Bill 2905. Q. 4579-39. Answers of A.B.T. Kennedy, designer of the Stuart Sireet Station.

4. ibid... Vol. 3, P 661. 
variod between $\$ 20$ and $£ 25$ per $K W$, but the usual tendency in such estimates was to underestimate costs. In 1902 Merz predicted that Carvillo would

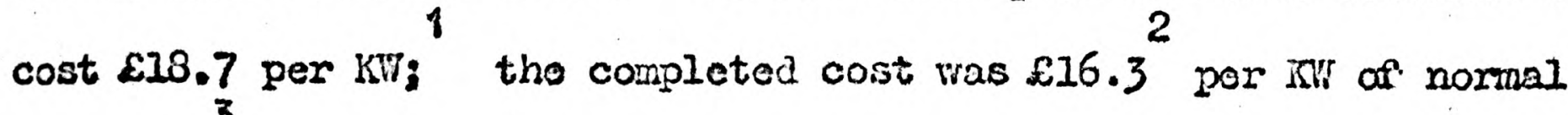
capacity. Fusl costs were lor at Carville, partly because coal was cheap on the Tyne, partiy because the power station was built on the river with good coal hanaling and condensing facilities, and also becauso desile its low cost the Carville generating machinery had as low a coal consumption as any, and mich lower than nost.

With Carvilie as the lowest cost power station in the country the Newcastle system soon eron north a south. In 1905 22,000 v. cables, using the highest voltage in Britain, were laid into Durham. Power supply developed rapidly and in 1907 output had risen to 100 million $15 \mathrm{~m}$, of which approximately 77 million were for power supply (excluding traction.) 4 This was 24\% of the total sales of electricity for poier by public supply stations in 1907, and the Nevcastle Ilectric Suply Co.'s power sales

2. Before the House of Comions Coraititee on the Horthumberland Power Bill. Q. 101.

2. Select Compittee on Administrative County of Iondon and District Electric Power Bill, 1905. Q. 569.

3. Carville was designed with a $36 \%$ overload capacity.

4. Data from the Newcastle Ilectric Sup ly Co. historical statistios. Soles for power supily are my estimates.

5. Tablo 22. 
alone were greater than the total sales of any other electric supply undertaking.

The Durhan Collieries Electric Power Cumpany was formed in 2905 to supply colliories in north Durham. A power station was built but the company was soon in financial disiculties and in 1907 N.E.S. Co. undeewrote its debentures and took over the operation of its power station. Its subsidiary, the Houghton-le-Spring Company, bought current in bulk from 1t, supplying mainly to collieries, and N.E.S. Co. began to operate this distribution system as well from the beginning of 1909.

From 1907 onwards N.S.S. Co. became interested in the Cloveland and Durham Cowpary. Iazard Brotiners, the Paris issuing house, whioh in 1906 had arranged the first iesue of the Viewcastle Electric Supply Co. shares outside the North Last, asked Nexz to investigate 1t. It had been badiy exgineered and wach of the initial investinent was misdirectea. By 1907 it had insurilicient capital for proper develop ment and in order to asisist, Horz helped to form the Waste Heat Company. Tho idea was that omers of blast furraces and coke ovens should co-operate in erecting generating stations to use vasto heat and gas. Some of the electricity would be uned by the coke oven or furnace and some sold to the supply company. The idea had started with Blaydon Power Station which had come into operation in 1904. N.E.S. Co. and the Priestman Colliery Company had together formed the Priestman power

1. Lanchester, the second largest undertaking, sold 63 million 8 mb in 1907.

2. C.II. Merz, Private Notos; and R.P. Sloan, ividence to Coal Conservation Comnission in 1917. 
company each subscribing half the capital for the power station. Waste gas from coke production was usad to divive a $2000 \mathrm{KH}$ Parsons turbine, electricity bein; fed into tho N.E.S. Co. grid whon gas was availablo. Elsewhore exinaust steam vas utilised through exhaust turibinos. Tho West Heat Company's power stations fulfilled the same purposo, most of the capital in this case being provided by the Cleveland Company. N.F.S. Co. and the Clcveland Compary drew more closely torether and in .1909 the two syetens wore inter-connected. In that year the two companies obtained very extensive perliomentary powers for linking up generating stutions, transforring majns and maiking agrocments on new woriss. This marks the beginuing of the first area grid which stretched from north of the Tyme to South of the Tees. As the Cleveland Company grew it began to buy electriclty fron the low cost Viercastle stations rather than extend its own plant. In 1912 it bought 12 milizion $K T h$, in 191421 million. In 1914 N.R.S. Co. bought a controlling share of the Clsveland Company's shares.

The otien electricity suppliers in the area were tice lorthern Counties Electric Supply Company, the Nercastle \& District Co., and the

1. A turbine which used steam at atmospheric prossure, discharging it at a high vacuun.

2. P.B. Henderson, on.cit.2 P 78 .

3. The connection was made on 26 June 1909 and thus two stations 45 miles apart were rum in parallel. Nercastlo Electric Supply Co. Lagazine, Nunber 45, PP 9 - 20. Surmer 1959. 
municipalities. The Northern Counties Corpany cirned a nunber of amall generating stations and provisional oxders scatterca over Northumberland, Durham and North Yorkshire. In 1966 it becane linked with tho Cleveland 1

and Durher company, which provided it with bulk supply for distribution within the Cleveland Company's area. In 1912 N.E.S. Co. took over control of the Northern Counties Corpany"s operations in the N.S.S. Co.'a and Durhan Company's orea and thus it was integrated into the H.E.S. Co. grid. The Newcastile \& District Co. remained separate and the Corporations of Darlington, Midalesbrough, South Shields, Stockion, Sunderiand, Tynemouth and West Hartlepool had their own generating stations. In 1906 however Middlesbrough and Iynenouth decicied to start buyine current in bulk rather than extend their ganerating capacity, and they were soon followed by Stockion. The others remained entirely separate until much later.

Thus before 1914 there was a large local "Bria" in the North East. The interconnecting of stations neant that tho rewest and most officient stations could be used for the base load and oldor smaller ones used for the syster peaks, thus substuntially reducing generating costs.

1. A holding comany Cleveland and Duriran Flectric Poitor Ltd., was formed to control both the Clevoland \& Durhan Dlectric Power Company (which hold the Parlianentory poriers) and the Nortinem Countios Company.

2. P.B. Henderson, -0.oit., $\mathrm{PP} 81$ \& 83 . 
Carville from 1908 onwards had an averago load factor of $5 \mathrm{c \%}$, which was an inportant reason why its costs were so low. Fron 1905 Neptune Banl became less used and from 1907 was only mun to west the peak. Similarly toviun porver station, planned as the County of Durihan Power Company's min station was only used for pear loads. flso the Interconnection of customers over a lare arca, and over a wido range of industries, led to considerable diversity of peak loads. In the years 1904 - 1910 inclusive the naximus sinultaneous load on the N.E.S. Co. generating stationis was on the average only 88,4 of the sum of the maximum loadis on each station. But in those years Carvilie dominated N.A.S. Co.'s power atations, a counting for 61,0 of tive system capacity on the average in $1906-20$. And by the timo Carville reachad its ultimato capacity of 39,000 II by 1909 it was tho second bigect porfer station in Britain and in fact had nore capacity tikn any otider supply undertaking except janchester which had 3 power stations. Thus the diversity of loads achieved because of the size of the If.S.S. Co.'s undertaling is wach under-estimated by the above figures. Merz attributed a large

1. Average of the load fector 1903 - 1914. inclusive. It is exceptionaliy high ior a pre-191/ porver station.

2. Later figures not avaijable. 1907 is wissing.

3. Cleveland and burhais Corrpany not included.

4. The Lots Roal Fowcr Station of the Incion Underground Railrays was the bigfest with $\$ 4,000 \mathrm{KM}$. 
part of the very high load factor of the systers, which was between 40 and $50 \%$ srom 1907 ormards, to the divorsity of loacis.

Eut costs werc also luw becauss of continucd excellent engincering. In $1905-0923000 \mathrm{KW}$ of capacity wero aclicd at Carville at an average cost oi' 89.8 per Kir. A new stition was opened at Duraton In 1910 with $23000 \mathrm{KW}$ of plarit, eit a capital cost of 1010.5 por KWW. This was very anch lower than tho national average.

\section{Table 33.}

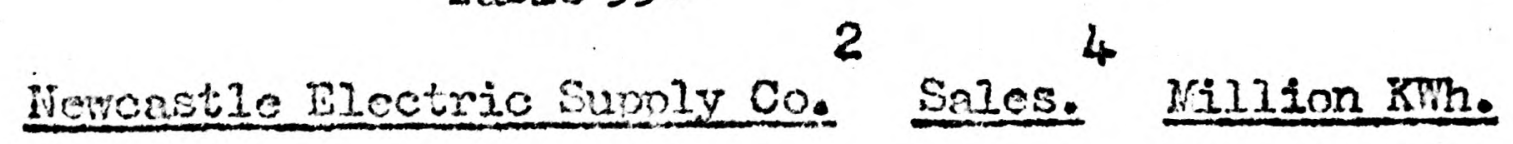

Year Iighting Heating Traction

Power

\begin{tabular}{|c|c|c|c|c|}
\hline $\begin{array}{l}\text { Snall } \\
\text { motors }\end{array}$ & $\begin{array}{l}\text { Vanu- } \\
\text { Sac- } \\
\text { turers }\end{array}$ & Collieries & $\begin{array}{c}\text { Chenical } \\
\text { and } \\
\text { Process }\end{array}$ & Bulk \\
\hline
\end{tabular}

\begin{tabular}{|c|c|c|c|c|c|c|c|c|}
\hline 1901 & 1.2 & & & & & & & \\
\hline 03 & 2.3 & & 2.5 & 4. & & & & \\
\hline 05 & 3.5 & 0.2 & 11.6 & 1.1 & 23.6 & 0.4 & & \\
\hline 07 & 4.5 & 0.4 & 13.3 & 1.6 & 36.7 & 7.8 & 30.6 & 4.8 \\
\hline 09 & 4.5 & 0.5 & $u_{t \cdot 2}$ & 2.6 & 38.5 & 34.3 & 36.1 & 4.6 \\
\hline 1911 & 5.2 & 0.7 & 25.5 & 1.9 & 48.0 & 44.9 & 42.0 & 7.6 \\
\hline 23 & 6.8 & 1.1 & 15.3 & 2.5 & 73.4 & 76.7 & 35.9 & 20.4 \\
\hline
\end{tabular}

1. The Ifercastie Nlectric Supply Co. statistics are ambiguous, but from 1903 onwards the load factor seen to have averaged about $45 \%$.

2. Includes Lurhan Conpanies, Durhan Collieries Co. and Northern Counties Co (af'cor 1911)

3. Bulk supriy to Northern Counties Co. before 1912, Cleveland and. Duribara Co. and Synomouth Corporation.

4. All estimates, except Iraction in 1905, and Chamical and Process.

Source: Calculations from the Newcastle Electric Supply Co. Historical Statistics. 
In 2905 a $\mathrm{Bill}$ was pronoted to try and reorganise Iondon's electricity suply on Tyneside lines. Exioting supply was given in the west by the companies founded around 1890, and in the east by the Borough Councils. The companies had built bigger stations around 1900 and in two cases companfes had combined to build and run joint generating stations. But by 1904 it ras clear that a good caso could be made out for considerable contralisation. The area allotted to each company and local euthority was small, different undertakings supplied adjecent streets and the optimurn size of gencrating station was constantly increasing. Centralisation could have taken place either by further joint generating stations and closer comperation between existing suppliers or the establishment of a new undertaking. The latter's porrers could have ranged from a complete monopoly to co-ordinating the generation of existing undertakings and linking than togethor.

West London was supplied by cornpanies and they had oy 1905 plans for somo co-ordination. But there was no great enthusiasm on their part. One would not expect mach froin the nature of the market. They hat primarily lighting loads, and thus an inelastic demand for their product. Only a substantial reduction of costs would have made a rapid expansion of output profitable. To combine at existing levels of output would have yiolded small results, as existing plant had a low market value, and would not have been Iikely to produce a worthwile return on the cost of the

1. The dewand for electric lighting was increasing; a rapid increase in output means a more rapid increase than tinis. 
Parllamentary povers. Tho latior would have boen very difilcult to get and thus expengive. The local authoritles in tho east ind wero anxious to eall olectricity for motive pones, which tho comanica wero conorally not. But they recanded thenselves as guito bic cncuch to tako advantage of all econonies of scale. C.I. Tozdingam argued that tho Borough power atations on the river were as ecanosical as one could expect any to bo.

The two chter contenders for a nes contralised schoul wore the L.C.C. and the Adriritstrative Coungy of London enc District Electrio

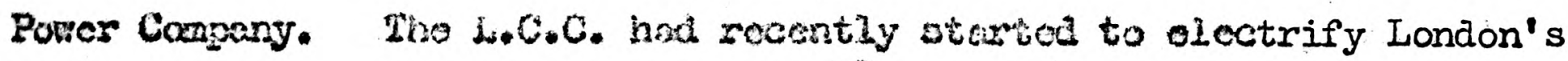
trams, but ito slowness in colng this, end lib obsoloto enginsering whon $1 t$ caro to do 1t, does not the we seel it would have managed ouch a ochomo

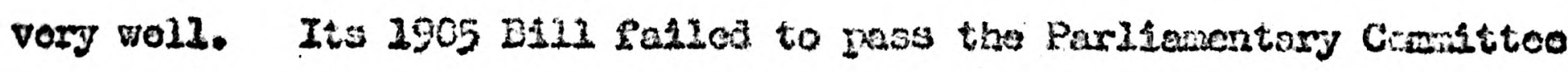
becauco in the opinion of the Board of prade it dia not exoure cheap auply, when at tho onio tino the Councli" 3 Financo Comitton thought

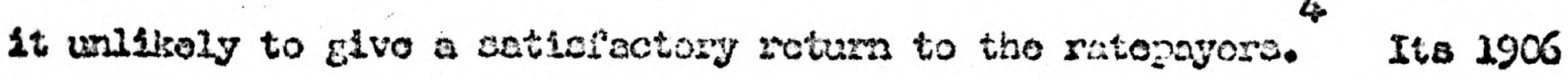

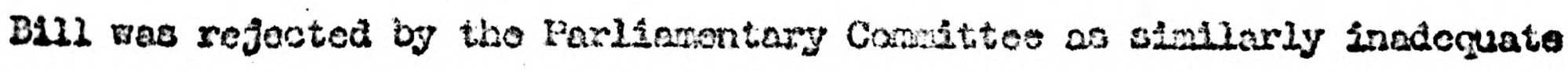
deaplte the fact that 6 of 9 momoro of the carnitio were elth Liboral or Laoour, and it constcored in grosal bosh that a contralised echero was the beet thing por Ionab electricity and rhat the L.C.C.

2. Seo Chapter 3. P 113.

2. Soo chapter 5 .

3. Seo Chapter 3 PIOT for conents on the Grocmich Power Station openod in 3906.

4. E.H. Vol. 60, PR 4 \& 5. 4 January 1907. 
should car.y it out.

There vere several conpany schenes, the Bast London and Iower Thames Bill of $19 \alpha_{4}$ and several in 1905 by tho oxisting supnliers, but the one which nearly succeeded and the only one of all of them which was radical enough in technology to succeed in practice was lierz's, that of the Adninistrative County of London Company.

Merz's plans were based on an increase in output resulting from the development of a power load. In 1905 in the relevant area there wero 39 undertakings with an ae regato capacity of $201,706 \mathrm{~km}$. Mera proposed three nev porfer stations with an aggregate capacity of 210,000 $\mathrm{kH}$. In the two big stations - each of 90,000 $\mathrm{kW}$ - he was to put 20,000 IJV turbo-alternators, each unit thus being noarly twico tho averago sizo of existing undertakings. No generating units of such on output had ever been consiructed, although marine turbines larger in alzo but not in output had been built by Parscns, and on the Continent Brown-Boveri had built turbo altemators of $7000 \mathrm{~km}$. In lingland there. was nothing bigger than the rather unsatisfactory $5500 \mathrm{kl}$ turbines of the London Underground Railways. But Lexz, Parsons and C.K.I. Brom olaimed that by building $10,000 \mathrm{~kW}$-turbo altemators when the largest machines being installed at the time voro of about $3,000 \mathrm{KW}$, tho cost of generating units per $K W$ could bo reduced by at least $20 \%$. Iarge

1. E.R. Vol. 59, PP U4 \& 15. 6 July 1906.

2. Select Comittec of the House of Lords on the Adninistrative County of London and District Blectric Porrer Bill, 1905. Qs 1852-5.

3. ibid: $3 \mathrm{~s} 1888,2005$. 
generators would reduce other capital costs and with good design her: estimated that he could construet the bif power stations for 18.8 per $\mathrm{KF}$. This was an extremely low figure and was attacked as impossible by the opposition. In the following zear the I.C.C. brought out a scheme for an $80,000 \mathrm{KW}$ power station using $10,000 \mathrm{KW}$ turbo-altornators at an estimated cost of $\$ 15.8$ per KW. This latter figure is about what good engineers thought might be obtained irom biff station incorporating the latest practice, and was considerably less than the 125 per KII and more which was what big power stations in the jears 2900 - 05 had cost. "The cost of Merz's transmission and distribution system, although at the modest pressure of $12,000 \mathrm{v}$, , was very low, and was similarly queried by op onents. Colonel Crompton told the Select Connittee of the Comons on the Bill:

"When I studied the projoct, knowing Mr. Merz was a mon who was an honest engineer, who thoroughly bolieved in what he vas saying, and what he was doing I tried to find nut for ryself whore he had deceived hinself in putting cown what appeared to be e. zin.ict!-orsily lor figure as the cost of distribution in London ..... and I conscss the task of justifying Mr. Herz's Pigure is beyond ne. I think it is beyond any encineer who has had experience of laying mains anywhere in the rorld.... I think it ought to be doubled and yery probably trebled. I should say treble was nearer the correct maris".

Merz was trying to do what Ferranti had attempted, and his opponents predicted the same failure. But althou h there are similarities there are considerable diferences. Ferranti tried something quito rovolutionory; Merz was going well beyond what had been done, but nothing

1. E.R. Vol. 58, PP $709-10,777-9,822-3,839-60,900-901$, $918-919,2906$.

2. Except of course Carville.

3. House of Lords Select Comittee on the Administrative County of London and District Electric Power Bill. Qs 6353 and 6854. Nera's estimates were based on a terder Prom British Insulated and Helsby Cable Co. 
like as far as Ferranti. The London stations vere to be based on the very successful layout at Carville, but were to be about threo times the sice. Ferranti was a visionary and a genius, and allowed his imagination to irfluence his calculations. Herz was equally a brilliant encineer and a man of vision, but his calculations were very precise and his predictions usualiy accurate, certainly as close to the mark as those of his conservative opponents. His scheme seemed more radical than it was because of the backrardness of British electracal engineering; In the United Statios and in Gemany it would have been more easily accepted. Capital cost estinates of these schemes are nearly always on the low side, but oven if the actual costs had been as much as $25 \%$ more than estimated it would have been a very cheap scheme. Not that there is any reason to suppose underesination. Running costs also were to be very considerably loss than those of existing stations. Running costs vary usualif with the load factor and lierz hoped for one more than double that of the average Iondon undertaking. Aster making a rough correction for this Merz's estinated ruming costs seen to have been between a fifth and a

1. It is worth quotine Prosessor A.B.W. Kennedy, under examination: "Whe promoters suy that we are old and untiquated - the last vord has not been spoleen in electrical a vance yet; will Mr. Merz be antiquated even in ten years after he has been established?" - "I Ieel quite ceriain that in 15 years fron now wo shall not be having a three phase transmission plarit - we shall be having a single phase". This prediction, like Wordinghan's on the saine occasion, that the steam furioine was a "passing Pashion", has not only turmed out to be quite encorrect, but was clearly unjustifiable at the timo.

2. ibid. Q 4573 . 
a quarter of the avcrace and about a thind of the lowest station. By using $10,000 \mathrm{kr}$ furbo-alternators kerz hoped to reduce the amount of coal lised per unit by $18 \%$ compared with the Carville turbines, which wore roughly the size currontly being installed at the best London Stations. Parsons and Brown wero prepared to guarantee inis. Building the power station on tho river bank with good whare faciljtiles, would have reduced fuel costs coingred with the inland stations. Cartage to the big power stations at Bow, Willesdon and Banisside could cost botween I/Ild. and 3/2a. a ton, a large proportion of the delivered cost of $11 /-$ - $14 /-$ a ton. lierz wanted to use Northumberland coal at a delivered cost of $7 / 4$ at the power station. It had a themal value of only about $75 \%$ of that of the Welsh cosl tineis generally used but the thembl efficiency of the proposed stitions would have been about double that of most recently installea plant. 3 These fectors would reauce coal costs por Kin. generated by about 60\%. Iabour and repair costs would also have been very mach lower per unit generated with larger plant.

\section{The Adninisirative Courity Company thus proposed to supply at}

roughly one third of the costs of the best existing London stations. But

1. Average woriss costs were 1.46a. jer unlt generated for 39 under tokings. The best was $0.89 \mathrm{~A}$. Increasing the load factor to that forecest by Herz would have reduced then by about half. lierz estinated 0.152 . per unit generated for his siation. The Contral London Railway had a 55, load factor against llerz's of $35-40 \%$ and had a works cost of $0.544_{2}$. per unit generaled $(Q .2619)$ and Hest ham hoped to get dow to 0.416 . whon a gocd power load had dovoloped.

2. Carvilile's works costs, with cheaper coal, wero 0.12a. per unit generated.

3. There is very littlo instomation on thermal efficiencies and comparisons are complicated by the load factor. 
despite this it could still have foundered on ovcrestination of the rate of growth of demand. Werz had tried to calculate tise demand for electricity. That for power was based on extiniates of the total steam power in existence, that for traction on the existing suburban train service and that for ligiting on an extrapolation of present trends. 1 By 1910 when one of his proposed pover stations would be in full operation he predictod seles of 64 million $\mathrm{kWh}$ for power, 50 million for lighting and 23 for traction. Fis power estimate was certainly not excessive; in 1910 the existing undertakings sold about 56 million Kh for power in the relevant area. As the Administrative County Corapany's pricos would have been lower and derand was probably elastic 64 million units would probably have been easily reached. For his traction sales lherz reckoned on suburban electrificaiion. In fect there vas scarcoly any, although there might have been had there been a cheap onough suply. Traction sales by existing undertakers erew by less than one million units by 1910. For tho lighting load lierz estirated his possible 50 million KWh on the basis of getting hals the increase in output. By 1910 the actual increase in output in this class was only 39 million units. Demand was not elsitic and so a reduction of prices would not have belped auch. But what had compjetely upset his estimates here was the invention of the metal filament larip, which cut by one half to two thiras the amount of current used for lichts.

1. Select Comnittee of the House of Iords on the Administrative County of London and District Electric PCincr Bill. Os 2858 \& 2010.

2. The company sought to sell power direct in tho "industrial area" the Eastern area - as woll as through authorised distributors, and through authorised distributors only in the remainder of the area.

3. See Chapter 5. Section 3. 


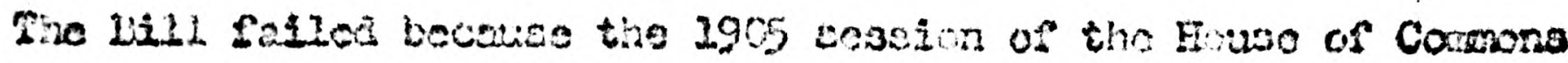

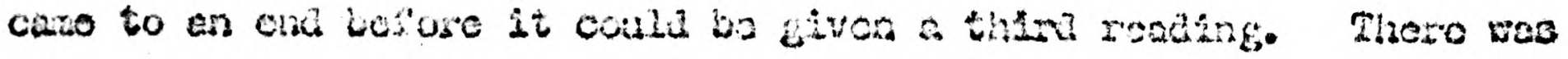

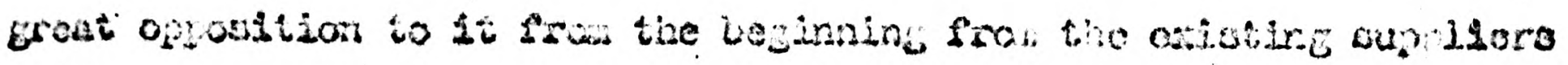

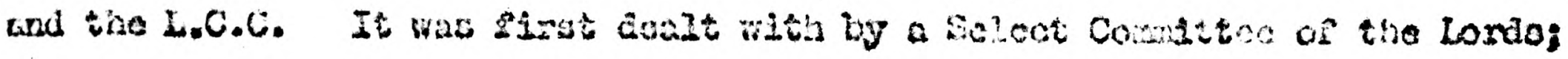

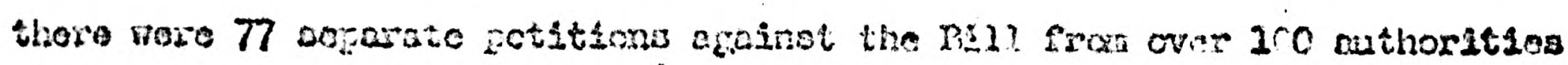

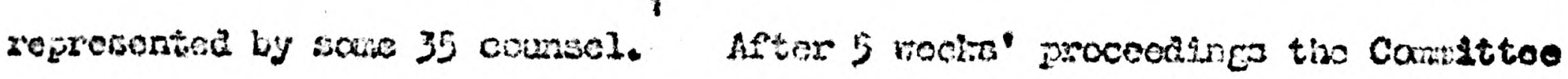
decided to recomend tho 2512 , althoun not for the whole exen caked for.

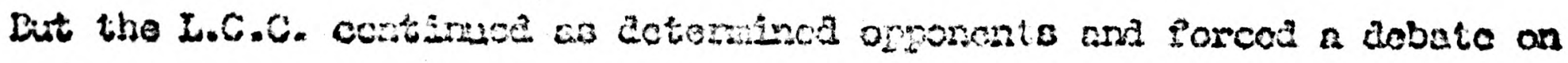

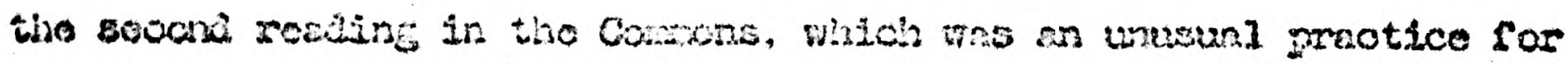

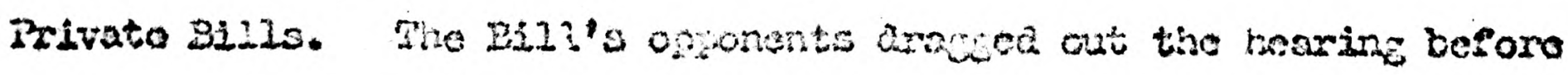

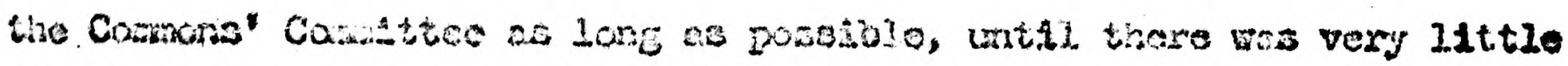

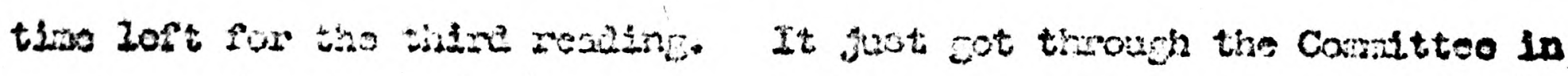

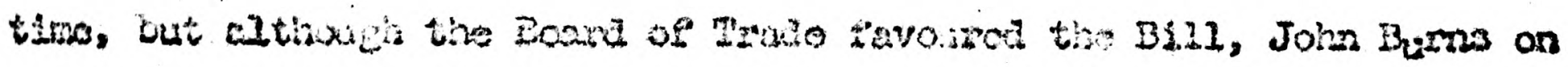

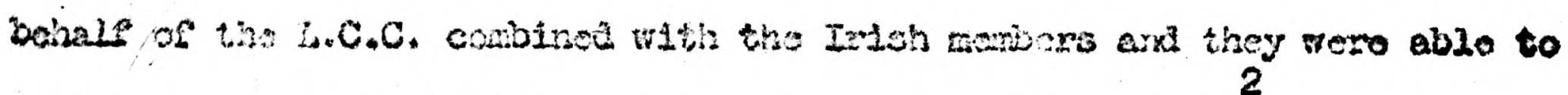

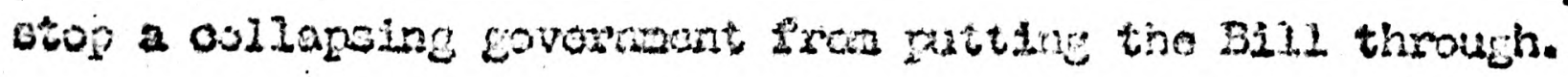

Fhe Itional eovermant widh tollowed was no sriend to privato

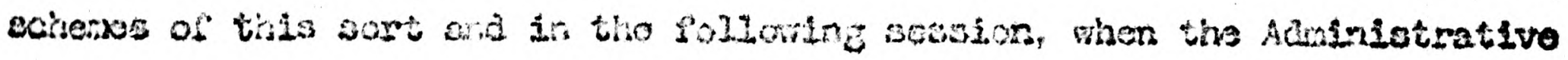

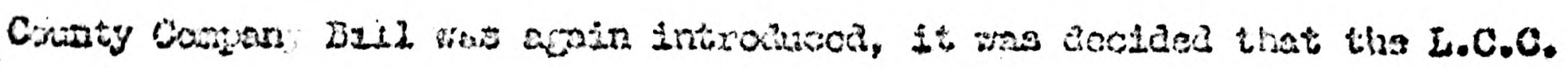

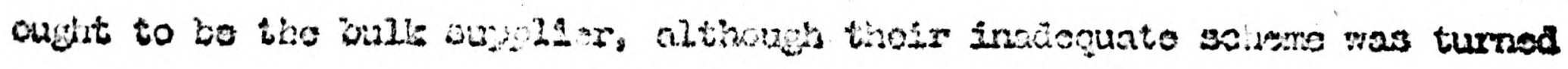

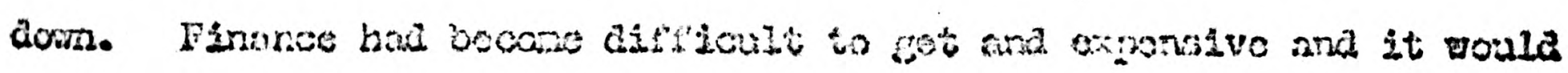

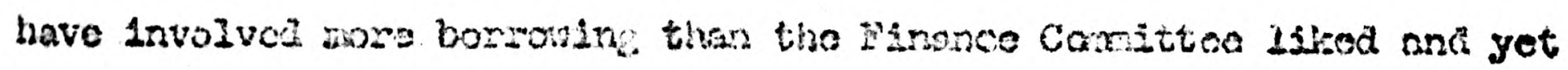

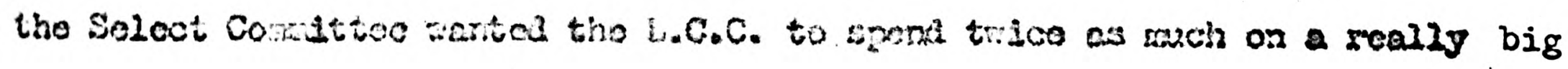

1. C.H. Yoxz, wetrats Dotos.

21. Lierz later mote "one noturnily aske whother anvibing could have boen

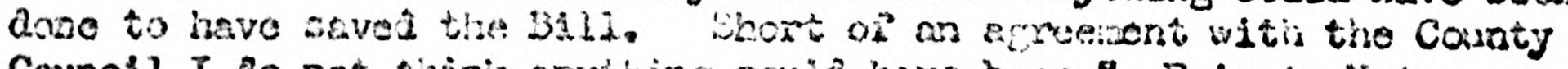
Counchl I do not thirit enyining could havo boon." Privato lintes. 
scheme. Ihen came the L.C.C. Clection of Harcin 1907. Expenditure on public works in genersl and electricity suprly in pirticular was a major issue. The Conservatives gained a sweepin viciory, and dotermined not to proceed with a bulle supply schone. The Chairman of tho I.C.C. Parliamentary Conmittec said that the promotion of anotinor L.C.C. Bill would be a waste of the ratepayers' money. 'Jy then the i.c.c. would have preforred a big private scheme, but the Iiberal Goverment was opposed to this and vented an I.C.C. schere. Thus the prospects for any privato Act of Parlianent wero slin. The cost of a pxivate promotion was very high, the Adninistrative County Compary had spent \&50,000 in vain, and the two things in cunbination were enough to deter any private prosotions.

There the untier reited. Acts of 1908 and 1910 allowed existing suppliers to associate, subject to the aproval of the Board of Prade, to supply power to each other and to work conion generating stations. Not much was done; in 1909 a joint conrittee of ranicipal and company ongineers did not recon ena a general inusing up, being satisfied that existiug stations were cepable of reeting all requiroments for the next ten years. Prom one point of view there was wash to bo sata sor their recomenation. Only herz's plan wis n sufficiently radical innovation to reduce costs very greatly by an overall scheme. Between 1965 and 1913 the Ioncon supiniers added $131,758 \mathrm{kP}$ of ca acity to their Eenerating stations, spending 4.2 million. Power stations would account for no more tiran half of this - i.e. about $\$ 26$ per KW addeci. It was a

\section{E.R. Vol. 61, PP I - 2. 5 July 1907.}


a lower figure than the nationel avoiace, bevase it nerely invelved

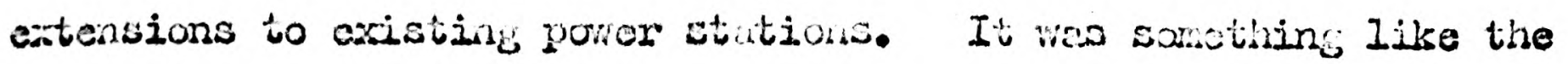
best estinates of tho i.C.C. and the bieger existing suppiers in 1905 and 2906. But it was about trice what it colida have becn. 


\section{Chapter 5.}

Blectric Traction.

The story of electric traction falls into three parts: the oloctric tran, electric urban railways, principally London underground, and the electrification of suburban railway lines. A fourth section on the oxtent to which lichting and traction wero complementary follars.

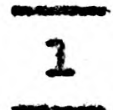

Electric trams started late in this country, being pirst almost entirely an American inport.

Table 34

Electric Tramay lislease.

\begin{tabular}{|c|c|c|c|c|c|}
\hline Year & $\begin{array}{r}\text { Great } \\
\text { Britain }\end{array}$ & Germany & Erance & $\begin{array}{l}\text { Other } \\
\text { European } \\
\text { Countries } \\
\end{array}$ & $\begin{array}{l}\text { United } \\
\text { States }\end{array}$ \\
\hline 1890 & 8 & - & - & - & 1,300 \\
\hline 1895 & 45 & $2 \mathrm{C}_{4}$ & 60 & 111 & 20,363 \\
\hline 1397 & 88 & 400 & 174. & 202 & 13.765 \\
\hline 2900 & 572 & - & 470 & - & 19,314 \\
\hline 1903 & $14: 62$ & 2310 & 1245 & - & 27,754 \\
\hline 2906 & 2195 & - & - & - & 36,212 \\
\hline 2913 & 2595 & - & - & - & 45,004 \\
\hline
\end{tabular}

- Includes elevated railways. Bigures aro for route mileage except for the United States where they are for miles of single track.

Sources: Elcctrical Trades Dircctory Eloktrotechnische Zeitserift (quoted in the Ilectrienl Reviev), Board of iracie Returns, Historical Statistics of the U.S., H.C. Passer, on.cit. P $34 \mathrm{I}$ I'Irdustrio Electrique. 
1

They had been pionecred in the United states, and clectric traction hat soon become nore inportant than the old horse trams. As oarly as 189251 ; of the tranerey nileaye was worked electrically, and by 1897 88;\%. In Great Britain only $9 \%$ of the mileage was run electrically in 1897 and only by 1905 had it risen to $89 \%$. The Continent of wurope had also adopted trans after the Americans and there the early clectric tramways were constructed on American Iines. In Gerinany in 1893, 98 miles of electric tramvay were under construction, and of this 81,0 was on the Thomson Houston and Spracue systems (botin Avierican). In other countries the same is true. But in these countries tho Anerican innovation was digested more rapidly than in Ereat Britain. By the midale ninetios there was a boom in electric trammay construction and German manufacturers were quick to make traminay equipment. In England there vas scarcely any activity until 1897.

One reason for the delay was the effect of the 1870 Tramays Act. This was passed to iacilitato the construction of the tiren brand new horso trans, and to provide some public control of them by stipulating that the tramray should be able to be bought by the relevant local anthority after 21 years operation, at the plant value. By 1878, 269 miles of horse tran had been built, and another 542 miles were added between 2878 and 1885. Thereafter rileage eren more slowly. By 2889 the horso trans reached their maximun mileage of 940; they remained at

1. See H.C. Passor, ov.cit., Chapters 15 and 16.

2. Fele Vol. 33 P 319, 22 Septenber 1893, quoting the Electrical Vorla oi Now York. 
Table 35.

Gross invostrnent on electric iromways.

Year $\quad 8000$

Op to \& including 1893

530

1894

120

5

400

6

420

7

570

8

1,680

9

2,550

1900

7,000

01.

6,780

02

6,780

03

6,780

4.

6,224

05

5,903

06

5,914.

07

4,103

03

2,823

09

2,918

1910

I,731

21

1,705

12

1,982

13

1,618

1. Before 1904 the figures are rough estimntes, based on mileage open and the total capital spent by 1903. The Iirst corplete Board of Trade Returns aie for tire end of 1903. The 1898 - 03 estimates for 
that lovel until 1899 when they began to be replaced by the electric tramay. Thus a large mileage would have been purchaseable between 1899 and 1906, and some of courso earlier. In gencral the trampay undertakings nover felt that they would get moro than tho "scrap" value of their plant on compuleory purchase and that ten years was too short a tine to get an adequate return on clectrisication.

This was strongly reinforced by the low profits of the horse trams. In the early ninetios those were almost certainly operated at a 10s5. Depreciation allonances were inaciequate, equipment was often in poor condition and dividends were ofton below the long torm rate of interest. Receipts probably covered no more than 80 - 90; of real costs. Even in the $1870^{\circ} \mathrm{s}$ there vere per profits. Gross profits in 2878 were only $5.5 \%$ on historical cost. From 1878 to 1835 they seem to have built ahoad of demand and the gross profit porcontage had failen to $4.9 \%$. But it is diflicult to believe that deprociation and interest arounted to less than $8 \%$ of the value of plant. In the late eighties $30 \%$ of the trampays paid no dividends. . In this situation there was no enthusian to try and find the considcrable capital required for electrification. Tho gencrally Iow denand for tramay transport would

1. This is argued by Vasey inor, the Econonic Elfect of the Tranmay Act 1370, Econonic Journal, 1901, P. 507.

2. The capital expenditure figures given in the Tramay rciums are unsatisfactory because depreciation was generally inadequate. This Fould give the profit porcentage a tendency to pall over time.

3. E.R. Vol. 26, P. 717. June 1390. This is no doubt an approxinate percentage. 
not have encourated the building of new electric tramays where there were no horse trons. For although there were oniy 131 tramway systems in this country in 1890, they were in general in the centres of large towns where demand was highest per route milo. But demand continued to grow after 1835 although capacity was added to more slowly. Tablo 36 attempts to give an index of capacity utilisation. Is a consequence of this growth of demand relative to capacity gross profits as a percontaco of historical cost rose to $5.3 \%$ in $139 \%$ and $6.4 \%$ in 1898 . This probably underestinates the real rise in profitability.

Table 36.

Capacity utilisation in Iranmays.

\begin{tabular}{|c|c|c|c|}
\hline Year & $\begin{array}{l}\text { Passencers pala. } \\
\text { per routo mile }\end{array}$ & $\begin{array}{c}\text { Passerigers p.a. } \\
\text { per car }\end{array}$ & $\begin{array}{l}\text { Index of passencers p.a. } \\
\text { per car \& per route mile }\end{array}$ \\
\hline & 000 & 000 & $1878=100$ \\
\hline 1878 & 543 & 132 & 100 \\
\hline 2886 & 444 & 115 & 84.8 \\
\hline 1890 & 555 & 133 & 103.9 \\
\hline 2824 & 633 & $u_{i 7}$ & $23 \div .4$ \\
\hline 2898 & 807 & 161 & 135.7 \\
\hline
\end{tabular}

- Obtained by combining columa 1 and 2 with equal weichting Source: Board of Pracie Returns.

1. H. Finer, Munioipal Prading, Iondon 194. I, P. 53. 
Som municipalities had boen interested in tramiays from 1870. But these were only a fer, and by 1890, 26 local authorities had spent only \$2.9 million on capital account against 810.8 million by 105 companies. Moreover only Huddersfield was actually working its lines, the others being leased to a company. But in the early 1890's the manicipallties sought to become operators as well as omers of the tramays and from 1892 many Important municipalities obtained operating powers. Having leased tho tramays would have made it rore difficult to change the forn of motive powor, but the corporations showed little desire to do this in any case. As in the caso of electric supply in the early nineties they were not anxious to Innovate; they still sar this as the function of private enterprise. This was not universaliy true: Bradsord, which had built the first municipal power station started experimenting with electric traction in 1892. Against this however one can quote the example of Glasgor, whose trams were leased to a compony. When the leaso expired in 1894, the Corporation started to woris its trams. Its girst act was to buy 3000 new horses. 3 In 1895 - 6 they started to consider electric traction, but it was as late as 7998 bepore they had equipped as little as $2 \frac{1}{2}$ miles of electric trarstay.

In the event private innovations largely failed to materialise. The very early experiments with electric imans had not been encouraging.

1. H. Finer, op.cit., P. 53.

2. E.R. Vol. 30, P. 58I. 6 May 1892.

3. Vesey Knox, op.cit., P. 507. … Vol. 43, P. 597. 21 October 2898. 
One of the crucial tochricel problens at first was getuing the elcctricity

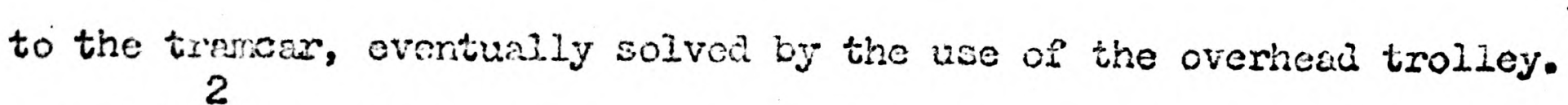
A conduit line 2 miles long was built on Wlackpool Promenade in 1885 but it did not rook velz. Insulation was poor in the conduit and the plouch wes regularly fouled by dirt. Also the tramay motors gave trouble.

Another carly systen was with accurculatory on the trans. The idea of accumalator trons was attractive as fer modifications needed to be made to the horse fran systems. Bat despite constant experimentation from 2382 onwaris, they were nover satisfactory. At pirit they continualy brolie dorn but eventually by the late exighties some battery cars had been unde to operate adequately but they rere excessively costly. One experiment with accurdulator cars was at Barking. The North Letropolitan Tranray Co. Was approached by the Elejson Electric Praction Co. in 1889. Tize latter wanted to work a small part of the former's lines with accumlator cars. They vere to be paid 4.d. per car mile, the cost of horse traction. Eut the Electric Iraction Co. suffered from so many oreakdowns that they were uneble to run to the full scheduled service. After 2 years they acked to be peid 5ta. per car mile. The Tranmay Company agreed to do this for 12 nonthe, al thou, in it made the system 1. Ir.C. Passer, op.cites Chaptere 1.5 and 16.

2. The electric cablos wore loid in a slotted conduit in the ground. betwe the rails and contact made by a plough.

3. L.R. 31 cetolor 1885, 7 Uay, 24 September 1836.

4. Charles Klapper. The Goldon Are of Tramvays London 1961 PP $69-70$ 
Irore costly than when mun with horses, but before that period was up the traction compony asked for 7 ta. They were ofiered and took $6 \frac{1}{2} d$. The number of brcaikdowns began to increase and on July 12th, 1892, the North hetropolitan Co. decided to return to horsos. Tho real costs of accumulator traction in this case are unlonom, as despite many attempts by the Pramvay Co. to bo jiven full muning costs, these wero never forthcoming. The Tramvay Company thought that costs were about 9d. per car mile. Accumulator cars also were tried in Birmingham. In 1891. the first year of operation, the cost of roper and repairs to machinery was 5.lid. per car mile, which was sonowhat above the usual cost of horse traction, but the speed of operation was a little hijaser as other costs fell to compensote. But power and repairs rose to 9.9 d., 10.6a., 9.71d., 13.2\%. In the following four years. It was an eccumulator loconotive system and by $1891_{4}-5$ track repairs were costing over 20 . a car mile, a above

figure mach nthe usual horse cost. Receipts per car mile were unusuaily hich, averagine 25.5a. over the sive years, but scarcely high enough. Accumlators continualily broke doin at consiacrablo expense; in 1392 the Electrical Review quotes soneone responsible for workine them "We patch them up by night, and the following day the patches come of "."

In the eariy $1890^{\circ} \mathrm{s}$ the Anerican syston ot the ovorhead trolley did begin to appear. In 1891 the South Staffordshire Pramway decided

1. E.R. Vol. 27, P 30. $11 \mathrm{Juily} 2390$.

2. EeR Vol. 35, PP $290-2,7$ Septonbor 1894 , and Vol. 37, PP $300-9$ ard $364-5$.

3. E.R. Vol. 31, P 398.30 Septemier 1892. 


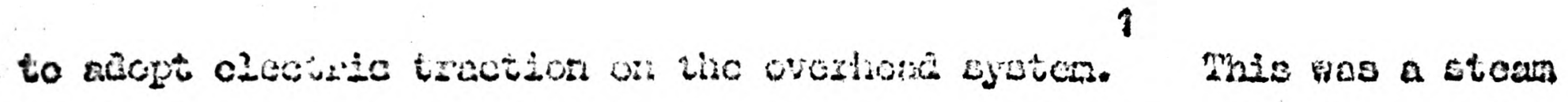

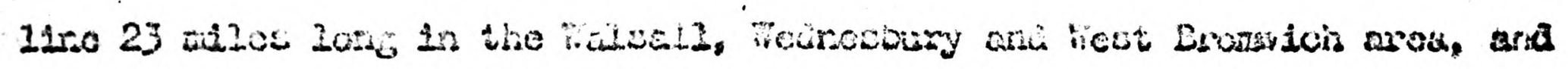

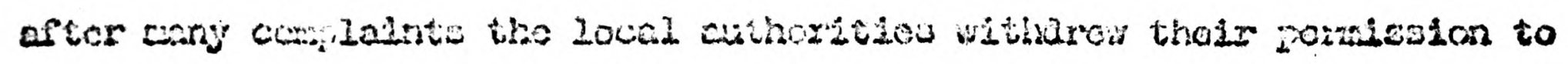

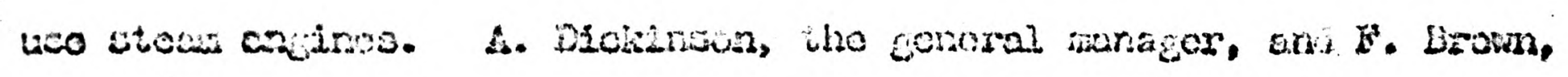

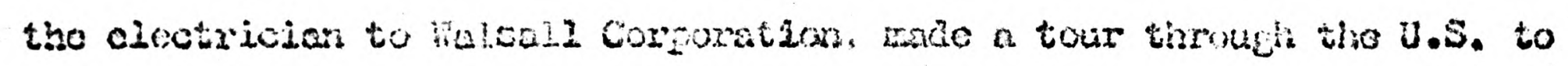

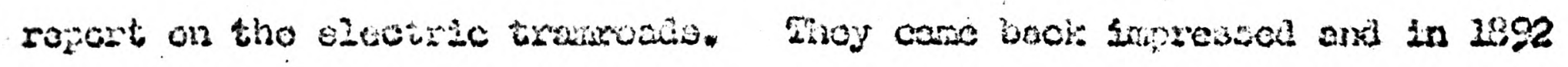

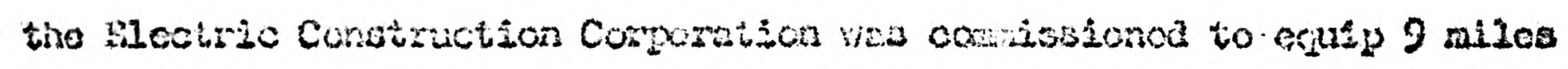

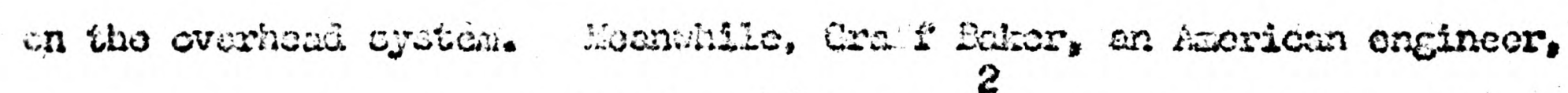

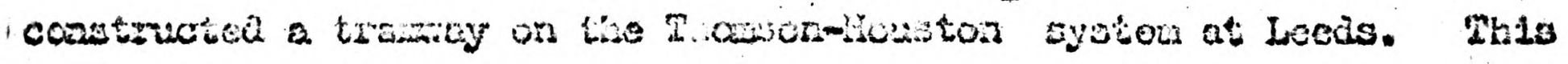

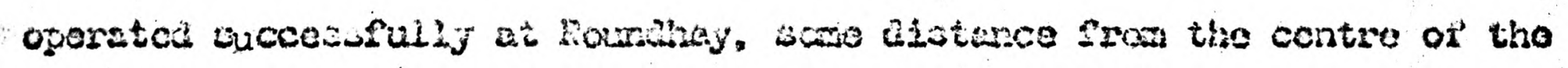
eity.

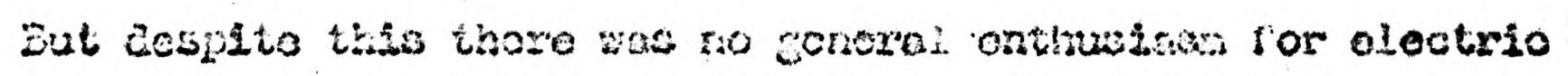

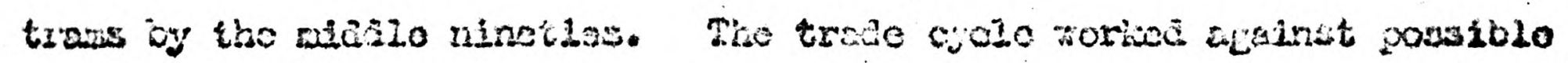

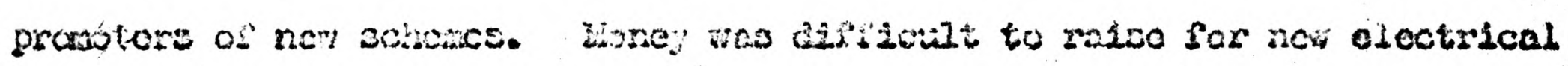

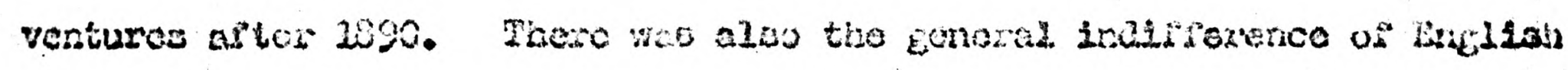

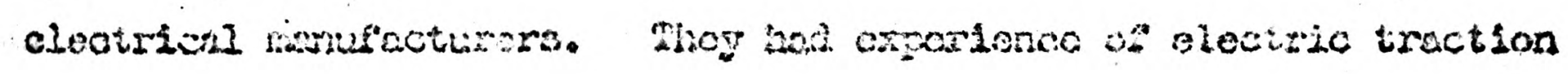

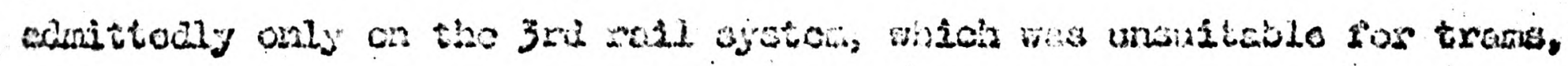

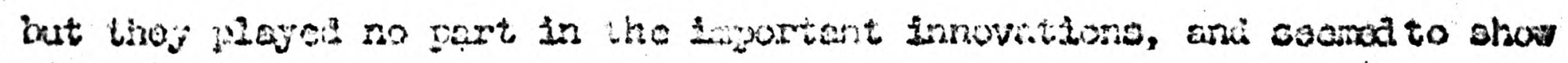

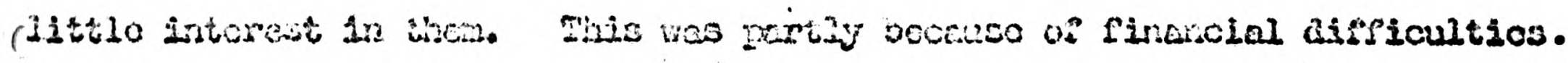

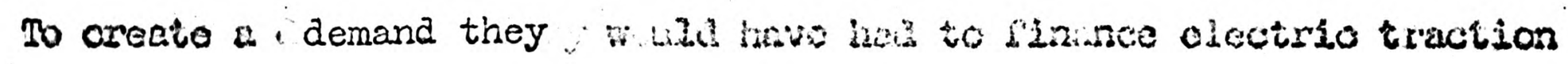

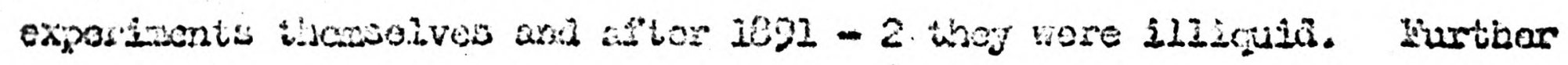

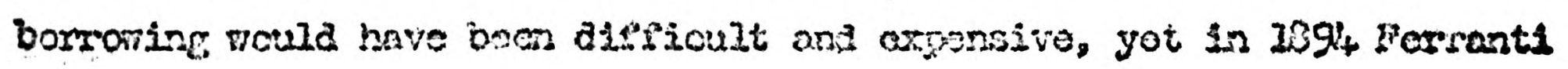

1. E.R. Vol. 29, as $350-1.25$ sotchuer 1091

2. Cno of the main U.S. bystan. C. Wamar quecit., P 65. 
comented ... "everything of a new nature reguires an i.nense amount of personal efiort and continual work to bring it forwara. Electric troction required all the enerey of the whole elccirical lindustry ..."

With no-one able to acaonstrate in pretice tho advantages and costs of electric trans there was little knowledge of either by 1895. It is in this situation that one can appeciate the great contemporary argunent against electric overhead trans - that tho wires were so hideous as to be intolecoble. This was used to a survising extent in the fixwt half of the nineties, although ra one might oxpoct, when the utility of elevtric trams had final ly becone obrious to all, it was discovered that overhead wires could be made quite unobtrusive. The aesthetic arcumert was an excuse for delay rather than a cood reason. In 1897 Vanchester Coxporation decided to change over to electric trans on the overheed systom. It was on 0.1 erounds excent one the best, and the only objection, the asstinetic one, was aisposed of as follows-...

"the overhead construction hos becn brought to such a state of perfection that the objection on aesthotic grounds is extrencly small; indeed there are rrobab7y not half a dozen stroets in the rinest cities, crchitectually speaking, in the vorld in which it would be held to bo a disfigurement. Cortainly in our opinion, it would be none in tho busy comrercial streets or lianchester in whicin the trains at prosent run".

The midale ninetics san the fornation of Britisi Thomson-Ilouston. It was lergely finariced from Cemany, but was staffed by frocican ongineers.

2. E.R. Vol. 35, P 780. 28 December I89\%.4

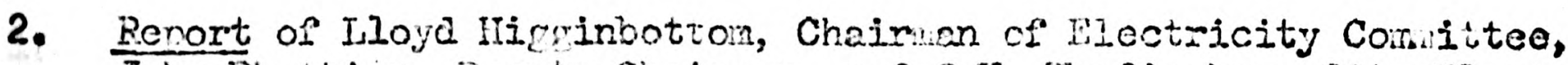
John Phythian, Deputy Chairman, and C.H. Wordingham, City Electrical Engineor, 11 October 1897. E.R. Vo1. 41, IP 568 - 9. 29 Octower 1897. 
This gave a great impetus to tramay elcctrification. Its first customers were the Bristol and Dublin Tramay Comanies. Both wcre con ected with the Imperial Iranavay Corpiany vinich in 1392 anpointed J. Clifton Robinson to its stafe. Robinson, bom in Birkenhead in 2348 , hat worked in trams ever since he had Deen employed by G.I. Train, the horse tram jioneer. He had from the early days been an advocate of mechanical traction, first the cable, thon electrieity. Ha had spont the late $180^{\circ} \mathrm{s}$ i. California, where he had seen the American innovations in electric traction. After his return to this country he had begun a series of conversiors of trans to electricity, starting at Bristol and Dublin, Yle worked closely with B. T-H., who completely ecuipped the Bristol-Kingswood line, opened in October 1895, and the Dublin line, where in 1396 B.M-II. were ecquipping $6 \frac{1}{2}$ miles of overhead system. The initiative was partly D.T-II.'s and they followed these pioneer lines with a rumber of proposals to existing undertaicers. In January 1396 they wrote to the Town Clexk of Newcastle upon Tyne where the Council had been debating tramay improvenents, principally hinging on builaing a cable tramay. They crfered to equip the Iine owned by the Corporation ond leass it for 7, 14. or 21 yoars, supplying their own trams. They would charge the fares sugecsted by the Town Inprovement Cormittec. They also proposed to paj a $7 \%$ rent on the cost of the reconstruction of the lines, 3 on the value of the land, and 15\% of tio net prosits. In December 2896 they prote in sinilar terms

1. E.R. Vol. 37, PP 442 - 53. 11 October 1895.

2. E.R. Vol. 38, PP 18 - 19. 3 January 1896. 
to Yamouth Corporation.

The success of the Dubin and gristol schcnes, the very successful trowans of the U.S. and the begining of substantial clectric tranarey contruction in comery all combinod with tise riving derand for trabray

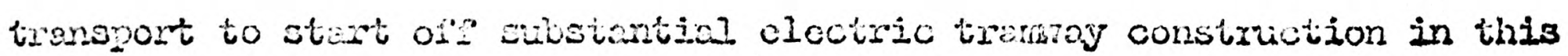
countwy. The Inperial Iranivas expanded their schenes. In 1896 the Bristol Iramay Comany prowotse a Parlianchtory Bill Por wice extension of their elcotide troiley crack into Dristol. By logs the Madiecbrough, Stockton and Thomaby trows bed boon cleetrified under J. Cliston

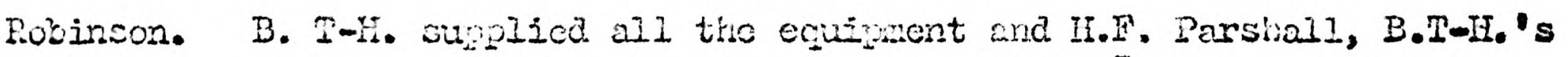

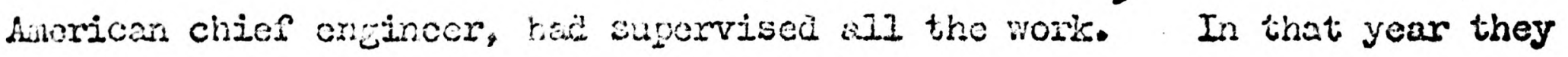
proposed a big sclowe for the Loncion united Tramays. 9 mizes of existing track were to bo scetrified and another 54 miles acied.

The othei tramay conpanies still anomed litole interest, but a lurge schent for elcotrifying then wos put Porvad by tho British Electrio Fraction co. This camping was tomed in Deto cr 1896 witis the object of gaining control of exioting andoridking ant electrifying them. Iy the

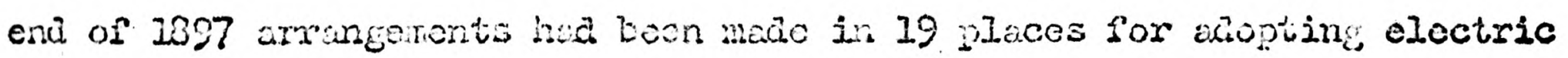

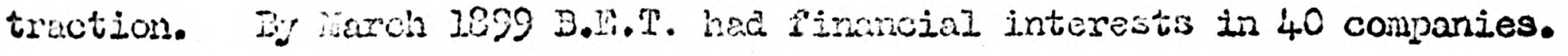
Mlso it warted to build new tramays where none existed. B.b.I. soon cons to doninate compary tramays. 3? of then were electrified and

1. E.R. Vol. 39, P 800, in Docamber 2896.

2. 6? miles, mostly of double track kero involved.

3. E.R. Vol. 43, P 235 22. 12 Nugu, I 1993. 


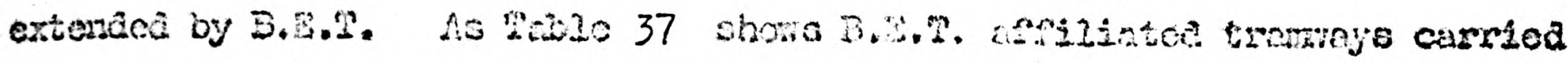

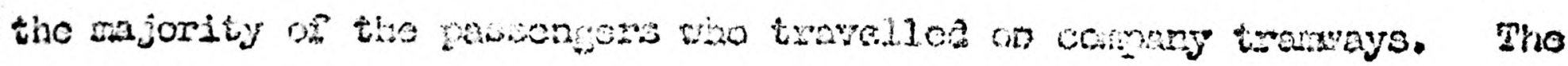

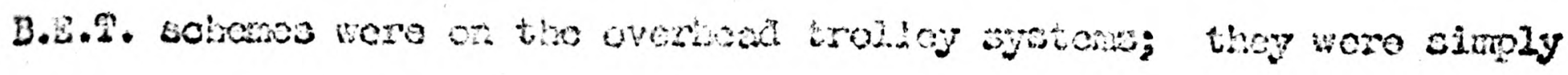

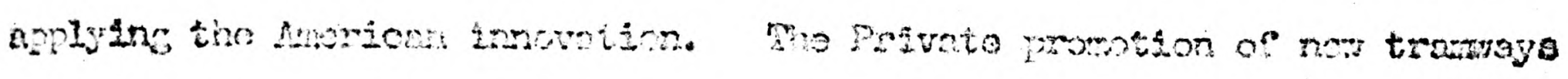

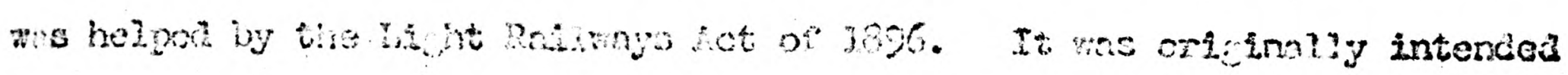

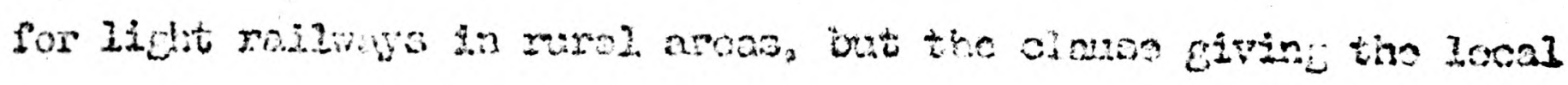

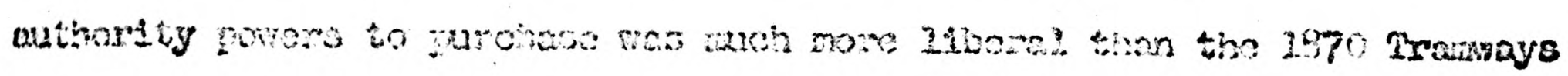

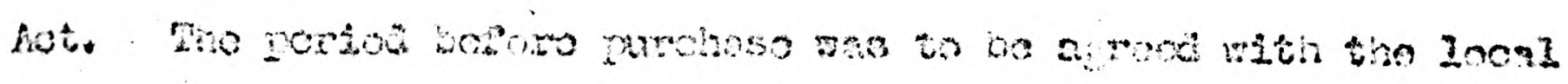

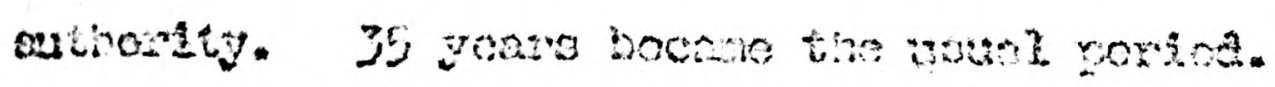

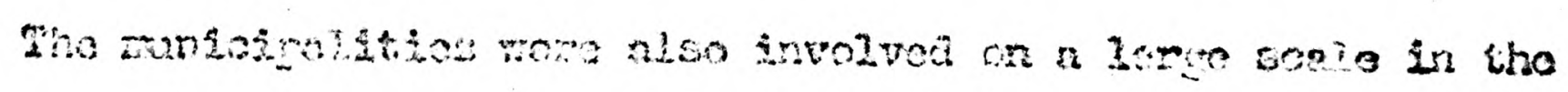

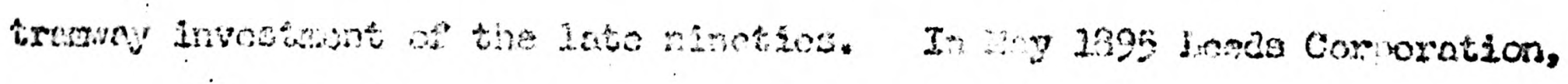

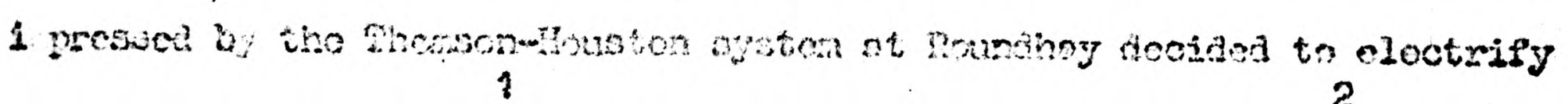

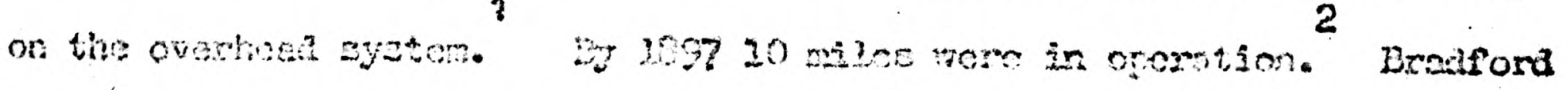

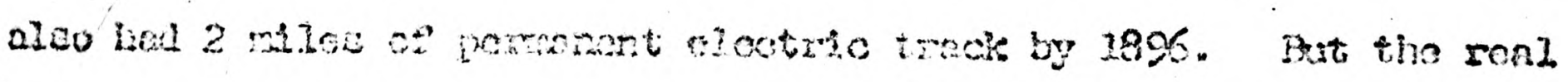

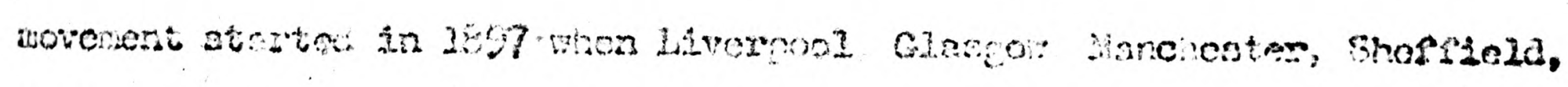

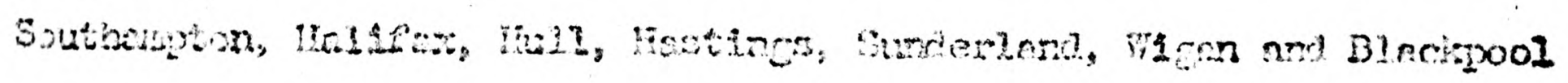

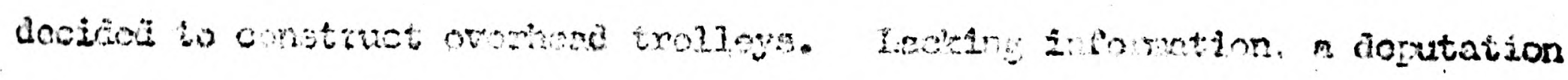

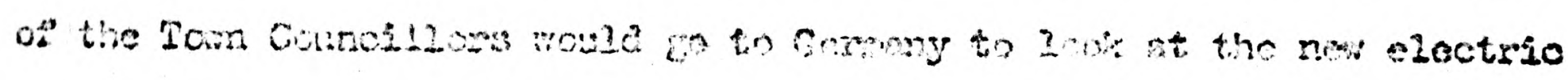

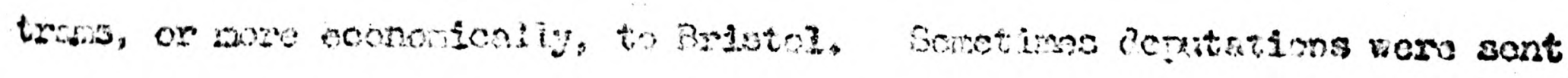

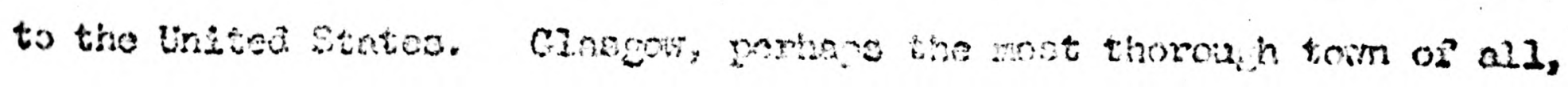

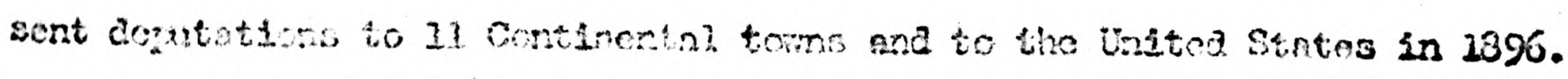

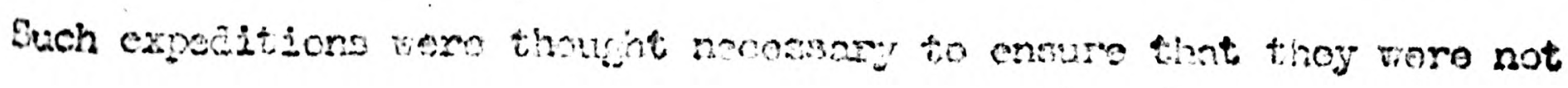

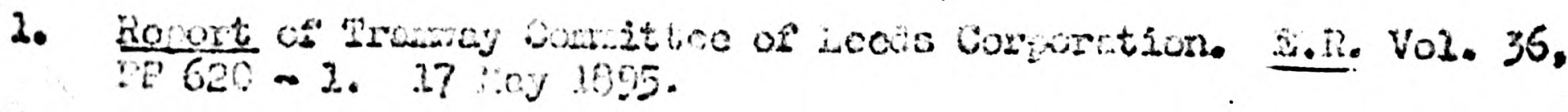
2. 2., V. Vol. 4, 2426. 29 octibar 3897 . 


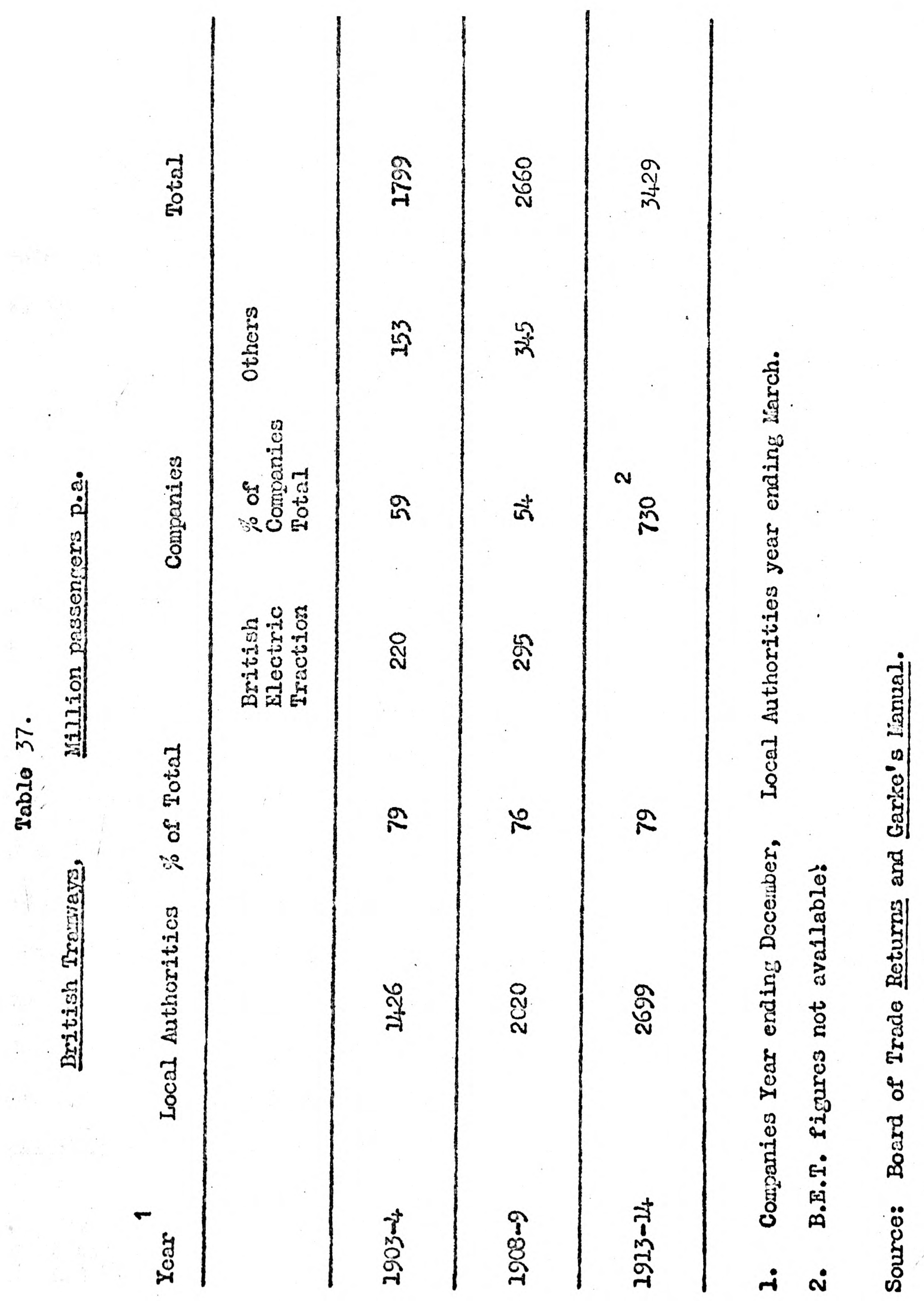


engaging on a speculative venture. They took a long time deciaing what they ought to do but one they had made up their minds they wore usually quick to act. The wave of tramay construction which followed was dominated by the minicipalities.

The only large town where the electrification and extension of troms was seriously deloyed was in Iondon. Although the L.C.C. had obtaincd powers to run trammay in 2396 , and London was bally served by trams, they dia not consider major tramray extensions and the use of mechanical porrer until 2900. By 1905 when other big torns had eliminated them the I.C.C. carried 23,0 of its passengers south of the Thames by horse tram.

Alone of the local authorities they were still sure that the 1 overhead trolley was too ugly to be adopted and resolved to build all their lines on the conduit principle. They were following the practice of many capital cities: Berlin, Brussels, Budapest, Washington D.C. and New York had conduit systens, but they were very mach nore exponsive then the overhead trolley, both to build and to work. F.S. Pearson, the encineer to the For York conduit line estinated that the cost of cleaning and mainterance was 2180 p.a. per mile against $\& 60$ with the overhead systen while it cost $\$ 9,648$ per mile of single track to build against $\$ 5,822$ on the overhead systern. The cngineer of the Vashington

1. The I.C.C. tried to force the I.U.T. to alopt a conduit for the 4 miles of its lines which were inside the Adninistrative County, but Parlianent overruled it.

2. Renort to Iiverpool Corporation. E.R. Vol. 47, PP 24,6-7 19 August 1900. 
and Baltimore conduit line estinated its cost per mild of double track at 1 \&17,221 against $\$ 8926$ for the ororhead. Thus an expensive systern was adopted, and to make matters worse actual expendituro exceeded estimates by a wide margin. At first the cost of the first 200 milcs of track was estimated at $\& 3$ million; by 1903 it had risen to $\$ 5$ million. The. adoption of this expensive system vas to have unfortunate repercussions later.

The overhead trolley turned out to be on innovation which substantially reduced costs. When it was first considered it tended to bo thought of as reducing costs by providing a cheaper form of motive power, but eventually this proved to be a minor point. Much of its economic value lay in its increased speed and carrying capacity. The electric tron travelled at a speed roughly half as Past again as that of horse cars in crowded street conditions, and relatively faster in the suburbs. The mach more powerful electric motor meant also that the size of the tran could be increased so that instead of carrying about 25 people the double decker electric tran could carry 60. The electric tram improved the value of the tronsport ofiered, by raising specds. But it also benefitted the comanity by providing transport which used less resources than the horso trams, and tis also was partly because of higher speed. It is difficult to conduct a precise analysis of costs, for there

1. Roport to Nanchester Gorporation, ibid., These figures agreo vell with other contemporary ones.

2. Royai Commission on Iondon Iransport. Report by Advisory Board of Enginecrs. B.P.P. 1906. Vol. 45, PP 24 \& 25. 
is inadeguate information about capital costs. Dut the genoral outline is clear.

The best unit of output to take is the car mile. The size of capital expenditure was prinarily a function of the mileacs of track. About $75 \%$ of the investmont of a trarstay was in its track, overioad equipent and power station, when it hod one. Expenditure on trams and horses renained a fairly constant proportion of aggregate capital expenditure. This we should expect, as there is a Paizly constant ratio of tramears to the route mileage. Table 38 eives capital expenditure per mile of single track. Other fifures are in route miles and as double track was usually used I have doubled these figures. It is aifficult to knom what chares to make for interest and depreciation. I have taken $3 \%$ interest charce throughout, 50,0\% p.a. depreciation for electric trans and for horse trans $6.5 \%$ in 1878 and $7.2 \%$ in $1898^{2}$ Except for horses these depreciation figures are considerably higher than the depreciation provision maie by uhe tramays theraselves yet I do not tinink they are too high. In Table 39 capital costs per car mile are calculated on this basis and vorking costs and recoipts per car mile have been talen from the Board of Trade Returns to shom total costs and profitability.

1. About hale the elcctric tramay mileace in the country was supplied by tramay power stations.

2. Assurptions are based on years of life of equipment., They are:

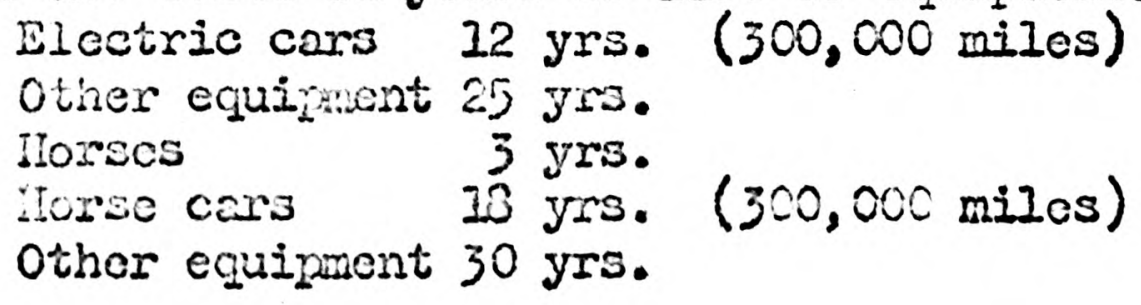


Table 38.

Tramrays. Canitel Utilisation ond invostment.

\begin{tabular}{|c|c|c|c|c|c|c|}
\hline Year & $\begin{array}{l}\text { Cors } \\
\text { mile }\end{array}$ & $\begin{array}{l}\text { per route } \\
\text { of track }\end{array}$ & $\begin{array}{l}\text { Car miles } \\
\text { per cor } \\
\text { p.a. }\end{array}$ & $\begin{array}{l}\text { Car miles } \\
\text { per route } \\
\text { mile p.a. }\end{array}$ & $\begin{array}{l}\text { Capital } \\
\text { exponditure } \\
\text { per mile of } \\
\text { single track }\end{array}$ & $\begin{array}{l}\text { \% of Capital } \\
\text { expenditure } \\
\text { on track \& } \\
\text { power station. }\end{array}$ \\
\hline & & & 000 & 000 & $£$ & \\
\hline 2878 & & 4.2 & 26.7 & 70 & 9077 & 79.5 \\
\hline 1886 & . & 4.0 & & & & \\
\hline 1890 & & 4.0 & & & & \\
\hline 1894 & & 4.3 & & & & \\
\hline 1898 & & 5.0 & 17.0 & 85 & 10,59 & 74.5 \\
\hline 2902 & & 5.2 & 28.7 & 93 & & \\
\hline 1906 & & 4.9 & 22.7 & 212 & 1764.8 & 74.2 \\
\hline 1910 & & 4.9 & 24.4 & 120 & 17873 & 75.8 \\
\hline 1912. & & 5.0 & 25.3 & 125 & 18332 & 75.1. \\
\hline
\end{tabular}

- 2879.

Source: Calculations from the Bosrd of Trade Returns. 
TabIo 39.

Trangrays. Costs and Rovenue per car mile.

\begin{tabular}{|c|c|c|c|c|c|}
\hline Year & $\begin{array}{l}\text { Working costs } \\
\text { per car mile }\end{array}$ & $\begin{array}{l}\text { Capital costis } \\
\text { per car mile }\end{array}$ & $\begin{array}{c}\text { Total costa } \\
\text { cen mile }\end{array}$ & $\begin{array}{l}\text { per Receipts } \\
\text { per car } \\
\text { mile }\end{array}$ & $\begin{array}{l}\text { Surplus (t) } \\
\text { or Doficit (-) } \\
\text { per car mile }\end{array}$ \\
\hline & a. & a. & a. & a. & d. \\
\hline 1878 & - & 6.4. & & & \\
\hline 1895 & 9.2 & 6.3 & 15.5 & 11.9 & -3.6 \\
\hline 1398 & 9.3 & 6.1 & 25.4 & 12.1 & -3.3 \\
\hline 1906 & 6.6 & 5.8 & 22.4 & 20.7 & -1.7 \\
\hline 1910 & 6.6 & 5.7 & 12.3 & 10.6 & -1.7 \\
\hline 1912 & 6.7 & 5.6 & 12.3 & 10.7 & -1.6 \\
\hline
\end{tabular}

1. Car miles per route mile p.a. extimated.

Source: Calculations from Board of Irade returns.

Despite the higher investment per mile of track, electric trams secm to havo been capital saving per unit of output. This was achieved by using their higher speed for a relaivively intensive rather than a Matively extensive service. For the trans were prinarily for urian areas.

Oporating costs 2150 fell dramatically. The cost of horso traction per car mile vas high, between 3.5a. and 4.5a. in the nineries. The amount of elcctricity used per car mile varied botween one Kih for the small cars of around 1900 and two for the double deckers of 1913. 
novie 40

Biecuricity used por car mile on.

$\begin{array}{ccc} & \text { Companies } & \text { innicipalities } \\ 1905 & 0.95 & 1.49 \\ 1908 & 1.34 & 1.69 \\ 1913 & 1.4 .2 & 1.90\end{array}$

Energy cost 2a. - 3a. por kin in the ninetics, but rell to 1a. - $2 d$. by 1906 when the conversion to electric traction was corplete. Thus when electric trans nere first introducca the cost of traction per car mile was about 2.5\%., roughly 60,\% of the cost of horse traction. By 1913 the power cost per car mile of a large double decker tram must have been still only 2.50 .

Traffio expenses, mainly the wages of operating crews, fell with the increased speed of electric tram. They were half as fast again as horse buses and with this increase treplic expenses fell by about two thirds, Pron about 3.52. to 2.5a. per car wile. Wanngement costs were partly overheads and purtly varied with tho car nileage. In so fas as they were overheads they would have fallen with increased speed.

The relatively low operating costs of eleciric traction are arikingly shown in Table 4 I. 
Table 41.

Tranmay operating cxpenses. 1900.

d. per cor mile

5 horse lines

5 steam Iines

8 electric lines

Vintenance of permanent way

0.44

1.30

0.77

Power

3.72

3.51

1.38

Renewals \&

Repairs to cars

1.10

2.24

0.88

Trapicic cxpenses

3.05

2.32

2.67

other expenwes

1.15

1.31

1.15

9.45

10.68

6.85

Source: Profits on Mraway Uniertakings, Paper to the Trantays \&

Light Railmays Association. 29 June 1900. E.R. Vol. 47 PP 75 - 7 .

The capacity of trans rose very constderably, and this would not have been possible without electrification. Thus couts per passenger seat mile pell at least twice as fast as costs por car mile. Loading aid not bowever increase. The service inproved, many nore people travelled, but about the sarze number rode in each car. (Table 42)

By comparison the other possible porrs of mechanical traction, 2

stean and cablo, were ruch inferior. Stean trams offered little if

1. It is inposibible to be more accurate than this as the averace capacity of trans is not known.

2. Worked by an endiess cable working in a conduit between the tracks. The car has a eripper which is released for stops. 
any cost advantage over horses. Power was expensive, partiy as smokeless fuel was expensive, partly as the stean engine is very inefficient when stopping and starting. Although the greeter speed reduced trapic expenses it made up for this by Eeater wear and tear on the lines. But they were uscd. In the miadsle nineties thore were ratiner over 500 steam trams in Britain.

$$
\text { Table } 42 .
$$

Utilisation of Tramays.

Passengers per cor mile Passengers per route
mile p.2. 000

$\begin{array}{lll}1878 & 7.7^{-1} & 543 \\ 1398 & 9.5 & 807 \\ 1902 & 9.6 & 940 \\ 1906 & 9.1 & 1.025 \\ 1910 & 9.4 & 1,194 \\ 1912 & 9.6 & 1,204\end{array}$

- 2879.

Source: Boand of Trade Returns.

1. C. Kapper, op.cit., P 47.

2. ibja.2. 
Cable trams were seriously considered, and were actually installed in a lew pleces. Eut the capital cost was high and in return the running costs scem to have shom no improvenent on those of the electric overinead, except where the donsity of trafic was very high. Power costs were in general no lower than those of the clectric tram and maintenance costs were hither. However the major ecuromic disadvantage was inflexibility. Cars could mun at one syeed only and if the cable broke, which it often did, all cars were imobilised. Inis, ewhward sur small systems in the centre of tom, would have been Intolerable with extended lines of 1905 - 13 carrying large numbers of passengers.

Demand for trarsway transport was risjing continuously from 1886. But both the series for total passengers and that for passencers p.a. per route mile increase more rapidly after 2894 . Fron 1886 to 1894 inclusive passengers were increasing at an absolute annual rate of 30 million p.a.; fron 3895 - 1899 this wises to 70 million p.a. Passengers per route nile from 3806 to 1894 rose at an absolute annal rato of just under 50 p.a. and from 2895 to 3899 at one of 85 p.a. This coincides renarisably closely with the increase in the rate of

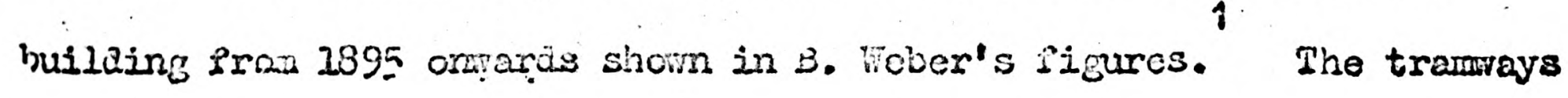
of the nineties were short but at least took people part of the ray out to the suburis. And the nineties vere a period of migration to the towns.

1. Sctttish Journal of Political Econony 1955. Also J.P. Lewis. ioid., 1961. 
0

igure 1. Tramways

(a) passengers p.a.

(b) passengers p.a. per mile
Passengers mithins 1700

1600

1500

1400

(a)

1300

1200

1100

1000

900

820

Passengers 700

p.a bes.

mile lov

$-900 \quad 500$

400

$-800 \quad 300$

200

$-700 \quad 100$

$-600$

$-500$

$\odot$

$-4+00$

$1886 \quad 85990929496 \quad 98 \quad 1900 \quad 02 \quad 04 \quad 06$ 


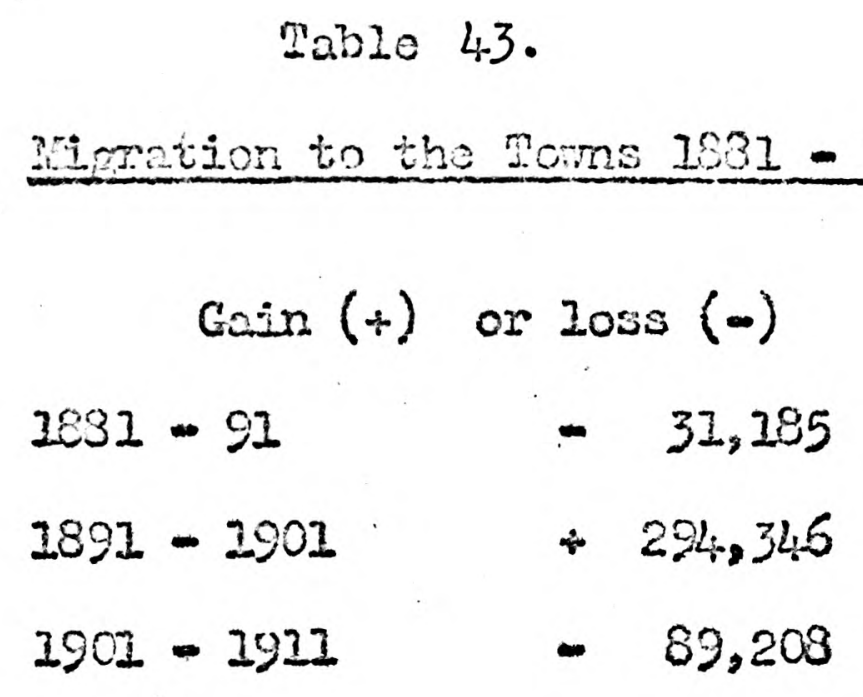

Lordon has been onfited because of its peculiar transport situation which neritis particular attention. The pigures cover 126 toms.

$\begin{aligned} \text { Source: A.K. Cairneross, yone and Noreign Investment, } & \\ & 2870-1913, \mathrm{P} .70\end{aligned}$

It scems hichly likcly that builaing and migration increased the demand for tramays. Short of a completely disaggregated study of building and trenmay experionce in individual toms one's conclusions must be unccrtain. Eut avgregates do cast a little light on the matter. The trannays were in the big toms. The boroughs with populations of more than 25,000 had 34.8 zinilion inbabitants in 2891 and 18.4 million in 1801. Dividing the numbers of tramuray passengers by these populations we get 38 and 71 respectively. If the number of tramay passengers had grown troughout the decade at roughly the sane absolute rate as irom 1891 to 2894 the inder of joumeys per head would have bean 40 in 1901. Thus if population increase in the toms was steady throughout the decade the increase in possengers in $1891-4$ could

1. This is not a good figure fur the nubor of journeys per head in the towns but will do well enouth as a type of index nunber of average iravel frequency. Undentiking cotublished under tho light Railraya Act are cxcluded from the published statistics before 1902. The 1901 figure of passengers is estimated, the estinate being 1300 million as against tho publisicd 1793 million. 
simply have been because of povulation growth. If passengers had grom at the sare rate as in 2595 to 1893 (or 2899) the index of jouneys per head Fould have been 50. This nay be said to be the rate of incrense due to builaing although of couxse such a conclusion can only be very tentative. This assumes thet the hotging boon han the sarne influence on the later staces as in i.e carlier. If it is correct to assume this, the remaining increase nust be due to the effect of the electrification and extension of trans. They vere mach fnoten than horse trams and fares were often a littie lorer, expecialiy workmens fares. On these assupptions 23, of the increase in passengers up to 1901.was due to popuzation growth, 50; to building ara $32 \%$ to trararay innovations. The builating boor wes not crucial to the decision to electrify in a number of cases at least, wit it probajly afisected the length of line pinally built and pexhaps the tinine of conversion. Wany local authorities had in the early and middle nineties been generally investigating mechanical traction. Cavie and stear traction, particularly the former, were considered. Dat the rhouson-Lunston lines and developnents abroad shomed that the electric overheal system was nuch cheaper and asso faster and more plexible.

The electrification of the tranrays, and the extension that wont with it brought an increase of demand of itseli. Inis was helped by a recuction of pares. Tany manicipalities recuced fares when they

1. The passengers figures for 1895, 97, 99 \& 99 all lie on the line of equal absolute grom assurce in the calculations. 
took over the ruming of treumeys. Iiverpool Corporation reduced fares by $30 \%$ when they took over and electripiad the trons. In Manchestor the average fare per mile if the sull staje vas covered fell from $0.93 d$ for the horse cers to $0.1,8 d$ for the rmanicipal electric cars after 1903. By ig14 it was dom to 0.35a. They vere expocially arxious to have

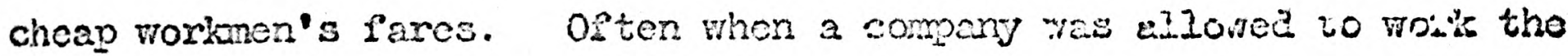
irans, low workmon's fares wero insisted on. To construct an index of fares is virtually imposeible and the following table of recoipts per passencer suffers in that the length of journoy is unlnown. What is Iikely is that the average Ienth of joumey travelied roso at the time when the trans were being exiended and specded up.

Table 44.

Irompays. Averoge receipts per passenger d.

$\begin{array}{ll}1892 & 3.46 \\ 1896 & 1.41 \\ 2896 & 1.31 \\ 1890 & 1.27 \\ 1900 & 1.23 \\ 1902 & 1.15 \\ 190 \% & 1.14 \\ 1912 & 1.12\end{array}$

Source: Board of Irade peivums.

1. c. Klapper, oo.cit. PP $134-5$. 
The extent of the increase in acrand was considerable. By 1905 there were 2,236 million passengers carried on the tramrays. If passengers hod increased at tho same absolute rate ais in 1095 - 9 theie rould havo been only 1,200 million. Individinal towns tell the sane story. In

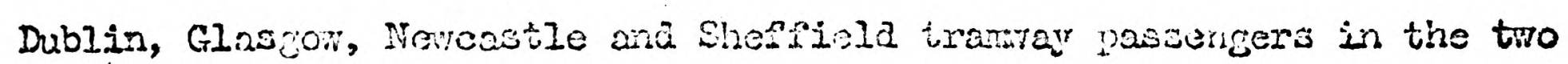
years following elcetrification were $70 \%, 79 \%, 394 \%$, and $591 \%$ greater than in the two years preseding elcctrinication. Sone trafic was gained from horso busss and cabs, but in the cases where figures are available it was less thar lis of the total increase.

By the cnd of 2903 the intoluction of electricity had led to a doubling of the tramay milenge but thoreater the tramavs extended wore slowly. In the four jears 1399 to 1903 inclusive 776 milos of tramay were built; in 10 years Pron 1904 to 1913 another 834 wiles were added. The tratray boom aid not die aroy as quickly as the building boom but it desincd at the same time.

In the Unitod Statcs tromby construction utinulated residontial builajngs but in this country the chect was men lesi ponorful. Beforo one crn dran any very fimm conclusions about the relationshis botween bullding and trarmays, a detoiled stidy rould have to be made of indi:idual towns. In its ejscnce one can only weculate on the likely strength of the infuchec of better transport on buizing. Better, 1.e. Paster and/or cheaper tronsport on building, reüuces tho cost (in monoy and/or time) of living in the siburbs. Wut the extent to which a civen reduction in tho cost in trunspont (noney plus tinc) will stimulate the

1. Royal Cuaisoion on London Transvort, B.P.P. 1905 Vol. 42, P 938. 
demand for suburban housing will vary. One would expect it to be considerabje either if the incone elasticity of dement for suburban housing, or the rate of growth of inceme was hich. In the relevant period British incomes do not seen to have been hich enough for one to expect a hich incone elnsticity of domand for housing. Trans were always reearded as being rather proletorian, and thus i's is the incomes of the artisen and lorrer midale classos that are relevant. Also at the time income per head was prowing only very slowly. In this situation on would erect better transport to silmulate suburtan building onIy slorly. Contemporary evidence as to the matter appears at first to be rather comilicting. During the building boan 1895 - 1903 many people arcued that botter tronsport had led to considerable suburion building. Irany of the witnesses beiore the Royal Comrission on Iondon Transport put fomard this vicw. Yet after the end of the housing boom vicws berin to change. Vriting in 1910 the Electrical Revier commented "it was thought ... when electric trams vero being intoduced that they would help in the develonent, of the suburbs, but while to sone crtent this has been roalised it is generally admitted that it has proved somemhat of a failure. One could point to many miles of tiatwoy built to opon up a district but which on those secitions are finsincially hopeless."

2. Brinley Thomes, Migration and Econimic Growth, Conbriace 1954, Table 28 for valoulations from A.R. Prest 3 IVtional Income Estimates. 2. ER. Vol. 67, PP 481 - 2. 23 Sevtembor 1910. 
However, these two viers are not necessarily inconsistent. The lor level of building in the 1880s and the considerable internal migration of the 2890 s ma a builaing boom in the late nineties inevitable. The situation of the now houses was no doubt considerably affected by transport facilitice. But the insluence of better transport on the anount of building may not have been rered. The esfect of curient transport improvements perhaps prolonged the building boom, but their main influence on building may have been to detemine the siting of suburban building in the rext boom. In any case what f.s irrortant here is that the efpect was small in the short mu. Investinent in tremways involved discontinuities. It wos not likely to be undertaken umess the rate of growtih of demend por tran journeys on a proposed line was high. Thus the fall of in tramey construction after 1903 is to be explained largely by the very slow rate of urban growth in Britain. It has been suggested that this is primarily due to micration, biat the explanation of slow urban growth, if the argument of the last fov paragraphs is correct, is not relevant here.

In Britain trans remained vithin the towns. By contrast mich of the tromray building in the Unitca States after 1900 was of inter-urhan lines. By 1906 most British tranmeys had been electrified and extended to meet roughly all the urban deiand at the time. Considerable extensions on the outskirts of the towns would not have been likely to be

2. By A.K. Caimeross. Op.cit., Brinley Thoms. Op.cit.., 
profitable. Costs barely covered revenue as it was and costs per car mile were only kept jow by frequent services. The only figures available which throw lj.ght on the erequence of service are those of car iniles por route milep.a. If we assume a tracway day from 5.30 a.m. 1070.30 p.m., 365 dajs a year, on the average, there was a frequency of servico of 6 - 7 minutes during 1905 to 1912. Fares were 10\%, pertlj beoa'ise worleteg class incomes wero low and it was feared demand was elastic, and party because the municipalities wantea choan travel for the working class. When passengers vere poying a littie over la. per fare about 10 passengers on the average throughout the day had to bo on the tram to got a revenue of 11 . per or mile. J.R. Salter, general manager of the Lancoshire United Trams jn a paper in 1910 stated that ho thought that 11d. per car mile was as mach as could be hoped for with the existing fare structure. And a well populated area was necessary for thats.

If extension of Ijnes on the outakirts of the tom vere unprofitable, interwuben lines would have been less profitoble. The fast inter-urban trapic was already catered for by the dense network of steam railmays, which did not exist in the inited States. Iack of comoperation betweon adincent municipalitics and bad relations between tramay companies and Incel authorities also delayed intermuben tramay

1. J.R. Salter. Iremay Economics. Parer to the Mrarmay Conjess printed in tise F.?., Vol. 67, PB $5-3$. I July 1910. 
connection. However, consideration of the cost and revenue situation of the tranways docs suggest that political difsiculities reirifored the effect of the coononic siturtion.

It is significant in this context that the companies did not expand arter 1905. Their enthusiasil of 1900 soon turrea to aisappointment 'as the electric trans were found to $b$ : not 3.3 prof'itable as had iven thought. The British Mlectric Traction Co. Was soon shown to have over-reached itself and its profits dried up. It ras not in a position to bor ow further, but in ony caee there vere no financial inducenents to no so.

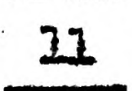

Trarmays ran through the strests, but any urbur rainiay winich wanted to operate at highor specds had to co underground. Excopt in speciol areas eleveted strect railways would have been probibited on aesthetic grounds. Stean traction tas not suitable for und.creround operation, even thou h it had been used on the Inner Circles, which was completed in 188\%. Yet there was a dosand in the largest towns, and esnecially in Iondon; for more ranid transport than could be provided by horses. As early as 106 ? P.W. Brorlow, who wos on expert on tunizel construction mrote a parmilot advocating "owibus subrajs". There were other proposals for shout unierground roilliays, and in the 1330 s

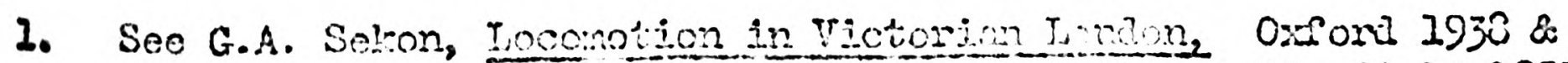
T.S. Lascelles, The City S Suth Landon Railiay, Lingield 1955. 
a crop of such schomes. Cable traction whs an inprovement on steam and in 1354 Parlinent wes asked to crant porers for the construction of an unierground line fron the Sity to the Elephant and Castle, on which cable cars were to be used. But electricity was obviously a campetitor, even in the midile eighties.

Sientins Jros. Were tine nost smportant pioneens of alectric railways in Britain. Werner Sionens built an exhibition electrio rallway In 1879 , and a street railway (on the third raij system) in 1882 . The Pirst elcctric railyay in Mritain vas built in 1832 - 3 by Magnus Volk on the beach at Brighton. Te used Siemens ogvipmont. At the same time the promoters of a railway being built along the Grant"s Causeway in Northern Iroland decided to iry elootric traction and called in Sienens. Siemens built the electrical equirnent for the railway. However, for many years electricity was usec for only a mall part of the traffic. Plectricity was at a reiative disadvantage in a rumal area but the technical success of the line showed that eleciricity could be ueed in this way. William Siemens died in 1833, Wut his chief assistant, Dx. Ndward Hopkinson was very ovon asked to design an electric railixy to zun from Bessbrook to Nerry. He soon noved to jessrs. Wather k Platt, who had recently opened an electrical dopartment to manufacture the Bdison-itopinson dynorso. The

1. As vell as the ones discussed belon there vere Bills: in 1832 for for tho Central letropoliten Railnoy (King's Cro s to Parliament Square); in 1834 for the London Central Electric Railway (Northunberlend Avenue d. Piccadilzy to the Old Bailey); in 1385 for the Charing Cross and Euston Railway \& the King's Cross, Charing Cross and Waterloo Railway.

2. c. Klajer, op.ett., PP 57 - 9 .

3. Borm 1859, wos 10th Wrangler at Canbridge in 1881. In 1993 ho became a Fellow of Eumanuel College, Cambiage. 
latter was ar inprovernent ou the Bdison dynawo made by Dr. Join Iopkinson, Edrard's bzother. Ilus liation \& Plati built the clectrical equipment for the Bowbrook - Inewry line, which opened sucuesisully in 1835.

In 1803, Vather \& Platt approuchea the Directors of the City \& S. London Railway, whose turnels were already uncies construction, to try and persuade then to adogt elcctrid traction rather tha: tho cable. They adceedod and were anarica the contract for the electrical equipment. Sienens meie alwo interowted in the schene. Hexender siemens later told the Dritiati bsociation that "a persect agreenent had been arrived at

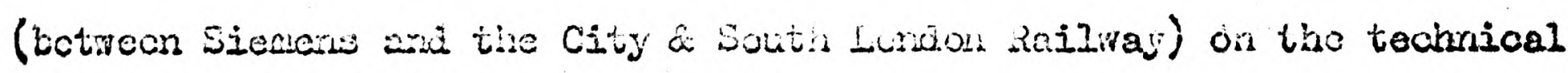
points of the gueition, "bit that the contract has not been given to them "for financial consiciexations." - prownably Lather \& Platt's prices were lower. Hectric loronotives were to bo used and Kather \& Platt built the first 14 , althouh in 28012 were bought from sievwens. "The railinay was opened in 1890 , 3t miles in Iength and extending south to Stockwcil.

Sichens Bros. hal ajo helpes to jionoto un uncerground railway

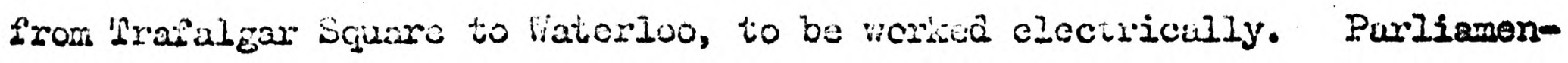
tary powere were obtained in 1882 but work on the nailway was then abardored in 1035.

We initial injetus bohind ihese schemes was inprovenente

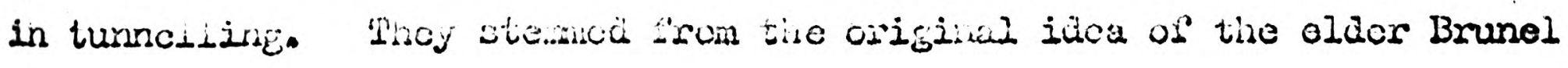

1. G. Anvesley Grivale. The City a South London Elcctric Railway. E.R. Vol. 31. PP $140-2$.

2. I.R. Vol. 31, II 189 - 92. August 1822.

3. T.S. Lascelles, op.cit.r Apgendix, P 34. 
for using a shield, which protected the roof and walls while they were being bricked in. Inis was developed by Barlow, who patented the idea in 1864 and then by his pupil J.H. Greathead who was one of the original pronoters of the City 2 South Iondon Iine. It was the Greathead shield which made the decp tubo lines possible. The combination of easier tumelling and electric traction made "tube" railways seen very attractive. They prrmiscd rapid transport; the City o South London roilwas was to take 15 minutes to Stockmell against 45 by hurse bus. Iondon was groning big enough for there to be a demand for specd. In 1891 parlianent a avo permission for the construction of a tube railway tros Shephends Bush to the Bank of England, the first railway to cut through the centre of the metropolis. In 1892 a joint select comittee of both Housas was set up to consider four new schemes and extensions to the existing two. The new crios were the Great Northern ond City, the Fampatead and Charing 3. Cross, the Waterloo and City and the Baler Street and Waterloo. The Central Iondon Railway was to be extended to Iivorpool Strect Station and the City \& S. Iondon to the Angel, IsIington. The Waterioo \& City scheme was sponsored by the London \& South Western Railvay, who had since the fifties been considering an uniercround convection betwen the city and their terminal station. Barly estimates had put the cost at $\$ 3-5$ millions, but they found that electric traction could reduce the cost to $\$ 500,000$

1. T.S. Lascelles, op.cit., PP 2 - 4.

2. The Central London Roilway, part of present Central Iino.

3. Now part of the present Northern Iine.

4. Part of the present Bakerloo Iine. 
and decided to cary out the schere. The other schemes were new ones. The Comattec reported that "the evidence subrattod to them was conclusively In favour of the sufficiency and the special adaptability of electricity as a motive power for the purposed undercround tubular railways ..." and recominded that the scheme should bo passed. The narrow tunnels used by the City \& S. Iondon were to be used. The L.C.C. Wanted ones big enough to take tine rolling stock of existing main line railways but the Cormittee agreed with the prowoters that this would increase the cost so mach as to mun the risk that the proposed railways might never be built. So there was no possibility of mining min line coaches through the tubes although the gange was the sane. The lines were to run under the street as the prornoters wanted to avoid poying property omers for wayleaves. This was very unfortunate and was opposed by the I.C.C., who argued for the more direct routes. It is a clear case whore private cost to the pranoters exceeded social cost. They were also built some 60 feet bolow the surface, to avoid all difficulties which would be caused by aisturbing severs, gas mains, water pipes, etc. The shallow tunnels of the Inner Circile had been maile very expensive because of this.

But actual construction was slow to start. Work did not start on the Waterloo \& City line until 1894, or on the Central Iondon Raliway until 2895. The delay with other electric schernes was even greater.

1. E.R. VOI. 43, PP $72-4 \cdot$ 2. Renort of Joint Select Comittec to consider electric and cable 
This in itsclf was not unusual; nono of the schemes of the 1830 , except the City \&: South London were ever finished, and some nover started. Fork only really started wisen all the various schenes, except the fiaterl 100 \& City and the City \& S. London, were taken over by the Anericans. The Central London Railway come to like when It entered into a contract with the Electric Iraction Co. Itd. to build and equip its lins. They were to be paid 22.5 million in cash' and $£ 700,000$ in devontures. This was closely connected witi

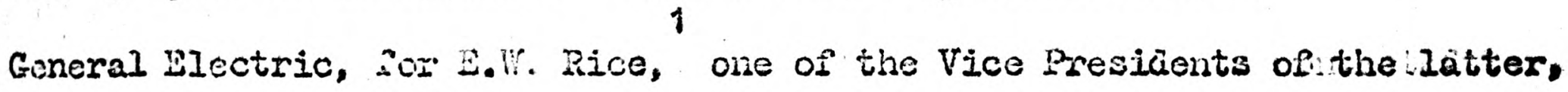
was closely irvolved with the construction of tise Central Iondon Railway, its electric equizment was manufacturea at Schenectady, and was ingtalled by British Mhomson-Houston's Anerivan enginoers. When it opened in 1900 its gencral mander was a Canacian.

The other lines rero evon more complevely taken over. The story begine with the clcctrisication of the jetropolitan Railway and tice Betropolition District, both sulurban railways with Iires into liost London, but also joint operators of the Inner Cincis. Tho latter line had toen built initialiy to link up nost of the main line railwos termini, but had been adied to by the various suburban

1. E.R. Vol. 49, DP $709-20,744-6,791-4,862-3$. Reports on the Underground Railway incuiry before a Board of Mracie ariitrator. 
1

line of the Retropolitan and the District. The Inuer Circle had never been successful. Its rain trafeic then as now wos east to west and not from railway station to railray staticn. R.W. Perles told the Royal Comission in 1903 that circle trains regularly ren empty while east-west traffic had from enorrously. The circle was a shallow line with periocic outlets for smolse and steam, but it was novertheless extremely unpleasant to travel on, beini popularly inom as the "sewer" Iine. Despite the foulness of the line neitber the Metropoliten nor the District Compantes were very interested in electrification, which seened the obvious answer. I Peomary 2897.

1. In 2846 a Rojal Comission reported against a project for a grenti central rallugy station in Loneon, a line being drian which the main line termini were not to pass. At the time railway trapeic ros primarily 800 ds. In 1855 whon pasienger traffic appcared, a Select Comitice of the Comons suggested linking the exivting station $3 y$ an iner cirole. In 1964 a Joint SelectComittee advised Parlianent to sanction an inner circle. It $\mathrm{nas}$ not finally conploted witil $1934_{4}$ whon it ran past Padington (Great Nestem), Kings Cross (Creat Northern) and St. Ptncras (Mjoland), Ijiveroool Street (Cront Ecetcrm), Cannon Strect (South East and Chathan) and Victoria (South) Tast and Shothom, ane Ionzon Brigiton and the South Coast). It had stations very close to Charing Cross (South Last and Chathem) anci close to Euston (Iondon \& North testern) and lienchurch Strcet (Great Eastern \& London, Tilbury \& Southend). Waterloo (Iondon and South Westerm), Holbom Viacuct (Soutir Bast \& Chatham) and London Bridge (London, Brichton \& South Coast) vere not served. Royal Cormission on London Transport. B.P.P. 2905. Vol. 30. PP 533 fr.

2. ibid... \& 19602

3. The Netropolitan did show sose interest, but not very moh. The District showed none. 


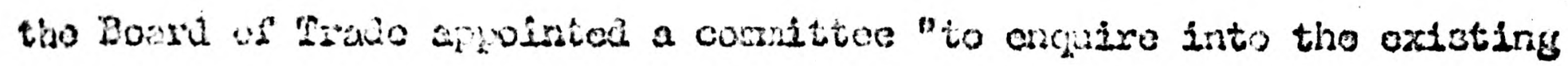
ayetea of veutilation of turuels on tho vatropoliqar Railiay, and

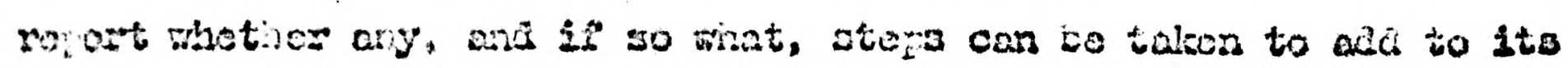

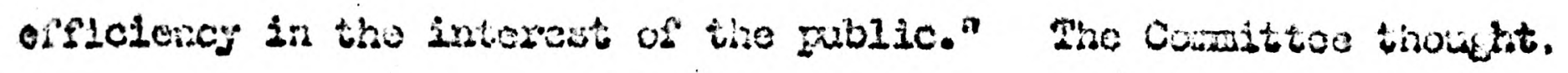
howevor, that the only satistactury asaner was alectrifiostica. It

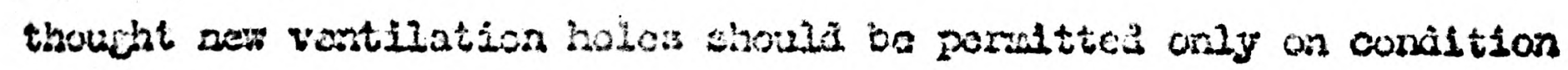

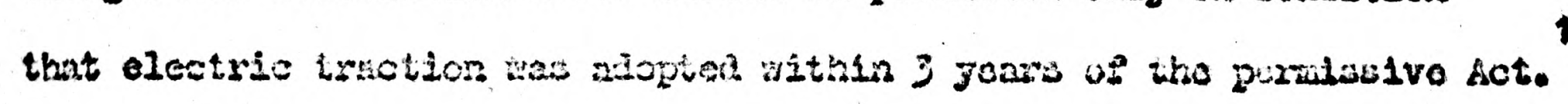

2001045.

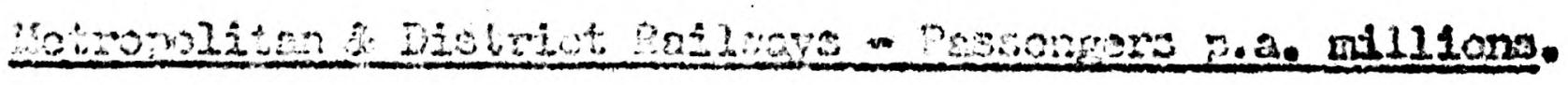

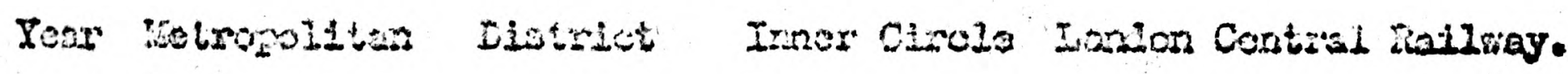

$15 \% \quad 55.3 \quad 50.0 .4$

$2397,201.3,2.5$

$\begin{array}{lll}2029 & 201.9 \quad 574.5\end{array}$

$1900,99.0 \quad 55 \%$ 1.5

$1502 \quad 32.3 \quad 5402 \quad 3.5 \quad 43.2$

$\begin{array}{lllll}1902 & 95.3 & 48.8 & 2.5 & 49.3\end{array}$

Sourca: Piostricul Mrades Mroctory.

1. 2.R. Vol. 20, 820 - 2. 1500400002327. 
Over a year later the Chaiman of the Uistrict hailway was at pains to point out to the sharcholders thot althowh they were seleing powers for elccticic runing they were not going to rusia into electrification. In November 1398 the two conpanies carrica out exporiments, whose rosults they though sotisfoctory, but nothing more was cone until the opening of the Central London Railway began to cit into their traffic.

By 1901, howsver, they had both dectiod to olectrisy, but despito the fact that they had joint I Ines and oporated over each other's track, thoy chose afferent methods of olcctric isaction, tho Metropolitan wanting to try the ner: 3 pheso traction boing cievoloped by Gant \& Co. and the District the stanciard a.c. traction used on most other electric lines. Eventually the soard of Inode had to arbitrate and decided in favour of the latter mothot. The. the chang wover took place, but not until 1905 mes there a thIl clectric service.

It was not only lack of anterpideo which dolayed electrification. The District was in very bad finacial shapa. Its lasi orairary dividend was in 2832 when it paid $3 / 8 \%$, and it was rach in arrears on preference and guarantece stock dividonds. But in 1901, it cass to an arrangement with Charles T. Yerleci, a Cnicago Pinancier, who tojether witi a group of New York and Boston Pinanciers and banke fomed the Netropolitan District Electric Praction Coipany which nas to supidy unch of the monoy for electrification. The Ilectric Traction Co. Wois to build a generating

1. E.R. Vol. 42, P 690. 20 kiay 1398.

2. The two Iines had a Iong history of matual antagonism, going back to tho 1870 . 


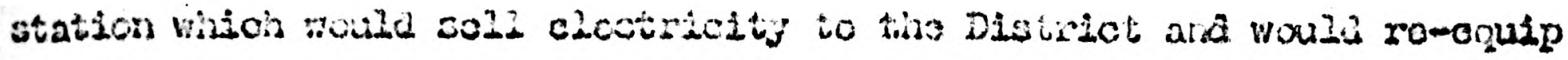

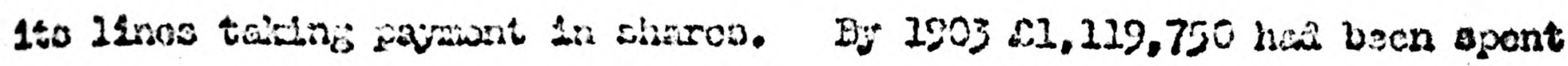

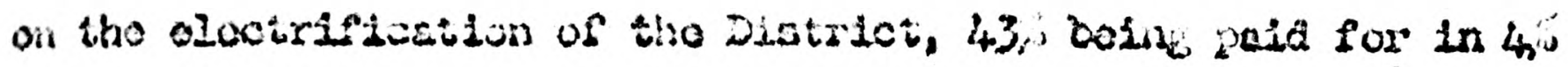

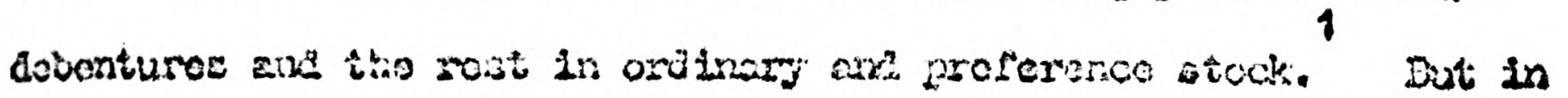

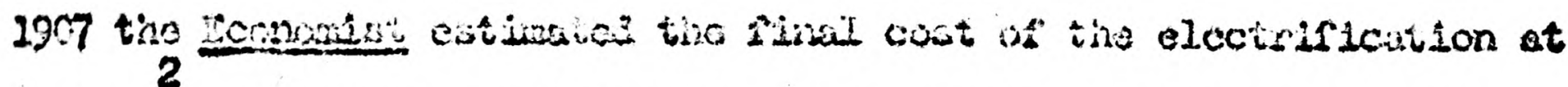

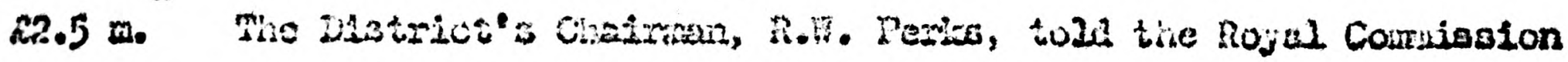

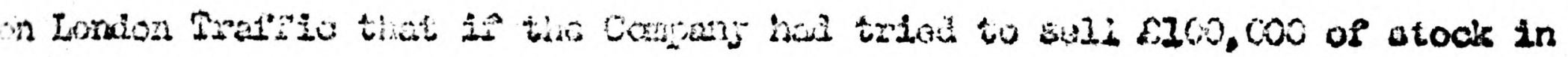

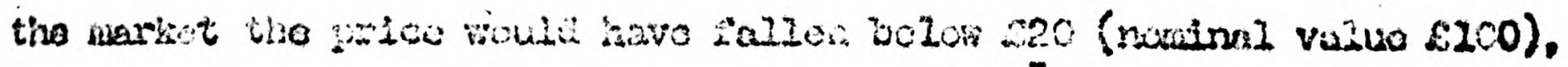

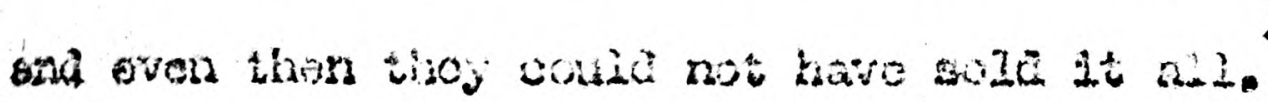

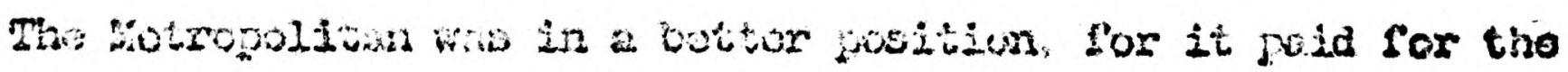

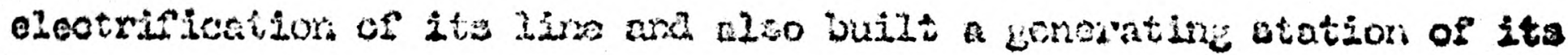

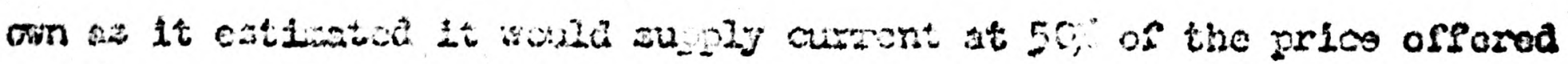

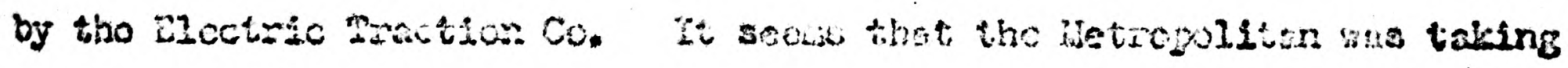

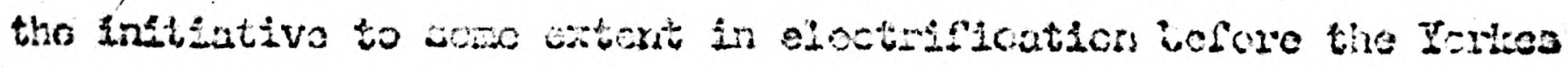

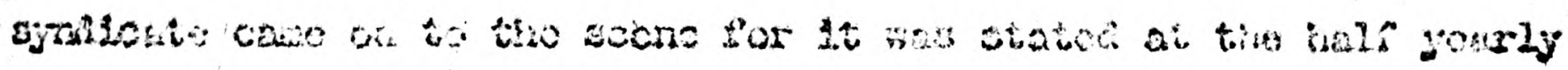

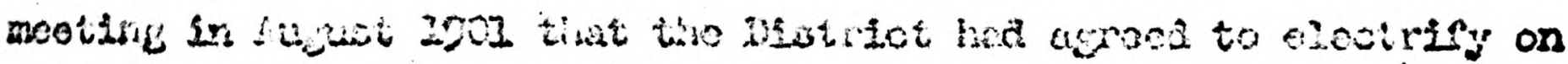

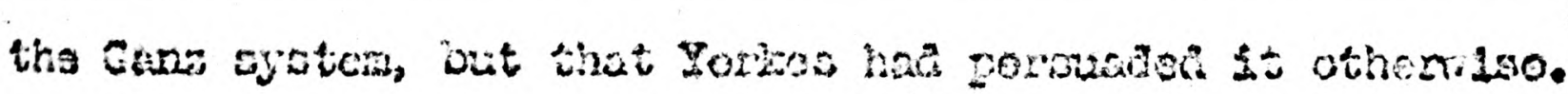

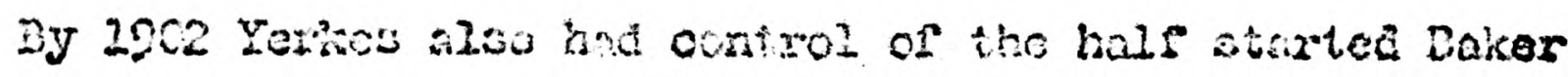

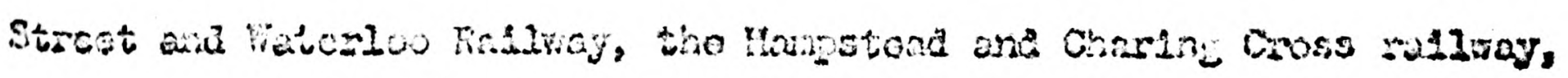

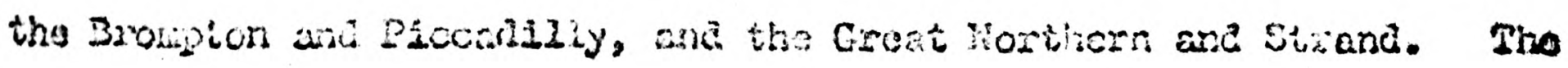

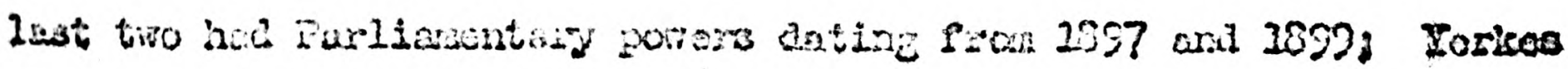

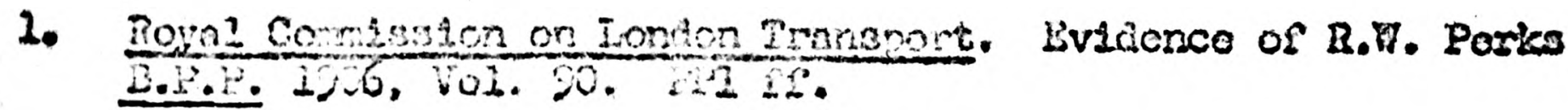

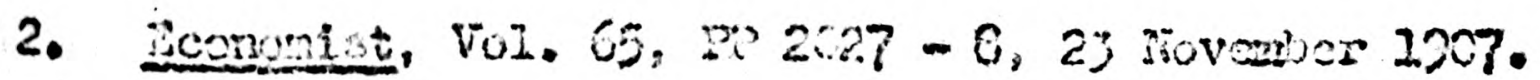

3. Royal Commission on Iondon Transport. Q 19,839.

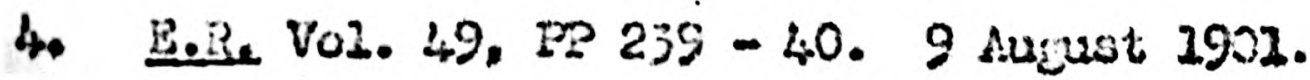


got powers to merce thesn into the Great forthem, Iiccadilly and Bropton Railway. Thon in April 1902 he, tocether vith Speyer \& Co. of New York and the old Colony Frust Company of Baston, formed the Underground Nlectric Roilways of London Itd. \&il6 milition was to be spent in constructing (or cowplettig) the Jines which were to form one unified system.

The Balcer Street and preterioo and Piccadilly lired opened in 1906 and the Charing Cross and Hamptead in 1907. There were intiexchenge statione where thoy crosscd with each other and whero they linked with tho District. The Yorkes tubes were egiuipired and run on stanrard American linss. Tostingonse built the cenerating sots for the Rond porer station, Gereral Rlectric sunglied tide train equipuents. The fare syster was Anericin, tho, Central. London started with a standard 2d. fare and Yerites plaried to introduce a uniforn fare on each of the lines controlled by nim. When in 2907 the Unieroruand canpany wanted a Eenoral nanacer for the fubes it controlicd it chase A.H. Stanley, the managar of the Pblic Service Coryorition of the State of New Jorseg. By 1910 the Undercround Raizways Company accounted for $53 \%$ of

1. The present Piccadilly line.

2. Uiconomist Vol. 64, P. 2047. 15 Docomber 1906.

3. Westinghouse and General filectric sct up factories in England in 2900 and 1902 to exploit the irection boon. So daxch of the equi-iment was manufactured in tingland, but of course to Amorican desipras.

4. Later Lori finfield, first Chrirnn of the London Passencer Transport Boara.

5. Report of the Under round ilectric Railways of London Itd., E.R. Vol. 61, PP IC24 - 5. 20 Decembor 1907. 
Table 4.6 .

London Underground Railwavs, Gross Investment.

(including Metropolitan and District Railways)

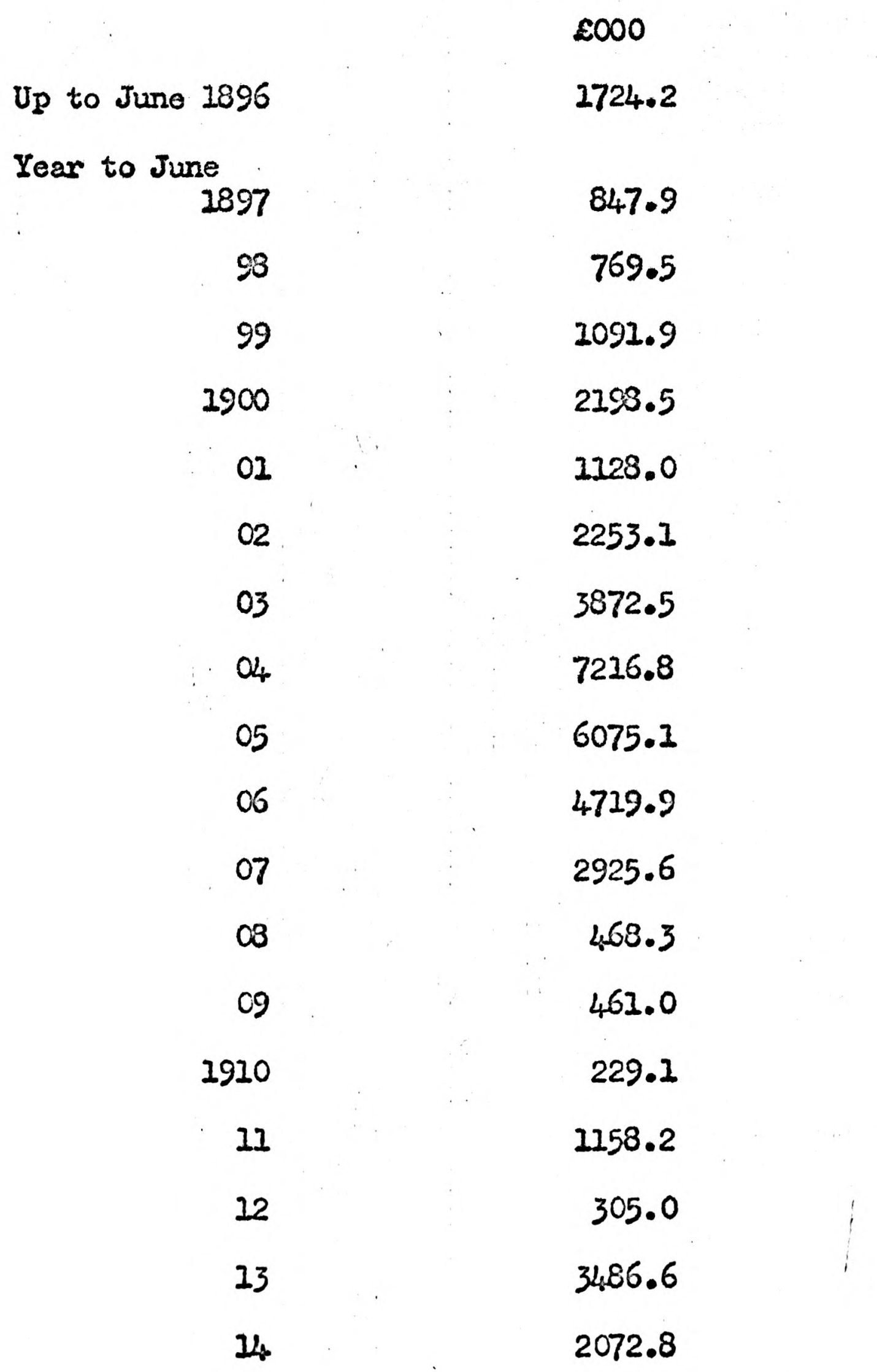

Source: Garke's Nanual.

Returns of tho Railway Companies (B.P.P. various years) 


\section{Table 47.}

The Growth of the Undercround - passencors n.a. millitions.

Inner City \& Waterloo Central Great Baker Strect

Circle S.London \& City Iondon Northern \& Waterloo

Total

\& Piccadilly

Charing Cross

\& Hampstead

\begin{tabular}{|c|c|c|c|c|c|c|c|}
\hline $\begin{array}{l}\text { Year of } \\
\text { open- } \\
\text { Ing }\end{array}$ & 2884 & 1891 & 1893 & 1900 & 2904 & $2906 \& 7$ & \\
\hline $\begin{array}{l}\text { Year } \\
2892\end{array}$ & 1.5 & 6.2 & & & & . & 7.7 \\
\hline 2894 & 1.5 & 7.0 & & & & & 8.4 \\
\hline 1896 & 1.4 & 6.5 & & & & & 8.3 \\
\hline 2898 & 1.4 & 7.3 & 1.4 & & & & 20.2 \\
\hline 1900 & 1.5 & 9.7 & 4.1 & $14 \cdot 9$ & & & 30.1 \\
\hline 1902 & 1.5 & 19.8 & 5.1 & 4.5 .3 & & & 71.6 \\
\hline $190_{4}$ & 2.3 & 19.1 & 5.4 & 44.9 & 8.3 & & 79.0 \\
\hline 1906 & 0.9 & 19.46 & 5.3 & 43.1 & 15.9 & 10.6 & 95.2 \\
\hline 1908 & 0.6 & 22.7 & 4.9 & 41.9 & 12.3 & 85.8 & 268.1 \\
\hline 1910 & 0.6 & 25.1 & 4.9 & 40.7 & 12.7 & 96.7 & 179.7 \\
\hline 1912 & 0.5 & $24 \cdot 05$ & 4.9 & 36.1 & 22.8 & 200.9 & 279.7 \\
\hline
\end{tabular}

- The District and Lietropolitan lines, except for the Inner Circle, are not regarded as undereround railways.

Source: Electrical Trades Directory. 
underground prosengeres and 47,0 of the pawsengers on the tubes plue tho Hotropolitan and District, which voro otrictly not unieruxound rallways excopt for tire Inner clrolo, but winch direotly fou the unierground notworis. In 2912 tho Undorground Rallnay Campary acquired tho Contral London and tho CAty and South London Raslwaja. Thore were almeady intorchango stationo with the forrwor at caford Cirowo and Tottonhaid Court Boad. Tho lattor had axtondod as far. as Euston by 1907 whore it mot the Claring Cross and Itompotead line. It shared tho 01d Strect etation connocting with tho Great florthern and Clty and et tho Bllophant and Castlo it vas connectod by aubray whth the Bater Strect and Viatorloo 1130. Tho Underground Conpany Intendod to widon tho turneid ord ohango the rolling atods, so thet the line could ve intogratcd into the rest of tho systom, but the war intorrened and the 31 ne was not reconsimucted unill the twentios. The ahort creat llozthorm \& Clty was dosignod to Ilnk tho Great Northom Rallway to tho Cliy. It was perhaza tho loast auccesaful of the tubes, partiy becauso it went no further than Brosa Stroct. In 1912 it was acquired by the Lotropolitan who hed tho backing of the Groat Westorn ard the Great Central and plans laid to oxtend it to tho Bant, whare it vousd join tho Contral London. the Pateriloo \& City.

Thus crcept for tiso City \& S. London, tho Vatorloo \& Clty and the Groat No therm \& C1ty, all the tubes wore an extonsion into

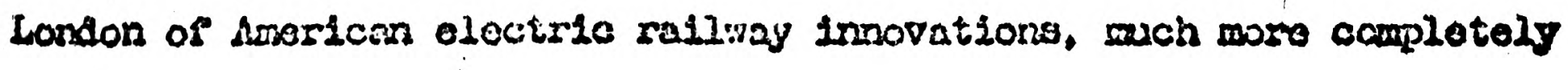

1. E.R. Vo1. 71, PP 898 - 9. 6 Deocibor 2912.

2. T.9. Lascellos, on.cites 9226 and 28. 
80 than in tho case of the trans. In view of the great criticism at the time of English backwardness in electric railways it is interesting to note that they did not cover their costs. The cost of construction seems to have becm rather high.

$$
\text { Table } 48 .
$$

Capital Expenditure per mile open.

City \& S. Iondon

Central Iondon

Baker Street \& Vaterloo

Charing Cross \& Hampstead

Great Northem \& Piccadilis

$2903 \quad 2908$

$\begin{array}{rcc}377,200 & \stackrel{2}{\approx} \\ 631,600 & 432,000 \\ 1 & 585,000 \\ 1 & 665,000 \\ 1 & 703,000 \\ 120,000\end{array}$

1. Not open in 1903.

The cost of the Yerke's lines may have been slightly inflated to yield a good return to the promoters.

Sources: 1903 - Evidence to Royal Comission on Lonaion Transport 1908 - Electrical Trades Directory.

Table 48 shows that the American equipped lines cost considerably more than the City \& S. London. They were much better equipped in their capacity per mile was mach higher, but it was many jears beforo the traffic was large enough to justify this. The initial cost of the power stations was on the high side. The Central London one cost 
Table 49.

London Eloctric Roilways. Deraity of Trafeic.

000 cor miles per route mile

$\begin{array}{llll} & 1906 & 1910 & 1912 \\ \text { City \& S. London } & 1,27 & 444 & 415 \\ \text { Waterloo \& City } & 161 & 166 & 133 \\ \text { Central London } & 710 & 596 & 493 \\ \text { District } & 226 & 280 & 324 \\ \text { Gt. Nortinerm \& City } & 306 & 262 & 252 \\ \text { Baker St. \& Waterloo } & & & \\ \text { Charing Crosi \& Hampstead }\{ & & 399 & 426 \\ \text { Piccadilly } & & & \end{array}$

- The leuropolitan is omitted as it was worked by stcarn on its outer lines.

Sourco: Board of Irade Returns relating to Electric Railways in the U.K.

E34 per IN which was good for the laie nineties but the Lots road station cost not mach under 2,23 per KI: although it was not comploted until 1903. It was the largest power station in England at the tirce, with $5500 \mathrm{KW}$ turbo generations but its cost compares very unfavourably with Carville wisich opened the following year. The electrification

1. Hums of Lords Cormittee on Aiministrative County of London \& District ilectric Pover Bili 1905. Evidenco of G.C. Cunningham. Q. 2568

2. Accounts of Underground Electric Railways of London Itd. 
of the District soems to have been expensive, nithout leading to $10 \mathrm{r}$ working costs. On the contrary the District's working costs in 2906 were very high, being 53\% higher per train mile in 1906 than under the old steam regime. The coaches were heavier and more comportable but revenue had shom no signs of expanding enough to compensate for higher costs.

Trapfic did not grow as Yerkes hal expected, and the fares were too low for the degree of capital intensity chosen. In the United States the rate of growth of demand for transport was much higher, and by 1908 the New Yorls subway, opened at the beginning of the century, reached the limit of its carrying capacity while in London travelling facilities secmed to have outgrown travolling habits. By 1907 the Economist noted that there was "an accumulation of evidence that the "tubes' are not financially successfiul." They were highly efficient at moving people but as Table 50 shows never earned anything like an adequate return. This was only partiy because of over expansion. The original prediction of the Central London Railway, given in its prospectus of 1895,3 was for $45-52$ million passengers per year. They soon got all but $6, \%$ of this. The return on this trafilic was no more than enough to pay a $4 \%$ dividend, and peak hour capacity had been

1. H.IR. Vol. 62, P 1014. 19 June 1908.

2. Economist, Vol. 64, P 1907. 9 November 1907

3. E.R. Vol. 36, PP 803 - 5 . 
Table 50

Erositebility of the Undersround.

Gross profits as a percentace of capital expenditure.

\begin{tabular}{|c|c|c|c|c|c|c|}
\hline Year & $\begin{array}{l}\text { City } \\
\text { and S. } \\
\text { Londan }\end{array}$ & $\begin{array}{l}\text { Contral } \\
\text { Iondon }\end{array}$ & $\begin{array}{l}\text { Great } \\
\text { Northerm } \\
\text { and City }\end{array}$ & $\begin{array}{l}\text { Baker St. } \\
\text { and } \\
\text { Taterloo }\end{array}$ & $\begin{array}{l}\text { Charing } \\
\text { Cross and } \\
\text { Biston }\end{array}$ & Piccadilly \\
\hline $2895-6$ & 2.2 & & & & & \\
\hline $96-7$ & 2.5 & & & & & \\
\hline $97-8$ & 2.1 & & & & & \\
\hline 2907 & 3.1 & 3.4 & 2.1 & 1.6 & & 1.2 \\
\hline 08 & 3.0 & 4.7 & 1.7 & 2.6 & 1.2 & 2.1 \\
\hline 09 & 3.1 & 3.2 & 1.6 & 3.0 & 1.6 & 2.5 \\
\hline 2912. & 3.1 & 3.3 & 1.8 & & 2.8 & \\
\hline 12 & 2.7 & 3.4 & $2.0^{\circ}$ & & 2.8 & \\
\hline 23 & 2.3 & 3.6 & & & 2.6 & \\
\hline
\end{tabular}

The Central Iondon Railway was more profitable between 1900 and 19c6. But it never paid a dividend of moro than $4 \%$

Source: Garkes lanual. Reportis of the London Fraffic Branch of the Board or Trade. B.P.P. 
reached. Bus competition prevented higher fares. The later competition of other lines reduced the Ccntral Iondon's trafitio and reduced profits to a low figure. By April 1903 the Underground Company was in financial difliculties. \&7 m. had been borrowed on short term profit sharing notes, which had to be renewed.

It is impossible to discuss the cemand for tubo transport in London, and the competition of surface transport without considering the layout of the system. There can be littlo coubt that it was poor and that a better one would have been more profijtable. The lines followed the streets. The nev tubes connected very bady with the existing District and Netropolitan lines, particularly around the northern part of the Inner circle. Iines were run parallel quite close to each other. The public utility control of the time prevented an overall private scheme and the local governinent of Iondon among other matters made an overall minicipal scheme impossible. Porallel routes are what one expects from competitive railnays. Happily ono piece of proposed competition wish would have made the layout even more unprofitable without being of use to the Hetropolis fell through. In 1902 J.P. Horgan sought Parliamentiry powers to construct a tube railway from Piccadilly to the City and then to N.E. London. This was to be fed from the west by the Iondon United Irans who were to butld

1. Economist, Vol. 66, P 828. 18 April 1908.

2. Soc Chapter 9. 


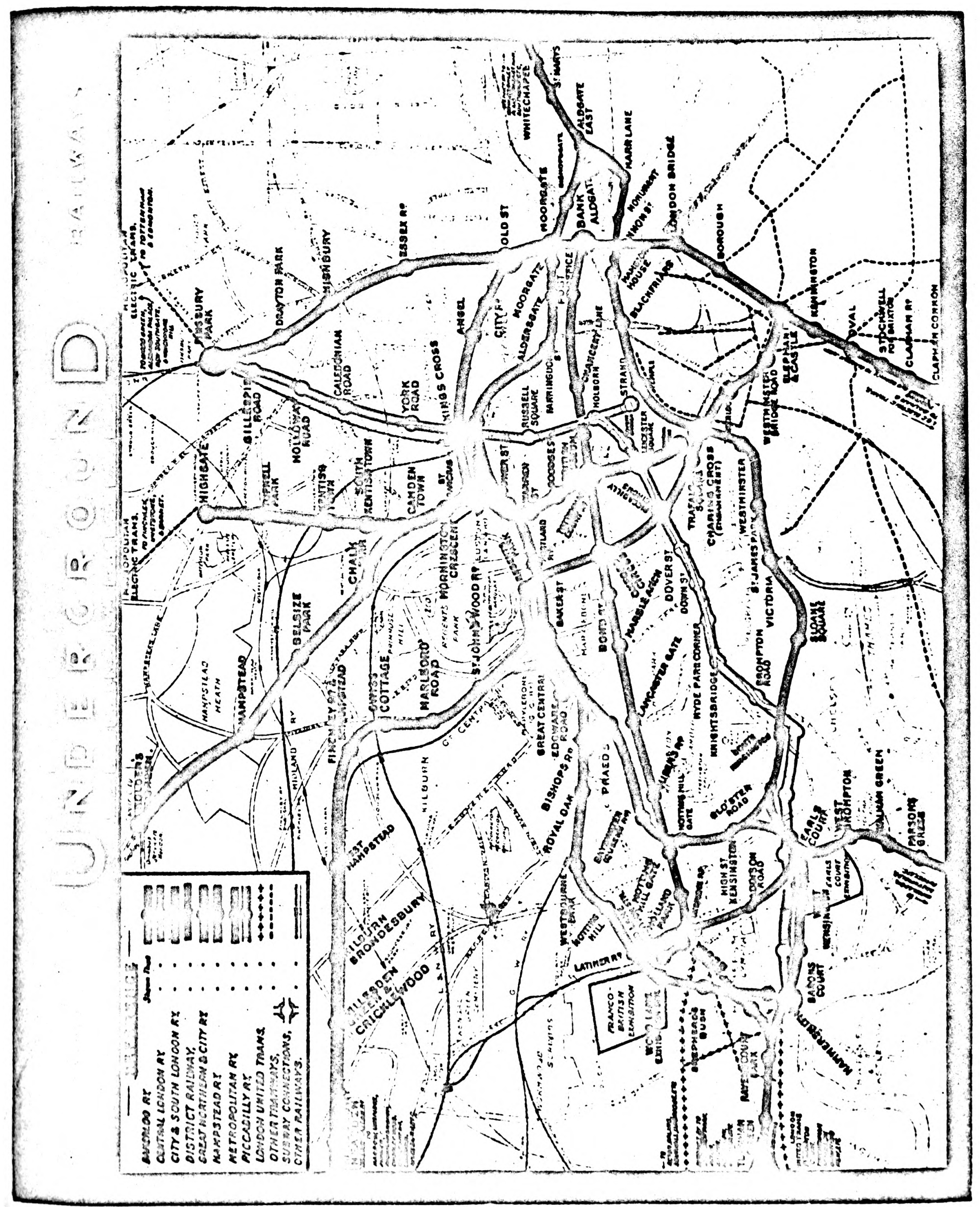


a line to Piccadilly. These trans had hitherto fed the Central London at Shepherds Bush and, alarmed at the posisiolo aiversion of the troms, tho latter pronoted a Bill to extend 1ts lines to Ilamnersmith and thon to return via Piccadilly and Charing Cross to the City, making a circle route. Parlioment rejected this scheme, but it is not likely that it would have refected the schene of Morgan and the I.U.T. This was now only opposed by the Yerkesmistrict group on the grounds that "organ's soheme would parallel their lines, running betwen the existing District and the proposed Great Northerm, Piccadilly and Bromption, and Parliament felt that the Diatrict railway was not entitled to special consideration as they had not been so mindful of the public interest in the past as to" deserve it. However, a dispute arose between lioritan and the I.U.T. as to the representation of their various interests on the management and Speyer Bros., who were helping to finance Yerkes schome stepped in and got control of L.U.T. by purchasing ordinary shuros, thus folling the diorgan schene. 1

The relationship of surface transport with the tubes was unfortunate. Ideally underground and surface transport aro complementary. The question whether ono should have subsidised the other or not, is not to the political situation of the time. But good planning of routes and stops so that it was simple to transfer from underground to surface transport and vice versa would have raised the demand sor transport by reducing the time taken trateling - which is one of tho major cost iters. Elimination of sorde competition would have reauced

1. Econumist, Vol. 60, PP 3838 - 9. 25 October 1902. 
the costs of the provision of given transport facilities, as competition between a few transport undertikings tends to produce porallel routes With Inadequate facilities for transferring from one to the other.

A good example of the beneritis of good linkaye was shown by the great advantage the Central London Railway derived from sharing a terminus with the London United Tramway, at Shepherds Bush. The two together provided an excellent mesns of transport from Acton, Ealing and even farther out to the City. Although Iondon's tranways were being electrified and extended at the timo the tubes were beine built good connections between the two were rare. Before electrification the trans were scattered in separate units some distance out of the Central area. From 1896 the L.C.C. bogan to take them over, and from 1900 it began to electrif'y them and combined the separate networies Into two big systens, one north of the Central area and south of the river. The borough east of the County boundary also had their electric trams. Ixceptifot isolated cases thero was little competition with the tubes. An exception was the Great Northern \& City tube, which suffered greatly from the I.C.C. trams. Dut it was a badiy sited tube. Generally tubes and trams occupied contiguous or nearlycontiguous areas, and thus the lack of good connections between the tro is rather surprising.

But the relations between the tubes and the L.C.C. were poor, and by IgC6 both were very short of money. The I.C.C. was unablo to complete its rians. Ihis nas portly because it vas comitted to the high cost conduit sysiem. but also becauso borroving was becoming more disiicult. In 1906 Lord Willby, the Chaiman of the Financo Comittoo, 
told the Council that tho "policy involved a heavy demand on the money market in the next two to three jears. We are already payin a hich price for our trasis and we shall have to pay a higher price in proportion as our trams are larger ... I hope the Counoil will not entertain new scherses until this one is finished." A year later the libnioipal Reformers won the I.C.C. clection on a policy of opposition to L.C.C. public utilituy schenes.

Central London was served by buses on the surface. The tubes suffered by the appearance, just as they wore complete, of the motor bus. In 1905 there were tem of them, by 2907 there were large numbers operating in central Iondon. The Central London Railway lost a considorable numaber of passengers to then, its traficic felling by $14 ;$ botween 1906 and 1907. The decline was particularly marked in short distance traffio and forced the tube to abandon its standura $2 d$. fare.

The advent of the electric train and particularly the motor bus led to price cutting, and in 2908 the Iondon Iraffic Branch of the Board of Trade reported that almost ail operators were maicing 10sses. 3 The motor bus operators were doing as bacily as anyone; by the second half of 1906 the working costs of the London General Omibus Co., the largest operator had risen above receipts.

Ihus part of the unprofitable operations of the tubes was due to transitory factors, particularly the timing of the introduction of

1. E.R. Vol. 58, P 757. II liay 1905.

2. London General 1856 - 1256, published by London Transport 1956. 3. B.P.P. 1908. Vol. 93. 
the motor bus. But part of the unproiitability was due to the competition of afferent rorms of transport in their choice of routes. Better joutes and connections between different forms of transport would in have stimulatci the denand for travel, a denand which was probably inelastic, at least over the ronge of fares betieen profitable and unprofitable operation. This competition betacen buses and tubes was brought to an end in 1912 when the Underpround Rallways Co. acquired the London General cranibus Co. The laiter had ganated with the other bis bus operator, the Iondion Road Car Company, in 1903. By 1914 buses and tubes were virtually ail controlled by one compang.

Eoth the L.C.C. and the Royal Conuission of 1905 wanted shallow subwey electric Iines, as had been constructed in New York. Tho easior access to the surface could have substantially roduced travelling time, especially on shorter joumeys. The relative cost of aubrifys and tubes was examinea by the Royal Cormission. The Inner Circle had cost from between $\$ 665,000$ and $\$ 1,283,000$ per mile. It used: bigger tunnels, some being built for the broad gauce Great Westem trains, and the Royal. Cormiszion's Advisory Board of Enejineers estimated that subways rould cost $\$ 229,892$ to $\$ 333,206$ por mile. But a large proportion of the cost was the payment of compensation to omners of property disturbed. How costs were divided between streot improvements and subway consisuction, and how macin between private ana social costs, cannot bo known. Also ono of the difficuities of the subways was that tho cost of damage to pipes, sewers, etc., was unpredictable, as their exact location was often unknown.

1. Royal Coumission on London Transport. B.P.P. 1906, Vol. 40 PPI fP. os 19574 - 19585. Evidence oi R.W. Perks. 
The Royal Commission was also impressed by the fast and slom 1

four lane tracks of the Nen York subwa. The averice speed on tho express lines was 30 m.p.h., double that on tine local, and they wero correct in seeing that the prime economic poini of the underground railway was that it should provide rapid transport. The average speed of the Central London and the City \& South Iondon was 15 m.p.h. It is thus arguable that the undereround. Iine might have been very much more shecessful than they wore, and that the choice of routes and the type of line used are inportant explanations of low proritalility.

Tavie 51.

London Mransport. Passengers 2.2. milizions.

\begin{tabular}{|c|c|c|c|c|c|c|}
\hline Year & $\begin{array}{l}\text { Luses } \\
\text { (2 main } \\
\text { companies) }\end{array}$ & Trams & $\begin{array}{l}\text { Tube } \\
\text { Roilways } \\
\text { (including } \\
\text { inner circlo) }\end{array}$ & $\begin{array}{l}\text { Fietropolitan } \\
\text { and District } \\
\text { Railways }\end{array}$ & $\begin{array}{l}\text { Other } \\
\text { Local } \\
\text { Railirays }\end{array}$ & $\begin{array}{l}\text { Suburban } t \\
\text { on main } 1 i \\
\text { Railnays }\end{array}$ \\
\hline 1890 & 149 & 191 & - & 267 & & \\
\hline 1898 & 242 & 312 & 10 & 158 & 26 & \\
\hline 1903 & 290 & 394 & 74 & 153 & 63 & 280 \\
\hline 907 & 364 & 586 & 125 & 251 & 88 & 344 \\
\hline 917 & 437 & 822 & 234 & 186 & 67 & $u_{45}$ \\
\hline
\end{tabular}

Seasolz ticket holders are excluded. Zus passcngeru are those of the two main companies only. Thus zuburban railway and bus passengers are scriously underestinated - bus passenicers perhaps by a quarter and suburban railway passengers by one fifth to one third. Only a srall proportion of the passengers on locai railways seem to have boen scason ticket holders.

For construction of the rigures see Appendix If 500 .

Source: Reports of London Iratic Branch of the Doard of Irade, Electrical Trades Directory, Royal Cormission on London Transport.

1. The disadvantage of this system is that it makes the subway hidoously noisy. Anericans were more willing to pay for rapid transport than the English, and in more ways than in higher fares. 
In the provinces the Liverpool Overheal Railways corresponds in some ways with the City \& South London. As eariy as 1352 an ovcrhead rallway was proposed to run 4 milos along the docks, but was rejectod by the Docik Boand despite the strong support of Iiverpool merchants. But by 1880 tho trartray munine along the docks at ground level was overcromaled and other facilities had to be provided for passengers. A tunnel was rojected as too expensive and A.G. Iyster, the Dock Board's enfineer, was sent to New York to report on the overhead railways. His report led to the Dock Board asking for powers for a single overhead line, but the Board of Brade insisted it should be a double line. In 1885 the Dock Board proposed a schese for a double line to bo worked by stean at an estimated initial cost of $\$ 585,000$. By then, however, Lyater was consiciering electric traction, boving been in touch with Sir Villiam Siemens before the latter's ceaih. In 2387 the undortaking was leased to an independent company which vas ircorporated in 1883 and which in the fullowing gear had no aifificulty in raisiag all the capital it required in Liverpool. They decided on eleciric trection, wisich was estimated to cost $12+66,000$, a saving of 20,0 on the steam cost. An electric sorvice with light frequent irains meant tise structure could ve cheapor. With an electric locomotive car it was not necessary to have a heavy locomotive engine to provide tractive gripe The lanhattan ilevated Railway ran trains of $1 a_{4}$ tors . Lully lade, againet 33 tons on the Liverpool overhead. The former took twice as many yajuergers but the weight per pewsenter was higher, 43 tons afainst only 34 tons on the latter. Thus horso power

1. The above is based on a paper by J.II. Graithead and E. Fox road to the Institute of Civil Engineers. (Elect. 24031, Auguist 1894) and an account in the Electrical Revieip (Vol. 33, PP 151 - 9, 10 Eebruary 1893) 
per passcn or could bo lesis with the eloctric systein, which could be offset against tire higher cajilal cost oi electrical enuiments per horse power. Also running costs wers lesk. In 2093 running costs were only 3.7a. per train mile (incluaing drivers' vages, but not other traftic and managenent costs). This was no more than the poror costs of horse trams earrying no more than a quarter of the passengors. But electricity could provice a faster service than steam, and thus receipts could bo expected to be hishes. The contract fors the wholo equipping of the line, boilers, engines, dynanos, rolling stock, motors and signals, was arranded to tho Blectric Consiruotion Cormany. Mhey installed everything and operated the service at first, handing over whon it was shown to be zurining satisfactorily.

The railway was successeul; the old horse lines along the dock, which coritinued to run unciomeath the overined, had arried 2.5 million passengers per jear. By 1398 the overhead railway ras carrying 9 million. The initial equipcont was souerhat expcrimental erde in 1902 new motor and control equipment was substitutea inor it. This was built by Dick,

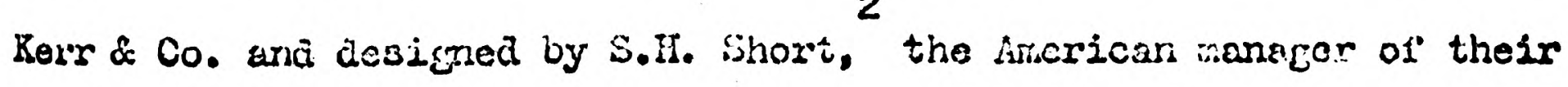
Preston vorks, incorporating the bost fmerican praciice. Acceleration was inproved. The everage speed was increased froin 12.5 to 29.5 m.p.h. while power consunption rose orly 25, s waking it the fastest atopping urban railway in tiso world.

1. T. Farker. Wleatrical enuiment of the Livemool overhead Railwar. Elect. 2 rarch I394. Purper was the cngineer responsiblo, but even if wo make a genorous aridition to his iligures costs wore still very lor.

2. Stort carne to Ingland in 1898 after very succesiful work on railway motors in the U.S. 
There were two other urban underground railways this country, the lifersey Railway (Iiverpool. to Birkenhead) and the Glasgow subway. They contrast interestingly. The Glagow subway was first proposed in 1887. traction to be by cable. Powers were obtained in 1890 and a consulting engincer appointed in 1893. He invited cable and electrical manufacturing firms to propose ways of working. In 1893, the year after the subwat had opened as a cable line, the Contract Joumal comented:

"This (proposing ways of working) the electricel contractor scemed very loth to do, while on the other hand, the cable people cano forward with all particulors and rigures, and entered most fully into the matter. This enabled the encineer to laj before the directors a very complete scheme for cable traction, whereas practically all he cculd say with regard to electric traction was that certain firms offered to carry out the contract in a satisfactory manner if placed with them. Had the electricel monusacturers cosse forward in a similar manner, we have a strong feeling that their infomation and experience combined with Mr. Horton's (tho consulting engineer) sound mechanical ideas, and also with the large amount of experience he gained in America on troction plants of all kinds would have enabled him to draw up a specification for electric traction that would have convinced, not only himslef, but also the directors."

The Mersey railway was a stean line running from Iiverpool under the rivor to Birkenhead. In 1895 tho directors became interested in electricity and sought poivers for electric working. Nothing more was done until the electrification of the Birkenhead trains in 1901 started to reduce the Hersey railway's receipts. Then in 1901 a contract was signed with British Westinghouse to re-equip the railway for electric working. The contract was worth $£ 635,303$, but only $£ 15,000$ was to be paid in cash, the rest being in $4 \%$ perpetual dobentures. Wostinghouse agreed to provide up to $\$ 240,000$ in cash should the liersey Railway Co.

1. Vol. $38, P 156$ fr. 26 January 1893. This was not a journal comitied to belief in the natural superiority of eleotrical mothods.

2. E.R. Vol. 49, P 549. 4 October 1901. 
require it to pay off its debontures so that elcctripication should not 1

bo delayed. If debentures were not paid off Hestinghouse was to guarantee inierest on them (a possible liability of 217,000 ). Most of this money cause from the Westinghouse porent company at Pittsburg. Electric working starled in 1903. The electrification was a successful piece of engineering. It provided a much botter service and more than won back the passengers lost to the trams. In 1900 the railway carried 8.4 million passengers and by 1902 only 6.9 million, but by 1907 it was carrying 11.2 million. Thereafter the figure rose only slightly. But it does not seem to have been a profitable venture. Before electrification working, expenses exceeded receipts. By $19 \mathrm{Cl}_{4}$ the company was making a surplus above working costs and this grev. Yet even by 1907 this was only 6.2\% of the book value of the cost of electrification. Traffic never seems to have become dense enough.

\section{1}

It was also reasonable to expect electric traction to be used on the suburban routes of main line railways. There ras a good deal of interest shown by the railway conpanies right at the beginning of the century, but the rate of electrification up to 1914 was very slow.

1. E.R. Vol. 60, P 717. 3 Lay 1907.

2. E.R. Vol. 52, P 875. 22 Kay 1903.

3. Excluding scason ticket holders.

4. \&371,571 at June 1906. It was not Eiven before this. This is onfy $58 \%$ of the sum paid to irestinghouse. 
In 3902 the North Bastern Railway decided to adopt electric traction 1 on 40 route miles of their lines between Newcastle and the Coast on the north bonk of the Tyne. In the same year the Lancashire and Yorkshire railway announced its intention to electrify 23 route miles of track between Liverpool and Southport. . Detailed plano had been under consideration for the previous 12 months and a large number of tests had been nade. The Ionäon Brighton and South Coast RaIIway applied for powers for elcctrical working. the managing comittee of the South East and Chathem cave notice of their intention to do so, and the Great Eastern was considering the subject in "all its bearings". "The London \& South Western told a Porliamentary Comitteo on a Bill which sought authorit, to construct various tramvay in Surrey and uidalesex that it intended at some future date to convert part of its suburban lines to electric working.

In Jarch 1944 tho North Eastem and Lancashire and Jorkshire electric lines were opened. They used multiple unit trains, with a.c. motors collecting current from a 3 rd rail at 600 volts, the standard mothod being adopted for the London underground at tho tine, developed principally in the United States. The Brighton railway continued in its desiro to electrify but was anxious to avoid the livo 3ra rall, which it thought dangerous, especially on the complicatod tracks over which it

1. 82 miles of single track.

2. Economist. Vol. 60, PP 1211 - 12. 2 August 1902.

3. E.R. Vol. 51, P 709. 24 October $19 \mathrm{C2}$.

4. Econoinist. Vol. 60, P 1802. 22 Nove.ber 1902.

5. E.R. VoI. 51, P 74I. 31 October 1902. 
operated in conjunction with other companies. Also they did not want to interupt traficic during electrificstion. Comutation above $600 \mathrm{v}$. with traction motors was vory difficult at the timo and overhead Ines were impractical at this voltage as the cross section of the conductor would have had to be very large. The use of a.c. would have solved the transmission problem but the difficulty ras that a.c. motors have poor torque at low speeds, thus being particularly unsuited for treation. The 3 phase motor was bettor in this respect than the single phase one. It was developed for traction by the Ganz Company of Budapest and used in several installations in Switzerland and Italy. It ros almost used by the ifetropolitan Railray in London, but otherrise found little favour in this country. A difficulty was that it required 2 overhead conductors. There ras also considerable activity in developing a single phase motor for traction. In 1902 westinghouse at Pittsburg, followed in 1903 vy G. Finzi of Hilan and the Union Electric Company of Berlin announced that they had satisfactory single phase traction motors. 1 Encouraged by this the Brighton Cormany asked R. Dawson to investigate the possible electrification of its lines and he reported that the singlo phase overhead system was satisfactory. The work was put out for tender in 1905 and awarded to A.E.G.; who had taken over the Union Co. But it was not umill 1909 that the first line on this sy3ten, $8 \frac{1}{2}$ miles long from Victoria to London Bridge, was opened for trafilc. It was quito satisfactory and In 1910 the directors decided to extend its electric lines almost

1. E.R. Vol. 56,PP $115 .-720$ January 1905.

2. ibid.... 
1

to Croydon. Then this was done thoy had $70 \mathrm{mlles}$ of single track working and in 2913 announced that thoy were to convort another 250 to eleotrio working, thus extending it beyond Croycion to Sutton and Coulsdon, and adding another electrified line from London Briage to Croydon.

In London the other companies proceeded even more slowly. The London \& South Hostern did not start on any conerete plans for electrifloation until 1912, when it decided to convert a circular route from Waterloo, running through Wimbledon, Kinget on, Trickenham and Richnond. This involved 73 miles of single track, and was to be followed by another 173 miles so that electric worling should extend as far as cuilaford.

Work began in 1913 and the first port was opened in 1915. The system used Fos 600 v. d.c. with thind rall transmission. Heanghile the Great Eastern, which handled more suburban traficic than any other main line railway, decided to drop electric traction for the monent. In August 1904 the Chairman told the sharcholders that

"In regard to electric traction they had thought it sdvisable not to undertake new schemes for the present. Thoy were watching the develoment of that position of the Lancashire and Yorkshire between Iiverpool and Southport and he, together vith the general manacer and five other principal of ficers of the company, had recently visited france to see whother there was anything to be learnt in regard to the working of the Fronch railways. They had como back thoroughly satisfied that there wos nothing in what hhoy had seen ... that would prove of use to the Great Eastem Railway." 5.

1. E.R. Vol. 68, P 763. I2 Nay 1911.

2. E.R. Vol. 72, PP 176-7. 31 January 1913.

3. E.R. Vol. 71, PP 941 - 2. 13 Docemiver 1912.

4. C.E.R. Sherrington. Econonics of Rail Transport in Great Britatn Iondon 1928. Vol. 2, Chap. 11. PP $231 \mathrm{fP}$.

5. Quoted in the E.R. Vol. 55, P 218. 5 August 1904 . 
In 1906 the Iondon \& North Western throught it was time to develop suburban traffic. It thought of electrifying t ino from Euston to Fatford, but not until December 1912 had they a definite proposal. 79 miles of single track were to bo electrifled from fiationd to Euston. 600 v. 3 ra rail d.c. was to bo used.

Interestingly the two pioneers were slow to extend electrio

working. The only further scheme on the North Eastern was the eleotrification of a short inineral line in County Durham, from Newport to Shilion, which ras opened in 1915." The Lancashire and Yorkshire waited for several years before extending its electric inos out of Ifverpool to Ormskirk, and not until 1912 did they decide to electrify the Ine from lianchester to Bury. On the new line d.c. working was used, with a third rail this time at $1200 \mathrm{v}$. It was also at this time that the Midland Railway, noted for its efficienoy and good managemont, entered seriously into the question of main line electrification. In 1906 it had constructed a light railway 11, miles long from Burton to Ashby, but this was an intor-urban tramsay and not a main lino railway. Stondard trarwoy equipwent was used. This was a pilot scheme and both. Hestinghouse and Siemens equipment was used. It was not a line with dense traffic, but the company was thinking of electric traction on mach used intermarion lines, rather than on suburban lines. For longer distances and with less frequent service a.c. was at a comparative

2. E.R. Vol. 71, PP 941 - 2. 13 Deceniber 1912.

2. Immediately after the $194_{4}-18$ war the Company had virtually declded to elcctrify the main line from Neveastle to York. Amalgamat1on stopped this.

3. E.R. Vol. 59. PP 301-2. 2L. Anmist 7906. 
advantage. The pilot schome apporently worked woll, for the company's engineer, J. Dalziel, told a joint meeting of the British and Amorican Socleties of Mechanical Encineers on rallway electrification, that main line electrification seened imminent, being the cheapest way to extend capreity on busy lines.

Thus main Iine electrification begar to bo quantitatively important in $1910-1_{4}$, and looked at frora the engineering viewpoint this seems late. It was also late compared with the United States. To try and explain this one nust look at the attitude of the main ine railways towerds suburban traffic, and how mach they wight have gainod by electrification. Unfortunately the evidence is sparse, but there seem enough for a general outline.

Suburben traffic had been crowing since the 1860s, and although there aro no statistics, it scems to have been growing rapidly in the nineties. The railways do not scem to have actively encouraged it, as it is doubtful if it was profitable. There is no very good evidence on the latter point. Tho Great Euston, which had more suburban traffio than ans other main line railway, argued that workmen's fares were unsemunerative." But this may have been because they wished to resist Parliament's tondency to impose Iow vorimen's fares. This Parliamont had done fram the 2860 on

1. E.R. Vol. 67, PP 234-9. 5 Aligust 291C.

2. Iloyal Commission on Jsondon Iraffic. B.P.P. 1906. Vol. 40 PP IfS. Evidence of J.I'.S. Gooday, General Manager of the Great Eastem Railway. Qs. 18517 - 18564 : 
In roiurn for perminston to jonoirato further into the diotropolis. Fhan the Gt. Eastern has extenasd ita line fron Shoroditoh to Ulverpol Btroot

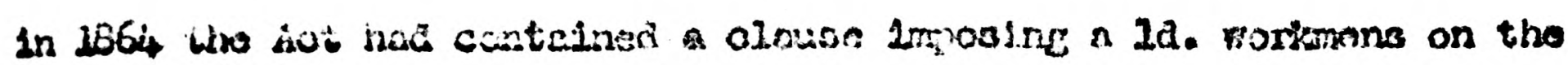

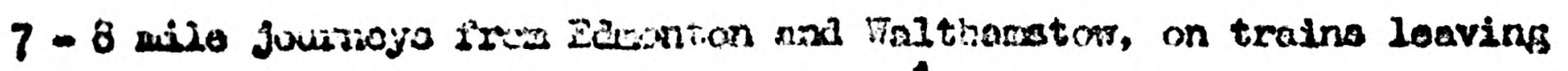

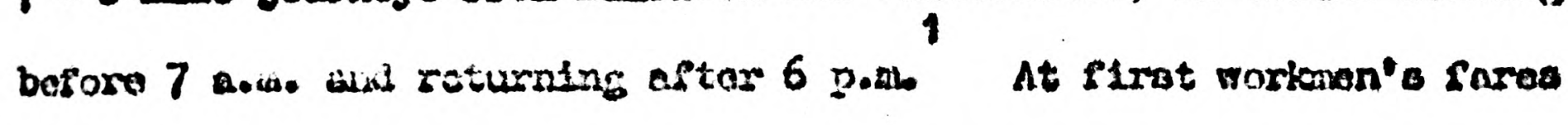

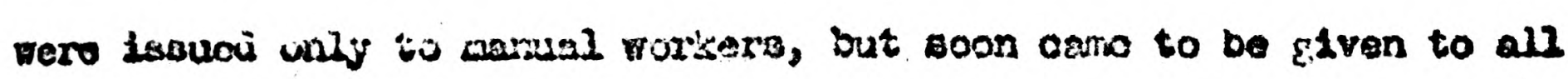
paserngers at cortosin bouss.

Fares for cther guburban gasengers wero hipher, and may havo

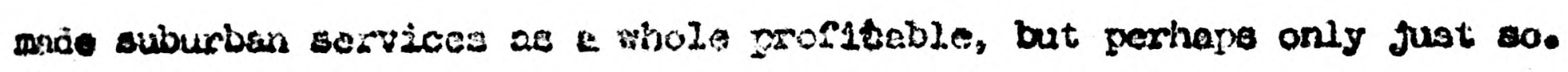

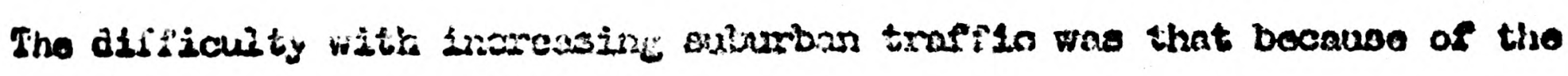

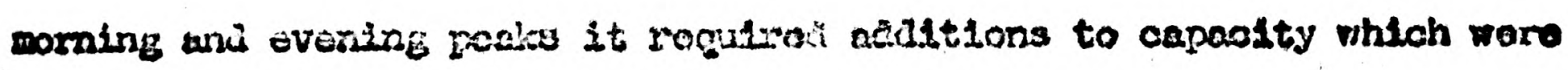

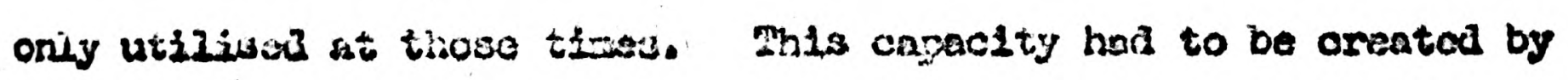

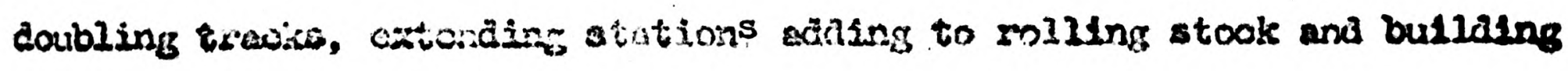
nore poweriul aninew. Convidaring the degreo of capitad Intensity involvod fares a sock to bavo bow 10\%. Ralaing fares wos largoly

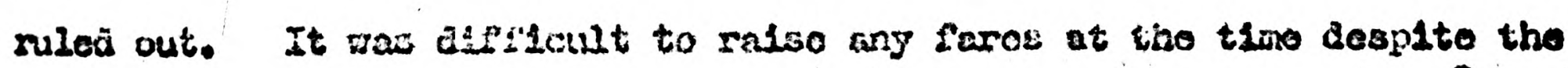
genoral ail round inproverent it the sorvice given by the rallays.. A high peais holit sare rould havo becen regarded by Pryllariont as smproper discrinination, ard incunsigtant pith she polioy of rolleving arotaing

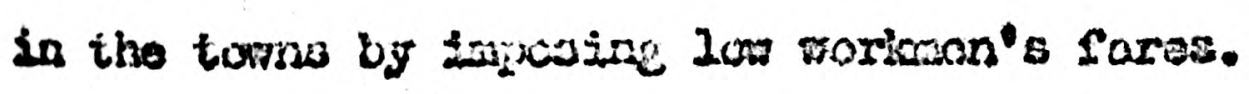

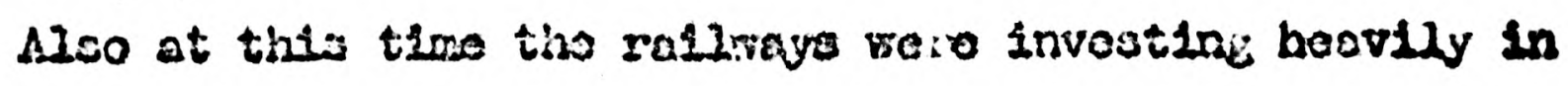

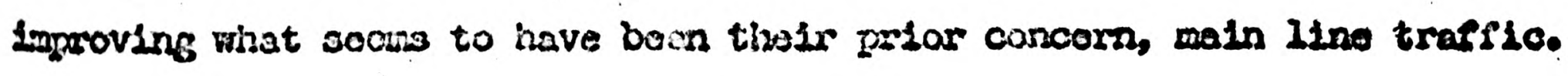

1. G.A. Solion, QD.c1t, PS $16-27$.

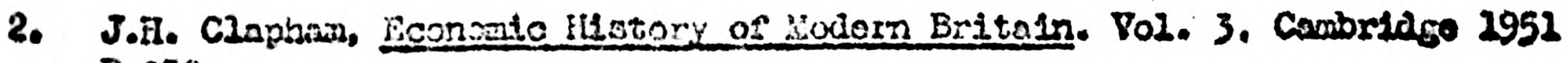
P 350. 
Many traciss were doubled, the signalling system was improved, coachos were increased in weight as standards of comfort rose, dining and sleeping car faclilities were increased, and stations were extended to deal with densor traffic. These improvements for both main line and suburban trafile caused the rallways paid up capital to increase mich more rapidly in the 1890 s than in any neighbouring decade, and the paid up copital per route mile to riso steeply, particularly between 1894 and 1904.

The attitude of railways generaily in the nineties seems to have been a pasisive one in the face of a rising demand for suburban transport; increased facilitics seem to have been providod for a growing number of pasiengers, but there was no attempt actively to stimulate demand. In so far as suburban traffic was not very profitable and a considerable user of capital when demands on the latter were heavy for other purposes, this is understandable.

The Railways regarded electrification primarily as a moans of extending capacity more cheaply than oould be done with steam working. In this they were correct; the advantage of electrification was not simply that it might have been a cheaper way to run existing services, but that it could transforin the type of service offered in order to meats passenger demard better. The running costs of electric trains were 1038 than those of stearn trains, the latter being very extravagant with fuel

1. J.H. Claphan, op.cit, Vol. 3 IP $349-50$.

2. W. Ashworth, Economic History of England 1870 - 1939. Iondon. 1960 IP 121 - 2 . 
because of the length of time the ondine wes usling o0al whon atationary. o1thor in otation or warming up or when aloving down. P. Dawson

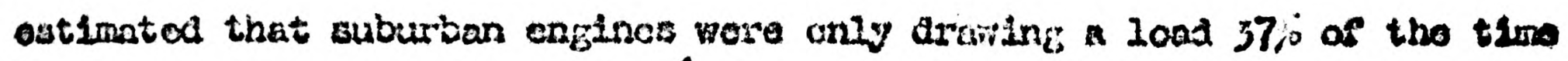
that thotr boilers were allight. But conoldorablo investaent in olectrinying tho track, nuti rolling stock and pror stntions wero nocossary, and 16 is very uniliciy that tho returns in ruol saving would have been sufficient to justion it. The gront econcois odvantnge of oleotrio irection was thet aburioan traffic could be greatly iroressed, and tho quality of serviou mach tingrovea, at great saving in boch zunning and capital costs. In tho first plsce much frotor use crald bo mate of oxisting capital. Loro insensivo uso could be man of tarninal atations.

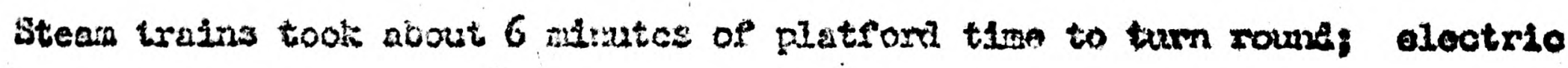
totor car trains which trevallok agally well in eanh almotion would take

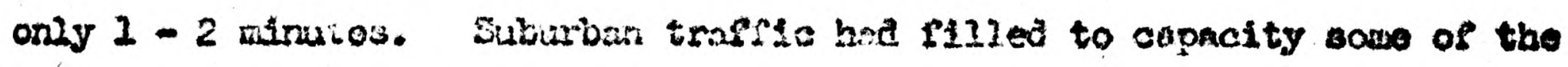

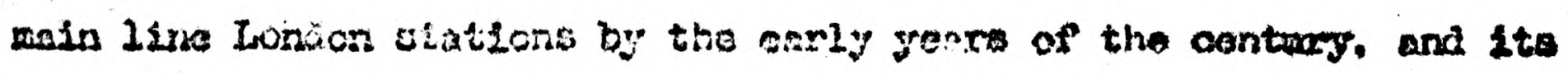
Increase roula have irvolvos hoary investmont: in atntion extonslons. Dawecn estictited that elcotrification ought to double the oomuter capacity of is terminal. It is interesting to that in 2911 tho

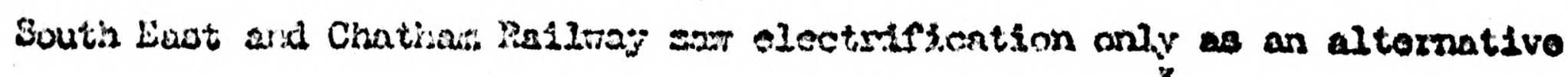

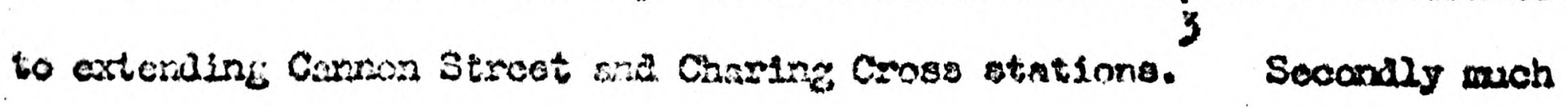

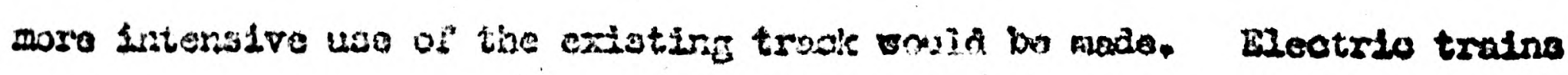
acoolorated ropidis arid could this nu at highor apeeds. On tho North

2. P. Dawson, Roilgav Elcotrlflcation. E.R. Vol. 64, FP 2C4 - 6, 275-7 5 6 12 lebruary 1002 .

2. 2. Dawron, ibid:

3. R.R. Vol. 69, P 218. 11 Aligast 1911. 
Eastern and Lancashiro ond Yorkshixe oloctrifiontion Increatod avortec 1

opedo by $30-50$, Dowson thought that ono could doublo the capaolty of crioting truok by the invoatront in olectrification. In prectice tho Horth Eastem Increased Its ton miloago by 217, and tho Lancashire and Yorkohtro Its car alleage by Q4po Inoreasing the apsod of stean enfines also required consideraulo investerant. Tho great Eatern Railnay devoloped the Dopapod ongino to opood up itio mburban services, but apant from the cost of the now onglnes, their greater woight rould havo involved strongthoning the trock and bridges.

J. Dalziel tola a wecting of a Britich and Ascrican mochantcol onelnooro In 1910 that catra capocity on bisy 21 nos could bo obtainod moro cheaply by eloctrification than by doubling or regrading. Speaking unofflclally he cald that costs were ovowholaingly in favour of olootrifying ratber than regrading, for instanco, the Mllland Company's Dorby - Wanoizester. and Shoffleld - Wianotheater zocilono. Thiraly tho uso or rovorulblo multiplo unit trains would roduco the number or turntablos, slalne and other turning round equipment and the epace occupiad by them. Pourthly because eloctric motors wero realy for 1 mediato oorvice at full porer. a smiler argrogato horso power was nocoswary to mm any given sarvico. Tho Prusojan Stato Eovormont ostinited that aspuming equal resorves and

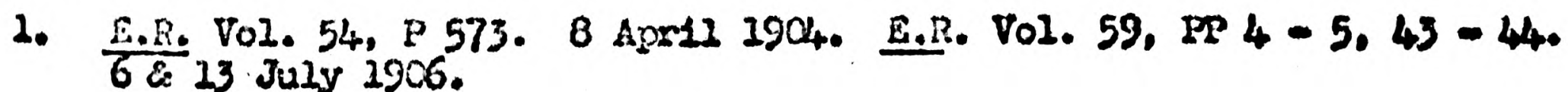
2.

3. E.R. Vol. 58, ? 257. 16 February 2906. E.R. V01. 59, $2 P$ - 5 . $43-4$. 6 \& 13 July 1906.

4. Lord Claudo Iorzliton at hall yourly wooling of the Great Bastorn Railway. E.R. Vol. 54, P 217. 5 Fobruary $19 c_{40}$

5. E.R. V01. 67, P? $234-9$. 
equal work $36 \%$ less electric locomotives were required than would bo necessary for a steam service.

Fuel costs were lower per passenger mile, as tralns wore lighter por passenger, and the thomal efficiency of the electrical methods was much higher than that of the steam. That of the Lancashire and Yorkshire clectric trains must havo been no less than $5 \%$, against, porhaps, $1 \%$ on ordinary steam locomotives. Also higher speed and denser traffic would much reduce other working expenscs. On the North Bastern IIne expenses per ton mile fell froil $17.5 \mathrm{~d}$. With stean working to 9.02. with electrio working. Speaking roughily tho service could bo doubled for the same morking cost.

In this situation the Railway Companies could only be expected to electrify if traffic increased sufficiently to ithilise the extra capacity, and produce an adequate return on investment. In the light of this one can understand the apparently ambigious attitude of the main ine companies. In $1900-03$ many of tham seemed about to eloctrify suburban Iines. Then the new electric trams began to reduce their traffio. The loss was often consicerable. As early as 1902 the Great Westorn reported that its short asstance passenger traficic was declining in Iandan

2. The thermal efficiency of the power station was $7.5-8.25 \%$ I have assumed that $40 \%$ of the electricity generated was lost in the power station, in transmission and in the motors. E.R. Vol. 59. PP $4-5,43-4,6$ \& 13 July 1906.

2. Doputy Chatman of the N.E. Railway at half-yearly meeting at York, 9 February 1906. E.R. Vol. 58, P 257. 
Blrmingham and Briatol due to the competition of electrio trams. 1 2907 the Iondon Brighton and South Coast Railway had lost 2 million of Its 8 milition passengers per an um on the Victoria - London Bridgo line to the new L.C.C. trams. By 1909 the number was down another 3 million. Betmeen 1903 and 2907 five rallway companies serving the suburban districts of North Eastern, Eastern and South London had lost at least 34 million suburban passengers, largely because of the compotition of the trams. This was about $19 \%$ of their estimated suburban trafíle in 1903. By 1909 they had lost another 20 millions.

It was argued that they could always remedy this and capturo back their suburban traffic by electrification. Sometimes compotition had this result. Merely potential competition was enough to move the North Eastern to electrify. But it was a model railway, in the forefront in adoptine most inproverents of the time. Competition was also an important factor in the Brighton Company's electrification, for many of Its services vere short listance ones. The Lancashire and Yorkehire

1. Half yearly report of G.W.R. Quoted in E.R. Vol. 50, P 370. 7 liarch 1902.

2. E.R. Vol. $66,2504.1$ April 1910.

3. P. Dawson, London to Brighton in 45 minutes. Paper to the R.A C. read 8th Docember 1911. E.R. V01. 69, P 1006. 15 Decembor 2911.

4. See Table 51. The Companies vere the Gt. Northern, the Gt. Easterm, the S.E. \& Chathain, the London \& S. Western and the L.B.\&S. Coast.

5. Reports of London Trafic Branch of the Board of Trade. B.P.P.

6. See Chapter 4 P 140 .

7. See C.E.R. Sherrington, 100 ycars of internal transport, Iondon 1934 P. 263 - 4. J.H. Clapham, op.cit., Vol. 3, P 351. 
was like the Brighton Company, without long distance main 1ines, and had considerable suburban trafilo around Liverpool and Manchester. How mich it was airectly atimulated by oompetition is not known but it is worth noting that Liverpool Corporation started electric trams in 1898. and at the same time B.E.T. and Southport Corporation were planning to electrify the Southport and District trams.

But the other companies simply lot their suburban traffic fall. Suburban traflic of the Great Enstern alone fell by $21+$ millition passengers between 1903 and 1909, and the South East and Chatham lost 18 million, In the same period. In 1909 the Great Eastern substantially reduced their suburbar pares and tho fall in their traffio ceased. Elootrifloation was no longer serously considered. The Great Northern did not lose as mach traffic es the Great Eastern. But the pressure of demand on capacity was irelieved. In 2905 O.R. Bury, Hanager of the Great Northern told the Select Committee of the House of Comons on the Administrative County of Londor and District Electric Power Bill that "wo feel convinced that .... In as much as our suburban traffic is incrensing overy day that socner or later we shall have to electrify ...." In $1907-8$ the Great Northern's suburban traffic began to fall. If, as has bean suggested, suburban traficic was not very profitable this attitude is oasy to understard.

1. In 1898 B.E.T. bought the Southport and Birkdale trams with intention to electrify. E.R. Vol. 43, P 384. 9th September 1898.

2. Report of London Traffic Branch of the Board of Trado B.P.P. 2912 - 23 Vol. 39, P 57 sf.

3. $Q 2786$ 
Interestinfly, tho London \& South Testorn which oventundly aid decide to olectrify did not lose much trafilc until 1912. Once the loss began it very quickly electrified. The London and North Festern never had much suburban traflic and electrification seens to have boen undertaken to develop 1 t.

Now we must investigate how much treff $10 \mathrm{might}$ have increased If electrification had taken place. Unfortunately there are not adequate figures on the experience of those companies which did electrify. Traffic 1mmediately rose. On the N.I. Railway passengers rose $40 \%$ botween 1903 and 1907. On the Victoria - London Bridge line of the L.B. \& S.C. Railway passengers from 8 million to 3 million owing to tram competition, but rose to 10 million on eleciriflcation, an overall inorease of $25 \%$. Only for the North Eastern is there any Pinancial information. Gross profits (recoipts less muning costs) on the North Eastem rose from $\$ 86,239$ for the last half year steam working to $£ 103,201$ for the last half of 1905 . They would have fallen without electrification owing to tramay compotition, and if we had assurned that thoy would have disappearod and thus the whole of the 1905 gross profit was a return to tho investment on electrification, it would have provided a $20 \%$ return on an investment of $\$ 25,000$ per mile of single track. As electricity was purchased from North Eastern Supply Co. this was an attainable figure, but

1. Out of this aepreciation would have been $4-6, j \cdot \$ 25,000$ is roughly equal to the investment per route mile in tramsays by 1913 , half of which had their own power station. The latter had lighter equipment, but a greater traficio density. 
unfortunately no inforilation is now available on the actual cost of electrification. But it would not have providod a big return.

The Limediate increase in passongers upon electrification was probably barely enough to justify it. The crux of the matter was whether a better suburban service would bring a long torm increaso in trafilic as more people were induced to move to the outer suburbs. In this respoct results wero disappointing. On tho North Eastem passengers rose slowly after the initial increnso. In the second half of 1903. the last year of steari working, they were 2.8 million p.a.; in the flrat half of 1905, 3.5 milition, and by the pirst hall of 19104.1 million. After 1912 they did begin to increase more rapidly and in the first half of $19 u_{4}$ reached 5.4 millions. No attempt was mado to olectrify the IInes on the south bank of the Tyne unt1l woll after tho $294_{4}-28$ war, which suggests insufelciently high density of trafric to wake eloctrification zeally profitaile. Passengers per eleotric train milo. wore only 6.0 in $1905 \& 6$, and 6.6 in 1907 \& 8 . There are no figures concerning the Southiort - Iiverpool lino, but the fact that the Lencashire and Yorkshire watted until 1912 before starting suburban elcetrleication near linanchester suggests the sanio story.

But both whare suburban lines were electrified and where they were not, the traffic figures ahow the of fect of electric tram compotition. Because this either reduced traffic or reduced the rate of its expansion, it slowcd down sliburban eloctrification. OnIy very fast urban growth would have changed this. The rate of growih of the bif towns howover slowed down after 1903, Iondan 13 a gocd example. When builaing wes 
booming in 1903 the Royal Consiosin on London Trafile vos told of the large incrosses in suburban ropulation consequent on the provision of bettor iranisort. The population of arcas served by the Great Eastern sukurban servies had Exam substantially and was clustered round the 1

atations. Wang araas sorved by the District Rallway had doubled thoir population in the precsaing 20 years. In tho late ninoties this movement to the London suburbs scams to have accelerated. Tho population of the arca served by the London Unitcd Tranvays rose $26 \%$ from $1899-1904$. $^{3}$ But there secmed to have been considerable overbutlaing by 1905 . Thus further building was unilkely and it is not likely that in thses ofrcumstances better suburban scrvices rould have been enough to stimulate it.

Evidence on the relation betreen transport faollities and bulldinis is inaderuate, and thus conclusions can only be tentative. However an examination of the question from the viernoint of transport electrification, both of trams end suburbon railways doos sucesest that the maln line of influence in the short mun was that of house building on tho demand for transport, rather than the other say roud. Better iransport. secoss to have been permissiva rather than rapialy stimulating.

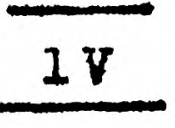

Electric traction and electric lichting wero to sume extent complementary. As J.W. Soutidern told tho Sclect Lomittoo on Lunioipal

1. Roval Convisizion un London Transnort. Report B.P.P. 2905 Vol. 30 P 2 Is. 2. ibid.1. E.P.P. 1906, Vol. 40 II f. Evidence of R.W. Perkos. Q 29629

3. Ibidi... Evidence of J. Clifton Robinson. QQs $24776-24780$ The district vas Chisrick. Ealing, Acton oto. 


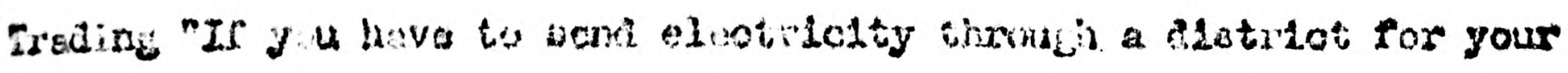

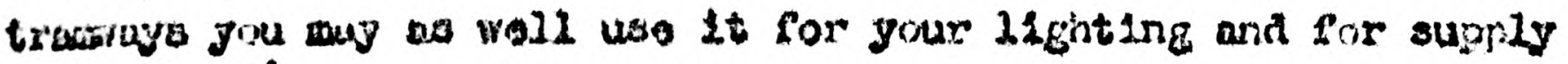

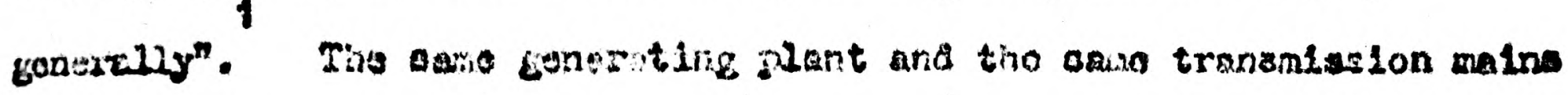

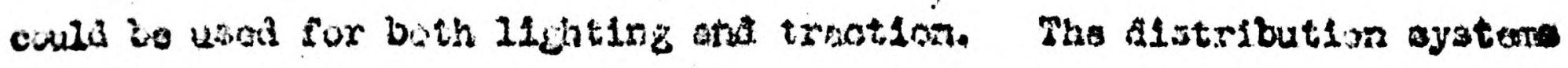

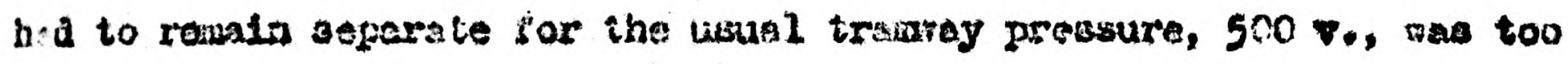
hich for general, euppiy. The exception wes that atrent lang could bo

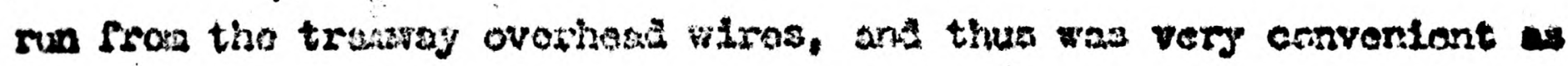
uro 12,ilto were the best way to 14.ght a strest lmportant enough to have

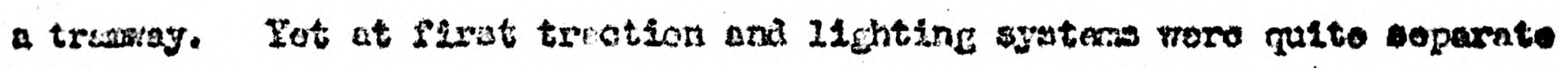
frow cech otter. In 1997 there was 21,617 horwo pwer clectrlo tranway wallag rotoris in operation. excludine thos on the City and South iondun Ensition. All woro ariven by alcotricity generated in thels om trarsay power houses. The City and South London Inilaty also had a

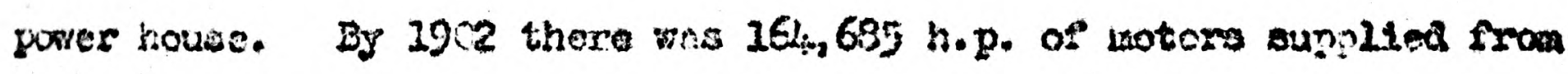
public supgy statione, Dat anothar $282,600 \mathrm{h.p.}$, agnin exoluding the City ana Boulin London, supilied Iron seyerate powor atotiono. Blectrio

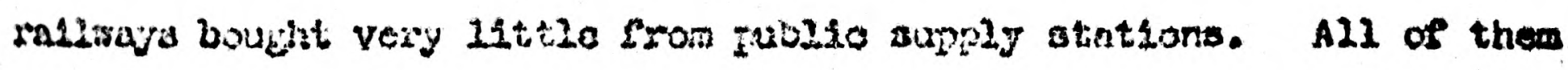

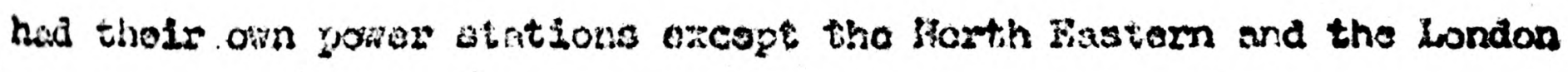
Brighton and South Coast. Tho avallablo infomation is summerlsed for 1903. 1967 and 1912 in Table 52.

1. B.P.P. 19CO. Voi.7. Q 24:65-6.

2. Electric 1 Trades Directory.

3. ibid. 
Table 52.

Source of suply of electricity used by electric trams and eleotric rallways.

Iear

Tranurays

Blentrio Railways

Totel

Generated in

Purchased

own power

station

from public

supply

$\begin{array}{ll}\text { Gonerated in } & \text { Purchased } \\ \text { own power } & \text { Irum publio } \\ \text { otation } & \text { supply }\end{array}$

in $\sin$

$\mathrm{mINm}$

m $\mathrm{Km}$

m $\mathrm{Km}$

$1903 \quad 107.7^{1}$

103.4

209.4

35

none

246.2

1907204.2

238.7

198.9

$1912 \quad 347.4$

24.5

24.8

38.4

645.6

839.0

Figures are on calendar yeor basis for all electric railirays and electric trams owned by compentes but on year onding 3 let liarab in following year for municipal trams.

1. Resianal.

2. 20.4 us $\mathrm{sinh}$ cannot be allocated.

3. No more than an extremely rough estimate is possiblo. The gneneration of the Central London Railway in 1904 is known and the guneration for other lines is based on this and the number of passengers they carried comparea with tho C.L.R.

4. Includes estimate for Brighton Railray.

For methois of calculation ses Appendix P.499.

Sources: Board of Trade Returns relating to tramays

Board of Trade Returns relating to electric railways

Calculations Pron Gariec's Manual

Select Committee of llouse of Lords on Administrative County

Electrical Irades Directory. of Iondon Electric Porer Bill. 
There are several reasons for this. In the first place when -iectric traction startis it was on a big scale compercd with existing ligiting loads. In 283891 aillion KMn were sold by problio aupply otations, virtually all for lighting. By 1903 traction was using 246 million Kith. Finus plant would have had to be extended very considerably. In bis cities the troms required a ereat deal of plant; Claviol for axample, contemplated a tramay power station or 10,000 KW. Fhere was no gain at the time in combining one of this alze with the lifinting plant as all possible ccononies of scale fore already explotted. The London Unierground railways built at Lots Road a power station of 44,0C0 KII capacity, which rerained the bitriest power station in the counticy up to 1914. But after Merz had shom the advanteges of really bie porer stations it $190_{4}$ - 5 tho arginent is no longer valld, and ecoramiss of scale would have been posslble when both general supply and wrantrays wcro being extended. As for the trangmission lines, tramays and Iigite were initially in tho contro of towns, and economies of scale could only have been achieved when both were extended to the suburbo. Sccondly, in the ninetles traway gencrators were of different design from liduting genorators. This ws party becuuse of the different characteristics of the lowa. Then there were only a fert tramears large sudien variations in the load vere produced when each car startod. Ordinary iivbling generators vere not sersicned for this type of service. Again this argunent becane irrelevant in tho oarly 2Cth century when the umber of caris in each trussiay rose to produco an even loed, when generaturs had increused in 8120 so that rariations were small comparod 
with output, and when the design of generators had changed so that they were designed for Uif variations which could occur on power circuits. But it was partily because electric traction in the late nineties used American methods ard its equipmont was designed by Amorican eng.tneers. They were used to large slow speed generators, and not the small high speed machines used by Eaglion lighting stations, and wero probably correct in thiriking lhat the small fost English generators wero too flimsy and likely to breuk down for heavy traction work. The Amerioan typo tramay stations were cheaper than the averace finglish lighting stations. The latter were costing $\$ 40-\$ 50$ per KW at the end of the nineties; the yower house of the Central tonaion railway cost 834 1 per Kif. H.F. Farishall tola Glasgon Corporation that a 10,000 $\mathrm{KN}$ poper station woula cost 532 per $\mathrm{xW}$. Lots Rosd cost under 528 per 3 porrer station would cost \$32 per KW. Lots Road cost under $\$ 28$ per KW. But the average Englisi Pigure includes a number of grall stations. The bigger public supply stations at the turn of the century cost much the same as the trannay poiver houses. The former were however on American and Continental lines and nost English consulting engin mers who would have been responible for designing plant for extenälng most public supply stations for trasway supply mould have continued with the usual

1. Mdrainistrative County of Iondon Bill, House of Iords Comittee 82568 1905.

2. E.R. Vol. 44, P 372.10 March 2899.

3. From Underground Electric Railways Itd. accounts. Ine cusi hure inclucies transinisition mains. The porrer otation may have cost as Iittlo as \$2O per KII at a gueas. 
English practice. Pinirily there is the pricin policy of public supply stations. They of ton ceen to have seon a trammey load as a way to subsidiue electricity for lighting, as a woy to incrcase the atd which electrio supply wa oitur givirs to the rates, or a $79 y$ to increase profits. In the late nineties they thought of $3 \mathrm{a}$. a unit as a normal charge for trackiay current, but the trans could gonorate for themelves at a litito over haif that price. The situation was aggravated by the cases where either the trams or electricity supply in a tow was run by the corporation and the other by a company. Thus Bristol Corporation tried to maks the zurchese of curront from the electric lightine station a condition of peinisision for the Bristol Iramays Conpany to rus traxs in the streete of Bristol. The Company refused; H.H. Parshall considered tiney could generate moro cheaply themisclves, and tinat the Corporation's Ii zhting machinery was not ouftablo for a traction load. Relations wero bad for other roasons, and oven at a cost of prouluction price the company rould have been unlikely to want to buy current. Siniles Iy Corporations roula not want to buy current fras utility cowjonies which they tended to regard as monopolies secking opportunities to explcit the rublio. It was understandable tinat Corporations like Prostion ana Realing should build thelr orn tramwa power houses. Sntagonism went very deep in somo

1. E.R. Vol. 41, PP 393 - 4. 24 Septemior 2897.

2. E.R. Vol. 39, PP 751-2. 17 Decomber 1396. Both Lord Kolvin and Johu llopkinson, two of the wost distinquished theoretion engineers at the timo, agreed with Parshall. 
oases, particularly when enthusiasn for municipal trading was at its poak. It is only in auch terms that one can explain the action of Newcastie Corporation in builaing thoir own tramway power house, whon current could have been bought from N.E.S. Co., at a price almost oertainls below the Corporation's cost of production. But separate tramar power houses were not always due to antagoniam betwcen minicipalities and companies. In 1907 wo find Glasgow Leeds, Sheffleld, Lolooster, Hull, Portsmouth, Liddersfield and Birkenhead with both general supply and tramray power houses. In Glasgow when electrification of tho trams was first decided upon, the tramray coximittee's docision to build Its own power house started a conflict betwen the tramray and eleotric lighting committees which was oven more violent than that betweon Company and Corporationin Bristol. As at Bristol, the tramos side won, again supported by the opinion of H.F. Parshall. In the majorlty of municipalities supply came from the Corporation's lighting station. In the frear ending Karch 1908 municipal trams bought $276.1 \mathrm{million} \mathrm{Km}$, and generated 448.7 million $\mathrm{KMTh}$, but of the latter quantity only 71.7 million $\mathrm{KWh}$ was in towns where the Corporation had a lighting station. The acounting price fixed for the transfer of electricity betreen the two departments fell with this municipal controversy to between $1 d$ and $2 \alpha$, where it remained. Once the separate traction power station was bullt It was rarely worth changing the siturtion. The demand for olectriolty

1. E.R. Vol. 43, P 597. 21 October 2898

2. Pousibly up to 3\% less. 
for trams, rising frow 316 million KWh in 1905 to 630 million in 1913. could bost be met by extensions to the tramway power house, or by substituting new generating plant with a greater output but oecupying the same space.

A potential loss with soparate tramyay and lighting power atatlons was that if the peak loads of each did not colnclde, wore plant would be needed than if there was ono station, or if the two wero connected. The extent of peak demand diversity is not known as it does not generally seem to have been studied. But the loads overlapped, both with a peak in the early evening usually between 5 and 6 porn, and there is not Iikely to have been very much diversity. It is not, however, safo to assume that the diversity of demand was not worth conslderation, as seems often to have been assumed in contemporary discussion.

Charles Merz argued that the fallure of Iondon electricity supply to exploit potential economies of scale was a great hindrance to railway electrification. He considered that cheap supply would atimulate the latter and estimated a very large sale of eleotricity from his proposed power stations for traction. He was supported by evidence from the Great Northern Railway. 0.R. Bury, its manager, told the Seleot Committee of the House of Comnons on Herz'B Bill that if they could take cheap outside supply "it would remove one of the chiel alfelculties wo havo in tho way of adopting electric traction, because the power station Is of courso a larger percentage of the total cost in changing the mothod of traction... sooner or later wo shall have to electrify and it would hasten our decision with such a power house as la now suggested at our 
disposal". Electric power costs would have bcen about $25 \%$ of working 2 costs, and even if halved, as Merz promised, it is not by any means certain that it would have made a crucial difference. The reduction in the amount of capital that had to be found for electrification was probably more inportant, because of the heavy demands on railway capital at the time.

It is aifficult to know how mach veight to give to this as rallway companies seemed to prefer their own power plant. Phllip Dawaon told the Comnittee of the Lords on lierz's Bill

"I am consulting electrical encineers to the London, Brighton and South Coast Railway. I have thereforo had to examino the question very carefully as regards the cost of electrification and cost of onerey for traction purposes and I have reported on them at length. In fiact at the present moment we have asked for tenders for the purpose of electrifying a portion of our system experimentally. I know therefore at what price we could produce our own energy if wo required it on any scale, and it would certainly not pay us to consider purchasing power; and oven if there were prices approximately equal, a railway company would never consider taking power from an ' outside source, and running the possible risks which might be involved in the stoppage of a supply from an outside source over which they had no control." 3

Ironically enough, the Brighton Railway was one of the only two which bought all its electricity for traction from the publio supply. but other late elcetrification schemes, the London and North Festern and, the London and Scuth Wostern plarned to butld their own power houses.

1. House of Comrons Comittee on Administrative County of Iondon and District Electrio Power Co. Bill. Q 27781 \& 86.

2. Morsey Rallway figures - the only ones apari from the untyploal District Railway.

3. Q 5273. 
Yot Herz's plans for Landon failed to materialise.

Thus there is unfortunately not enough evidence to come to any firm conolusion; cheap power might have hastened the eloctrification plans of 1910 - 11 in Iondon, but we cannot say more. 


\section{Chaptor 6.}

Electric Power.

By 1907, when for the first tine ovorall figures are avallable, more electricity was used for electric power than for either lighting or traction. Statistics are incomplete and imperfect but estimates suggest that 2,385 million Krih wero used for all purposes in that jear. Between 1,000 and 1,400 million Kini were used for power, that is $40-60 \%$ of the total. Wost of it was generated by users. Mining and manufacturing, the principal users of electric power, usod 2256 millian Iin of electricity in 1907. Only 283 million Kinh had been bought from outside. By 2912 power was still more important among uses of electricity. In that year something like 4, 146 million units were used; botween 2,400 and 2,800 million, 60 - 80\% were for power. The use of electricity for power was in 1907 a very recent development. In principle the electric motor is a dynamo working in reverse, converting electric into mechanical enersy. This had been knom from 1873 anirards, but for some years no comercial use had been mado of electric motors. Apart from traction use scarcely any electric motors were in operation in the 2880s. The carly ninoties saw a for motor installations. By 1894 the Electrical Revion was able to point to

1. See Chapter 3, Table 25.

2. It is said that the use of a d.c. generator as a motor was discovered accidently at an electrical exhibition in Vienna in 1873. See Pleming, op.cit., 238. 
electric driving in the works of Siemens Brothers, the Electrical Construction Corporation and Howard and Bullaugh's, but to no other 2

largo installations. There wore also a numbor of small installations, each with a few motors. Two years later there wore enough users of eleotric motors for it to be clear, that in certain cases electrio motors were cheaper than mechanical drives. Electrification at this stage seems to have been concentrated on the North East. As D. Selby Bigge told the Cleveland Institute of Engineers in Noveraber 1897

"In no part of the country has the progress made in electrio driving bcen so marked and rapid as upon the North East Coast, in fact it may truly be said that the encineers of the ihidalesbrough, Hartlepool and North last Coast districts have, to a very largo extent, been the pioneers of the system in this countryn. 3

What motors there were then were d.c. ones. Hoanwhile the a.c. motor was being developed abroad and this was to provo a great stimulus to factory electrification. 'In $2883 \mathrm{~J}$. Hopkinson showed that It was theoretically possible to run alternators in parallel. Ho argued that they would control cach other and keep in fhose if started in stop. It followed that from this that an alternator could be used as a motor. In the eighties however only single phase a.c. was used and the single phase motors of the time whan they were heavily loaded could oasily got

1. Nanufacturers of cotton spinnini machincry.

2. E.R. Vol. 35, P 4C5. 5 October 1894.

3. Quoted in the E.R. Vol. 41, P 845. 10 December 1897.

4. J.A. Fleming, opecitien P U.1. 
out of stop with the generator and would then stop. They then had to be restarted in step. Improvements in the a.c. motor took tro directions; one, Improvements in single phase motors and the other, the devolopment of multiphase motors.

A d.c. series motor could be used on 1 phase a.o. circults, although not as satisfactorily as on d.c. circults. In 2889 winhti Thomson doveloped a repulsion a.c. motor. It was not very satiafactory owing to sparking at the commutator and a low pover factor. Harever the repulsion and compensated series motors wero combined in a comutator type induction motor. This worked well enough but was still inferior to the d.c. motor as the cost per horse power was higher and the bulk greatcr than with d.c. motors. There were of'ten difficulties in starting as the a. c. motor had poor torque at low speeds. The d.0. motor on the contrary peiforned very well over a very wide range of speeds. Much of tho work on the single pinase motor was inspired by the hope that motors could be doroloped for the single phase a.c. lighting circusta. Unfortunately these motors would only work properly at a $10 \mathrm{w}$ Irequency, $40 \mathrm{~N}$ and below, whlle most of the lighting stations had frequencies well above thiss usually ranging from $80 \mathrm{~N}-3_{4} 0 \mathrm{n}$ Under $40 \mathrm{~N}$ the 11 ghts Plickered and are lamps were particularly unsatisfactory. Thus the bottan frequency 21 mit for lighting was the top limit for poiver. For these reasons one could expect few a.c. lighting stations to be able to develop a power load. A factory putting down a sjstera of clectric drive coiplete with genorating plant would naturally choose d.c. as it was cheapor in first cost and more sat1sfactory in operation.

2. J.A. Floming, op.cit., P I42. 
The only extensive use of the single phase a.c. motor was in traction. This involved work on a motor specially designed for traction. It was used on several railways including the Bri, hton railway, but the great weight of the motors compared with d.c. traction motors and thoir inferior torque at low specas told against them. It proved simpler to raise the operating voltage of a.c. motors by improvements in comrutation. Polyphase motors appearca to be more complicated at first but eventualiy pere shown to have great advantages not only over single phase a.c. motors but over d.c. motors for some applications, namely those where constant speed operation was desirable. The use of 2 and 3 phase alternating currents to prociuce a rotating field occurred independently to Professor G. Ferraris, Nikola Tesla and Von Dovilo Dobrowolskl between 1885 and $1388 .^{2}$ Ferraris published his work in Warch 1888 , and in thay of the sacne year Tesla siowed a rotary motor runnine with four wires. Various improvements and modifications were introduced by Bradloy, Haselwander, Westrom, Elims Thomson, Dobrowolski. C.E.I. Brown and others. The first practical demonstation of 3 phase power was with the FrankfurtLauffen plant. This showed beyond doubt that a.c. could be used for power and all the advantages of voltage transformation could be used for motors as well as lifhting. The first large scale power schome with

1. See Chapter 5, P 223.

2. J.A. Pleming, op.cit., P 346 .

3. A.B. Snell, Distribution of porrer by a.c. motorse Paper to the I.E.E. read 13th April 1893. E.R. V01. 33, PP 635-7.

4. Bradley was an Amorican.

5. See Chapter 3, P 100. 
polyphaso a.c. Fas tho Niagara Falls scheme opened in 2895, demonstrating that polyphase power was not only possible but in many cases comercially desirable. The NLagara schame used 2 phase a.c. This is infertor to a 3 phase, the latter being cheaper in first cost and giving a more oven turning motion. It seans to have been adopted because of the disiributian complications of 3 phase current, principally the diffloulty of balanoing the load on a 3 wire systern.

Thus by the midale of the nineties there were two competing systems of electric motors, d.c. and polypiaso a.o. But although competing over a range of uses they each had relative advantages in certain uses. The d.c. motor was a better variablo speed one and had high starting torque. Thus for driving cranes, lifts, hoists and traction it was the obvious one to use. The a.c. notor was able to maintain a more constant speed over a wide range of loads. Thus it was particularly useful for driving lathes, looms spind?es and similar pieces of machinery. The 3 phape system horrever, when developed, had ane vary important general advantace over the d.c. system. The induction motor itself was very simple and rubust. It had no comrutator, and thus could not sparis. It - would operato without dif'iculty under much dirticr conditions than could the d.c. motor, and consequently for similar operating conditions roquired vary much less maintenance. A large number of running difficultios with d.c. motors were due to comutation and to have designed a motor without a 1 commtator was an enormous advantage.

1. See H.C. Passer, op.cite, Chapters 18 and 19. for the story of the development of the a.c. motor in the U.S.A. 
Englioh electrical ongineers had taken no part whatever in the

development and improvement of a.c. porer during the nineties. Their

attitude was woll described by the Electrical Review in 1394

"The polyphase system is highly praised by those who know 1 t best, and although it has not yet. In this country, met with the same open hostility through which the single phase method successfully passed, it has becn treated cven zoro shaboily by indifferenco, a sort of pasisive resistance even rore deadly than active var .... In othor countries, polyphase macininery has already become a catalogued part of every manufacturer's trade"."

Wher polyphase a.c. carne up for disoussion at engineoring

meetings it was disinissed as an unimportant, and not very sat1sfactory development. This attitude shows well in the report of the remarks of Alexander Siemens at the I.E.E. during the discussion on A.B. Snoll's payer on the "Distribution of power by a.c. motors".

" English entineers should not be too much blamed for holding back on this question of a.c. They rere, after all, a body of practical people who had to apply science to overyday life, and that which had to a graat extent to govern there in what they did and what they investierated was the eternal question of is s.d. Ilis firm had been very rasch interested in rotary (polyphase) wotors and had rorked a good deal in that dircction. They had not done so much in Enclaila because it was obviously unnecessary to go to an extra set of experiments winist they had the experience of Berlin (Slemens and Halsko) at their disposal. Whenever they had to work out a problem for transijiting porrer to a distance they gave the exact problem to their Berlin house and askcd then to work it out according to the rotary system, and up to the present they had not had one instarce in which they could not carry out such a problem fust as well by eithor d.c. or the ordinary a.c. machines. ..... They must vait until they had got a thorcughly practical a.c. motor whir's they could use on the ordinary mains and then they would use $1 t^{\prime \prime} \cdot 2$

As the ordinary a.c. wains were single phase the last sentence

is a stronger rejection of the value of polyphase power than it at flrst

1. E.R. Vol, 35, P 226, 24 August $18 \%$.

2. E.R. Vol. 33, PP 728-30. 16 Juno 1893. 
sounds. Also, as public supply mains were in the centro of large towns only, It Implies a dismissal of the large potential market in isolated electric powor transinission schemes for large factorics.

Possible infringoments of the Tesla patents of 1838 were sometimes eiven as a reason for tho lack of interest in polyphaso mot ors. The Electricien argued in 1395 that it was not entirely duo to 1gnorance on the part of British marufacturing firms, nor even to a natural conservatisn tinged with the feeling that the advantages of polyphase motors have boen somewhat overstated.

"The cause of the delay in this country has ... to a largo extent been due to the uncortainty that exists as to what clains would have bcen made by tizo ormers of certain patents and as to the ground they would consider covered by such patents". 1

The Tesla patents wers very wide and English companies had ouffered from several Infiringement cases in the $188 \mathrm{Cs}$ but this cannot be enough to explain the British attitude. Coneral Electrio in the Unted States was able to Pind ways around the patent difficulties, and the big Continental firms do not secm to have been deterred in this way. There seem to have been no attempts in this country to find a method of using 3 phase power without infringing the patents quite apart from tho fact that there was general doubt as to whother tho Tosla patents would have been sustained in the courts becauso of the parallel work of Perraris and Dobrowolski. The Electrical Roview confessed it could think of no good reason why polyphase power was negleoted in this country lamenting that "Its advocates (those of polyphase) are enthusiastio and

1. Elect. Vol. 35, PP 262-3. 
make roat claims for 1t, have spent timo, monoy and brains on perfecting it. anci yet the ordinary onginecr jogs along the beaten path quite obilitivious to all their efforts."

Such was the position in 1893-5; British engineers were olearly not in the vanguard of englneering developnonts. But in 1897 att1tudes were still the samo. In the discussion at tho Society of Arts on W.B. Esson's paper on the "Tranamission of porrer to long distances by alternating currents of electricity" Alexander Slemens again argued the superiority of a.c. over a.c. porter, for, it seems, all purposes. At the same meeting V.ll. Liordey, tho Brush company's chlef electrioal onginear, with ten years successful work on the design of a.c. machinery behind htm, said that he was sorry not to bo ablo to speak from experience with regard to polyphase motors.

The first polyphase porer installations came in 1897. The West Hartlepools firm of Thomas Richardson \& Sons, who had not hitherto been involved in the manufacture of electrical apparatus, decided to install a 1250 h.p. 3 phase porver system in their works. The machinery was bought from Brown-Bover1. They also made arrangements to start mamufacturing 3 phaso plant under Iicence fron Brown-Boveri. C.F. HiEgins, Pirmorly chief assistant to the latter was sent ovor to suporintend RIohardson's - lectrical department. Tho patent problem was easily surmounted; a 1100noe was obtained frore Festinghouso to manufacture under the Tesle patents.

1. E.R. Vol. 35, PP 121-2, 3. August 1894 .

2. E.R. Vo1. 40, PP $474-6,508-10,543-5.2,9$ \& 16 Apre11 1897. 
In 1897 Brown-Boveri had made two other installations of polyphase machinery in Britain, one in Edinburgh and one in Glosgow, involving 130 and 100 h.p. respectively. 1897 also sam the f1rst G.E.C. polyphase Installation in the Liverpool Grain Storage Company's warehouse. This seems to have been the first in this country to combine lighting with 3 phase porver. G.E.C. Was not an ostablished P1rm manufacturing electrical machinery, it was primarily a wholesaler of eleotrical goods, although it hod made light bulbs from 1893 onwards and also made telephone equipment and Iight clectrical apparatus. But it made an agreement with Haschinenfabrik Oerlikon to manufacture polyphase plant under 11cence." In 1897 there was one, possibly two more very amall polyphase Installations making five to six in all. A year later there were mores the Electrical Review stated that "every week we hear of frosh advances in the polyphase line in England on the part of Continental and American makers". Yet relative to other countries there were very low, for It continued "Polyphase work has become almost universal on the Continent since the famous Frankfurt-Lauffen installation; whilst on the other hand It 13 yet hardy thought of in England"." Not that this worried Fnglish manufacturers. At the British Association in 2898 A. Siomens told Sootion $G$ that in nearly all cases a.o. power was to be preferred. In the

1. E.R. Vol. 4I, P 665. 12 Novamber 3897.

2. The General Eleotric Company.

3. E.R. Vol. 4I, P 117. $23 \mathrm{JuIV} 1897$.

4. E.R. Vol. 43, P 377. 9 September 1898.

5. E.R. VoI. 43, PP 406-3. 16 September 1898. 


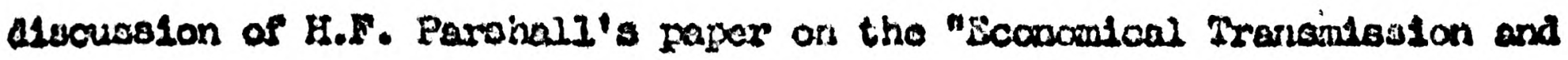
Dlotribution of Hloctriclis fras a Distauce" at a Conference of the Inttitution of Civil lingineores in the sumos of 1399. 2 . Parkor asd that ho hinself thought that there vas no noca to use 3 phaso curronte, as his S1rw wore guste propared to build 0.0 . wachinery up to $2500 \mathrm{v}$ and ho thought It rousd not bo disficult to busid them for $5000 \mathrm{~V}$.

In a papor to the Eimingham siotion of tho I.t. In. In 2303 F. Fyld gave dotalis of 16 polydzuso invtallatlono aggregating 4,590 xW. Tho 21st is probobly almost cocoplote and shows the very a all amount of

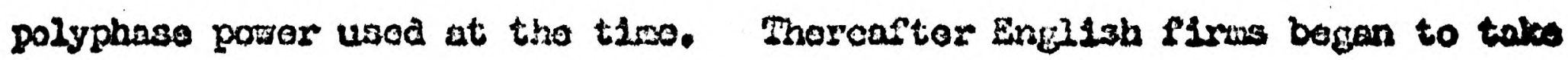

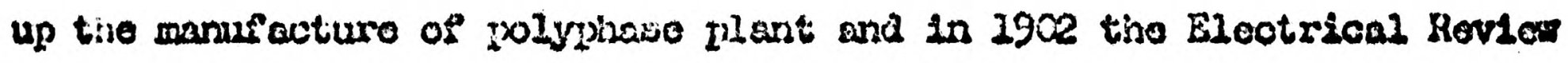
was able to say that "olodly but curoly, the interest taken by olootriond engineers in thle country in polyphase noxiring is incressing".

The Englion manufacturers advocatod d.c. wotors in proforance to a.c., but ware acarcoly very enthusinstic about the foraver. It mas tho mocinanical ration than tise olectrical onginoors who wero ardon: advocates of tho olectric notor. It was beloro tho wochenical enginooring ocoletics that tho rosults of olectrical ariving nero publiabod. The Elootrical Rovicr canconted in 2596

"Althou'h tho oloctrical ondinear is cecsoionally enthusiostio on tho wujoct of electrio motors ho ins ion tho bout part nollootod 1t. There aro of courso russorous inctances or electrical

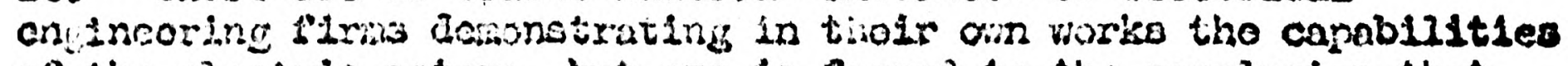
of the clectrio cotor: but ons is forced to the conclusion that thoy aro not ectivo cnough in sotisint forth tho worito of oloctrical driving". 2

1. E.P. Vol. 44, P 1044. 23 June 2899. Caxutat1an wos vary

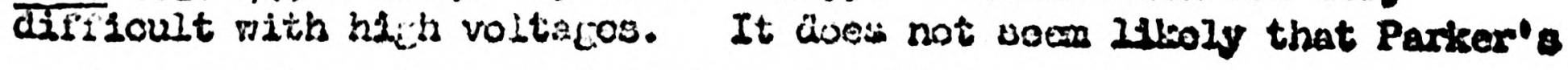
claim could have bon oustained in proctico.

2. E.A. Vol. 39, pP 483-4. 16 Octubor 2096. 
Mechanical cncineers often wanted to find out about the inerits of the electric motor, and sometimes had to go to the Continorit to get an answer.

English electrical engincering firms thus waited for a damand for motors. That is to say, they walted for an increase in denand. Por at a tims when innovations were boing made resulting in lower initial costs of electric power transulasion systens, and in lower workind costs because of Ereator roliability, output could have boen mich Increased by an active policy of innovation on the part of Engliah manufacturers. Demand, moreover, cannot in this situation be considered apart from the activities of manufacturers. In the nineties potential users had ilttio knowledge of the electric motor. Rosults of the working of electrio motors wore published from timo to time, but could only give a general guide to possible users adout the advantages of electrical power transmission to them. All lamps were much tho same and produced a fairly aimplo comodity, light, but turning motion could be used in a vast varlety of ways. The driving of cranes, steel rolling mills, machine tools and cosl cutters, posed an arrey of particular problems, whose common elements might be féw. Beifore users could know whether it was worthwile to apply electric motors for these purposes careful consultation was necessary between possiblo users and motor manufacturers. Lack of initiative on the part of the latter would lead to a much lower demand than might otherrise cxist. Tho power unit was often an integral part of the machine. Thus close co-operation was required botween the manufacture of machinery hitherto powered by mechanical moans and the 
makers of elcctric motors. In wany cascs this would be more important than consultalion with finul usors, but initiative by tho motor manufacturers would have the same effect of increasing demand. The behaviour of Insilis electrical manufacturers is only a part of the explanation for the slow adoption of electrio motors in England. It partialiy explains the slow growth of knowledge of the value, potential and actual, of electrio motors; whore the nocosaary knowledge was principally of a variety of possible practical applications it would not spread rapidly over long distances. It partially exploins the high first cost of electric power transisission schemesi Britioh plant was expensive, and Continental plent had to pay highor transport costa. These transport costs were particularly high in the nineties because the manufacturerg often had to erect, or slipervise tho erection or, plant. When Continentel and Anerican firms had no permanent representatives in this country total transport and orection costs could be high. The entry of Continental and Americal firms into this country greatis stimulated the introduotion of eleotric power. This ocourred in several ways.

Firstly, there was the formation of selling firms in this country. In the midale ninoties A.E.G. Incorporated the Electrical Company as their English sales agents. Westinghouse formed British Mestinghouse for the same purpose and Gerieral Blectric used British Thomson-iouston as an outlet for their prodicts. B. T-li. and Nestinghouse developed traction equipment as their chief product as their 
soles expanced in the late nineties. But both G.L. and Westinghouse were manufacturing non-lraction motors.

Secondly, there was the granting of licences to English firms not in the heavy electrical equipment businesi, Brown-Bovert to Thoms Richardsons \& Sons anci Derlikon to G. E.C.

Thirdly, there was the building of three now large factorles to manufacture electrical plant just ofter the turn of tho century. Both iestinghouse and $B . T-5$. Cecided to begin manufacture in this country, and Dick, Kexr \& Co. decided to begin the mamufacture of electrical equipment. By 1902, these three Sactories had largely ceptured the morket for heavy plant. The English firms did not manufacture very large plent and the optimum size of power station plant was sharply Increasing at the time. Firns like Crompton and Hather and Platt decided to abando:2 the manfacture of power station plant. As Crompton told a Select Corrultes of the Lords in 2905 ,
"...... two years ago deniand for srall generating plant closed up ... consequently all the machinery that we used for wanufacturing the smaller class of gonerating plant seened likely to remoin 1dle, and we therefore wont completely into the question of turning out motors in very large quantities and putting down extra special machinary for that purpose"."

Also the American firms were large scale manufacturers of motors. Lastily the peak of a strong bonm in tho sales of electrical ecuiprent in Gormany was reached in 19c0. A shamp recession followed and German firmis started to export plant at very low prices. The rcsult of all this was that motor prices fell dramationly

1. Select Comittee of the House of Lords on the Administrative County of Iondon and District Electric Power Bill, 2905. 84990. 
at a tiro when the advantaces of electric motors wero becoming fairly widoly appreciated. Cronpton before a select Comalties of the Comons quoted as an example the fall in the price of 10 h.p. motors from 860 . c65 in 2901 to $£ 30$ in 1905.

Deriand secms to have been elastic in these circunstances and the substantial adoption of electric power datcs fro.n the yearis 19624. Same confiniation of this pattem of development is provided by ficures of the sale of electricity for porer by public supily atations. Unfortunately no Pigures at ail exist for 1solated installations. The latter were wuch more important and there are soveral roasons for supposing that the timing of adoption of electric power whan isolated generating plant was used was differont from that whon supily was takon from tho public mains. Also the figures for supply oi porter from the publio mains are incomplete. An important deficiency is that where a supply undertaking gave fleures of the olectricity it sold for power it usualdy only did so when such sales had become substantial. As the flgures for the first fely years are missing, indexes of output based on thoso undertakings with good figures difier from those based on estimates of tho power sales of all undertakings. F'or cxample an output index (1907 = 200) based on those undertakings with figures going back at loast to 1965 w1ll onit firms which started selling elcotricity for power perhape as early as $19 \mathrm{Cu}_{4}$ but qiving no figures until 2906 or 07 . Such an under-

1. Solect Cormfitce of the ilousc of Cowions on the Adwinistrative County of London and District Electric Power Billd, 1905. Q 6835. 
taking may irulividually have beon of litilo ingortance, but there woro a Large number of them. On tho othor hand, if we included all power fícures before 1907 this will amit the early yearis of purer sales for some, perhays many undertakings. Unfortunately we can only use crude toohntques of extrapolation to ostiraste tho missing figures (winero wo moy thinix Pigures are intising). Table gives output indexes on different seta of elgures. C is probably the best, but half the aggregate is ostirates which individually have a possibly wide narein oi error. That the correspondence of exiduated sales for 1907 is quito close to the most probaile iligure of actual sales does however suggest that the aggragate is not far off the mark.

\section{Table. 53.}

Sales of electricity for power from publio supply stalions

$$
1907=200
$$

A

Unciertukings with good i'igures going back to at least 1902 .
$B$

Undertakings with good rigures poing back to at loast 1905.
All undertakings (includos numorous estimatos)
2900

01

$\infty 2$

03

$a_{4}$

05

06

07
20.4

16.6

25.2

37.2

49.8

62.9

78.3

200.0
4.8

7.7

21.6

8.9

17.2

33.9

23.8

50.6

37.2

74.2

100.0 
Thus at least half of the motiors driven by purchased electriolty In 2907 ware installed after 1905, and all but 10,\% after 1902. It 1o IIfoly that a highor proportion of motors drivon by olootricity genorated by the user mas installed bofore these dates, but it is impossible to apy how mon hligher.

Any attcmpt to measure tho extent of eloctrification rung up against a conceptual difficulty. The most obvious method is to measuro the brake horsopower (b.h.p.) applled by electric motors to machinery and that appliod by stoam angines. shafting eto. The problem arises from the fact tizat in the carly days partioularly, group, rather than Individual electrio drive was used. Electric motors were usually used to drive a section of shafting winfoh drove soveral machines. As electrio motors became cheaper they were used more and more to give individual drive. But up to 1914 fractional horse power olectrio motore wero generally much too expensive, and at least up to 290581308 bolow 10 h.p. were rarely used.

Despite this dif'iculty I have attempted to moasure electrification. Lif moasure takos the ageregate horse power of eleotrio motors used and compares this with the total amount of power of all typos. Total power is derived fran tho total eneine porer less an amount used to drivo dynamos, plus an citimate of electric motors driven by those dynamos, plus an extimato of motors driven by olectricity purchased from outside. Poirer applicd electrically Includes group drive and individual drivo indiscriminately. Thus the tendency torvards individual drive which indicates a greater degrco of elecirification, is not revealed. 
In 1900 the proportion of motive poiver ap lied elootrically must have been almost neglifiblo. By 1907 something like one ninth of the motor porrer applied in ninine and manufacturing was driven olectrically. Pive years later it had probably risen to about a quarter. Blectrifioation of factories continued, and by 1924 about half the motive porver used was eloctrioally applied: Such figures cannot be prectse, espocially for 2907, when they havo to bo constructed from partiol figures of electriotty generated by factories, and from probably incompleto figures of motor connections to public sup.ly stations, and for 1912, when the Census was only partial. Nlso for all three years figures are only available of ongino power installed in factorios and this will differ from motor power applied to machines, bocause of transmission losses and diversity. These tro would offset each other, and it has been assurned for Table 54 . that they simply cancel out. There 1s, horrever, no evidence to suggest that this is, or is not, the correct assumption to mako. Thus marilns of possiblo error are high. An attempt has been made to suggest likely percentage errors.

A striking result of these caloulations is that the total amount of porrer applied in non-electrical ways, mainly through mochanical methods liko belting, and shafting, does not rise between 1907 and 2924.

'Th1s does not mean that the growth segment was fillod by tho introduction of electrio motors. Betrieen 1907 and 1924 most of the non-electrio power transmission would have had to bo replaocd if oloctricity had not oxisted. W. lloff.. ann presents evidence suggesting that this type of 


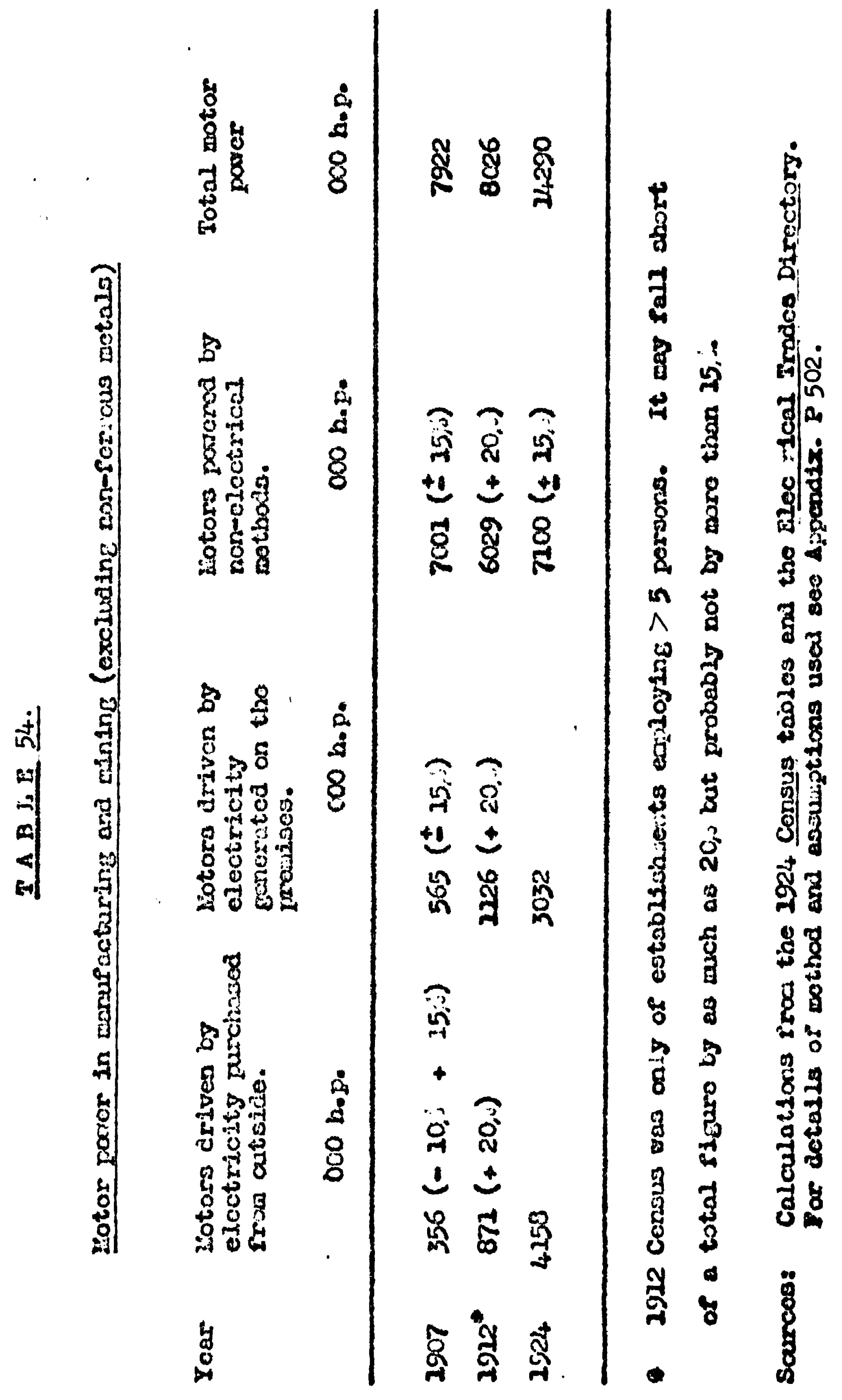


plant had a life of about 20 years. Unufortunately wo do not know when the 1907 powor equipment of industry was installed. It 18 horever possible to arrive at somo idea of how much might have been scrapped between 1907 and 1912 and 1924. Lat us assums that all tho equipment in 1907 had been Installed since 1887, and furthermore that the timing of its installation follows the pattern of Catrncross's "value of 'machinery' retained for home use" series. Thls can be. applied to non electric porser to inciuire how much of the 1907 plant st11l existed in 1912 and 1924 with an assumed 20 year 11fo. For electric motors it is adequate to assume that half of the 1907 motors were installed before 19c5. Many objections can easily be mado against such calculations; but for what they are worth they suggest that fust over hale the now ${ }^{3}$ power plant installed, measured by horse power at tho machine ariven, wos electrical. The calculation assumes that tho length of life of plant was not affectod by the introduction of the nem electrical methods; this is theoretically indefensible, and allowance for it, were this possible, would reduce the proportion of electrion plant in the total of nor plant installed.

1. H. Horfman, British Industry 1700-1950, Translated by Hendarson a Chaloner, Oxt'ird 19.25, PP 202-9.

2. A.K. Caimcross, Inme and Inoneirn Invostment $187 \mathrm{Gm} 1913$, Cambridgo 1953, T'aj10 3\% P $10 \%$

3. For $2907-12$ it is $56, \%$ for $1907-24$ it is $54 \%$.

4. New power plant in this sense includes replacements. 
The above caloulation does suggest that electrio power transmisolon mothods by about 1907 had gained something 11ke a 50\% share of the porrer equipment business, and that this ald not change muah botween 1907 and 1924. Thus It soems to have becn the case that thero was a sharp change in the relative attractiveness of electrical and mochandcal power transmission systems between roughly 1902 and 1907. The degreo of electrification affere with industrial groups, and was lor for some of the most important ones. In 2907 some 30\% of motor pomer was in mines and quarries, whore the percentage of motore powered electrically was only $5 .^{2}$ Another $25 \%$ was in textiles, whero only $4 i^{\circ}$ of the motors pere electrically powered. Iron and steel, the third largest power user among the major Census groups (20,0 of the total), had $22 \%$ of its motors powered electrically - that is roughly the national average. At the other end of the scale, marine ongineering and shipbuilding had 55; and general and electrical onginoering had 524 of thoir motive poiver applicd electrically. But they accounted for only 2 and 5io respectively of the power used.

1. On tho Census of Production chassification.

2. The general basis of calculation is as for the aggregate in Taible 54 oxcept that the fisures for siotors driven by electricity purchased from outsido have had to be allocated to industrial groups in a way which can slightly increase marcins of error. Soo Appendix, where the full figures for all groups also appoar. 
Th1s pattorm porsists. In $191234,{ }^{\circ}$ of total porror in industry ras in mines and quarries; only 19,0 of that was eloctric. Text1les took.another $27 \%$ of industrial power with only $9 \%$ of 1 ts motors porered electrically. Iron and atoel accounted for another 22;0 of total poirer, but hed only 22\% of 1 ts motors driven by electriolty. Again marine engineoring and shipbutlding, and genoral and eleotrical englneering had $89 \%$ and $72 \%$ of motors driven by electriolty with only 2 and 6\% respectively of total power. In 1924 the tro Industrial groups with a degree of electrification or power well below the national avorage wore mines and quarries, and textiles. They accounted for $27 \%$ and $28 \%$ respectively of total power and hod only $42 \%$ and $26 \%$ of tholr motors driven by oloctrioity. Iot by then three groups had more than 90\% of their motors eleotrioally porrered, marine engineering and shipbuilding, general and eleotrdoul ongineering, and cycles, motors and railway wagons. But only 22.5, of the porrer equitiment of Industry was in these groups. It is appropriate at this stak o to inquire into the c1rcumstances in which it was economically dosirable to install electrical rather than mechanioal power transmission. As the task performed, proviaing turning power, wes similar in both cases one can cancentrate on asking what resources, if any, were saved by adopting eloctricity.

1. Bor 1912 this rofers to establishments employing more than 5 persons. 
Turning porier has a vast varlety of applications, for example driving looms, lathos, coal cutters, steol rolling mills, cranes and rivetting machines. In all these the relative advantages of olectricity will differ. The information nooded to go into dotalls of multitudinous applications of electricity ls very great, and all that is possible within the scope of this work is to make some general points.

Indeed, to do the woric in details would require an inquiny Into production methods which is impossible now, and would have been a very large task then, as neceisiary records of actual production methods were not generally leept, and studies of possible onos rero not generally made, and certainly not disclosed. British manufacturers were secretive about the results of electric driving as they were about most matters where openness might reveal the cost of production. Ono example will suffice. In the early days of cotton mill electrification it was said that owners of electrifled millo were vory loth to make known the results fearing that their competitors would oeln. The Electrical Revich made the following coment in 1899

".... There is no lack of infornation on the results of applying (elcctric) motors to machino ariving, but unfortunately much of It is in a fugitive form and the ordinary enjincer who sots out to give details of the advantages and disadvantages of olootrio motors, must have a spccial gift of research; and moreover, in dealing with the surce abundance of matcrials that will eventually be disccrered he must exerciso rach perspicacity and discrimination in order to arrive at correct rosults ... In spito of tho accumulated expcrience that exists on the subject of machine driving it is notable how fert are the conclusions one may dron from it"."

1. E.R. Vol. 45, PP 41 - 2. U4 Juls 1899. 
As the leador went on to point out, published information was doflolent. That given in papors to enginecring sooleties was too vagues that Given by mamufacturers of electrical plant was often conflicting.

The flrst element of cost to be considered, and perhaps sicnificantly the main one to be considered by British power users, was the cost of the porrer 1tself.

Among the various poiver uses there wore some where the rolative advantage (which might be negative) of olectrical comparod wlth mochanical methods of power irensmiscion was greater. Firstiv, thero was the situation whore porer had to bo appliod in severnd scattored points in a roriss, in fairly small quantities, that is mall in relation to the minimum officient size of steam anginos. If steam methods alone were used three alternatives were possiblo. One engine could be used with long lengths of shafting; but losses here could be rery high, especially where the density of motors along the shafting was low. One boiler could be used connected to a number of onghes by long steam pipes; but heat losses in the plpos could be hf gh and amoll ensines wero thermally inofficiont and had a high Initial cost per h.p. The third mothod was to use a large rumber of englnes and boilers; again they were thcmally inefilcient, capital costs per horse poiver were high and the cost of labour in tuelling bollers large. In these casos electriatty offered advantages from as oarly as the nineties. Generation could be centralised, transmission losses were lower than with lone lenfths of shafting ar 
lang steam pipes. Small electric motors were cheaper in the first cost and maintenance than small stearn engines.

Even in the nincties electricity was not the only alternative ,to stean methods. There was the gas engine introduced in the 2870s. As early as tho early elghties both Sir Froderlak Bramell and Flooming Jenkln thought that it would fairly soon roplace the steam engine." But in the 19th century gas ongines wero very omall. Not until 1898 was one of $22 \mathrm{C}$ t.p. built. Thus in the ninoties it only competed with amall isolated stean engines. But first cost was high and lower nuning cosis wiere probably: largely absorbed in ingher maintenenoe costs. The big gas engines of the ycars 1900 - $u_{4}$ wero not alternat1ves to elootrlo drivine but alternatives to steas ongines to drive dynamos or shafts. In fact with their high speeds and poor low speed torque they wero poculiariy suited to driving dynamos. Compressed air was also coming into use in the ninoties. It was particulariy suitable for operations like rivotiting and drilling, but was a less simple method of conveying poirer tizan olcotricity. Compressed air tubes wore gonerally not as convenient, eficient and choap as oleotric cable. For rotating plant olectricity was better.

Scconaly as an extension to the first point eloctrio power transuission was relatively moro advantageous where connection to a

1. J.II. Clapham, op.cit. Vol. 3, P 133.

2. 1 bid. 
central porror sup ly was difficult. Travolling cranes are a good examplt. Before electric power they were virtualiy obliged to have their own boller and stcan encine. Also stntionary holsts etc. were diffleult to connect up to shafting because of frequent stopping and starting. Hero hydraulic plant vos frequently used. But it usually Involved a separate power unit which was relatively expensive. Similarly varlable apeed tools and mnchinory could not be connected simply to shofting. Gears and clutches were expensivo to molntain and puch power could be lost in them.

Thirdly, in any single factory, electricity was relatively advantageous, not only where jorticulion tyms of inser applioation wero needed but where several types of power ware needed under the somo roof. . For electricity could cope with lifting and turning at constant and varlable speeds. Other forms of power migent co ws usoful for partioular operations but had not the same range of usefulness. This range of usefulness meant that power generation could be centralised with oonsequent economies.

Pourthly, elcctric power was at a relativo advantage whoro power was used intormittently. Thoro machines are being switched on and orf during the worizig day it is extremely unlikely that all the machines would be switched on and off together. Thus the enount of prime moving and generating plont needed was loss than the total horse power of motors powcred. How mach less depended on proportion of tho working day when machincs were actually running, tho loss function to be attrohod to not 
being able to provide enough powor for the machines, the overlood 1 characteristics of the prime moving and generating plant, and the correlation between the time of use of the various machinos. This diversity varied with different industries. It was low in textiles where machinery was used continously during the day cniy, and quite high in engineering where machines were used internittently. H. HoColl sufiested that in encineering woriss it was usually found that generating plant equal to $50-60 \%$ of the aggregate maximum porrer of each machine was surficient. lhis saving of power plant because of diversity applies to any centrilised powor gencration system, mechanical as well as electrical. But diversity would rlse as the mumber of machines connected rose, especially as machines of differont typos and with difierent patterns of use vero oonnected. Thus divorsity was generally greater with electricity. Also lsolated steem ongines driving single machines if used only intermittently wero vory wasteful of fuel, and by definition had zero divorsity. Compared vith these types $02^{2}$ porer requirements eleotricity was at no relative advantage where power was required to drivo machinory all grouped together and all requiring the saine type of power. Por

2. Prime moving and gencrating plant can bo built to give, withtn IImits, givon overlood capacities por varying lengths of tiro.

2. During the discussion on J.F.C. Sf,ell's papor on the Anplication of F]cctricity to Industrinl purnoses to the North East Coast Institution of Shipbuilders \& Engineers, 24 February 1905. Prococdins.s, Vol. 21 PP 153 - 176 and 239 - 250. 
examplo, in a cotton mill all the machincry was grouped together. Sharting could be uscd to its best advantage as shafts did not need to be long, and the density of machines per foot of sharting was high. Nearly all raschinory was used continuously. All the machlnery roquired constant speed rotating power. Thus a central and officiont prime mover oould be used.

Textile factories had conditions particularly suited to driving by central ongine and shafting and it is thus not ourprising that in auch factories this system was best devcloped. IHill owners and managers had paid grcat attention to their power equipment. Their prime moving plant was more economical on the average than that of any other branch of industry. Steam enuines wore often spocially designed for a particular mill. One of the important external economies of the cotton textile industry in S.E. Lancashire was the existence of woll developed engincoring sinns skilled in providing for their needs.

"Probably in no other branch of industry, considered as a whole, will there be found such well designed and carefully built enginos and auch sraooth running sharting as is the case in tho cotton mille ... until the adoption of electrical transmission of porfer in racent yeurs (in outher trades)... the cotton mill was infinitely better equipped as recards its power installation than was tho averago engineoring shop or shlpyard".1

This was despito the fact that it was in the saine engineoring shops and shipyards that engines and power equiprent vere bullt. liatther's staternent ras not likely to bo contradicted; it seems to havo been the generally held vien.

2. P.S.A. Viatthews, Lancrshire I:IIlls and Electric Driving

Supplement to the E..R. Vol. 63, IP 551 ff. 
It was primarily in the engineerine trades that power was used Intermittently in a scattered a $d$ /or varying way. There, thero were chances of reduoing power costs even in the nineties when electrio driving was still in the development stage and the first oost of electrio motors high. Perhaps the carliest industrial application of electricity was to cranes. As early as 2888 the engineering finn of Baston and Anderson adopted an electric travelling crane in their foundry. As they were also using a steam crane they were able to canpare the two, and came to the conclusion that electrioity wai both cheaper and more satisfactory. No exact cost comparison hod been made but it ras sald that fucl costs had been reduced to betmeen a quarter and a thind of the steam crane, that labour costs were also less because there was no need Por a stoker to start work $1 \frac{1}{2}$ hours early to raiso steam. and malntenance 1 mas also reduced.

Blectricity also spread to other uses where transmission by existing mothods was difficult. Shipbuilders were quick to uso 1 t. In the late nineties several yards, particularly on the Tyne, Installed olectric power. Significantly when Charles Herz was considering tho application of electricity for Industrial purposes on the Tyno in 2900 - 01 ho was particularly anxious to use a system which would appeal to ahipe 2 butlders.

2. L.W. Anderson, Notes on Blectric Cranes, to Section $G$ of the Britioh 1scociation, 21 uepteiaber 2396. E.R. Vol. 39, PP 478-81.

2. See Chapter 4 P. 137. Also Neptune Bank used narine engines partly to holp in inducing shipbuilders to buy eleotrio power from N.E.S. Co. 
Shlpbullders had scattered and variable power uses. Merz argued that the adoption of electric driving by Tyne shipyards resulted in a $40 \%$ oaring over tho old steam driving.

In the coal mines power uses varied betwe:n those typical of text1les and those typical of encineering. Inderground power roquitromonts were scattered. Small units were nocded for pumping, haulogo and coal culting. Punping was often done by engines fod by steam from the surface. Haulage was effected either by engines again fed from the surface or by horses. Coal cutting machines sore very little used but were very sultable for electric driving. On the surface there were often scattered power units for screening, repair shops, and also large economical engines for winding and ventilation. It was unlikely that -lectricity would be economical where large engines wore already used. But for the various scattered applications it was comparatively bettor placed. For haulage it should have had sonothing 21 ko the advantage of lover motive poiver costs over pit ponies that the electrio tram had over tho horse tram.

Where electricity could reduce actual power costs by reducing the cost of transmitting porrer over a given distance it would produce two prinolpal types of saving. Fuel costs por unit of work applied to

1. Select Comnittee of the House of Iords on the Admintatrative County of London and Distriot Rlectrio Power. B1Il 2905. Q12. 
the machingry could bo less if an electric transmission system had a higher officienay than a systein of shafts and belts, or if an eloctric tronsmission system was installed instend of a set of small scattered enginos, as small scattorod onginen had a relativoly low thermal effloiency. Also the capital costs per undt of rork appliod to the machinery would be less. A higher tiansmission ef fllolency would reduoo the capacity of prime roving equipment for a glven powor applied to machinery. Greater diversity would do the saule. If the capital cost of an clectrical system wero less tisan the wist of a mechanical system the cost of a given capacity would fall. The same result would obtain if a central power unit replaced a serlos of scattered ones, as the latter had a relativoly hi, $h$ rirst cost per h.p.

, The reduction of fuel costs and the reduction of capital costa by reducing the primo mover capacity requircd was possiblo in some engineering factories, but was much more dificicul in the largest of the factory trades, textiles, prinarily because of the tecknique of production. The effect of the naturo of the porrer requirements on the rate of adoption of electrio driving in the tertile industry was 11lustrated by contemporaries by the more rapid adoption of olectrictity by bleach and print works than by mills. F.S.A. liatthens argued that it was "not on account of any hostility on the part of the ormers" that in 1907 there was littlo use of elcctric driving in Lancashire mills. This was clearly shom, he ment on to argue, by the f'act that elootrio transmisision was adopted first in bleach works and print works, where "conditions are different from those obtaining in the spinning mills and woaving 1. Uscd hore to mean rato of doing work dit where w = work and to = t1mo. 
shods in so much as in those rorks a large nurber of auxiliary onginos 1s requircd, and these being not so contrally situated as is the ongino of a spinnini mill, great cconony in transmission could be sham by the adoption of tho oloctric drivon.

Thero is not really ang ovidence on the relative capital oosts of electric and mechanical power tranamission equipmonts. But before the b1g fall in the price of electric motors $1902-05$ eleotrio motors wore notorious for their high firut cost.. It was sald in witigation of this that electric motors had lower maintenonco costs than shapting, but one cannot be suro that the comparison was not being mado botween new motors and somerthat elderly shafting. It seams almost cortain that up to about 1901 the capital costs of electric tranamission systems per unit of prime moving capacity were on the average above those of mochanical systers. By 1905 thero ras probably little differenoo between the two and elccirical plant prices fell relatively, although at a slower rate than Pron 1901 - 05, from 1905 - 14.

Ons can say more about fuel costs, largcly because th1s was what engineers were most concerncd about. Even hore tho ovidence is somevhat less than might be desired, prinarily becauso of the lack of data about wechanical driving. Lieasurewionts of power and work are not too difficult with eleotrical methods as fairly good measuring instrumonts wero soon devised. But there were no such good instruments for moesuring the work dono at various parts of a sot of shafting and belting. 
The thermal efficiency of olectric power transmission was 1

fairiy constant for most anplicalions. But it varies with the tim tho aystom was at varying percentares of full load. At full load it 2

would be aboui $80 ; \%$ but at half lond it could easily be as $10 \mathrm{w}$ as $60 \%$ In the early and niddle nineties it wos lower, perhans $10 \%$ 1esa.

The effiolency of meohintoal transmission varled a great deal. T. Gelpel sumiarised the evalloble evidence for the British Association In 1898. In 2894 Prosesion Kennedy had ostimated tho 1083 in aharting at 22;0. Crompton cave it at 32\%. These we1 overall averages. S1r Thamas IIIchardson at his own works found 10sses of between 25; and 70; w1th a walghted avcrage of 43;. Messrs. Furness; Festgarth and Company's engine works at Midrilosbrough had an avarage loss of 50\%. At the Bristal Maggon Works the loss had varled between 22 and $57 \%$. In several pactorles In Oleveland, Ohto, C.H. Benjanin found the loss to vary between 50\% and 80\%6.

1. This is a rough and ready statement. Efficiency would for examplo be affocted by the length of cables used, or by the cross section of cablos. Cables could bo designed for varying losses in transmission.

2. Allowing $7 ;$ loss in the dynanos, 2,0 in the cables and $22, \%$ in the motors.

3. Elcctric poirer and its apnlication on the three phaso system to tho Bristol Warson and Caritinge Wories, Paper to Soction G, 12 Septeriber 1098. E.R. Vol. 43, PP 427 - 9. 16 September 1898. 
On the averace electricity was thus not a great fuel saver. In textiles it 18 unliknly that on the avorage electrio transmigsion saved any fucl at ail. In 2907 a paper was read to the lianchester section of the I.E.E. suggesting that for mill using 100,000 spindles 3 phase electric power was slightly cheapor than mochanical porror $0.425 \mathrm{~d}$ per $\mathrm{kg}$ ain against 0.445 . For smaller mills the author thought mechanical working was choaper, and the comparative advantago of electricity increased with the size of the mill. But his elgures were challenged in the discussion, and it seems likely that the margin of orror was as large as the difference in cost. A 100,000 spindlo mull was a big one. In 1911 the average mill had 60,000 splndles, but recently built ones were above the avcrage.

In coal mining, an important examplo because of the size of the Industry, the very $20 \pi$ opportunity cost of coll meant that when fuel could be saved, the value of the saving was small.

In ongineering where fuel might havd been saved the saving could rarely have been sufficlent in the nineties for it to bo worth replacing mechailcal drive with electrical drive. If we compare eleotrio power with 70,0 eff'iciency with sochanicol power vith $50, j$ oft'iclenoy the roduction in the coal bill would give a gross rotum on investment of porhaps between $2 \frac{1}{2, j}$ and $8 \%$, with the averago nearer $2 \frac{1}{2}$ than 8 , on the initial cost of the new equipment. In the years 1901 - 05 the cost of electrio motor equipments halved and thes the rate of return would

1. E.R. Vol. 61, P 2006. 20 Docember 1907.

2. J.H. Claphom, op.cit., Vol. 3, P 176.

3. On P. 279. 
3. This calculation is intcnded to shor the orders of masnitude involved. - Lificient reciprocating stcara cngines used about 3 lbs. per 1.h.p for averac ondition in the ninctios. Cool lis the factory buntors cost botween $\$ 0,5$ - $\$ 1.0$ per ton - usually noarer to $\$ 0.5$. issumine $90 \%$ cngine effioiency, 50,0 of ficicncy in mechanical transmission and $70 \%$ in electrical transinission, the cost of fuel per brake horse powor hour is

Coal cost per ton. Blectrical Hochanical Difference

$\begin{array}{lllll}21.0 & 0.518 \mathrm{~d} & 0.712 \mathrm{~d} & \ddots & 0.20_{4} . \\ 80.5 & 0.259 \mathrm{~d} & 0.356 & & 0.097 .\end{array}$.

Factory motors ran between 2000 and 1500 hours por jear on the average. Thus tho saving p.a. per b.h.p. used was

Hours usod por year

Coal cost per ton

\begin{tabular}{|c|c|c|}
\hline & 81.0 & 20.5 \\
\hline 1000 & $2 \alpha_{4} a_{1}$ & $97 a$. \\
\hline 1500 & $306 a$ & $246 a$. \\
\hline
\end{tabular}

Tho initial cost por b.h.p. of nn elcctric motor transmission outfit depended on the size of motors used. Sires bolow $10 \mathrm{~h}$.p. wore very costly and for general factory power firs rould rarely co below this 8ire, at least up to about 1905 . In 2895 A.L.G. were sclling 20 h.p. motors at about $\& 8$ per h.p. The prico por h.p. declincd up to about

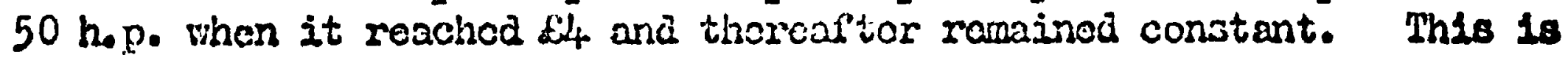
for d.c. motors; a.c. motors vere otill in ticir infancy and although tho 10 h.p. sizc vas again about $\& 8$ they did not fall bolow $\& 7$ as tho size rose. Lot us talse $10 \mathrm{h.p.;}$ biecer motors nero used, but froguentily to drive small picces of shofting. Dynamos being bigger, wore cheapcr per h.p., say an elcctric porrer transmission system, assuning tho same stcam cnirine could bo used, would cost about 4 il por h.p. in 1895. This is a minimum 23 the cost of orection has not been included.

Thus we can calculate the gross return, before deprociation, pean on replacenent of sharting by electric motors.

$£ .0 \quad £ 0.5$


be doubled. As dersectation on this type of plant was about $5 ;$ even then it is a barely adequate raturn on the avcrage.

A comparison of a centralised electric drive with a muber of scattered stean engines brings out the same point. In 2898 \%. Havor of Havor and Coulson, a Glasgow firm, one of the pioneers of electrio motor driving, sent a questionnaire to menufacturers in an attenpt to got betler information. The replies he' got were admittedly incorplete but sufficiently good for him to be ablo to divide firms into two groups. One wes mills and similar astablishments where one or two officient engines were lied. The other was where powor was derived from a number of swall steam enzines. On the everage the first group used 3.2 2bs. of coal per 1.h.p. hour, the second 5.3 lbs. In the former case no fuel saving coula be expected Pron electrification. Electrification could Improve the Becond group until the same amount of fuel was used as in the firet. The value of this fuel saving ras slightly leas than that in the earlier examples of mechanicol and electrical driving and thus the 2 roturn on investment less.

1. Both averaces are reijited by the anount of power used.

2. If a central enisine was used witis elcetrio potrer transmission using 3.1 lbs. cos! per 1.h.p. hour then assuming 90,j oncine efficiency and 70,0 elficiency in tronsnission, 4.9 lbs. coal would bo used por b.h.p. hrux apolicd. Scattered engines using 5.3 lbs. por 1. ho po hour ap lied direct, assuming $90 \%$ engino off'lciency, would use $5.92 \mathrm{bs}$. por b.h.p. hour employed.

$$
\text { Costs por b.h.p. hour }\left(\alpha_{0}\right)
$$

Coal cost per tan. Electrical Scattered stoam enginos Difference.

$\begin{array}{llll}\text { \&1. } & .526 & .631 & .205 \\ 80.5 & .263 & .325 & .052\end{array}$


Beforence 2 continued.

Fucl saving per year (d.) of electrical method por h.p. Coal cost per ton.

$\begin{array}{lcc}\text { Hours por year } & \& 1 & \$ 0.5 \\ 1000 & 105 & 52 \\ 1500 & 258 & 78\end{array}$

Thus on linvor's figures the eleotrical savings cone out at a smaller figure than in the provious notes. The argument used there applies a sortiori. 
Thus up to the big fall in motor prices of 1901 - 05 there was Ifttle reason on the average to convert to electric driving to save fuel. But the dispersion of fuel costs of ateam plant was very large. Navor found instances of extremely wastefur engines. Som he found were using 53 - 280 jbs. of stean per i.h.p. hour, even in factories where other engines were rorking at the very economical rate of $\mathcal{U}_{4}$ lbs. ilany of these engines were very old, often 20 years 01d. They could, he thought, be profitably replacod by electrioity. But it is likely that it would have been profitable to replaco than by up to date steam engines. There is sore truth for the ninoties In the contention of G.T. Duncan provoked by a paper on electrioal porer transmission in 2895
"In papers of this sort cornorisons have crily been made with steam engines, which in wost cascs are apparantily of ancient design and construction and ill adapica to the rork in which they were engagred during the tests, thus shoring an abnormal and unreliable coal consumption ... vihile on the other hand the electric plant has becn of modern construction ..." ${ }^{\text {n2 }}$

Also in the nineties it woula be worth replacing mechanteal with eloctrical plant to save fuel if the encines woro vory amal, or the shafting was very losis or transmission very difficult.

In the case of equipjing ner factories, electrio driving was more likely to be adopted. But for a large muber of applications for much of the ninotics the fucl saving was slight, of ten not enough to offaet the higher capital cosis of an electrical system. Throughout the

1. W.C. Lfountain. Desinn and Esicicieney of Plant for the Transmission of nuer by electricity. Paper to tho North w'ast loast Institution of Linginecrs and Shixpuilders, 15 January 1895. Proceedinge Vol. 21 PP 213-32, 247-63, 287ff.

2. Communtcated remarks of G.'T. Duncan, ibid... PP $161-62$. 
nineties the cenitis costs of an electrical system fell slowly relative to the capital costs of mechanical systorns, thus changing the position Srun that of the mide? ninotics when aloption of electric rather than mechanical driving very rorely reduced power costs, to that of the late rinotles when it only occasicnally reduced porer costs.

After 2905 the position was eubstantislly changed. It was much more Ijkely to be worth replacing existing mechenicel plant, and thus a fortiori installing clectrical plant in new factories. The detcrent of hich corital costs was generelly romoved. In the typical cazineering shog the balonce seesz to have been firmly tipped in favour of electric drivinf. But in textile mills it was still an open question. Nlso the reduction of motor prices brought power within the reach of small worisshops who had. hitinerto used no porver at all, and suall Lactorice which had used very littlo. Clapharn notes the much more rapld risg in the nuabler of factories than worisshops. The distinction 18 made accordine to whother power $\nabla 33$ used or not. The number of the formor, uaine power, roso by 26:" from 2901 - 2923, and the latter, not using power, by $13 \%$. From 1895 to 1913 the former hod risen $22 \%$ and tho latter 32,0 .

By the niretics the reciprocating stcem engine was near the limits of its potentialities. Prom about 1907 - 10 onsards two new oconamical prine novers cane to be used in factorles, the steam turbino and the internal combustion engine. However they otimulated the use of

\section{J.H. Clapham, op.cit, P 194.}


electrioity, for they operated best at a high speed and for use with mechanical transmission would have noeded gearing. Electric trans1 mission automatically met this need, and met it much beiter where large powcrs vcre involved. It reduced the amount of electricity which might have been bougint from public utilities, but to confuse buying electricity with using it is a mistake of the first order. To consider power costs alone is quite inadequate. It can indeed bo argued that they were of minor importance. Other resources could be saved because the use of eloctrical mothods could increase output without increasing inputs, or more generally because it ald not increase the cost of all inputs proportionately as much as the value of output rose.

The simplest way in which this could happen was by incroasing the physical output fron axisting machines, or the value of output. Thta could occur because of more accurate control of machinery. One such application was the use of electrioity on the Ward-Leonard principle to control very large motors. In this way the etopping, starting and speed of large machinery could be much more accurately

1. The principle behind tine diesel electric locomotive is that electricity is used to provide the transmission instead of cears and clutches, as in a diesel bus or lorry. Electricity can much bottor deal with large poirers than gears and clutchos. Another illustration comes from ships where turbo-eleotrlo power was experimented with rather than gearod turbines. 


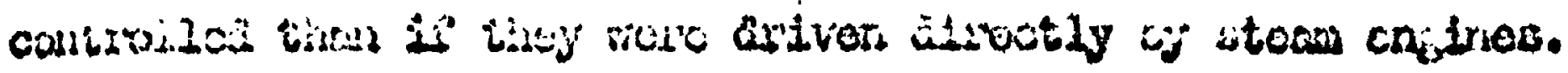

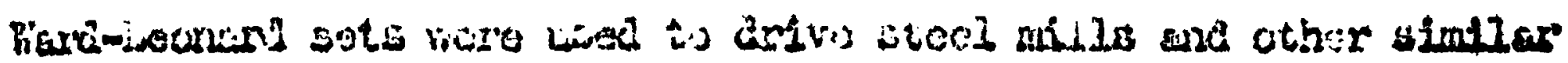

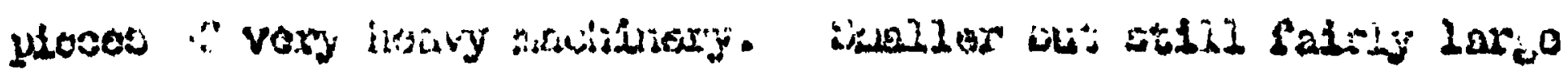

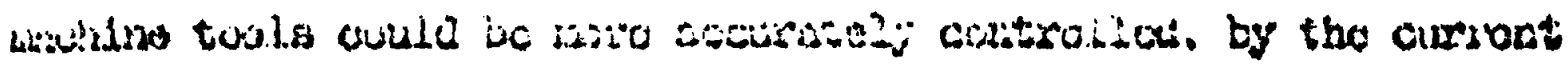

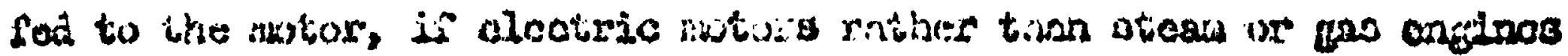

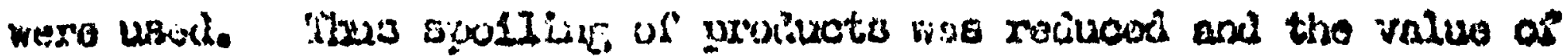

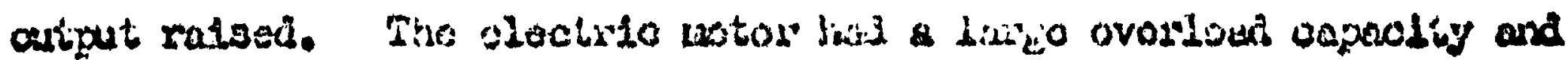

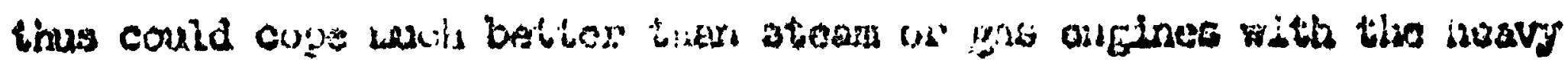

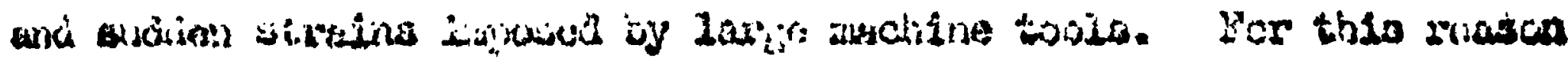

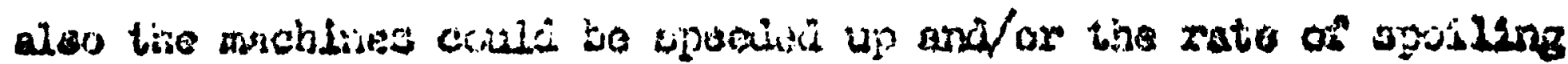

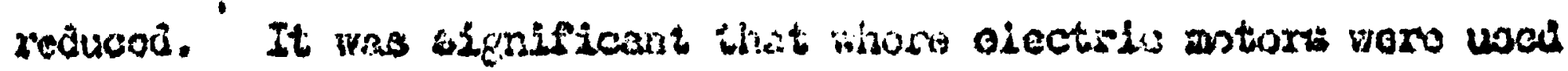

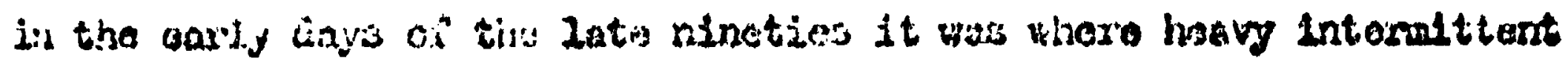

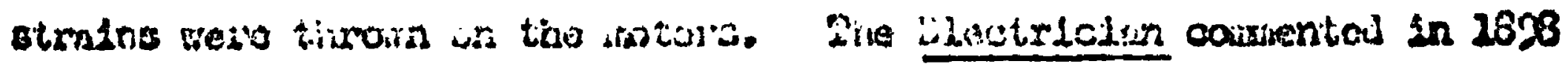

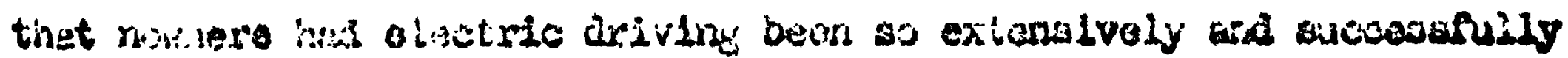

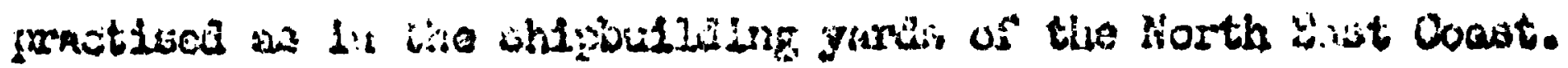

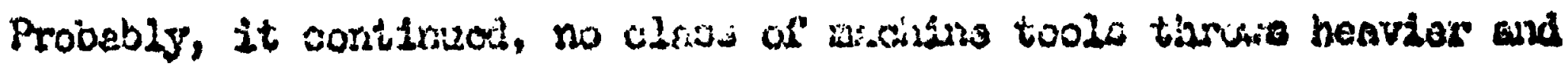

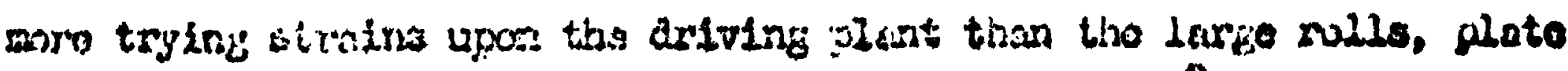

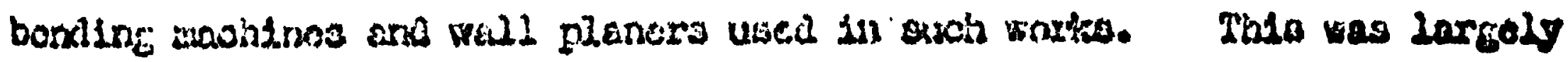
becauss of the contribution of olcetricity to raising output. At

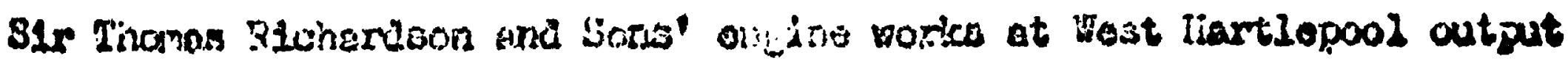

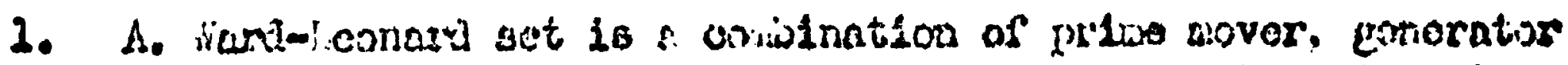
end oloctilo wotor. The prier oxortat by tho olootrio motor

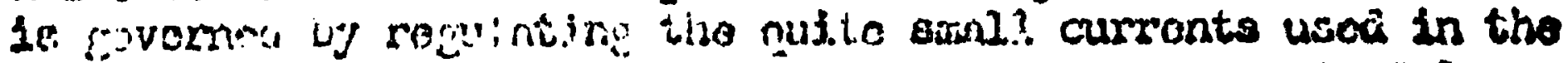
flcid colles o: the concrater. "Itus dollcate control of 2arice power 13 roseiblo.

2. Electrician. Vol. 40, 138 Bj39.9. 22 April 1890. 
roso by $20 \%$ as a result of the introduction of 3 phase electrio driving. Hers argued that the output of Tyne shipbuilders had risen because of the 1 adoption of elcctric power.

3 phase electric motors maintain an almost conitant spoed under varying loods. Their specd variation was rach less than that of sharting and belting under similar oonditions. J.r. Crowley made a study of this in the case of textile machtnery. Hils results are in Table 55 bolow.

\section{Table. 55.}

\section{Speed variations in textile machinery.}

Type of machine

Liaximum speed range as $\ddot{\%}$ of nean opeod.

\section{Spinning}

Valle Countershaft

mechanical drive

Individual elcctric drivo d.c.

individual electric drive a.o.

25

27

Ring doubliner fratio

mechanical arivo

ofter conversion to individual

olectric drivo

0.5

Moaving

Ioom Shaft line $\left(\begin{array}{l}\text { near belt drive } \\ \text { miadle of shait }\end{array}\right)$

Loom (Indivioual electric drive)

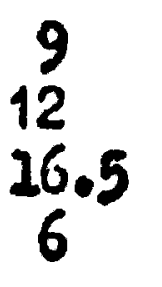

2

Sourcel J.F. Croviley. Pancr to the Congress of the Pext1le Inbtituto, 13 Septeiliber 1912. E.R. Vol. 71, P 454. 20 Septembor 1912.

1. Select Cormittee of the House of Lords on Administrative County of London and District Electrio Powor Bill 2905. Q 12. 
The reduction in speed variation, it is shown, depends not only on electrification but on the degrec of sub division of the electrio drivo. A more even speed of driving roduced the number of times the thread broke, and thus increasod the rate of output of the machino. In 1905 It was said that output could bo increascd oy up to 4\% in weaving and up to 8jo in spirning by edopting electric driving. In 1944 E.J. Wi2llems roported on a study of the use of electricity in hosicry manufacturing. He argued that the loss in cloth due to the poor speed regulation of the stoam engines usually driving powor frames was very considorable. Blectric driving would oliminate this, which ho thought was of the order of $25-30, j_{0}^{2}$

If variable speed power was required electrical driving also offered the advantage that the spced of the machine could be divoreed from the speed of othor machincs in a way which was more diffioult with belting and shafting. Hence machine oporators voro no longer restricted by the speed of the shasting, and output could rise.

In all these cases capital and labour would be saved per unit of output. Sometimes rair matcrials would also be saved. If the ratio of capital to labour remained constant the proportionate savings in labour and capital could be the same. But ease of opcration of machines might load to a fall in this ratio, thus saving rolatively more labour.

1. Filctricity in Yills. Leader i:: tho E.R. Vol. 56, 10 Pebruary 1905. based on papers read by H.ii. Wilson to tho ianchostor section of the I.I.E. 17 January $19 C 5$ and by V'isodhouso at Leods, December 1904.

2. Electricity in the losicry :'anuf'ncturini Trado.

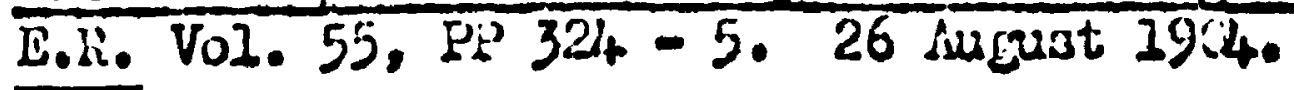


There are also cases where output could be increased by the applioation of eloctric power whore power had not hitherto boen applied because of high cost. This was the caso in amall light industries where the establishment was very small, and also in coal mining. Both were heavily labour intensivo and thus the main resource to be aaved was labour. Coal mining is particularly important in this context because of its importance in the econcry and as a power user.

In coal mining one micht have expected that output ond labour productivity might have been increased by the use of electrioity underground, prinoipally for coal cutting, purping and haulage. It would seem to have been an improvement on what power was used undercround. Haulage and pumping were sometines offected by stean engincs fed with steam by long pipes from the surface. Wechanical coal cutters were used in the nineties driven by compressed air. Compressed air transmission underground was difi'icult and of ten not satisfactory. Tho electrio coal cutter became more popular. In 1912, 59, of the coal mined by coal cutters was mined by olectricaily driven ones.

But coal cutters were very rare in British mines right up to 1912. In that year only $7.7 \%$ of the coal raised was ilined by coal cutters. This 18 incidentally one of the reasons for the slow adoption of electricity in the mincs. Had half the coal output of 2912 boen minod by cutter half as much electric porver again would have been used. 1 so

2. Soe Claphan, op.cit.e Vol. 3, PE $193-5$

2. E.R. Vol. 73, P 597. 20 october 2913. 


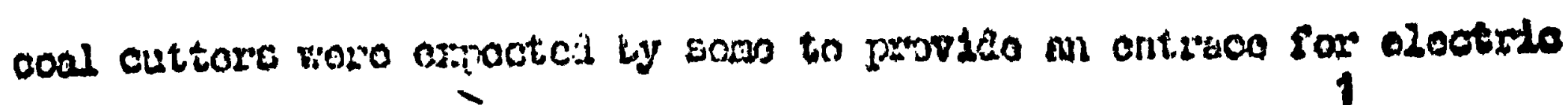
power In to the aincs, lexalng everitually to 1 to wider wae. In the evont, In 2912, coal cutiers (inoluded under portable machineny in Tabla 56 ) wore rolatively unimgortent.

\section{Taule.56.}

Bloctrical h. p. uoci in Britioh coal minos in 1922. COO hop. it of total.

Surisace

$$
\begin{aligned}
& \text { Ginding } \\
& \text { vonitiniton } \\
& \text { Fisuleco } \\
& \text { Coel rashing } \\
& \text { iliscollanoous }
\end{aligned}
$$

23.9

30.9

23.8

43.6

72.0

Undorground

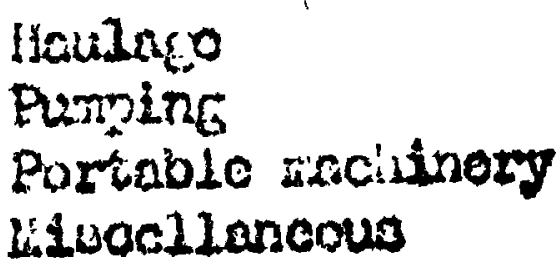

Total

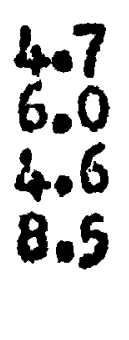

25.4 20.2 6.2

Sourcol E.R. VoI. 73, P 8Q4, 24 Novaisor 2913.

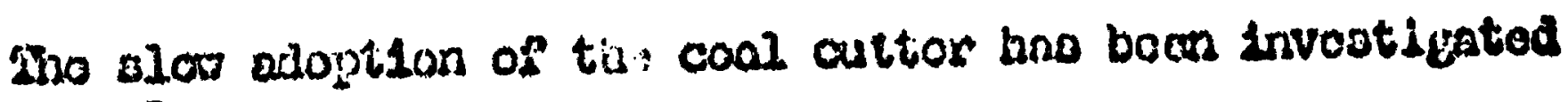

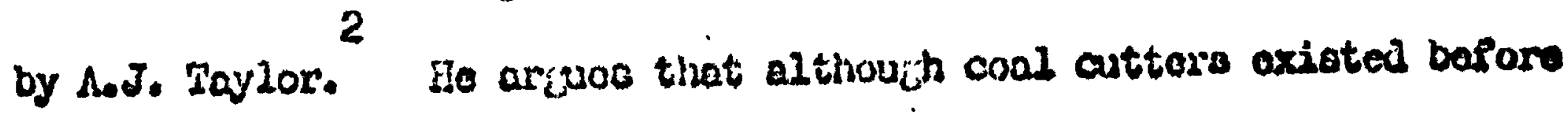

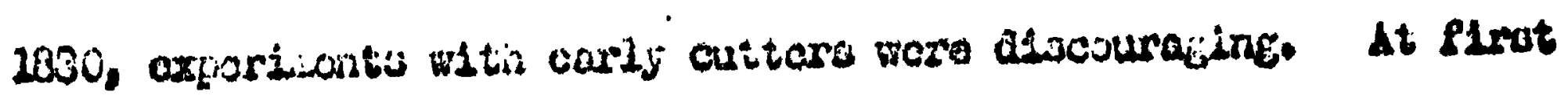
ocmpressed alr was the fovoured cothod of driving them but tranacisolan

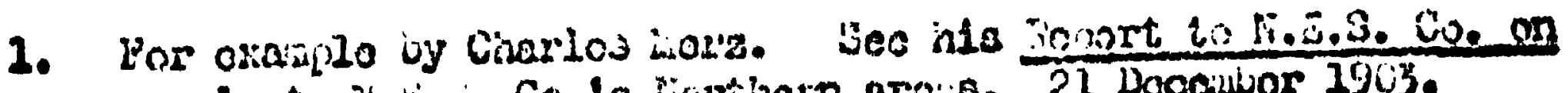

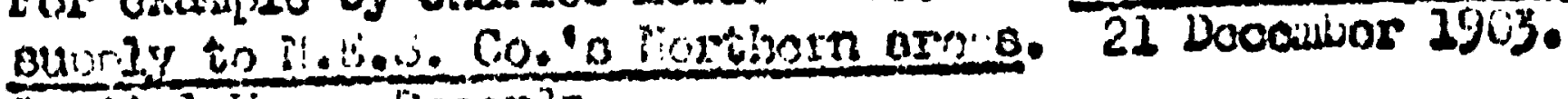
Cavilol lleuso Iecorvas.

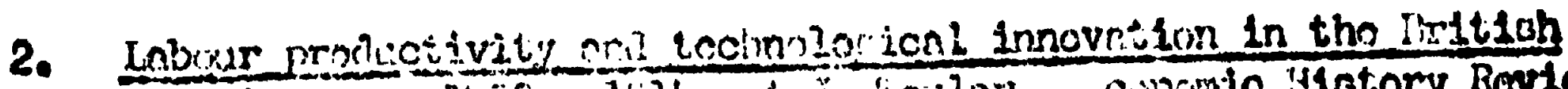

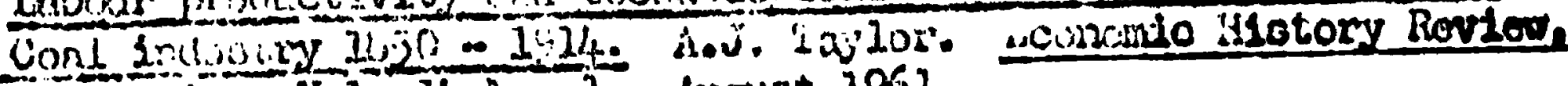

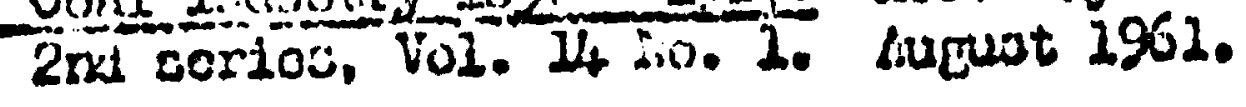


was difficult. Electricity was disliked by colliery managers and also by mine inspectors at loast until tho $294_{4}$ Homo of fice Degartwont Committeo investicated cloctricity in the mines. Also it must bo adied that up to this poriod eloctrical ongincera had dono ilttle to develop motors for conl cutters. As has been pointed out their genoral attitude to electrio poiver was pasisivo. Particularly relovant was thoir failuro to develop 3 phase porier, for the 3 phase motor had no commutator and thes did not spark. As late as the end of 2903 there ware andy 2 British 3 phase coal cutters. Taylor argues that thero is not onough ovidonce for one to say that the cool cutter certalnily reduced costs or increased output (elther in quantlty or quality) sufflolently to be worth acopting 1t. The wain reason for 1to adoption he argues, 1s that 1t could make the mining, of very thin soams possible. Ho quotes with approval the statement of the offiolal spokesman of the mine omers before the Samel Corintssion in 1925 - "Generaldy apoaking the arving in labour chares at the face is absorbed by the oapital charges and the running costs of the machine."

This argument that increases in labour productivity were often not sufficient to make the adoption of porror worth wh1lo to explained by Taylor by the abundance of labour supplies. This argument can rork In two rajs. One is that in the long run, that is over a poriod longer

1. The "llurd" manufactured by Kavor \& Coulson and the "Diamond" manufactured by G.:.C. C. C.II. Hiore Roport on supply to N.F.S. Co. Northern aroa (Northumberland Coaleiold) 21 Docanber 1903. 
than the wage cycle, the elosticity of suprily of lobour was so hi, h that wago costs per ton mined did not riso, and thus the riso in the domand for coal led to little mechanisation. The othor is that the woricling of the wages cycle was on additional dampening factor.

The following chart presents an index of vage costs. This 1s simply an index of mincrs' wages divided by an Index of tons minod per man exploged. Thus it relotes to all tine operations of the coal mine and not simply to underground ones. The index shows an upward trend but wago costs do not riso sharply unt1I aftor 1906. Lookdng at the picture up to then there would have been no reason for mino owners and managors to suspect that wago costs were turning aharply against them docpito tho falling producitivity of labour.

The stimulus of what rise in wages there was before 1907 was lessoned by the roy in which the wage cycle worked, and by its ,timing. On the upswinis wages rose although not sharply unt1l the later stagos. Physical productivity foll as wages rose. In the downswing the reverse occurred; wages foll while produotivity rose. Employment also rose in the downswing, and thus thore would have boen little incentive to mechanise. In the upswing, however, especially in its later stares, there would be quite a powerful stimulus to do so. Hero labour supply certainly does not appear to havo been elastio. It is a doubtful procedure to try ond establish the olastioity of supply of labour fram time series infornation aione. But the analysis which is possible, and not perhaps too implausible, sugsests that the elastiolty of supply of labour, althou,h high in the first yoar of an 
292

figure 2. The Labour cost of coal.

Wage index/production per man employed (tons)

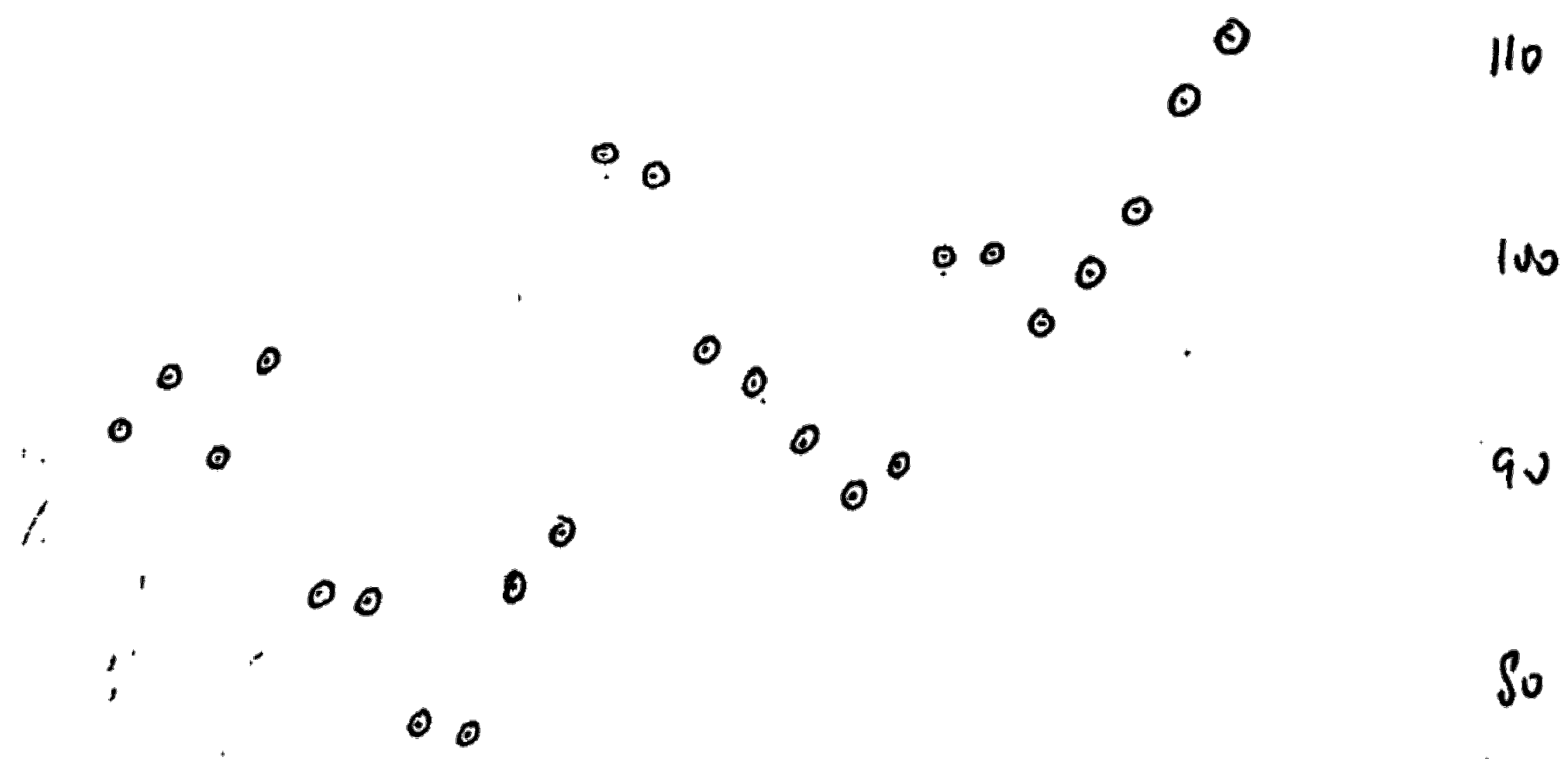


upswing soon becacie low.

Simizy on theso grourds ons yould expoct ooal cuttors to produce suffiolontly largo increases in labour productivity to justify themselves In the lator staces of the upswing of tho boom. The boon which broke in 1900 care too early, bcfore thero were good erough and cheap enough electrio motors. From 2900 - 05 falling wagea and profits would act as a disincontive. From 2906 ómrards cyclical and socular influonces both push rago costs upirards. And ns far as ino can toll the number of conl cutters responcis to thic. In 2902 If.ll. Inspection of lifines reported that thoro roro 445 electric conl outters. In 1912 there were probably 2 10,000 - 15,000. And they wore rapidy incrcasing in mumber; in 1912 $7.7 \%$ of the cosal raized was mined by cuttor, in $29138.5,2$

1. I I assunod a 2 year lag botricen rage rises and an increase in the supply of labour (nossured simply in numbers employed). Por the uysizings of 2895 - 2900,2905 - 0 and 1910 - 11, the following figures of are elastioity of sup iy amerge

$\begin{array}{llll}2895-6 & 1.53 & 1905-06 & 1.21 \\ 2996-7 & 1.49 & 1906-07 & 0.17 \\ 1897-8 & 1.06 & & \\ 2398-9 & 0.12 & 1910-11 & 1.12 \\ 1899-1900 & 0.15 & & \end{array}$

A one year lar lives the same pattern, with, as one would expoct, lomor elosticitics.

If labour nere reasured in man hours the Plgures would be lowor as ebsenteeism incroased as wages rose.

2. Tortable manchinory argregated 30,000 h.p. Coal cutters took about 15-25 h.p. each.

3. Taylor, op.cit., 
Ihis sitartion vihcre the acioption of electricity was labour saving and capital using has been dealt with at samo length, partly vecause of the size of the coal lindustry and partly bocause it was the general situation which woula apply when eleciricity made it economical to use power, when it had not otherwise been so. But in the case of many factory trades, where electric power might be used rather tisan mechanical power, there would orten be consideraolo capital saving as well.

The adoption of electricity could hotrever prodice savings of inputs in other ways. Electrio cables were lighter than shafting. Also they toak up less space arid thus new factorics could bo of lighter construction and need not be so high for a given purpose. Nem and expanding firns could buy a cheajer, buildini for the sano purpose. Unfortunatoly we have litile data on the difference of builaing costs between mochanical and electric transmission. That the mattor is raroly mantioned may mean that it vas seali.

Huch wore important tian the voight of electric calles was thoir greater flexivility. This could reduce the effect of the powor system on tho layout of the factory. When shafing was used machinery was usually

1. One caso miv be vorih cuoting. In 18\% wessrs. Cejpbeil built a new clothing factory at Iecds. Electric driving was installed from iho cutset, necesfsitating a lichter construcioion of building than usual, which was said to save i200C. "Before building operations, specti'ications :rere ableed for slerm plait witil ordinary ohafting and bolting, as well as for the elcctrical schems. The first cost (of tils $i$ is ior oquijizent) mas aix)ut cquel but electricity offered distinct advantaices in that a choaper kind of building was anly nccosiary".

E.R. Vol. 35, P 405. 5 October 1894.

It is a sivnificant caricht on the value of the information that wo do not know the size of the factory. 


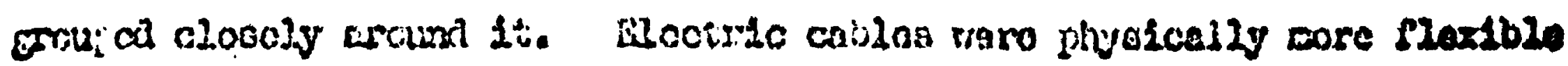

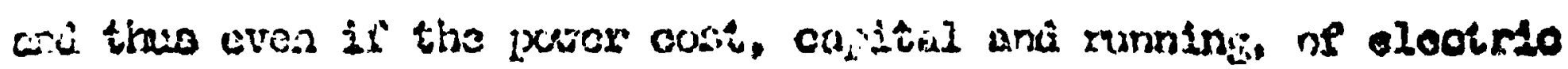

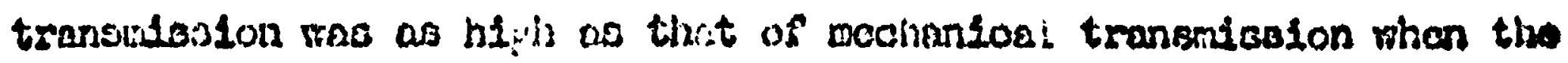
madinory was closoly gratrad togothor, it mouid bo lown whon meshbrory was ance alsporsed. Slectirlo motors could bo put in any josition. Thus woro weight could be attaciven to othar sactrora liko

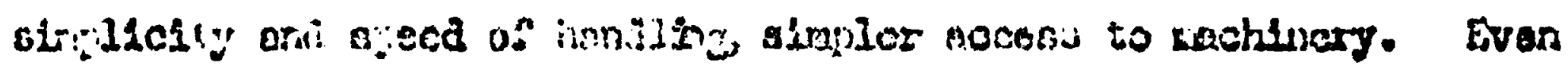

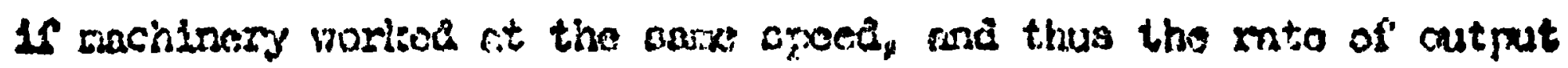

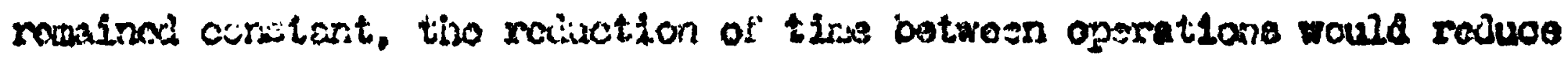
labrur costs, arde alco cenital costo ns tho value of wrote in prograse soll. Sven the oxistenco of shriting ayort from its affoct on the arrangasont

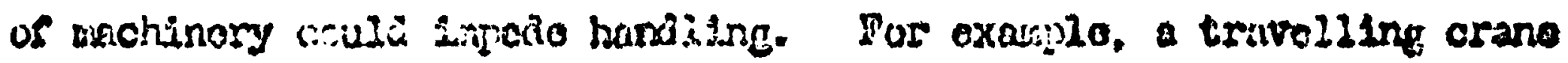
would bo slowad dixm. Lightive who wro difileult Fith ohofting, and thus would oost maro, or operations would be Blowed cown bocauso of poor Visiu11ity.

The axtent of the cost Eaving varded lith tho cegren of roorgan1eation which thas trace in the armigersont of tho abop. It could bo cunsladorable. For exnmple, in an Amorican rolling mill the aroption of - lectrio arlving had roiuced tino membs of con ronuinad frem 6000 to 4000. Lars argiod that ono of the very lmyortant advantages of olectrlo porer

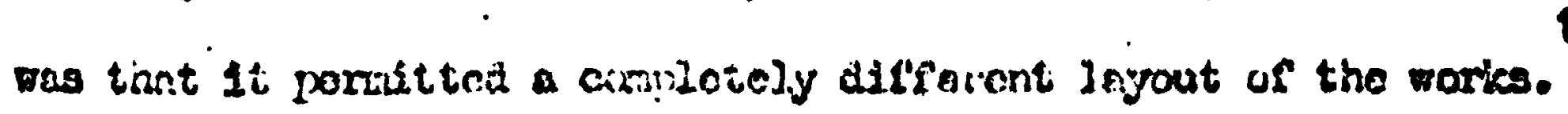
The enoing asl not ord with inktry trittor oriantration pooslble, far olectrio driving could stimilate furthar thoujit on batter planoing

1. Soloct Cinilitec of the llouso of Loris, zB-iz-end-15,

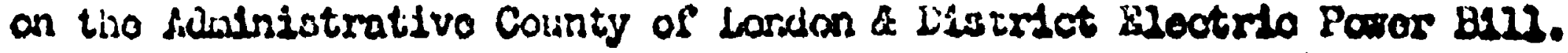


ans arsangenent of vork. It could do this in tiro ways. Pirstly, by aonsiderabily veokening the tlos botwean the lajout and the porrer oystem It could stirsulate much more cansidoration of foctory loyout. Once a constraint on whot oan, recsonably cheaply, be done 10 removed furthor innovations an easily follow. The potontialities for this wero grast. The majosity of British woricshops andic factories at the time wereivery well plained. Machinery was budaled togothor in snall, dark and dirty buildinis, the latter wore often badiy laid out and difficult to manage. There is mach justice in the cornont that it was the atato of bullaing and layout raticer than the age of the machine tools used that contributed to the ofton hich costs of British industry. One anst not overrate the contribution of elcctric driving to beiter laymout. There are a number of other recions for planning improvonents wnd the influence of olectidc ariving in this respoct was only permissive. But ono otill may suppose it was considerable.

The other efiect thiat the introduction of electricity had on maneqewont was that wasureisent became mich simplor. At tho wurn of tho contury vory fer rroasurencents woro taken of the eneres ingut in lanufacturing. Thore were neithor many measuraments of physical Input nor of the cost of this input. Dngincers who pionecred electrio driving soon discovered a brcat deal of antiquated luachinery, machinory which probably would havo been scrapped if rational calculations had boen made. Such plant was not to bo found simply in the backerand industriess

2. The Scrap Heap. E.R. Vol. 51, P $645-6$. 
often manufactivers of poivis plarit wore content to uso obsoloto equifecont. One of the ingortant thing which intording sellers of elcotrical driving plant coulc do wis so draw manufacturers' attention to their power plant and persuade than to invoutigato tho costis of the oquilpnent thoy could use, and that plizich they rere usine. Once encouraged caroful scruting of corts oould be applica to othor inputs as woll as porer.

In this context it $i$ worth paying attention to the viowe expressca by W.3. Alarich to the Niflwaukeo meeting of tho American Sooloty of Hecherical Engineers in 2901, when he was disoussing the uso of 1 elcetricity in manufacturing. He argued that the advantage of eloctricity was not in the small saving in the fuel bill, but the very largo incroase in outfut vinich was znsic pussible by using it. Output por wan, output per squire foot of fuctoing space, output per sacidine all rose cubstentially. /. It was men easior, he rent on, to increase output in thiss wiy tivan throuch nei buizaings, mon and rachines. Labour conditions were improveds the men were eniblod to wow: faster, not being tied to the opeed of the belting. Tis ahops colla bo better laid out riben no overhead shafting was nceden. All parts of the machinery would be accessible and thedr meintenance costs reduced. Tho various buildings need no longer be croupred round the perror house, and thus cauld be botter arranged for effleient rorieing.

Adoption of eleciricity did not elrnys facilitate produotion. For cxample, in cos! minimis it was somotimes snid to be disadrantageous 1. E.R. Vol. 49, IP 6Ut - 5, 650-2, 11 and 18 October 1901 . 
becauso it increased danger. Colliery managers were quick to point to the posibibility of sparking at the cambutator of a,c. motors and to stress the dancer of this in fiory mines. They were also afraid of the consequences of underground cable fallts. Those difficultios were mach exaggerated as the riak was only vory slight with caroful onginoering. But they existed. It was not only the use of electricity underground that they mistrusted; they foared that winding and vontilating machinery If ariven by electricity would bo more liable to break down than if arivan by steam encines. The consecquonces of such treakdorms could be vory serious. It mast be remombered that up to about 1900 eloctrical machinery was not entirely reliable. To see this one aniy has to read 1 accounts of the rorking of cariy porier stations.

It is also sald that in textiles a disadvantage of adopting electricity was that a considerable amount of steam was required for. process work." This, horrevor, was only a disadvantage of electrio driving on electricity bought outside. If electricity was genorated by the mills, and there was usualiy little reason to suppose this was more expensive, there rould bo the same supplies of steam as if mochanioal arivingt were used.

The carlior argument that electric ariving would save moro resources if allied to reorganisation of the works and/or botter planning of voris can bo extended. Innovations may be couplementary; if two Innovations aro adopted jointly they may save more resources than the sum.'

1. See R.H. Parsons, on.citer 
of resources saved if both were adopted independentiy. Coal mining providos a good example. In the years $1900-194_{4}$ thero can be $21 t t 10$ doubt that in some mines resources could have been oavod by a better layout of the mine, for example by bigger, botter and wore level main gallerteo and by ossior working conditions at the coal face. Electrio coal cutting and olectric hallage would also have saved resources in somo cases. But one would expect the joint saving to bo greater than the sum of the tro applied separately. This is because quicker coal cutting and quicker haulago explo1t more fully the straighter, more level gallerles and oaslor coal faces.

In engineering the sarro apolies to more accurate machine tools which could reduce the cost of engineering products by substituting 11ghter, more oxactly made parts for the robust, heavy ones usually used. British ongineering products wcre relatively heavy compared with those of say, America. This was partiy a sujstitution of weight for good design and caroful machining. For example, in the eighties electrical machinory was often flimoy. Hechanical encineers took up its manufacture in the ninoties, and considerably improved its robustress. Dut they did this by bullding very much. heavier machinery rathor than by verycareful attention to 1 ts dceign.

In tho Tyneside shipyards electricity was adopted at a timo whon the general technique of production was changing. In the late ninetios Tyno shipyants were changing over to a system of working in covered bhods rather than in the 1 Nen. Nlso wore portor was boing used espocially for 1. J.R. Parkinson, Economics of Shipbuilding, Cambridge 1960, P 119. 


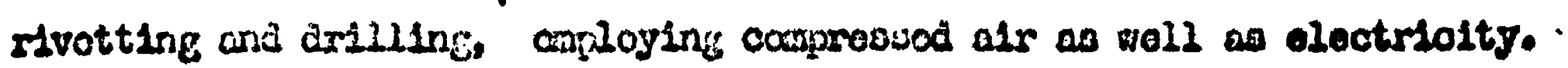

Factory bulidinge aro anothor example. If they were mado moro regular and hlgher so that norizinory could bo woll lald out and elootrie travollin; cranes used, olectric ariving vould bo abie to mako a groatar contribution to coot ceving then if it woro roly installed in the same bullajings. Dul core ragular bulldings would have reduood othor couts even vithout elcotrio ariving.

All theso innovations firich Involved cisanios in capital ochuignent. woro more Ifikaly to bo adopted in an oconoxy whero capital was rapldy growing. The Eritisin occnowy was grovine only alanly at the tiwo. W. Hoffican has calculated inat fros 2875 to 2915 induotrlal output was

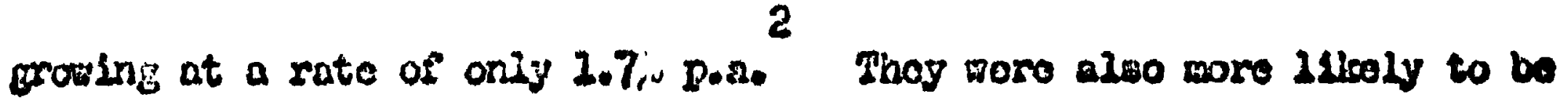
adopted whero the rato of scrapilin; wao hl $h$. Tho moro froquently

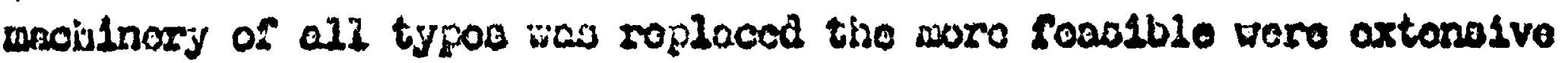

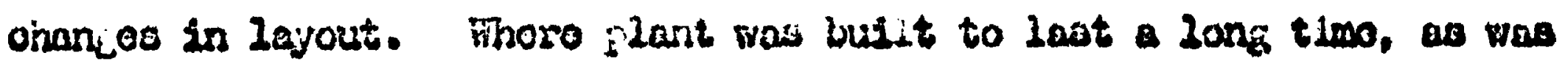
most British pactory plant, patcialng up an existing laycut by chentinis

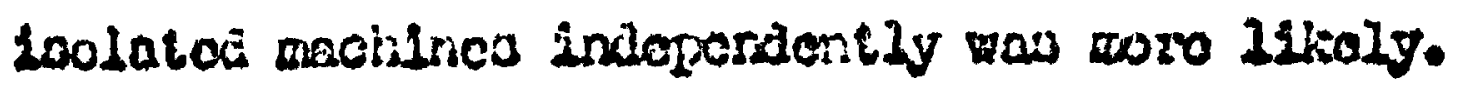

Contasiorarios arguod tinat electricity was too olonly adopted In Enelard, and sijat two imjortant explariations were lack of toclunical knowledio, and, ouro koneralli, conacrvation. It is not difscoult to

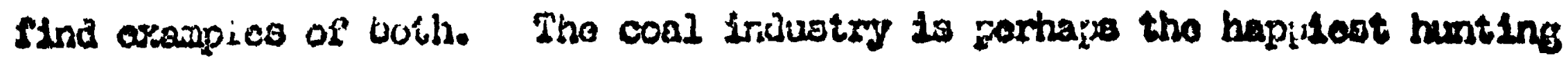
ground. "Electricity," wrote Claphaus, "es mfibt bave been oxpeoted made

2. J.H. Claihrom, op.cit., Vol. 3, P 252.

2. D. Hofiman, op.c.1t., I 35 . 
only slugeish progross in tho mincs". Ile argued this on the grounds that coal mining soemed alow to dovelop most new techniqucs. 2 collsery managers wero ex-pitmon, not enginocrs, and thore is much fustice in the contemporary complaints that they had only onough training to think of objections to Innovations which coms to their notico. In the case of olootriolty, possiblo danger was quickly spotted, and so generally used as an argument afainst olectrification that in 1904 a Home Office Departmontel Comittee ras appointed to conslder the matter. But coal is not typical, and Is to be contrasted with engineering. For example, K.I.S. Co. found that while Tynesile engineers naturally came to them to disouss power matters, the coal ormers in Durhem had to be offered all sorts of inducements even to open nogotiations.

Conservatism is a very wido term, not sufficiently woll dofinod to be userul as an explanation. But the discussion of the relation between the adoption of electricity, increases in output, and resouroe saving enables one to be more preciso. The more ready businoss men were to consider large changes in the techniques of production the greater the possible cost saving. Their readiness to look at the advantages of electricity was alled to their readinoss to take advantazo of other improvements, associatcd with electricity only in so far as they wero complementary innovations. British business men tended to think of the advantages of electrification as being largely those of saving the oost

1. J.H. Claphari, on.c1t. Vol. 3, P 164.

2. 1bides PP 162 - 6 for examples.

3. N.B.S. Co. Historical Reconis. 
of po:I $r$. This reluctance to think of and undertiake radical chengos oen be described as a type of conservatiom, lut it is clearly not the ano as the reluctanco to undertike rny changes. But any tendency to conoentrate attention on power. costs would lead to less electrir'scation than could be rationally justifisd.

The mesttor oannot to exhaustively considered here. What would be noeded is studies of individual industries covering all potential Innovations during the period, and their relation to electrio pown. It would te a very large undertairing indeed.

This is closely connected to the allegatione of lack of tochnical knowleàge. When poople began to worry about this in the 18700, there ras a general lack of technical knowledge. Hut by 1900 this had been partially remedicd. There had boen a bils inoreaso in the mubor of engineors truined to a nodest levol in particular branohes of the subject, for exauple olectrical enflneers trained at ovening claswes. But few peoplo at tise highost level of industry had onginoering troining. Such men would, no doubt, pick up a lot of engineoring lonowledge of particular anters with which they wero closely connucted, but would not have any troining to be oble to consider a wide range of anginearing matters. It was wido and varied knowledgo which would equip a man for consideration of sho potontial orofitability of a wide rauge of innovations to bo adopted jointly. 3pecialist advice could only be of iared about adoption of singlo Innovations.

Thorn was an Inoronaing number of complaints during the decado beforo 1924 that the prime manporver defictenoy in British enginoering 
particularly was the lack of food "coviucrcial enginecrs", that is of mon who combinerl onjinocring sktll with akill in thr maricet place. There seems litilo doint that thore was such a shortare.

Flectric driving, it ia.s boen arguod, saved infuts per undt of output primarily by onabling grcator outrut froin a similns sot of productive resources. Ijero one must look at how offor British business men were tis increase output. Ihis depends on the olasticlty of demand, and the expansion of marisets, as well as on lack of whllingness to find and develop now maricets. I'he latter can be oullod consorvalism, but not the formor.

There are not enough studies of the elastiolty of domand for the products or British industry for one to be able to say mach about the matter. In the case of the stocl incustry, D. I. Bum has arguod that demand pros ofton Inelastic vecauso tirns enjoyed a considerablo olenent 1 of loual monopoly. But about tho s] ow growth of demand in genoral thore can bo no doviot. I'hus campared with a fast growing ovonumy there would bo wuch less incentive for British businoss mon to oloctrify.

Another way in which doternination to 1ncress output in the Sairly short run - over a year of so,- becausse the expocted value of future profits ins high or thought to be high, could lead to electrio driving wae bocause it was much simpler to install new olootrio motors, than to extend a sjstein of shasting and belting. Thus awall exteosions to capocity wero mach cheaper with electrio driving even if large extensions, whore a new set of shafting could be installed, would have

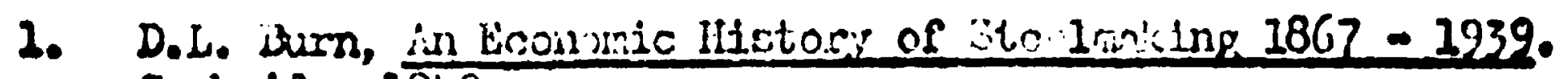

Cambridgo 2940. 
been moro cheoply made with a mechanical porfor transmiastun system. In other words oleotrioity could make indivisibilities divisible.

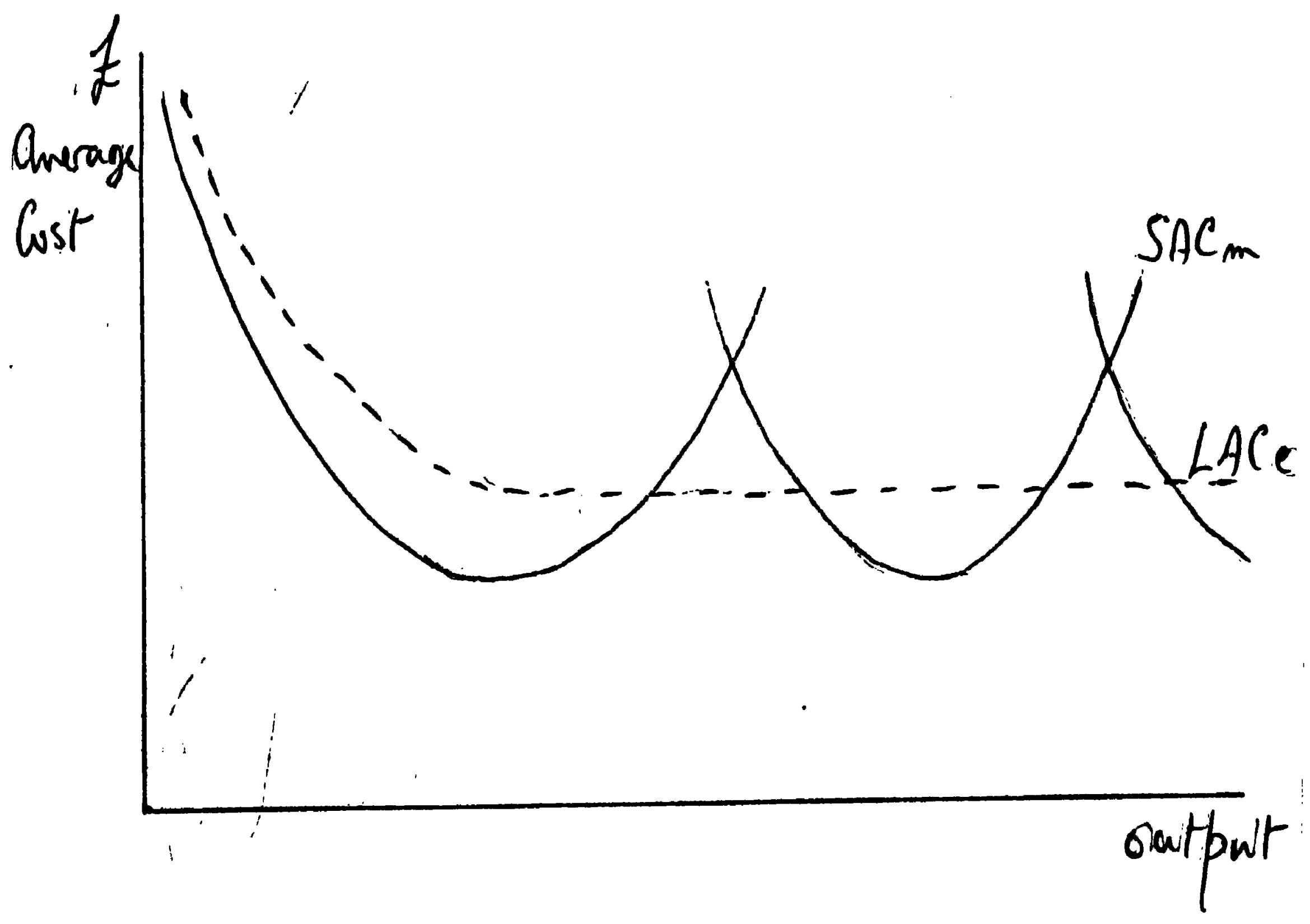

LAC Is drawn as an envelopo assuming constant costs and no

- Indiriolbilities boyona a lom level of output.

SAC - short run avernjo costs of mechanical drivo.

LAC. - Long run average costs of electrical drive.

Conorratiam in the sonoe of reluctance to consider radical changes in the process of production could be overcomo by a vigorous sales polloy on the part of the manufacturers of plant incorporating innovations. It was asserted by thase canrected with N.R.S. Co. who 
wore vory succosiful in porsuading manufacturers to adopt electrio power, that a vigorous sales policy was cssentinl, but if pursued with determination would be succossful. A vigorous cales pollcy moant oheap electricity plus overy attempt at persuasion. As Charlea Mers told a Solcot Comittee of the Lords
"It is therofore essential in this country that there should be current avallablo at an exceptlonally low price? - Yos, and the body who wants to sup.ly the poirer mast adopt a good deal of enorigy and push, and put every posuible convenienço before the manupacturer, or he vill not give un his old plant".' "The manuracturers in this country hod in the majority of cases established his rorks beforo olectricity was a connercial quostion. The result is that he has not got his plant, and is very loth to spend money on buyine ner plant .... L Lvory possiblo inducomont melst, thereforo, bo of ferod to sot that wanufacturer, by offering to make all sorts of arranjements with him to simplify the operation of modifying his rorks. It may bo that motors are sold on an Instrilment schemo, it may be that they aro hired out .... Bvery man has some special whin or idea as to the ray in which it should bo done.... On On Tyeside at the present time tho powor company have in manufacturers' worles ovcr $\$ 1 C 0,000$ worth of apparatus either hired out or exchanged for old plant or dealt with in some way; and it is largely due to the fact that the porver company, from tho vory start, determined to got all the businoss that thoy have got $1 t^{\prime \prime} .2$

Among supply companies N.E.S. Co. was the one that stood out w ano with a vigorous sales pollay; it was also tho most sucoessnul. Thls suggests that there were obstacles of the type mentionod to overoame. The same typo of argument applied to eloctrical plant manufecturers Who wiahed to soll plant to poner usors who would generato their orn current. It was argued, for examplo, that A.E.G. had been ablo to soll

1. Solect Comitteo of the House of Loris on the Administrative County of Iondon and District Electrio Porver B1ll. EvLdence of C.H. Herz. Q 39

2. ibit.a. $\times 97$ 


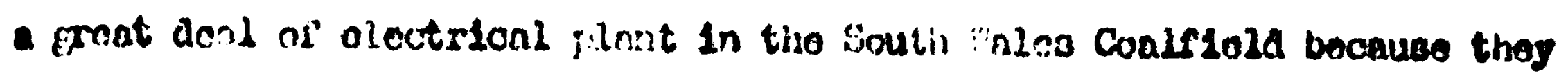

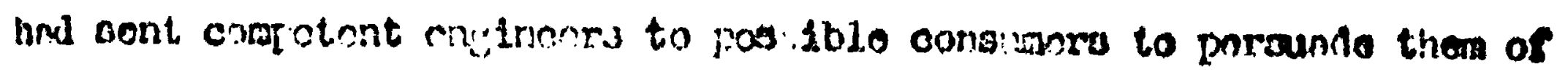
tho advantries of clectrificntim.

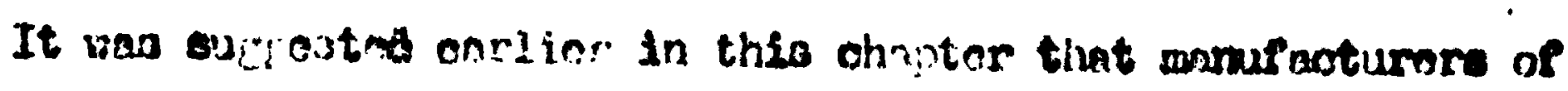
ulootrical plant, 19 timir manivity, inelnyest tho introduotion of electrio

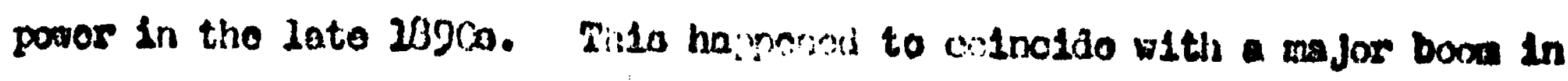
Pactory ogulpwent. Th16 10 cloarly oham in Calrnorous's table of growe

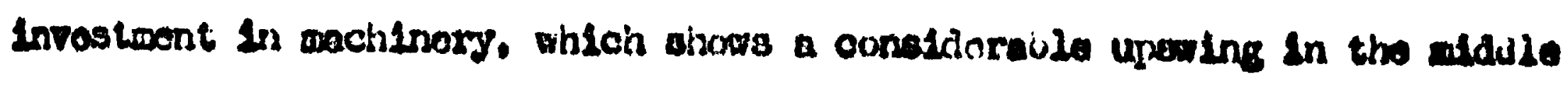
ninoties.

Table 57.

Value of "Lachinery" rotalned f'ur hope use

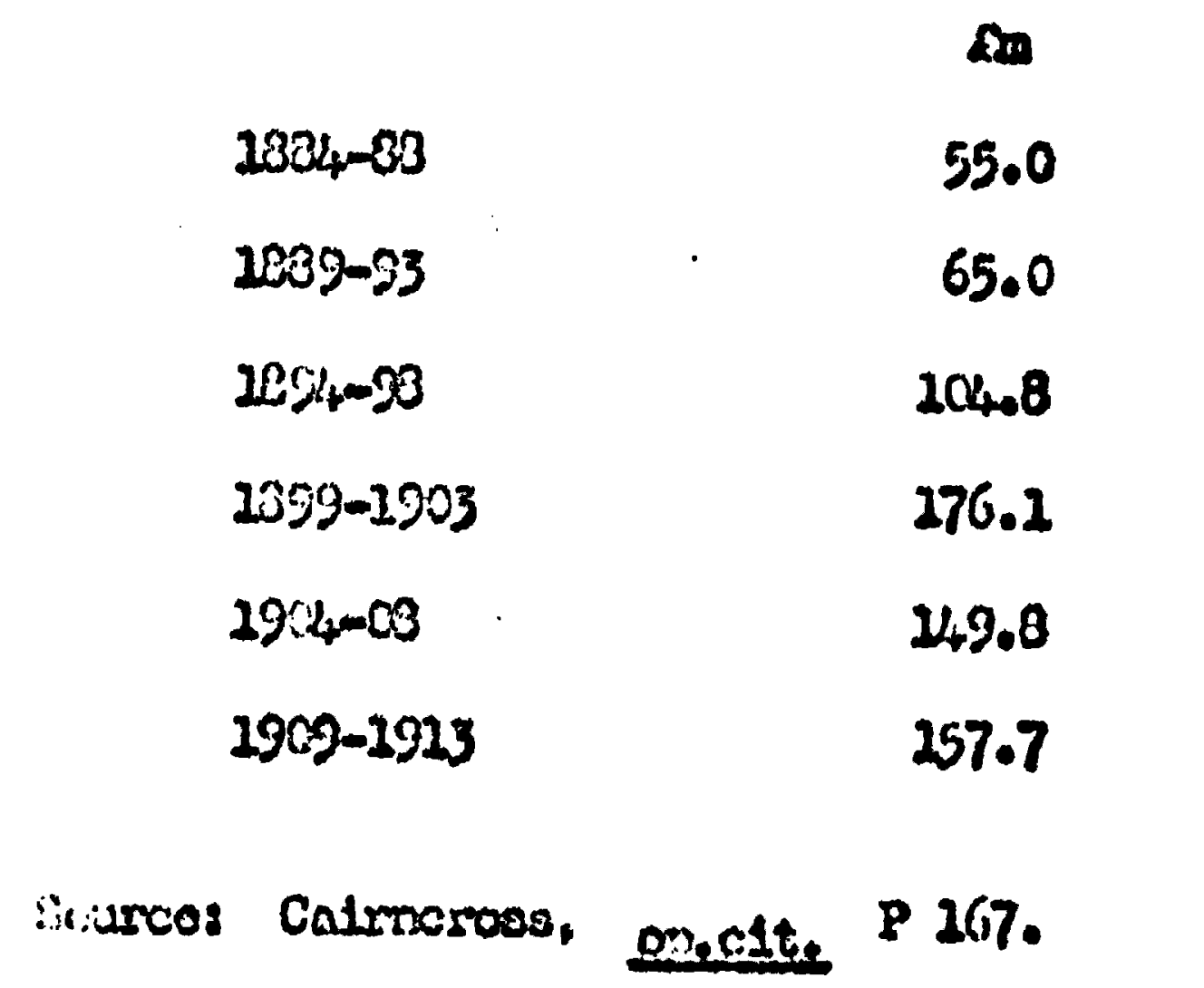

Iy $29 \%$ when tho price Sall in elcotrical oquipoents was eninging tho balnaco taviris abstantial cloctrificaition a largo anount of

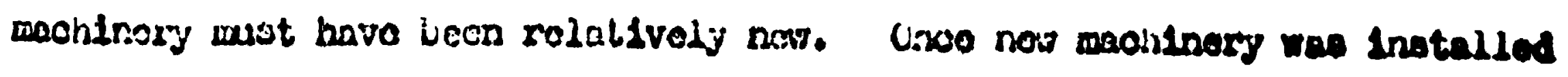
It would delay aloctrification because tho Iattor would we cocompaned 
only by minor changes in other machlnery and would thus reduce costs loss. The timin: of cyclical fluctuntions also affected olectrification In the important text1le industry. The last big text1lo investment boan was $2905-08$. It has beon argued above that the advantaces of oleotrisication wore loss in textiles than in other industrlos. They were probably very slight before about 1910. To have no preclse information on this. In 2910 the Electrical Revion comented that omors of electrified mills werc very loth to make knorn the results, fooring that thelr competitors would gain. But it went on to conolude that the reaults were not likely to have been unfavourable or a great deal of grmbling would have boen heard. 
Chnpter 7.

The Manufncturem of Fleotrd cal Machinery 2875 - 1895 .

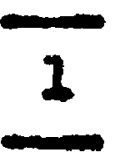

In this chapter we shall discuss the beginnings and oarly grorth of the manufocture of electrical machinery. Electrical machinory is hare taken to cover generators, a.0. transformers, converters, motors, switchgear and arc lamps. This group of products by no means covers all the equifment used in connection with the generation and use of electricity. Porrer stations use boilors and steam engines an well as generators and transformers. Blectric tramrays and rallways are rolling stock of which only the motor equipments are eloctrical. Nor does this group cover all the olectrical equiprent used for eleotrio 1ighting, electric traction and eleotrio porer. Bloctrio inoandescent 2omps, electric cables, storage battories and eleotrical Instrumento are generally excluded.

Elcotrical machinery has been groupod together largely bocause all the products in this eroup required similar teohniques of production. Similar knowledge was required for initial designs, simflar labour and machincry was used in acturl sampecture. Generally spoakeng those inputs

2. Rotary convertcrs, motor gonerators, wotor transformors and motor converters. They vere used for convorting a.c. Into d.o. or changing the voltage of d.o. They have all been superseded. 
could bo oasily ohifted from one product within the group to anothor. Sk1llod labour and general purpose machinery was Largely used. Machinery was built in largo shops not usually opecially adapted for any particular product. There are same differcncos botwoen produote and these differences are sometines important. Excopt for small wotors and trawnar motars noarly all electrical machinery was bullt to order. Thls was partloularly true in Britain.

Another reason for grouping electrical maohinory togather wa that 14 was made by a fairly distinct group of firms. Libst of our Information about oleotrical machinery manufacturo is besed on rathor patchy biographical information about individual firms.

Special attention has been paid to the manufaoture of machinery for several reasons. Firstly, innovations in machinery were often orvolal, for example the Brush high voltage dynamo, the American traction motor, or thron phase a.0. machinery. Secondly machinery is in a central position touching the introduction and extension of olectrialty for 11ghting, traction and power. Even when irnovations take place outside this sector, for example the introduotion of the itearn turbine, whloh is not nn - lectrical machine at all, modifications have to be made in electrical machinery. Thirdly innovation in the machinery group was more contismous than in other sectors. In incandescent lamps there were two periods of Innovation. fimbtly the Invention of tho lamp itself in the yoars $2878-2883$. and socondly the invention of a motal fllament laup in the yoare 1897 2922. In cables there was the developosont of not malns in the yeare

2. Bod. Bright Junr. op.oit. 


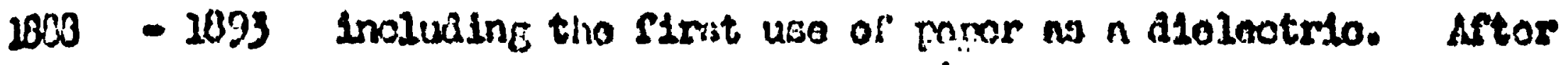

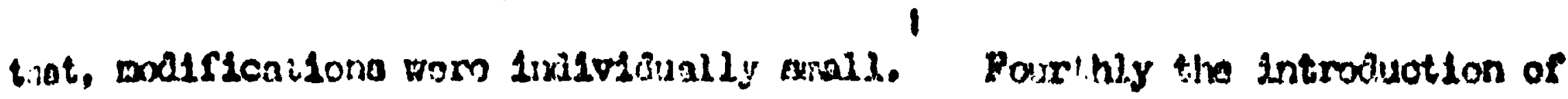

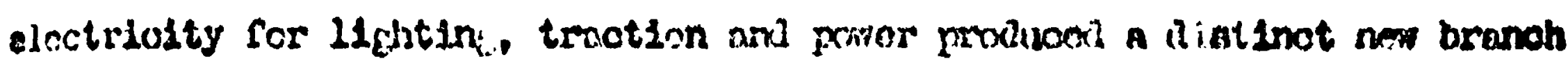
of anufecturing. Cablo unkers manurnaturod tningringlo onbles bofore

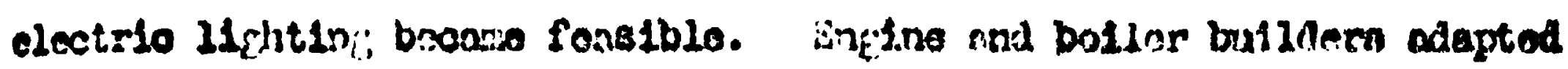
thols product for use in confunotlon with eleotrical maolinary, but thos

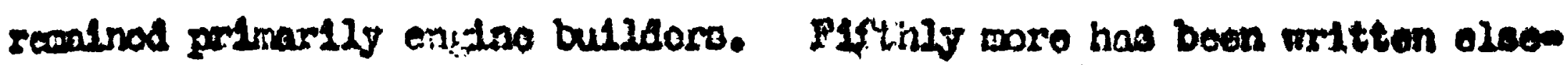
where on cables ' ard electric incericecent bulbs.

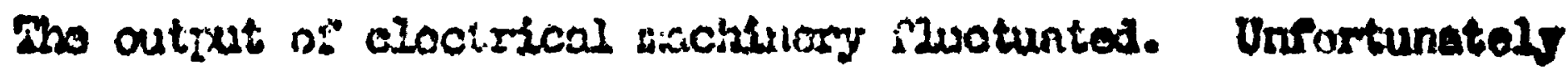
It Ls not posislbls to colictruct any tias borios or output beforo 2096. Irom 1896 ouch a tico soriea has been construsted and is in Table The ganaral ohage of fluctuntions 10, however, clear. From 2379 to 1802 both the value and voluse of output pere rlaing. In 2033 both slumpod and from then until 1887 whilo the volutio of ostput seess to have rioon, the value reaninad genorally statlonory. Fras 20:0 - 91 another bom came with comothing $21 k 0$ a trifling of the valuo or output over these yours. From 2891 - 95 cones enothar rockselon. The value of output hovever soent to have cono on rioing olorily. Prices fell cteeply ard the voluen of output must have quite aubotantioliy risen. Boglining in 2896 cano anotior upowing, this timo a very big one. lending to a liajor boom which lasted unt1l 2903. Aftor 1963 the value of outpat bo,an to docline, elthough only olowly at firit. Tho volumo of outpest continued ts rlso, althouith

1. P.V. Iunter \& J.T. Ilazoll, o=0.01tel

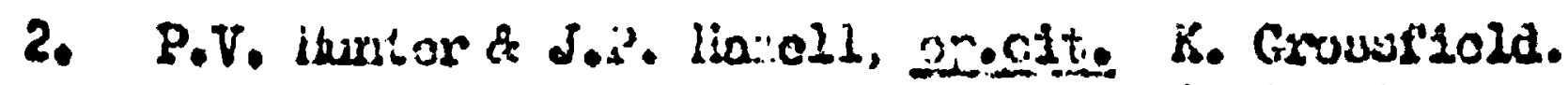

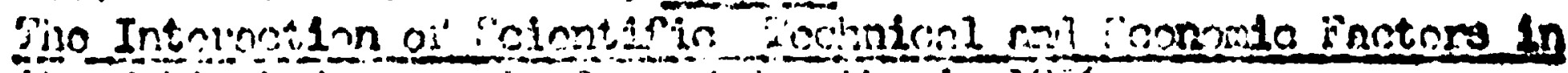

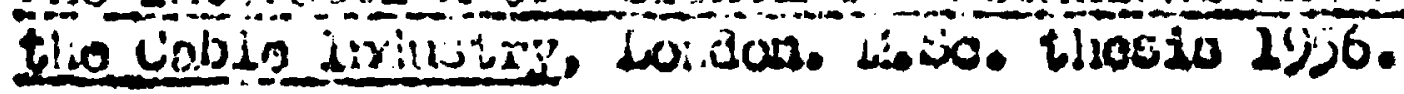

3. A.d. Breght Juns. onocst. 
more slow $2 y$ and only Intermittently. Prices, which began to fall in 1901 because of Corman competition continued to fall raplaly. This perlod 2asced unt11 2910. In 2911 the velue of output began to rise, and continued to do so until 1914. The bocm perslated during the $294_{4}-18$ war but partiy beoause of spocial wartime conditions. Thus although there ware strong uporings in output, thore waiv, excopt for 2893 no etrong downorings.

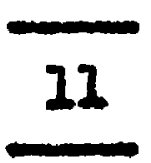

In this section wo shall be conosmed with the first boom and olump, 1.0. Srom 1878 - 2887. In this period the matn products wero aro Itrop and are and incandescent Iighting aynatos. Dynamos wore much the more Important. Until about 188:3 - 5 aro lighting oquipnent ought to be troated as a rather distiwat product.

The Hanufacture of electrical machinery was rather slow to start In Englend. As the nanes Jablochkoff, Lontin, Granto, Brush and others reveal, most of the are lizhting equipmont used in the vory early daye woo mamufactured abroad. In 2878 there were only two flrms manufacturing dymamos in Britain, Siemons, itsclf the inglioh part of a largely coman 1 Iirm, and Henry liilde in kinchester. In 2879 and 1880 a fer more firmo ontered this business, notably Crompton, but until Brush bogan to make aro 21ghting equipment in this country Imparts must have boen a very large proportion of the ho:e consupption of machinery.

1. On the relations betircen Sieunens in London and Slemens \& Haloke in BerIIn 800 J.D. Scott. Sicinns Bros. 2358 - 2958 Landon 2958. 
After that, howover, many home firms began to make olectrical machinery. They can be divided into three majnr groups. Firotis there were thase who were existing tolegraphic manufacturors. Secandis thare wero now firms founded on particuler inventions - often made by poople utterly unconnectod with elootrloity. Thirdiy there wore machandoul ongineoring firms.

of the first group, those with a solentific conneotion with eloctrlo lighting, the only really successful entrant was Siemens. Stemente had been to the fore in dynamo improverent. In 2867 and again In 2873 the Gerwan part of the firm had been responsible for major Innovations. It wos not ourprising that Slemens gained first place in tho Trinity Ilouse Aynomo tests of 1877 . Stimulated by the possession of a 81 rat rate dynamo, Sir William Slemens, head of tho Ionion branch, medo several Improvements in arc lamps in the late $2070 \mathrm{~s}^{2}$. He determined to apply arb lighting to the 11ghting $2 f$ large spaces as well as lighthouses. Slemens aro lights soon began to apnear, and in 1881 Siemene was one of the four companies to tender for the important lighting, proposed for the City 3 at a considcrablo 1033. But Sienens did not Soreseo, as far as wo can toll, any rery rapla expansion of electric 11 inting. The onglneering of the system was dirreted more perhaps torards a high quality than a Low cost lamp. The early aro lomp did not glvo a very ploasant 11 ght.

1. Soo Chapter I P. 2.

2. W. Pole. Ilfe of Sir Tilliams Siomons, Londan 1838 P 247.

3. Siemens charced 23,725 and in the rirst ycar losi $\$ 2,246$ an th1s contract They cost a similar sum on tha Albort Dock lichting whlch thay installod in 2879 (Elect. 27 Lay 1882, \& Siemens Bros. accounts.) 
Stemens improved than and prodiced porhips tho lesst unattractive of are 11:hts. Buti to do this he used a low voltago gatving a small arc. This made current control more difilcult, and thus increased the difficulty of nunning sevoral lasups from one dinamo. In other ways Sicmons were noted for their high onginoering otandards. Fircs were lald underground in many waye this was admirable but it was oxpensive. This is not to say that 81 W11210m Slemens was uninterestod in the camerciel prospects of aro 11ghting. Ho saw that it wis at a rolative advantago when hlph poworod lights were used. Siemons arc lighting was intelligently plaoed on high poles. But at least, as his biographer states, sir William, by the seventies was woving andy froil conenercial interests towards more purely oclantific maitors.

Another irforiant cable manusacturer to take up the manufacture of dynarios and are lamps was the India Bubber and Gutta Peraha Co. They secm to have begun with the manufacture of aro larm carbons. Howeror, although they cantinued to make dynaisos up to $19 U_{+}$they were never very important. The Telegraph Ccnstruction and Vaintenanco Compang, anothor large telegraph manufacturing firm founded an electrio 21 ght dopartmont in 2882 - 2. It was set up under J.E.H. Gordon, a young man of 30 with a background of aclontifio research. Gorlon busit a $350 \mathrm{KI}$ alternator, with three timos the output of any machino then oonst.ucted, to $1 i_{i}$ ht the company's worles. Ito soon bocano intcrosted in contral station work. The Chasman of the Telegraph Construction and "uaintenance Co. Sir Dantel Goooh, who was also Chaiman of ihe Groat ineutern Railmay, belleved in

1. V. Pole. oproctt. P 283.

2. R.H. Paraans. On.cit, P 42 . 
Gordon, and in 2383 it was resolved to begin works on a scheme to light Paldington Station, the G.if. Hotel and ncighbourine goxis yards and Znes. Tiih over 400 incandescent lamps and 100 are lame it was sald to be the blegest installation of mired ligiting hitherto mado. Unfortunatoly 2 there were very cunsilerable teching trouble:s, and Cordon hirasole was so disappointed with the results she.t in 1838 ho said he was prepared to abandon his oun syitiv and overy patent he held. 3 The Telograph Construction and liaintenance Co. see: to have lelt wach tho same about oloctrio lighting In on form and when this installation was sold to tho G.H.R. In 1887 thoy lost the electric 2igiting fleld.

The cnly other telegraph manfacturer to begln the manufacture of eloctrical racininery at this tine was the small pertnership of Johnson \& Phillips. First they made aro lamps but soon built generators as well. Lator they adjed sritchigear, transformors, wotors to their range: But thoy remoinod primarily conceined fitit cables and their share in the market for lectrical machinery was amall.

The socond class of firm was that founded on particular inventione. lost of the early elsciric lighting inventors sold their patent rights to a firm. Wany firms viere founded to buy those ratent rights and manfacture the now yruduct. In itic carly 2890 a the inventions wore often forolen.

\section{1. ibid... $P$ 44.}

2. ibid.e P 48 -for details.

3. R.H. Parsons, on.cit, $P 37$.

4. Soo C. Brooks, Johmson \& Phillins, Iondon 1950. 
The fallurs rate was hich cusons this $t_{j i}$ e of fira. All systems of lighting In the early efilties hod sorious racticil dificulties; these flom were often without edequate techndcal knowlodge and the quality of general managent mis often por. The nost buccessful of theso compantes was Brush, but even Jrush had its flare. No has been pointed out it had the best of the ocrly are 1ichting systems. As a result of this it seemed rery prosprorous at first. 1881 was a very gond year. 1891 \& 2, the company was also able lo sell concosstons for tho axclustro right to 8011 Brush equipmant in various parts of the country for high pricos. The first half of 2832 socred so prosperous that in the sunnier an interin dividend of 100, $\mathrm{was}$ declared. Manufacturing facilities woro woro than 2 doubled jet as we have sein the boon soon collapscd.

The rapid expansion of 2982 showed up considerable wsolesesses in the minacenent of Brush. Tho marufacturing profit foll from 835,464 in 2881 to 233,723 in 2882 although turtiover mare tizan doubled. As oarly as July 1882 thare were doubts about the quality of the management. R. Ifamond, who as ane of tire early purchasers of concessions was in a knowledienblo positlon, rondered whether manufacturing was not, nunning at a 2038. 3 At tho meotine of Junuary 1383 thero more accusations of bud managanent which

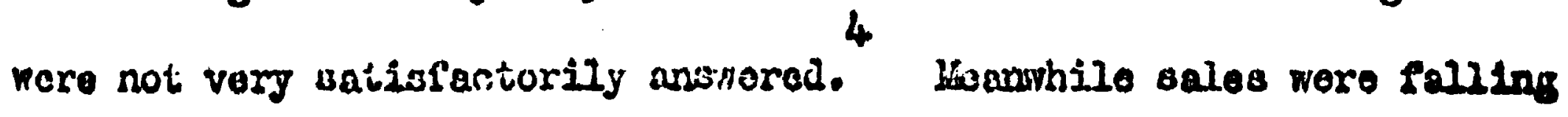
rapldly, Brush leing rorbe hit than the othor wajor cosapandos by the collapes

1. Chapter 1. PP $11-12$.

2. Iixed assots rose from $\$ 25,013$ in December 1881 to $\$ 66,490$ in Docomber 2882. !

3. Brush meeting July 1882. Ellect. Vol. 9 PP 285 - 6 .

4. Elect. V. 10 R. $259^{-60} 27$ January 2083. 


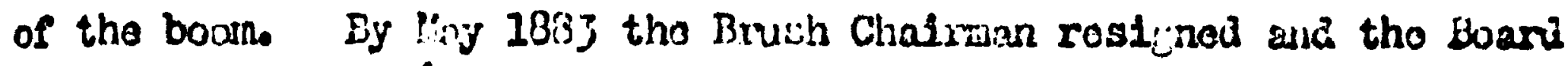
mas reconstructcd. A considerable recrianisation of tho Company

22

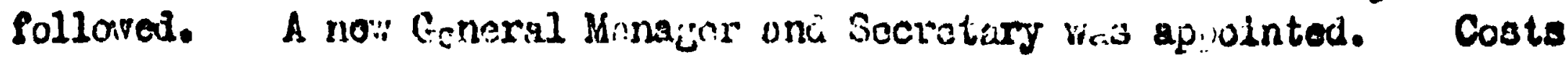
wore thoroughly invest1 fated aid substantial oconomics made. It was sald that genoral expenses wore reduced by 50,i. A.sset values wero also sharply written down.

Pollcy wes ahanged in two directions. Firstly the company was no longer to rely on arc llijating alone. The concosstonary compantes formed in 1382 had coriplained about the lack of an incandescont 21ghting systew in the patents they bought. In 2882 Brush had sought to rewods this by buyine for \&50, COO the patents of Lane-Fox. But they did little with them at flrst exoept core to arran amento with thoir concesisionaries to sell Lane-Fax incandescont lanps as well as are lighting equipment. But after the reorgantsation Brush began to dovote more attention to Incandesoent

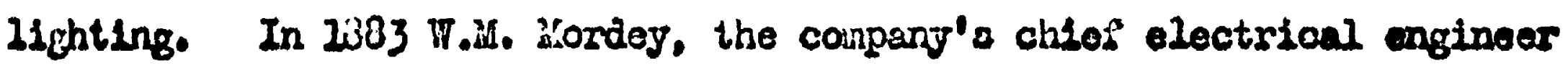
started work on a dyasiso for lncandescent 1ichting. In 1884 be produoed the succossful Victoria djnamo. Incancicscert 11ghting equipmont soon beoarse important, as is shown in Table 58.

Secondly the conpany saw that central otations wore no langer going to develop rapiulit. It thereforo repurchased concessions whore these wore for the exclusive warkoting of Brush equipmant in various parts of the 1. Elect, Vol. 11, P 1. 19 liay 2883.

2. Elect. Vol. 12, Pi 286 - 7. 2 Fobruary 1834.

3. The New Secretary waj E. Garke. Garke was boin in Germany in 2856. In 2887 he boents nanag : of Brust. In 1891 ianaging Direotor. In 2893 ho resigned fros Brush and becase inatini Direotor of the B.C.C. He left E.C.C. In 1494 and from then onwards was pripolpally canoernod with Britioh Eloctrio Traotion. 
Tablo 58.

Brush Salns of are nnd incandoscont lishting equippent.

\begin{tabular}{|c|c|c|c|c|}
\hline Iear & $\begin{array}{l}\text { Value of sales of } \\
\text { arc linghting } \\
\text { equipment }\end{array}$ & $\begin{array}{c}\% \text { or total } \\
\text { sales }\end{array}$ & $\begin{array}{l}\text { Value of sales of } \\
\text { incaniesonet } \\
\text { I1ghting equipmont }\end{array}$ & $\begin{array}{l}\text { \% of tote } \\
\text { sales }\end{array}$ \\
\hline 1885 & $u_{4}, 909$ & 23.2 & 29,438 & 37.4 \\
\hline 86 & 6,713 & 21.4 & 27,040 & 37.2 \\
\hline 87 & 10,908 & 24.0 & 13,980 & 26.8 \\
\hline 88 & 25,545 & 23.7 & 17,037 & 24.2 \\
\hline
\end{tabular}

Bourcel Historfcal records of Brush Electrical Engineering Co. Loughborough,

country. So Brush retumed to contracting rork, often 1tself Instaling Its orm plont for customers,

An example of a very poor performance by a firm founded on patent rights is that of the Electric Light and Power Generator Compans, later the Maxima Feston alectrical Company. They began by getting the contract for aro Iifhting in one part of the City, using Lontin aro lamps; they lost 44,000 on a crintract worth $\$ 3,000$. They then bought the Maxim incandescont lamp patents, a usoful asset. In 1881 haxim cano to Europe to investigato the use boing made of his natents. The U.S. Elcotric Ilghting Co., which hold the Marin patents in the U.S. considered that the London Company wae not making enough progress. In his autobiocraphy Haxim tells us what ho found at the Bankside factory of Maxim - Neston.

"I have never seda anjding lite it, in my life. The place was unspeakably air'ty, everything was so out of order that wo were tripping ovcr coppor wires everywhere; the windows were so thick with dust that thoy odmitied little light; and the for men at pork wore burning gas out af the open end or the pipo without any burmer. In walleing about the place I sam a hligh priced Brom and Sharps milling machine. It was mothered with dirt 
and appoarcd 10 bo in a very delailicated condition. The roof was loakfing and the machinery hed been rainod on and was sllghtly rusty in places."

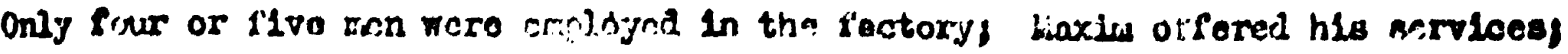
he was offered a guinea a ycar.

The company aftor their unprofitaile tirne with luntin are lampe 2 bought the patonts of Edward Woston. Ihese paterits cout largo suns of moneg. By March 28338113,8 CO had been spent on patents, as against only 82,391 on fixnd plant and 621,373 on stock. Also large sures had been spent in 2882 on 11hiting instaliations. S4,405 had bean lo.it on tho City 11gliting, \&1,225 on the Metropolitan Railway 11ghiing, \&382 at the Edinburgh Post Office and $\$ 26$ on what had bean thought to ve a gocd contract at the Botanleal Garions, 81,868 had been spent on exhibitions. Dut all this hed bourgt them no business - by Hay 2834 the losy ovor the frevlous two yeare was 232,284. Business 1 proved a 11ttle ofter that and small dividonde were paid beginninf: in 2885. Yet it is not clear that profits wero boing made, for in 2888, when a new board or Direotors took over the auditor disoovered that assets were velued at $\$ 17,445$ in excoss of thoir true value of c24,723. Trading results had not been truly stated in the past.' The making of losses by Maxim-lfestion was, consldering the c1roumstances of the time not significant. Eut thoy were vary large lossen, the rlr.a was obviously badly managod. It was 2 um by businoss mon, not englneors, and what business men meant in this case was feople with

1. Hiram S. Livexim. iviv Life, Lonion 1915. P 156.

2. For the woris or Bdicurl Peston see H.C. Passer. ap.cite PP 31 - 34.

3. The above lis Deived on roperts enil moetings of the Haxim-lioston Bloctrical Company givan in the Electrician und tiro E.R. 
expsrionce in buying and selling. Patents wore to largo extent treated as a conndity. There wita no sorious atlempt to manufacture plant, although the conpany har a omall factory. Thus the firm was usually one stop bohlnd with technical progress. Por oxample it anncunced with dold ht in 1885 that the U.S. Electric Lightins, Co. had decided to stop using laxin dymnnos and lamps (because they ver: obscloto). The Engleh Plrw was thus ablo to buy large quantitios at loir prices.

Hore exemples of this type could be given. It la surprising how many good patents found theis way into incompetont hamia. There was often poor comperation between inventor and conpuny, and inventore raroly did more than sell the patents.

The thind type of firm begtuning the rromfacture of oleotrio

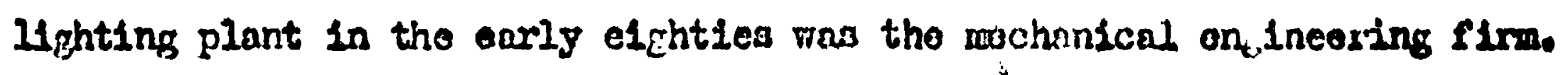
In many ways they vere tho most sriccessful group. Elocilical maohinery was mach heavior than telegraphio exuirnent, dynamas had wach in oormon W1th other rotating plant like stoam angines and machine tools.

There vere three important entrants from mechanioal onfineerine In the 23800. The firot was Crampton \& Co. R.X.B. Crainplon wes an ox Indtan army ongineer who was a partner in a small mechanioal enginoering sirm in Chelmsford. Ho cano to the bitmufacture of eleotrion machinery almost by accident. Ho ras supervising tise building of a foundry in 1878 and experinented with new mathors of casilis; plpes. The work got bohind

1. Craraton formed a series of partnershipa. Crompton \& Albright was the prircipal one in the 2080s. In 2858 it was turnod into a joint stock company. I shall olaply spoak of Crompton \& Co. (or almply Cromptoa) throughout.

2. Soe Chapter 1 P 16. 
and to hurry it Crompton decided to try the now are 21,inting. He docided to manufacture aro lighting equipment himsolf because it secmed usefur and because of defloiencies in the Grame equipment. At flrst he morely Improved the are lamp, but when he heard that Brush and Fallace Parmor in the United States wore using sevoral arcs on a series clrcult ho sot out to copy them. At first he used the Grane dymamos at a hich apood to give the necessary voltage but mechanicilly it was not adequate for this. Together with a Salss, Bmile Burgin, he dosigned a now high voltage aynawo. Ho noeded more space to manufacture it and the old partnership was diseolved and Crampton took over the wholo works. By Decenber 2880 the elrot Crompton-Burgin dynamo was ready, oapable of providing current for 6 - 8 aro 2emps. Crompton arc 21ghting, although behind Brish in the mumber of lampe nun from ons dynamo, soon becemo succossful. The works at Cholmaford soon bad to be extended and by 2881 Crompton was sald to be one of the thrue most important firms, togother with Brugh and S1emons. But output was probably less than that of the other two.

Crompton seems to have been the sirst elootrloal manufacturer to mako machinory speoifically for incandescent 11ghting. In 2880 Crompton began the monufacture of aynamos for Swan Lampe, and in 2882 and 1882 when

a number of installations were made of Swan lamps, Crompton cupplicd was dynumos.

1. R.B.B. Cromptan. Remeniscences. PP 81-2.

2. R.B.B. Crompton Remintscences P 95. 
Although a firm with less financial resources than Brush or S1emons, Crampton was sufficiently optimistic about the suture of eloctrio 2ighting to bo involved in a scheme for a contral station in Blmingham. Lost of the money was to be supplied uy Winfield \& Co. manufacturers of brass work, chandellers, etc. but Crompton was oupply the machinery. But the scham failed, Minfields went Into 11quidation and Crompton lost 1

a $20 t$ of money.

The second entrant of th1s typo was illother \& Platt Itd. It was a long established firm and in the soventies it was principally engaged In the manufacture of textile finighing machinery. In the elghties under 2

the drrection of Sir IIIIIam Hather three Iraportant ner IInes of manufacture wore atarted. Two were as a result of a visit by Mather to the O.S.A. in 2882 - 3. There he acquired the English patent rights of the Edison dynamo and tho Giniell sprinkler. ${ }^{3}$ is a result the company began an electrical department and an automatio fire protection department. Lather also started a pump derartment based on the development of the designs of Professor Osborn Roynolds of Orens College for contrifugal pumps. The now electrical department had first rate tochnical advioe.

1. R.E.B. Crompton. Reminiscences. P 109.

2. Born 1838. 1855 articled to his Pathers and unclo's works, 2858 ho becaice essistant manager. Visitcd Russia and the Continont 1859 - 63 and Amorican 1882 - 3. He was the first Chaimon of the Castnor-Rellnor Alkall Co. In 1395. He was the Chaiman of the Chloride Blectrical Storace Co. (battery manufacturers) fron 1992 - 1896. (seo Sir 7. Mather. Ed. L.E. Liather. London 1925?)

3. The antifire sprinkler was Invented by P. Ginnell of Provldanoe, Bhodo Ioland. 
1

John Hopkinson, Professor at Owens Collogo was appolnted consulting - lectrioal encineor. He rodesimod the Ealoon dynamo according to solontific prinoiples. A machino for 150 11ghts after boing remodellod and constructed according to Ilopkinson's prinoiplo was capablo of oupplyins current for 250 1ights. Together with his brother Edwand ho deslened the "Lanchester" aynams and motor in 1884. The Edison-Hopkinson and Manchoster dynamos, with later modiflcations mere the main produots of Kathor \& Platt's electrical department right up to 1900.

Another Important, but at first very awall electrical machlnory mampecturer cmerged out of mechanlcal enginearing in 1882. Th1s was the partnership of Elroll-Parker. One of the partners was Thomas Parkor. Borm in 2843, he had been cmployed by the Coalbrookdalo Company from the age of 9. and had became the manager of the engineering side of the businoss. Throughout the late seventies and the early olghties he had boen intereated In Amamo design. In 1882 he joined Bedford Blmoll who was in business In Folverhampton as a Patent TIp and Horso Shoo Compang. An eleotricul dopurtmont was etarted, wh1ch, at flrot employed only throe won, but expanded rapidily after 1885.

During the midale and late elghties a muber of establsohed meohanical engineers adced an eloctrical dopartment. Also a muber of

1. Born 1849. Died 1891. An extremely good mathematioal enginoer. At Cambridge ho was Senior Franglor in 1878 and firet Sutth's priseman In 1872 be becamo a S.R.S.

2. E.R. Vol. 43, PP 338-9 2 Septamber 1898.

'3. Soo Chapter 5 P. 194.

4. Electrical Times Vol. 59 PP 405 - 40828 Apri3 1921. The Early days of the Electricel Industry.- tho B.C.C. 
mall partnerships with goncral anginoering baokground bogan to make electrical machinery. They usually made only dynamos for use with the lamps of other manufacturers. An important reasin for this was the exorgence of princlples of dymaxo design. In the early elghtios the desion of electric lighting machinery was a question of inspired emplriolam. Unt1l 2881 there wero no standardised units of electrical measurement and Instruments were primitive in the extreme. Crompton was sald to design dynamos by looking at them. Changes in aro lamps Involved ohanges In dynamos. If pieces of equipment were put together which were not deslgned to be run together a large number of incalculable ad justmont: would have had to be made. But by 1882 - 4 much more was known sclentifically, and it was less necessary to treat are 21ghting oquipment as a unit. Nevertheless it tended to be so treated until woll into the 2890s. In the case of incandescent lamps, the situation was different frok the carly days. Swan made only $11_{1}$ ht bulbs and relied on dynamoe bought from outside. In $1880-2$ he used both Crompton and Siemeno dynamos, and from 2883 ontrands Edsson-Stran bought a mumber of dynamas from Lather and Platt.

Once the principles oi dynamo dosign wore known, other mechanical ongincors started to produce them. From an ongineoring polnt of viow this was to be axpected. They had experience of non-olectrical rotating plant, steam ongines, machine tools oto. and this gave them advantages, as many of the difficultics with carly dymomos were machanical as woll as eleotrion. They rotated quite rapidiy for the atate of engineering lonowlodge. 
Clearances had to be quite small botween armituro and fiold coll for the efficioncy of the machine to be high. Although machines wore ting by later standaris - under $50 \mathrm{kN}$ for most of tho elchties - these rero much bigger loads with correspondingly Eroater wachanical stralns than wore Involved with telegraphic apparatus. Fowlcrs of Loeds, makers of steam engines and egricultural machinery, Greentrood and Battey, ongino bullders, W.H. Allen, also enfine buildors, Clarke Chapman, marino and goneral ongineers, wore acions the establishod general englneers who otarted Bmall dynamo departments in the midalo and late 1880 s.

The possibility of using electrio motors in factories attracted wore mochanical enfinecrs, especially those already maleing rotating tools driven by steam ongines or shafting. Often a special rotor was noedod for a special tool. There was scarcely any eleotrio power in the late elghties but one firm of mechanical ongineers at least. Easton Anderson and Goolden sam the possibilities of electric cranes as early as 1888. They were formed by the amalgamation of Easton and Anderson with the small firm of dynamo butlders, T.T. Goolden \& Co.

During the elghtios eloctrical machinery manusaoture was highly oancentrated. Table59 gives what figures can be collected of the grose output of four of the major firms in the 1830s. The only marfor firm ertirely amitted is Elvell Parker during the socand half of the olght1es. It is doubtful if its turnover was bigger than that of Hather and Platt's oleotrical departrient. Brish Siemens and Crompton seem to have had a very large share of the market in the early elcht1es. Aftor 1882 thoir ahare scems to have doclined, but they rematned very important. It is not likely that the accregate output of the amall inms was vory large. 
Table 59.

\section{Gross output of electrical machinery.}

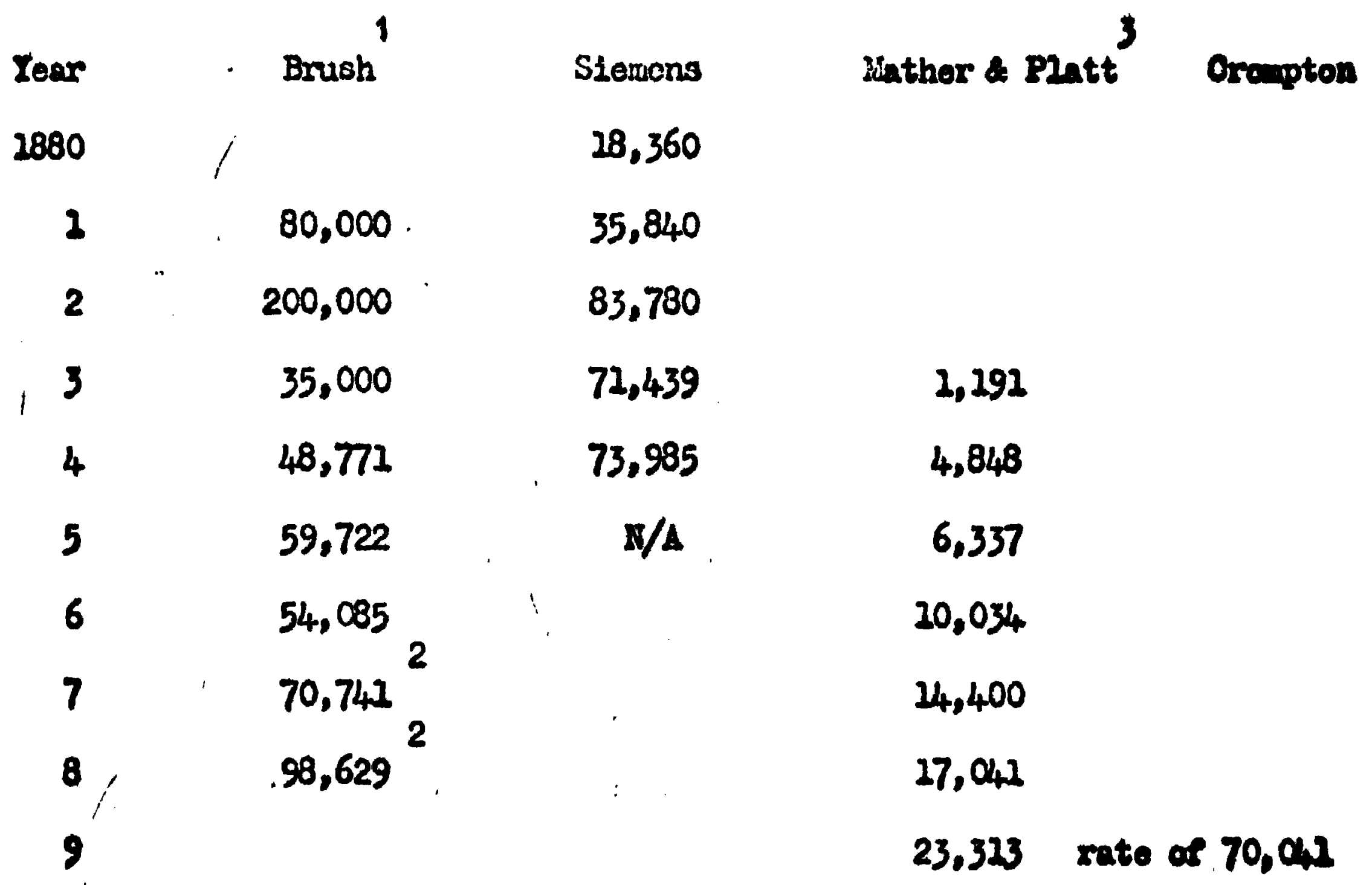

2. Excludes Incandescent lamps.

2. If wo inolude production at the Brush factory in dustria output is $\$ 80,746$ and 8115,629 for 2887 and 8.

3. Bstimated from output in $\mathrm{KW}$.

In the case of incandescent lighting dynamos in the midde -ighties we have nuito good information about market shares. Brush hold Important patents covering the best method of winding constant voltage dynamos. Thoy were willing to lasue lioences if a royalty of $2 \%-$ per INI (5 - 20ji of contemporary pricos) was paid. The only major firin to refuse was Crompton. If we assume- on 21terary ovidence - that Crompton's 
output of Incondescent lighting dynamos was oqual to that of Hather a Platt, Table 60 can be constructed.

Table 60.

Shares of the market for incandescent 21ghting aynamos early 2886 - end 2887.

\section{Percontage.}

Brush

30

SLemens

19

Cramptan

36

Uather \& Platt

16

Elmell-Parker

21

India Rabber \& Gutta Parcha

3

Ulanchester \& District

- Edison-Swan

2

Othors

25 and 1085

The are lighting equipment market seems to have boen more concentratod. Litering ovidence sugeests the manufacture of are 218titing onutpoent was pritrurily in the hands of Brush, Sicmens and Crompton. By 1883 the three principal firms wore making mult1-are dynamosi slemen and Crompton made them for up to 22 Lamps, Brush for up to 40. By 2888 the number had risen to 28,30 and 55 respectively. The lamps had been standaraisod at about 45 - 50 volts, and were now bullt to burn up to about 25 hours. Siemens had thus followed Crompton in produoing a spoter 
11ko that of Brush. Aro 11ghting, hoverer, nover developed in this country as $1 t$ did in the United States. This was fartiy because it was $11 t$ lo used In the streots. Aro lighting equipment was a declining share of Brush output 2885 - 8, and we may essume both that this was true of Crompton and Slemens and that tho percentage continued to fall.

The collapse of the boon of 1882 advorsely of fected all manufacturers of plant, although the magnttude of the effect varied vory considerably. Brush, the one rbo hed expanded tho most was the worst affected. The company comployed 8CO men in 2882, and by 2886 the mumber had fallen to 300. Slemens' output foll by anly $15 \%$ Crompton who asd not expand in 2882, doubled the size of his works in the deprossion year of 2883, and further expansion took place in 1834." This riso in output Beercs to have boen due to Crompton's concentration on expanding tho demand for 1solated plant. Siemens soon followed, and then Brush. 3 1885 demand had xisen crough to koep the principal factories falriy buny. Cromiton was doing particularly well and was oven ablo to koep a night ohlft going.

The value of output by 1885 was, howevor, well below that of 2882. Prices had fallen very shorply, partly because of the sales of equipment of flrms going linto liquidation. Iven though the aferegate amount of plant sald for this reason was smoll dewand was inelastio in the short run

2. Klect. Vol. 122, PP 184 - 5. January 1884 .

2. Elect, Vol. 14, P 161. 3 January 1885.

3. Orampton, Reminiscences P 210 . 
This factor was said to be particularly important in 2886 when prices foll sharply. Prico data aro sparso and difficult to Interpret boceuse of the varying sizos of equipment. But ons cannentator stated that the price per KNT of an $80 \mathrm{KW}$ Incandoscant 21, hting dynaroo was 129 in 2882 and only 16 in 2887. Other date 18 consistent with th1s. The fall went on all through the period 2882 - 88. Brush arc Iighting dymamos sold in 1885 at en average reveme of $\$ 174$ by 2888 average revenus was ond

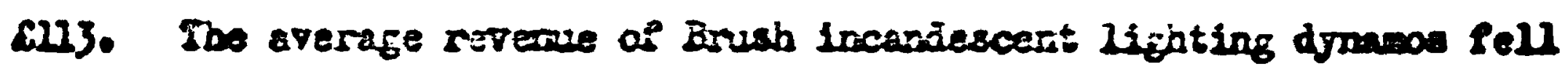
from 6125 in 2885 to 8112 in 1888. But the alze of dymato was probab25 rising and this would cause the fall in price to be underestimated. Brush are Lamp pricos; where there is no oize ambiguity foll from 012.4 In 2885 to 28.2 in 2838 .

Ior prices and low donand, particularly the absence of domand for Central station plant drove English manufacturers to wider markets. Crompton soens to have led the way hore. In 2883 the Ring Theatro in Vienna was destroyed by fire and it was doclded to try olectrio 11ghting in the now theatre. The joil to be done was b1Eger than angthing attempted In England; for examplo the generating station was a mille fron the theatro. Crompton's scherre, using Willans - Crontoton genorating sots and a 5 wiro d.0. distribution was a forerunner of the Iondion stations of 0.2890 and the Irst Instance of the very successful British practice of diroct coupled ancinos and dynamos. By 1836 the plant was working and Crompton went in soarch of more Continental ordors. In tho next fow years be risited

2. Ti. Lafint Carpentar. "On tho Posilion and Prosvects of Electrie Llehting In the "etrono1 is". ijlect. Vo1. 22, $24248-9023$ January 2888.

2. Brush Historical Recoris. 
Gothenburg, Stockholm, Copenhacen, Belgrade and Sophia. But he got few orders and in his autoblography states that this was because of the credit facllities given by the German banks who backed the German - lectrical mamufacturcrs. British bankers refused to glve him oredit to bo extended to his customers. In 2386 Brush, whose sales to the Continont had boen "hampered by high tariffs and great competition in North Corrany" bought a factory in Vienna. In 2587 and 8 the output of the Vlenna factory was about 10\% of the total Brush output.

Because of its connections with Slemens \& Halgke, Siemons dia not seek markets abooad. Siemens seems to have withdrawn from elcotrio lighting more than other firms. This may have been partiy due to the death of Willem Siemons in 2883. It nusit also havo boen due to the high level of domand for submarine cable and ito considerwole profitabillty during the 1880s. Tho Electric 11ght departwent showed regular lasses from $1380-84$ except for 1832 wisen a ver'y small profit was shown. The doparture of Edward Hopkinson In 1833 way be a Sarther indiontor as a contraction of interest in the field.

Total exports of electrical equipmont were substantial. Tho I1gures in tho statistical abstract relato to all olectrio lighting apparatus. But it 15 possible to mako a guess at the grows output of.

1. Crompton Reminiscences PP $217-136$.

2. See J.D. Scott. op.cit., $164-5$. 
Tablo 61.

Slemens Bros. The Eloctric Light Dopt. Net profit as a percentage of soles and stook.

$\begin{array}{rr}2880 & -33.5 \\ 81 & -22.2 \\ 82 & +0.7 \\ 83 & -3.8 \\ 84 & -4.3\end{array}$

Losses include losses on I1ghting Installations which were heavy $3880-2$.

Sourcer Slemans Bros. Historical Records.

electrio 11ghting plant. In 1886 exports were roughly $30 \%$ and in 2888 roughly 35\% of production. Imports were not roconded in any satisfactory form unt1l 2903.

1. Tho output of Bnush and liather \& Platt is given in Table 59 An estimate for Slemens and Crompton 1s:talken from the level of their sales at other tires. I assune ElWell-Parker output was the sane as that of liather \& Platt. Let us assume that these flrms had the samo sinaro of tho markct for machinery that thoy had for incandescont lighting dynamos. Edison-Siran output of incandescent 2ight bulius is lnown. Iot us asiume they had a 75,i sharo of the markot in 2886 and a 90,j share in 1888 . The resultant estimates or Liosis outpati are $\$ 320,000$ in 1856 and 2181,000 in 2838. Thts does not include the output of cable firms, but caibles exported axcept as part of assembled olectrlc lightine plant would bo separately enumerated. Cables sold other than as part of eleotrio licivting equipruent would be excludod frois production and exports and cablo sold as part of olectrio lighting equipment included in both. 
211

The second cycle in the demand for olectrical plant is from 1888 to 1895. There was a bie upewing from 1888 to 2891 as central station supply at last began. The value of output of eloctrical machinory seems to have roughly trebled. After 1891 the value of output seems to have continued to rise, although at a wuch slower rate. That 1 igures we have however suggest that 1 t may have risen by as much as 25 - 20\% botwoen 2891 and 2895. But it was not a steady rise. From 2891 - 5 prices foll sharply and there was probably a failly considerable riso in the roluew of output.

The bnow brought about a considerable expansion both of the muber of producers, and of the major flums. The market contimed to be highly concentrated. Five flrms supplied the bulk of the traction equipment for the new centrel stations. We have figuros of dynomos Installed by makers measured In KW, and because it was at that time the usual practice to award the contract for all the electrical equipment, excopt the cables, of a central station to one firm the flgures are reliable Indicators of the narket shares of the floms for all central Btation electrical machinery. Later Iigures are in Table 80 P 396 The beglnnings of central stations also mado for changeo in machinery. The only major change tras a rise, not a very large one, in the 81ze of dynamos. Home manufacturers took this in their stride. Somo, 2lko Crompton had already been makelng central station plant for 
Table 62.

Isorufacturora of olcetriont inohinery 2832 - 1905

2892 2804 2810 $2300 \quad 28932393$

Dymemos

16

19

5. 72

73

69

Lotors

225

$27 \quad 45 \quad 48$

49

Are Lnans

26

$27 \quad 42$

52

Iremsformers

212324

Lloters

Traction Equipment

$\begin{array}{cccccc}2 & 5 & 21 & 20 & 22 & 18 \\ & & 1 & 4 & 8 & \end{array}$

The data havo boen tolen fraz a Euyors cusalo. Thenovor possiblo

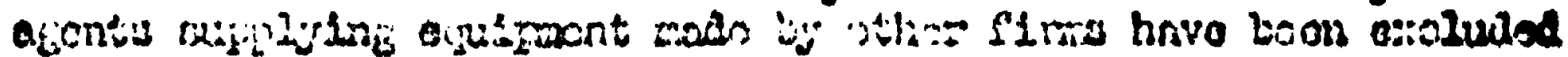
out it is not possiblo to garanteo that tisis has boen entirols

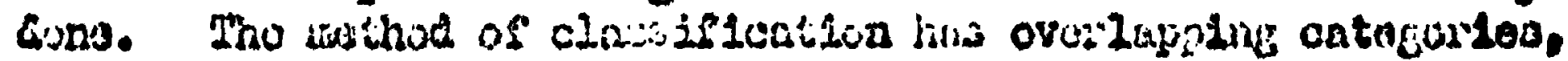

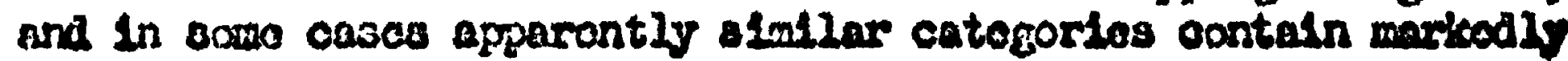

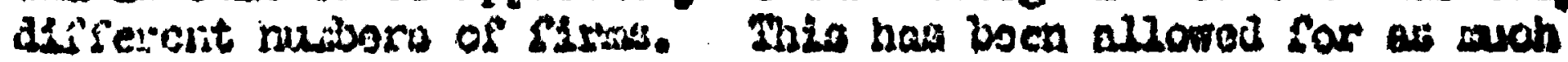
ac possibile.

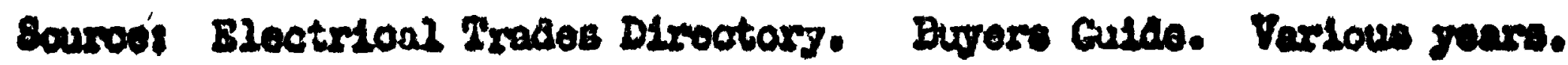

Tabio 63.

Dymemos installod by 5 prinolpal fir:o in Contral station ure to tix ond of igen.

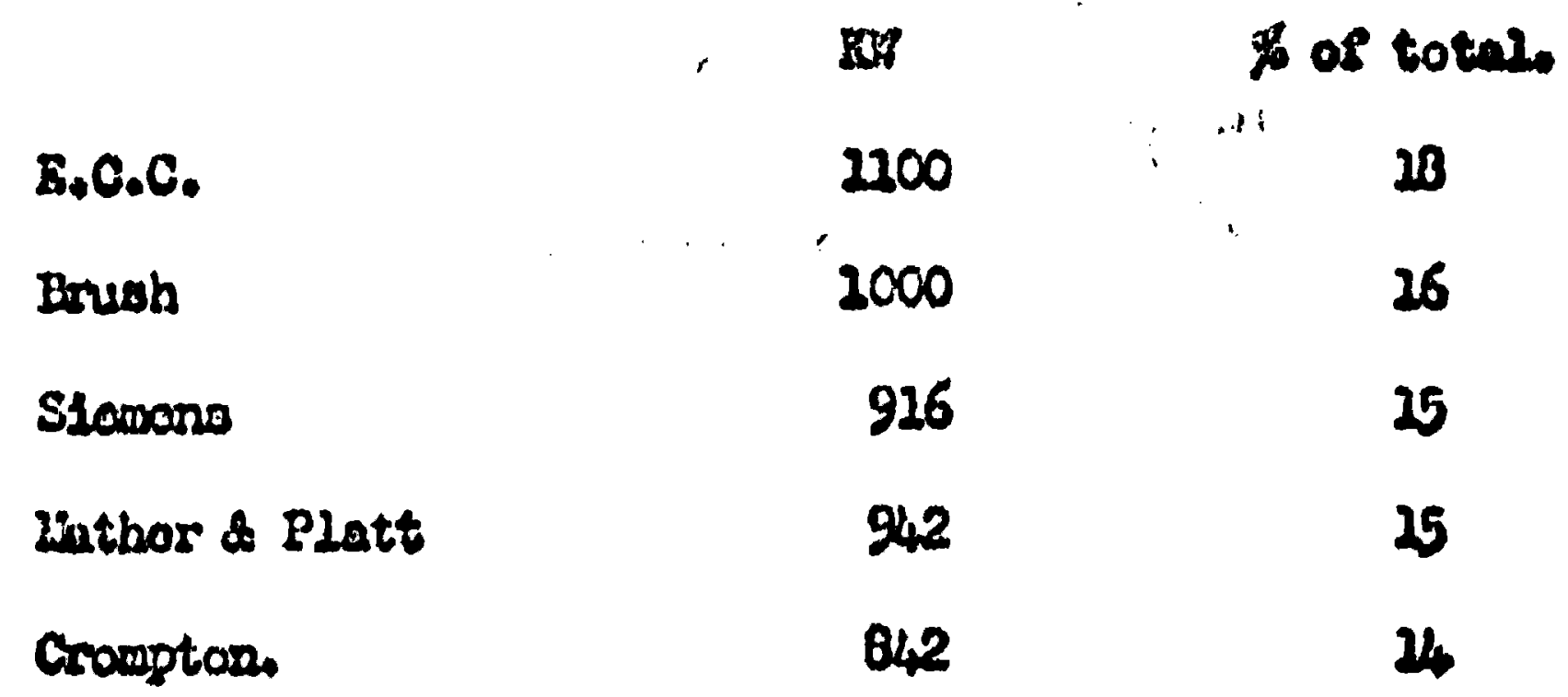

Source: See Table 80. 
Table 64.

Gron3 output of the major P1rno 1888-96. $\quad 8000$

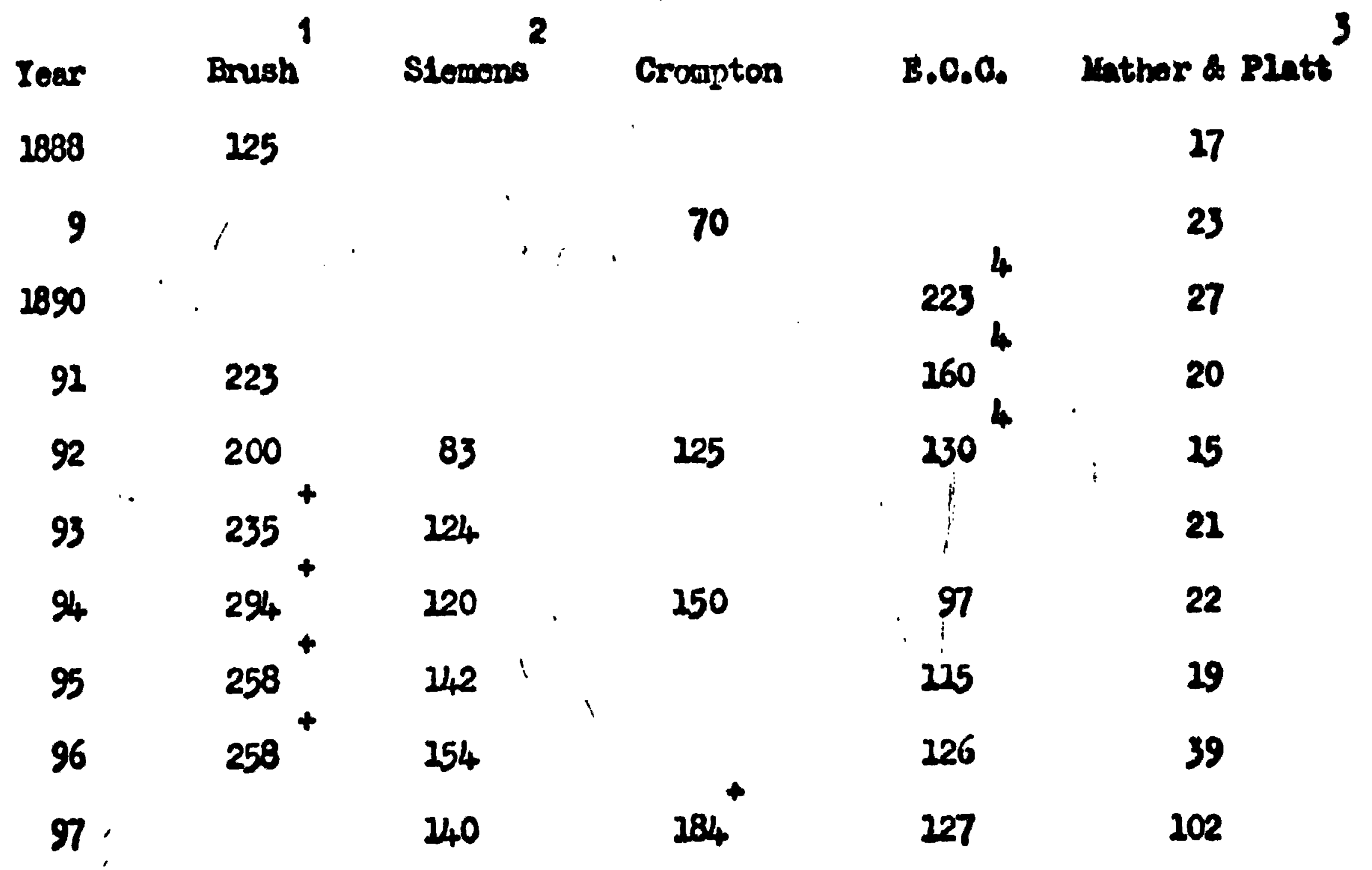

+ Estluatied from size of stocks plus work in progress and etatiotion of . oapitali output ratio.

1. Inoludes engines and tramay rolling stoak after 1890.

2. Dynamo department output.

3. Lstimated from KW flgures at an average revenue of 810 par $K W$ A.R. data for liather \& Platt meohinory support this.

4. Includes E.P.S. Storage batterles, and nay include aalos of "papere"

8ourcess Brush Historical Records

Sicmens Historicnl Rocords

E.C.C. Iistoricol Rocords

Crompton IIfstorical Records

Wathor \& Platt name plate books

Various statamonts at company metines. 
export. The Inoreasing size and welght of oloctrical machinory was part of the reason for the Brush move. The heavior work was to be done at Loughborough and tho 21ghter work in Iondon. It is also shown by the expansion of Elwell-Parker Into now and lurge works, Into a faotory from rarkshop.

The other major way in which the 1888 - 2895 oycle atf fored from that of 2879 - 2887 was that the boom was successful in Iaunchtng ol cotrlo lighting, and as a result of this there was no catatrophio recesslon. Tho bullding of the early munfolpal central stations indeod led to a continued increase of demand. Yot the falling prices of 1891 - 5 In some ways seemed to do more damage than the collapse of 1883. For during the midale ninoties the British electrical machtnory makars began to fall technically far behind the Amoricans and tho Germans In ongineoring progress. In the late oighties and early ninetios thoy were not backwardi the change soems to have come vory quiakily. As wo saw in Chapter 2 they showed considerable ingenuity in designing the early Iondon central stations. Outside Londion tho B.C.O. bullt 04000 ssiul central stations for Oxford and Wolverhampton on the high voltage d.o. system. Although not the fight solution to the oleotricity distribution problem it wgs well worth trying. In 2892 J.S. Raworth of Brush made a vory Impartant innovation in switchgoar. Ho placed owitabos in motal pillars for the Fandstrorth station of tho County of London Co. Paulty unitohes were comon at the time, and more than one contral otation was

1. RoH. Parsuns, op.cite PP $165-6$. 
very severely damaged by fires caused by arcing at sirltcheri. The nmorth p1llar was the forerunner of the metal-clad sxitubjobur used with inat ouccess from 1905 omaris. 2 Several very gord sioctrical am moohanteal onglneers worked for the manufacturing compantes. J.S. Rnwnth, W.M. Nondes, R.B.B. Crompton and Th:mas Parker were all elrst class englnoers. However by the Iate ninet1os the E.C.C. and Crempton and Co. bad quarsolled with Parker and Crompton. Mordey and Raworth had loft Brush. English manufacturers mado no attempt to devolop traction oquipment after 1391, dospite their good start. Tho great new dovelope wont in the early ninoties, polyphase a.c., they ignored ontirely. Some explanation for this is to be found in the worleings of the reoeselon of 2891 - 5, some in the nature of the capitel market, and some in the workings of joint-8tock companies at the tine:"

The recession was in prices and not in outjut, and thlo rall in prices is at first ratior surprising when demand was growing, espoolally as thore 18 no real ovidenoe of overcapacity at the and of the boom. On the avorago the major firms scom to have boen falrly fully coployed by 2891, and in the following years slightly expanded capaolty to allow for rlsing output. Tho number of producers rose sbarply from 2887 - 90 but not afterwards. There is no good evidence about the aotifition of the

1. 1bid, PP $26-7$ and 77 .

2. H.W. Clothier, Switchrear Steges, Nowcastlo upan Tyne. 2933. P 27. Lotter froin ii. if liordey.

3. English manufacturers also exporled plant. Both Brush and Cro. pton Invostod in Australian branches. Those becano vory unprofitable with the Nustralian depresion which began in 1892. Domand was novertholess dominated by home demand. 
mall fIrwo and flrmo with a mall electrical departwent, but what does oxlot ouggests that output was rlsing. 1891 - 4 and that thay woro working 1

olose to capacity. Despite this contemporaries noticed "unreasonablo prico outting". As exrly as 1893 the Elootrical Reviow had a special loader on the state of the electrical industry comenting,

"In spite of tile rapia extansion of el cetric 11.hting and the abundance of rork ...... Wo really question whether the state of the industry Wn: ever more unsatisl:actory than it is at the rresent moment ........... Although wost workshops are fully employed conpetition is responsible for $t$ ie cuttin: doim of prices to such an extent that the narrowest margin of profit is left; .... In many instances the acceptance of tenders must have rosulted in actual loss ..... a fer days ago a well knom dynnmo maker remarked that his firm considered when tendering that if they added 10,3 to the total works cost oi a dymamo they would expeot to lose the order. "m2

Eleotrical plant was ueually built to order. Th1s wns true of work for 100lated plant as well as central stations. An Individual ordar was often larie rulative to the output of a firn. An extremo examplo 13 provided by the Brush contract for tho City of Lnndon Co., begun in 2891. It was worth over $\$ 300,0,00$ when the firms average annual output was abeut $\$ 250,000 .^{3}$ With intermittent large ordurs queueing theory loads one to expect elther very long delivery datos or that firms would find some part of their capacily unemloyed perifleally. Capaoity does seem to have beon high enough to keep delivery dates sairly short - 1.0. not much longar than ths avorage tiue of manuf ccture at somothing aproaching a maximum

1. E.R. and Elect. Reviews of $1890,91,92,93.94$ and 95.

i. Elact. 2 and Io January 1891, I January 1892, 6 January 2893, 5 January $139+, 4$ Jariary 1395, 3 Janniary 1896. E.R. 6 Jaswary 2893, 5 Jamung 2894, 12 January 2894 and 19 January 1894.

2. Eell, Vol. 33 PP 85 - 7. 28 July 1893.

3. Eleot. Vol. P 28 Soptember 1891 
1

rate of work. Also references in company reports do suggest short torm variations in the dogree of ut111sation of capacity.

Costs varled little with short term fluotuations in output. 2 Capital costs fell only slightly as work in progress fell. Labour coste foll $21 t$ tlo as skilled labour was largely employed, and could not be raried in quantity in tho vory short zun. Thus whon capality was undorutilisod thore was a temptation to quoto low prices.

If prices were fallinis for this reason one naturally wonders why capcity should be rising. But the tocmique of production coupled with largo Lrregular orders provldes an answor. Eloctslcal machinory was made by Bkilled labour with relativoly simple mult1-purpose machinory in large orocting shops, Building a new shop was expensive but once on existed 1ts possiblo throughout oapacity could bo simply and chouply extended by adding a forr extra machines and using the filoor space moro Intensively. A firm would not hesitate to tender for a contract which roquirod slight additions to capact ty of this kind. Onoe it was croated sirns would wish to use this oapacity which could then exeroles a dempening influence on prices.

These factors were reinforced by the fact that suoosssive jobs diffored widely. Small improvements wero continually taking pleoe in

1. This concept is unfortunately far from precise. But all that is Lisplicd here is that. Eiven usual techniques of production, a plece of machinery took (roughly) a minimum time to manufacture. This time could not be reduced without a chengo in tcchnique becauso of limits on the number of men who could work simultancously on 1 t and tho traditional livits to the workin day. In the absence of any detailod evidance it would oe Sussy to worry too much avout pricioion.

2. There are tuo many difficulties in figures of capltal employed and too fow output figures for one to be able to say buch obout the importance of capital costs. The fixed capital and stocks: output rat10 seoms to 
dosien. Firms undortook a wido range of jobs and there were few jobe In the aggrecate. Also customers ofton had firm viows about the opecifications for a job and thoy usually diffored from oach othor. Thus the cost of a job could not be forcseon accurately. Under pressure flrms wore optimistio about costs.

There was a change in the mothod of selling plant to contral otations in the first half of thr nineties whloh Intensified the forces which could load to low tendoring. In 2888 - 91 an olectrialty oupply company ordered all or nearly all of 1ts initial plant from manufaoturor. Tho latter was largely responstble for the deslgn of the plant, and subcontreoted for 1tems he did not wish to manufacturo. Somotimes the onglneer to the supply company was also a mameroturer, two notable oases being Crompton and Ferranti. But this system soon gave way to the techntques of employing a consulting enflineer. Ho designed the plant and opeolfied more or less olosely the desired operating performance of the oquipwent, for example the efficlency of transforners at rarying $20 a d s$ and the steam consumption of generating units. The tradition beceme quidely established that these consulting engineers ahould be independent of the manufacturers. Naturally thore vas a poriod of transition. In 2893 the Elootricel Revien carmented soveral timos on the alleged oonneotions

1. B.R. Vol. 33 FP $85-7.28$ July 1893. 
1

bntmosn consulting onclnsors and mamufnoturors. But by 2895 thay do unars to havo bnoorse Indepeniont. The chango wno lnx i,ely, the roeult of the bogluning of w nlclpal olootrlolty aupply.

The ohange had two lmportant effocto. In the flrst plece spoolfications becano more antallod. Varlationo in the operating oosto of the mochlnery of alfferent makers wore thus oubstantlally rectuoed. In order to got the plant with the loweot total coate (capital and oporailing) bupere could simply choose the lorrost tencior. Competition betweon flrme moved In the alreotion of wore prico oompoiltion, aray from procust oompotition

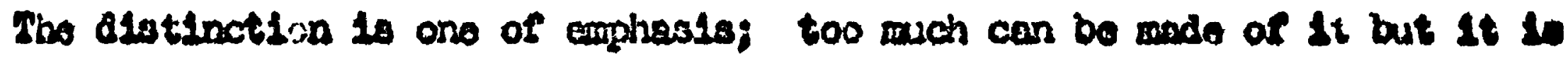
pleusible to euppose that in fact if not in 20 glo prioe ocupotitlon woura rouce profita mach more rapialy in tho ohort run.

In the socond ploos closer apociflcations, togother wh the attituic of manicipal purchasors in particular, brought in the apparatus of guarantee and ponalty olausos. Lunlcipalitios genorally alotruoted compantoo operatinis for profit. bucin of the work cornatooloned by muntolpalitica In the past was bullating work whore thoy bad boen confroated With local monopolios. Thus thoy had ot1ff contreot torwo, ane of the Important clausso bolng that the corporation's oncinoer ahould bo the

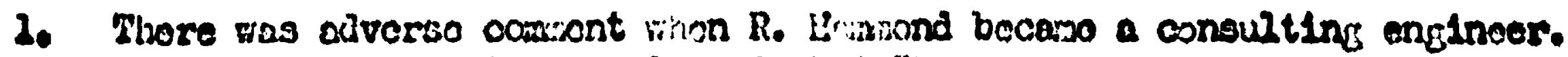
Tho Eloctricol foviow conjilntngd that "ho canrwot poso as an Indepondent

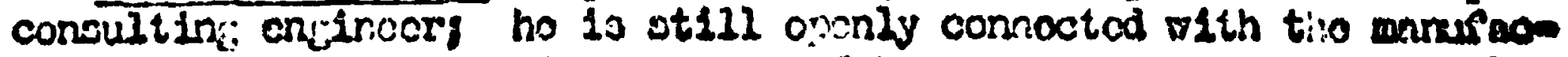
turing and contracting dopartinorits of 4 or 5 difforont couppanlas." E. R. Vol. 33 P 241. I Sojteniver 2893. It 1700 aloo alleged that Harrond's conrections oith J. Eossler \&: Co. lod to tho aocoptance of Fonler'o tenjer for Coventry. IB.R. Vol. 33 PR 670 and 701. 22 and 29 Decomior 2893 and Nexport, 24.R. V02. 34 IP $35-7$. 
80le judge in alsputes botween contraciors and the corporation. Penalty clauses were strong. This type of contract was applied to the building of eleotrialty supply stat1ons, where sellews had much less monopoly power. The machincry msnufacturers were not in a position to resiet these olausen. In their siturtion one would expect the propensity to accopt them to bo atranger than that to offer lower prices. Possible penalties could secm a long way wray. Tot if the firm failed to mot its guaranteo it could be very expensive. This factor often lowered prosits oven though it did not lower pricos.

Even though electrical machinory manufacture was hlghly concentrated, firms did not in any way act togother to koop up prices. On the contrary they cut pricos as soon as there was a possibility of working under capacity. Crompton in particular becamo somewhat notorlous for tendering 10w prices. At the anrual meeting on 9 August 1896 one of the shareholders remarked that he heard a good doal about olootrical businoss in the C1ty. and ho had been informed that of all flrms that went in for cutting contracts Crompton and Co. were the very worst. To this Crompton roplled that it was dfficioult for any firm to get profitablo contracts unless thoy took financial risks. The Chairman declared that business could not be obtalned unless the tender was very 20 w.

There was another important reason, in addition to those dsecussed above for the fall in prices 1891 - 5. This was the state of mochanlonl

1. E.R. Vol. 37. EP 228 - 9. 23 August 2896. 
onglnoaring. liany of the firws ontoring the market for oloctrical equifment in 2838 - 90 wero established asechanical enspinoers, who added an electrical dopartmont. In 2389 and 2890 the Economist reported that mochanical engineering was vory busy and prosporous. Then prospects began to wane and 2893 wes a year of "particular anxiety and dopresolon." In most branches mamuracturers were working woll belon capacity. Employment was below that of 2892 and prices and profitis were $10 \%$. But oloctrical engineering was rolutively active. In 2394 mochonioul engineers, Lron founders and machine tool makers wore dopressed. But the demand for electric 21ghting plant continued to bo hlgh. Luch work was done by "those who having bad axporionoe as nakers of steam ongines, have added the manufacture of speoial eloctrical appilanoes."

i. The accopted way to develop a naw 1 ino secms to have been to charge low prices untll there vore satisfied customors. And the elastlolty of demand for electricel plant was low. In 1 ts 1893 articio on prios cutting the Electrical Revier arguod that the principel roason for prioo cutting was "advertisement". "There are many notorious exmples ar work done at a 208s, simply to attract attention." It thought amall firw wero

1. The Roviers of the year.

2. Beonimist. Revier of 1893. Sup. Iomont to the lasue of 27 Pobsuary 28940

3. Esonamist. Review of 1894. Supplanent to 1csue of 16 Pebruary 2895. the Flcctrician also cannentod on the competition of thoso who cambine eloctrical and mechanical angineoring V02. 35 P 716, 27 soptembar 2895. 
matnly responsible for leading prices down. "

"It is no uncomnon occurrence to find in a list of tenders some three or four of the largest firms quoting within a $f \mathrm{ew}$ pounds of each othor for large work and amoller f'irms of fering to do the work for, perhaps tro-thirds of the price at which more responsible firus would undertake 1t."

The recession reduced propits. But manufacturing firms wero also handloapped by the structure of the capital market. As J.B. Jof freys 2 has ohown the capital market was to a large extent geared to dealings in fixed interest securities. They were what lenders most wantod to purchaso. But he has also pointed out that in the olghties and nineties there were considerable supplied of funds which bought oxdinary shares in time of bocm. Horrever, in the case of the shares of eleotrical compantes there 15 a difference between the eighties and nineties. In the boon of 2882 it was easy to ratse money for electrical onterprises, in the boco 2838 - 92 much Less easy. The speculation and over optimism of 1832 and the aubsequent losses by shareholders made lenders vory outious concerning olectrical anterprises. Matters hod been made worse by the practico, conmon in $2882-3$ of lssuing partially paid shares and making calle whon tho company's output slumped. Electrical manufacturers had to borrom at loast some of the money they required at fixed interest, even In the boon. Such was the case with Brush. At the end of $1838 /$ boginning of 2889 som now shares wcre 1ssued bringing in 84,640 . In $I 899$ a call was mado in partially paid shares making them all fully paid, and somo moro 1ssuod, raloing 824,356. As late as $1892 \$ 11,223$ mes raised by the issue of chares. But

2. E.R. Vol. 33 PP $85-7.28$ July 2893.

2. Trends In Bus1ness Organisation sinoe 2856. Unpublishod Iondion Ph.D. thesis. 1938. 
In 1890 Brush 1s3ued $\& 75,000$ of new debentures. Yot oven f1xed Interest borroning could be difficult. Crompton soencd to bo particularly unfortunate. In the end of 2889 and first part of 2890, 625,000 was raised on 5io debentures. But an attempt to s011 another 125,000 of then asd not succeod. They wero offored to the publio in the suminer of 18908 by learch 2891 only 810,800 of them had been sold. In the custumn of 2891 an attempt was made to sell 850,000 of preference shares. But thoy did not sell very woll and a year later the company triod to bell ordinary ehares to tine value of $\& 120,000$. How well the ordinary shares sold wo do not know, but in February 2894 the directors onked for power to borrew up to 8100,000 in $4 \frac{1}{2} \%$ debentures. They wore to pay off 850,000 of colsting debentures (presumably most of the socond batch of 5\%s had boen sold by then) and the Loan from the bank which was \&18,000. Although by Lugust 1894 the purchase of only \&32,000 of these debentures had been promised, by Karch 1895 E82,850 had been subscribed. This pald off tho bank loan and left some funds for working capital.

The speculative nature of ordinary shares, whilo it made it difficult for same firms to raise money excopt at fixed interest, In other cases oncouraged IInanoial manipulators. The E.C.C. suffered badly in this way. The firil started with the destre to help the extension of eleotric lighting not only by supplying mechinery but by provlding elnanoe. Some contracts were paid for partly in cash and partly in shares. Largo oums wore spont on backing Lano-Pox in a patent suit against the Kenoington and Knightsbridge Electrio IIghting Company. There was 280 oonalderablo 1. On the parallel comeotion of inoandoscant lampes. 
buying and selling of patents, 2iconces and oth:r speculative paper. Preference shares efl debentures were issued to pay for alleged increases in business while as carly as Soptember 1892 the ordinary dividend was passed. Some of this activity was probably fraudulent. The Chalman of the B.C.C. was Jabey Balfour, who was also involved in the freuds that brought down tho Liberator Builaing Society. In 1892 Balfour was exposod 2 and Iled to South Aperica.

Borrowing diffioulties pressed particularly hard on the eleotrical manufacturers bocause they wore also substantial lenders to their customers. Plant wes often paid for partly in shares. This partly replects the defficulty olectricity supply companies had in selling ordinary shares. In the 1890 these shores were of now companies and they yielded a vory - Iow return. Often no dividends were paid for the first few years.

The munsolpalit108, hapnily for the mampacturers, pald cash. But thoy was ally did not pay promptly, keeping a large share of the payment unt1l the equipmant was exected and working. Brush cladmed in 1894 that it had c50 - 60,000 tied up in this way.

1. R.C.K. Ensor. Encland 1370 - 1914 London 1936. P 323.

2. Seo also J.T. Beck. A brief history of the Blcctrical Porrer Storage Co. Unpublished typescript in the library of the Institution of Eloctrical Eneinoers.

3. The return on such assets was low even aftor the 18908. Data 1s available for tro companies. For the L.C.C. in the 19 years betirean 1896 and 1914 the percentage return was above: 5,0 for only two years when undistributed profits investod in a roserve account are included and for 9 years was belor 3;. These shares horrevor inaluded E.P.S. shares. Foo Brush figures are available for 9 jears between 1901 and 292 Tho rate of rotum was above 5 i for only two jears, and below. $3 \%$ for five years.

4. Slect. Vol. 35 P 716. 27 Soptember 2895. 
The blg increases in lending to consumers came durlng recession porlods, when electrioity supply companies colld not coolly soll shares, and whon compotition among the mnnufacturera wns at 1ts atrongest. Londing incrensed moch more rapidy than output. The best P1nanolal sloures avallablo relate to Brush, and aro given in Tablo 65.

Palling prices secm to have squeezed proflt margins from 1891 onwards. But as output was rising and capacity could be added at the margin quite cheaply total profits generally did not docline untll arter 1894. Novertheless lending to customers reduced the rate of roturn. Brush 13 the only company for which we bave good elgurow. They are given in Table 66 ore probably fairly typioal.

For a temporary recession propits were not very low when calculated in this ray. But the return on lisued capltal was considerably smaller. In the case of Brush the return on 1ssued capital plus loans seems to have been $6-7 \%$ in 1892 and as 21ttle as $2.5 \%$ in 1895. The difference between liabilities and assets was largely made. up of the value of patents. The market for patents was very volatile and 1t is inpossible to say mich about thoir value. Nevertheless there can be 2ittlo doubt that firms consistentiy overvalued thoir patents. They often aimply paid too much for them.

The combined effect of falling pricos, rialng lebiling to customers, borroring heavily on bonds, and pret overoapitalisation of patents and goodw1ll would easily produce liquidity difficulties. As a largo mroportion of output was in a few large contraots profsts could calculatod in a slightly differont way. 
Table 65.

Brush ossets 1897 - 2895.

(1)

Fixed capital

$\varepsilon$

As at Jume

2887

‥ 82,733

$2890 \quad 134,701$

92. 228,551

$92 \quad 138,044$

93

94

$95 \%$
(2)

Stock \& work

in progress
(3)

Shares in

other

companios

\&

988

21,534

15,092

39,399

42.732

42,925

61,237
(4)

Not tradg londing

\&

33,262

26,638

32.734

27.491

78,455

86,367

9,543

2. For some years figures are estimated by interpolation.

2. Debtors minus creditors.

Souroe: Brush annual reports and statewents at anmual mootinga.

The rapld rise in financial assets $(3 \& 4)$ stands out. Betrecon 2890 and 1995 they incroased by $460 \%$ while real assets (2 \& 2 ) increasel by 16;0. The exparience of the E.C.C. 2s sintlor. No figures are availablo before 1894. But betwoen 1894 and 1896 the value of output rose by $30 \%$, fixed capital rose by only $\$ 7,077$ (2\%) and stocks and works in progress by $\$ 15,026$ (35\%) while financial assots (net trado lendlag plus shares of other compantes) roso by $\$ 37.053$ (35\%) 
Tablo 66.

\section{Brush prof1ts $1890-25$.}

\section{Prorits 20 on items (1) \& (2) \\ $\&$}

Year anding

June

2890

20,029

9.2

8.1

1

23,854

11.5

9.4

2

35.661

26.6

23.4

3

34,395

2404

9.5

4

35,281

13.3

8.9

5

15.394

6.0

3.7

Sources Brush anmual roports and statements at moetingo.

Sccurate calculation of profits is not possible. The published flgures aro given not of debenture and other interost parments. It $16 \mathrm{coly}$ possible to make a arude adjustment for this.

Pluctuate ardenly. Somotimes penalties led to losses on ble contracto which would hitherto have been profitable. Somotimos costs were bady underestimated. Brush ran into diffloulties in 2895 because of a 2000 on the City of Iondon contract. Gonerally Brush profits were falrly stable. On the other hand the profits of the dymamo departmant of Siemens very considorable fluctuations.

Those Ifquidity difficulties secmed to have caused oonslderable 1 termian betwoon tho engineers and business men in several of the 20 re

1. Lo. men simply with cociseraial experience. 
Tuble 67 .

Gicmens Bros. Frorits on olecirical machinery.

\begin{tabular}{cr} 
& \multicolumn{1}{c}{$\approx$} \\
2388 & 2,646 \\
2839 & $-2,695$ \\
2890 & 27,823 \\
1 & 1,226 \\
2 & 629 \\
3 & $-12,577$ \\
4 & $-4,255$ \\
5 & 9,824
\end{tabular}

Sourcer Slemens Bros. Historionl Records.

11rme. Frow tise early days business men had an inportant sey in the polioies of eldotrical firus. Control-or partial control - by businese man was part of the price of becoming a joint stock compeny. Electrical

manufacturing firms tended to be ountrolled by esginecrs only when thoy wore rmall partnerships. Brush had always been controlled by business meno In 1898 - 9 IIvoil-Parker beceme part of the B.C.C. and Cromptan and Albrsight becaw Cranpton \& Coupany Itd. In 2890 the Electrical Revien collectod figuros of the occupations of company diroctore in establishod oloctrical companies. Only 20; of airectors vere englnoers. The non angineors wore often skilled in the market place - in buring and were businoss and gentlemen. 
sclling. But they had no basic underctanding of tho tochnical $15 s u o s$ 1mvolved. They no donibt picked up a lot of technoloky but they had not onsugh wide knowlodge or doep undenctonding to bo ablo to sce the Importance of new develogkients. They tended to be very aroited about the prospects of ner inventions in boorss, and very cautious about them in recessions.

In t.70 companies, the E.C.C. and Crowption, we know there wero sorfous quarrols betreen the technical and coumerctal 3 taif in tho mladie nineties. In the case of the E.C.C. It was compliented by the Balfour frauds. The financial position was such that the company had to be reconstructed in 2893. The management structure ras altered. The board was alrost completely changed. Tire old onc had becn largo with sub connitteos. Comordination was bod and the main board was often Ienorant of what wais going on. Several of the senfor officials ware ahanged. B. Garko, a corviercial mon who hod helpod in the ro-organtsation of Brunf In 2883 was appointed manains director. The ner administration soon horever calie into conflict with Parker, and In $2 k 94$ ho, and three important heads of departinonts resignod, presumably not ikking tho way tho ro-argan 1sation was taking place. The Boord had no desire to retain Parker as Forke Diroctor yet wished to keep hin as consulting onfincer. This Parker deolined and in $\Lambda_{\text {. }}$ il 1894 he left Z.C.C. to set up a campany of hlo orn, T. Parker Itd. 'The ner: E.C.C. board secons to have thought that extravacant oxperimentation was one of the causes of the troubles of 28903. 
WLthin Croiption and Co. thore was a quaridl for goars between

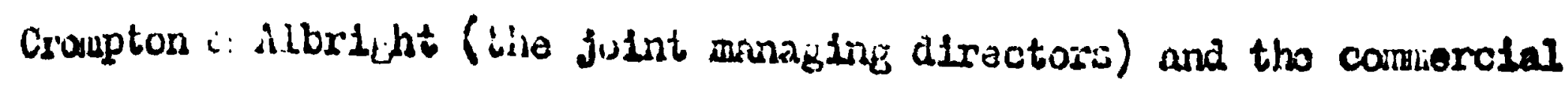
min. Dy the end of 2393 tine Buard had come to alislike tho ldea of two managing alrsetors ostonsibly bacauso thoy felt thol salarles were too hlgh. The major disegrecments seem to have been with Albrti, int and In 2893 ho laft the company. But Crompton also had his difforences - "oven before the Boer wiar a certaln amount of difficulty had artson, and id rolations with tho 3

flrm had suffered". Wie was horrever to "continue to superintend the technical sida". In prastice Cronpton took profressively less part in the affairs of the campany ana certainly had no mafor influence until after the first world war. 4 I'R. Reeves the Sicrctary becawo the genoral manager. Control tius passed decisively into tho hands of the business mon. The Chairman's specch explaining this is rorth quoting for the light it Nhows on the disputo betweon the busiross and tochnteal sides of the businose.

"In the early dujs of tise conipany there pas a great deal of exporimental work to be carried out ...... It required a great deal of applicaition and atienizion on line purt $0 i$ those who wars responsible for technical details and there is no doubt that, whilst the technical side of your businesu has been developed to the rary highest stato of efflodenoy. tho businesis side had got into a somemhat confused condition..... Nftor considering aif siciss of the culestion lt was declacd that what was required was to define more completely the two departments, nemely the teciarical side end the businesis sidc. I have already 3aid, thanks to the work of your technical advisor, principally $\mathrm{kr}$. Crompton the techntoal aide of the busines. is very goud inaced. In order to provide for the busines: side, the Board rosolved to appoint a general manager, who should not be a nerbiber of tive Buard, but open to overy possible critiolam and under the most canplete control.5

2. Letters from Viscount Emlyn (the Chairman) to Crompton 27 Norember 25 Deceribur 1893. Crompion iilistorical Rocorls.

2. Elect. Vol40 2708 is irarch 1890.

3. R.E.B. Crompton. Ii.cininisccnceg P 207.

40 He was very mach involved in foundinc the Electriod Enginearing branch of the Royal Engincors. He sorved in the Board Var, ifter it his main interest reverted to road transport. 
Those was sanothins in what he soid. Som technical developmente had been pursued without carotul consilcroilon of frossible proflt ond 1088. R.di.B. Crampton had startad an eleclric hocting and cooking departmont in 2896, oonsidering that they were going to bo riore important than olectrio power. This was a curlous declsion considering the vory high cost of

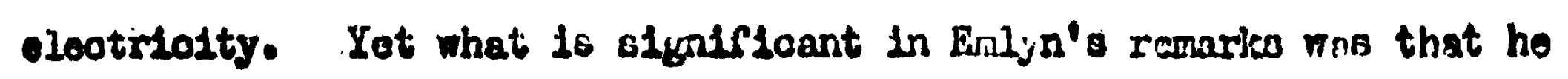
wanted to define more complately tho two aldos of the business, not to unite thom The conmercial mon had always folt that business matters whould be kopt awry frow the engineers; tilis was nom to happen all the more. Of the backwaranoss of Dinitish oleotrical : achinery manufaoture in the midale and late nineties there is no doubt. This 13 shom both in largo ara omall watters. The tiro mojor dovelopunts of the oprly and middle ninetios, electric traction and polypbase a.c. wero neglected or 1Emored.' In makings smbler improvements like adopting mult1polar rather than bi-polar aynowas tibey wiore aloo slow. Brush was slow to develop improvementas When it movec to Leugiborough the connopy resolved to develop Lts om high ypoci ensino. But it tock a long time to do this, and it was not until 2396 ihat J.s. Rarorth had developed the "Universal" onglne to the stage whore it could bo placod on the markot. This was too slow. Brom the late eigintios vin, tise succe.s of the fill ans high oped onuine must havo made it clear list the rato of return from a siaflar ongino wa

1. Seo Chanter 5 PP 170 - 1.

2. Soo Chapter 6 PP $251-3$.

3. Profossor Guldo Semenza writing in L'Elettricista.

Quoted by R.H. Parsons, op.cit. P 265 
higb. Also tho small high spoed enisino was obsoleto for most power stations by 2900 , because of big incroases in the mintrum effloient size of generalor. Llow whoh financial stringency delayed the dovalopment of the Brush ongine we do not know. But Ravorth was an ablo onglneor, and the Falcan works were qquipped for buildins steam angines. Also thero soems to have been no groat laterost in electrio porer. In 1893 Brush made an agreemont with the Ot1s Elevator Company to make eleotrio I1fts, but the first Otis lift was not built until 2893 . Tiare was no other apjarent intarest in elcotric porror - certainly it vas not conaidered inportant onough to be ment1oned in the quite full roports and Chalrman's epeocines.

I havo arguod that illiquidity was a major faotor retarding development expenditure. The offect of the return and the struoture of the copltal market in causing this 11liquidty apjly to three of the major producere, Brush, the E.C.C. and Cruspton. But lfather 8: Platt and 8iemone had other businesi activities. Unfortunately wo know littlo alout lathor * Platt. However mochanioal angineor'ing was depressed in the cards ninotios and wo may presuine that they too sufferod from liquidity problews.

Siemens beews to have had the same trouble but for rather opectal reasons. In the early ninoties it was st1ll primarlly a cablo maicing Plrmo In the four years 2092 - 5 tho value of the output of dynanos areraged EL17,586 p.a. while that of cavle avorajed 1407,038 . In the late elghties

2. Notoalf. Early liistory of' Brush $1879-12 y_{4}$. Unpublsabed typecourpt among the BruBh Historival recurda. 


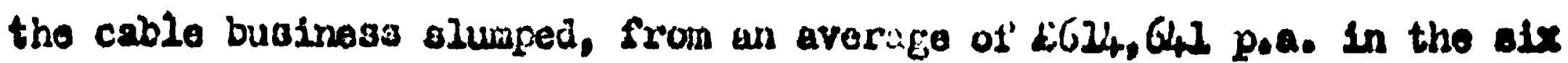
yoars 2880 - 85 to an arorage of only $\$ 271,059$ in 2086 - 92. Henco dynamo manufecture could bo expanded in tho yoars 1890 - 92 wathout as b18 an Increase in fixed capital as in the case of the other companios. Iot fixed plant continued to inaroase whon the anblo output grew agatn and eloctrlo wiring was instailed in tile worka. No inarease in finunoin assets appears in tho cocounts, but they wore vory heavily wolghted wh th the cable businoss.

Tesse 68. Sienions Bros, Assets 2837 - 25952 Pixed Capital, Stook and work in progross

Shares in other companies and not trede Londinge

$\begin{array}{rrrr}2887 & 154,966 & 73,391 & 290,978 \\ 89 & 162,069 & 103,396 & 274,278 \\ 2891 & -255,473 & 85,292 & 275,768 \\ 93 & 289,337 & 212,195 & -4,233 \\ 95 & 207,569 & 243,069 & 281,542\end{array}$

Sourcel Stemens Bros. Historlcal Recoris.

Slemens Bros. In the ninetios was olosely controlled by Siemen and Halake in Berlin. When Fillsam was alive it was more indopendent. !

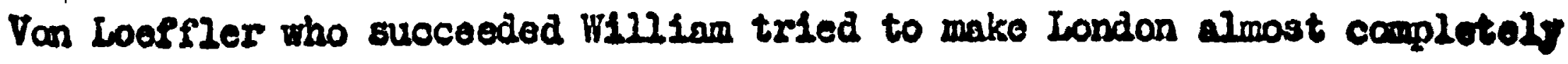
Independent. A quarrel with the Slemens famtly In Berlin developed but Looffler lout, resigned his managing directorshtp in 1830 and loft the company altogether in 2890. Hierner SLemens detenninod

1. For dotalls of the dispute seo J.D. Scott op.c1t, PP 66 - 67. 
that the new manacing dircctor should be one of the family and under olose contral. Alexandar Slemens, a third cousin to the brothers, who had boen 1 In charge of electrio lighting developwent since 2883 was chosen . Ito was kept on a tight rein. Almost all matters of significance were rulls reported to Werner and Karl. Werner died in 2892 and Kard seems to have treated Alexander very much as a junior branch manager. Shart term capital camo largely from Siemens and Halske and tho Deutsoho Banik in Berlin. Thls hampered Aloxander oven in his rather cautlous policy. J.D. Soott comients that the response from Berlin to his augjestions does not seen to havo been as arm as he might have hoped. Bexlin soems to have boen responsiblo for technical developments. There were probably oomomios of scalo In th1s arrangement, but it would havo hindered SLemons Bros. In so far as close contact between the market and innovation was nocesanry for innorations to bo adopted.

2. Born 1847, educaticd in Germany, Forked in Londan in 2867. Returnod to Geithinij. Inturned to Encirind 1871 and worked as a pupil of ifilizaw's mostiy on rogenerativo turnaces. Died 2928.

2. J.D. Scoit calls Aloxandor's policy an "smbitious, fighting polloy".. ithilo I huve not had detailed access to internol material on this point this view is not consirmed by the tone of Alexander Slement" puilic statencents. Sos Chapter $6 \mathrm{P}$ for comients on eleotrio power. 
Chapter 8.

Tho Manufacturors of Eloctrical Machinary $1396-194_{4}$.

This chapter covers the great boom of the late ninoties, the following recession and the boom just before the f1rst World Nar. Table 69 glves an indication of output trends, although the boom of $2911-\mathcal{U}_{4}$ soems to be underestimated. Section I doels with tho bock and poriod of new entry from 1896 - 1903. Section II doals with the dificalties of the recession $2904-20$. In Section III the strusture of the industry after the upheaval of $2896-1903$ is discussed. Soction IV 21scusses the 2921 - 44 boom. Soctions 1,21 and 27 contaln tables showing the expansion of flrms in the alternating poriode of qulakely and very alorly rlaing demand.

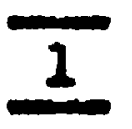

A now phoso began in British eleotrioal manufacturing in tho late ninoties. Thore was a major boom lasting from 2896 - 2903, a Large number of nerr manufacturers, and the rlse of important new firmo who ocl1psed the existing industry leaders. Tro prinolpal sactors 210 behind the change in the order of Importance of firms; ono was the very rapid sise in demand, and the reluctance of existing home manufacturers. to expands the other was the development of nerr products.

Op to the middle ninoties elootrical machinery was prinolpally

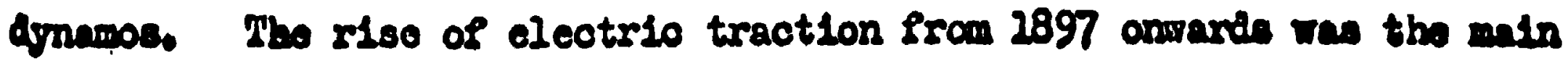


Tab10 69.

Sales of Electrical Hiachinery

Sales to

ut111t100
Other hom Total home Total hom salos

sales

ourrent

prices:

8000 647

2896

97

$98, \quad 1,210$

$99 \quad 2,799$

$2900 \quad 2,740$

$02 \quad 2,705$

$02 \cdot 3,200$

$03 \quad 3,329$

O4 2,827

$05 \quad 2,347$

$06,2,062$

$\$ 000$

$\$ 000$ valos

2907

prices

$\$ 000$
Export balance

(exports - imports)

Current 2907

prioes prices

$\$ 000$

8000
646

2,243

2,905

1,847

2,054

2,436

2,329

2,869

3,502

4,215

2,339

3,083

2,990

4,478

5,224

5,972
$-82$

38

285

304

426

808

938

$1,080 \quad 1,342$

$800 \quad 2,770$

8862,042

2,023

2,772

1. Bleotricity supply electrio tremays and the Iondon Underground. For mothod of calculation see Appenaix P 504. 
factor that changed this. The traction motor of the late elchties was a modsication of a dynamo. Homever the traction boom in the Unsted States 2890 lod to tho devalopment of a specialist traction motor, complote with opeolal control equifmant. Between 2889 and 2895 thero was very rapid progress in design., Tho operating effictency of traction motors rosel thelr wolght por horse porer fell; their eloctrical design was improved to make waterproofing tham possiblo; gearing was inproved to reduce nolse and matntenance. At the same time when demand was high American manusacturers vore ablo to build large numbers of traotion motors at 20 m undt costs. Flotor prices fell dramatically: from $\$ 4,500$ for a tro motor equipmont in 2889 to $\$ 2,600$ in 2891 and still further to $\$ 750$ in 2895. All prices at this time wero falling rapidly lut H.C. Passar attilbutes 35\% of the fall in motor prices from 2891 to 1895 to Improvements poculiar to motors - that is in addition to the improvenonts 2 whioh reduced the price of rallway generitors. In those vory youre 2891 - 95 Bnelish electrical manufnotivers 1Enored traction motorw, for whioh there was no demand.

As well as introducine spocinlist traction motors and control oquipsent, the riso of elcctric traction stimulated furthor changes in generators. Mraction put much heavior strains on generators than a1d 21 ghting and traction generators had to be more robust." 1100, both because tho anount of power used by a tramray in the average tom was woh greater than that usod for electrlc IIghting, and booume

2. H.O. Passer. op.cit. Chapter 17.

2. Ralliway genorators winy bo taken as typical of all rotating plant expopt, trnotion motors. If there is any bias in using thcir prices as ootimators it lies in overstateront of the average prioo fall.

3. Chanter 5. Section. 40 
the change In the load throughout the day was 208B, it became better to use bigger genorators. This ralruforced the move towards bigger generatore for I1ghting stations, whiah was taking place at the same t1me. Th1s was a Iimited movement, as most of tho plant Installed in Britioh Central Stations in the late ninotles was still quite amall. But novertheless it cought home manufecturers on the grong foot, for tro reasons. Flrotly bocause they wor conmitted to bullaing amall generatore sor high spoed onglines, and tho stze of hich spood onfine oould not easily be Inoromad. The Larger, elow speed generators made by Gorman and Amerlcan firme were of a deferent design and requifred different productivo resources to manufacture them. They wero phjsically mich larger pleces of machlnory. 3 Then in 1899 the I.C.C. declded to begin making slow spoed generatore they had to put up a now ohop oquipped with tro special extra-large drilling machines, Socondly these large generators rore partly becoming mare advantageous because they genorated polyphase a.c. For traction, d.0. motars were moh bottor then a.c. ones. But a.0. of fered moch cheaper transmission at high voltages. Thus in the midale ninetios American engineers doveloped a system of high roltage polyphase a.c. transmission and conversion to d.o. for fooding soctions of the tremray or rallway. Single phase a.0. was not sustable fors tho converting plant. Ifighting was often on a.c. distribution notwarte. A choap way to increase capacity by the late ninoties was to builda now polyphase a.c. central stations, transmit at high roltages and

2. Chapter 3.

2. Chapter 3. P 98.

3. The $4000 \mathrm{KNI}$ flywheol altermators at lianohester's Stuart Stroet otation rolghed 232 tons oach. 
convert to d.o. to food the clatribution notrork.

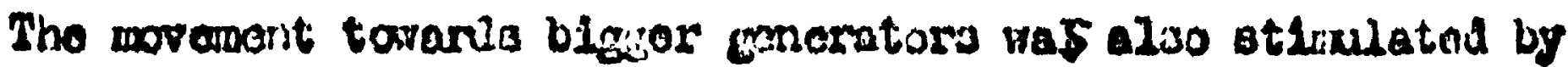
1 the dovolopront of the Parsons atnam turuine. The turbine had aroats

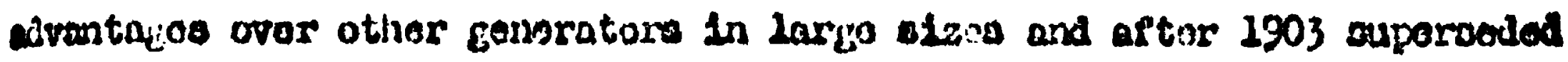
the large low opecd ganorating sot. Lynanos for lurbinas wore rathor

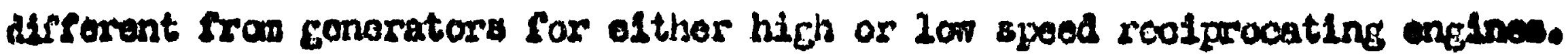
Thes were abjoot to particular woobanioal stroins bocauso of wioln vory Heb opoed of rotation. The stresses wore particulariy bed with b18 plant. For examplo quito conoldorablo difflaslitos voro expertoncod

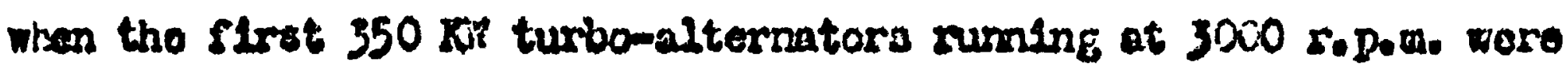
Installod. ghore wore teothing troubles, particularily with the alternatore, whloh pent on for about 01 uhtoes wonths, although aftar that the sote warked we22. Tho dovelogwent of the htigh opood altermator is as much

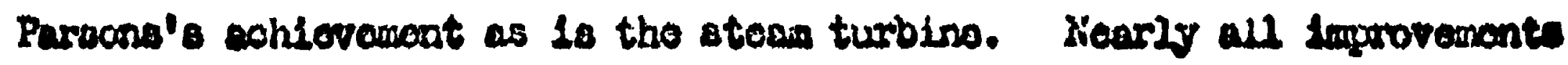
aro due to hlm, and until aster 1902 - Os no othor Britioh eleotrical onesinoare shered and intorost.

4. Thore wore ofthor motor generatoro or rotary convertors. The formar

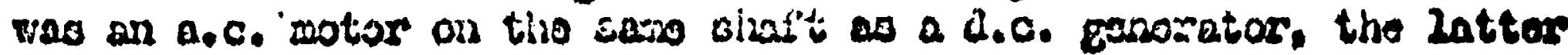
a machino with an armature wound for both 0.0 , and $a_{0}, 0_{0}$, with a.0.

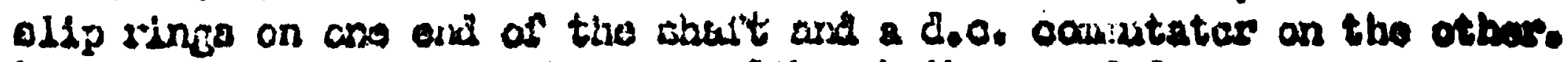
Rotary canvortore were oheaper, although thay needod a marromers exequoncs rango.

2. Chapter 3.

2. R.B. Paracos, gpacite IP $79-83$. 
The edvent of factory porrer Introduced a rather nerr and more speolalist produot - factory motore. Bofore the late nineties most -lectrio motors were little aifferent from aynamos. This was because very 21ttlo eloctrle power was usod. But with the advent of throe 1 phase a, c. and the big reduction in motor prices 2901 - Os many more motors were used, and attention was given to partioular dosign problews, and to particular manufacturing mothods. During the years 1901 - 05 opoclalist machinory wastpat dota in Englishislectrical machinery factorlos for making Industrial motors. But there was no divorce botween motors and other plant. Large motors - more than 50 - 200 h.p. were $11 t t 10$ difforent in particular technique from small generators and rotating converting plant.

The emergence of these new zub division of olectrionl machinery, traction equipments, large generatore and factory motors lod to considorable 'entry into electrical teanufacture. Praction ofuipment alono attracted three very large Ploiss, all bigger than exliting home manusaoturers. Two, Brit1oh Thomson-Houston, and British Westinghouse were offshoots of exlating 2 Americon manufacturers of olectrical machinery. The third, Dick, Korr 4 Co. was an established mechanical engineering firm specialising in road transport with considerable experience in butlding equipment for cable and steam trampays. B,I-H and Britiah Wostinghouseo did not bogin manufacturing In Britaln unt12 1902, but beforo that large quantit1es of equipment bullt

2. Chapter 6. P. 258.

2. Brit1sh Thamson-Houstan of General Electric Co. of Soboneotedy N.I. and Britioh Festinghouse of the Wostinghouse Bleotrse and Kanuecturing Co. of Pittsburg Pa. 


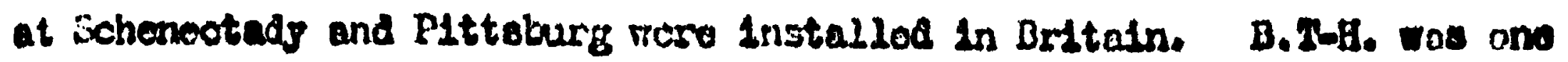
the

of the primo movers behind beginrings of eloctrio traolion. 2

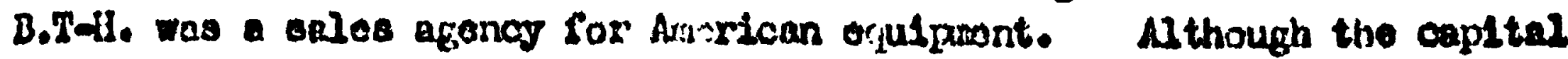

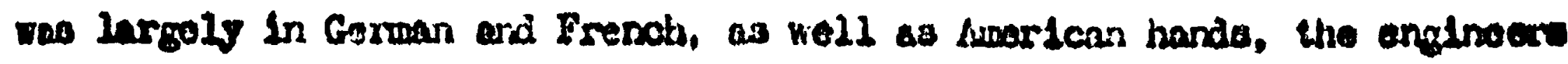

ware Americars. General silectrla proviled two of dta bast traotion 3 angineare, II.F. Parshall and H.X. Llobart. ouse Sron Genom sloctrio.

All tho plant exospt moters 5

2. Chapter 5. PP $171-2,198$.

2. In 2036 Laing Pharton and Dam had been formod to soll Thomsan-linuston

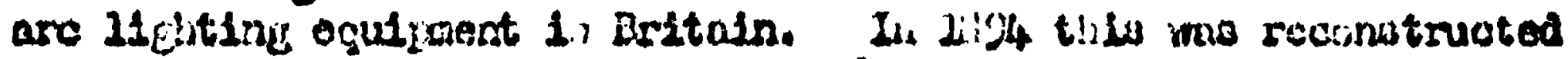

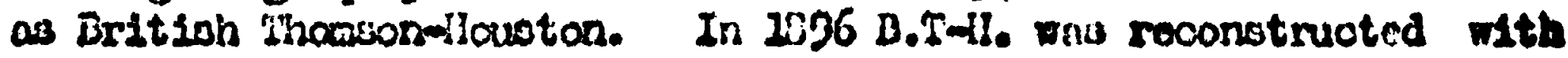

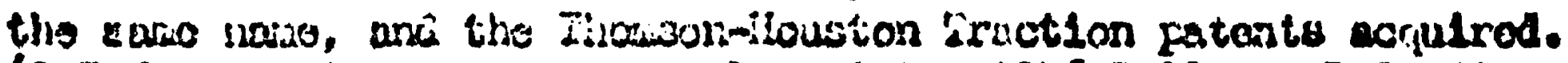
(B.T-1l. 130-1nisconcos, privatcly printed 1246 P 21 and R.3. Edwario

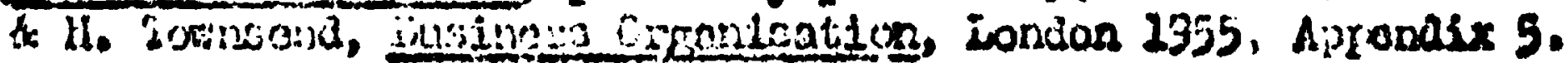
Tho Devaloxiont and Orianichtion of A.R.I. by G. Naller, 8305.

3. Born 2865. L31ford, Her Horls. Elucatod ot Cornoll a Lohtgh

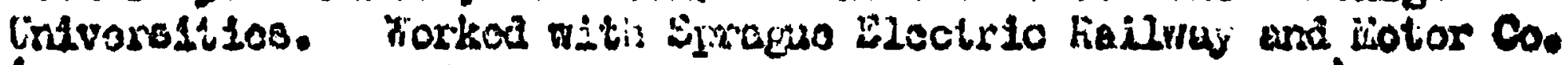
(Spracuo vow one of the rost inpartant traotion plenears) ilo

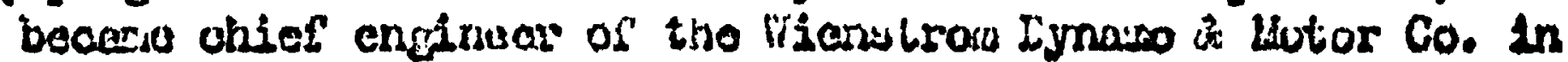
Beltimoro where he levolojod tho 4 polo slon spoed rallwar motor.

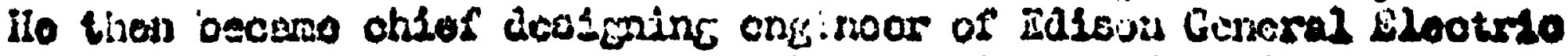
and staved on as such when Constul Eleotrio was Sormod.

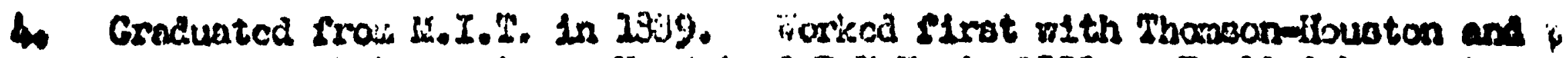

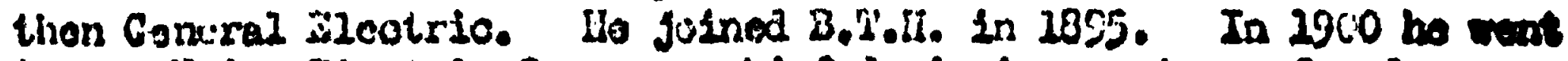
to the Union Electrio Co. as a cinich dooluning engtnoar for doco. wailuory. In 1903 ho roturnod to singland as a consulting onglnoar.

5. Berti. Reninlocencos P 20. 
A very large mount of the traction motor equipment, used In Britatn in the early days of electrio traotion was Amertcan. As the ear2y olectrio traurray and rallway contracts woro usually for all the electrical oquipment, the statistios of the makers of generatore givo good ploture of the ecneral situation in the absence of other 1iguras. It the beglnnting of 2898 the Electrical Trades Diractory gavo details of $3840 \mathrm{KW}$ of generators in traction power houses. $2830 \mathrm{ITI}$ was distinguished by maker; $35 \%$ of this was made by General Bleotrlo and Mostinghouse. Cenerators totalling 11,420 $\mathrm{kW}$ were in the course of manuracture or erection in new traction powor houses. 20,860 KI was distinguished by maker; General Electrio was supplying 9,000 kW and . Testinghouse 1,200 km. Figures of motors supplled are unsatisfactory but there is no doubt that in the years 2897 - 1900 the General Elootrio motor supplied through B.T-H. was not only used more than any other make of motor, but probably more than all other motore put together. B.T-H, wore so successful that is is not surprising that they wero soon 20oking for manufacturing f'aclities. A union with Slemens Bros. was proposed which would provide B.T-1I. with a factory, reduco compotition 1 and pool englneoring experience. But the Siemens Directors in Berlin . 2 doloyed and the ldea lapsed. Genoral Elootrio then bought a controlling

1. Siemons \& IIalske were strong In troction equipment and SLemens Brow. was perhaps the strongest potential competitor in England. They were bullaing the electrical equipment for the Waterioo and Oity resizay at the time.

2. J.D. Soott. op.cit. PP 70 - 1. 
share In B.P-H., a factory was butlt at Rugby during 1900 and 1901 and momushor buring bogan in Irarch 1902. All the inportant starf of the new faotory oane from Genoral Electric's own organisation.

Testinghouso hed also had a sales company in Britaln for somo 3 time. In 2897 an lraportant contract was obtalned for three $2500 \mathrm{kII}$ tro phase altermators for the Millesden contral station." Whon eleotr10 traotion began to dovelop in Britgin, Goorge Mestinghouse becam Improssel With the sise of tho potential mariset. Ho particularly noticed the 5 density of traffio on British railways. In the sumnor of 1899 he bought land at Trafford Park, Lianchester and founcied the British Festinghouse Blectr'so and lianuracturing Co. Until manufacturing began at the end of 2902, Westinghouse plent which was installed in this country in oonsiderablo quantities, was built at Pittsburg. The key posts in the new worke wero fillod by Alocicans. Americans were also placed in $20 s 3$ important posts and Weatinghouss even brought oighteen forowen from Pittsburg. Ho also anlisted a number of Bnglishmen, mainly from technicol Institutions and sont them to Pittsiburg for two years training, proparatory to tholr oocupying the lesser poots at llanohoster. Later they would fill the

\section{B.T-H. Raniniscancos, P 12 .}

2. They were the Hanaging Directar, The Managing Encineer, the Traction Engineer, The Horks ifanager, tho Asslstant Horks Manacer, the Hanager of tho Rugby Lamp Forks and the Genoral Commercial Nanager. (B.T-HI. Rominisconcos P 17).

3. The firgt Enclish Testinghouse Conpany was Po ndod in 2839, no doubt in connection with the supply of genorating plant to the Sardinte stroot Station of the ietropolitan ileotrio Supply Co.

4. Chapter 3. P 101.

5. J. Dumolor 2899 - 2949. Privately publiohod Hanchester 1949. P 2.

6. 'ibid. PP $13-18$. 
Important posts wisen tha Angricaris rent hose.

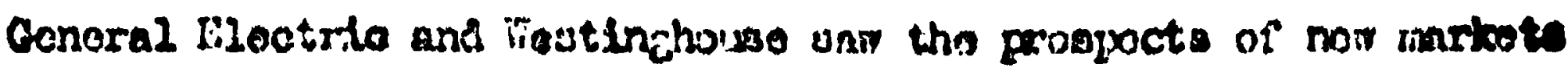
In Dritain, but thoy wera alko drivon lo luak. for nen oitlote by the deep

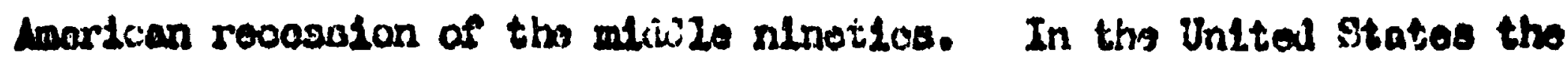
domand for elooirical mechinury ineroosod raplaly during the olphtios with

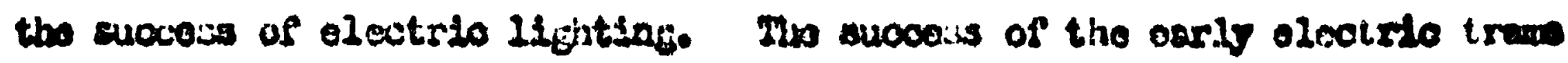

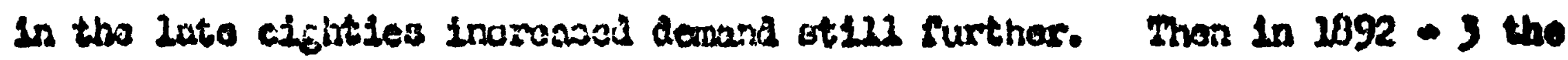
bocm broke ard tha subsequent rocosolon wos ling and soverv. Not unt12

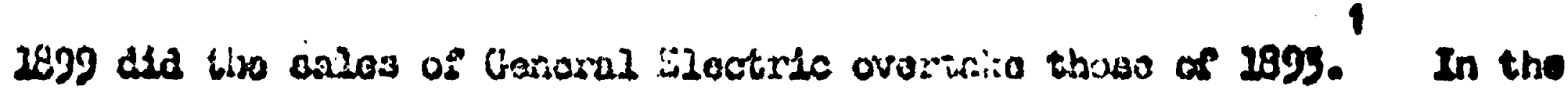
ofroumatarcos it is alenost odrtain that there was ascoess onpacits untll the Late ritnotios. Tho Tiost ingbouso gosition ras doubtiase similar.

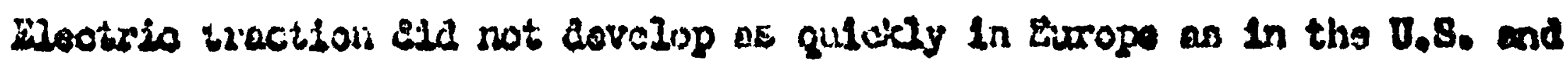

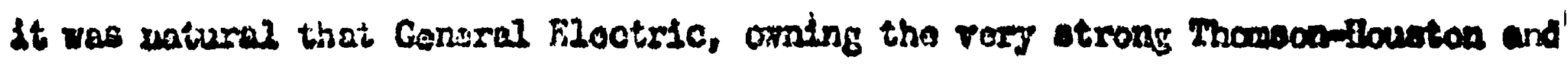
Sprrabuo patonts sbjuld souk to opon up the European eloctilo treotion martert.

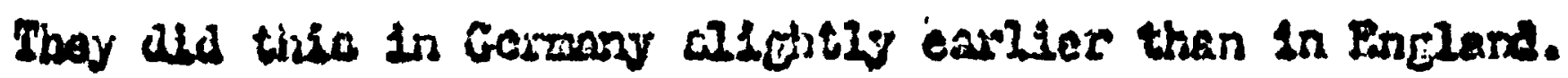

\section{In 2097 Licis, Kori and Co. Woulht a factory in Prosten to}

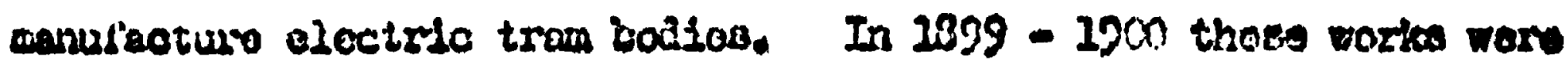

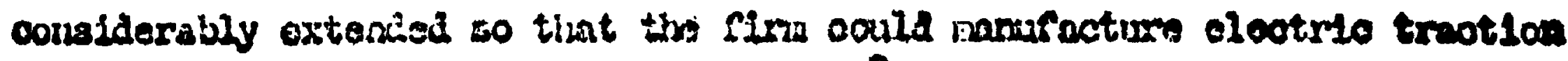

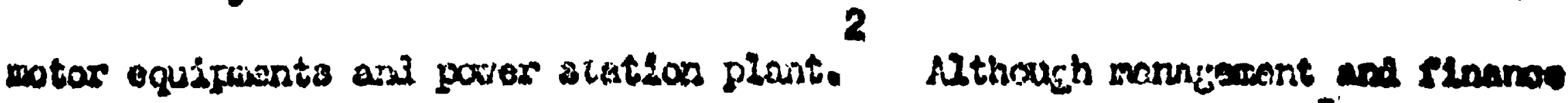

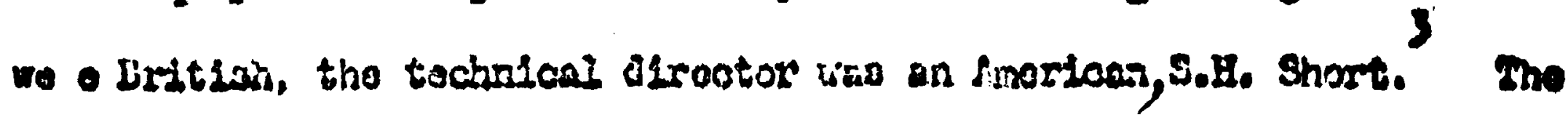

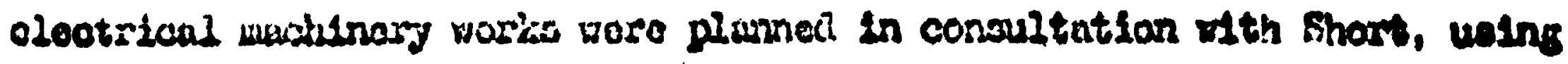

1. R.C. Pessar, onacit, P

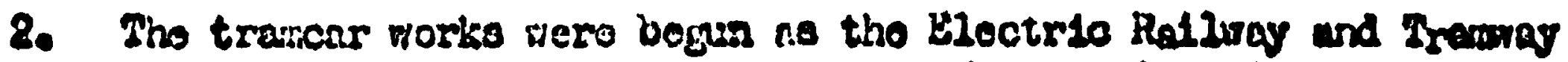

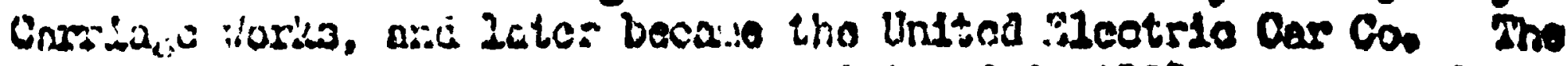
- loctrical inchinory woriso noro roi Lotored in 1898 as the Bnylloh

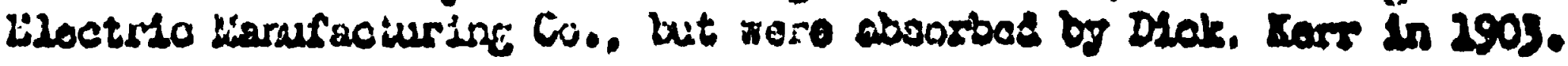

3. over ... 
Amcrican machino tools and the wachlnory wis to bo built under his patents. Although thoso three firms wero attracted by the traction plant market, they were all producers of all electrical machinery. They wero ready and ablo to build polyphase equijmant, large Eenorators, and factory motora as nell as smaller jynawas traniforwers convorters eto. Dut there were also more specialist entrants. I'vo f'irns entered because of the possibilities of blecier genoraturs - Ferranti and Parsons. Striotly

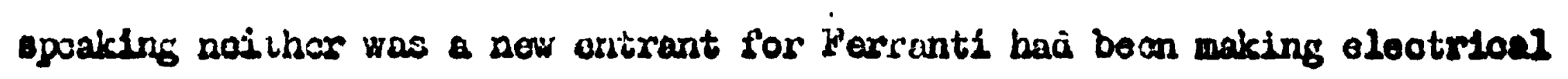
machinory since 2882 and Parsons from 1889 (1884 when a partner with Clarke Chagman), but in the buom period 2896 - 1903 thoy botth becano new large producers. Tizere was considerable similarity between then, ther wers both foundod and controlied by greati inventors, businoss man woro Important in neithor. Tho major differance is that Porrenti fallod whllo Parsons succoudeâ.

8. Born 2858, Columbus, Ohio. Educated Ohio Stato Univorsity. In 1878 he becam sissistant Profestur of Fhysics at Deivor University. Ho workod on ratlway motors and in 2885 resignod his Professorship to concentratio on olectiric railway work. In 10339 ho moved to Clevelend, Ohto and formicd the Short Eleotric Railiray Co. (Brush was a largo sharoholdor) to inanusivetirre railway muohinery. In 1893 ho became connected with the Falker lanufacturing, Co. of Cleveland. The Walker Co. entcred electric traction and was so ouccessful that it was boul ht up in 2893 by financial interests controlling the liestingliouse Co. In 1373 Short cano to England to complete tho arrangemonts with Dick, Kerr. He intended to return soon to the U.S. but aldd in 2902 af appendicitis. (E.K. Vol. 52 P 74732 Ootober 1902)

1. S.11. Saul. Ths Anorican Impact on British Industro 289.5-1914

Business History Vol. 3 ? 33 . 
Forrant1 was the one English electricel manufacturor who bulit dynamos for direct coupling to slow speod ongines in the middlo ninotles. After be left Dopford Ferrantil concontrated on bullaing slow sped alternators. Ho got several contracts including a $2000 \mathrm{kN}$ alfernator for the Iondon Eleotrio Supply Corporation in 1393 and two $2500 \mathrm{KMT}$ alternators in 2895. In 1895 he decided to becin the mamefacture of stoem oncines, and thus produce tho whole generating sot. Thus ho bought a larger rorks at Hollinwood, in 1896. This was a good time to begin the manufacture of large steam altornators. The market for electricul plant was expanding rapidiy, and one would have expectied the future of Large slon spued generaturs to ive good. But the firm did not suoceed. In 2903 it went into the bands of the Receiver and the manufacture of stoam dymámes ceased.

The principal reasons for this fallure secm to bo in the personality of Ferranti hinseif. There is no doubt that ho was an engineer of genius; there is equally no doubt that ho did not have muoh comerotal senso. As early as 1893, Ince, his finencial backer, had crpressed unease at Ferranti's habit of endlessly improving machlnos whise makeng them. His complained that there was a groring numbor in a sentcomploted state whllo very fer had boen finished. 3 At Hollinowood the altuation was similar. Engines wore produced incorporating flrst rato onginsering design, and each with 1ts own innovation. But. dozraxy

2. Botween Hanchester and OIdham.

2. And also his father-in-lar.

3. Lotter Prom Ince to Porrant1. 23 April 2883. Porrant1 files. Hollinwood. 
was noarly always very late. Penalties for late delivery were usually heavy. F. Bailey tells of mary examples of late dolivery and the consequent finnnclal losses.

"(At Banks1do) he acceuted an order for two stcen alternators of 15 :0 Kr cach. and once nore improved on everyt ing he had done before, but, unfortunately there wns on alarning delay in delivery. The first enfine, pronisod l'or the end of 1836 wis not at work until 1898 .... The second machino was finished in $1899 \ldots$.... These englnes were full of novel an ingenious improvenents; ....... At Pajaley dolivery was two years late under a penalty of $\$ 5$ per day ...... At Horcester $3 .$. tho delay was three ycar's before a satisfactory test could be mede. 12

Also it is very ourprising that Jerrant1 socms not to havo ouncomod himself' with polyphase a.c. All his alternators wero oingle phase. By tho late nineties it must have been clear that large polyphase alternatore had additional advantages, and one of Berrenti's missions aince 1887 had boen to parsuade supply authorities of the advantage of large scalo generating plant. In mitigation, however, one must zemomber that the average oupply undertaking was not intorested in polyphose aoce and the smorioan enginoers engaged in dosigning trwotion soem to have proferrod roll tried Amerionn moohinery.

Parsons by contrast was very auccossful, by 1904, as Tublo 80 shows, 22; of the generators Installed in British Central Stations wero built by that pirm. I'his was a poaks later, othor turbino manufeoturers ruducod tho Parsons share. Bnglish oentral station wore slow to adopt

2. Perrantl was ablo to escapo this ponalty in tho ond.

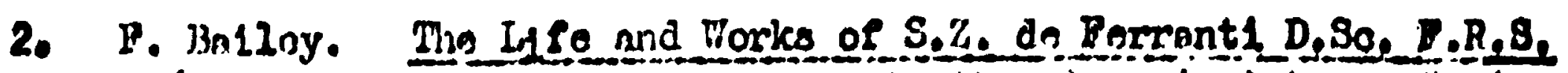

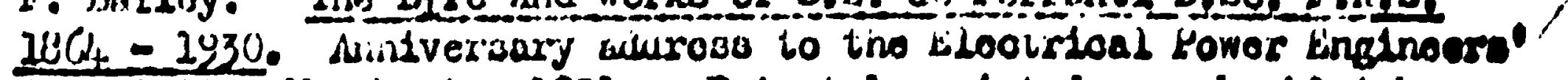
Aisuciation lenchestor 1931. Privately printod wa bodelot by Perrenti Ltd. HoLlinwood. 
tho turbino, but this was partly bocause tive devolopnont of the turbine

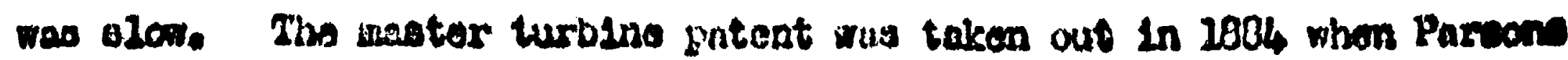
was a Juntor partrax ulth Clarko, Chaprosan and Co. In 2309 ho quarrelled wlb Clarise, Chaponas and left then to found a firn of his

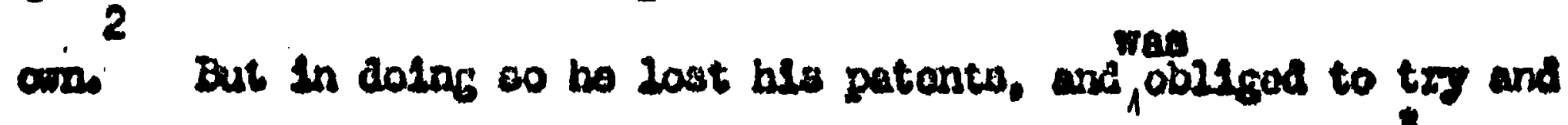

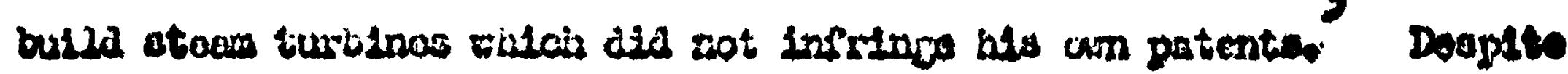

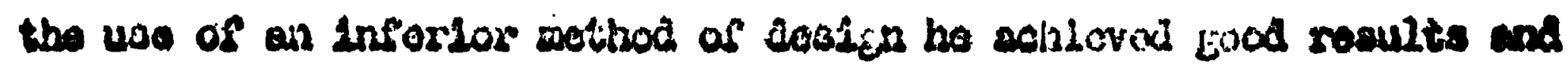

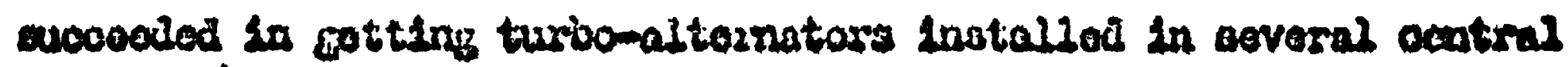
otatlons; In 2894 he purchased his paisonto srom clarke, Chopean but by the oni of 2393 hod already ceclued to covelop tho stoan turbine far

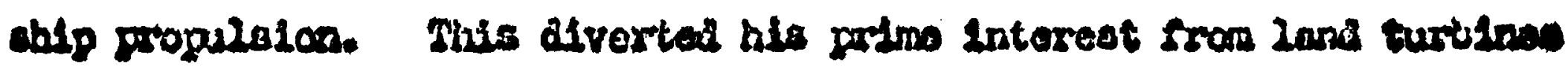

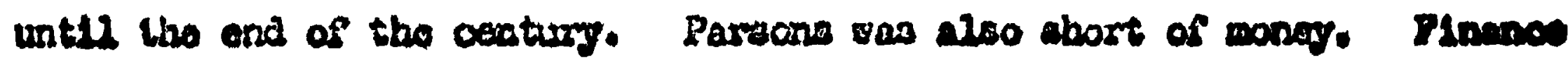

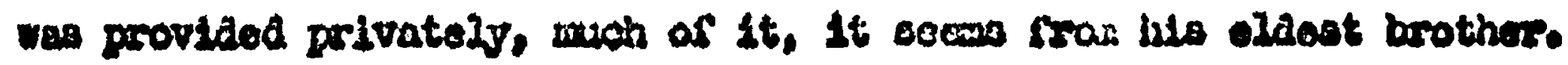
Siot untll 2913 ald his 1 Irm becows even a private company. Parsans oniy turbo oloctrio genarating mochinong."

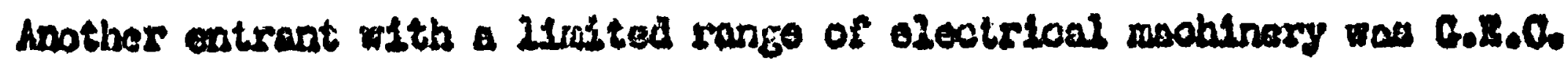
Orlginalis a firm of aloctrical apparatuss wholosilars, it began to mate

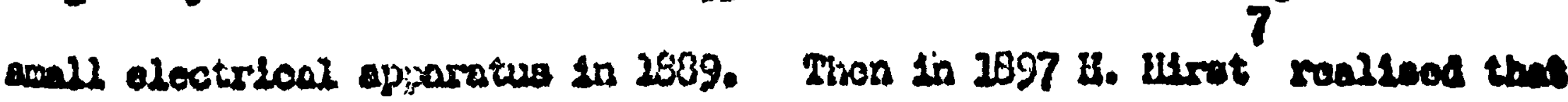

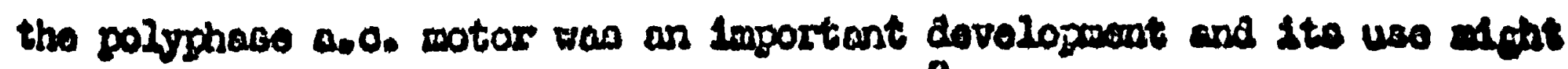
8

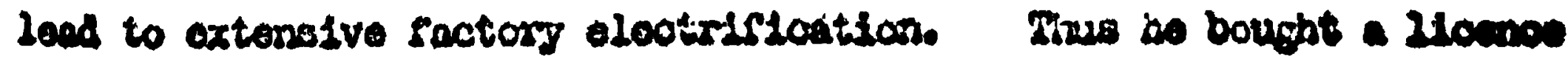
1. Chaptor 3. $28105-7$.

2. R. Appleyari. Ciandos Parions PP 06 - 7 .

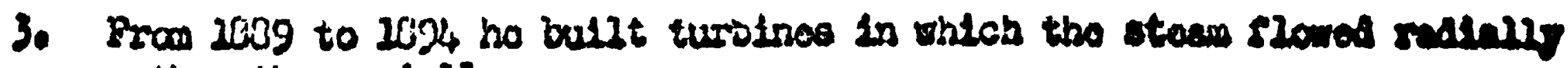
rathor than asially.

40 Rolt. Farsons, groolt. EP $273-9$.

5. The flrm aloo mode condersore. inzine turbings were mado at the Parsons iarino Turbino iior:s at hallound.

6. Tho Conoral Eloctric Company. Roforiod to as G.R.C. to distingulah 18

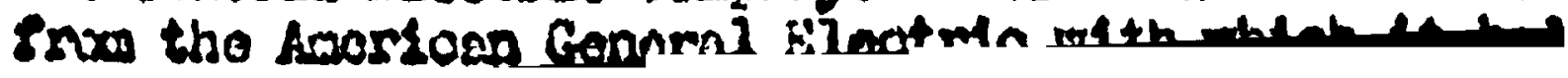




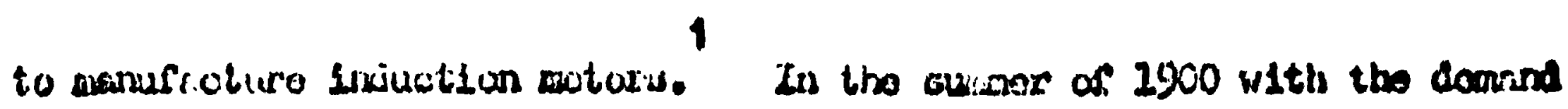
for heavy plant mich in oxce of tice culply G.i.C. deolded to construbt

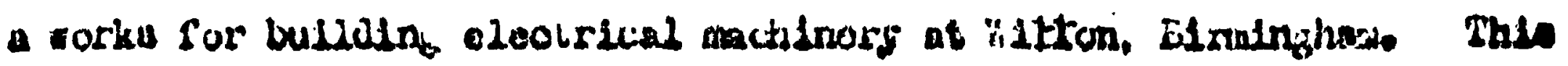
was for larko plant, ellelly cenoratura, and large wotors, whoro tho

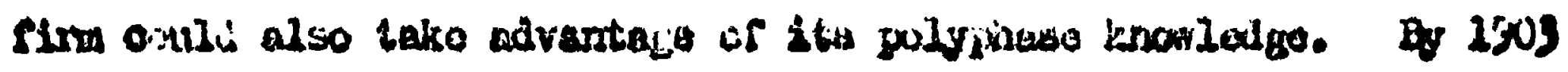
the soctory was at work. In tho eurliest ays very largo senoratore were not mado.

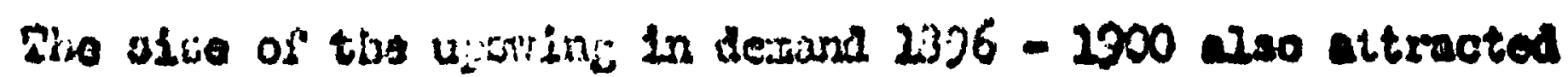

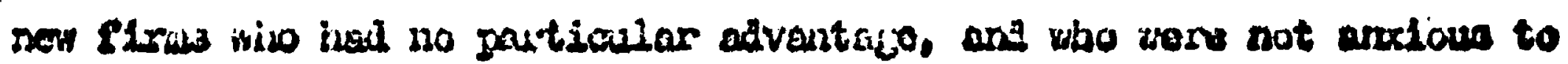

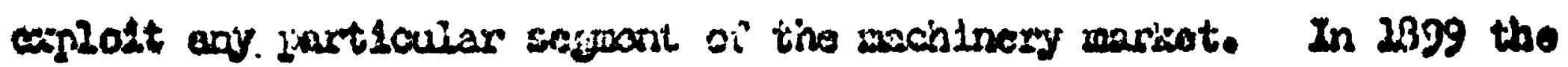
Firm oi D. Irvoo Peebles, having very recentily started the manuracture

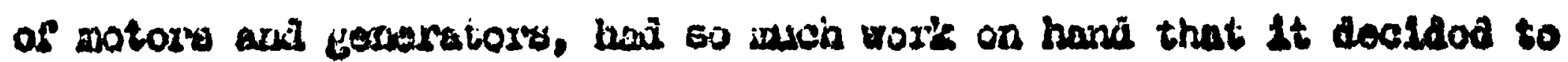

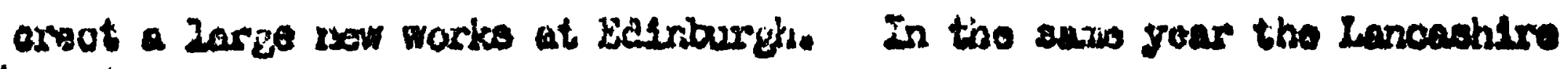

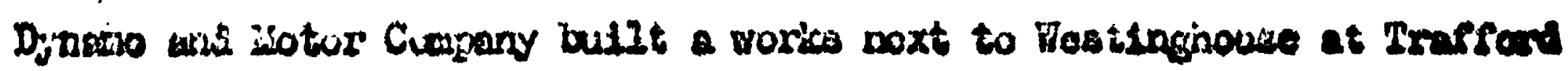

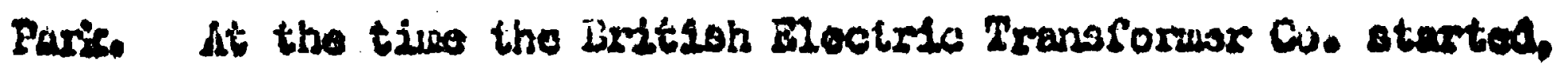
concentrating an the sesnufocture of aliatic tranuformers.

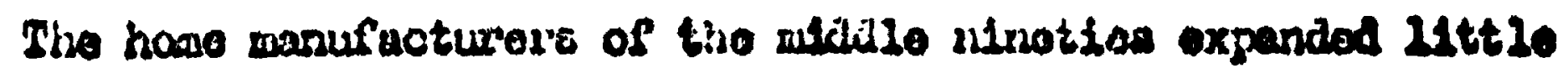
In the bucta. Ihay wore IIIIsald, they had boon tiursugin a lean timo of rising outfut and fulifing prices, they had ecen the optinietlo axpoctatione of $28 x$ ar and 2083 - 90 fodo raplaty. Control had paosed Into the hands of

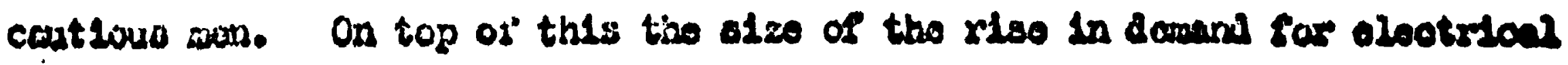

7. Born 1863. He was educated at the Connercial Industrial Schools and the Polytechnitoum of Munich. 2882 joined L.P.S.

8. Craplor 6.

2. In Indution wotor to the ardinoering term for a palyphase 4.0. wotor 
Table 70.

The Expansion of Assets. $2896-1904$.

\begin{tabular}{|c|c|}
\hline $\begin{array}{l}\text { Incronse in } \\
\text { Ixod assets } \\
\text { after } \\
\text { depreclation }\end{array}$ & $\begin{array}{l}\text { Increase if } \\
\text { stocks \& } \\
\text { work in } \\
\text { progress }\end{array}$ \\
\hline
\end{tabular}

Increase in Inanotal ussets.

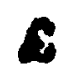

British Test Inghouse

(to July 2904)

$2,008,321$

$2,249,493$

257.042

B.T-H.

(to liarch 1904)

427,635

$266,233^{2} 744,452^{2}$

Dick, Kerr \& Elect.

RIy \& Carriarge Co. .

(to Juno 1904)

$\begin{array}{lll}710,050^{3} & 191,880 & 278,479 \\ 276,767 & 121,839 & \\ 202,975 & 445,828 & 208,592\end{array}$

S1emens Bros. Dynamo Works

(to Doc. 1904)

93,695

$56,494 \quad \cdots \quad 29.512$

(to Deo. 2903)

Co.

Brush

(June 1896 - Deo. 2903)

55,819

86,357

40,822

(March 1904)

35,928

E.C.C.

(Juno 2896 - Lay 2904)

$-6,335:-8,645$

Parker

(to Apod 2904)

25,802

28,856

23.552

G.B.C. (Witton)
$($ to Dec. 1906)

214,913

58,352

British Elootric

(to Dec. 1904)

29.313

21,21

28,294

1. Lending fros the parent firm has been deducted in the accounts. Inis is likely to have bocn $\& 100-200,000$. Aloo the parent leant hoav14y to custumers through Traction and Porer Securities Itd.

2. Wous in procress is included under "debtors".

3. Includes goodrill.

4. As Siemens \& G.E.C. Were involved in business othor than the manufaoture of elocttical machinery firm data is not rclovant. 5. Earlior 81 gurve 


\section{Table 71.}

\section{The Source of Funds $1896-1944$.}

\section{Borroring}

on ordinsry on Praf- on Daben- on Loans shares

erence tures

Rotalned prosis

before dopsen sharas

\& $\quad \&$

8 clation.

British Festing houso

(to Jury 1904)

750,000

$2,500,000$

616,353

200,750

$\boldsymbol{s}$

B.T- $-\mathrm{Hi}$.

$\begin{array}{llllll}\text { (to Larch 2904) } \quad 200,000 \quad 395,690 \quad 212,000 & 313,178 \quad 253,563\end{array}$

Dick, Kerre \& Eleot.

Rly. \& Carriage Co.

(to Juno 1904)

270,000

$200,000,273,642$

$N / 1$

$x / A$

Brush

(Juno 2896 - Doo

$31,009, \quad 32,009 \quad 75,000$

43,976

72,958 2903)

Crompton

(Marah 2896 - 2904) 259,050

200,$000 ;-4,606, \quad 60,680$

Li.C.C.

(June 2896 - Lias,

4,200

30,094

77,870

$-95,500$

66,500

Parker

(to April 2904)

23,636

$20,700 \quad 21,596$

29,653

The l'igures in this table are only very crude. Nert shares are shom as boing sold at par, except where thero is ovidence to the contrary. Dut it is likoly that thcy oitien wore not eold a.t par. These strictures aleo apply to Tablest and it is only possible to collect these figuros for some companies. Sosietires reconstructions have meant ono has to eliminate flrm, comotimos, as for example with Siemens, the balance abeot Informatim is utterly inaciequate.

Bourcos Company Balance Shoets.

- 78 and 87. 
machinery in the late ninoties was quite unoxpeoted. Brush and Siemene were the only ones to expand substantially.

The Brush expansion was ohlefly in the traction department, and was more in rolline stock than in motor equipment. Capac1ty was first extended in lifarch 1898, and further extensions were made to the car shope in 1899. But not until $190 J$ was a plant lasd dom for makeing trucks. After 1900 Brush often made bodies to be porered by another manufacturer'. motors. Inpansion followed the rise in demand. From the end of 2896 Brush began to work in assoctation with British Eloctrio Iraction. The association became [rogressively closer until by 1906 (or possibly oarlier) B.B.T. controlled the majority of Brush sharos. Othor Bruch dopartmonts were neglected. They ohowed no enthuslasm sor large genorater work or faotory eloctrification.

Siemens like other home flrms socens thot to have been anxious to expand rapidiy. But by 2899 Berlin was dissatiofied with the slow progress of the London flrm. They wanted a large hoavy plant worke in Ingland similar to those of Siemens and Halske at Charlottenburg. Bventualis land was purchased at Stafford and a factory busit. In 1903

1. Chapter 2. PP $92-3$.

2. Lather \& Platt built a new works at this timo. Unfortunately wo do not know how wuch the electrical department expanded.

3. The truck consists of wheels and motors. The very early eleotrio trams were built on the horso car principle, motors boing eltted to a body which vas built to be pulled. This was not very satisfactory and was changed to tho truck principlo - bodies being mounted olthor In two sct3 of tractor bodies or on a four whecled trucks the advantage of the lattor design was that the motors wore an integral part with the whoels - tho unit thus being atronger and 2080 Iltedy to be damaged by running. 
tho dynamo departmont was moved there from Woolwich.

The fallure of Lour of the five maln producore of the early and midale ninetles to dovelop the now very large generating plant, meant that they wore slowly squeezed out of the central station generator market. Wather and Platt shlfted quickly to bullding plant for factory electrifloation In 2898 they bullt their first induction motors, and their doliverfes of contral station generators fell off vory sharply after 1901. Parker, when taken over by Rees Roturbo in 2906, also gave up central station gonorators. Brush concentrated on traction and nover bullt very largo generating plant. Crompton too never bullt vory large plant, but continued to build central station plant for electriaty supply station In small towns where there was insuffiolent demand for blg plant. Tho B.C.C. having Installed special plant for $2 a g^{\circ}$ generators In 2899 contloued to build somo. But they rere not important in this fleld nor was it of major importance to E.C.C. afthe 1900. Thoy do not seem to have nade genorators for steam turbino driven units.

1. 75 years of Blectrical Engincering. A brier hlotory of the Wathor and Platt Electricol Departmont.

2. Cranpton had a special arrangement with the Eleotricity Supply Corporation. Lato in 1902 Crompton helped to foril the B.S. Corp. It took over the Chelmsford station and several provisional orders from Cronpton. Supply was berun in Dalkoith, Dollar, Jedburch and Molrose in 1904, in Exmouth in 1905, in Dumbarton and Falmouth in 1906, and in Totnes in 1911. Crompton was to act as contractors for the Corporation at prime cost plus 15\%0. In lisay 1905 this ras modified to prime cost plus 10,jo Theso ware all small control stations - by December 1906 the E.S. Corp. had spent only \$272, 024 on capital account (oxoluding Chelmoford). Only a swall proportion was on olootrical equipment. (Based on the lisinute Book of tho E.S. Corp. Among the Central ElootrLloity Generating Boand llistorloul Reconds at Groat Portined 8truct 


\section{II}

The demand for eleotrical meohinery rose very rapldly from 1896 to 2903; after 1903 1t rose much more olowly up to 1910. But as Tablo 72 shows there was no marked recession in elther the value or volume of output. But there was a considerable fall both in pricos and profit margins from 2900 - 01 orwards. There are two reasons, the collapse of the Cerman bocm in eleotryical oquipment in 1900, and the fact that by 1903 - O4 therv

\section{Tablo 72.}

British Production of Eleotrical ilachincm 1903 - 1923.

Cubrent pricos

8000

$2903^{\prime}$

2904

05

06

07

$\infty 8$

09

2910

21

12

23
3,967

3,721

3,556

3,676

4,547

2,972

4,209

3,487

2,824

3,253

3,625
2907 pricos

8000

2,387

2,353

3,026

3,818

4,515

3,223

3,967

4,332

6,248

7,265

8,743

Sourcer As Table 69. 
hed been so much ontry into eloctrical manufacturing that there wae oreroupelolty at home.

The traction and central station boon in Germany had begun oarlier than in Britatn, and fintshod earlier. In 1901 there was a oharp rocession in the demand for eleotrical plant, and this lod to a sharp rise in the propensity to export to Britain. As a result prioes fell sharply. In the years 1901 - 04 thero are many Instances of German flrms tendering particularly 201 prices. Tho tenders for the L.C.C. tramray generators in 1901, givon in Table 73 provide a good exemplo. The Continental tenders were particularly 201 for the throe phase a.c. generators. Othor examples could bo given for anall and medium aleo as well as large contracts. i The slow growth of demand after 1903, made the overcapacts of 2903 - 4 difficult to digest. Prlces contimued to fall and profite declined to a low level. This overcapacity was largely concentrated in throo firrs, British Festinghouse, Slemens and G.K.C. The first two trled hard to achieve sull capacity working and were rosponalble for driving dorn prices. 111 three made loror profits than other manufacturare. British Westinghouse's factory was much too bif for its noede. flso it had been built in great haste and was consequently expensive." The shope were lavishly equippod with expensive American moohinery. It 1s 2ikely that highly capitel intensive methods of ptoduotion wore used, whlch wero not woll adapted for English wage rates. The rate of growth

3. D.H. Robortson. A Study of Industrial Fluctuatlons Iondon 2915.PP 77-9

2. See Chapters 3,4,5 and 6. 3. J. Dummelow, Qp,cit. $\operatorname{PP} 4-7$. 
Table 73.

- Tonders for generators for the L.C.C. trameys 1901.

Average of lowest tenders.

Continontal Pirms

d.o. plant 3 phase a.c. plant.

American Ping

${ }_{28,260^{1}}^{1}{ }_{29.763^{2}}^{4}$

c 1

42,029

Beitish Pirems

29,498

$50,243^{3}$

$51,493^{5}$

20. A.E.G., Schuclkert, Hellos, Lahweyer and Witting (Cermany) Brown-Bovers (Sritzerland) International Electrical Engineering (Bolglum)

2. British Wostinghouse, B.T-H, and Bergthoil and Ioung (Bullook UPg. Co.)

3. British Hestinghouse and B.TषH,

4. Brush, Crompton, Dick Korr, E.C.C. Ferrant1, G.B.C. Wather \& P2att, Parsons, Siemens.

5. Brush, Dick Kerr, E.C.C. Ferranti G.E.C. Johnson \& Phillips, Parsons, Siemens.

IB For the d.c. plant the Brown-Boveri tonder was vory high. If excluded, the Continental average is \&26,820.

For the d.c. plant 29 firms sent in 212 tenders.

For the a.0. plant 22 firms sent in 260 terdors..

Sourcel E.R. Vol. 49 P 81015 Norember 1901.

of demand was substantially over-estimated. In December 2905, tho company otated that finanolal results would get botter when the lang araitod 1

traction boom came. But by then the traction bocan was over.

There also soems to have been poor managamont. Iabour rolation were bad than the wark roquired a blgh proportion of akd1lad mon. This wo :

2. Bloct. V01.56 P411 22 Dooomber 2905. 
partly becouse of the rather unthinking use of Amorican practice. Relativoly more priority was given to incroasing output then to Pinancial alsoiplines "On top of the very heavy initial outlay there had been too lavioh expenditure in many diroctions" ${ }^{2}$ Ordere wero late on complotion and unpropitable whon completed owing to optimlstio tendering. By 1905 the situation had become so bad that the top managrement was changed.' In Novamber Goorge Westinghouse sent his immodiate assiotant, Newcomb Carlton to llanchester, and he soon becam solo managing director. Pht11p A.Lango, manager of all the Amorican Companj's works in East Plttsburg, Allogheny, Clevelond,Newark was sent to assist Carlton by making a oix months review of the situation. But he stayed and in July 2906 was appolnted general manager of the works, Lnjox roforma' sollowed and matters soan bogan to improve.

Siemens' diffioultios at Stafford stemned inftially from having been too alom in extending their heavy plant business. The new worke were not fully roady unt11 1904. The Slemens share of the hoavy plant market had fallen and this was difficult to regain. In 2904 the Stafford workes ware only partiy occupiod and businoss was again unentinfeotory

3. J. Dumbelor, op.cit. PP $27-8$.

For example, Tho Pittsburg practice of works polloe patrolling the

$\therefore$ shoys to see that everyono was hard at work was used. The Amorican fonwon wore hard task masters. Labour was engaged and discharged Indiscrimately, and dismissal olipo wero constantly expocted in
pay packets.

2. "ibid:, P 29

3. $\frac{i b i d .2}{\text { P }} 33$ - 5. The accounting Bystom was changed. Soparate trading departiments wore formed with their own accounto. An attompt was made to improve industrial relations. The design of machinery In Britain compared with the U.S. 
In $2905^{1}$. Iosses were heavy, and as w1th Fest inghouse the management was not boyond reproach. Corl Frledrich Stenens was in charge of the 3

now works at Pirst. Then ho mins replaced by Carl Tottgen, the lattor. ocmplained of past miomanarement.

These difficultics led to the transfer of the Stafford workes 5

Irom Sicmens Bros. to Siemens-Schuakertwerke in Germany. In 1906 the Stafford works were reglstered as Slemens Bros. Dynamo Morks Ltd, and loased to S1emens-Sahucketwerke for ten years. This arrangement did not, howerer stop the losses, for the Stafford rorks continued to be the leant prositable of British olectrical machinery flactorios. In the docade 2906 - 26 the accumulated 20sses shown in the books : vere over $\$ 700,000$ ) ading interest on money lent at $5 \%$ tho figure camo to around $M$

The Witton works of G.E.C. were not in full workding order unt12 2904, and they secm to have been working woll undor capacity for somo geárs; indoed it is unilkely, fudęing by turnover and flxod plant Ileures that they wore filly occupled unt1l after 1910. ThSs, dosplte the faot trat their early entry into the manufacture of polyphase ano. oquipmont should have put them in a good position to sell plant for reotory electrification. Witton lost money. . Lost of these loseen werw

1. Report of the Directors for 2904 and 1905.

2. Born 1872. The son of Werner Slemens by his second wife. Ho hed worked with Jay Could in the United States.

3. Soon after 1906

40 J.D. Scott, op.c1t. PP $75-6$.

5. In 1903 Sicmons and Halske and Schuakert and Co. amalgamated thols heavy onfireering dopartments.

6. J.D. Soott. op.o1t, P 87 
Wo to the carbon works, whlch were adjocent to the on inooring workto. Cerbon'wortes 20950 avoraced 210,000 pola on a turnover of 220,000 230,000 pou. But as Table 74 shows englnooring also dici beilly.

The other compantes did not do an badly, an it bhown in Tablo 74. Thio was partis bocause thay ald not have the apodal alfriculties of Nostinghouso and Slomenz. Also the maninery market was to sorre axtom eegrented. Those fir. concontrating on treotion and Industriel olectrification did ratier better than those concontiating on contral stat1on wark. Tho derand for tramenes kopt up reasonably well untll urter 2907, as is shown in Table 75. This partis wocounts for tho prorltabllity of Dlak, Korr. , Profits did not Pall untll the year onding Jund 2900; bosore then they gavo a good return on assots. Propite in car bod1es soem to have boen rathar bettor than profits in eleotrion machinory manufacture. DLek, Korr ocosis to have froresed lto chare of

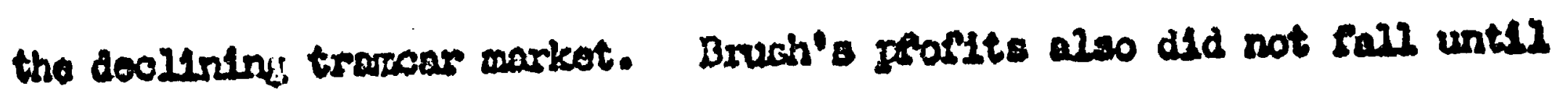

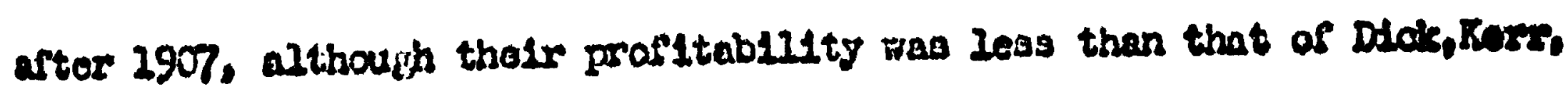
probably simply bocauso they wero less exclaient. Bruble valuen of output scoms to have been rising up to and inoluding 2907, when output was cald to be a record for the firra. Then 2908 was ropartod to bo a yoar of oxooptiansl doprosalon. B.I-F. olotilarly afforod a covoro drop in

2. The profito of tho car boly oubsidiary woro wo good as those of the main flrm. The main IIrra's resilits inclikio contracting which was

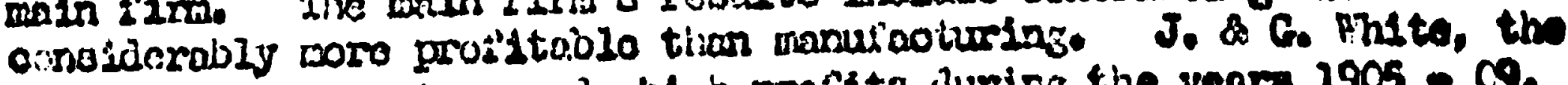
olnctrical contriotiors made hluh protizta during the yoar 2905 - $09 .$,

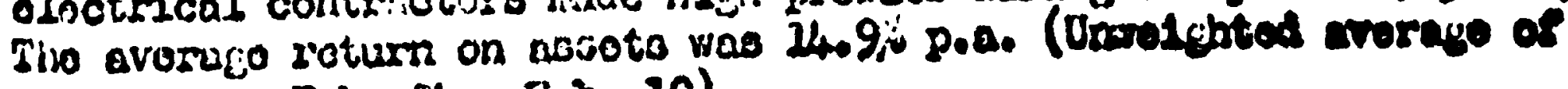
annual rato Feb. $\alpha_{4}-$ Fob. 10)

2. Elect, Pol.61 P353 12 Juns 2968.

3. Elect. Vol. $63 \quad 8199$ 4t wiag 2909. 
tavio 74

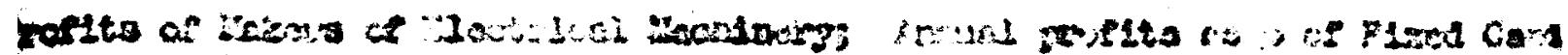

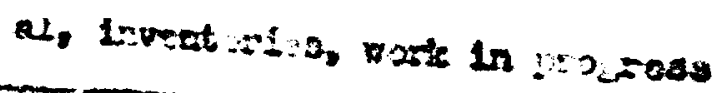

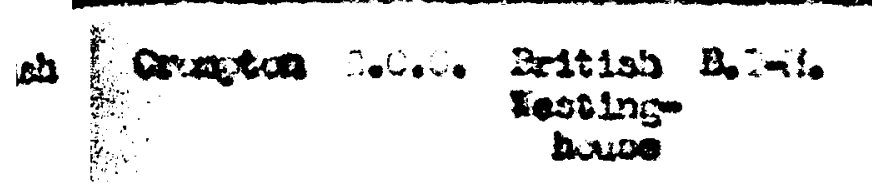

5.6

2.1

2.6

2.8

$0.5 \cdot 20.0$

20

$6.3 \quad 25.7$

3.7

3.0
$3.2 \quad 0.21 .2$

L.4 030.0

5.0

6.3

2.7

1.5

6.5

4.3
5.9

5.5

5.2

6.7

49

504

0.9
0.7

0.7
1.4

2.7
2.6

2.6
9.6 c 2.0 $\begin{array}{rr}5.0 & 0.7 \\ -.01 & 9.7 \\ 5.3 & 10.2\end{array}$ $12.3 \quad 3.8$ $8.2 \quad 12.0$ $5.6 \quad 9.7$ 4.6 $-3.4$

5.5

0.3

74

2.9

$-6.5$

$-7 \cdot 1$
-3.8 $\begin{array}{rr}6.2 & 2.3 \\ 1: .7 & 9.2\end{array}$

$$
9.9
$$

8.2

4.3

400

2.7

5.0

5.1

7.2

20.6

3.0
3.9
1.2
0.7
0.2
2.4
2.0
2.5
3.1
4.0
7.4

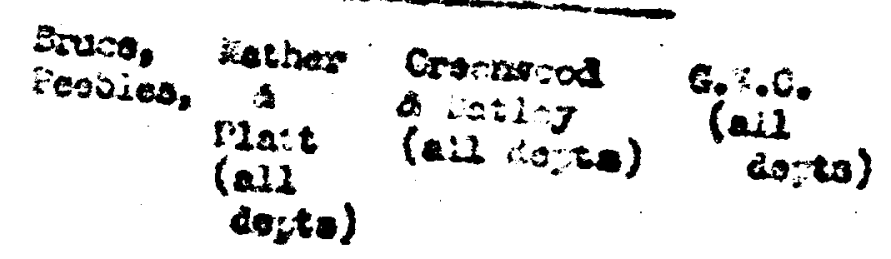

2 worke who burnt conn Liz $20 \%$.

See notes on P. 380 a.

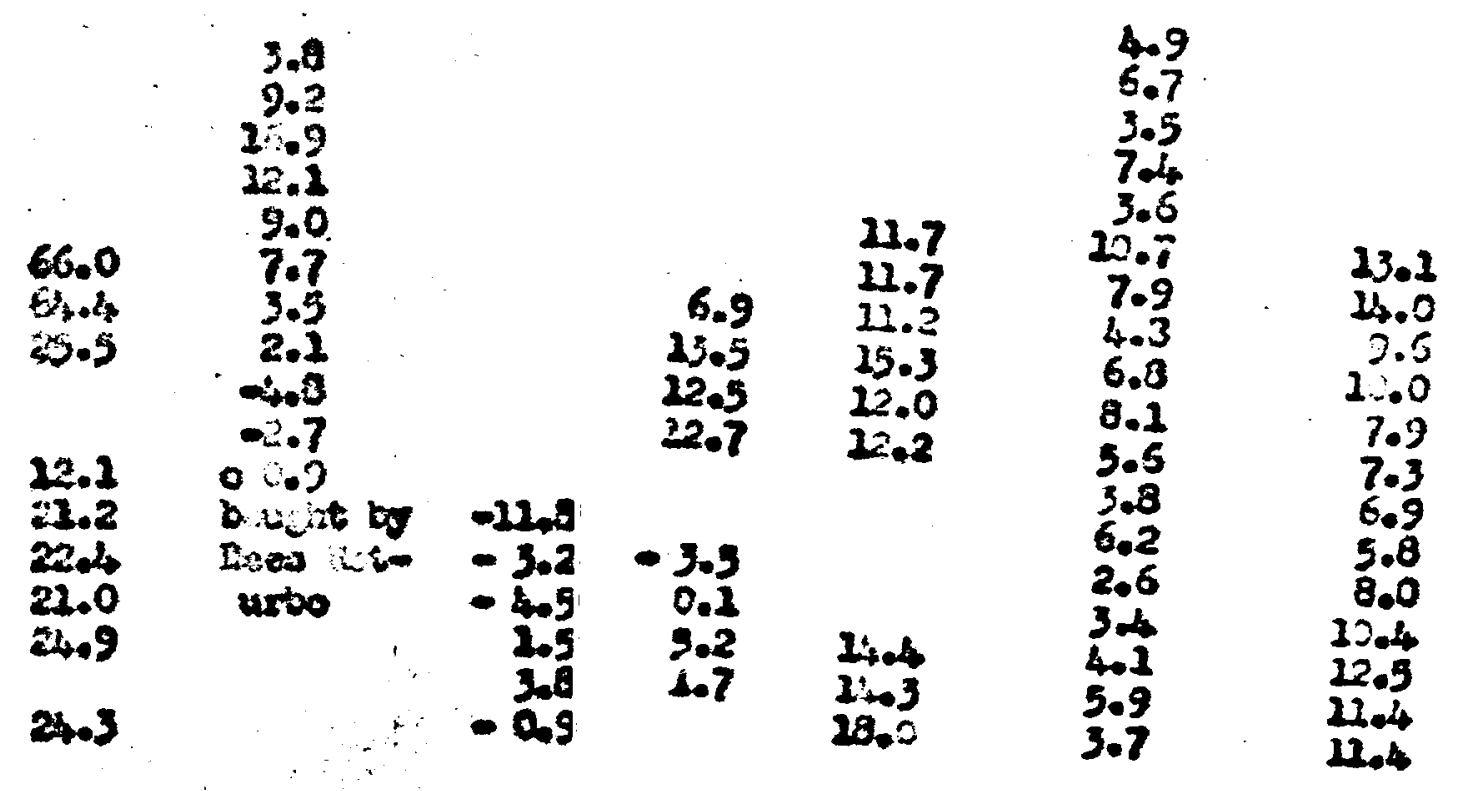

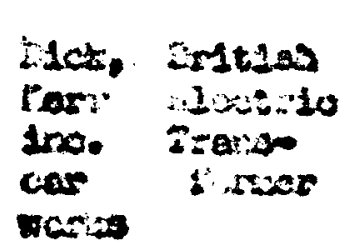

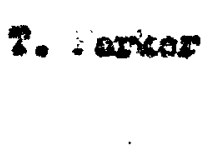

. Costots Feries!
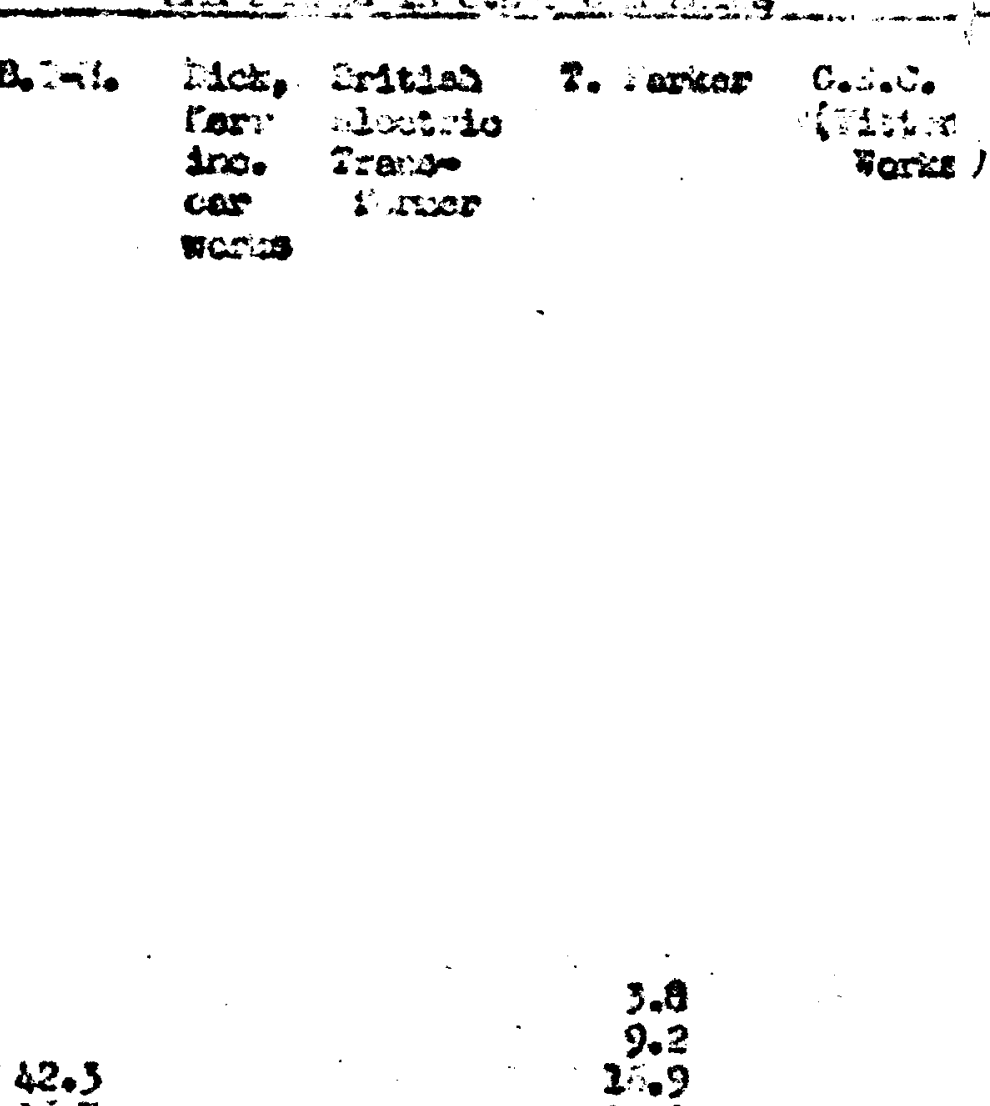

9.4

4.3
5.3

4.7

3.7

3.2

2.0

2.2

44

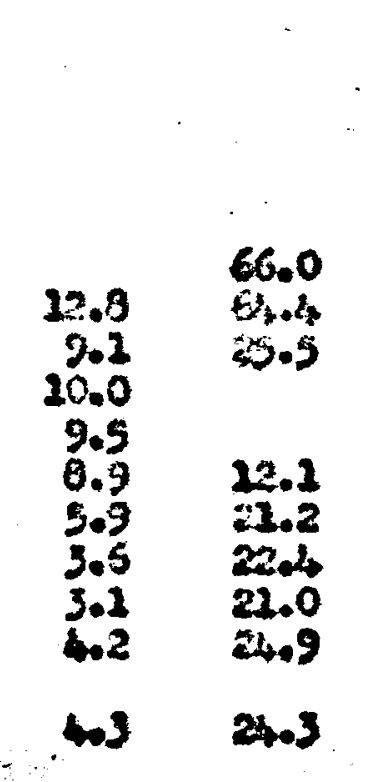

4.9
6.7

$$
3.5
$$$$
20.7
$$

7.9

6.8

8.1

3.5

6.2

2.6

34

5.9
3.7
13.1
4.0
2.5
1.0
7.9
7.3
6.9
5.8
8.0
12.4
12.5
21.4
11.4 
Notes to Table

Statistios are not available for other manufacturers of heavy -lectrical plant. Siemons monufactured plant and cables. Thelr profits are given under the cable makers. Sienens Brothers Dynamo Worits which made heavy machinory for Siemens, from 1903, made profite which seen to have been cither zoro or negative for 1907 - 2913.

Prorits are takcon before the paynont of debenture and other interest and after dopreciation. As interest peyments are of ten not shorn in the published figures provided by the corapany estimatos have ofton had to be made. They can only be based on loans and debontures as shown in balance sheots and are thus crude. The situation is particularly bad in the 1890s. For B.T-H. who borrowed heavily from General Electric considorablo estinating has been necessary.

Dopreciation was allowed for in a somowhat irregular way. Often it was Inadequate and had to be mado up in a capital reduction.

Capital figures are those in balance shects, and as inventories were 11 ablo to fluctuations they are only a modorate indication of the average capital employod throuchout the year.

Goodv1ll and the value of patents have been excluded. Although a case can be made out for Incluaing tham they were often valuod at a figure which bears no real relation at all to thoir markot value.

For these reasons the percentages are 2 lable to conslderable Inaccuracy, and although given correct to ono docimal placo, may oanlis contain errors of $10 \%$.

Where published information is particularly dofioient, but not absent, ostimates are given as very approxdmate (e.g. 06.5$)$.

Sourcel Company Balance Sheots, profits and 2088 accounts and Company Roports. 


\begin{tabular}{|c|c|c|}
\hline \multicolumn{3}{|c|}{ 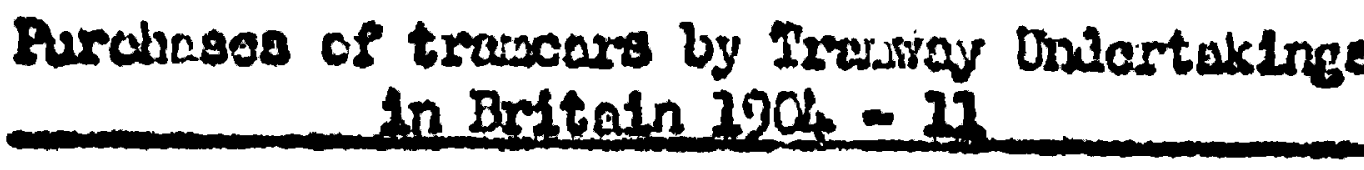 } \\
\hline Yoar & 10000 & \\
\hline $1904_{4}$ & 735 & \\
\hline 05 & 577 & \\
\hline 06 & 459 & \\
\hline 07 & 534 & \\
\hline$\infty$ & 467 & \\
\hline 03 & 386 & \\
\hline 2920 & 338 & \\
\hline 12 & 329 & \\
\hline
\end{tabular}

Yoar anding Docamber for companios. Ilear ording laarch $320 t$ In the following year for tuntol palities.

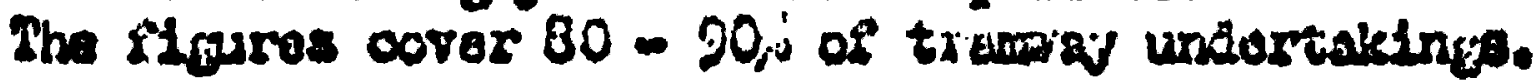

Souroor Boand of Trade Roturing.

prosits when traction darina foll. Tablo 76 obars hor traotlan ordore,

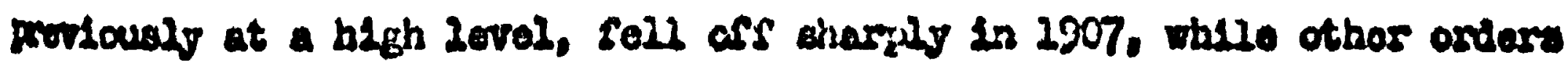
rematrad ot exaly.

The darand for plant for factory olectrification rose after 1903 Sust whon contral otation comord was ceclintng. Also bowo mamuracturare vere alow to turn to t a barisct for factary plant, concentrating on central otation woris. S1Endsioantily portiage 14 was the Gorwan

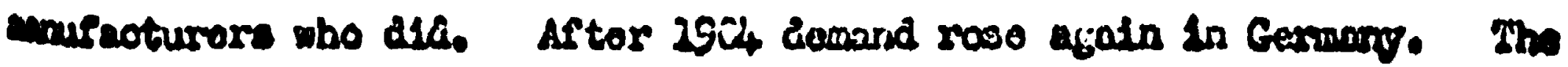


Tablo 76.

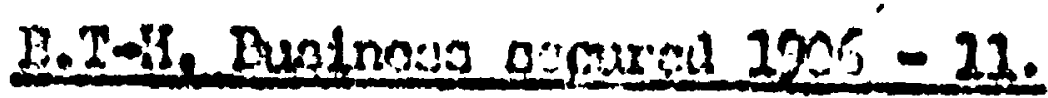

\begin{tabular}{|c|c|c|c|c|}
\hline $\begin{array}{l}\text { Year } \\
\text { to } \\
\text { yerob } \\
2906\end{array}$ & $\begin{array}{l}\text { Arnotion } \\
\text { oquitpont } \\
266,853\end{array}$ & $\begin{array}{l}\text { Othar } \\
\text { oquipunat }\end{array}$ & Contraotins & 843,646 \\
\hline 7 & 62,344 & 423.625 & 160,321 & 635,290 \\
\hline 8 & $29,21,1$ & 428,759 & 225.737 & 583.757 \\
\hline 9 & 25.777 & 376,216 & 219,232 & 521,025 \\
\hline 2910 & $34,54,0$ & 391,011 & 99.34 & 524,865 \\
\hline 4 & 34,442 & 506,234 & 203,524 & 644.279 \\
\hline
\end{tabular}

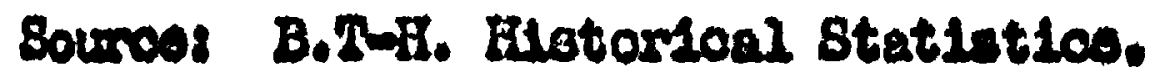

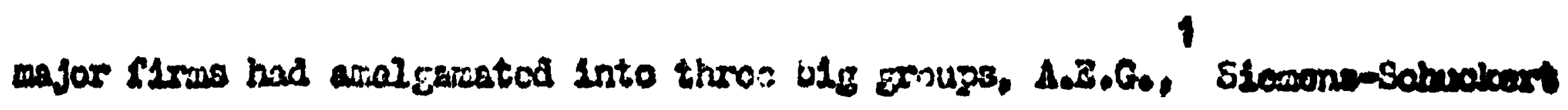

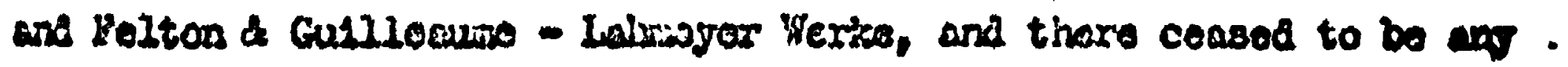
particulariy law tendering for Irfitiab cantral station oontracts. Instoed

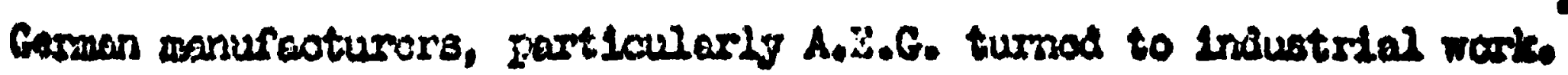
A.B.G. had boon Bolling eloctrio porrer tranamisalon plant both A.0. and 3 phaso a.c. In Ingland airce tho midale ninotios, and tho lock of Interost

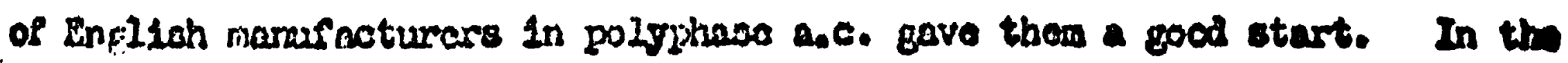
years $29 \alpha_{4}$ - 20 a grent doal of h.S.Q. plant wast have been sald in thlo country. It was cald that a preat deal of tho cloctrio plant in tho

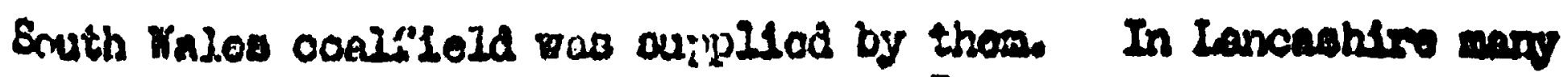
Installations wore aloo macle by A.E.C."

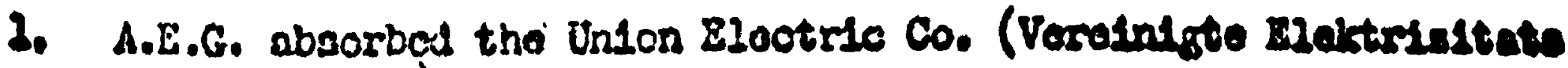
Cocollochart.)

2. E.R. Vol. $62 \mathrm{PP} 21,9$ - 50. 24 Robruary 1908.

1. S.R. sour on.cit. P 35. 
Proflts seed to have been ruther hichor in fhotory olootrirtontion thain central otation work. As Inkle 74 shorro B.C.C., conoentrating on

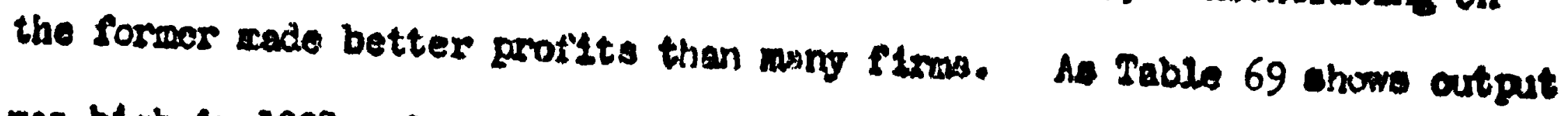
was hith in 1909 - 9 at a tims when contral otation dexand was 10w. Tho Lancashiro Dymano and jioter Co. which concentratid on standard 2.0. and d.e. motor and ganeratoss for factory eleatrification ald very wall. No accounts wero gubllahed but in lotter to the Bleotrioul Reviow in $2907^{\prime}$

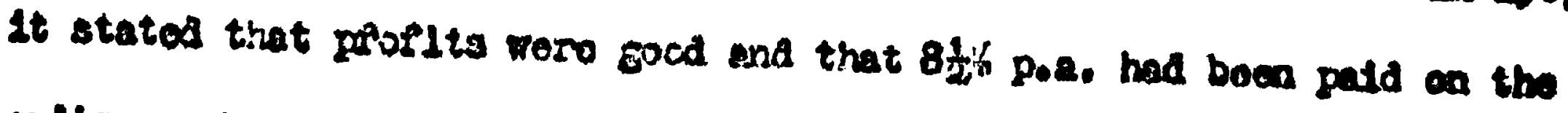
ondinury aharse for the lnst alx yoars.

But there are also differancos botween the prosttablusty of firw $\therefore$ islah do not secon to bo eccountsd for by the dipforences in condition in difforent cerments of the anrkot. Ao Table 69 ahows dosplte all the exry atories of the other electrical annuspoturere Britin Eleotrio Iranarursor contimud to malko hlgh pmetta throughout tho porlad. 1100 the fortunas of Ilrsw uouzd fluctunts sharply. B uco Pooblos ard Co. 10. a good exanplo of thio. Tho oomrang was rogioternd in 2903, having boen - private IIm beforchand. Murnover gxew un to 2907, the worke seen to have been fully omployed ond profles wore hifit. Thon exoossive denalng

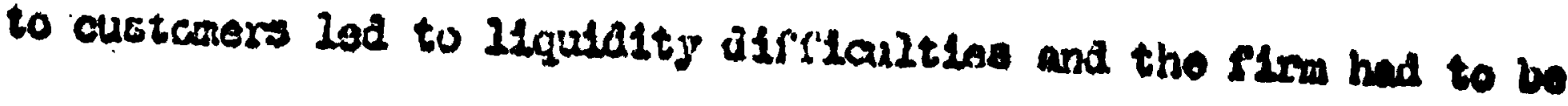
roconatnucted. For tho noxt fow yours prosits woro vary low.

2. Delle Vol. 61, I 168. 2 August 2907. 
The recession in prices from 1901 and the slow growth of demand oqused afficulties similar in kind, but more acuto in degreo, to those of the early and middle nineties. In Jamuary 1905 the Eloctrical Reviow polnted out that in 2904 engineering shops wero only partially pliled with orders at unremunerative pricos. Prioes hod fallen in the last 3 yours to an extent "whlch would have scarcely been thought positblo." Two years Later the Elcctrical Revien comented that the manufacture of -lootrical machinery had bocono alatinotiy unproritablo." Pricos, it was cald hod fallen $30-40 \%$ in the last 3 - 4 yoare. Ion prioes were the trouble.
There has been a modertte demand for electrical plant for some time past, and the condition of wany of ihe principal vorkshops ouggeote that they are well off as regards output, but on every hand ono heare the lament of low prices ..... one has witnessed a rather curlous phase in solling which has at some time or other affected nearly every firmo With the prospeci of erapty shops many firms have rushed into the market and procured work at any mioe and after a fow repetitions of such actions ..... a close student. 6 of affalrs mot have long recognised that, despite the conslderable demand for hoav machinery this section of the industry is suffering from over
production."

Prloes oontimued to Pall; in the three yoare 1905 - $\infty$ they ware satd to have sallen another $25 \%$.

The poriod of falling profits was a long one, extending frow 1900 to 1920. It began earlier than one might have expeotod boowes of Continentel campetition in the years 2900 - Q4. It was not a perlod of rapid decline; it was a long slow squeeze. Profits were often below the long term rate of interest, but were very raroly negative, In a was the

2. E.R. Vol. 56 PP I - 2. 6 January 2905.

2. E.R. Vol. 60 FP 85 - 6. 28 January 2907.

3. Crompton Company Reports. 
wes unfortunate; capacity was not reduced as 1 it might have boen $1 f$ profito had falien furthor and faster. Only one eleotrical manufacturor went out of business, T. Parker Ltd., which was, significantly one of the smaller 11rms. Heohantoal oncineering firms with omall olectrical dopartmont. would be in no mood to abandion them as thoy ware probably not unprofitablo cocopared with mechantcal enginooring products, and future prospoots alray secmod promising. .

As Table 77 shows finanoinl assets aid not rise as they ald in the 2890\%. But increases in the volume of output ot1ll put severe flnancial strain on fins. This strain is best documented in the case of 1 Brush. Brom 2900 owrands the expansion of worlaing captital was flnanced by 20ans. In 2902 there was alreedy an overdraft of $\$ 25,000$ with Parr's Bank. In the same year It had to be increased to 840,000 bocause of inareases in work in progress and the diff'lculty of collecting money ored to tho ocmpary. Two months Later it had to be inareased to $\$ 50,000$. By Dooember 2903 not only was 555,969 aring to Parrs, but there was a new overdraft with the London, City and uidiand Bank of E34,902. In Pebruary 2904 Parrs Bank asked for the overdraft with them to be reduced. The next attempt at raising money was in Warah 2904 when the Chairman (Lord Vaux) arranged a Loan, 815,000 at 5,0 in his orm name on the Bocursty of 2,000 British Electrio Traction shares hold by Brush. Bruah had also beon borrowing direot from B.E.T. The diffloulty of getting enough maney to carry out orders when in this situation was atrikelngly abow when Brush was arrarded a contraot for seven ccmploto olectrio traine far the Iondon Underground in liay 2904. They wero to bo dollverod between 
September 1904 and January 1905 at a total price of $\$ 75,674$. Brush wrote to B.B.T. With a request to borron 810,000 for this contract. They

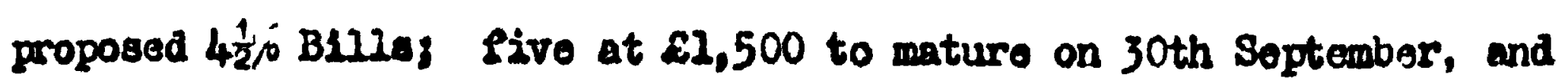
intervale of one month successively, and one of $\$ 2,500$ to mature in Fobruary 1905.

The absolute size of short term indobtednoss can be seen from 1

the position of ApriI 1905. \&120,778 was outstanding at the $11 \mathrm{mo,}$, wh110 the total value of stocks and work in progress in Juno 2905 was 6151,511 . Brugh was continualiy bumping along the colling of short torm borronding. After 1905 borrowing from B.2.T. and Parrs Bank rose, although othor chart term debts fell. By July 1906 675,083 was owing to Parrs and the bank wanted it reduced to 850,000 and declined the Brush request for an edvance of 840,000 on the specifte security of the St. Petersburs Trems contract. 'At the sane time B.E.T. wanted the load of $\$ 50,000$ to be repald In Instalments of 55,000 por month. This Brush was forced at a bad timo to ralse 679,765 on debentures, a movo accompantod by a reduction in capital.

British Westinghouse, B.T-H., S1emens Bros. Dymamo Morks and G.B.C. were fortunate in possessing extra sources of funds. Britich Westinghouse was very heavily financed froin P1ttsburg. At the ond of

1. Hade up as follows: $E$ B.E.T. $\quad 30,740$

Lord Vaux (Chairwan) 13,058

Parrs Bank Loan . 26,000

" " Ovezriraft 11,742

Chartered Bank of India 32,238

$$
120,778
$$

2. Expenditure on patents, lactory, plant, inventorles and work in progress, not trado Lendins, shares in other companios and experimontal works. 
Tablo 77.

The Expanston of Assets $19 C_{4}-20$

Brit1sh Testinghouse

(July 1904 - Deo. 1909)

Increase in
fixed assets
after deproo
Lat10n
$\mathcal{L}$
$-8,206$

B.T-H.

(March $2904-1910$

Diak, Korrs \& Elect. Riy. \& Carriage Co.

(June 1904 - 1910)

S1emans Bras. Dynamo Toxics

(Deo 1904 - 1909)

G.B.C. (Fitton Wories)

(Dec 1906 - 1910)

Bruah

(Doo. 2903 - 1909)

Crampton

(viarch $1904-2910)$

E.C.C. :

$($ Nag 2904 - 1920)

Brit1oh Elootrio Transformer

(Deo. 1904 - 1909)
Incrcise in Inorease in stocks and Pinancial rork in progress 6 $-326,904$ assets.

83,866 31,704 $-39,645$ 278,598

70,654 280,424

6,529

$$
2,472
$$

$-248,479$

$-71,280^{4}$

387

$-54.255$

69,026

$-21,365$

$-4,849$

$-37,260$

4,821

$-2,927$

$-619$

1. Work in progross is under "debtors".

2. Not distingulohed from Sienens Bros. In 1904. S.B.D.W. Warke "aroditors" Inoludes very substantial loan trom Siomons Schuckert.

3. Heavy plant manufacture was only a part of the cotivitios of G.R.O.

40 No allowance made for spectal writo off when Brush onpltal was roduced In this period.

Sources Company Balance Sheots. 


\section{Tablo 79.}

The Source of Funds 120\% -2910 .

\begin{tabular}{|c|c|c|c|c|}
\hline Rortc & $m \operatorname{lng}$ & & & \\
\hline $\begin{array}{l}\text { in ardinary } \\
\text { shares } \\
\&\end{array}$ & $\begin{array}{l}\text { on proso } \\
\text { orence } \\
\text { shares } \\
\&\end{array}$ & $\begin{array}{l}\text { on } \\
\text { dobentures } \\
864,300\end{array}$ & $\begin{array}{c}\text { on loans } \\
\text { E } \\
-276,036\end{array}$ & $\begin{array}{r}\text { Rotalned Pr } \\
\text { before } \\
\text { dopreciatia } \\
6 \\
-8,2148\end{array}$ \\
\hline
\end{tabular}

\section{B.Tolf.}

(Wharch 1904 - 10)

$$
\begin{array}{llll}
-7,060 & -200,750 \quad-339,000 & 213,715
\end{array}
$$

DIck, Kerr \&

Elect. RLy. \&

(June $2904-2910)$

Brush

(Dec. 2903 - 2909)

$79.765 \because 200,000$

29,382

Crompton

(Uarah 2904 - 2910)

E.C.C.

(June 1904 - 12:10)

9,375
(abort term

notes)

$-20,000$

$-20,000 \quad 32,620$

Arition Elootrio

Transf ormer

2,253

5,061

(D00. 2904 - 2909)

Souroer Campany Balance Sheets. 
ocmpany had provldod $\$ 3.74$ million. It had also lent money to British Mestinghouse's customers, principally the Mersey Rosliway and the Clydo Valloy Porer Co. through Traction and Power Securities Lta. Then In 2907 this source of support was suddenly cul off when the parent company foll Into the hands of the Receiver as it wos unable to meet its short run financial obligations in the panic of that yoar. Short run loons frow the Amerioan Westinghouse compeny were considorable - amounting to E186,374 in July 1907. Thus British Festinghouse was forced to go to the British capital maricet, at a time when the company's fortunos had boen very 10 for several years, Howevar k245,000 was ralsed dn 6,8 prior 110 n dobentures.

It is not known hor mach General Electric provlded to ostablish B.T-H."s Rugby factory. But short term lending was considerablo. By Laroh 1905, 6674,319 had becn borroined from General Blectrio and although the subsequent fall in businoss enebled this to be roduced to 8174,098 by laroh 2910 it began to. Fiso from then onwaris as business expanded.

Falling profitability and general financial stringency wore ossociated as in the nineties with a slow rato of tochnical progress. The now firms and new products of the yoars 1897 - 2904 seemed to have brought 1 Britioh electrical machinery manufaoture up to dato again, but there wes coon eridence of $20 . g 1$ ing behind Gernany and the United States. The gap nevor bochine as large os it had in the nineties, although this was partly at least becau:se of the different possibilities of tochnical progrese. In the ntneties there wero important new things to be developeds traotion, 
polyphase a.c., much bigger generators with difierent typos of primo mover. sfter 1900 - 03 all these things had been Introducod, and possible changes were all in the nature of atream of amoll improvernents.

Unfortunately the evidence is Inadequato to attempt any precise mcasure of the length of the techntcal lag. It does however seem to have varfed with dfferent products, and was porhaps longest in big generating 1 plant. For example K. Beumann told the hanchester section of the I.E.R. in January 2912 that "the inorease in the output (size) of turbo altermatore has been more rapld in the U.S. and on the centinent than in this country." The muncipalities also seem to have felt that British mado contral station plant was somewhat inferior. Dorenders of tho unprofitablo porformances of the electrical manufacturers state that this was wore profudice but there is considerable ovidence to show that municipalities preforrod English plant, and only bought Gorman plant because it promised lower operating costs or was cheaper. And on the whole it was not cheaper. Ingliah buyers preferred Inglish cables, and there are many cases whore they bought Ingliah cables at prices above those of forman cables. Why should they behave differently over oloctrical machinery? Iroft wing municlpaltitios had a reason additional to patriotiom and oasy accese to makers should the plant not operate well, tho desire to raise wages by stipulating that the contract be carried out at Irade Union rates. Tho I.C.C. and many of the Irondon Borough did this and suoh a claves offootively excluded foroign tenders.

2. British Wdstinghouso's new Chiof Nechanical engineser. 2. E.R. Vol, 70, PP 327 - 21 and 395 - 62. 
Hermann Levy, writing in 2908 - 9 pointed out the "greater ropoxted utility" of German, Belgium and U.S, electrical machinery orer that of English manufacturers - "a sact often noglocted by, or undorestimated by, complaining Britioh producors but well cupported." In this contaxt it is useful to look at the forelgn trade statistics of value per ton of electrical machinery. Tochnion progress reduced the veight of products for a given capaolty. Tho following figures of the value per ton of electrical machinery exported from and imported Into Britatn from 2904 to 2913 suggest that Britain was exporting less doveloped mechinery and importing more highly English exports Inglesh Importe Sran

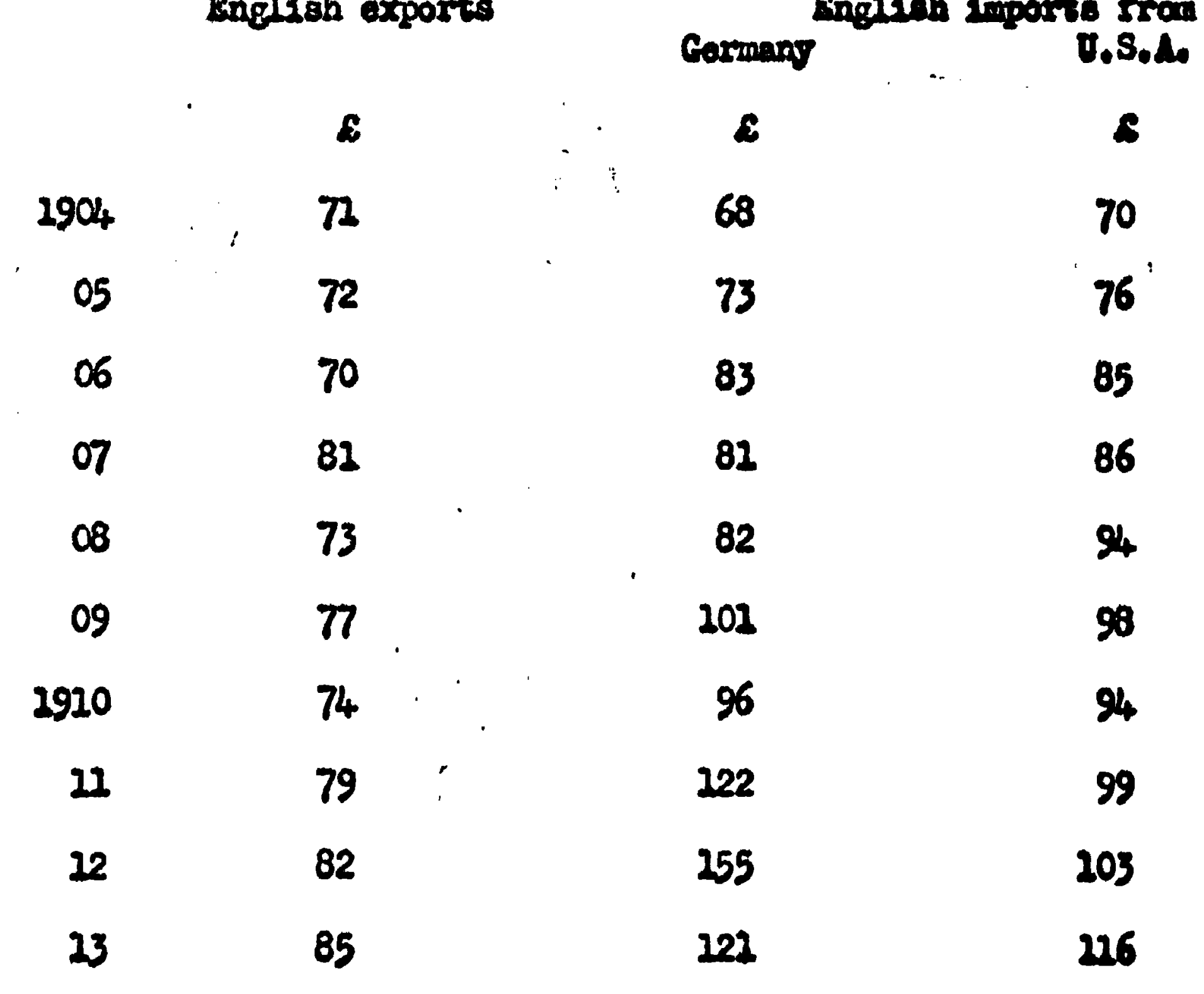

1. Honman Levy, Monopoly and Competition, London. 29U, 
dereloped machinery by 1910 - $\mathcal{H}$ although sho had not been dolng 80 in 2904 - 5. This is consistent with slowar technical progress, but this evidence is not conclusive. English exports were largely to the Ruptro, where oleotrical development camo a little later than in England. Thw amaller, simpler plant was often more appropriate. It is alao posslblo that there were systemativ shifts in the type of olootrical machinory Involred.

Despite the assocation between low proflts and 8 low technlow progress, the possible connectlons between the two are not elear. Bvidence is rather scanty. In some ways the very strong competitive pressure of the years 1901 - 20 could ve expected to be a stimulent. Successive small Improvements could be Introduced into successive contracts. Firms compoted both by fing better grarantees as to performance than competitors, and by tendering 20w0r prices. They tried to roduo manufacturing costs by cheapor designs of maohinory. But mattere did not seem to work in this way. Perhaps this was partiy becusase the profit squeeze went on for so long that it became enervating or porhape slow technical progress was connected with the relations between manufacturers and customer, and with the position of the conswlting 1 onginoer.

The situation then was different from that of the nineties in that there does not seem to have been as large a rift between engineere and businoss men. Yot there was a growing fooling that thore wa a gap botwoen

2. At this covers matters rather wider than manufacturing, this inowe will be postponed to Chapter $\mathcal{U}$. 
the two which ought to be f1lled. Thero was considerable supnort in eloctrical ongineering circles for the view that what was nooded was a generation of "comiercial engineers - or enginoer tradors" The lack of enough people who could camblno ongineering and business was an Important defleiency in the British coonumy at the timo. However it cooms to havo been most noticed in eleotrical ongineering alrales, and this mes indicate that the offects of this deficiency wore more marked In oloctrical machinory manufacture than in othor trades. Tho smorloan and the Germans were supposod not to suffer from this lack of comencial onginoors and thus it is interesting to soe that British Nostinghouse, B.I-H. and Stemons Bros. Dynamo Fiorks wore as unsuccessful as any manufacturers. This tends to direct onos attention towards difficultios like the structure of the market or the slow growth of demand for eleotrionl machinery in Britain, if one soeks to explain the slor technical progrose. It was also argued by many comtemporaries that Bnglish f1rmo were bakkward compared with the Germans and Amoricans, not only in their onginearing developwents, but in their market behaviour. The complaint: were subsumod under "Belling" deficiences. Bnglish Sirms watted for orders and did not actively stinulate business. This was aald to be one roason for the slow development of their electrio power equipment business. This point has been sade elsowhere; in essence it is that manufactursing slrms could Increase sales by roducing uncortainty as to the rolative oost of eloctrito and mochanical power transmission. It was argued that thes, 3 or oloctrio and mochanical power transmission.

1. Inaugural address of J.M. Railin to the Birminghom local seotion of the I.E.E. E.R. V01. 67, P 810. 18 November 1910.

2. I. Orwiok and E.F.I. Breob. The lkaking of Solentifio Manapement 1946 - s Vol. 2, PP 208 - 230.

3. Chavtor 6 . 
could only be done adequately 19 good comerolal englneers wore amploged to seak oxders. This 18 what the Americans did, this is what 1.I.O. did in South Walos.

\section{1}

Concentration remained high. In 1907 wo can loak at thlo for the whole olectrical machinery group. Gross output flgures are given for some of the major firms in Table 79. Unfortunatoly for Slemens and Diak, Korr estimates havo had to. be made. Because thore are no output f1gures at all to gutde ones crude estlmating prooedure, the Diok, Korr Plgures are rather spoculative. Tho 1907 Consus gives tho output of electrical machinery plus aro 2 amps at 84,541,000. To this wo must add somothing for contracting. As most contracting work was done by cable makers and flrms dolng only contracting, I have taken a third of tho totel. Thus total output of mechinery firms is assumed to be 4,967 . If all the assumptions made aro correct the sour major IIrms, British Festinghouse, B.T-H. Dick, Korr and Slomens accountod for $57 \%$ of total output.

Concentration however varled in different segments of the maricot. Tho market for contral station generators, as can bo soen from Tablo 81 was rathor more concentrated. The market for large central station generators, 1.0. $2000 \mathrm{KI}$ and avove was oven more concentrated. In the yours 2903 - 6 it was largely in the hands of four main produoers,

1. N.B. The Diak, Korr output includod tram oar bodies. 
Tablo 79.

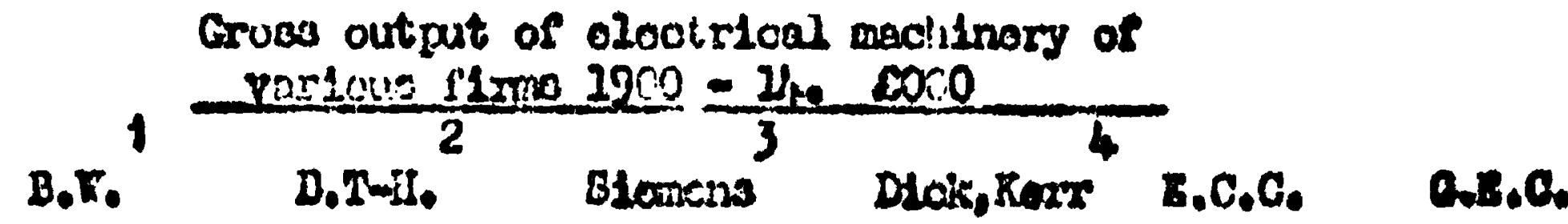

1950

02

02

03

0. 2,230

$05 \quad 2,492$

$\infty 6$

$07 \quad 2,109$

$\infty \quad 2,032$

$09 \quad 937$

2910

$12 \quad 2,266$

$12 \quad 2,433$

1,237

$23 \cdot 2,765$
253

245

277

802

591

539

483

409

589

2,307

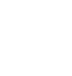

690

620

780

890

2,215

283

291

231

405

175

38

125

207

440

219

204

500

224

219

500

27

255

435

255

9

400

20.

208

340

340

240

370

252

380

225

510

279

Firos dren up the1" accounts at asfreronot timow aro gut undar the roaroct colondar your.

uls slames

1. Iret1sh Theotinghiuse.

2. Criors. Snles (Inoluding Incandoscont lanpo which have boen waluded srom arears) 2900, 4.539,401; 2909, 2535,$065 ; 2912,0578,067$ 1912, 8033,$234 ; 1913,61,255,620$.

3. Dyrano, Eloctrical Installations and Eloctrical Trado Dopto. at Foolmich

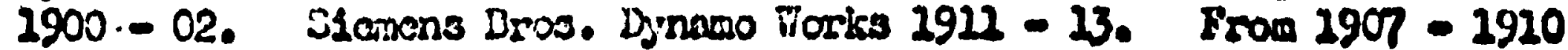

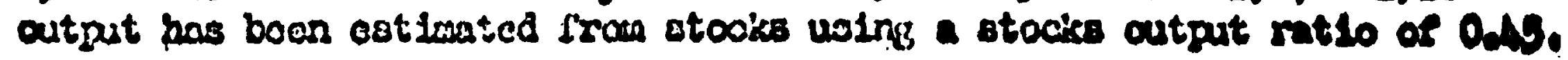

40. Cotinaied througdrout Irata stocks using a stocks output ratio of 0.155 For com.ents on tho uso of stockes output ratios ases Appends 
Dynamos installed in Central Statior1892 - 1913.

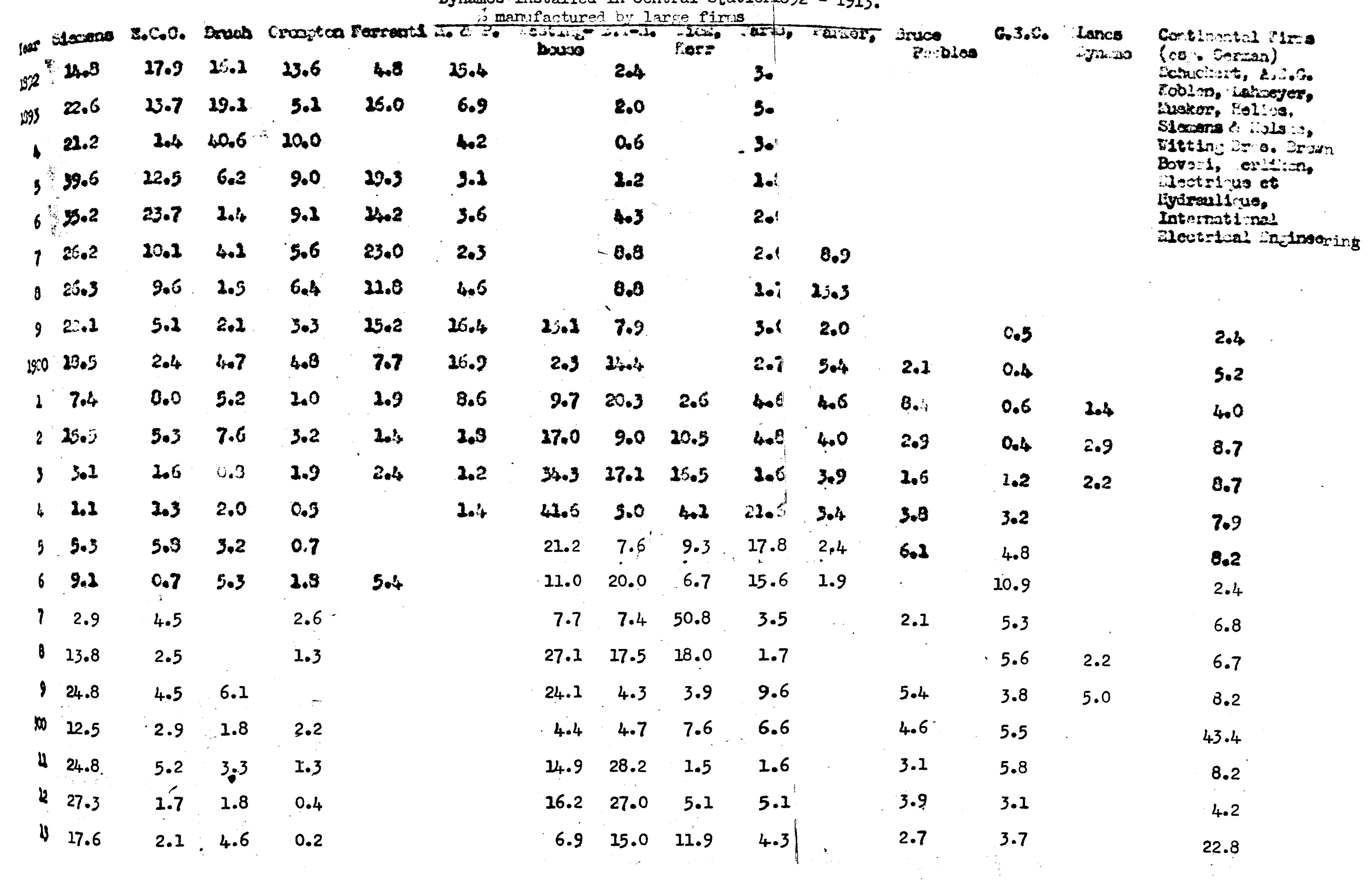

For method of calaulation see Appendix P 507

Source: Electrical Trades Directory. 


\section{Table 81.}

The market for contral station ronerators

Yoar if shares of the market in the hands of the largest $x$ homo producers

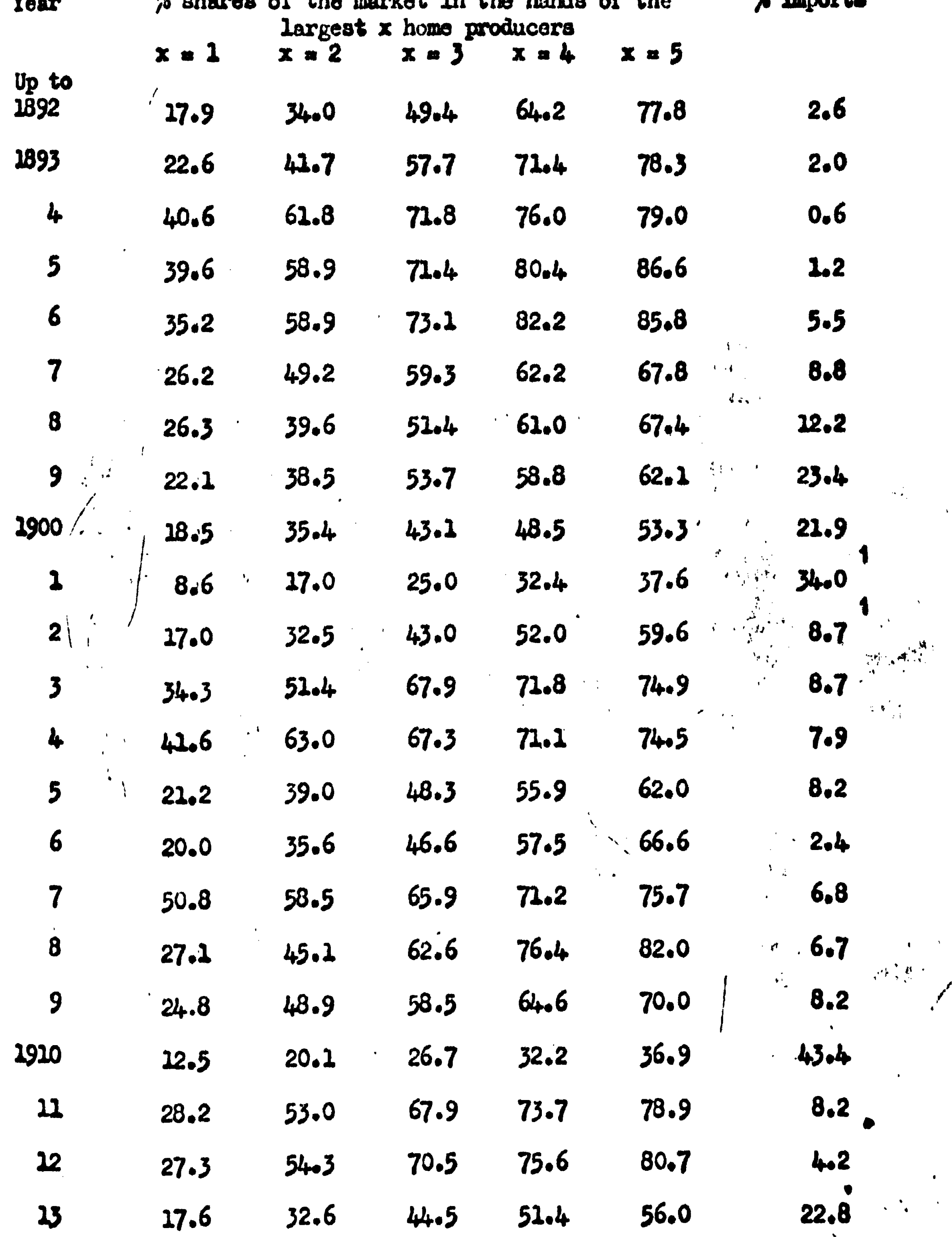


British Westinghouse, B.T-Ho, Diok, Korr and Parsons, Subsequentiy the share of Parsons declined and Slemens jolnod the other three in the flrat rank of quantitativo importance.

Tho market for traotion plant was much moro concentrated.

Pive homo producere ounplied th1s market and other firms were scarcely Involved at all. They were Britiah Festinghouse, B.T-Hi, D10k, Borr \& Coo Brush and Siemens. 2 At first B.T-H. and British Westinghouse providod most of the motor oquipments, but by 1901 - $0_{4}$ thoy were joined by the othar three. Information is avallable about tenders for tramas motor oquipwents and in nearly all cases only these plve firms tenderod." Brition West1nghouse, B.T-H. and Dick, Korr noarly always tendered. In the case of electrio railway motors and equipment, concentration wes oven higher. Tho London Undercround Rallways had thoir motor equipmonts oupplied almost ontirely by B.T-H, and British Westinghouse. The only exceptions were the short Waterloo \& C1ty Iine and the City \& South Iondon Rallway. Hostinghouse equipped the Harsoy Rallway. Tho two ploneer main 21 ne electrification scheres, the North Eastern and tho Lanoashire and Yorkshire were equipped elecurically by B.T-H, and Dlak, Lerrs roupectively. The only othor big scheme completed before $291_{4}$ was that of the London, Brightion and South Coast Railway. A.E.G. provided

1. Assuming Hestinghouse and B.T-H. imported all thoir plant from the American parents up to and including 1901 and manufactured all the1r plant in England from 1902 omrards.

2. Siemons traction equirment seems to have been made in Cormany before thy opening of Siemens Bro3. Dynamo Works traotion departmont at Stafiord in 1904.

3. Soe Tablo 82 for numbor of f'irms tendering. Hore firmo tendered for layling the Iine, oables and overhead wires, but this is a diffirent matter.

40 Soe T.S. Lascollos. The C1ty and South London Railway P 34 for dotallo np tha makers of olectric locomotivos. 
all the motor equipments. The swoller schemes wore the Dury-lioloombe Brook Iine of 2912, extended Into the Bury-isanchester line, the re-equipping of the Liverpool Overhead Railways with more powerful motors, and the Heysham, Horecambe and Lancaster 2ino of 1900. The electmcal oquipnomt was provided by DIok, Rerr for the first two, and by Siemons and Nostinghouse for the third.

High tension, beavy power owitch-gear was wloo rather highly concontrated. Sritchgear developed as a separate branch of electrical ongineexing from the beginning of this century with the edvent of large power circults at high voltages. In the last fow yeare of the 29 th contury two firms wero outstanding in developing onitohgear, Ferrants and B.T-H. 'In 2894. Forranti first put ewitohes into individual colle. In the following yoar he designed the first oil break witch. B.T-H. Late the foundations of its switch gear engincering whon carrying out the Contral London Railway contract. In $2903-4$ B.T-H. and Forrant1 wero tho two major high tension owitchgear manufacturers. It was also at this time that the firm of A. Reyrolle \& Co. began to become important. Reyrollo," a Pronchman who had set up a workshop in London in 2886, d1d a lot of spltchgear work for B.Il-H. In the lato ninoties. In 2901 ho expended hlo businoss Into a private company and bought a works at Hebburn, noar Newoastle. In 1905 he was joined by H.H. Clothier who had been with

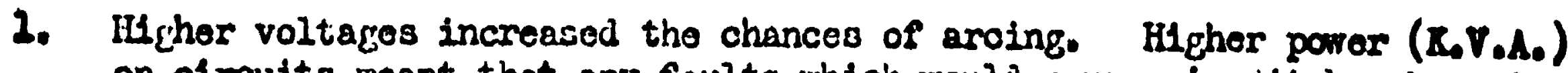
on clrcuits meant that any faults vihich rould causo circuit breakers to Intercept the current could lead ti mechanical strains of explosive force within the circult breaker 1tsolf. For the dovelopment of owitchgear see H.F. Clothier. op.cite

2. B.T-Hl. Reminiscences. P 12.

3. Camo to England 2883 and rorkod for 3 years with a flrm of colentiflo instrumont makors. 
Berranti. He very quickly developed the now famous Reyrolle motal olad owitchgoar. Tho first installation was made by Reyrollo in 1906. Ion tension owitchgear was made by a large number of firms.

On the other hand the market for electrical machinery for factory olectrification was much less concentratcd. A number of mochanical onfineers and tool makers were dram into electrical onfineering In the years 1888 - 91. The beginnings of factory porer arter 1901 drew in many more. The range of uses for electrio motors was very wido, from steal rolling mills to spindles, and was to some extent sogmented, with a few firms supplying particular types of motors. Th1s was partly because mechanical engineers would concentrate on bullaling motors for thelr range of machino tools. But motors could never be as differontiated as tools, and thus the degreo of competition between the various segments of the markot must have been high. Also the electrical manufacturers did not specialise in any one part of the motor market. Taking factory -lectrification machinery as a wholo, literary ovidence suggests that the major producers had a falrly large share of the market, although below that for contral station plant, but that there was a long tail of amall producers. This rather sparse information on the structure of sellers oan bo added to by data derived from published tenders. Mlost tenders wore not published but there were still quite a large number which were. They indicate the number of firms in each section of the market. But they only relate to utilities. The information is given in Tablo 82 . Fims ald not tender for all contracts. This is noticeable in totating plant, owitchgear and transformers, but not in cables and traction oquipment. 
Tab1o 82.

Elactrical plant \& machinery sold to utilities. Nuriber of flans tendering.

\begin{tabular}{|c|c|c|c|c|c|c|c|c|c|c|}
\hline \multirow{2}{*}{$\begin{array}{l}\text { Ioar } \\
2894\end{array}$} & \multicolumn{2}{|c|}{ Cables } & \multicolumn{2}{|c|}{ Rotating plant } & \multicolumn{4}{|c|}{ Sritchgear|Statio Trans- } & \multicolumn{2}{|c|}{ Traction Bquip } \\
\hline & $\begin{array}{l}(1) \\
7.5\end{array}$ & $\begin{array}{c}\text { (2) } \\
2\end{array}$ & $\begin{array}{l}(2) \\
6.0\end{array}$ & $\begin{array}{c}(2) \\
3\end{array}$ & (1) & (2) & $\begin{array}{l}(1)^{10} \\
9.0\end{array}$ & (2) & (2) & (2) \\
\hline 5 & 6.4 & 5 & 5.7 & 3 & 9 & 1 & 7.0 & 1 & & \\
\hline 6 & .7 .0 & 3 & 6.3 & 3 & & & & & & \\
\hline 7 & & & .5 .0 & 3 & $\cdot 5.7$ & 3 & 8.0 & 1 & 6.5 & 2 \\
\hline 8 & 5.5 & 4 & 8.5 & 4 & .8 .8 & 5 & 3.5 & 2 & 6.0 & 2 \\
\hline 9 & .7 .5 & 2 & 7.8 & 4 & .7 .0$. & 2 & 400 & 2 & 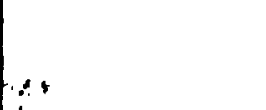 & \\
\hline 2900 & 5.8 & 4 & 8.0 & 3 & & & & & & \\
\hline 1 & 7.3 & 7 & 25.0 & 5 & .28 .0 & 3 & & & - & \\
\hline 2 & 8.8 & 4 & 23.0 & 3 & & & & & 6.5 & 2 \\
\hline 3 & 9.3 & 4 & 23.5 & 2 & 21.0 & 1 & 20.0 & 2 & 7.0 & 3 \\
\hline 4 & 7.6 & 5 & 5.2 & 6 & 9.0 & 2 & 5.0 & 1 & 5.0 & 2 \\
\hline 5 & 7.2 & 22 & $u_{4.5}$ & 4 & & & & & 400 & 2 \\
\hline 6 & 7.2 & 8 & 20.0 & 5 & 8.3 & 4 & & & 5.0 & 2 \\
\hline 7 & 6.8 & $22^{\prime}$ & 8.3 & 7 & 22.3 & 3 & & & 4.0 & 2 \\
\hline 8 & 6.7 & 7 & 9.0 & 7 & 9,8 & 4 & 400 & 1 & 4.0 & 1 \\
\hline 9 & 8.5 & 21 & 9.0 & $6 !$ & 7.7 & 3 & 6.7 & 3 & 3.0 & 1 \\
\hline 2910 & 6.9 & 7 & 6.0 & 3 & 6.0 & 4 & 8.0 & 1 & 3.0 & 2 \\
\hline 11 & 9.2 & 5 & 6.2 & 10 & 9.3 & 4 & 5.3 & 3 & 400 & 2 \\
\hline 12 & 20.2 & 9 & 6.7 & 6 & 21.0 & 2 & & & & \\
\hline 23 & 21.0 & 6 & 7.2 & 7 & 7.8 & 4 & 7.0 & 1 & & \\
\hline
\end{tabular}

(1) Averago number of firms tendering for cach contruct.

(2) Ilumber:of contracts for which such detalls wero published.

Rotating plant is principally generators, rotating convorters, largo motors. The flquros are of finns who were also manufecturere. It is howovor Impossiblo to guaranteo that all agents tendering plant not manufactured by themsolves are excluded.

8ourcos Tender dotalls publtahod in tho Eleotrical Reviere 


\section{Tablo 83.}

Rotating plant for Central Statlons. Firms tendering for and supplying plant,

(1)

Firms tendoring for rotating plant. sverago por contract.

2892

3

4

5

6

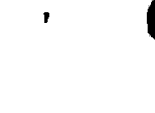

$\cdot 7$

- 8

, 9

2900

21

2

3

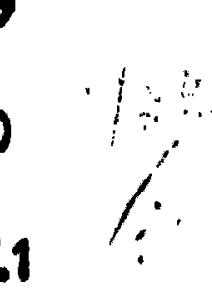

4

5

6

6.0

5.7

6.3

5.0

8.5

7.8

8.0

25.0

23.0

13.5

5.2

$5 \quad \boldsymbol{U}_{4.5}$

20.0

7

8.3

8

9.0

9

9.0

2920

6.0

21

6.2

22

23

7.2
23

21

23

12

25

23

20

(2)

Finns oupplying contral station generators. Total
Proportion IIrms tendoring for each contract.

2 year moving averagelo

3 yoar moving arerage of

.45

.43

.42

.37

24

.34

28

.36

34

.50

29

.54

33

24

.48

$24, \quad, \quad \ldots, 04$

24

.42

25

.45

23

.43

16

.47

27

.46

29.

.39

18

- . .36

16

.49

29

Sources Tander details for Col. I and Eleotrical Trades Diractoms Pnr Col. 2. 
In the case of rotating plant we can put together, as has been dono in Table 83 the total number of Pirms supplying plant and the avcrage number tendering In any one year. The ratio botwoen tho two is steady in the long xun. In the depressed oligopolistio aituation of oleotrical machinory manufacturing one would expeot some type of association betwoen firms. There were attempts to form somo agreements, but until after $29 \mathcal{L}_{4}$ they wore almost entirely unsuccessful. Flectrical manufacturers first began to consider comblnation over the harsh conditions of contract imposed on them by the municipalities. After the experience of the early ninoties, the principal manufacturers came together in 2895 to try and change tho usual conditions of contract. In Larch 1896 the Eleotrical Revien roported that there wero rumours that existing manufacturers were "taring: counsel togethex." The rumours, were correct and tho substance of tho matter is given in a letter fram R.B.B. Crampton to J.P. Albright, datod u $_{4}$ Pebruary $1896 .{ }^{2}$ Crompton says .
"I am suro you will be glad to hear one thing, which is that after a good deal of troublo we have at last got nearly all the princtpal manufacturers to agree to form an sasootation to be kept as quiot as possible, pirst for the purpose of arrooing to boyoott certain clauses in specifications ..... cecond to agres to insist on botter terms of payment in munioipal contracts (1.e. more rapid payment) .... thereby limiting the porrer of the consulting onglnoer .... The last firm to join has been Parker. Everyono is in 1 t but Siomens and Siemens' people are quito ready to join but Siemons himsolf is awas In the Amsons"

The Association (the Electrical Plant Lianufacturers Asecolation) ontered into nogotlations with the Kundolpal Eloctrioal Assoolation to

1. B.R. V01 - 38, PR 292 - 2. 6 Harch 2896.

2. Orompton Historical Rocords. 
establish standard clauses governing the relationship of consumers, manufacturers and consulting englneers. By iiarch 1898 comerclal 1 oonditions had bocn dealt with and 1 t was hoped that more would be dono by standardising many tochnical foatures. Brush, Crompton, the B.C.C., Forrant1, Fowler and Johnson \& Phtllips were the manufacturing Pirms involved. Tha Association doos not seen to have thought of price agroements or market sharing.

This document had 2ittlo effoct on practioe. Sinniclpalitios st11l proposed harsh condition in their specifications and these were accopted. Representations were made to the Institution of Bleotricel Enginoers and in Deccmber 1900 a comraltteo was formed to propare a draft sot of "model clauses". Representatives were rocruitod from the Lunteipal Eleotricel Association, the Blectrioal Plant Manufacturers Lssootation, the Cable frakers Association and the Bnglinearing Buployere 7und. In Aprell 1902 a draft of these clauses was publsohed. Thoir

1. The following model olouses were drawn up:

(a) Lixtra and edditional drawings to be pald for.

(b) Variation of works by (consulting or municipal) enginear on the spot to ceuse adjustment to the contract price.

(c) Penaltios for non completion of works not to exceed $2 \%$ por weok of contract value.

(d) Rent of $5 ; i$ p.a. to be peid if works used bofore contract comploted and paid sor.

(i) Payments were to bo made in each wonth for $75 \%$ of tho work dane in tho month until tho $25, \mathrm{~s}$ balances adcled up to $20 \%$ of the total contract. Then 90\% of the work dono in each wonth was to be pasd for each month.

(f) Jaintenance by contractors, savo for fasr wear and toan, to be up to 12 months only.

(g) Disputes were to be sottlod by arbitration. 
Intention was like the 1898 clauses to redress the balanco in favour of , tenderers. But this latter document had no wore effect. In thay 1900 the Electrical Heview comsented that the I.J. F. model conditions hod not came into general usc. Contracts, as one might expect in view of the deprossed state of the industry, were still very hand on contractors, particularly with respect to terms of payment, absence of arbitration clauses and abnormalis hoavy penalties for lato dolivery or fallure to 1 moot guarantoes.

Other attempts to restrain competition had no better results. In 2902 the National Blectric lisnufacturers Association (N.E.M.A.) was 2 formed. Its mombers horever did not include the bigest manuracturare. Britisb Westinghouse for exangle dia not join until 1909. Isargely because the largest flims wore outside, it achieved little. In 1909 1ts past achiovements were said to bo concermed with "railivey ratos, custows classifications, specifications, firc insurance, oxhibitions, Christmas boxes and other trade abuses, the establishwont of a banevolont fund .... "4 The tane of N.E.Xin.A.'s annual reports confirms thes. It was not intended as a body for restricting competition, but "to ropresent tho views of its members in matters of general interest to the industry. Yet It was olearly hoped that sornothing wight be done about prices under tho N.K.L.A. umbrol2a. In same branches of the trade this did happen by

1. EeRe Vol. 62. PP 725 - 6. I Viay 2908.

2. Lonopolies and Restrictive Practices Commission. Report on the Supn2r and Exports of Blectrical and Allied irachinerz and Plant, 1957. P 23.

3. E.R. Vol. 64, P 95021 Juno 1909

4. E.R. Vol. 64. P 95011 June 2909.

5. Honopolles Commission. op.c1t. P 23. 
1907 the condult makers had "formed an association for the better safow 1

guarding of their partioular interests." The Elcctrical Reples

caumented in 1907 that "in some smaller lines the menbers of certein

trades who happened to be members of the Electrical Menufacturero Assoolation

were roported to be successful in offorts to ralso prices when raw materiol prices rose." 2

But in generators, motors and other heavy mohinery nothling was achleved despite a serious attennt to reach an agreament in 1907. In Jamuary the Eloctrical Rovler said,

"Wo are told that atterpts are being wralo to bring manfacturers together again for the purpose of correcting prices, but while most Plmis have evinced a rcadinoss to particinate in suoh an aproement, we fear the wovenent is not 2ikely to succeod bocauso it is comonly understood that 2 or 3 firma aire strongly onposed to a combination."

Its prediotion was confirmed nine manths later by a lotter from $\Lambda_{0} P$. Wood,

the General Manuger of tine Lancashire Dynamo and Hotor Co. Ho said,

"Somo nonths ago various marwiacturers of dynamos and motors mado a strenuous effort to regulate the prices of eleotrical mnchinery. They got out a complete schcmo for the working of this, which mot with tho unanimois approval of all the inembers, yet throc or four of the largost finus in the country dofinitely refused to cons in and the scheme had to be abandoncd. In vier of this, and also of the faot that there aro so many aynamo manufacturers in this country, it soems to bo practically impossible to got a scheme togothor for a genoral regulation of prices." 4

1. 2nd annual report of N.E.M.A. B.R, Vol. 60. PP 601 - 212 April 1907.

2. E.R. Vo1. 61. P 432. 13 September 1907. There was an early prico ring for example in reters and wo mny supiose it was in operation by 1907. Also there were agrecments in electrio laups.

3. E.R. V01. 60. PP 85 - 6. 28 January 1907.

4. E.R. V01. 61. P 487. 27 September 1907. 
A "Lanufacturer" writing in the Electricel Review in 1908 put a similar mowpoint. Several times in tho pnst, he argued, manufacturers had triod to arrange ratters iogether whth a view to agteeing on conditions of contract, and limiting the fierconess of the compotition at present existing botween then, but they were unablo to agree among themselvess or, having agreed, were unable to abide by their undertakinge. Although only 10 - 25 firms vare involved, he had no high hopes of future agreement. Ho argued firstly that there were both hoelthy and unhealthy flrws and that any agrecmont frould handican the former. Only seter sano olimination of weak firms would combination be possible. Secondly he argued that the big four had divergent interests. Dick, Rerr hod British management and was Sinarced at home. British Festinghouse was of American origin, and was still zun by Americans, nlthough it had beon elnanclally disinhordted by 1 to parent. British Thomson-Houston and Siemons ram controlled and sinanced by Americans axa Germans respoctively.

In the ovont there was no olimination of "unhoalthy" 21rms, but the improvoment in trading onditions in 1911 - 12 did provide moch bottor ofrcumstances for prico agreerconts. In 2911 N.E.M.A. was rooonstruotod $w$ the British Electrical and Allied Manufacturers Association (B.E.A.M.A.). Thls tive all tho major manufacturers were mombers, From about 1912 those woro sare price agreements relating, to the turbo generating plant. In 1913 tho first afrecisent vas slenod rolating to the prioes of emall motors and generators. In the same year five transformer mamufacturers joinod togather to oprate a noti-lication agreement, and three years later bogan 2 to arranice constion prices.

2. E.R. Vol. 63, PP 566 - 7. 20 October 2908. The Proposed Electrical Leamue and criticism from a lranufacturors point of viers by" Hanufacturor."

2. Nomopolles Comnission, op.c1t. PP 59, 214 and 250. 
All this contrasts sharply with tile siluation 111 the cablo makine section of the industry. In 1899 the Cable Kakers' hissoointion was formed. Ostonsibly it was to provent deterioralion in quality whioh firms in the industry felt was taking place oring to conyetition. Fins joining agred to acoopt as a minimum the prices then suling and to compete only in quality. The cables of three crades then most in use wore otandardised both as regards weights aid rezistances of the coppor conductors, the thicknoss of the dilectric, and the protecting coverings overall. In 1900 the O.M.A. auggested contract terms for tise oupply of olecurio oupply main. These were sintlar to those suggested by the bleotrical Plant lianufacturera Association and liknicipal Eleotrical Association in 2890. But in preotice the cable makers were able to exerciso men more influence on munioipalities than tho olectrical machinery makers. Thos struck out clauses in spectfications which they objectod to, and were of ten awarded the contract despite this.

Thoy were successful for two reasons. Firstly the internal d1soipling of the group was wuoh greater than that of tho machinery maicors. Concentration seeras to havo boen higher. Tho trado in elcotrlo I1ght and power cobles was dominated oy British Insulated Firo and Callanderw, although olght or nine firms regularly tendered for contracts. As an be seen from Table 84 the product was much moro standardised than most

1. Letter from the C.M.A. to the Fiectriction. January 2906. Quoted in the E.T.D. 2908. IIS 209- II

2. E.R. Vol. 47. PP 486 - 7. 21 Septemior 1900.

3. In 2902 it took over the Telograph lianufacturing Co, and booseme Brit1sh Insulated \& Holsby Cables Ltd. 
Toble 84.

Tendor vertances enr elifecent product siouns $1891-1913$. Varionce Number of contracts.

Rotating plant

Switchgoar

Stat10 Transformers

Tramiray equipment

Accumulators

Cables
167

346

293

90

$334_{r}$

79
210

64

17

26

22

87

- The average of the variance of tenders submitted for each contract. To allow for differences in the size of controct3, all tender prices were expressed as a percentage of the average tender prioe for a contract. The variance of these porcentages vas then colculated.

Sourcos Caloulations from tenders published in the Blocirtcal Rovien,

machlnery and the C.M.A. reduced heterogeneity by introducing miniman standards. Thus competition other than on price was reclucod. Ay sheding of prices was more obvious to the group than rould have been the case with a more differentiated product. Individual firns had thw loss Inoentive to reduce prices, es such reductions would be obrious and Iredy to be solloned by other firms.

\section{Secondly English cable makers wers not at the sache cost} disadvantage compared with forsign competitors as oloctrical machinery manufreturers ricre. Tochnical prowress was wheh slover in cables, and quality was primartly 1raproved by carciul manufacture and the use of high quality materials. Although English cable makers do not noem to 2. P.V. Huntor and J.T. Hazoll, 2p.oft. Shaptors 9 and 20. 


\section{Tablo 85}

Propits of cable makers. Annuzl profits as \%o plxed Capital, Inventorics, work in pronress and shares in othor companies.

2895 B.I.W. Callender Siemens Henley Glovor I.R.G.P. Tol. Conr

96

9.4

21.4

5.5

20.7

97

12.0

4.6

7.7

98

16.7

21.2

6.9

6.2

7.9

99

$20.9 \cdot 3.0$

21.2

8.5

5.7

7.2

2900

$25.5 \quad 20.6$

13.5

6.2

8.2

02

$22.0 \quad 23.2$

13.6

6.8

8.5

$02 \because 8.9$

$8.0 \quad 2.8$

13.0

5.2

4.2

6.5

$03 \quad 8.6$

6.3

2.7

8.3

3.9

4.9

8.1

- a 8.2

$6.3^{\prime} 4.3$

8.4

2.8

3.8

058.3

$9.1 \quad 4.2$

$8.4 \quad 7.2$

5.2

5.9

\begin{tabular}{ll|l|l}
06 & 23.2 & 8.9 & 5.5
\end{tabular}

9.420 .1

or $9.0 \cdot 6.2 \quad 7.2$

$9.8 \quad 9.1$

5.6

$08 \quad 2269$

$6.3,8.0$

9.1

8.3

5.1

6.6

$09 \quad 8.3$

560

8.1

6.6

4.9

4.8

2920

7.3

5.2

8.4

7.6

6.8

409

5.4

219.4

7.2

7.7

9.9

8.2

8.9

$22 \quad 20.5$

9.3

6.9

10.3

11.6

$-2.5$

5.7

$23 \cdot 22.9$

8.2. $\quad 10.5$

22.2

9.8

4.0

6.8

น4 20.9

4.2

6.7

1. British Insulated Firo. APter 1962, British Insulatod and Heloby.

2. Inala Rubbor and Cutta Pcrcha Co.

3. Tolograph Construction and inintenance Co.

Tol. Con. and I.R.G.P. Were largely concorned with tolegraphlo cables.

Soume Comnanu. Bninnes shaets and Profit and Inas ancounte. 
have given the same attention to research as did the Germans, they weiv not left behind in the gcars 1904 - 10 as were munuracturcrs of electrical machinery. This seams partly to luave beon bocause cablo dosign was not changing as fast as machinery design at the tine, but the effeot of the price apreement in keeping up profits may have holped by providing adoçuate dovolopwent resciurces. Cable makars profits aro shown in Table 85

Because thero ras no appreclable gap between the quallty of British and Curtinental oables British Caible makars wero able to exploit the proference of municipolities for British plant. There are numerous cases, especially in London, whero wunioipalities disrogardod forolon cable tenders although at prices below those of hame monufacturers, prinaipally because no one could be sure that they would comply withithe fals wage clouse. This gave cablo makers a protected maricet, with an inelautio denind, and they seem to have practised sume prico alscrimination, charging Lose to compang purchasers where the elastiolty of demand far thatr products was hifiner.

After 1910 the demand for olectrical machlnory began to expand raplaly again. Exports had beon rising since 2908 as manufacturere ware driven to seek overseas markets by the low demend at home, Britich Mestinghouss with considerable surplus capacity had turnod to exports batween 2905 and 1907; they were trobled in value in those jours. Foroign compotition at hamo had declined as prices sold. In tho yours 
2900 - O4 there wore 26 afencies of large Continontal firms in this 1

country. By 1909 onily 5 ramaincd.

But it was the rise in home demand which provided tho main force bohind the upsiwing. This seems principally to have been a rise in the desiand for plant for factory electrification. The output of plant for Lisis purpose is probally underostimated in l'ablo69. Thts upsing morged Into a wartime boom, whioh was the procuct of furthor inoreases of darcand for plant, primartly for faotory oleotrification, and the interruption of Irjports. The profits of most compandes rose. There ras in general Iittle expansian of capacity, usuaily firms moroly achieved full eapacity workinc. The only fizin to axpand capnolty was british l'homson-Houston. A now lamp factory was built at liilleadon to help the fugby lamp factory moet tho Incroasod cemard for motel filament lamps, and nors plant was lald lawn for heavy equipwont manufacturing. An extra 250,000 square foot wes added to the 5CO,000 square foet of $2100 \mathrm{r}$ spece from 1402.

Iittle oi noie happened in this period. Boomomically It was uiuply a period of recovery from bad conditions. lechnically thore were no big changes. Ithe only significant technical change was in connootion With turbinos. After the success of the Farsons turbino, other manufacturers began to make steam turbines. Parsons built the whole

1. IS Fomign Comnotition Overrated? by A.G.H. E.R. Vol. 64. PP 1026 - T. 18 June 1909 . "... When the Goman sues that there 1s no roesonable profit left ho withilraws from the competitions our home flims on the othor hand 50 on paring prices dom until they cannot get conough out of a cuntract to meot office, otc. expenses." I. 
Tablo 86.

The Expanditon of decets $1210-y_{40}$

Britloh Fostinghouse

(Doc. 1909 - 2913)

\begin{tabular}{|c|c|c|}
\hline $\begin{array}{c}\text { Increnco in } \\
\text { Plxod assets } \\
\text { oftcr deproce } \\
\text { iation } \\
\&\end{array}$ & $\begin{array}{l}\text { Increcse in } \\
\text { otocks \& } \\
\text { work in } \\
\text { progress }\end{array}$ & $\begin{array}{c}\text { Increase in } \\
\text { financial } \\
\text { asseto. } \\
0\end{array}$ \\
\hline$-93,545$ & 265,976 & $-43,042$ \\
\hline 336,462 & $257.643^{2}$ & $230,222^{2}$ \\
\hline
\end{tabular}

B. TaH.

(Yarch. 1910 - Deo. 1913)

$-25,844$
(after salon)

77,745

2,268

(Juno 1910 - 1913)

Stemans Bros. Dynamo Forica (D30. 1909 - 2913)

27,412

176,087

$-235,440^{\circ}$

Brush

(Do0. 2909 - 1913)

$-5,084$

33,963

$-36,206$

Crompton 3

(Warch 2910 - 2914)

$45,423 \quad-32,603$

$-53.209^{3}$

E.C.C.'

(Hay 1910 - 1944)

6.736

38,652

$-40,304$

Bruce, Peebles

722

23,297

$-25,846$

G.B.C. (Witton)

(viarch 1910 - 29u )

$-6,968$. $\quad 216,952$

Britiah Electric Iransformor

(Doc. 1909 - 13)

$u, 245$

23, 779

26,329 ,

2. To Dov. 1912 for shares in other companies. Deo. 2913 rigure not avallable before itte off.

2. Work in progress is uncier "debtors".

3. Reconstructed 1912. Some write off mey be unallowed for. Inorease in PInanotal assets excludes changes in shares in otber compendes whose thore is clearly a big writo down.

4. 1913 accounts not avallable.

5. Croditors inolude loans from S1omone-Sobuckert.

Souroer Company Balance Shoots. 
- Táble 87.

The source of Funds $2910-191_{\text {the }}$

Borrowing

on ordinary on pres- on deben- on loans Rotalned proflt ohares erence! tures before dopreon \& \& $\& \&$ \& $\quad$ Lat

Brit1sh Hest-

(Dec. 2909 - 2913)

1,108

350,238

B. $T-$ B.

(Mar. 2910 - Deo

1913)

$-24,485 \quad 860,742^{\prime} \quad 228,909$

Dick, Kerr \&

United Electrio

Carriage Co.

(Juno 1910 - 1913)

$-70,370 \quad 200,000 \quad 20,967$

Brush

(Dec. 1909 - 2913)

$23.762 \quad-23240$

3,603

Bnuce, Peebles

(Deo. 2909 - $\left.19 u_{i}\right)$

16,238

4,802

E.C.C.

(Ling 1920 - 2914)

$-60,000$

57,031

1. 2818,731 came from Goneral Elootrio.

Souroet Company Balance Shoets. 
generating unit from the beginning, but this prictico res only partially followed In Britain. British Festinghouse built Parsuns typo turbo alternators and generators; B.T-H. bullt Curtis turbo-altemators. But Siemens and DIck, Xerr at flrst only bullt high speed alternators. Parsone Losued licences in 2903 to three flms to make Parsons type turbiness Brush, WLLlans and Robinson, and RIchardsons Wostgarth. Billans mado no eloctrical machinory, Richandsons Featgarth only a littlo. Fillans mode turbines primarily for coupling to Slemens and Dick, Kers altornatore.

Parsons eliminated turbine development in Britain; be had 2 designed reaction turbines. Only B.TrH. made the other type, impulse turbines. The Parsons reaction turbine was highly offinient but it had omall clearances betwoen the blading and the casing. This often lod to di'ficultios, not it seems with the turbines manufacture by Parsons, but with the Parsons type turbines made by Brush and F1llans. General Blectrio, A.E.G. and Sienens-Schuckert had made Impulse type turbines from the beginning. Outside England only Westinghouse and Brom-Boverl ade rosotion turbines. English manufacturors, exoept Parsons began to turm th impulse machines around 1910. Wostinghouse as oarly as 1903 had coolded to concentrate in future on 1mpulse turbinos as "exporionce had

2. Fiostinghouse bought the land rifhts for North Amorica of the Parsane turbines in 1895 (H.C. Posser, op.cit. P 311)

2. A reaction turbine dirites 1 ts poricr froit the expencion of the steam as it passes through the blades of the turbine whools. In an impulse turbino the steara is expanded betrieen the wheels of the turbino. No expansion tekces place in the blales of the wheel. After 1944 near2y all turbines were impulse-resction. with imoulse wheels at tho high presure and and reaction vheols in the low pressurs end. Parsons machines to this day have preserved a very hígil proportion of roaotion wheels.

3. Changes of steam temperatures caused difforential oxpansian and could lead to blado stripping. 
shown the advantaces of impulse blading in freedom from fine ruming clearances and thorefore from str1pplng". In 1909 K. Baumann was appointed chief ongineer of the on ine departmont to dovelop impulse turbincs. Ho was an assistant of Professor Stodola of Iurtoh, one of the great muthotities on impulse turbines. 2 In 1912 Barmann was appointed ohlof mechantcal engineer. Fillans and Robinson, after tholr lack of success with reaction turvines, turned first to arum and dak turbinos and then in 1944 to pure impulse machines. A 21 cence was obtalned from Bachor Fyss of Zurich. ${ }^{3}$ In 2912 Brush had brought to its notioe the Ifungstrom turbine developod in Sreden. It was ablo to doal safoly with rapidly changing steem pressures and temperatures, and it promised to be more effloient (thermally) than the Brush-Parsons, But its type of oonstruotion 11mited 1ts sizo. Its future loy in loolated rather than contral station plent. Brush took out a 21cence and soon ondtchod to this turbino.

In 2910 DLck, Korr began to bulld stoam turbines. Thoy were to be Impulse type and Dlck, Kerr arrangod with the patent holders, the 4

Borgmann Company, to make tholr deslens undor 110ance. In1s wove by D1ak, Karr also Indicates more concontration of the manufecture of

2. J. Dummelow, op.cit. P 36.

2. J. Dumnelow, op.c1t. P 42.

3. H1story of W1llans and Robinson. Tho Englioh Eleotric Journal, July, September and Decomber 1955.

40 Berguann was a German Company, third in Importanco to A.B.G. and Sicmens-Schuckert, with whom it had close finanotal 21nkes. Tho Lahweycr dymamo works of Paltan and Gullleaumo-Inymoypr works had bean taken over by A.E.G. 
turto-genorators by the oano Itrm. Just before tho first world war Slewons Bros. Dymano worite also began to mako turibinos. In 2926 Willans who had thus half last Its two bont cuvtanors, was aboorbed by DLak, Herr. Thio move towanis more vertical intogration socus to have takon place for encinocring ressuns. Iut it had the ooonousso effeot of Incroasing the amount of copital rocossary to begle the production of Larie conerating plant. Thus tho alotinotion betwoen contreal atation and othor genorators wldonad furtbox. 


\section{Chapter 9.}

The Public Control of Electricity Supnly and Tromers.

Wuch has alrcady been published on tho leglslation concerning the electrical industry. In many accounts of the development of the use of electricity it has played a very important, somotimes central, rolo. It has boen blamed for the slow development of elootricitys sometimes it has been pictured as the only villain in the stary. There Is no doubt that many other factors played a more decisive part, got it 1 must bo sald that legislation was an importent matter, and one cannot discuss the Increasing use of electricity without paying attention to it. Father than simply discussing logislation, it is better, howevor to put It In Its propar context - as a major part of an attempt to reculate natural monopolies in the public interest.

Public utility control in 1 ts varlous phases ercon $1850-2950$ often did have undesirable effeots. This was certainly the case with -lootricity oupply and eloctrio tramrays. But many of these offeots arose almost inevitably fran tho attempt to devise controle when the economio atmosphere wgs to a considerable dogreo dominated by Lalssersfatre views. Control of electrical utilities will be looked at in this chapter from this polnt. of vierr.

In the flrst hale of the nineteenth century $1 \mathrm{t}$ wes thought that competition was all that was neoded to direct the Individuals sooking for propits towands desirable social ends, and this doctrine was applied to what we would now recognise as matural monopolies. After 2850 this wew was to a large extent abandoned, because in water and gas compotition 
scemed to have been positively disadvantageous as it caused excossive 1

Investmont in distribution networks. Thus a new technique was tried. Natural monopolies wei'e granted franchioes whlch explloitely recognised their peculiar economic position but conditions were inserted to limit them where attempts to maximise proflts might lead to anti-social behaviour. Early devices wero maximum prices and statutory limits 2

on dividends. It is lmportant to notice that these conditions were establislied when the utility was granted its powers. No further interferunce with its workings was thought nocessary or desirable.

The other ramedy for the abuses of prifrate monopoly was munioipal operation. By the time eleotrie lighting beome comidrolally feastblo local authorities mero in many cases running gas and wator suppl108. Th1s was due to the infitiative of the $2002 \mathrm{l}$ euthorit108, and not to Parliament.

The Iramays Act of 1870, introduced into Parliament boonuse of the success of the new horse trams, is a landmark of considerable importance. Firstly, it introduced a drastically simplified procourvo Sor obtaining franchises, and for laying dom general conditions to provent abuses of monupoly power. Intonding tramey omere wore to apply for a Provisional Orier from the Board of Trade to operate under the general conditions of the Act. Hitherto utilitios had obtained

2. The reports in $1847-8$ of the surveying of ficcrs appointed by H.1. Commissioners of Foods and Forests to examine the Gas B1ils coming before Parliament marks a turning point. See W.A. Robson, The Public Utillty S.rvices. Chapter $\mathcal{H}_{4}$ in H.J. Laske, H.I. Jomings, and i. A.Robson, (eds.) A Century of luniclpal Progress - the last

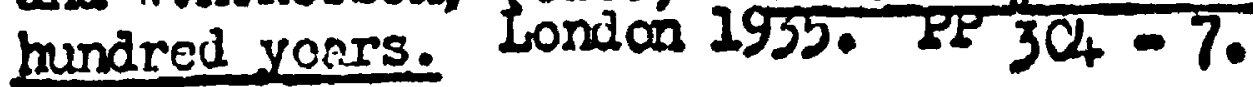

2. Liaximum pricos became custamary in Gas B2128 from 1847 anwerds. Robson, op,cit. P 305. 
their powers by private act of Parliameant, an expensive and rather cumbersane procedure, ospecially ns the muber of utilities was rapialy rlsing. Secondly, the 2870 Act brought together the two mothods of oontrol, the insertion of conditions in the franchise and muniolpal oporatlon. A clause provided for the compulsory purchase of a tramrar by the local authobsty 21 jears after the grarting of the provielonal order. The peloe was to be the value of the plant, and was to exclude goodv122. Coodw111 was exaluded from the purchase prioe beowse in the past looal authoritios had had to pay vastly Inflatod oums to purchaso Inofflcient monopolies. Blackburn "to get these manopollsts out os the war" had paid $\$ 559,000$ for a gas workes whose structural value was \$222,000 and Lssued capital \&238,000, and \&283,000 for the water worio whioh had hed \&119,000 spent on 1 t and was of "Ilttle value" at the time of purchase. Birmingham had a similar experience in 1857. The 1870 Act gave the towns powers to om the tram but not to sun them. They had to be loased to a company whlch would oporate them. On the other hand thoy could make byulams regulating the rumber and frequency of trams, and these would apply even if the trams wero privately omed. 3 unicipal operation vas, however, soon to follow. In 1882 Huddorseleld Corporation could find no one willing to operate Its policy and permit Corporations to wark the system themselves unlass a company made a "reasonable offer". This aid not ge Corporation general powers to operate the trams; in 1889 Ifverpool Corporation

2. Select Compitteo of House of Lords on the Eleotrio Lighting lote as 1836, Q 2728. B.P.P. 1836, Vol. 7.

2. ibidei Evidence of the Tom Clerk of Btrmingham.

3. H. Finer. Municipal Trading P 52.

4. ibidis. 
promoted $a^{\circ}$ Bill for poners to work the trams in case of need, but it was rojected by the Lords. But in the early nineties several locel euthorities obtalned powors to work their trans undor speoial circumatanoes and by 1896 powers wore boing freely granted to them.

Parliament was quick to investigate the possibility of Leglelative needs following the comercial application of electrio 1ighting, appointing a Select Committes as oarly as 1879. It did not rocomend ans legislation but the apperently iminent wldespread application of electric 1ighting in 1881 and 2882 quidkly produced the Eloctr10 Ilghting Act of 1882. It was modellod on the Tramsays Act of 1870. Prospective undertakers wero to apply to the Board of Irade for a Provisional Order or a licence. Licences gave rights for seven years but were rarely used. Provislonal Ordars were to run for 21 your, after which time the locel authority could buy the undertaking at the plant value. Initially the Act was designed for olose control by making Provisional Orders run for seven years only, but this was arionded to 21 during the passage of the Act. There was no doubt about the rights of the muniofparities to orn and opernte eloctricity supply station; in Paot the Board of Irade interpreted the Act as giving them preferonoo over a company if both should apply for Frovistonal Onders at the same time. But they were not to block the activitics of a company by holding and not proceeding with powers. Thore was also a standard maximum price of 8d. a unit. The specif10 power cranted under the fict was to opon tho troets to lay cables. An undertaking could supply eleotricity without Parllamentary powors il' its wires were all overhead. Overhead wires wore 
usod in a for early cases, but this clearly was only possiblo for very small undertakings. By the middle of the eighties many poople felt that the fet too much hindered the Pomnation of Electricity Supply Compandes and the purchase clause was amended to givo 42 yoars oporation bofore compulsory purchase was possible.

The 21 years purchase clause of the 2870 Trampays 1ct was also ouperseded. In the nineties the governont was anxious to rofuvenate the asricultural areas. A Comitteo was oet up to inquiro into transport In rural areas and recomnended light railways as ramedy. Thas in 2896 the Ilght Rajlways Act was passed. Again authority was given by the granting of a Proviolonal Order, but the Act was much more favourable to the operating company than the Tramby Act. Compulsory purchase wes not at ans speclfied timo but by agreenent between the local authoritij: and the company proposing to operate the line, and it was to be at a price determined by arbitration. Iramrays could not lay tracks within $9^{\prime} 6^{\prime \prime}$ as the kerb if one thind of the frontagers objeoted but light railways had only a centre line abd linfts of deviation set down. A Iight Rasiway wao assessed for rates at a quarter of the net annual value while Trammays 1 wero assossed at the full annual valuo. This Aot was soon used by compantes wishing to build eleotric tranrays, and al though initially besitant, the Board of Irade very soon freely granted thom the relovent poviers. Botween 1896 and 1914 tro thinds of the 21 nes butit in the streets and private roads were Light Railways. |

d. C. Klapper, The Golden Age of Tramaye. P 340 2. ibid.e. $P 35$. 
The porrer companies and the unclerground railways were granted powers by private Act of Parliament. There wore not enough of them for it to be worth wizile having tizo simpler system of Provisional Orders. Hore thero was no question of municipal operation. The Porrer Companies covered large area, while municipal operation was thougint of as being somothing for a uisity entireiy - or almost entirely - within the bundaries of the muntclpality. Corporations, with one exception, made no attempts to coubine for electricity supply, and in any case they would not have secen the supply of power over a large area as one of their proper aphores of activity. They rere acting for their ratepayers, to onsure for them roubonably cheap and adequate supply; they wore not general entrepreneure soeking a profitable return. The L.C.C. promoted no Bills to construct tube railirays, but this was partiy becuase the underground Acts were passed In the early nineties when the newly farmed I.C.C. was only fust beginning to Iind 2ts leet.

In neither of these two cases was compulsory purchave serlously - consldered. The porrer schemes covered too wide an area for it to be sensible for the big towns, or in some cases even tho County Counolis to take over the undertakings. The County Counc1ls, moreover, had no tradition of municipal t2rading. In the case of the Central Iondon Ratiray, tho L.C.C. certainly felt that it should have powers of future compulsory purchase, but the Select Conmittee on the Bill sal no reason why this 1 should be so. The only control in these cases was the fixing of maximum Hotropol1s. B.P.P. 2892. Vol. P 12. Q.252. 
prices for the power companios and in insistance that the underground rallway compantes should provide an oderuate numbor of cheap and corvenient tratns. Also Bchenes woro to be carried out in a rossonable poriod of t1mo. There was no unalterable time limit, whero thore was an Initial Iimit, extenoions of time were granted - and the best stimull to starting on the schene wore the expectation of profit and the sear that otherwise a similar carpeting schento would be authorised. In the case of the power companies no two comreting schemes were authorised at the samo timo. There two companies promoted Bille at the samo tino for ointlar areas only one was passed. As in the case of general eloctriuity cupply and tramrays, tho basic prinoiplo was ths establishment of a formula which rould stop the abuses of monopoly without further Interfurence.

The initial conditions under wilich a company might oporate an electrical utility were principally dotermined by Parliamont. But the local authority had some influenoe over these conditions. In the ase of undertakings not up by Private Aot they could try and influenoe tho flimal form of the Act, principaliy in Comatteo. In the case of the Powers Company Aots, all the Iocel authorities seemed to want to do was to got thenselves excluded from the area of supply. This was on the general grounds that the porver companies, who had no ooligation to supfly to all comers, rould simply compete for propitablo consumers, leaving the municipal undortaking to founder on the unjrofitablo ones. The romits would be a rapacious private monopoly. Tho large minicipalstios were usually ablo to got thomselvos excludod, oither in Cormittee, or by acroemont. The latter moant that the powor compans agreed to wolude 
them rathar than risk losing tho wholo Bill because of local anthority opposition. This was a curlously negative form as publio utility control. Its tendency was to ensure profits were not axcessive by keoping costs up.

In the case of the underground railways, the then new2y sormed L.C.C. Wished to Influence the original Aots. For example it wished to have the trains take the most direct route between stations and not simply follow the stroets. It also wanted bigger tunnels and cheap. 1

morkmen's trains. But al thouch they could object to cortain parts of the arrangements, they had no way of getiling any positive suggestlons adopted. For example, the Baker Street and Waterloo Rallway proposed to run 1ts tunnels under the streets. Anyone who looks at the stroet plan will see that this is arrkward and generally undesirablo, but the 2 Rallway wanted to avoid paying for wayloaves. The I.C.C. could, and ald say that the layout was foolish, but they wore in no position to perauade the Coundtee to make the promotors change the Bill failing the pronotion of an L.C.C. Bill. All they could do was to raise some very thin objections to the effect that they might, at somo unspecifiod timo, want to put sewers 60 foet bolow the streets, although they had no intention of dolng so at the moment.

They were able to block certain proposals in various private tube B1128, usualiy those which might lead to any private monopoly. This meant proventing co-operation, such as the joint ornership of several Iinas, or, to give a emaller instance, the buildini af a joint Interahenge 
Btation at Ifamicramith by tho London United Trains and the DIstrict Ratlizay. The prevontion of this type of comoperation however hindered the physical productivity of the transport oystom. Thus, as in the case of the powor companies, the intervention of the local authoritios kept grofite down by keeping costs up.

In the case of utilities set up by Provisional order thore is a sharp contrast between electricity supply and tremeys. In the oaso of the former, the local authority would be granted a Provlsional ordor in preforance to a compeny if both applied at the same time, but it had no further influence on the matter. . In the case of the latter it had ix considerable power, sterwing from the local authority's position as Road Authority. Before a tramray ocmpany could operato it had to agree with the 200al authority over its share of the expenses of road ropair and often on its fares. The local authorities were particularly andous to improve transport far the working classes and usually insiated an opeolal workwen's trans at very loiv Laras. There was also bargatning $: "$. over power supply in the cases where the local authority owned the puble supply station. The frequenoy of sorvice could be regulated by the loonl authority, although this seens to have been less often dono. If the tranway was beingepromoted under the Light Railmay Act, the compans and tho: local authority hod to negotiate the length of time which was to elapse before compulsory purchase. All these were devices intended to 21mit any possible exploitation of ths consurser. The intention was that traumen companies should make only normal profits, and if thts was not achioved by regulating thoir solline prices, it could be achiovod by getting 
opocial conoessions fCr workmen, or a general contribution to the rates.

The advantage of givin: these controlling porvers to the locul authorities was that they had excellent local knowledge of the potential perfitability of the transtays, as much information as the pronoters hed and more than a govermicht body would have had unless it had made detalled Investigations all ovor the country. But this was more than of'feet by the intense political antagoniam which usually existed botween $200 a$. outhority arid pronoters. The local anthorities generally considered that companles would exploit the public unless severe checks were put on themo When the companies rere optimistio of future profitability this oould loed to the local euthority driving a bargain which in the ovent roduood profite to a cultinormal level.

Unfortumatcly the whole attempt to control publio utilitios simply by fixing a variety of inftiol conditions was to attempt what was virtualiy impossible: Initial conditions could only control profits aciequately if the latter colld be accirately forecast; but tho profite of major linovations aro extremely diffioult to predict. The promotere, who ought for their orn berefit to have carefully studied a schamo, wore often wrong aiout potentlal propitability, not only in the early 2880s, but to a lesser axtent in all subsoquent boom periods. E. Garke, the head of British Eloctrio, scornful though he was of legislators, miscaloulated bodly about tramang profits in the yoars around 2900. H1s argument that the fallure to get the expected level of profits was due to the loglolation Itsele is flimsy, and, as he lonew what the lew was at the time, Inodoquate. Even if each particular case had been very carefully studied before the 


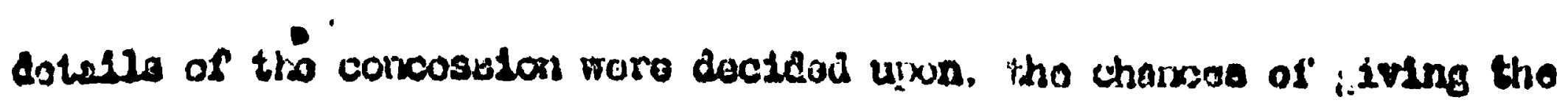

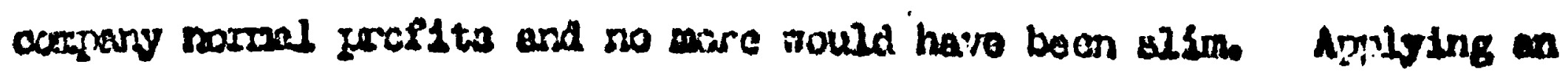

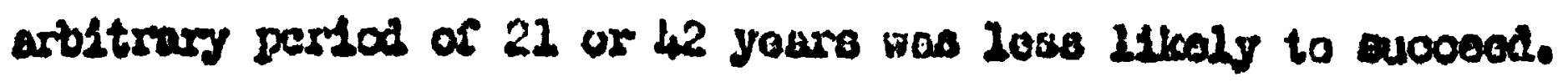

but vesy mels ware smporterit wes that thare was a versy Inodoquate

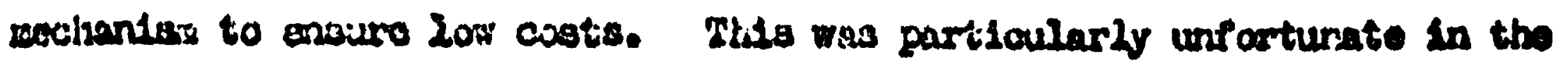
caso of olcotrictty sumply whore technigues changed rapldily and coute foll vitb thodo charges. These changos in cost oculd have a mob groute:effect on pricos than any change in proriti. The anly control woohanlem was the Introduction of conpotition. The early bolles that ocupetition. was tho colo pecossary rogplatar hed beon $200 t$ by 2350, but competition

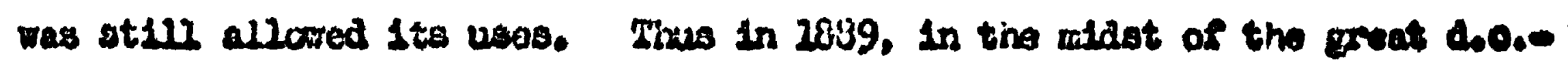

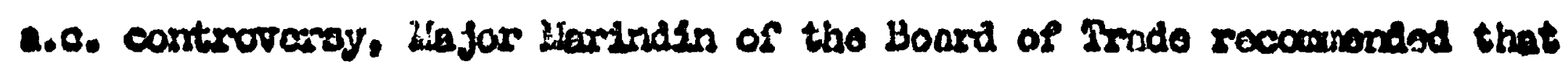
consuneers hoild be ale to aboose Dotweon those tro systecks. This for wach of the contral arese two aistributors roro cuthoriod. Similarly onveral of the Powor Congany Acts contatned what come to be known as the

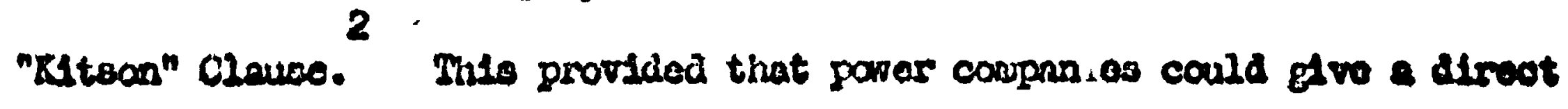
oupply to joxcr usoro within an area already suppliod by an euthorloed

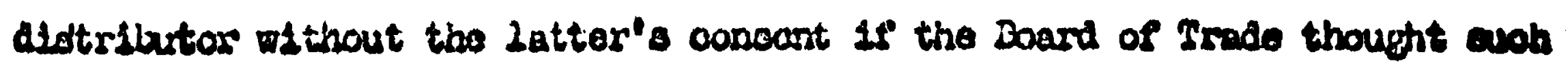

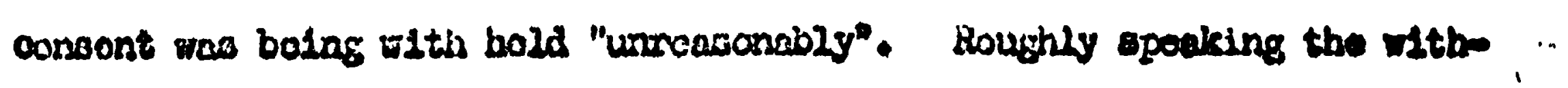
bolaling of concont was unfoaconablo if tho tartef offerod tho partsoular cansuwer if the cutharibed alestributor was above the 20 a run coute of the powar compansy.

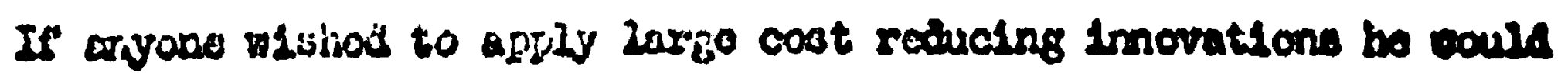

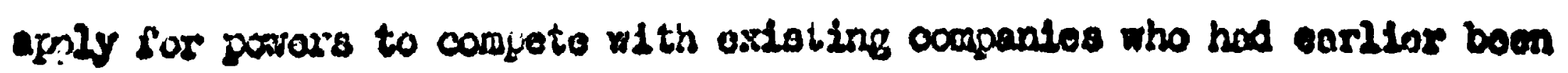
granticd monojoly pcriurs. If parlinant thought the plans ware $21 k 015$ to 1. H.A. Roboon. On.c1t. EP $306-300$.

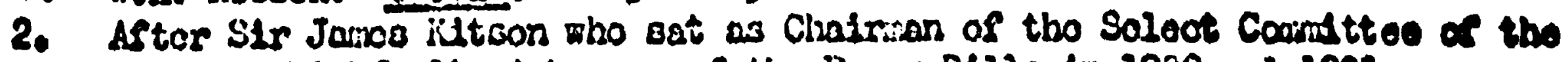
Corrooss whichdoalt with of tho Poryor B121s in 2900 and 2901. 
be carried out, and to reduce costs as clasmed, it would bo disposed to grant the roquisite authority. But in one way its hands wero tied. It had glven existing undertakers 1imited porrors under a bargaln struok when thoy sought their original franchise. Those were alroedy designed to prevent exploitation of the publio. Parilament was thus loth to reworo these powers unless those risking their money had recelved a fatr remuneration. It was particulariy loth to do so when the existing cuppliers were large and porrexful municipalities. Thus to some extent the desire to control monopolies simpis by inftial conditions restrioted Parllement's future actions.

If the consumer stbod to gain conslderably from now suppliors, Parliament would authorise them to compete with oxtsting ones. But the galn had to be large. It was not only the greater polltical power of the big municipalitios which onabled them to stay out of the Porer Companios' aross when smaller municipalities were included against their will. It was also their lower costs-in 2900 - 2901 as low as those of the lntending powex compenies would bave been. Also competition in situations of this sort might involve a long and expensive battie. Thus intending competitore exploiting now innovations would only compete if their costs wore $21 \mathrm{kel}$ to be very mach lower than those of existing suppliers.

Only substantial cost differences rould bo able to defeat an entrenchod oppanent. As par as regulation of thelr activities was concerned, existing suppliers, to pursue a line of thought accinotis put by Professor Hiciks, could lead a moderately quiot 21fe, but wers 21kely to be maken if they actually want to sloop. 
All the argunents usod above sugejost that in the case of private electrioal utilities there was no good sujstitutio fur detailed and contimoun control by sowe governmental, or publio body. This Parliament had no desire to sec, and it would have regarded governonat or public oporation as worse than governuent or public control.

Nhuioipal traws and electric supply seem to have worked very woll until about 1900 - 05. At first tho local govermment ureas were larger than tho minimum efficient aress of suplivi. Apart from Iondon, where both local government and electrical utilities wore pooris organised, In moot

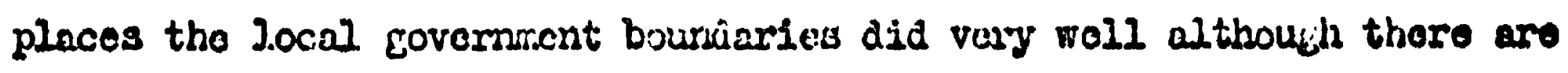
cases like lanchester and Salford, Liverizool and Bootlo where undfied ut1lity would have becn bettor. Electilicity supply and tramays were woll run by the Corporations. No cost comparison with the Coupany undertakinge Is fersible as the typo of area supplicd was different. The absolute costs of the mancipalities were 20ror, both their running costs and the Interest they had to way on borrorsed monoy. But thoy had the densely populated aresa, of ten bad a rolatively groater power losd, had moro

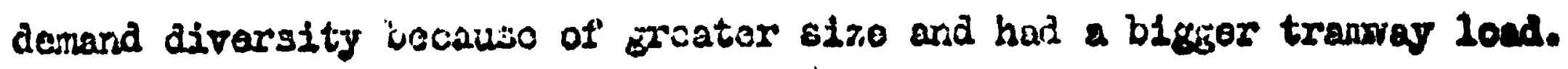
Thus their costa ought to have been lower. There is a substantial difference in performance cetireen difforent Corporations which makes the

1. W.A. Robson. The Govemment and iliscovernmont of London. Iondon 2939. esp. Part I Chaptica 14 and Part II lisajter 9.

2. There are guad siguiscs oi runnind coste but goou figures of capttal costa, accountine for about $\frac{1}{2}$ total costs, are not available or obtalnable The conjicications in a cost conparision botwocn companies and muntoipaldtie are very groat and the margin of error in the result preat. It 10 urilikely that such an opciation would produce results worth the great Labour of carryini it out. 
citing of pirticular casios casily mialonding. Manchester Corporation was for exanplo yore up to date and enterporising than that of Glabger. The population of Glaskor was lcrger and it was renowned as ore of the leading centros of orficlent municipol utility oporations. Fet as Tablo 88 whow Hanchoster was oif tho mark quicker and torards the ond of the pordod had coplosted the polentiel porvor load much moro.

\section{Tnule 88.}

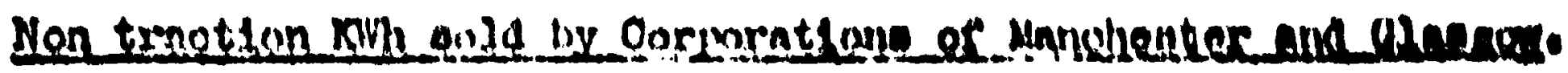
BLIIIOn Bah.

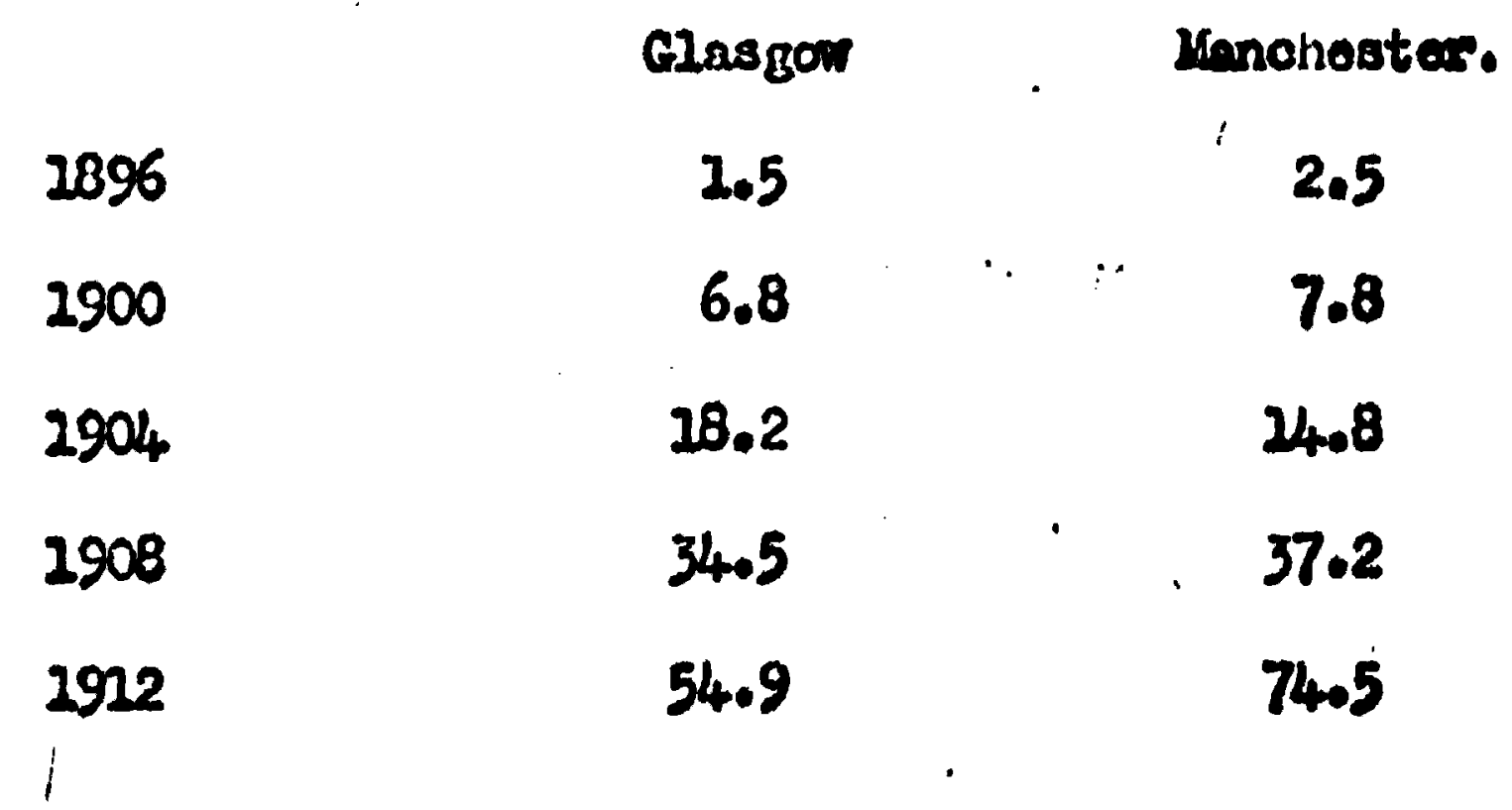

Sources Calculations from Garico's kianual.

It is casy to find instances of minfelpal stupiasty, but no more affiloult to find instunces of company stuplaity. No Coxporation was as

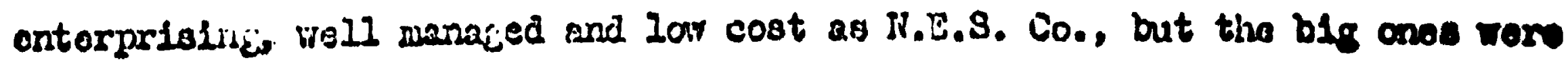
In genaral bettor tisan tho other power companies, and the areallor anos usually botion tisan tise supily comnanies of the sualler towns. After 1505 the position was much lass happy. By thon R.B.S, Oen had shown that tisose was a potentially largor power load wad that the 
elasticlty of demand for alectricity for power purposes wia high. In that year Charles liserz demonstratod to Parliamentary Comsilttocs of both Houses that large ecale sup:ly would be much cheaper tilan supply by the exloting omall scalo undertakings. From then until 19U, the succoss of N.E.S. CO. showed that the region was becoming the necessary unit for electriolty supply. In the cace of trampras, tho position vas somewhat similar. The urban areas hed eleotric trans and the noxt stop was to link those tom with Intermurben Lines, a step which was within the bounds or economic feasibilitiy in the densely populated areas, Like South Last Lancashire and the Bluck Country.

One would not have expected any movernent toivards general government control under the Unionist govesnwiant of 2326 - 1905. They had been quick to investigate the question of large scale generation and had appointed the Cross Camittee in 2893. Iut their anstior to the problem was to pass the Bills sought by the power companies in molified form. Thoy wore not against municipal enturparise but Halovy has suggested that the resson why they wore quite happy to encourage municipal sooialisen was that they regarded it as a saieguard giginst nationalisation.

In any case the problem fras not preising before 2905. But after that it was; from then onwards there can be no real doubt of the desirability of increasing the size or eleoirical utilitios. But the government took no initiative at all. Iho Llberal government was moro strangly in favour of municipal operation than its predecessors for examplo In 1906 Worz's schem for Iondon's Olecirioity was blocked until tho L.C.O.

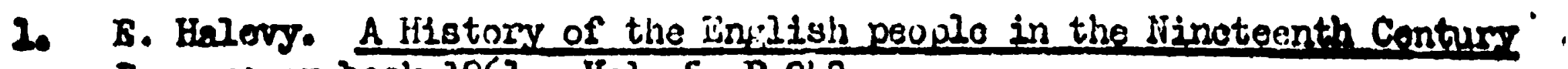
Bann paper back 1961. Vol. 5. P 24.2. 
should produce a good plan: of its own. But in general it was no good ofmply blocking Compeny schemes as the local government unit which was willing to run schemes had become too small. If big private schames were to be disallowed there were two altornatives. One was to group tocother local anthoritios. As 1s wagested below they were not 11kely to group themselves on their om. The other was for the gororment to devise its own national or regional schems. It did neither. This seeme to have becn partly a question of men and priorities. John Burns, the Presidant of the Local Government Board from 1906 - $U_{4}$ was a spent foroe by the time the Ifiberils came into power. Wwo of the forenost members of the government were at the Board of Irade, Lloyd George Iran 2906 - 08 and Churchill from 1908 - 20, but both were more interested in Labour relations than in industrial organisation. The gorerment was radtoul In Its dosure for social reform but not a supporter of gorernment interference with the econowy. They would have had to bo persuaded of the need for the latter, and there was no strong body wh1ch could have convinoed the government of publio noed. The realisation of the publio noed came only after the series of cormittees which sat during the $1944-28$ war had revealed the weaknesses, particularly of electrioity aupply. The only pressure group was that centering around British Electric Iraction, But 1t was prinoipally conoernod to argue for less government interforanco and control rather than nore. It vehomontly opposed minicipal operation

1. There is only ono caio of comporation, that of tho Stalybriage,

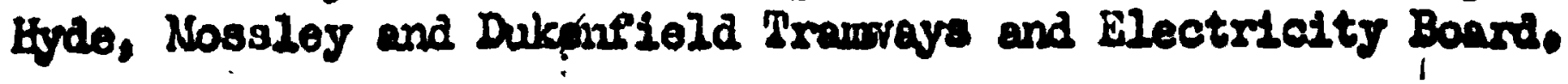


and restrictive legislation. What it wanted was bigger and froer prirate monopolies. A oase can bo made out for them in the public interest, but there was little chance of persuading the Liberal Government of their desirability. Where the Eovernment did intervene, as in the case of London's eloctricity surply in 1906, It Intorvened to favnur the London County Council ageinst the vigorous private interests.

The minicipalities did not co-operate with each othor. The reasons are princtpally political, but not solely so. There were also tho problens created by different tranway cauges, different frequonolon, and voltages in electricity supply. Inikaje of different networks would be expensive. This was particularly tho case with tronerays where it would involve relaying a great deal of track, but oven in the oase of olectricity supply whore cheaper expedients wore poselblo, linkage attul involved considerable capital axpanditure if the oconomios of foint oporation were to be realised. Unfortunately at the timo whon thore were beginning to be advantages in such combinations, 1.e. from about 1905. tho capital market was turning against the 200al authoritles. One must not over-estimate the difficulties presented by the different engineering charecterlatios of aifferent torns systems for there was a oertain amount of standariliation. llost tramras gauges rers 4 ft. $8 \frac{1}{2}$ ins., and - loctricity generating stations could bave been linkod up to considerablo advantage without great cost. The latter would have reducod future Investmant to meet a growing demand as less plant rould have been noedod Sor any given load. A majo: obstaclo to combination was that the Cerporations were primarily concarned rith thoir own aitirens. In the 
late 19 tb century they had undortiken a lare amount of utillty operations, water, gas, semerage, as well as traws and elocirioity supply. Lhulotpal trading had beon a porrerful movement sweoping uray mary laissezefalro 1deas. It had aroused tremendous opposition and deforted it, but much of 1 ts forco was spent by 2900. To expect them to persue matters still further, and ororcame all the obstacles to linkling up olectriolty supply and tramays throughout a region was perhapas too much. The experience of the Electricity Comiasioners in the twenties is 1lluminatings they had great diffiouity in co-ordiniting the various suppliers.

To do so wouid have required joint action with the ocmpanies, who operated the areas botween the big towns. No one oculd have axpeoted the Iniative for thie to have ocne from the local authorities. For over 25 years they had rocariod companies oporating public utilitice as potential exploiters of the caurunity. Lhentoipal trading had boen otrongly oppased iy the business comminity, and tinis antayonism as well as hatred of manopoly had leit its Eark on the Corporations. Betreen 1505 and 194 these attitudes mellowed, but only slowly. Some Corgarations, far axamplo Midalesboroush, Stockton and Tynewouth began to take a bulk supply from Nokis. Co. when their own plant became inadequate to meet the demand. The Lancashire Sisotrio Rower Cowpany fourd that tho Initial antagoniom of 1905 was passirig away by 1910. In transport however tho antagoniam had boen woh greater. Parliamant had given the local auchorities powers to control company utilitios or to operaie tholr own. 2he control powors bad becen mach dialiked by the new clcotrio trararay colupanies in tho yoars around PP 89 - 99. 
1397 - 1903, ospecially British Llcotric Traction. They felt that the local authorities were driving a very hard borigaln; and also that they used th their powers to opereto as a bargaining couniter. Take for exesuple the oase of Brit1sh kileotric Iraction and the Paisley \& Joknstone Rromrays. The former who to carry out a scheme oi single track elsetrio trans along the road between Johnstone \& Paisley on bohalt' of the Paisley Tramrays Compeny. At first they were given to urderstand by. Paiuley Corporution that pernisston would be granted fior this. But Glasgor Corporation opposed the schane, persuaded Paisloy to join tirem and lrasist on a double line. Thie B.I.I. refused to buifd and as a rosult Paisley Carporation opposed their application for a light xailway orios. As a result the order wao rejoctod although the Chainnan of the relevant carisitites was woved to say that "wo do not thinik that this Electrio Traction Company has been deait with in a falr and opon way in this matter." Such violont antagontem might havo boen expected when one body was givan power to control and to oporate. Naturally this antagonicas passed even wore slowily than in the case of olectrioity supply. If it was too moll to expact tho Carporations to take the initiative, it was ovan lo:ss 1tisely that thay would have reaponded to any an the part of the power corpanies. Hhat was required tochnicaldy was a monopoly over a wide district and this was what the 20021 anthoritios most goared. Concentration on largo generating stations with abundant 2. E.R. Vol. 42 P 807, V01. 43 IP 160 anci 494.1898.

2. O. Klappor, op.cit. Eives other exauples. 
water suprities for cooling, casy coaling facilitios and choap land would in many casos involve putting; thers outside the boundaries of the large toms. Once deprived of their genorating plant the municipalities folt they would be in a very poor fosition and would be exploited.

In this situation only the Government could bo expected to overoone the difficulties. But it would have meant considerable offort on its part. For it was not a question of granting new powors to amono, but of co-ordinating the oporaitons of extating undertakers. Iot doupdte the fact that by 1965 it shoula bave bean becoming clear that the old polley was not rorking well, and that what fras needed was not compromiso but comardination, Parlianent and ibe Government continued to to pasilve and pormissive, rathor tian active anc arganisinise Ihis is shown by the Lot of 1909. Hich carly logislation bad boen direciod against the combination of utilitios, as it was fearos thls might lead to monopoly. Parliament does havever ceem to have been willing to authorise the interconnoction of difierent networiss. Tizo liorth bestern power oompantes do not secm to have had any afficiculty in goiting Aots for this purpose, althouch consiacrablo municipal opposition could have provented Intorcon cotions. Ihe sict of 1909 ramoved many of the obstacles to running joint sycticils both for companios and for local authoritios. But to prornit them to coubine was not enough. 2'0 achieve any succoss tho Covermerent would havo had to have takon a much more active role. Ilo camblnations of any inportance resulted except in the North East. The situation is Landon in both trassport and electricity appiry

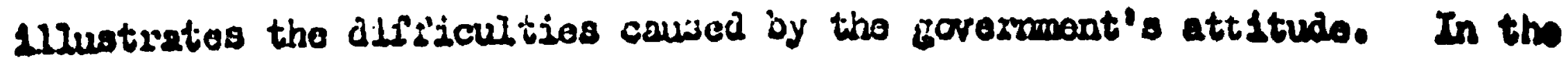


case of eloctricity suply the Minionist govorment foll before Hery's sohemo fassed 1ts thind readinc. The Libern?.r Inifed on the L.C.C. but the latter soon became both unable and untilling to carry out an overall schome. Also the optimm area of supply was laraer then the Aiministrative County of Iondon. It would have nesdod a goverment bodj to inpose agreanent on the oristing locel outhorities, the I.C.C. and the Boroughs, and on the extsting compans undertakers. A Royal Comission was apyointed to Inquiro into London's Transport but despite the sact that it reported that "the present unsatisfeotory conditions are laricly duc to the fact that thero aid not extst in the past any municipal or other authority having jurisdiction over the whole area and possessed of sufficient forer and recources, $"$ no further action was taken. Here agnin the L.C.C. Fas unwilling and unable to shoulder the burden of a complete schanc. Coubined with this it had an exaggorated fear that any private overall schemo prould have ald tho dangers of a vast monopoly. This foar had led to its stresuous opposition to Norz's B1Il In 2905, and it also led to opposition to any pritrato attempts to link up Ionaion's trafl'ic systems. Thus when the Iunian Onited Trams proposed to build an underaround transwy terminus at Hawrarsmith, with direct contact with the District railway, this was oyposod, successfully, by the I.C.C. on the grounds that it would help to create a monopoly. ${ }^{2}$ Iot It was lack of such a station at Shephoris bush that caused great traffio congestion as passengers chanced from the Central London Railizay to the Lomion United Trams. The Underground Railwajs Cumpany had wanted to Loase

1. Royal Conmission on Iioncion Transport. Roort B.P.Y. 2905. Vol. 30. P 533 fr.

2. R.C. on Londan Transport B.P.P. 2906, V01. 40 \& 29649. Bvidonoc of , R.t. Porles. 
the Baker St. and Waterloo and the Charing Cross and Hnmpratead Linos and 11nk them up with a single fare and Intorchange. But thelr B1Il was thrown out on the grounds that it rould givo too mich monopolistio power, although both these lines wore controlled by the Underground Company who 1

beld a majority of their shares. In this case the Parliament'a utility polloy led to the worst of both worlds. As the Royal Comission commonted, "The L.C.C. had no porrer to control the construction of (the underground) rasiways, and an attompt to exerolse in the interests of the public ouch control as is possible by formal opmosition to Private Bills does not give satiofactory results, while it adds to the cost of the undertakeng, and tends to produce a state of antagonism botween the Compantes and the Couno12, which is greatly to be regrotted and 15 detrimontal to the publse interest. $\mathrm{mC}$

1. 1blden Q 20202 ff Eridence of Charles T. Yerkes.

2. Lb1der Report B.P.P. 1905, Vo1. 30. P 573 
Chapter 10.

The pricing pollclos of Electrical Utilitiese

This chapter is primarily oonoerned with oloctricity aupply, although towards the ond there will be some discussion of trame and urban and suburban rallways."

\section{$\bar{I}$}

It was rery soon notloed that in tho production of eleotricity, as opposed to the production of most commodities, the rate of produotion at ans particular time of the day is governed Imediately and direotly by the rete of demand at that timo. The storage of oleotrioity, by . using batteries, although possible on d.o, olroults, was nover attempted on a large enough scale to oven out the rate of generation. llo ono was ablo to present a convincing arqument to support any oconomlo oseo for delng thiss and no supply authorities triod to use batterdes in this way.

The early 21ghting loads had a sharp poak in the oarly orentage, wh110 for the rest of the day demand was 10w. This light looding of plant most of the time soon rorried ongineers; they were quick to develop a. mossure of capital utilisation in the 20ad factor, and to soo the effoct of the load factor on costs. That seems to have directed their attention to this is not that it was partioulariy low compared with that of a great doal of machinery, but that it was noticeably 10w. In the 2890 the anmial load faotor of eloctriolty supply station was 8 - 22\% IP 
normal industrial machinary was usod continuously on an absolutoly steady Load for 9 hours a day in a 270 dey working year 1ts load factor would be only 28\% But in practice all machinory was used intermittently and with a rarying load, and the usual load factor was not more than $15-20 \%$. Power stations were nocessar1ly open for 24 houre a day, seven days a wock, and thus sale machinery was more obvious than in factories, which people expeoted to be closed on Sundays and usually at nlght.

It was also quickly seen that some form of discrinlnatory prioine could affect the electrlcity load factor, and thus costs in a way which was impossible in tho case of the manufacture of other produots. That is to say average costs, the cost per unit supplied, could be reducod. It was generally assumed, as far as one can see without any serious discussion, that this was a desirable objective. This is not so. What is desirable Is to reduce costs for a particular service or commodity and there is no simple roason for supposing that simply ovening out the lood will do this. For oxamplo, Inducing poople to burn lights all day and all night would ratuce the average cost of electricity, but would not reduce the ocot of provialing light when it was roquired. It can be arguod that tho best prioling oystem for eleotricity oupply is a tariff which primarily alscorminates betwcen units used at different times of the day, where the prico is determined by the long run marginal cost of providing aurrent at 1 that t1mo. Th1s implied a price at the peak hour sufflolent to cover

2. This is all argued in I.M.D. ILttio, the Price of Tual. 
capacity costs plus polk hour sunning costs, and at non peak hours sufflolent to cover non peak hour running oosts. Such price discriminatian would Luprove the lood factor but it doos not follon that any attempt to do the lattor will produce "correct" alloontion of resources. It might soen at slrat that a decriminatory prioling system which sought to improve the lood factor would be one which moved In tho direction of char, ing rates at peak and non peak hours whioh approximated moro closely to costs than a unlform tariff, as non poais hour subsialsation was not likely. Bat as will be shown the tariffs used did not do this, and this was pertily because the problen was man first and foremost as one of improving the 20ad, and not of charging conomilo oosts.

This was strongly reinforoed by the way in whioh tho relation of oost and lood was looked at, for this affeoted the typo of tardff uned. The clabsio atatament on costa ves made by John Hopkinson in a paper to the Junior Enginearing Socioty in November 1892. He Buggested that costs ooula be dividod into 2 categorles, standing costs, that is tho costs of being roed to supply current, and running costs, the oost of aotualdy cupply2ng 1t. 8tanding costs comprised the bulls of total costes thoy voro tho capital oovte of the equipment nocessary to meet the maximin load on tho supply station, the amount of coel which was used in parming up bollers and keoping up stoom In readiness to oupply electricity, and the bulls of the wages of the men cuplojed. Having estimated the lelative magntude of these two types of cout ho went on to oonsider how they should bo divided anong consumers. Bo conoluded that customers ahould pas for ruming costs on the basts of the number of units used, and that standing costs should bo divided among ountemore 
on the basis of the peak load which oach demanded. Charging was thus to be basod on the customers' load factor and only on the station load factor in so far as the peak damands of all customers colncided. They ald not. Tho rationale behind this was that the aupply undertaking had to be roady to give a rate of supply based on the total amounts whtch each consumer might demand. The actual situation onvisagod was that all consumers might owitch on thoir lamps in a fog. In Iondon peak loads did colncido with Poge and this might secm to justify the argument. But what Hopkinson noglootod was that the probability of the peak load occurring at any one time varied with the time of day, there boing an extremoly hich probability thet it would occur botween $4 p_{0} m_{0}$ and 6 p.m. on a weakday in the winter months whon comerolal and domostic loads overlapped. From this 1 t could be argued that customors ought to be charged a rate based on the standing costs multiplied by the probability of the maximum lood occurring at that time of the dayd plus the zunning costs. In practioe the probability was extremely high that the maximum demand would occur cluring a period of somo 2 or 3 hours.

Of these two charging systems the one accepted as both coonomically correct, and also equitablo by most onfineers, was one based an the consumers' lood factor. Compared with a time of day tariff it had 2 major disadvantages. It could only affect the consumers' load saotocs. and not the tining of the consumors' peak. As consumer pooks variod it had much less of fect on the laad factor tiran a time of day tariff would have dono. It failed to encourage off peak users like theatros, and perversely discouraged off poak users 2ike churahes who happened to use thodr lights for short period of the weak only. Allied to this, it ald not go as far as a time of day tariff would have done in aharghing consumare 
the oost of the resources which the corrwintty devoted to providing them with 11ght at particular tines of the day. It may havo been an Improvement on a flat rato, but a consideration of its application shows that it had other alsadvantages which lod to its boing partially abandonod, only to be retained in a form which allowed considerable misallocation of rosources.

At first eleotricity was oharged for at a fixed price per SWh. There are fer Instances in the early olghties of it boing sold by contract, that is unmetered, the charge being based on the number of 2empe, but by the time the boon of 1839 - 91 came meters were virtually universally adopted. Thus in the eariy nineties most electrialty was sold at a rlat rate In the way in which nearly all other goods and services are sold. The first discriminatory tariff antedated llopkinson's paper, belng introduced by the Ifiverpool Electric Supply Company in 2889. Therv were three rates. For any number of kith up to a hundred times the maximum demand of each consumer in Krit, he was chargod 28. per Kith. Thu

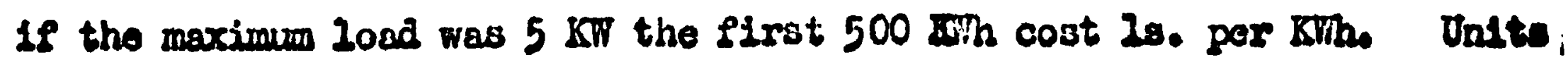
from one to two hundred times the maximum demand cost 8d., and all subsequent ones 4d. The tartff was thus 1dealdy directed towards the consurnor's individual 20wil factor, and not towards the porrer stutions' Load factor. However, there was no way of measuring the consumer's maximum demand and so charging was based on the consumar's posslble maximum demand, measured by the number of I1ghts he had Installed. Fow peoplo 21ked the tariff. It was argued ajainst it that it fasled to encourage obvious off peak useres like churabes, warkeshope and othor pleoes 
which might requiro light in the daytime. It was also sald that the customers had difficulty in understanding tho systemo Those disadvantages led to the systam boing abandoned four yoars later.

Hoplednson's paper of 1892 aroused great Interest and was genorally approved of in principle. Irmediatoly following 1t, Arthur Wright, the elootrioal englneer to Brighton Corporation, wrote to the Bloctriolon atating that ho was engaged in starting suoh a aystem. Ho was to moasure the mardmum demand of the consumer by means of a thermal type maximum recordine 3 ampeter. The Wright demand Indicator, as it came to be called, was to bo set overy month in the 2 winter quarters. It recorded slowly, taking about 20 minutes to reach the correct value. Hence the oustamer was not charged for poaks of very short duration. The mean of the 6 maxima was taken as the basis for charfing. The consurner was to pay 7d, por unit for the eirst hour per day the demand had boen used and then 3 ide for all eubsequent units. In other words 70. per BJih was the charge for (biax everage demand in $\mathrm{KTT} \times 365 / 2$ ) KTh. This tariff began in February 2893." The price differential was not, Wright told the first convention of the Lunfelpal Electrical Assoctation, ideal. If charyes had boen based on costs they would havo becn $8 \frac{1}{2} \mathrm{~d}$ for the first hour and then 3 ad. But the Proplsional orich had fired a maximum price of 7d, The fall of costis with

1. Ce Letters from A.B. Holmes and $\pi . B$. Sisling to the Eleotrical Revien. E.R. Vol. 31 PP 716 \& 748. December 2892.

2. Elect. Vo1. 30 P 221. 23 December 1892.

3. Aralagous to a clinical thormameter.

4. Elect, Vol. 31 P 407. 20 February 2893.

5. B.R. Vol. 38 PP 808 - 12. 29 Juno 1896. 
technical inprovements soon led to a lower "off peak" proloe wh1lo the otanding chnrce remainod at 7d. By 1897 the former was down to $2 \frac{1}{2} d$. and in 2898 fell to $1 d$. $^{2}$

Wright consldered that this system had boen responsible for the Ifprovemonts in the 20 ad faotor which took place from 2893 ormards.

$$
\text { Table } 89
$$

\section{- Beighton Ioad Raotor}

$\begin{array}{lc}\text { Yoar } & \text { Ioad Factor \% } \\ 1887 & 24.1 \\ 2888 & 21.7 \\ 2892 & 21.1 \\ 1893 & 21.4 \\ 1894 & 23.4 \\ 1895 & 23.4 \\ 1896 & 26.0\end{array}$

The load factor is basod on the evera of the maximum demands of the year in question and tho previous year. This makes an allowancie for the effcct of the rate of growth in the load fleotor, which is not allowed for in the usual mothod al caloulation.

Sources A. Wright. Profltable Extension of Eloctrlo Sunnly Stations. Paper to the National Electric Iight Assoolation, Nlagare Full, 9 Juno 1897. E.R. Vol. 40 P 857.

2. Elect, V01. 38 P 653. 12 Warah 2897.

2. B.R. V01. 42 P 477. 8 Apred 2898. 
IItis conclusion was supported. The Motropolitan Coinpany asserted that their maximin demand type tarife helped to improve the load faotox: by discouraging the type of wealthy consumer who would connect 11 wo to six bundred lamps for ornamental purposes.

Wright preferred a tariff based on the maximum demand of oach consumer to one based on the station poak load. He told the Hunfolpal Bloctrical Association

"Theoretically, it ing ght be said that the standing charges ought to be divided into anounts proportionate to the maximm demand of each custorin, at the daj and at the very time the maximum dcmand occurred on the mains each year. This is obviously impossible to determine in practice, and would not be, noreover, necessarily equitable to the consumers who might or might not have used thoir maximum demands at the exact moment in question."

Ilo thought his tariff gave "as neariy as possible the fatrost atviston of the standiags charges."

Tho Hopkinson-Mright tariff apread falrly quickly. By 2897.

29 of the 223 existing cupply undortakings had adopted the Fright system with demand indicators. There were 2130 varients on this incorporating the same principle. Often, as is the early case of liverpool, the consumor's maximum denind was based on the mumber of IIghts installod. At Hanchester C.H. Hordinghan who had been one of Ilopkinson's assistants and who was then In chario of the Mancinester Corporation olootitical oupply station used a tariff with a standing charge of 612 poan per III of maximun demand, and then 2d. unit. The maximum danand was based on the sumbor of 11ghts installed. Forlingham would have preferred to uso

1. A. Wright. The Load of Eloctricity Supply. Paper to the Plrot Convontion of the bunicipal Electrical Losociation B.R. Vol. 38 PR 808 - 22. 29 June 2892. 
Tright's system but the Corporation would not carry the consumer's eccount 1

over for as long as a quarter. In 1893 the Sretropolitan Eleotrio Supply Coo was using reduced oharge for all units used above 8 per 35 watt 2ampo These maximum demand systems incrosed in popularity during the late ninoties and by $1904,40 \%$ or all undortakings relled entirely on this form of tarisf, while another $38, j$ used it in conjunction with some other system. 3 The remaining $22 \%$ wore on a uniform rlat rate tariff. Thereafter the maximin demand tartff becamo the standard tartfs for very b2g consumers. The Porrer Companies adopted it as the standard system for large consumers and bulk supply. But for analler consumere It declined in popularity. From the boginning it had boen undor firo beoause it was sald to be too complicated for the average consumor to understand. Also there was a constant stream of complainte from consumers about 1t. Not from all consumers, however; the blochrion Revler noted in Harch 1899 that the opponents rero often vocal and influontial, while supporters generally lept quiet. In sane places, Glasgow boing one of thean, the Irright system was so much dialiked by consumers that the demand indicators were beling taken out by the turn of the century. It was the shop ksejer in the centre of the town who moet disliked the systom. He temaed to use his Iiginting for andy an hour or 2088 per day in the winter ovenings. Yet as W.A. Chamon, Glasgow'.

1. C.H. Torilingham's comients on Trhitht's paper on the Cost of liectrialtr Supply. E.R. Vol. 38 IP 808 - 812. Elect. Vol. 37 PR 538-43.

2. E.C. de Segando. Tho Cost of private eloctric 11ght. E.R. Vol. 33 IP $513-4$.

3. R.G. Gray. Inaugural Address as Presidant of the Institution of Blectrical Eneineors. 12 November 2903. E.R. V02. 53 FP 842 - 4 and $880-3$.

40 E.R. V02. 44 P 442. 17 Warch 2899. 
electrical enfineer, told the Lunicipal slectrical Asociation in 1901. those vore the henvily rated and influential consumers, who were wite uble to mal:e their voloes felt in the Council Chamber.

Th1s consumer reaction was not all pressuro group pollt1ou by ang means. For the quarterly bill could fluctuate quite widely if thore wore varlations in the number of lamps left similtanoously burning for any guarter of an hour in the quarter. Thus it did produce considerable uncertainly as to the mount of the bill uniess consumers vere extrumely careful to seo tizat no more thas a glven number of lights were over left on simultaneously. Onder the Wright tarifs at Brighton any extra 60 matt (16 candle power) lang left on for a quarter of an hour in each month would Increase the qualter's bill by $2 / 9$. This would usually be a notioeable proportion of the bill. In the nineties the 21ghting consumer used about 500 units per year. If 200 units were used in oach winter quarter, the maximum slowitanoous load was ten 26 c.p. lamps, and tho Fright system used with charges at 7d. and $1 d$. tfo quarter's bill would be 62. 45. In this caso each extra 21 iht left on srould raise the bill by $6 \%$, althoulh no mors electricity was being uscd.

Such a tariff is more like a systen of fines for exceeding som - tated amount than a way of charging for the extra costs Incurred by the eupply authority. If the extre lichts were not switchod on at a period of the station's poak no extra costs were involved. If on the other hand.

1. W.A. Chamen. Presidential Address to tho Ulunioipal Eleotrical Association. Co sent by Elcctrical Roviow in a Leading artiale. E.R. Vol. 48 PR 1089 - 90. 28 Juno 1901.

2. $0.6 \mathrm{KN} \times 92$ davs $\times 2$ bour $=54.6 \mathrm{KWh} \div 7 \mathrm{a}=382 \mathrm{~d}$. $200-55 \mathrm{KINB} \odot 2 \mathrm{~d}$. $\quad-245 \mathrm{~d}$. 
It was gonernlly at around a peals time that such extra lights wore used the probabillty that all consumers yould do this on the sarie day was very 10w. Consumer cholce is partially eliminated. Instead of boing able to deoide whother peak hour units were worth their cost, as the consumer would have been able to do under a time of day tariff, he was sharply penaltsed for exceoling some Eeneral linit, often when he would bo unavare that bo ras doing 80. Futting the matter rather extravagantly, it was as though there were something rather ant1-social about switching on a large muribor of Iights at any one time, lilse keepine library books for longer then the stipulated time.

Also it was oftan folt that the maximum denand tariff had only a slightly favourable effect on tine load factor compared with that which would exist with flat rato chercing. The metter was investigated in 2902 by C.A. Baker who collected figures of the load factor of all otations winioh had no tramray porter load where ouch figures existod. Eo concluded that as the average loed factor of stations using a lat rate mas slightly better tisan that of those using a maximum donand tarfe, tho maximum demarid system dia not improve tho load factor. Ilis analysis was crude. The annual loak factor as it usco a capital figuro relating to Doccmber, is influonces by the rate of aroitho Ilowever, ploiting tho load factor against the rate of gronth for both types of tariff reveals that allowance for the rate of gronth would not malce ans of anificant defforanos

2. B.R. Vo1. 50 EP $458-9,534-5.21$ \& 28 Larch 2902。 
to the result. I have taken therefore those of Baler's flgures where the rate of growth of demand was given, and 23 the folloring table ahows, It is impossible to say that there is any significant alfference between the load faotors of stations on maxim $m$ demand and elat rate tariffs.

Table 90. The effect of pricing on the load factor of a 11ghting stations

$\begin{array}{lccc}\text { Tarife } & \text { No. of stations } & \begin{array}{c}\text { Averace load } \\ \text { Faotor }\end{array} & \begin{array}{c}\text { Standard } \\ \text { deviation. }\end{array} \\ \text { NLat rate } & 34 & 21.63 & 2.96 \\ \text { Haximum domand } & 49 & 21.35 & 2.28\end{array}$

The analjais is crude. Pairing stations sinflar except in respect to tariff wight have produced a slgnificant differinoo betwoen tarlffs. But it is very doubtful if enough information exists to do this now. On the othor hand it may simply be that the load factor the 21ght using consumer demanded was completely inolastic. In that case tho use of a maximum demand tariff could have no effeot on resource allocation or on average costs. Ints is not to argue that it would have no effect where eleotriolty was used for power.

As a result of the complication and unpopularity of the Nright tarifi, elcotricity supply undertakings began to modify the maximem demand principlo. They wore and more used the rough and ready way of asseseing maximum demand by the number of 21ghts fixed. Somotimes the tarlfe took the form of a robato depending on the number of units usod por lamp invtalled. In some oases it was modif1od otill further by basing the 
estimate of consuner's maximum derisnd on the rateable value of the house. This Intte. method was ploneered at Norrich and by 1911 there were a number of other oupply undertakines using 1 . $^{1}$ During a discussion at the Institution of Eleotrical Enclineers on a peper on Damestic Electricity Supply Tardfes In 2908, the President remarked that undertakings wore drifting oway from tho maximum demand system torands simpler methods of charging such as wore in ronue for alnost every other conmodity. The general trend of argument both in the paper and the discussion wes towards a charging system based on the rateable value of the house or the number of 11 ghts comeoted. ${ }^{2}$ suoh tariffs were simpler, consumers pald for $x$ units, $x$ boing determined roughly by the sice of their houses, at a high price, and the rest at a 10 m price. If a demand indicator was used a fresh calculation hed to be mode to determins $x$ for each quarter's b1ll. But the former mothod was moh less Iikely to achieve the desired result, which was to encourage onnoumers to ralse their lond factors. It became simply a rather arbitrairy way of apportioning standing charges, with very little influence on resource allooation.

Then eleotricity began to be used for traction and power purposes another type of tariff designed to improve the power stations' load factor was introduced. A specially low price was charged in caseo whore the load factor was knom to be high. Th1s type of oharging had already boen used In the ninotiss for street IIghts, which usually had a bettor load faotor

2. A.H. Soabrook, Rostilence TarlffE, Paper to the I.E.B. $U_{4}^{\prime}$ Dooember 192. F.R. Vol. 70; PP 129 - 32. 26 January 2922.

2. W.R. Coopor, Dorestic Electricity Supnly Tar1ffs, Papor to the I.B.B. 26 November 2968. 


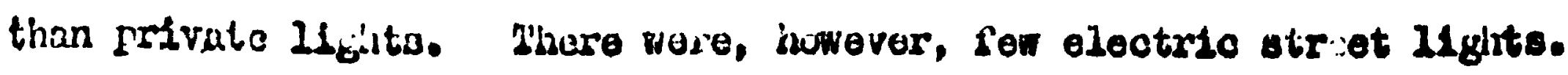
Then the eloctric trass ciwe th wise oni of inis ninoties aupply undortakinge were anifous to supsly tho power, for traways hail a 20 - 25\% 2oad factor. At flrat hibir atiitude socesis to have bean to chargo the highest price the tramprays would pay. There are several posisible reasons for this. One is sinply tinat they linougint tho elasticity of amand for tramray porror wois 201, anothar tiat they liought tinis; and that the demand for oloctriolty for Ilohtinis was olastio. Whey may simply have wanted to subsidso If ginting at the oxiainio of tine trans, or most 2ikely of all thay olmply thought that tho adititian of a high loed factor consumer would roduce oosto and thus lichting pitices could bo reducod, There is unfortunately very littlo direct cvicance on intenibion, but the general felling derived fren readint miny of tho contenporary argunents is that they almply thought that a hf her load faotor would cheppon eloctricity by roduoing costs. Yot the trawingis weie in fuct charged on a flat rato basis or on a sliding scillo with disocunts based simply on the quantity of 1

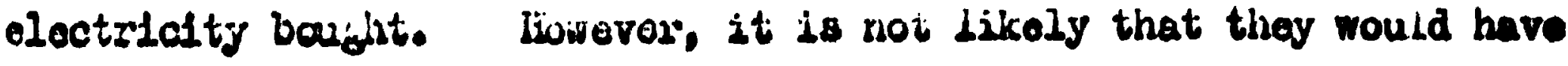
thought that tho pationa of truwras dewand could have boon altored more then a voxy alight azourt, by tho use of a maximum dewand priolng bystem Thay do not, howevor, sean to have aiscussed this.

In practice the dound for eloctrioity trom tramays turnod out to be more elastio tiven supply auchoritios had at first thought, as tho tramiay olther threatenod to build thoir own porrer house to get a cheaper cupply, or actually did so. Thus by 1900 the charge thought appropolate

2. Thero are a few cases of the use of the maximum decond aystem C.E. N.E.S. CO. and tho N.E. Rasimay. 
for transays lad fallon to about a thind of the usual lighting price. There waro two ways in wilich the community could wave resources

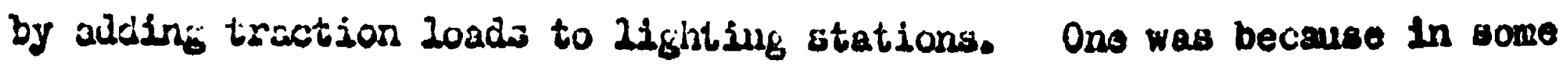
cases there rero econainies of scale to exploit, and the other was because in so far as tho poaks of the two loads did not coincide less plant would bo

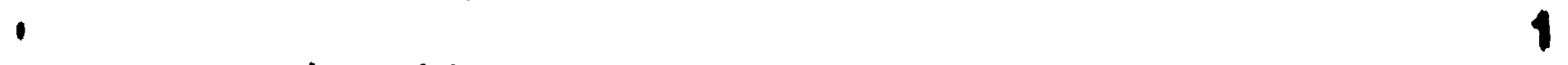

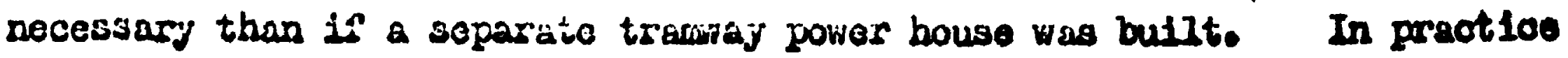
the transay load bad morming and ovening peaks and the latter overlapped

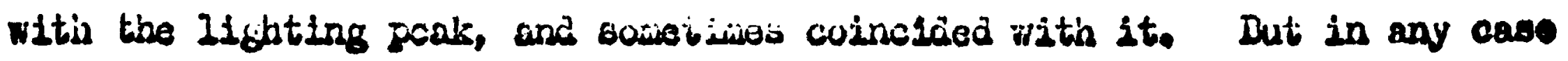
avorage cost was a micieadin calculution to make. If uricing had been based on averafe costs, the trawnsys would have built their orn power houses and and advantagois of combination would have boen sacrifiegd. In so lar as this war dono in the late ninoties that is procisoly what happoned.

The throat of the separatie poirer house 20 supjiy atations to charge transiajs tize average cost of traotion kriba for a givon trammay laad factor. This is what they meant by charging the cost of supply, which was what the tracirays tried to insist upon. Strictiy speaking it was only the cosl of iraction jower whon tise trankigy poak deward coinolded with the station peak. Whus compotition forced tho sain ef i'eot as woula have boon

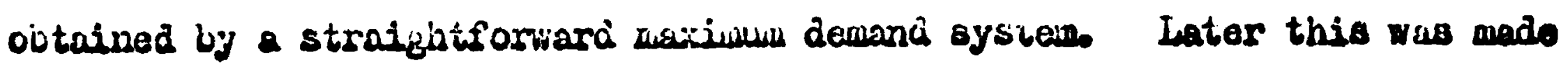
wore explicit. In tise fow years before 1934 whon power rales were lower than tractian rales line traniways began to feel they were boing explofted. Thus a joint comuittos of the Jiunioipal Electrical Association and the Linfoipal Iramyay Association was appointed to consider the prioe of eneres 
for traction. It reprited in 191.2 thnt the charge $\pi: s$ to be based on cost. It aivided costs intin standing and running, costs, and argued that tramase Bhould pa a proportion sf the standine chargos of the power otation detesmincd by tho ratio of the maximum domand for electricity for traotion to tho totol naximum demand, plus running costs per untt used. In1s was thus a rersion of the moximum dcinand tarife.

The next important form of load was the porrer lond. Industrial consuwers often had quito a low losd factor, but taken togethor it was bifhor owing to diversity, althouch there is unfortunately littlo prealse infornation about the extont of this diversity. People turn lights on when It 18 dirk, fun trans when psople cease work, but thero is no similar reason who all interwitisent polver users should switch on together. The contimous pover uscr had a hich load factor in any case. Supply undertakinge rosolved. to eupyly at a very low price to pomer conzumrs, partly because of thols high load factor and partly because at first it was thought that the demand wculd bo nearly all at off peak times. Both fint rate. With and without quantitiy discounts, and ranzimum donand systms were used, the firat generally for the cundl po:ier user and the second for the bIg ones. The use of a flat rato witil cquantity discounts in general led to Lower rates for power, Sur tino very bif ussers of electricity, apart from the otreot 1ighta, where discuunts rarely applied, usus? ly were the power users. This was not always wo and thus this method of nxice discrimination was very orude. Wuste apart fram this the costs of electric porrer compared with oteam porror was such that eloctricity rouzd have to be sold at 1d. a unt bofore salos were large. In 1904 - 6 whon the Important power load was gust beginntus 1. Charges for vlectrical Energy supplied for traction purposes from Combined Stations - Report of a joint Canmittoe of the Incorporated

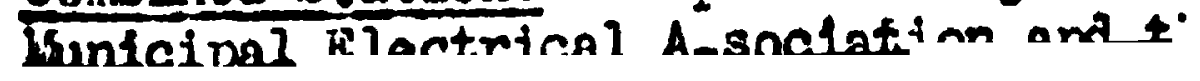


this was about a quarter of the usual lighting charge of $3 \frac{1}{2} \mathrm{~d}-4 \frac{1}{2} \mathrm{~d}$. and loss than the usual tramiay charye of $2 d-2 d$. It camo to be acoepted as the usual parer price, although from 1908 - 10 orwards an ovan lower poner price was thought appropriato.

Thero were sugzestions that at a price of ld. or less per KTh power was being oupplied beluw cost. It is unfortunately imposelble to bring aderquate ovidence to bear on this. The dellvered cost of off poak units, including distribuition cosis could uot have been more than 0.54 .

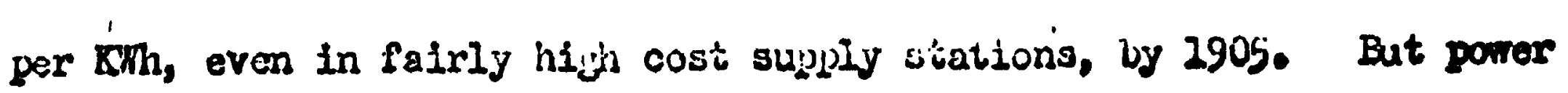
units vere aloo used at peak hours, although oven at the timo very 21 ttlo seems to have been inowin about ihis. In 1909 it was argued by S.A. Ruseoll that it was no longer economio to sell olechrio parior at a "by product" prico as it contributed substanitialiy to the 20ad. Ilo went an to produoe Pigures wílich were iniencied to show that porior was ofton supplied belon cost. These are not, however, convinving begond reasonablo doubt as they ware done on the basis of Individual comsumers' load factors, plus an allowance bor aiversity of consumer poals, and not in relation to the station peak. In the same year Mest ILan Corporation arjued beiore the Iocal Goverrment Boand

\section{1. (continued) 18sued 22st Sepbember 1911.}

2. In Sunderland In 1907 the rat1o of agregate Individual maxima to the

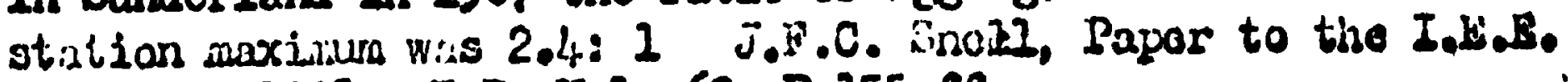
9 January 1908. E.R. Vol. 62, P 255 \&f.

1. , Inanchester is fuirly typicel of a biE uxicriakino at the timo. 'In tho yoar onding Narch 2905 the average revenue from difforont olassos of sujply was:

$\begin{array}{ll}\text { Privato lighting } & 3.86 \mathrm{~d} \\ \text { Fublic livitins } & 2.60 \mathrm{a} \\ \text { Trams } & 1.49 \mathrm{~d} \\ \text { Motors } & 1.18 \mathrm{~d} .\end{array}$


that if canital cosis rero divijed promrata amonfost lighting and power cuslomer; po:ker woul? cost $0.59 \mathrm{~d}$ per $\mathrm{Km}$ on the average. $5 \frac{1}{2}$ milizion $\mathrm{kmh}$ were boing sold at an avarage price of less than $0.5 d$ at the tims. But caphtal costs ouint to have bean allocated to hours of poak supply and thus again the examila is inadoruate. There ras a goneral sealing at the tiso that porcr suyily was bolng suboidised, although there was ueually no vary cloar 1dea of the crucial importance of the time pattern of the porar 20ad.

There poiver was sold on a marimum demand system, the rates wore often lorer than for lightine on the sams princlple. This was to allow for the grcator diversity of Indiviudal consumers' porer peake. In this cace and when power was sold at a llat rate, consumers using both power ardi Iifitinde hal lo havo tro seporate olroults, each with its own meter. The difforcnce betieen lighting and power loads was arbltrarlly determinod In voth oases, in ipnorance of the time patterns of consumer demands and witiout ans allowance for the different demand patterns of difforent consuluel. Thi could cause considerable alatortion in the allocation of rouources, bccalivo biz power consumers nould install their generating plent as an altornative to taking public sup-ly. In this situation ascurate pricin uased on cust is verj important. As, however wo do not know how close prices wero to coste in the case of pewer supnly no judgement an be ufforod un ti:c josislble exient of auch distortions.

ithen clectrio cooking ard henting semed to be beooming camarcially feacivia in the last thres or four years before 1944, oupply for ocoking was dealt riith as for porver, a special rate being lovled which was to rof'lect the relative use of poak and ofi peak undta. 
by 191 ? ten or twolve toms had a halfpanny cooking rate. It seemed as though the pook Inad was often scarcelj af joctod. A.H. jeabrook, St. Marylebone's electricnl entineer, asserted titat a $U_{4} 00 \mathrm{KW}$ cooking and 1 heatine lond hed boen adied to his supply systew in 1911 without affocting 2

the peak 2oad, which was 374,0 ini.

The thind moin molikod of cinariziz was tisat based on dfferent rates for differen: tirgis of filc duy. Ill the oconowic arouments are in

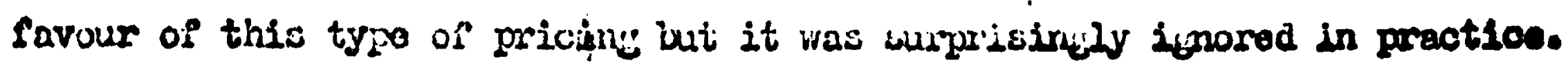
It wes not without 1 ts proninent aâvocaies but ille maia body of optaton

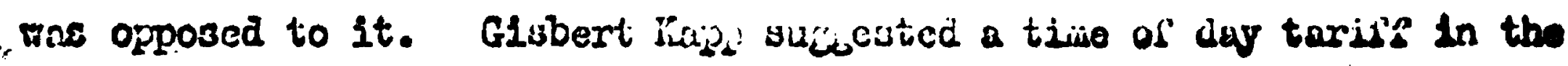
correspordence fullowine Horkinsion's arieginal papur on tho cost of - lootricity sujply. Ho proposed a clock whici would adjust tire moter at predetermined tines. The best and wost corapeling argunents for a timo of day tariff ap. carea in a series of articles in tho vilectrical Rovien in the second half of 1894 writien by filtred ij. Gibbinga, the ilectrion Englneer to flull Corporation. Stressing that ocsis variod with the time of day he argued for a teriff wintch should havo tho fallowing characterlatiow. Thore should bo a hijh jrico in joriods of maximum domands; be mggested from 4 pomo to 7 pome. in the vinter quarters and 6 pois. 109 pous In the

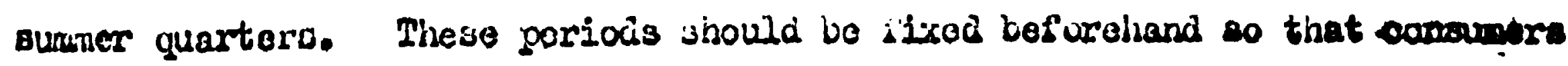

1. 1.0. the ackregate power of the apparatus conneoted.

2. During a discussion on a papar by F.IS. Long to the Munfoipal Blectriand

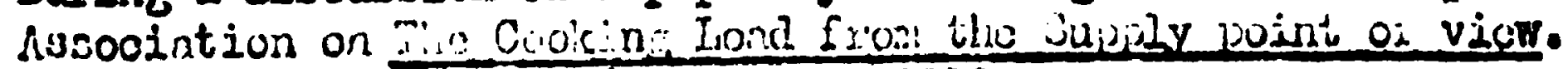
E.R. Vol. 70 PP $1034-6.28$ June 1912.

3. G. Kapp, Lotter to the Elect. Vol. 30. P 201. 26 Dooembor 2892.

4. Alfred H. Gibbings. The Various liethods of Charging the Publie for Electrlclty from a Central Striion. E.R. Vol, 35, PP 96-7, 225-7 and $257-9$. 
should know exactly what the price of using current would be. At all other times a low price would be charged based on the costs of off peak generation. The tarifi should apply to all consumers, for whatevor puspose supply was being used, and no robates should be gaten to anjons. Bo argued quite corroctly that the individual consumer's peak was not relovant to the 1deal tarles.

Such a tariff noeded a consumer's moter whtch ad fustod matomationlly to allow for the time of day. Ho considered that Kapp's devico was quite adequate for this. The latter was based on the prinolple of "ahunting" the meter. It had an automatioally rewound clookrork mechantam vorking a switch which adjusted the amount of ourrent going through the meter, and hence the rate at which it rocorded. Tho amount whloh went through at peak hours could be adjusted, which oontrolled the prico dfferential botween poak and off poak units. Suoh a motor roally recorded in money rather than physical unsts. Swoh a devioo oould bo cannooted to any excloting moter at a cost of about d3, thus boling about hale tho cost of the moter 1tsolf. Same extra superviolon wes requirid but this would not add greatly to costs.

Gibbings considared that his ldoel tariff was muoh simplor than maximum demand tariffs. He argued that much of the consumer objection to deferential tariffs basod on their maximum demands wes the undortainty as to the final amount of the bill, whioh could be considerably affeoted by the bilght of the consumor's poak.

If adopted the tifo of day tarlff would have been mach almpler than the complsanted set of tarif's which had grown up by 294, with the 
varlous versions and modifioations of maximum demend tariffo and spoolal prioes for spectal 20ads.

This important series of articles provoked no editorlal comnont: and no correspondonce whatever. The tariff advooated was neter given a reasonable trial. In Bristol a for houses had Kapp's "timo owstah" but only a few. In Norwich a time of day tariff was Inst1tuted, and tho consumers' moters controlled from a olock at the Central station. But In noithor place did tho tariff last.

There seem to have been tro reasons. The flrst was the alleged unrellability of the clockrorle time eritch and the alloged high cost of the contrally controlled system. The second was that most supply anginoere thought the timo of day taripf mistaken thearetically. There is evidonos that olook controlled meters were neither as reliable nor as choap w GLbbings argaed. In $1913 \mathrm{H.H}$. Perry, one of the foremost exporte on motere, told the Manchester section of the Institution of Electrical Englnoors that olock controllod moters had made 21ttlo hoedway booause of thatr high first cost, the need for monthly winding, the dogree of skell noodod for ropalrs and the prolonged poriod of testing roquired bofore they could 2 bo Installed. Centrally controlled systems required a 3rd wiro to tho moter. They wore thus said to be very oxpensive to instal in exteting networks, but in the middle nineties when most towns did not yet have elootricity supply the extra cost of installing it in now notwarice would

1. R.P. Wilson, liethods of Chargin, for Electricnl Sunnly, papor to the Northern Society of Electrical ingincers 8 th Liarch 1897. B.R. Vol. $40 \mathrm{PP} 365-6$. Elect. Vol. 38 PP $695-7$.

2. E.R. Vol, 73, P 821. 21 Novamber 2913. 
have been much less. Also contrally oontrolled clooks do not seen to have been perfeot2y rellable in operation. Howorer, time owitohes wore beling used, apparantly with sucoess, in seven towns in 1910, for speolal restricted hour tariffs. Also It is possible that the lack of interest of eleotricity supply engineers in the time of day tariffs elowod down possible improvement in these motere.

As has been noted Hright opposed the timo of day tarlfe, and this viow seems to havo been hola by most supply enginoers. Jar excomple, W.A. Chamen, the Glasgow Corporation's Electrical Enginoer, argued that "It doos not seem to me to take a grip of the correct principle for it would result in oharging a long hour consumer the additional price during part of twenty four hours for the simple reason that somoone 0180 wants to make use of the plant which is supplying him and makes him pay extre for the other consumer's shortcomings". In 2ater papere on supply tariefs the time of day charge is usually ignored or very brierly dismlssed.

Restrioted hour tariffs wore used and provide some appreximation to a time of day tariff. It was used for olecttiolty for motors, but appealed only to the small user who ran mechinery intermittently. Woll suitod for fans, refrigerators, sausage machines oto., $1 t$ could not bo applled to factories whore most of the demand exdsted. But with sultable Loads it seemed to work quite rell. First introduced at Burton on Ireat In 1906 it produced a rapld rise in that torn's load faotor, from 22.7\% to $19.6 \%$ in 1908 when power KWh sales had risen by $50 \%{ }^{3}$ iThere all but

2. Op.o1t.

2. W.A. Chamen. President1al Address to the Lunicipal Elootrical Assoolation. 29 Juno 1903. B.R. Vol. 48 P 1128.

3. R.J. Pringle. The Restricted Hour System of Porfer Supply. Ee Re V01. 67, PP $354-6$ and $365-7.26$ August and 2 Sovtember 1910. 
10,0 of the motors conneoted were on a restricte hour basis. It was also -

used in Bradford, Dewsbury, Glasgow, Grimsby and Forcester where $21 \%$, $53 \%$ $7 \%, 26 \%$ and $29 \%$ respectively of the motors were on th1s tariff. Iot. bocause of 1 ts lack of genoral applicablisty it was clearly inferior to a time of day tariff.

\section{$\underline{\text { II }}$}

If the pricing situation which omerged to cope with the aleotricity poak was a little chaotio, that of the tramays and suburban raslways was srankly perverse. In 1910 J.R. Salter in an Important paper to the Iramray Congre.s pointed out that tranray costs could bo divided between standing charges and operating costs as in the case of electricity eupply, lamenting that the Hopkinson prinosplo had not had rull applioation to trams or railways. But not only was the Hopeinson principle not applied in that fares at peak hours wore at the same rate as off peak fares, but they were often lower, because of worlonen's t1alotes. The latter were disliked by the companies. For example, both the Great Bastern and the Central Iondon Railways complained before the Royal Combission on Iondon Trafflo that they were unprofitable. Prosumably they meant below average cost, but if this was so they would bo far below long run marginal cost. It was Parliament and tho local authoritios who forced them to have thom. The latter wore partioularly anxious to

2. J.R. Saltor, Tramiay Iconomics. Paper to the Tramay Congreas. B.R. Pol. 67, RP $5 \odot 8$. I July 1920. 
have cheap workmen's transport, partly os a way to re-distributo incame, but more as a method of trying to Induce workers to leave the crowded unhealthy areas of the centres of the torms and move into the more salubrious outskirts. Naturally whore they operated trameays themselves they usually had cheap workmon's tickets.

I have uncovered no evidence of tramay or rallway compandes deslring a higher peak hour fare although th1s would have more nearly allocated the costs of the services to those demanding them. It is bowever extremely unitkely that thoy would have been able to adopt suoh a fine structure. The minioipalities would probably havo rogardod tranday companies as tryling to exploit the public. The publlo would have felt the same of the rallway companies? public optinton secms to have exercised an important regulatory function with respeot to rallway charges in genocal. It was particularly alfficult to change from a flat rato to a timo of day rate once the former bad boen generally adopted. Once Low fares at the peak hours were adopted competition between trams and ouburban trains made it difficult for elthor to ralso them bocause of the high elastiolty of substitution botween tram and suburban traln travel. To do so, collusion would have been nocessary and oould harely fall to have been notioed. 


\section{Chapter 21.}

Soms further comments.

The Electrioal Industry is an Important one in the Britioh Bconony during the period under consideration. It was eald to be a key sector, and 1ts allogedly slow growth ls somotimes sald to be one of the reasons for the slow growth of the economy at the time. Yot despito its slow growth it was an important componont of total imrestiont In Britaln. The relevant figures from 1897 on are in Table 91 . Ther understate the stat1stical importance of olcotricity in throe ways. Ilretly, all electrio ratlways except the London Underground are exoluded. Socondly, Investment in viring in the premises of consumort buying olectriolty for lighting and power is excluded. Thiraly, nonotraotion motors and 11ghts are excluded.

The Importance of the growth of the electrical Industry in stimulating the growth of the economy cannot simply be measured by its ohare of capital formation. A considoration of the stimulating effect of elootrleity would, however, be rather complex and w1ll not be attempted here. Mo matters will be considered in this final obapteri siretiy the pattern of innovation and how it was affected by coonomito feotore, and cocondly a Bkotch of the sources of finance.

\section{$\underline{I}$}

P1ratly wo mist look at the process of innovations. Innovations vary in importanoo. In thls Industry, where Imovations were directed 
Table 21.

Gross Investment in Fixed Capital in the Fiectrical Industry $1997-1913$.

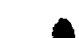

Yoar

2997

98

.99

2900

02

02

$03^{i} \cdot 7.60$

$\alpha_{4}$

05

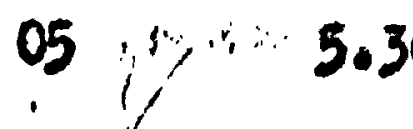

06

$06 / 4.58$

$07: 2.89 ; \%$

5.92
4.27

08 . 2.73

2.82

2.92

$09: \because 2.60$

1.73

2.72

1.98

1.62
0.73

1.90

Total

Isolated

don

Undereroyn

fectory

powor

plents

An din

0.81

0.93

2.65

2.66

1.69

3.63

5.54

6.65

5.40

3.82

1.70

0.46

0.35

0.69

0.25

0.25

0.38

0.35

0.47

0.75

1.73

2.88

29.99

$2.27 \therefore 28.93$

17.32

14.95

8.35

21.08

$3.24: 8.38$

7.73

8.82

8.97
Porcentago of Gross Investo ment In the ${ }_{3}$.T. (Folnstoin) 
towards cheapening same final product which was already in oxistence, sor exomple, 21ght, tranaray transport and turning porer, the Importance of an Innoration could plausibly be moasured by the oxtent to whlch it roducod the cost of the final product (or products). There is unfortunately very 21ttlo good information on costs, and whit does oxtot can only moavure general long nun trends. Thus one must rely on impreselon. Roading the technioal 2iterature one lo left with a strong impression that the oleo distribution of innovations was highly skew - a large number af anall Innovations, and a fow big ones. Because of the lack of oost information one is only well informed about the important innovations. I shall atteupt to generalise about innovation from the evidence about ono end of the 1ze distribution. This must, however, bo dono with caro.

The rate of Innovation is not only determined by oconomis factare, although they have been concentrated on here. Howover economio factors touch on the other factors. One important, largely non-oconomio deteriminant of the rate of Innovation is the scientiplo possibility of adrance. This is non-eoonomic in that pure scientific research may by somo discovery open up new f1elds. An excmple is the discovery of the principle of sole excitation in 1867. Dut evon pure science is connected with oconomio matter bocause the comcerolal uso of somothing liko oloctriolty stimulates "pure" research, as well as research work directed to long range economio onds. In the electrical industry throughout the period 1875 - 1914 the

2. "This is not to argue that, for example, eloctrio lighting provided the same 21ght as gas 11ghting. I have argued that there wore quailty differences. Novertheless it provided a similar 21ght. 
possibilities of techntcal advance were high. This was partlcularly so In the 2830s and 2890s. But although thero wero for completely now developwonts in the years 1900 - $U_{4}$, considerable progress was possible with axdsting basio types of equipment.

Another important determinant of the rate of imovation 10 men's ability to exploit the potentialities of technical progress. This 1s a funotion of daucation, and, what is an associated matter, the allocation of skilled man power between various sooial neods. The oduoational system and the general ocolal forees which help to direct ablo pon into particular occupations will roflect the valudition whioh the soolety places on increasing the national income. But becuase we are talking of Innovation and not invention, economito facts aro important bocause akilled men with varying spooffic interests and ability can work In different framerroriss. In the United States and Germany the oloctrion Industry was mach more contralised in the hands of a for bif rixm than in Britain. In Britain sciontifio research was carried out in Unireraltiec or by Indopendent inventors. Although samotimos, 2ike Parsans and : Percanti, they wore ensaged in dovelopment work often they wore not. Users of electrical plant were separate from manufacturere of plant. There was 2ittlo vertical or horizontal integration. Thus in Britaln co-ordination was through tho markat place.

There are soveral groups of economic factors which must be discussed. Pirstly, there is the existing factor endowment of the Brit1sh oconomy at the time and the rate of erowth of the British ooonows. Secondly, there is the effect of the degree of vertionl intogration within 
the electrical industry. Thirdiy, there is the degree of hordzontal integration.

The effect of the factor endowment of the British economy on the rate of innovation is closely Ilnked with the rate of growth of the -conomy. Because gas was cheap compared with the Undted States, olootrio lighting was established on a relatively small scale in Britain. Because the rate of urban growth was Lower in Britain electrio 11ghting sproad less rapidly. Electrio tranmay development was hindered in Britain by factor endownent and the rate of growth of the econom (or particularly of certain sectors of the economy). There was little house bullding between 2890 and 1895 and after 1904. After tho first wavo of elootrle tramay butlaing $(1897$ - 2904) the existence of a dense network of ateem railwaye dolayed or prevented the buslding of Intermurban tramrays. At the sano time it was often not worth electrifying short distance steam rallways, even though, if there had been no trains, transport would have been most obeaply provided by a licht eloctrio railway for intermurban tranray). The growth of factory olectrification was also hold up by the slow growth of the oconomy. The growth of Ilghting porror and traction was slower in Britaln than in the United States because of the relative scarcity of oheap water power. Electro chemistry developed littlo in this country prinolpally for this reason. Comparative cost considerations ruled against any Rnglibh Ningara Palls eleotrio power scheme.

In the cases of electrio 11ghting, power and traotlon rossone for the slow growth of electrical mathods have been ifien in the relovant chapters. What is to be considered bere is the offect of this olon growth 
on Innovation. In the 1880s, (more strictly 1879 - 91), when electrio lighting secmed to have failed at the "take off" point, thero was considerable Innovation in Britain. Many Inventions and Improvements woro mado. Naturally they wore not widely applled, but they were applied, and thus count as innovation and not simply invention. Britlsh engincers wero quick to follow innovations made abroad. Crompton quickly followed Brioh's lead in developing wili-aro dynamos. Stran invented the eloctrio Incandescent I1ght bulb at the same time as Bdison, and oven though bo ald not, as did Edison, design a whole system of oentral atation 11ghting, bo and Crompton co-operated to produce the same innovations. Bdison wes in front of them, but not very far in front. In the case of the a.0. transformer and the use of high voltage transmiasion Ferrant1 in Aritatn saw the economso advantages of the transformer as quickly as anjono. His achiovement was as great as that of Filliam Staniey in the Onitod. 1

States. Orompton and Willans developed high speod steam dynamos, an improvement on the small belt or rope driven dynamos used in other conntries In the 2880s. Ferrant1 was the prinolpal plonear of paper insulated cablos. Parsons developed the turbo generator. In small as well as in: major matters there was great progress in innovation in the oleotrion Industry when the economic situation was very discouraging. The 2890s, (more striotly 2892 - 99) show an almost diumotrionlly opposed set of conditions. The eleotrical industry began to dovolop falris rapidly, especially after 1895, and yot the rate of Innovation at hom foll array to a very low level. The important developmante in traction and powor came from the Untted States and the Continent. A vory olon rate of Innovation was particularly markod amang British manufecturore of 1. H.C. Passer. op.cit. Chapter 9. 
-lootrical machincry.

It would be odd to arguo that a slom groith of the applioation of electrical mothods stimulated imovation. On the other hand it is osay to soo how liack of canneroial success could deter further imrontian and Innovation. Thus the eridence seems a littlo perverse. Howover we must distinguial botween the making of Innovations and tho application of innovation. The rise of electrio traction in the late nineties was the application of en Innovation - or a serles of innovations - made abroad. Thus one reason why the rise in demand for transport did not utimulate Innovation at home was that the important imnovations had elready boon made.

Also there soams to have boen a considerable time lag in the response of Innovation to economio conditions. The slow Innovation of home manufacturers in the nineties is partly a response to the coonomio diffioulties of the eighties. Because the finanoial return to innovation had been $10 \mathrm{w}$ in the eighties both lenders and the commerolal alrectors of electricel firms becamo reluctant to finance and encourage 1t. This attltude se shom particularly clearly in the case of the eleotrion machlnory manufacturers in the years 1896 - 1902.

After 1903 the slor grouth of the market does seem to have had the offect of dompening dom innovation. The slow rate of growth of doma for capaolty in electricity supply delayed the adoption of some of the possiblo economes of scale in electrialty generation. Yet a sion rato of erowth of demend for oapaolty is clearly not necesserely, a bar to Innovation. The experience of N.B.S. Co. shoms bow arocesaful Innovation 
could nevertheless lend to a considerable growth in capacity. The Enancial difficulties of the years 1901 - 10 do secm to have reduced tho devolopmont work undertaken by British manufacturers.

The second important oconomio matter to consider is the offect of the degree of vertical integration. The cmall amount of vertical integration in Britain compared with the United States and Gormany produced atructure of the mariket for electrical plant that was sald by comtemporarled to be a handicap. Becuaso electrical utilities and elootrical manufacturere wore separate and indopendent the consulting ongineer was used to bring the two togother. The consulting engineer laid down spectelcations usuaity rather strict ones - for the equipment required. Manufacturors responded with tonders. In the Onited States by contrast the relation betwoen plant manufacturens and utility were close, and utilities often almply ordered plant automatically frora ono manufacturer. In Germany the situation was mach the same as in the United States. The samo Elnanolal groups had interests both in utilitios and manufaoturere. Conternporaries in Britain argued that the British system hindered progress. Inuch of the evidence does secm to bo on thoir side. Standaraisation fras more likely to occur when manufacturors had more say In the typo of plant they were to supply. Of course standaralsation by Itsolf was not necessarily en advantage; it could involve stagnation in design. The consulting enginoer could stimulate manufacturers. In 1892 the Electricion argued that "porhaps nothing olse has done so much to derelop and improvo the d.c. dynamo as the stringent conditions as to wolght, size and heating which have boen laid down in tho Admiralty opoolfioations". Iot in Britain thero was cortainily too 21tt20 
- tandardsation. Th1s doos aeen to have kopt oosts up rathor than anth. By how much we carnot sayi one must be careful not to exaggerate the possiblitics of standardisation. Inevitably most plant had to be designod for a particular job.

Wore important than the question of stendarisation, secms to bo the possibility of developing plant by close co-operation betweon consumer and manufacturer, that is by contiruing dovelopment work when the plant was actually oporating. In Britain tho use of a consulting enginger, with the aystem of rigid specificaticns and heary pensltios for not meeting graranteas does seem to have made close co-operation between manufaoturart and utilitios afficult. Tho fact that man utilstles were locul whorities made for further estrangement.

This view is supported by the facts that on the North East Coast theré was close co-operation between mamfacturat and K.E.S. Co. and that this seans to have had benoficlal results. M.E.S. Co. had a purchasing polley quito alfferent frorn that of other sup ly underiakings. Mers often Imvited tonders on very opan specifications for individual iteme of plant or merely consulted sirns who be thought could bulld the machinery. Prloos were often flxcd by bargsining. If, aftor plant was installod, difflaultios were oxperiencos, the manfacturer mould be called in. Thore progress 'consisted in a series of small improvemanis mado boculse operating condition revealod snogs this was very fruitful. For examplo a good deal of the . Improvemont of motal clad switchgear was dus to the close and friendy relations between Reyrolle \& Co. and N.B.S. Co. The formor had based tholr Initial designs on the A.B.G. omitches Installed in Northumerzand 
In 1902. Knny of the Reyrolle improvewents wore swall changed after particular snegs occurred in working. The problems were mochanicnl rather than elcotrical, and diffleult to prediot theoretically. 011 s1led boxes burat when faults occurrod; they were replaced with stronger boxes, On such matters, Mors \& MeLallnn, the consulting englneers, N.Fi.S. Co. the operstors of the system, and Royrolls \& Co. the marufacturers and contractors for aritchgear comopgrated closely, often on Reyrolie's shop floor. It was not a question, as with other oupply undertakings, of collecting panalties and turning to other contractors. There was simtlar close comoperation botween N.E.S, CO. and Parsons. It was at the Blaydon ifisto heat a porrar. station that Parrons made his first ro-heating experiments w1th turbines. The low oapital costs of the N.I.S. Co. system suggest that no penalty in tarmis of high prices was pold for this reduction in compotition.

Thero aro degrees of vertical integration. Integration means roplacing a markot structure with an adminlstrativo structure. W1thoit arguing that complete vertical integration was desirablo one can argese that too much rollance was put on a market structure, which did not have the nocousary flexibility.

It can also be argned thut there was too 11ttle borlzontal integration. It has boen argued in Chapter 9 that publio utility control of the time lod to insufilolent horizontal integration in elootrlolty supply and olectric tramays. It may be askod whother the peivate monopoly whioh this control was designod to provent - or at least atrlotly control - would have benn more officient. In the Jnitid Stater 
so the minimum efficient unit in olectricity supply expanded, holding campanies wero iormed micin controlled sevaral locel companios. In the 1920 s private concolication proceeded particularly raplaly. Eloctrlolty apily after 1905 is a clear $2 y$ of where if private monopoly had been allowed prices inight have been lower as lower costs, because of economiles of

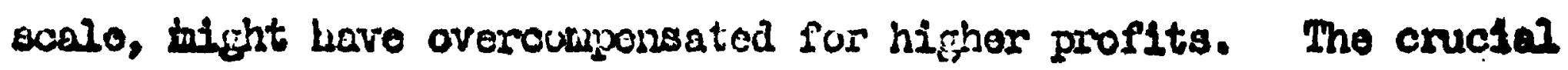
questions are the extent of scalo economies and the elasticity of demand sur electricity. The suale consmies were quite large as the low cost or H.I.3. Co. shor. Tizere is no information which would enable us to make any precise calculations about the elastictty of deand for eloctriolty. Nevertheless ono can try and maise sowe rough guesses basod on literary erldence. For electric lighting demand was probably genorally rather inelastic. It was certainly highly inelastic in the elghties when olootric lighting ras wuch moro expensivo than gas 11ghting. The elasticity oi domand for lightin: for II ghting rose during the nineties as eleotric lighting costa came dorn towards gas ilghting oosts. Also In the late ninetios the elasticity of demand for electriolty for traotion ocens to have been quite hich as tramava electriftuntion procoeded raphdy. However, it was easy to pructice prico discrimination. After 1900 the oloot1city of demaril for electric lighting mast havo doclinod again with the Introduction of the incanilescent ges lamp. But the introduotion

1. H.V. Paulkner, American Economic Historr, 7th Edition. Now Iork. 2954 P 620 .

2. Chapters 3 \& 4. The IOn cost of N.E.S. Co. eloctricity was due to othor things than BCale oconomies. But sollo coanomles wore luportent 
of the motal fllament lang in the years $19 C B$ - 10 ralsod the elastloity of demand for electricity considerably. Tho demand for eleotriotty for porer seems to have been quite elestio. The h1gher the elast1oity of demard for a product the less re need to fear monopolistic prioing. In these term therefore a case could ie made out for roglonal pritrate monopollo3 in elecirfolty sugily from 1905 to $19 U_{4}$ (and pertaps later).

In the case of electrio trantrays and the Iondon Underground thoro wezo certainly econamies of scale. There were not scale econontes In an 1solated large tom but in conurbations whore there were several operators. The economies of scale were economites of through runing and rould have reducod trevel timo rather than pares. It is very difescult to guess at the elusticity of domand f'cr trampay and urban railway transport. It was probably higher in londan than elsewhere. The genoral used contemporary index of travel froquanoy - journoys p.a. per heod of population - was remarkably low in London, not only oompared whth very large clties but with big. Brilish towns. Generally: howover, the domation situation suburban hodsing does not I Aad one to expeot a high olasticity of demand for urban and suburban transport. Hence the argumonts for privato monopoly are consicierably weaker, both on the demand and on tho cost side than in the case of electricity aupply. Iondon, howover, is an inportant excoption.

It is also possiblo to arguo that more horisontal intogration would have been destrable in the case of the olectrioal manufacturars.

1. While at the same time causing ance for all ansft of the demand curve to tho lert. 
In the Unlted States and Germany hi:h conceutration went hand in hand with raptd technical progross. In 2992, with tile formation of Gen ral Blootrio, olectrical machinory manufincture in the United Statos becano a duopoly. In Germany In 1903, the amalgamations of A.1.G. and tho Union Co, and Slemons and Schuckert lod spticliy tis a duopoly situalion. The consequemt reduction in compotition does not socun to havo led to any atagration. On the other hand it doea not $x y, z$ in hivo led to any quickening of technical progress. Howover it mifht have done in Brituin, elthough there is not cnough ovidence to be sure of the matter. Britiah Iinn serm to have been bif enoigh to exploit economies of acale. The manufacturing tochniques uscd in builoing olectrical machinery woro not ones wivere these cconorales were considorable. Llectilcal manufacturer did scarcely nny research besiore 2914. Thore do not apploar to havo boon coontriles of soalo in develoiment work which inflisis manufacturore could not benoplt fron. Yot it can be argued that tho typo of prioo outtins which reoulted from the existence of 4.5 Larga flrms in Britain ald slow up innovation by reducint proplts and causing 1312quidity.

It may woll be askei why greater concentralion did not take pleco In Britaln in electrical machincry man:tentimo. Not onough is known about

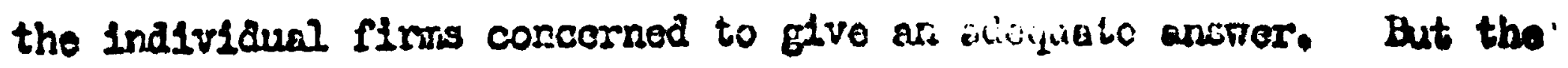
chnrnctar of the recesslons does proviao a partial anarer. It is -1gnificant that in Gerrons the malgamations of A.ti.G. and the Unton Co. and Slemons and Sohuckert were eased by the difficultios of tho Untan and

\section{800 Chapters 7 and 8.}


Schuckort Companies. The relative gentieness of tho Inglish cyole in electrickl oquipment $122 j$ havo been dicaaivantagoous. The moro violent recessions in tho United States and Curmany oven if they did not materially ald gamation, at least increased concentration by eliminating the reaker elins.

The electrical industry suffered fram insurficlent horleontal Integration in that ensineers and business men dia not work well together. In the United States and Germany tise major manufacturing firmo emplojed many 'of the best electrical eninoers. In Britaln this wes largely the case in the 1830 s but in the ninetics the major firms 20st many of thelr enginoors. Howovor it is clear that wero amalgamation could not cure this the gap between engingers and business moin was too big. In any astuntion there is an inevitable gas between the tro, but it does seem to heve been particularly wido in Iritijn. Dusiness mon had virtually no technical traininic; anglinocrs did not foel that comorcial mattere wero their province. Indeed tizey were not encouraged to concern thanelvos with the firn's accounts. Ijxst rate engineers like Parker, Perrantl and Parsons folt that they wawt vorls on thoir orn. Yot oven Parsons might huvs dono bottior if ho had had greater business akdll." Th1s cap made it dificicult for Endisin rirms to digest outsido invention. This is shown by the situation in the oarly eifhties and tho diffioultios Englioh flrwes had in building Parsons turbines.

1. Cf. D.II. ivbertson, ov.cit. i2 27 - B. "Inankes to Its moro modorate and controlled expansion, the Enclish eloctrical industry oscaped - Altocether the catisirophe that befel its Gennan nolghbour.".

2. Seu II.C. Passer. Og.cit. for thac Unitod States.

3. Sir Alfred Yarron comionted that Parsons was a "atupid cort of ahap in bueiness." R. Ap?lespord. op.cit. PP 269 - 70. Far commonts on Tammnt1 seo PP $366-7$. 
The rewards of an engineer working for an electrical manufacturing firm or an elocirical utility were falrly amall, unloss he wero a Direotor. Salarlos appear to have been falriy low. Thero is very 21tile oridence on this and it is diffleult to make a balanced sudgement. But there was constant complaint in tho correspondenos colum of the Eleotrical Revier and the Electriolan that muntcipal - eleotrioity supply undertakings and municlpal tramrays pald exoussively Iow salaries, and that this $20 d$ to their getting inferlor men. There seems to have becn a good deal of justico in this vier, although one can polnt to very good electifical encineers who workod for muntcipalltiea, Iow salaries may have lod to employing men with a pedestrian approuch to matters when what wee noeded (at least after 1905) was to persurado Town Counoils of the need for comoperation with adjacent operatorn." Iondon tranaport seems to have suffered from a rather uninspired traway manager, who wa reluotant to make through sunning agrecmente with othor operators.

In oleotrical machinary manuraoturing engineors were 2 lso not, It soems, well paid. Nor wero they given much scope for developing new designs of machinery. Kany of them were attracted into becoming consulting englnoers. There, as far as wo can toll flnanclal rowarde were botter, and there was also more scope in designing plant. It is

1. O.8. J.F.C. Snell and C.I. Fordinghsm

2. Soo Chaptor 9.

3. Charlea Rlapper. op.cit. P 246 
dikoly, however that socially witey had too mach scope. Consulting enfincers vere not intinately conreoled either with the manufacture or With the runnine of plarit. They were able to try out all thelr non 1deas, which werc of ten no doubt good ones, without worrying about the cost of production of electidical maciainery generally, as opposed to the cust of a particular order. To reduce costs by standardioing thay would ail huve had to have ucted, if not altogethor, at loast in groupa. Given a situation of no siandarisation, Introducing spoclal modifloation Ls often justif'iec.

In cossidorini insovation the guostion of patents has been 1enored. This has boen dono bockuse there scems 11ttle to say about patents in elecirical machinery nanufacture, and nothing to say about patents in electricity sujply and olociric traction Thlo 18 partly bocause many products were devaloped abroad and introducad by now canfinios holding the English patent rijints. But cron ndthout patent proteotion entry wolld have caken place because of a supertor product which courd not quiciliy be cupiei ut existing prices. The rather 3canty ovidenco suizestis bhat it was not usually difficult to get licances to work particular platents. Again evidence is inadequato but rojaitios do not jocen to have been high enough to restrict competition 2 aubstantioldy. A wibsidiary efi'uct oi the jatent lams was to oncourage overcaptalisation - patants being overvalued assots. But thts 18 more an 1llustration of tio poor unäeistanding botween techntal and comnerolal persomel, and tho specialutive nature of the markot for ordinary shares

2. S.B. Saur. op.cite P 21.

2. The evidencs of 'inns' costs which might enable one to deolde this question sooms to have beon dostroyod - if it over existed. Costing -na nofinitiven 
than a comnent on the economic effect of patents. One mat conolude th1s paragraph by saying that patents wore very important in Incandescont lamps, and 2 ed to a monopoly from 2888 to 2893.

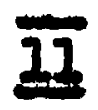

Parlous comments have been made about financing In earlier chapters. An adequate study of financing would involve surthor research. But some genoral coianents can bo made. Host of the borroming for electricily ouply was done by the municipalities. What of the money must have been subscribed locallyt how much we do not know. Electricity oupply companles were, it soems, largely flnanod 200ally. The diroctors were often locul men. liowever there worv also several national groups. British Gilootric Traction had considorable interest in oleotricity supply. This was usually in the areas served by the power companies. B.E.T. was the original owner of the County of Durham Power Co., and hold several Provislanal Ordere for Ifghting and tramrays in County Durham. It controlled the North Wotropolitan Powor Co. and hold many Provisional Oxiars in tho power company's area,

Edmundson's Eleotricity Corporation mas a Einanolal group w1th interests in small central stations in a number of amall towno oproed all over the country. Although it had holped to finance many electriolty cupply undortaklngs, as Tablo 92 shows, tho total amount of monoy provldad In th1s way was rolatively small. The Edmundson's money was probably $\therefore$ 
Tablo 92.

Edaundsons Eleotricity Corporation Investmento in and advances to Subsldiary Cose Jarch 1906.

Compary

Aderley and mizmsion

tromloy

Folkestone

Islo of ritght

Ilfrecombe

lomington

Nolton Norbray

Netromarket

North of Scotzand Co.

(Brechin, Inverness

and lontrose)

Kansegato

Scarborough Trams

Eelisbury

Orban F..S. Co.

(Cambourne, Rearuth,

Glossop, Twickenham,

Harich, Grantham,

Bervick, Godalming,

Newton Abinot, Starisord,

Dartmouth, Teybridgo,

Newbury, Caterham.

minchester

Wycombe

Lanosshire Porper Construotion Co. $\boldsymbol{\varepsilon}$

40,608

23,100

23,475

169,274

35,345

30,839

36,910

13,650

97,906

34,103

97,931

49,840

409,789
As a porcentage of capital expenditure. 
largely raised nationally and used to supplement the monoy ralsod locally. Table 92 also shors Edmundsons lending to the undertakdng they controlded as a percentage of the capital expenditure of those undertakinge. There wore also maller groups, for examplo the Electricity Supply Corporation and the Northorn Counties Blectriclty Supply Corporation. They, I1ke Edmundsons financed swall undertakings in omall towns. Bven quite big undertakings ralsed a large part of thelr capdtal zocally. For examplo, N.F.S. Co. did not make and publso 1ssue outs1de the North East unt12 1906. By then 2t had apent Q1,383,965 on capitel account.

Although the matter has not been fully Investigated it does seen that eleotrioity supply undertakings found it diffioult to borrom outsldo' their local1ty. The power companies (except H.E.S. Co.) sound borrowing difficult and yot othor olectricity supply undortakings seem to have bean ablo to extend their plant to meet demand without diffloulty. Because the powor companies were not based on any one town they had no natural local source of money. N.B.S. Co., the one power company whlch was ablo to borron fairly easily, supiorts this argument, for alone of the power companies it grem out of a local undertaking.

The finance of eleotric trameve ras similar to that of elootricity axply in that the minioipalitios were the prinolpal borrowers. But the private seotor was dominated by B.B.T. Howeror wo do not know where B.R.T. sold Its ohares. The Losion Onderground been simple to celculate is I have been able to use mv oolleoted capital expanditure sigures. 
-

Railways wore largely financed from the U.S., although the Yerkes - Speyor group must have borrowed heavily in London as well. To disentahgle tho financial arrangements in this case is a task on 1ts own. The capital Sor the Liverpool Overhead Rallway was ralsed entirely in Liverpool, and with great ease. The Hersey rallwas borrowed from Westinghouse for Its electrification and the main Iine steam railwars no doubt uned their usual sources of money.

Blectrical machinery manufacturers suffored more than the other soctions of the industry from borroring diffloultios. This mattor has already been partiolly aiscussed in Chaptors 7 \& 8. Britiah financlal compenies did not usually sell many ordinary shares. Wany of them wero held by the Directors. Some of the Directore were often membere of the original partnershlp or purchasers of the original patents, or the original Inventors. Sometimes a local Iandowner, who had bought many ahares, sat on the Board. Proference shares were held more widely but were not easy to Bell arcept in times of considerablo boom. Dobentures wore presumably more widely hold atill. Electrical machinery mamufacturere aso had heavy banis overdrafts and sanetimes tho Directors had to tide a company over a bad time out of their oim pockets.

Over a period of nearly 40 years from 2875 - $194_{4}$ conditions naturally changed. But the underlying pattern described above does not seen to have altered much. In the years 2879 - 82 money was very easy to rasso. From 1883 - 87 it was vary t1 ibt. Then from 1898 right through unt1l 29C4 borrowing was not very difficult excopt for the machinory manufacturers. In the recession 2892 - 95 prifate borrowing 
was not easy, but the municipalities were able to raise what they required. After 1904 interest rates roso, whloh could be a vorlous matter in a capital intensive Industry working on amell mariss (0.g. electrio treotion and eleotrlodty oupply). In the case of the L.C.C. capitel market difficultios ware in important cause of the scaling down of publlo utllity 1 cohemes. Insian 18, horrover, probably not typioal. If the other 200al authordtles had similar borrowing diffloult1es thay kapt rather quiset about them.

1. C.H. Yinsteln. Home and Forelgn Investinent. Cambriage Ph.D. 2959. 


\section{APIEIDIX. BETLIOD OF CALCULATIIG VARIOUS TABLES. \\ Gross Investmont in Eleotrleity Sunply.}

Table 23.

Before 2895 capital expenalture flgures are rather dublous. The Blectrician made estimates for capital expendsture at the end of 2894, 5 \& 6. I have also made estimates by the mothod descorbed on Pages 486 - 8.

$\begin{array}{rcc} & \text { Electrician } & \text { Mino } \\ & 6000 & 8000 \\ 2894 & 7,400 & 7,150 \\ 95 & 8,002 & 8,574 \\ 96 & 9,673 & 10,547\end{array}$

At the and of 28918 Londan Companies had spont 22,018,997. I have allowed another Elm. to cover other companies at the ond of 1892. I have assumod that capital expenditure at the end of 2888 was ondr 2300,000. I then Interpolated Eraphlcally between these points and the Later estimatos made by the Electrician and mo.

Gross Investmont was taken as the investmonit in oapital exponditure.

$$
\text { Gross investmont Sm. }
$$

Eleotricien estimates Using mo outimates.

2839

1890

91

92

93

94

95
0.7

0.8

1.2

2.5

2.5

0.6

2.4
2.3

1.3

2.6

204 
Tablo 26.

Eleotriolty oupply undertakings had, under the Elootrlo lighting 1cts, to make roturns to the Board of Trado. However these roturns were only published for 1899 and 1900, and in some respects are incomplete. A searah for other returns in varlous Goverment departmonts and at the Publio Record Office has proved fruttless. Thus I have had to fall baok an the Ilgures in Garke's Hanual. Data on capltal expenditure are given for most undertakings for most years. There are some gaps. 1180 somothing was spont on Capital account bofore the undertaking was openod, and of ten the amounts are unknown. Bstimates were mado for missing youre by linoar lnterpolation. To allow for capital expenditure before the -tation opened it has been assumed in most cases that capitul oxpenditure was zoro at the end of the 3 rd year before that in which aupply began. In the cases where the undertaking was small and capital expenditure was 820,000 at the end of the yoar in whtoh supply began it wao assumed oapital expenditure was zero at the ond of the 2 nd year bofore that in which oupply began.

The magnitude of errors in estimation depende on the size of the undortakings for which IIgures are missing and the alze of the gap between known flgures for undertakings. Happlly there are only short gaps for the big undertakings. Often it 18 only ane yoar and an estimato which is the arithetio averago of capital expenditure in the provious and following year cannot bo far out. The undertakengs with very lang gaps or very unsatisfactory figures are the ones. For a fell of them, oapital expenditure Ilgures have been estimatod from flopures of losued oapital. 
In order to get some idea of the possible errors which might be Involved in estimation those undortakings with long gaps in their published f1gures wore put into a separato group. This was dono when there were estimates more $\operatorname{than}_{n}^{3}$ concecutive years. However the period was not treated as a wholo as on several occasions a good run of flgures contains a cap at one end. The perlod was divided into two parts, 2895 - 2904 and 1905 to 194 Inclusive. Care was taken to see that long gaps in the pertod 1902 - 07 were not 1gnored. Where a mu of flgures for ono of the two sets of years had more than 2 estimates Ilnietne on to a sot of more than 4 consecutive estimates in the whole pariod 1902 - 07 1t was put into the separato croup.

Somotimes publishod If gures were rather uncortaln. Where this occurred they wore assumed to be rather more reliable estimates of the truth than are possible if no figures at all extst for a yoar. If the F1gures of an undortaking contatiod ostimates plus unoortain flgures for one more consecutive year than oimply where estimates alone were conoldered, 1t was put into the soparate Eroup.

The aggregate capltal exponditure in the separate (more unoortaln) group 18 below expressed as a percentage of aggrogate estimated onpstal expenditure (more certain plus uncertaln group).

$\begin{array}{rrrr}2895 & 2.4 & 2905 & 3.8 \\ 96 & 2.8 & 06 & 4.1 \\ 97 & 3.2 & 07 & 5.5 \\ 98 & 3.7 & 08 & 5.0 \\ 99 & 3.7 & 09 & 5.4 \\ 1900 & 4.2 & 2910 & 5.6 \\ 01 & 4.3 & 21 & 6.5 \\ 02 & 4.9 & 12 & 7.2 \\ 03 & 5.3 & 23 & \\ 04 & 6.2 & & \end{array}$


The orrors can ecarcely bo highor than thoso percentages. Brrors in the capital expenditure f1gures would be serially corrolated and the orrors in the gross investment should bo no largor than in capitul expondsture.

Depreciation normally tools the form of a sinking fund. There It ald not I have corrected the relevant capital expenditure 81gures, Where plant was sold I have allowed capital exponditure 11 gures to fall acoordingly. Hence gross investment in ant jèr is simply the inorement In capstal expenditure.

Not all undertakings drew up their balance shoots at the same time, : Compansos usually drew them up at the and of Docenber. Ingliah locel enthorit1es usually drew thess up at the ond of Starch, and Scottish loonl authorities at the end of May. There wore a sew exceptions to these rules, I have not attenpted to correct for this. New plant was usually Installed in the surmer, and thus I have taken tho gross invectmont of all undertakings and put it in the nearest calender year. This would ouses m capital expenditure series to lead the true sorles allghtly.

\section{Additions to capacity Tablo 26.}

The same procedure was adopted as for capital oxponditure excopt that no allowance was made for years bafore supply began.

Tho aggregate estimated capacity in the more unoertaln proup as a porcentaje of the total estimatod capaoity was

$\begin{array}{rrrr}1896 & 7.5 & 2905 & 5.8 \\ 97 & 7.9 & 06 & 7.4 \\ 98 & 7.5 & 07 & 7.3 \\ 99 & 6.5 & 08 & 7.3 \\ 1900 & 6.3 & 09 & 7.1 \\ 01 & 6.8 & 2910 & 7.1 \\ 02 & 8.7 & 11 & 6.8 \\ 03 & 9.5 & 12 & 6.3\end{array}$


Sorm cheak can be mado on theso flares by dita in the 2907 and 2922 Censuses of Production. Ifareror the consus flgares aro not unambiguous as trawray porror housos belonglas to munlolpalitles aro grouped togoticer with muntelpal oleotricity oupply. Aloo thore is rowen to aspeot that the Lots Road power atntion of the Underground Elootrdo Rallmaje of London 1s Insluded amone compang elcotriteltig augply. It

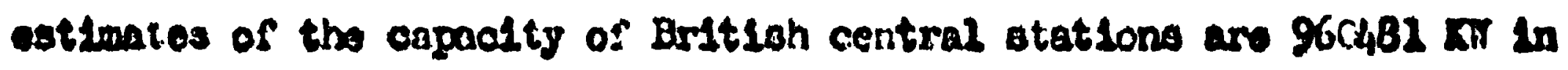
2907 and 2,405,77h $\mathrm{xN}$ in 1912. Tho Consus gaver 1,060,322 $\mathrm{kN}$ in 2907. but I cotimate that $72,848 \mathrm{xF}$ was in munsospal transay poner houses and

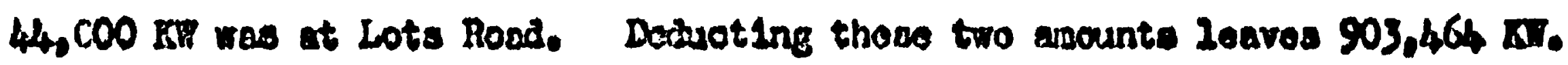

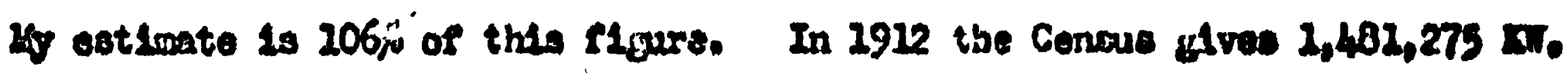

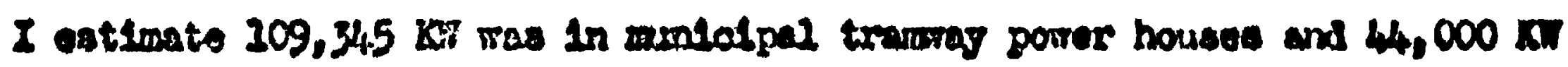

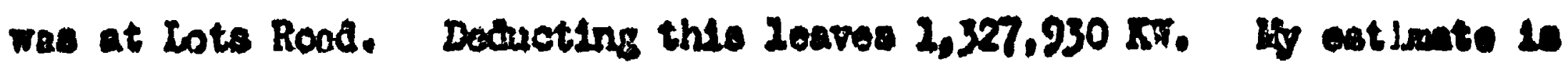
agasin $206 \%$ of thas.

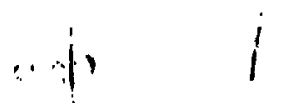

Botination of genration and eales of aloctriolty by elootrlalty sumly uncicrtakin:o. Tablo 22,

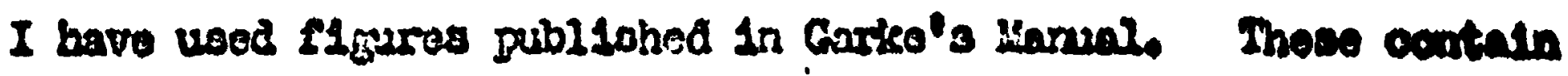
data roloting to most undertakings, excopt the power ocmpantes. In

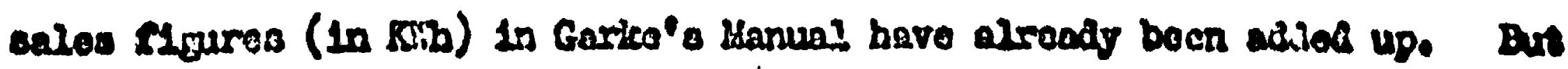
tho mothod used to unsetisfiatory. Mratly the fleures are given for the

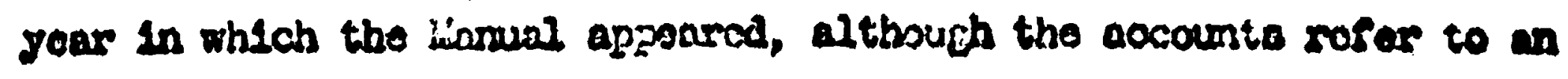
aurller year. Secandly dano accounts of same companies Iar asme yeare

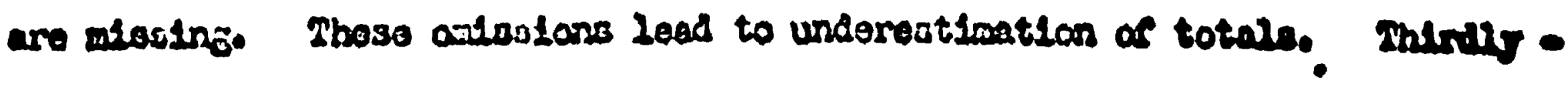

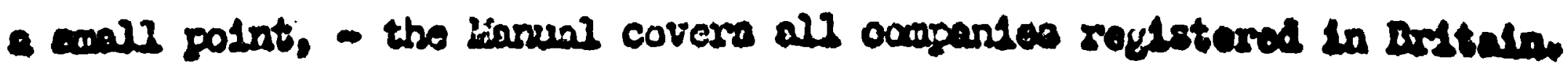


Bleotrloity sold in South Amorica and India appears to be Inoluded.

Garke's information on the porper compentes is rery deflolent. N.B.S. Co. 1s excluded aftor 2905, although it is vory important. Other power compantes are also excluded. The power companies' sigures are not centrally collected. Neithor the Bleotricity Council nor the Contral ileotricity Generating Boand have any knowlodge of themp Howeror H.E.S. Co. Plgures have been obtained Pram the North Bastern Bloctrlolty Board. Por other power compantes ostimates have been made from flgures of connections to mains given in the Electrical Trade Directory plue data of kTh sold p.a. per KII connections, derived from N.B.S. Co, data, Also odd Plgures have been found in the Electrical Prades Directory and in annul reports of the power companies. The figures for the power ocmpantes are rather shakg, but checks with the 2907 and 1912 Censuses auggeat mall margins of error. Estimition was based on individual undertakengs and then all figures were added up. Sales were flrst estimatod. Craphloal Interpolation was generally used to estimate 1 igures for years where ther are mlssing.

\section{One deficiency in the published figures was that salos $f 1$ gures} were usually not given for an undertaking in the year in which it bogan apply. As when most undertakings began, electricity was largely sold for 21ghting, the bulk of units sold were in the winter. Also when most undertalings began accounting jears ended in Decembor (evon in the oase of local muthority eupply). Thas it was felt that on the average the sales in the year whon apply began would on the whole be half those in the next year. A randen camplo of 20 undertakings, where sales in the year whon aupply began ars 2. Excopt for the Derby \& Notts Power Co. 
arallable, was taken and the statistie sales in flrst year of oupply/oalos In second yoar was calculated. The avorage value of this itatistio for the samplo was 0.504 , with a variance of 2.208. Thus misoing sales figures for the flrst year of aupjiy wore estimated at hale the sales of the second jear.

In Coluem 5 of Table 22 salos figures have been conneoted to an annual basis. The local authorlty figures for yoare onding in larch and Uav both showed strong Iinear trends.

As the 2907 Census gives Sigures of generation, but incomplete figures of sales, generation figures rere collocted, ostimated and axcrogated. There were many wore gape in generation figures. An attanyt was made to estimate mlssing figures for the wholo population by taking random samples at throe yearly intervals, and estimating intermediate points gaphically. Hotiever the varianoe of this statistio was vory high, and thus it would not have boen an officiont estimator. It was found that the atatistio miah more constent for an individual undertaking over a range of six years os so. Thus where 1t was avallable for noaring years it was usod to caloulate undts genorated from units sold. Then the statistio for the irdividual undortaking was not available the statistio frora the randum samples was used. The chocks with the Consuses of 1907 and 1912 aro difficult because of the peculiarities of the Census data. But for 2907 the aduated

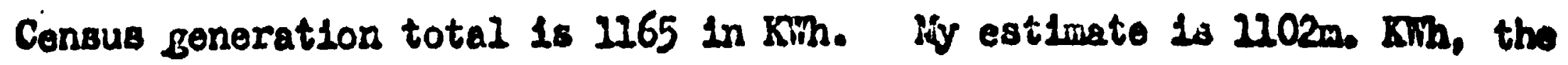
difference belng oniy 6\%. For 1912 the adjusted Consus figure is 1861 . $\mathbf{5 m h}$.

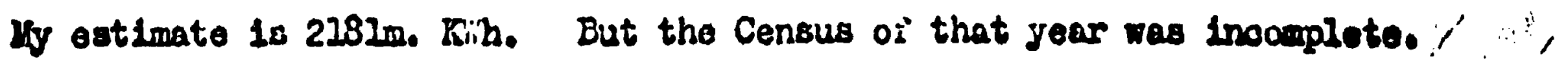
Howover, the fact that uy estiruate $1313 \%$ greator than the Coraw and 
Indicate greater Inaccuracy in my estimation towards the ond of the poriod because of the greater importance of the porrer companies,

Fstimates of traction sales were done by graphlcal extrapolation and Interpolation. As most Ilgures ware already given, and ostimates wero made easy by the foct that most tronmays caused a oudden bulgo in electricity seles, one would not expect too many errors. It has been difficult to estimate sales to the Brighton Raliway which makes the estimates Irom 1909 on more shakg.

Estimation of power sales was done elther by graphtoul Interpolation of use of the etatistic units sold p.a. por customer. This was often avallable for undertakings in the days when olectricity was only usod for 11ghting. The verlence of this stetiotic when calculated for all undertakings using only lighting for several jears was found to bo intolorably high. But It was fairly constant over a range of years for one undertakinge Somotimos a mixturo of graphical interpolation and the latter statistic wero usod. As the average revenue varled for units sold for different purposes changes In arerage rovenue wore helphis. But the whole method was rather impressionistic, especially for the oarly years of a company's porer sules. Date on power sales often appears from one to threo years after such eales begtn. Again the porser companies wero the most troublesome. Constdorable trouble was taken over N.S.S. Co. which accounts for very largo share of andes af electriolty for power. Por the others it was assumed that the Cloveland a Durtram, the Clyde Valley, the Lancashire, the South Nales and the Iarkshirs powor companios sold electrioity only for power, while the others wald ondy to authorised distributors. It ls Itkely that the powror eales of the 
othors will cancel out agalnst the non power sales of the forwer five. The methods used for estimating seles for pover are orude. Onfortunately estimates are considerable proportion of total sales for porier. In 2907 estinates made up $43 \%$ of the total. Iot although crude It is not I1kely that better resulte could be achieved, excopt portape with an excessive input of resources.

In the jears 1912 - 13 power sales are rrore diffioult to ostimate than earliex. 2 sum of individual estimates for 1913 came out at $911 \mathrm{~m} \mathrm{Km \textrm {h }}$. This seems too lor and I have rather arbitrarily increased it to 2,000me Kmbo The only check we can make in the estimates of sales for vardoas uses is with the 1907 Consus. This is done belorr. At first elght the differences secin enomous.

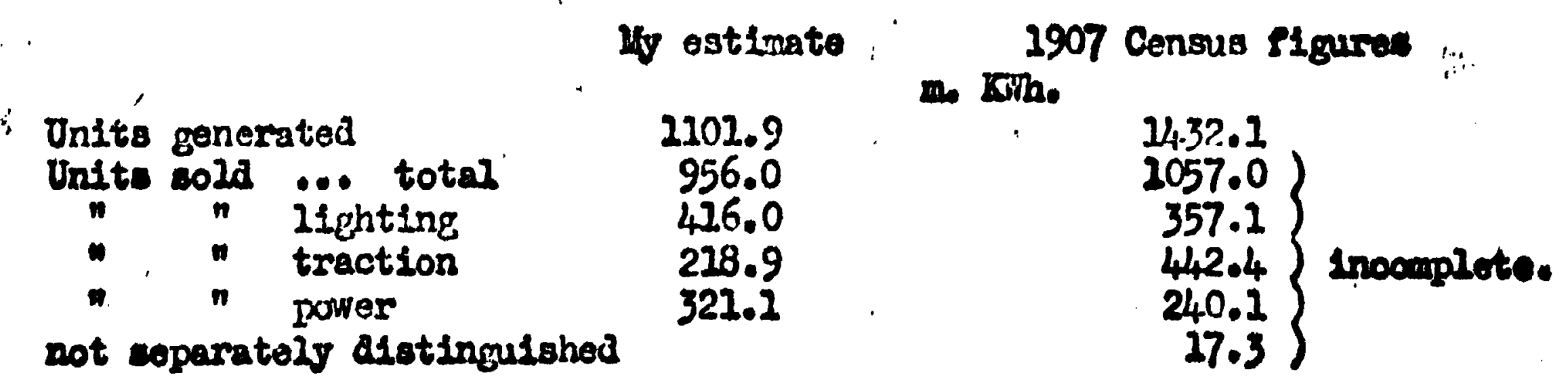

Tho main difierence 11 es in sales for traction. But it is fairly simple to explain. In the consus Muntelpal transays genorating their own curront aro included in municipal supply, although company tramray ganerating thoir orm supply are shown as users generating their own current. Mlthough tho Census glves no flgures of generation in miniclpal trenrey powor housen, It 18 poesible to estinate the amount from Garke's Manual. Such tram used 248.7m. Kmin in the relevant time period. The Board of Trade Returns

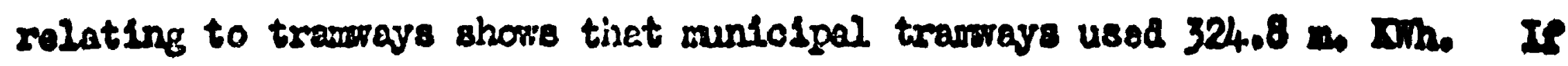




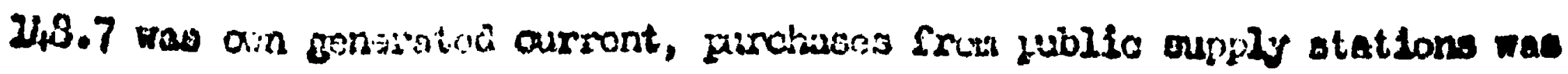

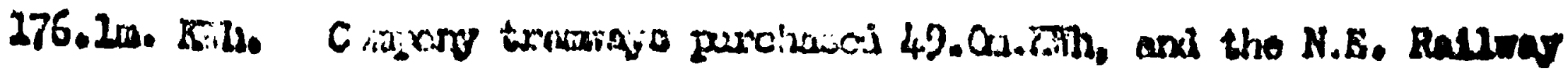

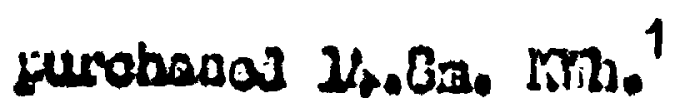

$$
276.2+49.0+9.5-24.6 \mathrm{com} . \mathrm{xh} .
$$

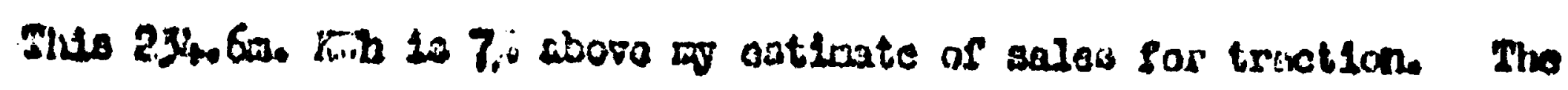

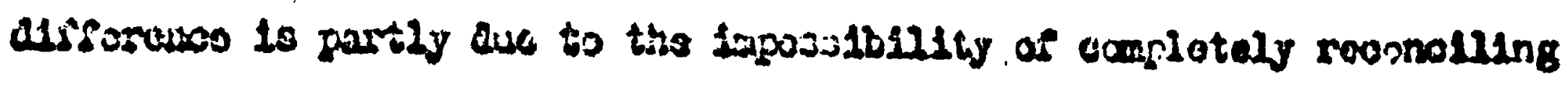

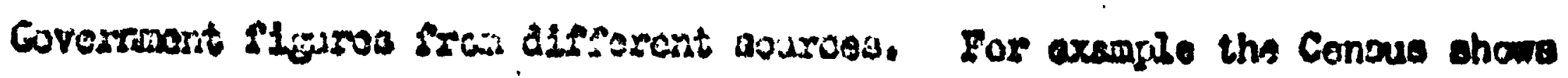

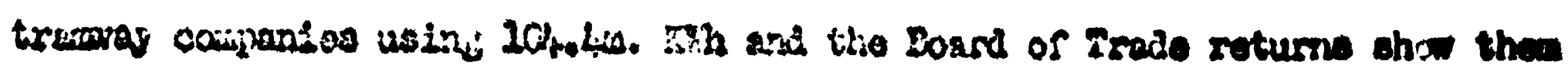

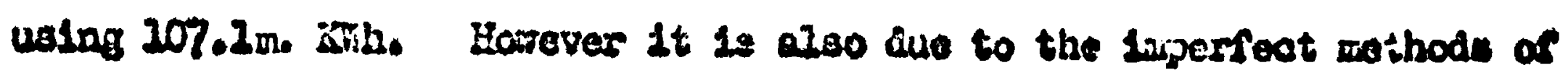

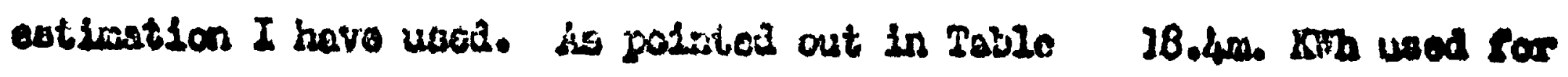
traction cannot bo allocatal betweon ond generction and furahasos.

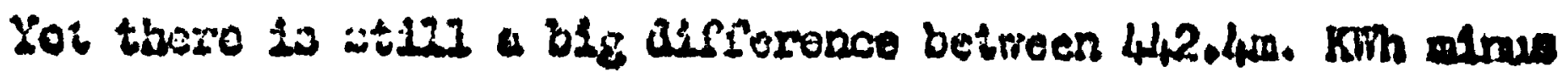

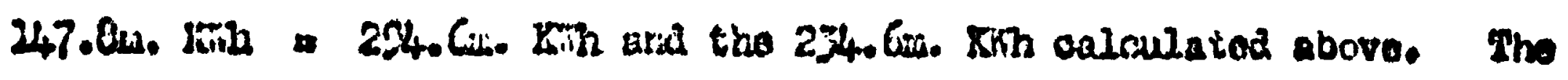
asforumio of $60.0^{\mathrm{m}}$ sectse to bo accounted sor by poculiarditios in salos to

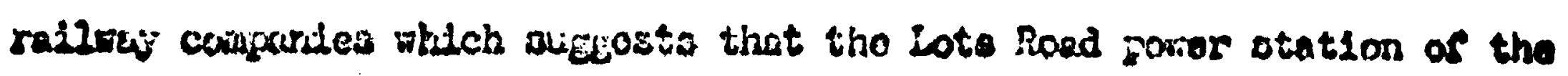

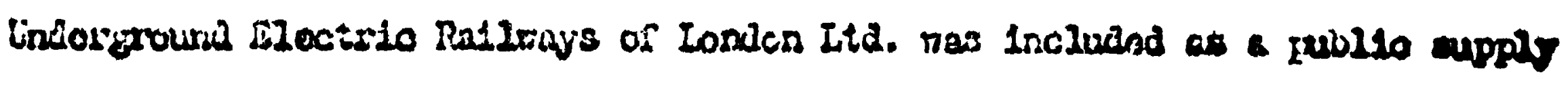

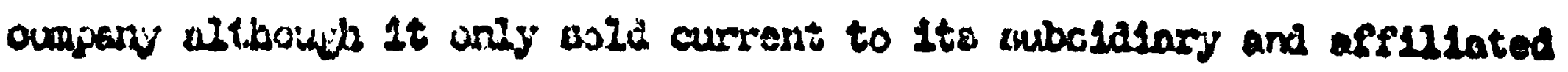

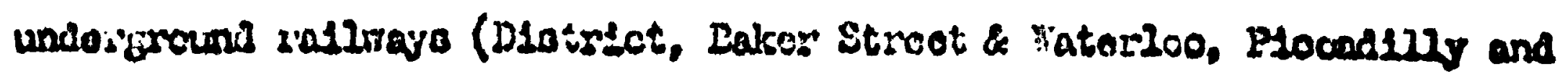

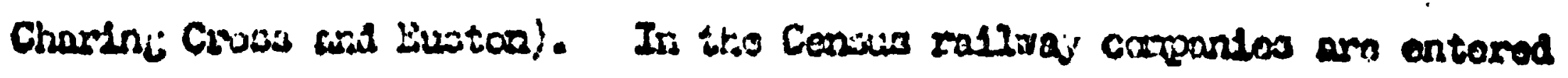

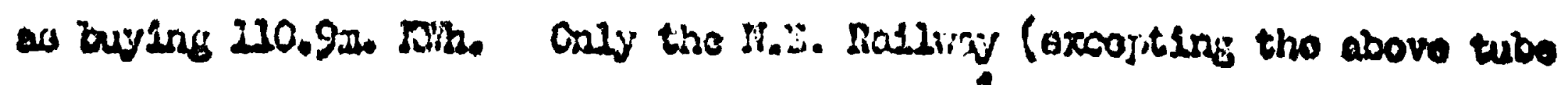

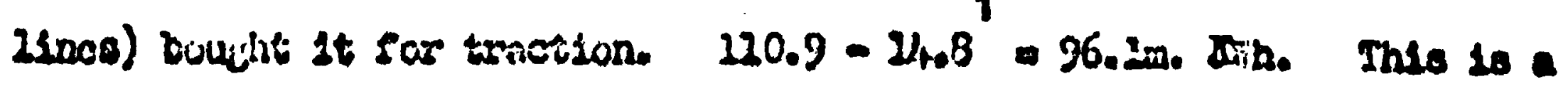

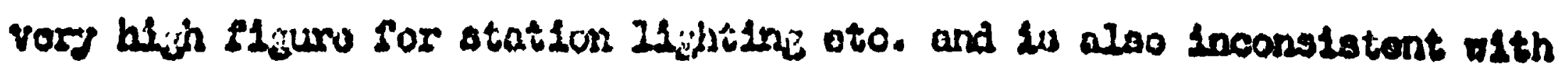

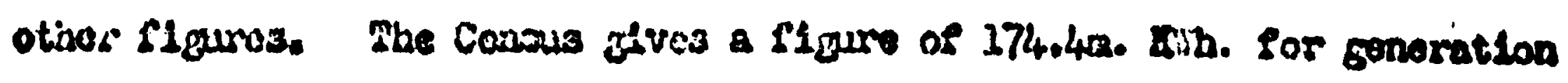

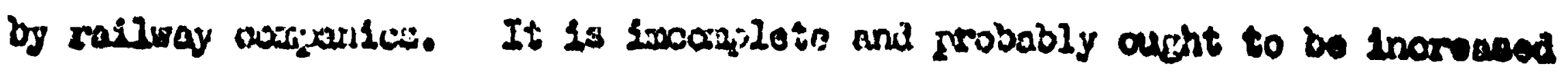

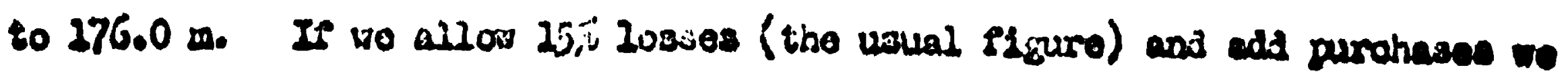
1. R.E. Rallway bougint 14.8m. altogothor - andy 9.5 was cor treotion. 
have 260.9m. The Bor uso. The Board of Trade Returns for electrio rallwaye give tholr use of eloctrictity as $213.7 \mathrm{~m}$. KTh. $260.9-213.7 \mathrm{gives}$ ondr 47.2m. KWH for station lighting rallway workshops etc.

There are no figures avallablo of generation at Lota Road or purchases fran it by tho tubes. But if wo take the electricity used by - lectric railisays and loduct the amount used by the N.E. Railiray plus estimates of tho anount used by the Lancashire \& Yorkshire Ralliwey the Mersey Railway and the Ifverpool Overhead wo gêt appraximately $175 \mathrm{~m}$. $\mathbf{5 m m}$. The rest was used by the Iondar. Undorground Railways. Those of them buying currenti from Iots Road carried 48,j of the botal passengars. If ther

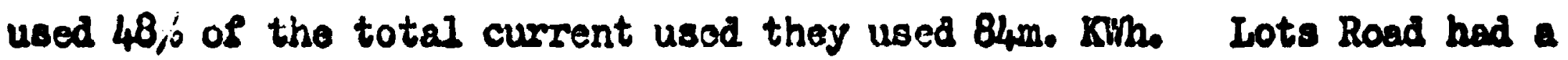
apaoity of 44,000 KT. If the maximum demand was 35,000 KH at the load faotor wa $30 \%$ generation would be $92 \mathrm{~m}$. KTh. Thus purchases of 84 . aro reasonable. This sugestis that of the $120.9 \mathrm{~m}$. $\mathrm{Krm}$ sold to rallways $84 \mathrm{mo}+240 \mathrm{dm}$. was for eloctrio traction and 12. Im for non eloctrlo railwars for station 11ghtlng, rallway workeshops etc. Also it suggests that $47.2-12.1=35.1 \mathrm{mo}$. Im was gonerated by steam rallways for station lighting and rallway workshopa. This is finally confirmed by the frot that the Consus states that raflway companies used 194.7m. KWh for traction. The N.E. Railway, the only one buying olectricity for traotion from publ10 supply station, unod. only 9.5m. Koith. Thus rallway companios unst have generated (294.7 - 9.5) - 285.2 m.kTin (after losses) for traction thamselves. Thus somo those unsts must be entered in the Census as purchases from outsice. Those can only havo 0000 from the Lots Ruad power station.

This more than accounts for the lost $44.7 \mathrm{~m}$. $5 \mathrm{~mm}$. But the cansus 
brentsom of sales wab Inormpleto.

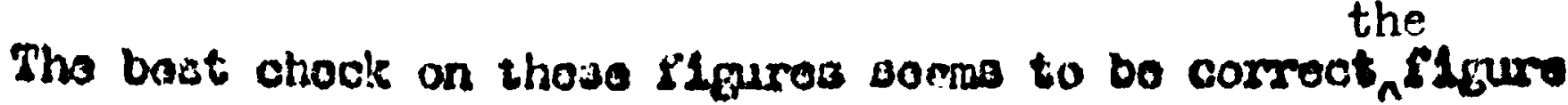
of generation In the Census by doducting cenoration in munlalpal trennay

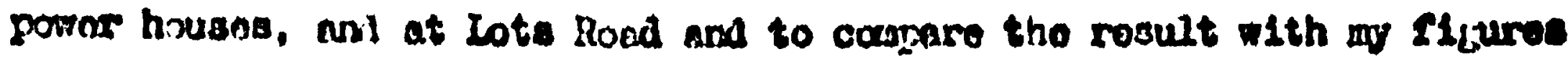

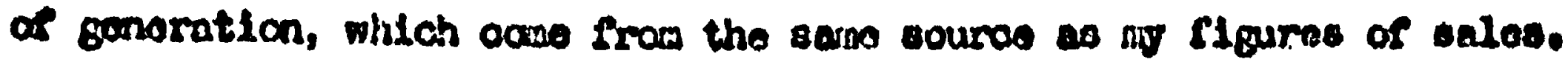
Thu srow 2432.1 deduct $\frac{y 3.7}{0.05}$ (to allon sor usual 20s8en) and $92 \mathrm{mo}$

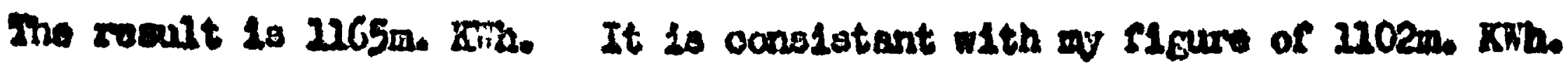
Once the traction alfference io explained it in oloar that the

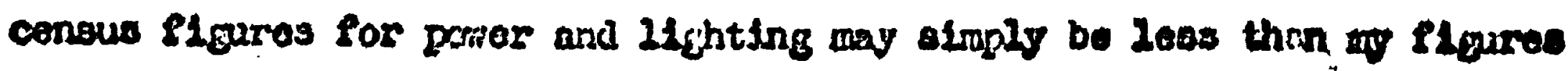
because they are Inocmplete. Ihus they tend to axpport, but do not cheak

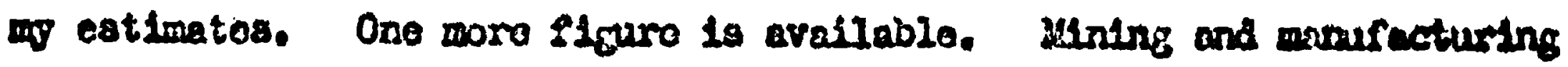

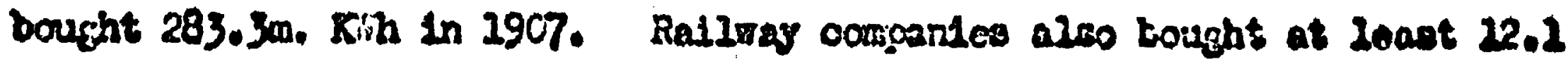

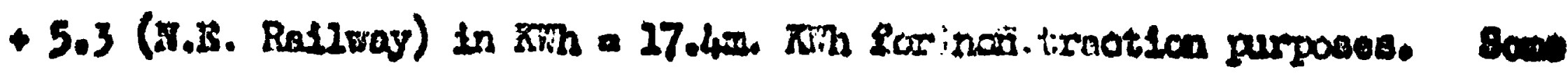
of this 300.70. or more units mas for 21ichting but most was for powers Also in so far as they bought olectriolty fran looel muthorlt1es the

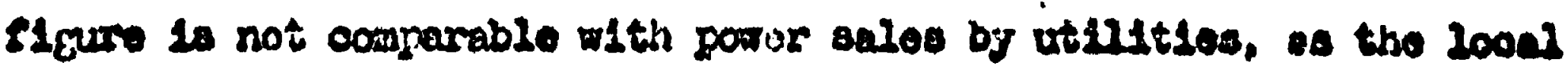
enthorsty year endod on 32 uarch 2908.

Lighting alles are a total salos loss anlos for power and trotsono

The 1130 of oleo: Fld ty in iglo and 2922 - Table 25 .

Docause moh oloctricity was goneratod by the mining and manifocturing sector, tho asount of olcotricitis usod can andy be ootsmated for 1907 and 2912. Unfortunately the Census flgures are Incomplote.

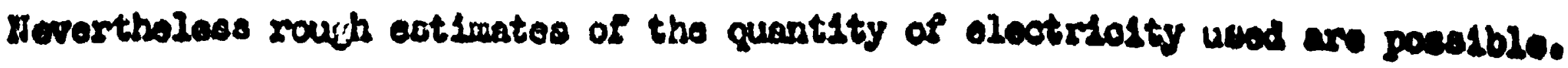


In 1907 returns were made of electricity generated by mining and manufacturing companios, But they relate to genoration by only $68 \%$ of the capacity of dynamos used. I have assumed that the dynamos for which roturn were not made generated es much electricity per $\mathrm{KW}$ capacity as those for which returns were made. Several objections could be made against this correction, but no besio is avallable for a better method, and it seeme better than almply lgnoring $32 \%$ of the dynamo capaity in oxistenco. On this basis industry generated 2035m. KMh. Assuming losses of 6\% (central otations themselves used about $6 \%$ of the eloctricity they generated Isolated Installations would use a smaller proportion, but there would be some distribution losses). 973m. KWh. were usod. Nost of this was for power.

In 1912 no flgures of generation are avallable. In the absenoe of information for a more sophisticated calculation I have multipled 973m. KUh by dynamos instalied in 2912/aynomos installed in 2907 $=973 \times \frac{1142}{591}=1880$. In 1907 non electric rallwry companies seem to have used 35m. KTIh for station Iighting, railway workshops otc. which they generated themselvos. In 2912 no data is given on this. Iat us simply doublo the 1907 figure and assume they used $70 \mathrm{~m}$. Kfh which they genorated themselves.

The traction figurea come fran Tablo 52. Publ10 aupply flourve Irom Table 24.

These figures relate to the calondar year in the case of all compandes, and to the nearest finanolal yoar in the case of locel authordt10s. 


\section{Gross Investiment on Electric Tramays - Table 35.}

Flgures of capital expenditure on trampays are given annually In the Board of Irade returns relating to tramrays. As depreciation provision was normally in the form of sinking funds, increments of capital expenditure are very good estimates of gross investment. Unfortunately many new electrio tramrays obtainod their powers under the IIght Railways Aot and not the Trampla Act. The undertakings operating under the former Not wore not included in the Tranray Roturns until 2903.

Thus capital expenditure before the end of 1903 was estimated on the basis of the miles of electric tramay open. This is given for most but unfortunately not all jears in tho Electrioal Trades Directory. There are no flgures for 1896, 1898, 1901 and 2902. Before 1893 the flaures are generally poor. Between the end of 2897 and the end of 2903, 2874 milos of eleotric tramay wore butlt whlie capital expenditure rose by S31 - 32 million. Thus each route willo cost approximately 223,000 . Th1s 1s consistant with a cost of $\$ 28,437$ por route milo for treak bulit botwoen 2903 and 1909. From the 823,000 per m1le and the mileage the following pross investment sertes emerges.

\begin{tabular}{|c|c|c|}
\hline $\begin{array}{c}\text { Up to and of } 1893 \\
1894 \\
1895 \\
1804,\end{array}$ & $\begin{array}{l}.2 m . \\
.53 \\
.21 \\
.40 \\
09\end{array}$ & $\begin{array}{l}2898 \& 9 \\
1900 \\
2901,02,03\end{array}$ \\
\hline
\end{tabular}

Up to 2900 the gross investment of each calendar year was then allocated by graphioal interpolation of the missing capital expenditive flouros. For 2901, 02 \& 03 each year has been allocated ono thind of the capital expenditure in the throe year period. There is no information which ans 
vould uso to improve this.

After 1903 the figures cone stralgint froun the elgures of oapdtal exponalture. For the munlolpalitios the acoounts run genorally srou Karch to Karch, for the compantes from December to Dacambor. No Nlownoe has been made sor this. Iocal authority Invostmont has been put in the nearest calenciar year.

\section{The use of electricity for traction - Table 52.}

2. Electric Tramars.

The total amount of electriosty used by tramrays 18 given by the Board of Iraile Retums relating to Bramrays and Licht Rallways, The amount purchased from publio supply atation wqs taken from my estimates. Tho arount genorated in tremier power houses was taken to be the remalnder. A check mado in 1907 shows that this cannot be quite corrects for an Independent estimate (mado fran Iigures In Garke's lignual; and the 1907 Census of Production) of the eloctricity used which was genoratod by the trawayo theaselves, when added to my ostinato of the amount bought from publio supply stations leaves $78.4 \mathrm{~m}$. ATh unsccounted lor.

2. Eloctric Railways.

The Board of Irade Rotums rolating to Eleotrio Rallway gaves the anount of electricity they used from 1905 omaras. Only two eleotrio rallways bought electricity Irom public supply stations, tho N.E. Rathray and the Iondon, Brighton \& South Coast Railiay. Sales to the N.B.R. are givon in the N.E.S. Co. inistorioal statistios. Sales to the L.B. A B.C.R. have boen estimated graphically from the data relating to the Landon Blootrlo 
Supply Corporation in Garke's Minnunl.

Not all the electricity used by trawnays and electric rallways was for traction, but most of it was. In 2907 eloctrio railinays used 223.7m. KTh (Boand of Trade Returns), and 194.7 (92; of tids) (Cenous of Production) was used for traction. I have included under treotion all eleotricity used by eleotric tramays and eloctrio raslmays.

\section{London Transport passensers - Table 51.}

Buses.

Statistics are only available for the two prinoipal compantes, the Lonion Ceneral Omntbus Co. and the Londan Road Car Co. The rlat Report af the London Iraffio Brench of the Boand of Trado (B,PR, 2908 Vo1. 93)

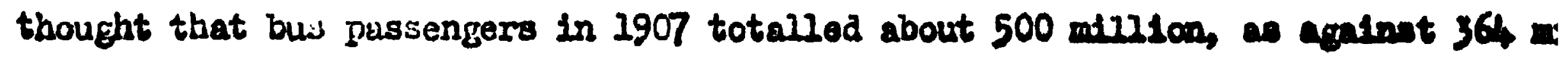
milizion by tho two major companies.

Other local railmays.

North London, East London, Benmersmith and C1ty \& Whitechapel

\section{\& Bow Railways.}

Surburban trafitio on main lino railways.

In October 1907 a census was taken of passengcrs booking tiakete to' Iondon at all stations within a 30 miles radius of Charing Cross. I have multiplied this figure by 24 to get an estimate of suburban journeys to and from the centre of Iondion. In October 1912 a similar consus was taken, and the same procedure used to get a 1911 ostimate of suburben journeys. Ior 2903 an estimate was made as followss Five companios, the Groat rantorn, 
the Great Northern, the Iondon \& S. Wostern, the S.E. \& Chathan and the Iondon, Arighton S. Coast, lost 34 mililion passengers p.a. betwcen 2903 and 1907, a fall of 9.7\%. As receipts foll by only $2.7 \%$ the reduotion was In suburban passengers. Long distance traffic was sald to have riron slightly. All the fall of 34 million was assumed to bo a fall in suburban passangars and a simflar fall was assumed in the suburban traffio of the Groat Festern, the Great Contral and the Mrdland - 1.e. 2 m11210n. 1903 cuburban traficic was then simply estimated at $444+36$ - 280 mullans. All these flgures exclude season tlaket holders. Por 1907 only, Ilgures are available for Journeys to Iondon which inolude them If I had Inoluded them the estimate of suburban passengers for that yoar would have boen 172 m11110ns - $29 \%$ more than 244 millions.

A chock in the estimates of suburban passengers from information collected by the Royal Comission on Iondon Tranoport. Thoy tabulate the hours of arcival and departure of pessengers at main line station on an average weelciay in 2903 (B.P.P. 1906 Vol. 66 PP 658 - 9) If wo usoume loag distance traffio follows a regular curve and that all midany trafflo 1s long distance, ve can calculate the traffio in the mornting and orenting peaks. This sirould provide a minimum estimate of suburban pessengers. The resulting figure is 250 million poa.

A chock on the mumber of season ticket holders lo provided by the Royral Caunission's table (B.P.P. 1905 Vol. 30 PP 608 ff) showing arriving at and leavine main Iino stations in 1903. 206 million were on ordinary tiakets, 204 milizion on soason tickets. Comparing this reoult with 2907 a big fall off in sooson tlaket holders is ohom, lndioating that 
1t was particularly the ocmuters who oritched to the trams. Thus tho fall in suburban traff 10 between 2903 and 2907 may have boen conalderably morv than 36 millions.

Motor poirer in mining and manufecturine - Table 54 :

What is required is the proportion of porer applied to toole ote. by oleotric motors. There is a considerable amount of data rolating to power in the 1907, 1912 and 1924 Censuses of Produotion. Onfortunately they give different types of information. The 1907 Census gives incomplote information of the amount of eloctricity used the inoomplete 1912 cansuse (1t only collected data from esteblishmants euploying moro than 5 pereans) gives Information about the horse power of electrio motors. Both give the total amount of factory porrer used, and the total power of dymamos in Sactories.

First a ratio was derived of dynamos: motors driven by electrlcity genorated on the premises. In 1912 and also for 1924 data 18 available to calculate this. But electricity was also used for lighting and the proportion used for lighting was cortainly higher In 1907 than 2912. Electricity was also used for olectrolysis and thus tino non-forrous motals group was oliminated. Por all other groups the ratio was 1.225 in 2912 and 0.884 in 2924. This 1s consistant with a smaller proportion of olootricity generated being used for lighting. A ratio for 2907 was found by taking the p.a. difference between the ratio in 1907 and 1912 and extrapolating it backwards (giving a result of 1.367). This was used to estimate the motors on own genorated eloctricity in $2907\left(565,000 \mathrm{ho} \mathrm{p}_{\mathrm{O}}\right)$ The Eleotrfoal Irades 
Directory. gave an estimate of motor porrer (excluaing traction conneoted to public supply mains for 1907 and 1912. That for 2912 is $99.4 \%$ of tho Census total. But the 1912 Census was pomplete. Thus tho motor comections flgure for 1907 was taken as a good ostimato, an it was hoped that gaps in the E.T.D. Iigures would be compensated for by making no doduction for non-ferrous metal.

For 1912 and 1924 the Consus Sigures giving the hopo of motors on orn generated and purchased electrioity rore used. Total oleotrio power was taken to the sum of these tro sigures.

Estimates of mechanical power aro crude. From the total, that used to drivo dymamos (assuring $20 \%$ dynamo effloienoy, as do the compliere of tho ccnour) was deducted. It was assumod that mochanical transmissian 208808 oqualied diveisity, (because tools eto. wero not used all the time tho angine power required colld be $20 s 8$ than the aggregate power of all toole). The method is inevitably crude. One cheak is provided by the 1935 Consus which gives Iigures of the porrer equipment of industry in 2924. For motor power in mining and manufacturing exoluding non-ferrous motals they aro

\begin{tabular}{cccc}
$\begin{array}{c}\text { Power applied } \\
\text { electrically } \\
\text { Oco h.p. }\end{array}$ & $\begin{array}{c}\% \text { of } \\
\text { total }\end{array}$ & $\begin{array}{c}\text { Power applied } \\
\text { mochanically } \\
000 \text { h.p. }\end{array}$ & $\begin{array}{c}\text { Total power } \\
000 \text { h.pe }\end{array}$ \\
\hline 6210 & 49.5 & 6216 & 12327 \\
65 & & 87.5 & 86.3
\end{tabular}

Thus the Pigures in Table 54 may bo genernily overestimatod, but tho peroentage of elootrification floure differs by a nogligablo amount. 
I have used the figures given In the 1924 Census throughout. 1907 Census gives slightly alfferent figures for 1907. For individual census eroups (Etven In Table 93 ) the difficulties of manlpulating the 1907 Cenous f1gures 18 greater, as the ratlo of djnimos: motors run from onn generated electrioity varies from group to group, and wo do not know how the motor connections given in the E.T.D. ahould bo allocated among Broups.

The figure for motors nun from arn genoratod eleotriolts was obtalned for each group by extrapolating backerds the poa. atfforenos botroon the 1912 end 1924 ratios of dynamos: motors run from orm generated electricity.

The figure for motors run on eloctricity purchased from outelde was derived by taking the statist10 KiTh p.a. purchased/Total power of motors drivon by purchasod elootricity. This was then multiplied by an Index nurber of statistio Kwh p.a. generated/power of motors driven by oin genoratod electricity for each group. (Tise averago Krin poa - genorated power motors driven by own generated electricity = 100.) The amount of oletricity purchased by each Industrlal group was then divided by tho appropriate resultant figuro. This 13 not a very good mothod, but portape ouffices.

\section{Gross output of electrical machinory. - Tablo 72}

An a.tempt has been made to prepare a timo sertes of the gross output of eleotrical machinery. Electrical machlnery io hero definod a genorators, motors, connectors, transformers, siltchgear, and are lamps. 
Table 93

Rotrial Group

\begin{tabular}{|c|c|c|}
\hline Whes and fuarries & .127 & 5 \\
\hline axtiles & 80 & 4 \\
\hline ron and Steel & 195 & 12 \\
\hline $\begin{array}{l}\text { eneral and lisectrical } \\
\text { Ingineering }\end{array}$ & 199 & 51 \\
\hline $\begin{array}{l}\text { feles, Notors \&: Railway } \\
\text { Wigons } \\
\text { wine Engineering \& }\end{array}$ & 21 & 38 \\
\hline Sher Shipbuilding & $\begin{array}{l}83 \\
23\end{array}$ & $\begin{array}{l}55 \\
15\end{array}$ \\
\hline od, Drink and Tooacco & 54 & $u_{4}$ \\
\hline & 36 & 34 \\
\hline imical and Allied & 46 & 18 \\
\hline Ner, printing anà Allied & 58 & 23 \\
\hline $\begin{array}{l}\text { ather, Canvas and } \\
\text { India Rubber }\end{array}$ & 9 & 17 \\
\hline
\end{tabular}

Motor power in mining and manufactu by industries

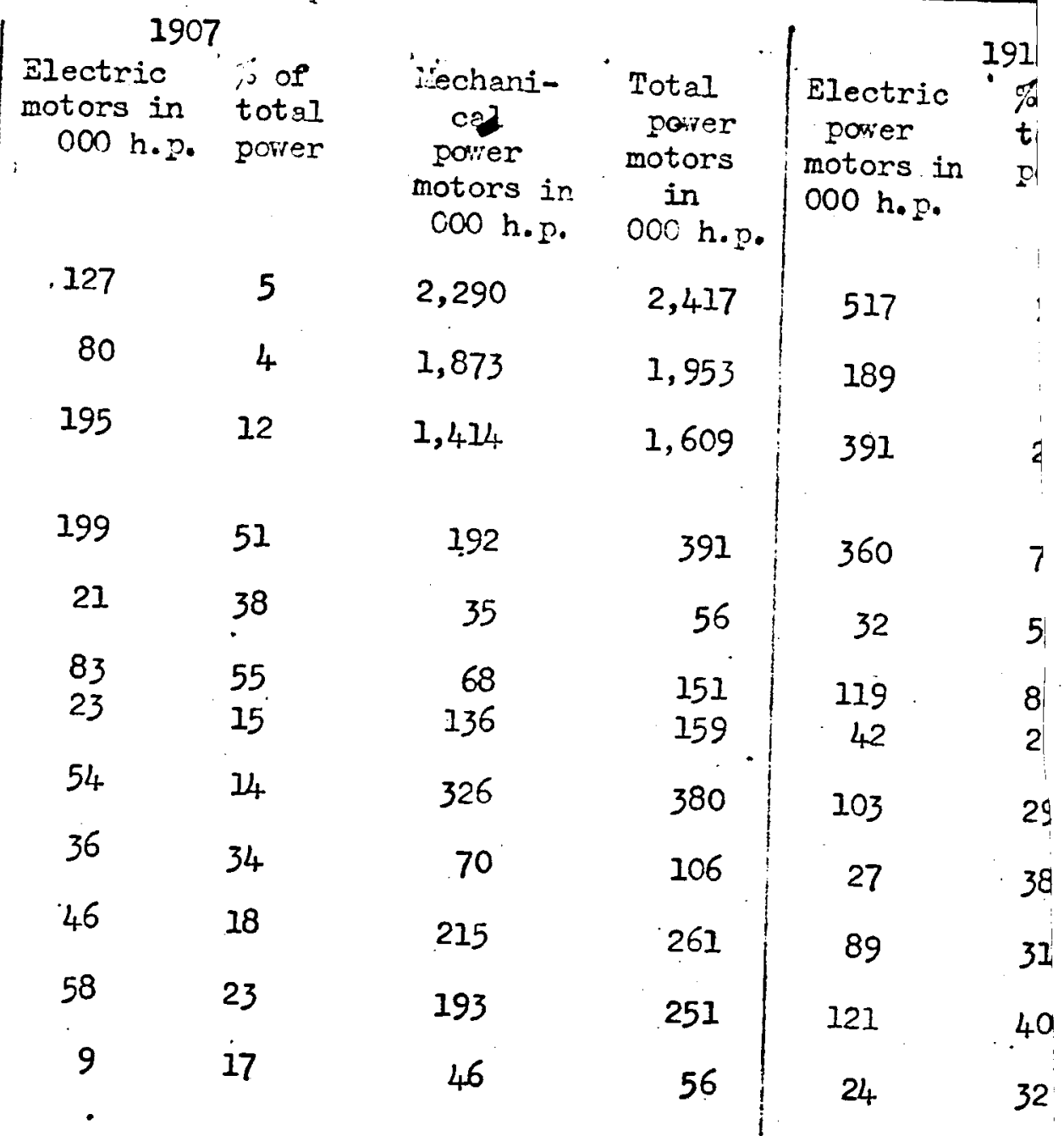

Hechani-
cal
power
motors in
ooo h. p.
2,215
1,958
1,379
143
26
15
104
254
46
197
185
50

\begin{tabular}{|c|c|c|}
\hline $\begin{array}{l}\text { Total } \\
\text { poiver } \\
\text { motors in } \\
000 \text { h.p. }\end{array}$ & $\begin{array}{l}\text { Electric } \\
\text { poiver } \\
\text { motors in } \\
000 \mathrm{h.p.}\end{array}$ & $\begin{array}{l}1924 \\
\% \text { of } \\
\text { total } \\
\text { power }\end{array}$ \\
\hline 2,732 & $1,611_{4}$ & 47 \\
\hline 2,147 & 688 & 26 \\
\hline 1,770 & 1,320 & 46 \\
\hline 503 & 1,027 & 90 \\
\hline 58 & 249 & 92 \\
\hline $\begin{array}{l}133 \\
146\end{array}$ & $\begin{array}{l}362 \\
149\end{array}$ & $\begin{array}{l}95 \\
53\end{array}$ \\
\hline 357 & 403 & 61 \\
\hline 73 & 103 & 59 \\
\hline 286 & 344 & 66 \\
\hline 306 & 305 & 67 \\
\hline 74 & 153 & 77 \\
\hline
\end{tabular}

$\begin{array}{cc}\begin{array}{c}\text { Wechani } \\ \text { cal } \\ \text { power } \\ \text { motors in } \\ \text { 000 h. . } \\ 2,295\end{array} & \begin{array}{c}\text { Total } \\ \text { porrer } \\ \text { motors ir } \\ 000 \text { h. }\end{array} \\ 1,920 & 3,909 \\ 1,525 & 2,6 c 8 \\ & 2,845 \\ 110 & 1,137 \\ 22 & 270 \\ 17 & 380 \\ 133 & 282 \\ 263 & 665 \\ 72 & 175 \\ 175 & 519 \\ 153 & 458 \\ 45 & 199\end{array}$


Luch electrical wachinexy was sold to electrical utilities (central station, electric trams, electric railivays.) Although for most of these ut121ties fairly good gross Investront figuros can be obtrined, there 1s much less information about the emount spent on various pleces of equipment. Nevertholess for the throe major groups of utilltios (eleolrioity oupply, electrio tramays and tho Ioniton underground rallingys) this was done.

Central atations often gavo flgures of capital exponditure 1

on various iters. Random samples rere taken for each year. The percentage in the various categories is remarkably constent over the period 2896 - 2915. Liost eloctrical machinery comes undar the heading "plant \& machinery", but would cosprise only part of this category.

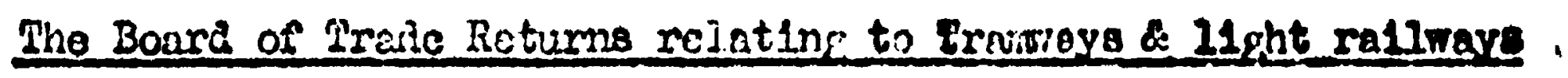
give from $190 ;$ onwaris expenditure on the electrical equipient of the $21 \mathrm{n}$ and an tramoars. Tenders for tramcars show that $42 \%$ of the cost of a tramcar was its motor equipment. The percentage of capital expenditure on eleotrical equipmant varies in tho yoars 2903 - 1924, but shows a declining trond. This trend was crudoly extrapolater backrands Into the 2390s. Inch of the expenditure on oloctrical equipment was an cable and overbead wires. It was assuined that one thind of the expenditure on eleotrical oquipment was on eloctrical machinory. This is a crude assumption. For the Larion underground the Bituation is worse. Only for the Materloo \& City ine aro there publlohed figures of the gurchase of eleotriond

2. Land and Buildings, Plant and Vachinory, Instrumente, Hains, moters, miscellanoous, Incluaing lefal oharges.

2. Soe Tablo 27. 
- guplpment. This was lly' of total capilal expenditure by the time the line Was opened. It was assumed that this porcentage apnlied to other 1lnes. A much smaller proportion of expenditure on electrical equirmont was in oobles ocmpared with the tramo. It was crudoly assumed that $3 / 4$ of expenditure on electrical equipment was un machinery.

The three sots of figures thus obtained were oummod and an cllowanoe of an extra 20,0 made for purchases by ut1lities out of revenue. The only major utility not included wos main line rallways. However they only becamo important purchasers of electrical mechinory just beforo 294. It is unlitsely that the N.E.R. and the I. \& I. Railway opent mare than 60.25m orah on eleotrical machinery for their 2903 - 4 eleotrification sohemes.

The sories was compared with the aross output Plgure for eleotrical maohinery plus are lamps in the 1907 Census of Production aster the export balance (exports minus imports) had been deducted. The remaindor, which was rather surpriaingly hlgh was largely salos to factorlos for faotory oloctrification, both motors for factories buyine eloctriclty from publio supply stations and dynamos and motors for Pactories generating their own oleotric power. 2907 soems to have been a rather 1solated year of high Investmont in factory electrification. This is shown in the Elootrician's 1 sertes of comnections to electricity ou:ply mains, and In my figures of tho Increments of sales of eloctricity for power from publio supply otatians. This fignure of sales to non-utility hame buyers for 1907 was uned together with an index for tho use of electrlolty for power, and a price Index, to derive flgaves of salas of plant to nan utilitios far other yoars.

1. Used by C.H.Feinstein for his Ilguros of purohases of electrical equipment. C.H.Feingtoin Home and Foreim Invostment unpublishod Canbridge Ph.D. thesis, PP 97-99 and Economic Jaurnal, Vol. 71 P 372. Trms 1061 . 
The use of electrioity for po:ier index wne sim ily the increments in the sales of electriolty for porror by fublic auplij stations. (Sce this appendix P 492 ). The prico Indcx used was calculated from figures of the cost of $\mathrm{KT}$ of new central stations. (Seo Talulo 28, appondix to Chapter 3.) As the p.rcentagos of capital exponditure for varlous parts of the cupply systom did not change over the poriod 11 was assumed that it could be used for olectrical machinery.

The whole series of sales of eloctrical machinery at have 10 vory drude. Harever it does ghow long run tiands ressonably. It does not soen to be very good in the years 1920 - 194. The Parsons Cormittee gave a flgure for the gross output of all the electrical tredes just before 1914. This was double the 1907 figure. Howover we know that thore wo a grest increave in tile volunio of output from 1911 - 194. hiy floures exclude main line railway electrification, which was important in those jears.: If estimates of the sole of electricity for power are probably deficlent after 1911. Ly price Index jrobably overcsilmates the fall in prices after 1909 - 10 as central station costs fell than partlo' becuwe of -oconomies of scale, which dia not exist in Pactory oleotrisiontion plant. But before 1910 the serics cioes not seem too bad.

\section{Shares if the Coitine stition Varict. - Pable 80.}

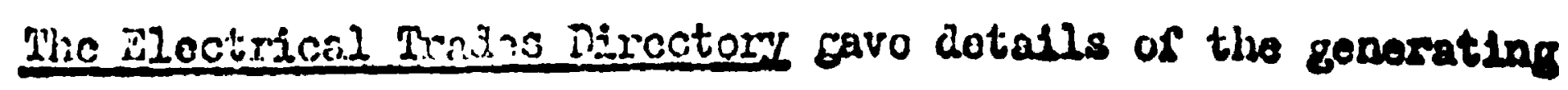
plant of most central stations. By canparing dotalls of adjacent years 1t is usually posciblo to soc who the watsor's of now dynamos instell ad wore.

2. Report on the Electrical Trades after the War, Cd. 9072. 


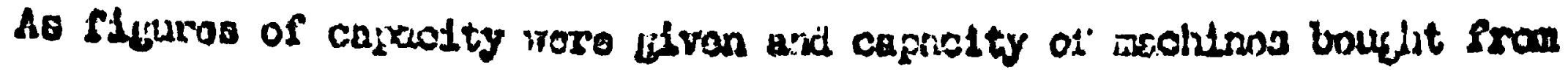

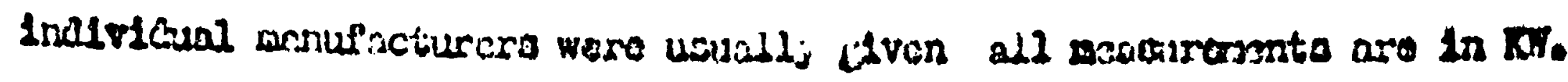

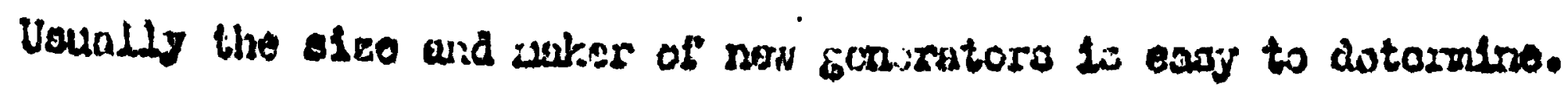

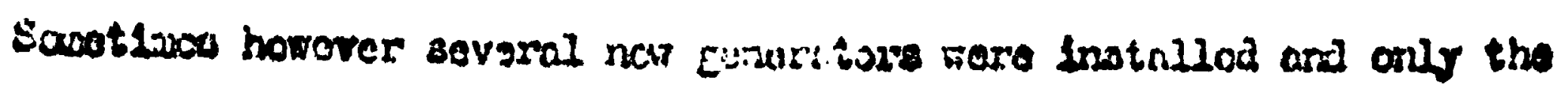

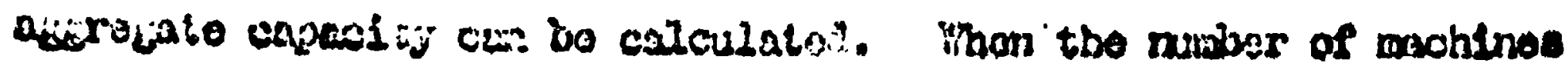

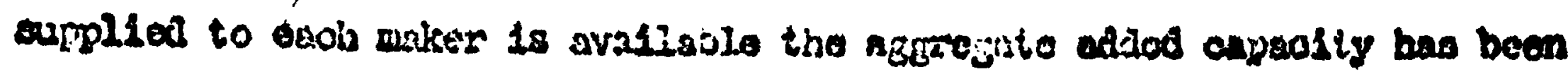

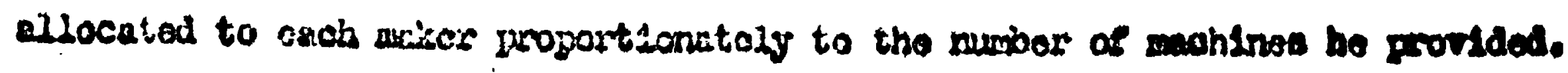

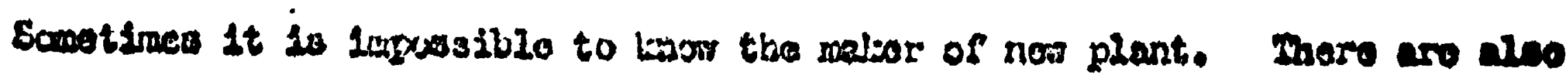

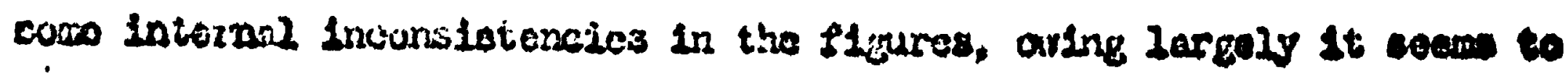

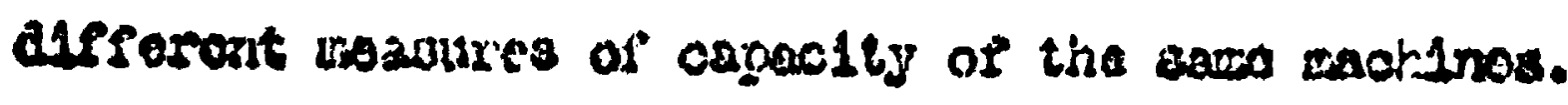

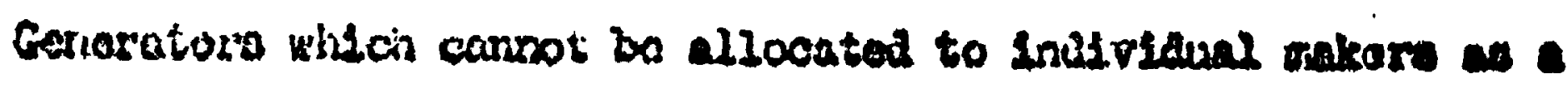
pervantage of ald ganezitora culcied.

$\begin{array}{rr}\text { Uo to and of } 2892 & 52 \\ 95 & 15 \\ 94 & 31 \\ 95 & 8 \\ 96 & 23 \\ 97 & 26 \\ 60 & 27 \\ 99 & 26 \\ 2900 & 22 \\ 02 & 37 \\ 02 & 0 \\ 03 & \end{array}$

Up to ond of 2044 0

क 0

06 牧

C7 25

030

095

i1 28

$22 \quad 26$

2326

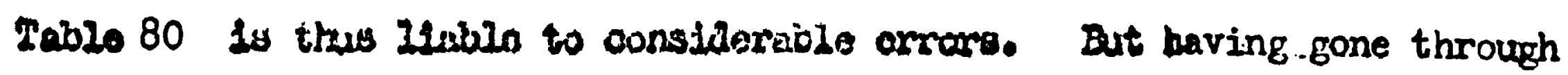
the changes in plonst from yoar to year for oach osutral etation, ano is

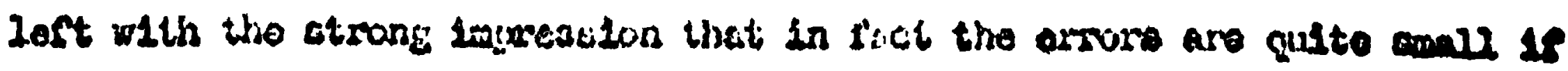
wo tule ooveral years togothor. lie oannot plwoe very wuch sollanoe an

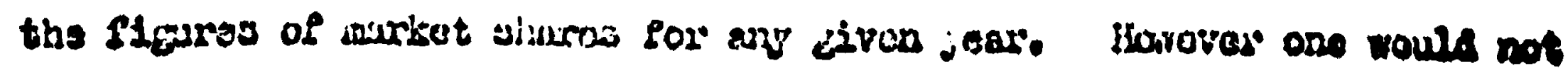

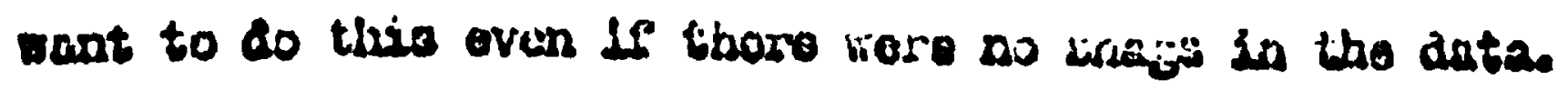


Somo plant was scrapied. No perícet allowance can bo mode for this, al though the errors introducea by imporfections hero must be very omall.

Total capacitj adied by all ner generators derirod in this way is Biven voluw, it can be checked with my estinates (Tablo 16 ) of capaoity

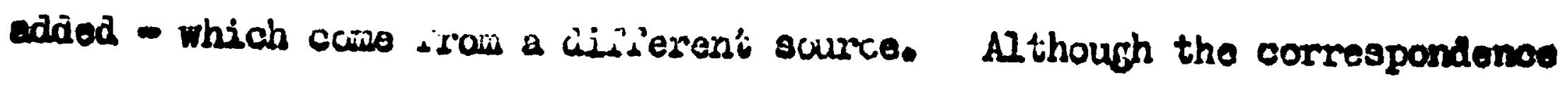
between the two is not very soud from year to year over a fer joare the tro gave einilar resulis.

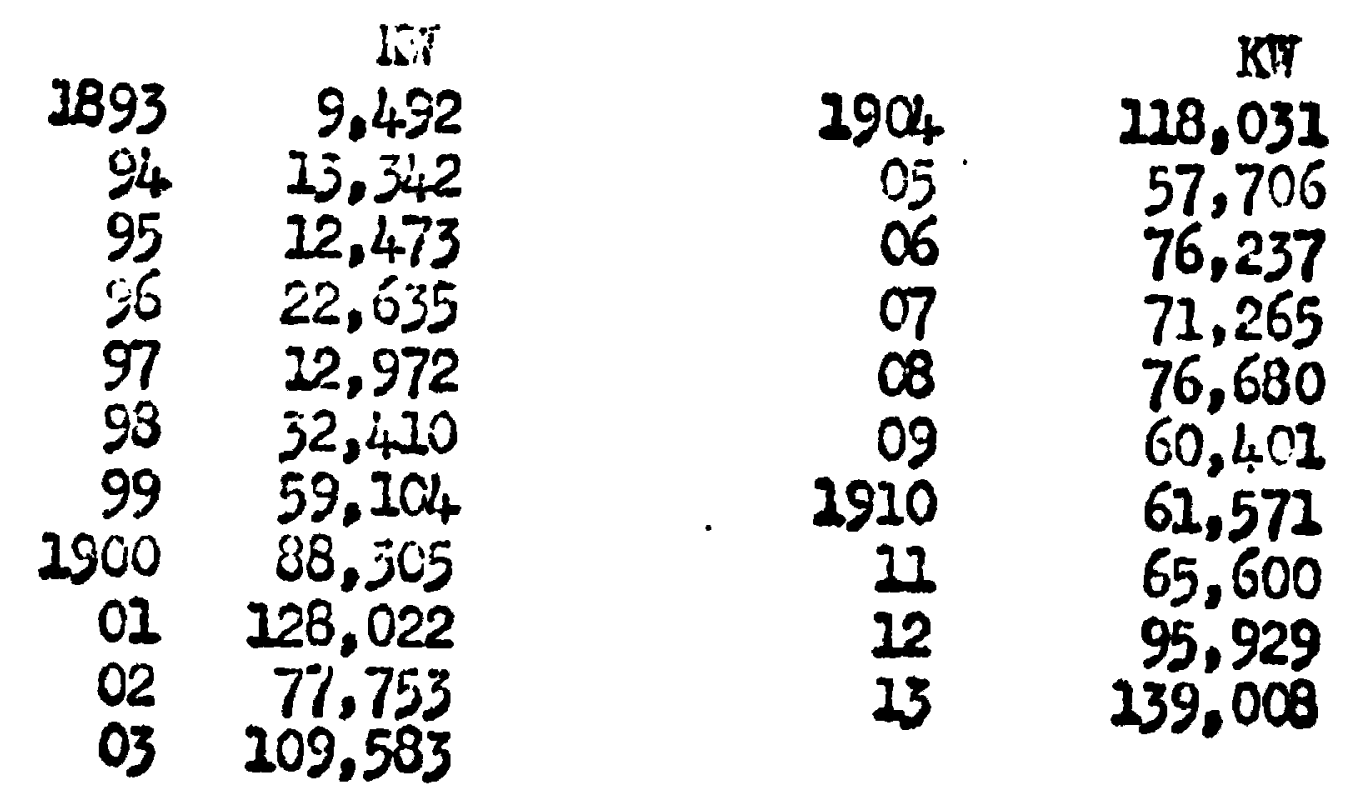

$\frac{\text { Gross Investment in Fixed Cajibal in tine ilectr1cal Industrs. }}{\text { - Teble } 91 \text { Column } 3 .}$

According to tire Census of Proiuction of that year factorles had 609,654 ith of dynamos insialled. This has been wultiplied by the salos of electricity for porrer fram publio utilities (in index form $2907=200)$ to give saiw idea of cupacity in othor ycars. The inoremont In capaoity has been found und cultiplicd by the cost per $\mathrm{kW}$ of power stations (iablo $26 \times 0.546$ - the averaje jroportion of capital expenditure apent on tho porros station.) It 1o thus assumed that the smaller mount 
of conotruotional work Involved in the generating plant in a faotory is offeet by the higher oost por XII of the emallor plant instelled in faotoistob. The reaultant serles is very coude.

Arerage S1ze of Generators, Table 21.

As for Table 80 except that only 21 gures whare the ales

of the genorator is preolsely known are inoluded. 


\section{TECHNICAL APPENDIX}

1. Generation of electricity.

A dynamo produces electrical energy by passing a conductor through a magnetic field. As the conductor passes through the field a voltage is induced in it which rises to a peak and falls amay again. Below is shown an alternating current dymamo (known as an alternator).

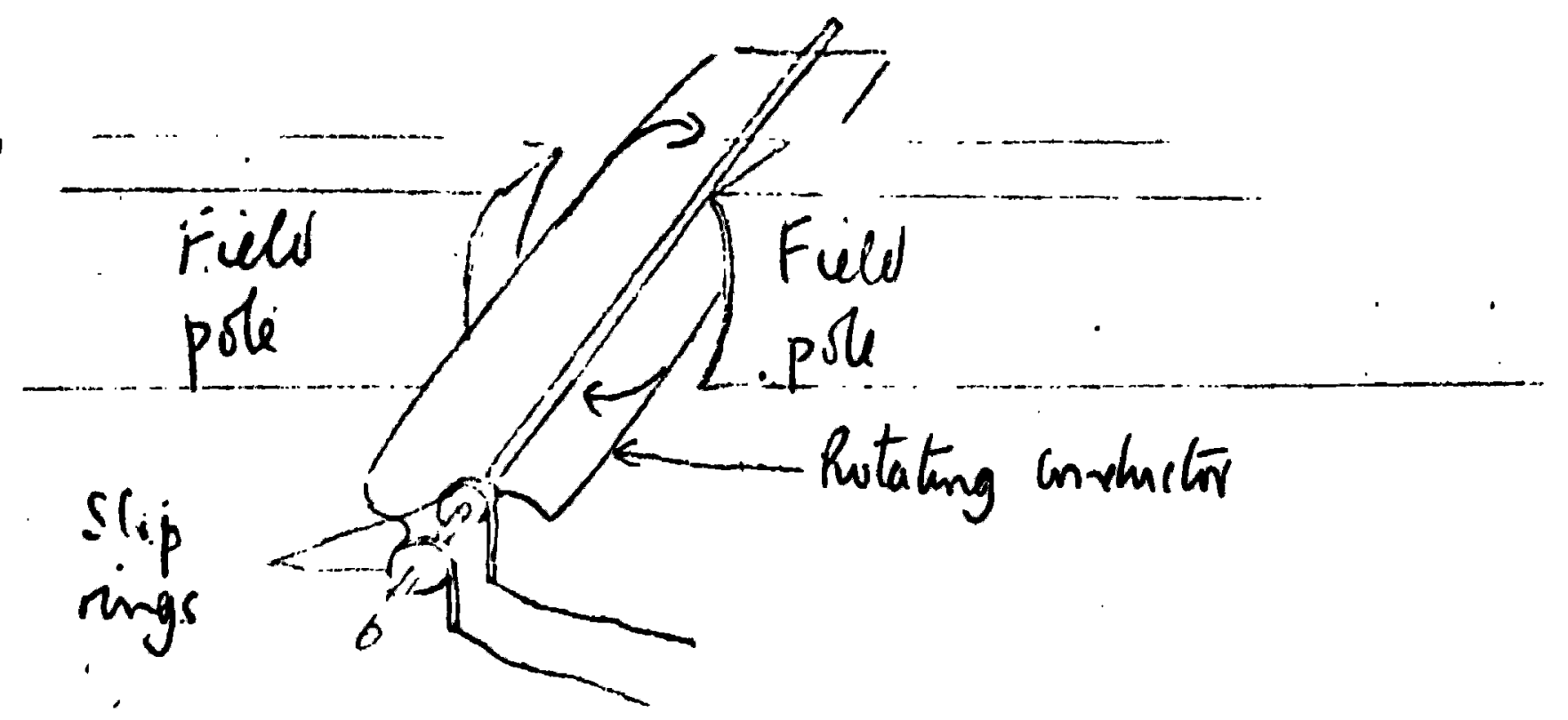

As the conductor rotates in the magnetic field alternately positive and negative voltages are produced. The voltage is collected from the rotating conductor by slip rings. The voltage fluctuates in a wave like way (a sine curve). This is shown in the next diagram.

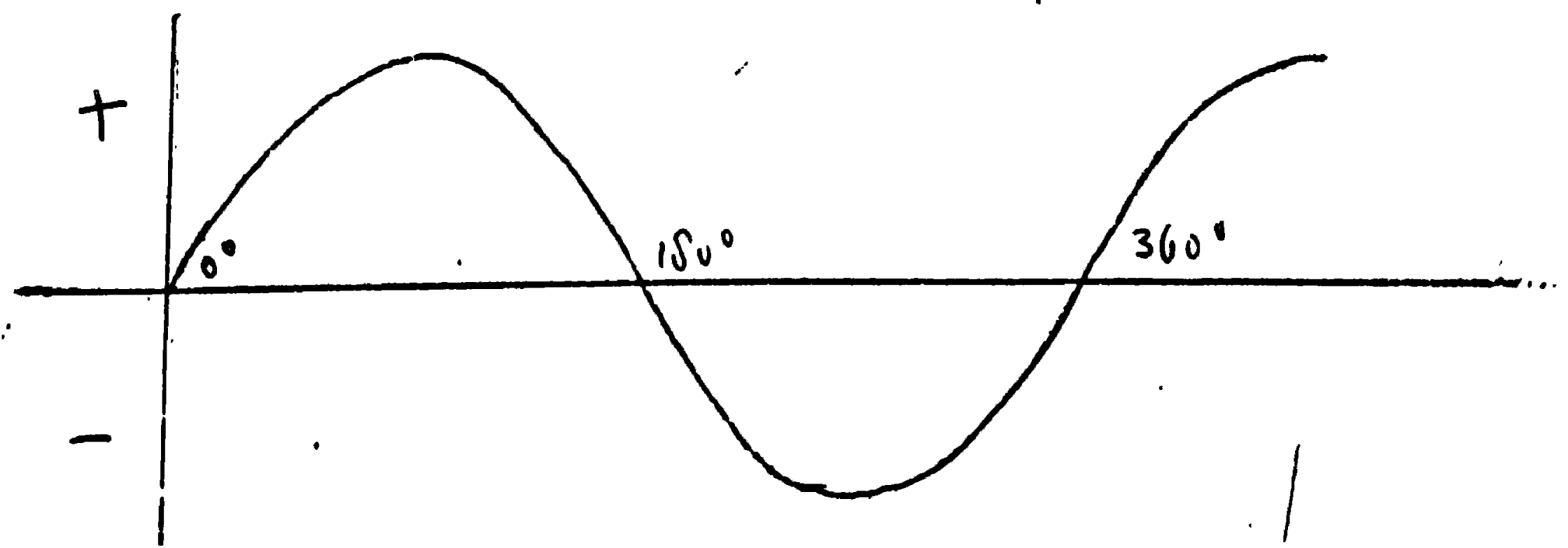

1. See J.A. Fleming. 20 years of Electricity, PP $113-5$, the theory of the dynamo. 
Tho usenul voltage doveloped by an alternator is the root moan square of the instantanecus voltage over a conplete cyolo. The frequency of a.0. Lo reasured in $x$ canjelcte cycles per second (written as $n$ ).

A d.c. Generator consists of a wholo serles of conductors. Togother they are known as the armature. Each conductor (annaturo ooll) 1s comrected to tiro segment; of a commutator. The conrutntor consists of wedge shaped cojpor bars, Insulated frow ecch other, set laniftudinalls along a drum. Against opposite slies of the computator are two bruabese which collect succossive raves of voltage frore each coil as it passos. through the magnetic field. These waves of vollage approximate to a constant positivo Ilor, as is shown in the following dagew.

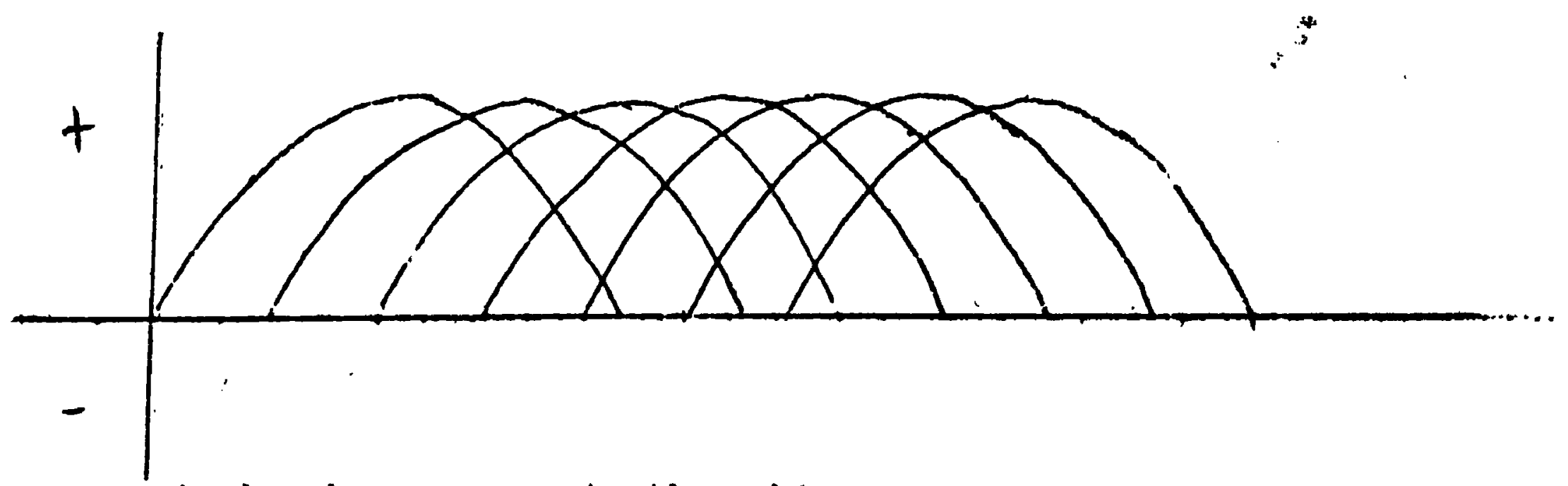

Because the brushos are constantly making and breaking contect with the bars of the ccrmcutator, a certain awounl of sparifing villl ocaur. This sparking maices the generation of hich voltage dirl'scult. D.c. goneratore provido current for thoir orin (eicctro) magnotic fieldo (ools excitation). Alternators, however, cannot do this, and an exciter (a d.c. genorator) is noeded to generato current for the siold coilo."

1. 10id. PP $209-10$.

2. at least - ain oven nuaber is necessary.

3. JoA. Fleming, op.cite P $121-6$, the theory of altermators. 
Aro lighting dynamos woro designed to produco a constant current (moasured in anps). Other dynamos wore deslgned to produco a constant proseuro (measured in volto.)

The first alternators were single phase. ${ }^{2}$ A polvphase alternator produces two or more currents which reach peakes at different times (1.0. are out of phaso). A two phase alternator is wound with two cots of colla; the second sot usually being $90^{\circ}$ behlnd the sirst. Thu two alno waves of valtage are produced, one lagging sllehtly behind the other.

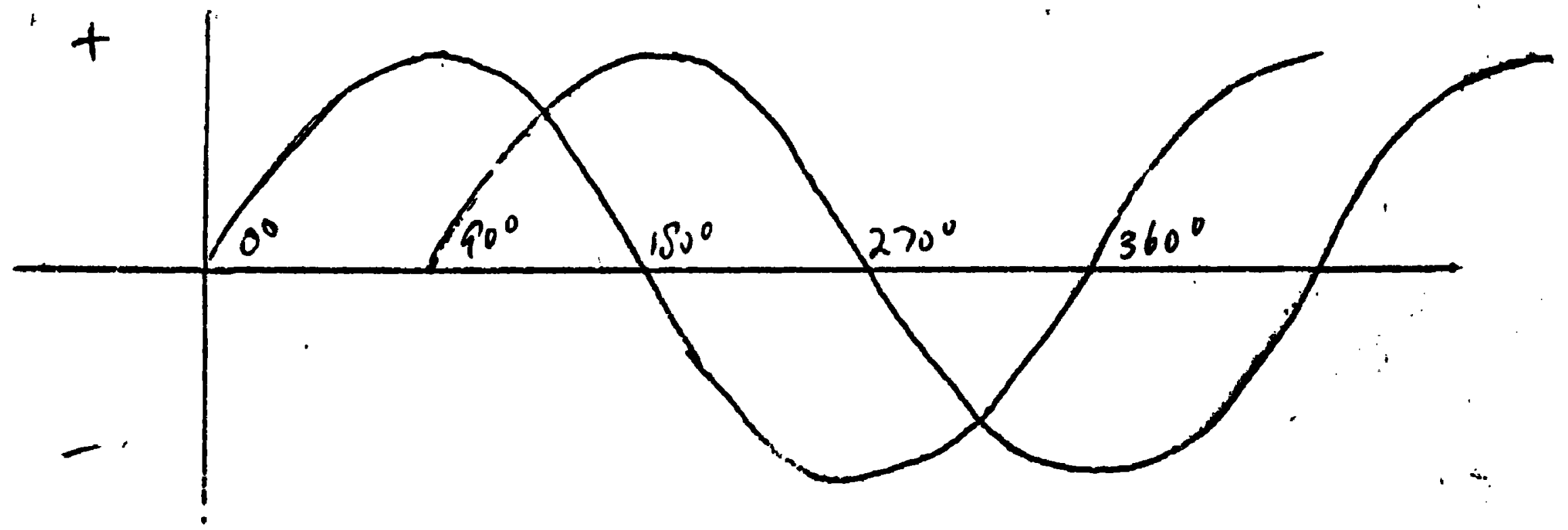

A three phase alternator has throo sots of armature colls sot at $120^{\circ}$ difference from each other. Thls produces three sine waves of voltage.

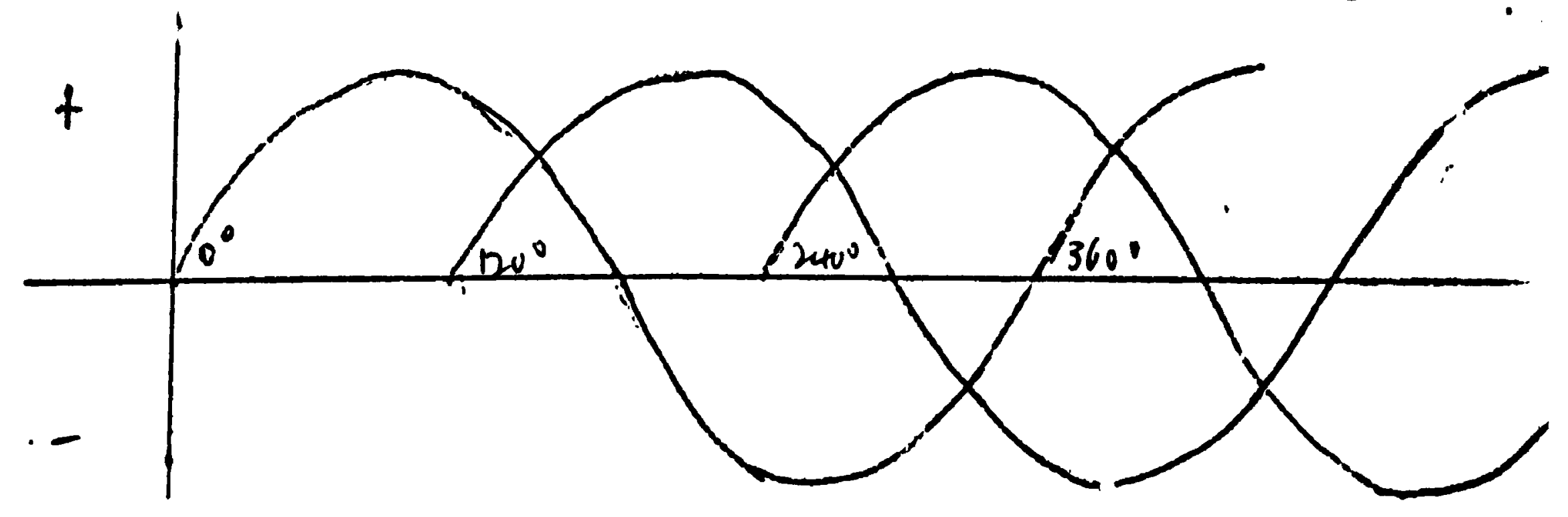

1. Powor, 1.e. rate of doing rork, conventlonally moasurod in $X_{0} \nabla_{0}=$ Volte $x$ anpe.

2. This is not striotly truo. Grame mado samo polyphaso alternators In the vory carly days. (P.8.) But thoy wore usod as alnglo phase machines. 


\section{Transmiogion ond Distribution.}

A given porrer (K. $\pi_{0}$ ) oan be transcittod either at a high voltage and all current or at a low voltage and high current. Cunductore rere usually coppor (aluminium was used at the ond of the pertod for bome purposes), and the oross sectioned aroe of" copper required to convey a Eiven power is inversely proportionato to the squaro of the voltage. High voltajo mains are more expensive to insulate, but it is olear that there are areet potential econcunios in transmitting at high voltages. Electrical appliances may be connected up to distribution malne -1ther in series or parallel. Aro lamps worked botter when oonnooted in corlos. The matter is vest illustrated in the following diagram

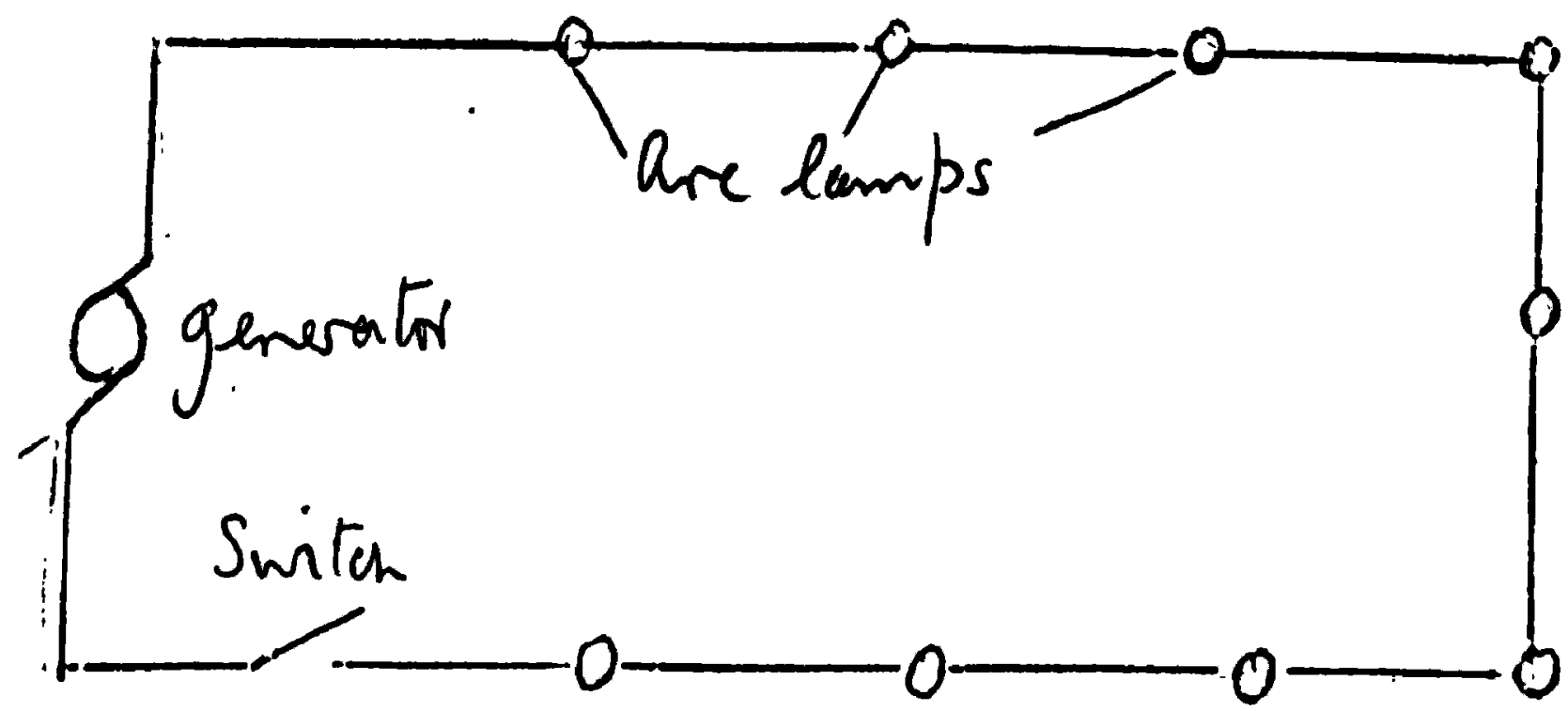

1. This and the noxt diacram come from H.C. Passor. QD,cit, P 82. 
The voltrge on such a ciroult 18 additive. If oach lamp takes 45 v. and there aro 9 lanpe the generator must provlde voltage of $9 \times-45=405 \%$. Bach extra 2 amp raises the voltage roquired. All lamps aro sultohed on and off togethor.

A parallel circust lo lliustrated bolow.

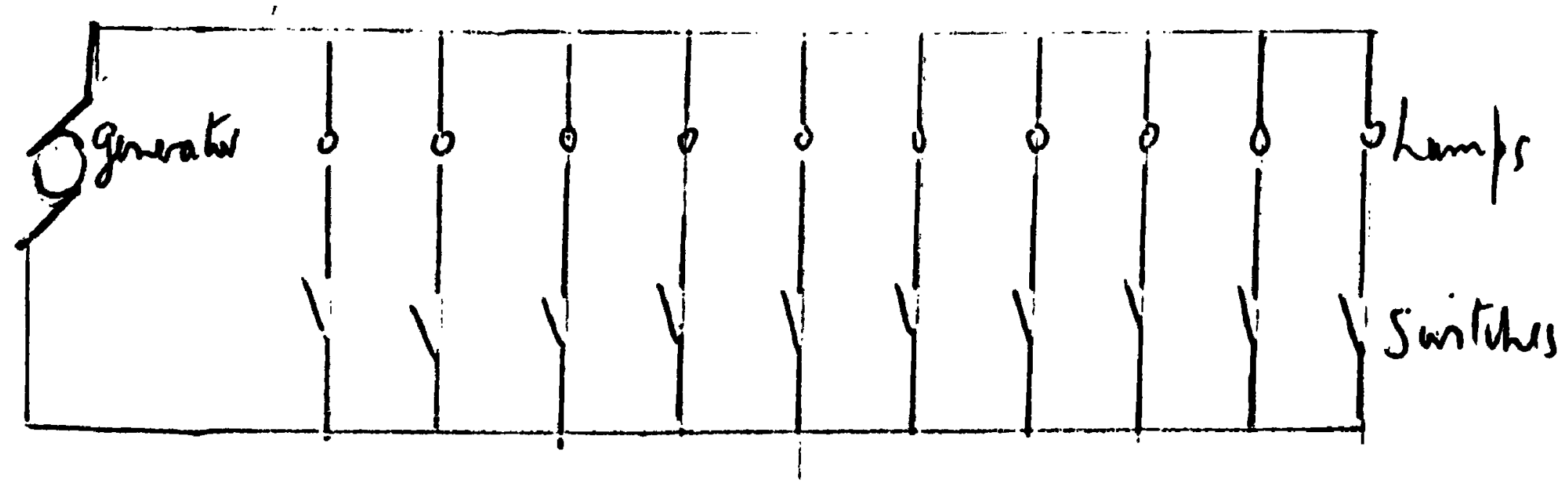

The voltage is constant throughout. Each appliance 1s separately ontrolled. The curront the generator mist provide depands on the totel reaistonoo (power of appliances) in the oircust."

Thess circults apply both to d.c. and single phase a.c.

2 phase a.c. roquired 4 wires, two for each phaso. 3 phaso a.o. required three wires, one for each phase. No return wiro 18 roquirodias positive and negative electro motive foross cancel out when all phases are taken together.

3. The use of electriatity.

Loot electrical devices work at a constant voltage, Aro lampe however require a constant current. The reslotanoo prosented by an aro 2emp to an eloctrical current is Invorsely proportionato to the curropt. This can lead to unstable oporation. If for example, tho aro 21 ght 
resistance ohould happon to decrease olightly (bocauso an imperfoct carbon feed mechantam reduced the length of the are), the current would Increase, the resistance would docrease, and so fortho Hence the noed for a spectal dymamo which kept the current steady. Incandesoont lampe on the other hand required a carefully rogulated voltage. Small fluctuations, 1.0. more than about $4 \%$ - could cause the plinement to break or only glow red.

Notors are the inverse of generators, converting electrioul Into mochanical oneres. A d.c. motor recoives a ateady flow of current which gives it a high torque (twisting movement). The woak point is the comoutator. Sparicing can occur which makes high roltage operation very difficult. There are throe types of a.0. motor, the comsutator type, the eynchranous type and the induotion type. The comrutator type is a modified d.c. motor, but has poorer torque, and Lower horse power for a given weight than a d.0. motor. Both the Fleld colls and the armature of synchronous motors require current, and thes they nocd Blip rings. Although they thas avold a comatator the synchronous motor (whon used on a single phase circuit) had poor torque. They wore not easy to start and if they got out of phase with the generator thoy stopped. Polyphase current produces two or throe magnet1a flelds rapidly following each other. This provides steadier power. In the Induction motor.the arrature is simply wound with colls but no current is sod to them Induction motors were particularly austablo for polvphase power. The confoint efrect of the successive magnet1o flolde produced a rotating magnetio sield, which acted an tho rotor (the armature) to produce a turning motion.

1. H.C. Passer, op.o1t. P 13. 
Althouch singla phase Induction wotors are now made, bosore 194 Induction motors wero nearly always polyphase. For single phase elroulto eynchronous or coumatator type motors were used. 


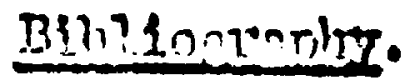

The evidence for this thesis has como vory largely from writings which were prinarily concornad with general matters of enfineering. To a considerable extent evidenco about the economics of the industry has to be collooted from odd caments.

The principal contenporary source is pertodicals. There wore a large muber of technical jurnals which concerned themselves with - loctrical engineering. After looking at them I camo to tho conolusion that tho best sources wore the Blectricsi Revicu and tho Blectriclan Although their primary interast was apilied aloctrical scionce, they also took an interest in conmorclul ratters. Thotr cocments are usually both falr and shrewd. Thls cantrasts with somo other journals.

The Electrical Revien and the Electrictan have boen partioularis userul because thoy contain the papors on matters consoctod with oloctrioity given to all the principal engineoring socloties and the discussions on these gapors. Hence referonce to these papers are to the Electrical Review and the Electrician rather than to the Proceedings of the relovant 80010 ties.

Becauso relevant material is diffloult to find I have ready overy 1ssue of the Electrical Roview from 1877 (whon it was the Telographic Journal) to 2914. I have also extonsively used the Electrician, espocially for company reports and reports of company meotings. Important ovidenos has come from records or compantes, and the publisbed and unpublisbed worken 21sted bolow. Howover, ono of the mast useful sourcos, the gonornd mun of comento in the technical pross cannot be convendently listed. 1. Tho anly exception is the Transactions of the Noxth Bant Coant Institution of ingtneors \& Shipbusiders. 


\section{Engincerincilliatoring}

Bott, M.H. and Gillham, Great Brit Sh Trnmpay Metworke, 3rid Edstion Londan 1957.

Canadalo, J.H4, Flectric Trasetion Jibjlee, B.T-H. Co. 1946.

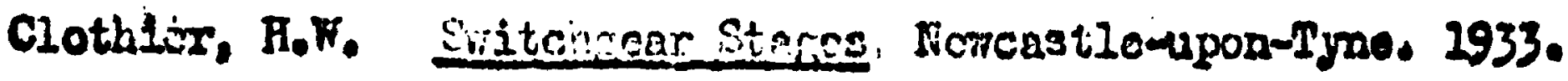

Fleminge J.A. 50 yeari of Mlecininity, Iondon 1921.

Hunter, F.V. und Hazel J.T. The Dovelormont; of Ponor Ceblos, Iondan 2956.

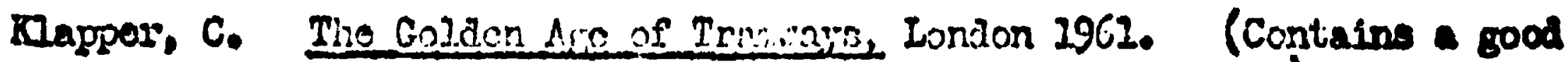
bibliography of the histories of farticular trantays)

Mactaron, The Thise of the Electrical Industry during the 29th Centurx. Princeton $29 ! \cdot 3$.

Pursons, R.EF The Early dive of the Foner Station Industix Cambridge 1939.

Sborrington, C.E.R. 100 years of [ninem-] trorspont, London 2934.

Contemorari ontinocrins

2. Bocks.

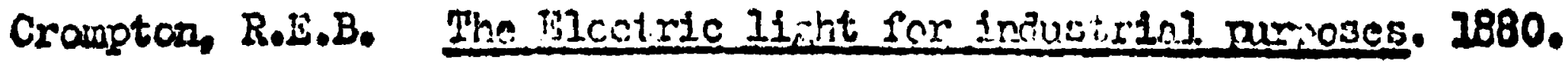
Higes, P. Electrical linht in itus Irectical anjicetion, London 1879.

Parsons, C.A. The Steam Turline, Carbriàce 1911.

Pring, J.N. Eurge electro tachricul centres, Lanchester 1908.

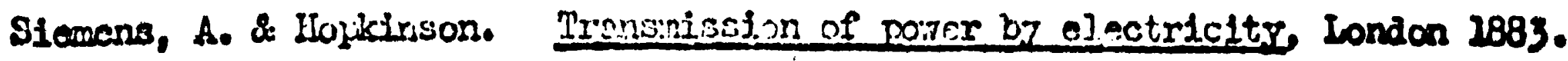

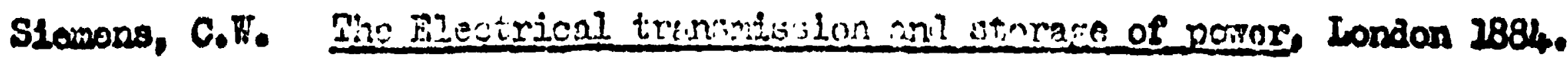

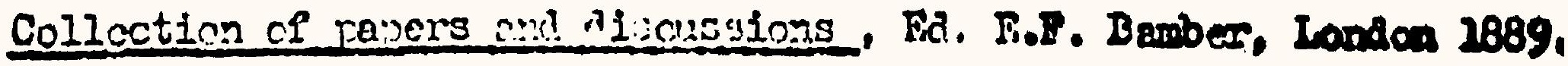

Stahl, C.J. Jlectriend strent lichting, New York 1929.

Tandinghom, C.LE, Central Elcetric Etations, London. 1902. 


\section{Articles.}

Addenbrooke, G.I. 'Value of overinad mains', F.P. Tol. 56 P 333 - 5. , 'The publio supply of porror', E.R. Vol. 64 PP 236 - 7, 278, 325 - 6.

Aldrich, W.S. 'Roguiroments of electricity in manufaoturing warics', E.R. Vol. 49 P $614-5.650-2$.

Anderson, E.i.. 'diotos on electric cranes', I. P. Vol. 39 IP 4.78 - 81.

Hege, D.Selby. 'Notea un j:odum practice in cleciric powar work and recent developments on the North East Coast', E.R. Vol. 41 P 845.

Boot, H.L.P. 'Street Iighting', E.R. Vol. 39 PP $372-7$.

Byng, Go 'On the manupacture of lomps and other apparatus for 200\%. olrouste' E.R. Vol. 42.P 271.

Carpenter, W. Lant. 'On tho pouition ara prospects of eloctrie lighting In the Wetropolis, Elect. Vol. 22 PP $248-9$.

Clivehugh, S.T. "Transmission of power in fuctories by eleotrdedty. E.R. Vol. 40 ? 759.

Crompton, R.E.B. 'Blectivically operated factories', Elect.31. July 2896. 'The most econamical mods of fecding a lar pressure notworik' Elect. Vol. 27, 22 lfay 1891.

'Contral statian supply - accuseulatars v. transformere, E.R. 20 April 2838.

, 'The cost of Qiecurical onvrey', Eient. Vol. 34 PP 324 - 6.

Cromloy, J. 'Speod variation in textile machinery', I.R. Vol. 72 P 4540

Dawson, P. 'Railway Ileotrification', ki.R. Vol. 64, PP 204-6, 275 - 7.

'Eloctrio traction in Europo', E.R. Vol. $36 \mathrm{PP} 3$ - 5.

'Hochanical power on our tram!ays', E.R. Vol. 36, PP 350 - 2.

'Iondon to Brighton lis 45 Einutes', P.R. Vol. 69 P 2006.

'Electrification of a portiun of the suburben system of the Iondon, Brighton and South Coost Rallray, E.R. Vol. 68, P 495.

-Electric traction and its application to auburban and notropolltan rallways', E.Re Vol. $441^{\prime}{ }^{\prime} 528$ - 9 . 
Sborall, A.C. 'Multiphase induction motors' E.R. V01. 40. P 437 'Polyphase work in 2903', E.R. Vol. 52 FP 213 - 4, 251 ff.

Esean, N.B. 'Tranomission of powor to long distances by alternating curronts of elootrioity", E.R. V01. $40 \mathrm{PP} 474-6,508-10$, $543-5$.

rlening, J.A. 'A.C. transtormors', E.R. V01. 31 RP $693-6,742-6$, $775-9,806-20$

'The efficiency of ylow lamps', Elect, 7 September 2894.

Colpel, T. "Electric porrer and Its application on the three phase system to the Bristol Waggon and Carriaco Morks.' E.R. Vol. 43 PP 427 - 9.

'Eleotric porrer In Bxit1sh works', E.R. V01. 48 PP 340 - 2.

Greathoad, J.H. and Fox, R. 'The Liverpool Overhead Rallwar', Blect, 24, 31 August 1894 .

Hobart, H.li. Tho continuous current system and the single phase for traction', E.R. Vo1. 54, FP 693-5, 765-7.

'RailFay Electriflcation', E.R. Vol 67, IP 234 - 9.

The rating and cost of steam olectrio gonerating atations". E.R. Vol. 64, IP 781-2,821 - 3, $859-60$.

Hopldison, E. 'Electrio Ralimays', E.R, Vol. 33 PP 244 - 5

Hopleinson, J. Report to Ieeds Corporation on the proposed tromays: E.R. Vol. 38, PP $68-70$.

Howell, J.C. 'Uses of accumulators', E.R. Vol. 36 PR 660 - 2

Korshaw, J.B.C. 'Electricity in rolation to the Chemical and Lotellurglow industries', Elect. Vol. 38 RP 277, 337, $385-6,435-6,501-2$, $605-6,692-3,757-8,466$

Inewes, Y.B. 'A century of work in the devilopment of IIght from ooul gen' E.R. Vol. 31 PP $252-3$.

Hatthows, I.S.A. 'Lancaishtre mllio end olsotrio driving', E.R, Vol, 63 PP 551 Pf.

Hers, C.H. and licLollan, H. 'Paicr station design', E.R, Pal, 54 PP $803-5$. $847-9,889-91,930-2,969-72$

Vountain, W.C. 'Dosich and efficiency of plant for the transmission of parer by eloctricity'. Transactions of the North Bast Cosst Inotitution of Englncers and shipbouilders, Vol, 21, PP $213-32$, 
Parker, T. 'The electrlcal equipment of the Llvorpool Overhoad Railwar'. Eloct. 2 liarch 1394.

'Relative advantages of different klnds of power for tramrays, 11.ht railirays and motor car trafflc, both heavy and 11 ght', E.R. Vo1. 44 BP 998 - 999

Parahall, H.F. 'Econcmical transmission and aistribution of eleotrioity for a distance', E. R. Vol. 44 P 2024

Paraons, C.A. The application of the steam turbine to the woxting of aynomos and alternators', E.R. Vol. 40 P 796.

Pearoo, S.In 'Power in the lanchester district', B.R. Vol. 63 FP 546 - 9

- Preoce, W. 'Electric IIght in the City', Elect. 28 April 1895

Reworth, J.S. 'Generation of eleotrioal energy for tramays', E.R. Vol. 40, PP $649-52$

Rookenseum, A. 'Ioad diagrams of olectric railways and the cost of eloctrio traotion'. Elect. Vol. 28, 8 ail 15 April

810mens, A. 'Mransmisston of porer by nlootriolty', E.R. Vo1. 43, PP 406 - 8

Sloan, R.P. 'Devolopment of the uses of electriclty', Transactiong of the North Bast Coast Institution of Engineers and Shipbutllders. Vol. 45 PP $345-72$

Snol2, A.B. "Distribution of porrer by a.0. motors' E.R. Vol. 33 PP 635 - 7

Scoll, J.F.C. 'The application of electricity to industrial purposes' Pronsactions of the North East Cosst Institution of Fnginoere and Shivbuitders, Vol. 21 PP $253-76,239-50$.

Squire, W.Y. 'Dock oquipment, including the rolative advantages of eleotrite and hydraullo appliances', E. $R_{\text {o }}$ Vo1. 61 PP 223 - 4

Sparks, C.P. 'Hodern applications of eleotricity to mines, E. R. V02. 61 $P 228$.

Storie, G.B. 'Steam turbino driving in text1lo mills, E.R. Vol. 66 P 617

Tay20r. H.L. 'Central Station Economies, thoir 8 tudy and what it promsenes in the way of cheaper supply'. E.R. Vol. 60 PP 610 - 3

Tatson, J.S. 'A modern porer station and 1ts devoloppont', Transactions of the North East Coast Institution of Inginoers and whipbulisdars, Vol. $36 \mathrm{PP} 496 \mathrm{ff}$. 
Wobver, 'llotes an the eloctrio 21ghting of London', E.R. Vol, 34, PP 292 - 5.

Tilkinson, Go 'Srmo notes on steam turbo-electrio generating plants." E.R. Vol. 53 PP $692-4$

Williams, E.J. 'Ileotrloity in the hoslery manufacturing trade! BeR, Val. 53 PP $324-5$

Tordingham, C.H. 'The aistribution of olectrioal onergs', E.R, Vol, WL PP $733-6$

'on the necessity for uniformity of plant and appernture', $B_{1} R_{2}$ Vol. 42 PP $854-6$

WyLd, W. 'Poljphase equipment of factories", E.R. Vol. 49, EP 429 - 30

Economics and Economic Histosy

1. Books, eto.

Aabmorth, W. An Economio History of Enctand 1370 - 1939, London 1960

Bught, A.A; Junr. The Elecirtc Lamp Industry, New York 2949

- 21 rears, B. E.A.M.A. 1911 - 32, Lordion 1933

Burn, D.I. An Economtc History of Steclmalking 1867 - 1939, Cambriage 2940.

Calmoross, A.K. Home and Foreien Investment 2870 - 1913 Cambridge 2953

Chantier, P. Tho British Gns Irfusim, Kanchester 2938

Clapham, J.H. in Economic History of liodern Britain, Cambridge 2939 - 52

Edwards, R.S. and Townsend, H. Businons Enterprise, Iandan 2958

Poinstoin, C.H. Hoive and Forelm Investmont, Cambridge PhD. thoals 2959

Fawlkner, E.U. Amorican Economic History, 7th Edit1on, Now Iork 2954.

Gould, J.li. Output and Froduct1vity in the Electrio and Gas Ut111ties. 1899 - 1242, Now York 1946

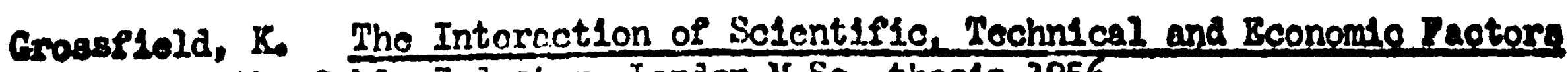
in the Cablo Injustry, Iondan K.So. thesis 2956 
Halovy, E. A Histury of the Engilsh peoplo in the ninoteenth century Eonn paporback, London 1962

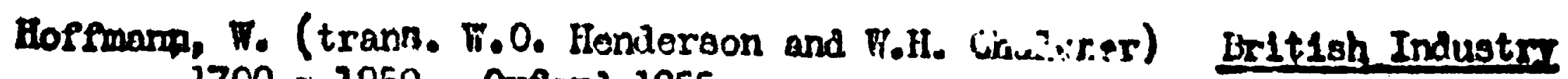
$1700-2950$ Oxford 1955

Jeffreys, J. Tronds in Busines3 Organtsation since 1856, London PhD.

Jewkes, J. Swrers, D. St1llerman, $R_{0}$ The Sources of Invention, London 1958

Idormann, R. Cartels, Concerns and Truuts, Iondon 2932 .

Lovy, H. lisnopoly and Competition, London 1912

- Industrial Gormanz, Cambridge 1935

- 15onopolies, Crrtels and Trusts in Brit1sh Industry, Iondon 2927

Hacrosty, H.W. The Trust liovement in British Industry, London 290

Parkinson, J.R. The Economics of Shipbuilding, Cambridge 2960

Passer, H.C. The Flectrical Manufacturers 1875-1900, Cembridge, Hassachusett3, 1953. (contains an excellent bibl1ography, largely complementary to this one)

Robortion, D.H. A Study of Industrlal Fluctuation, Iondon 2925

Sokan, G.A. Locomotion in Victortan Iondon, Oxford 1955

Shadwell, A. Industrial Efflelencr, Iondan 1920

Shorrington, C.E.R. Economics of Rail Pransport In Great Britain. Iondoa 2928.

Thomas, B. ilimration and Econonic Gromth, Cambridge 2954.

OrwLah, I.F. and Brech, E.P.I. The liakins of Solentifle Vinnarement Iondan 2946 - 8 .

Whote, A.G. The Eleotrical Industrye Iondon 1904 .

2. Articles

A.Golbo 'Is forelign competition overrated?" E.Ro Vol. 64 IP 2026 - 7.

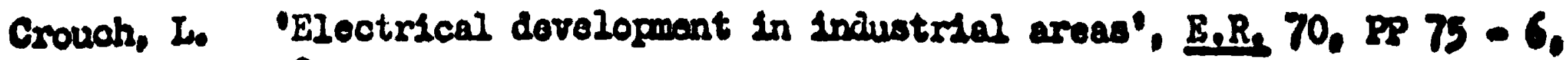
227 - 9 
Bvans, G.II. Junr. 'A century of entreprencurship in the United States' Explorations in Entreprencurlal History, 1957

Folnste1n, C.H. 'Income and Investment In the United KIngdom, 2856 - 2924' E.J. Vol. 71, EP $367-85$

Cadiby, C.H. 'Profits on Iranray Undertakelnge', E.R. V01. 47 PP 75 - 7.

Carke, E. 'Electrical supply', Article in the 21th Edition of the Encrolopodia irstannica

Gibbins, A.H. 'Lunteipal contracts', Z.Re Vol. 33 FP 749-50.

Gindlo, G. Annesley. 'The City and South London Rallway', E.R. V02. 31. PP $240-2$.

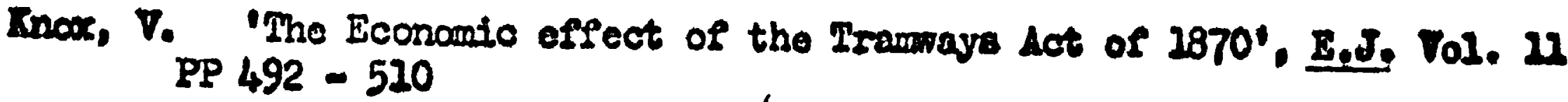

Loanard, H. Fard, Notes on Bloctricel Englneering In England and Frapoe, Elect. Vol. 34, P $602-4$.

Iopine, L.J. and Stelling, A.R. 'Notes on mothods and praotice in the German electrical Industry', E.R. V01. 65. PP 998 - 9, 1031 4,

Ion18, J.P. 'Indies of house huldain in $1054-5$. Solth Wales and Great bulate in tho lisanchester comurbation, Economy, Vol. 8

"Lanufacturer", "Tho pcoposed electrical league and criticiam from a manufacturers point of viow', E.P. Vol. $63 \mathrm{PP} 566-7$.

Herz, C.H. 'Pover eupyly ani its eff'ects on the industries of tho North East Coast." Z..R. Vol. 63, P 684

Lordey, W. if 'Sone comparison of the electricel industry in this country and abruad', E.R. Vol. 63, IP $618-20$.

Saltor, J.R. 'Tra:sw Econorics', E.P. V01. 67, RP 5 - 8

Taylor, A.J. Labour producitivity and technolosical Innovation in the

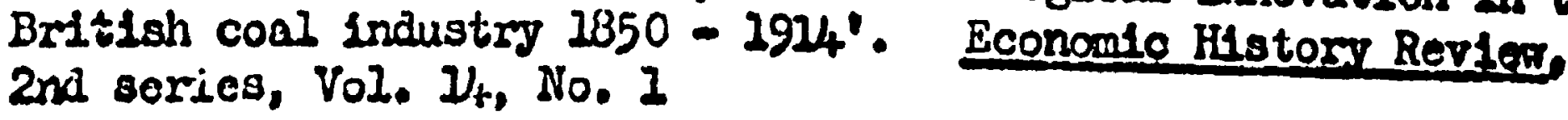

Tober, B. 'A ner index of residential construction and lang oyclos in Great Britain, 1838 - 2940', Scottish Hournal of Pollilical Eoonomr Vol. 2. 


\section{Parliamentary Papers}

1. Reports eto.

Roport of the Solect Comittee on Lfghting by Elootriolty with procendings and evidence. B.P.P. $1878-9$, Vol. 21 .

Beport from the Select Cormittee on the Electric Ligliting B111; with the Proceodings and Evidenco. B.P.P. 1882, Vol. 20.

Report from the Select Carmittee of the House of Loxds on the Elootrio Lighting Act (1882) Amnendinont Bills, with the Proceodings, Evidence and Amendix. B.P.P. 1836 Vol. 7.

Repont by liajor liarindin on the various applications for Provisianal ordore and Licenees under the Electric Lighting Acts in respeot of the Metropolis. B.P.P. 1889 Vol. 70.

Report from tho Joint Cormittio on the Eleoirlo and Cable Rallways (Notropollo) with the Proceedings, Evidence and Appendix. B.P.P. 2892, Val. 12

Repont Prom the Joint Select Connlttee of the House of Lords and the House of Comrons in Blectrical inergy: with the Procesdings, Eldence and Appendix, B.P.P. 1898, Vol. 9.

Renort from the Joint Select Connitteo on London Underground Raliware, with the Procecdings, Evidence and Anvendix. B.P.P. 1901, Vol. 6.

Procecdings bofore a Select Comsitteo of the House of Commons on the Cloveland and Durhain Electrio Power B1Il 1901.

Proceedings before the Comittes of the House of Comons on the Northumberland Poirer B12l. 1902.

Report on Wholesalo and Retail Prices in the U.K. in 1902, with comparative statistical tables for a series of years, B.P.P. 1903, Vol. 68.

Repont of the Rojal Cormission appointed to inquire into and report upon the means of Locomotion and Transport in Londan, B.P.P. 2905, 702, 30. Evidence etc. B.P.P. 1906, Vals. $40-46$

Proceedincs before the Corniltecs of the House of Iorde and the House of Cammons on the Administrative County of Iondon and Distrelot Electrio Porior Bill 1905.

Ranort of the Tariff Commission on the Engineering Industries 1907 Consus of Production 2977, B.P.P. 1910, V01. 109 and 2912 - 23. V02. 109. 
Interim ronort of the Coal Conscrvation aub-con:uittee of the Roconstruction Conittas on Electric Power surply in Great Britaln, B.P, Po 2927 - 18, Vol. 28.

Report of a Compitteo appointed to consider the question of Bloctrio Porer Supply, B.P.P.1918, Vo1. 8

Uinistry of Roconstzuction Advisory Counc12. Report of the Compliten of Chatrmen on Elootric Porrer supply, B.P.P. 2919 Vol. 29

Report of the Conmittee appointed to consider the position of the Engineoring Trade after the war, B.P.P. 1918. Vol. 23.

Report of the Engineering (New Industrios) Comittoe of the Ministry of Roconstruction, B.P.P. 1918, Vol. 8.

Report by the Starding Com.1tteo on the Investigation of prices of Electrio Lamps, B.P.P. 1920, Vol. 23.

Comolttee on Industry and Trade (Balfour Comitteo) Surver of Metal Industerles. 1928.

Proceedings, before the Select Committee of the House of Comnons on the North Eastern Fleotirto Supply Act. Session 1931 - 2

2. Ammal

Report by the Board of Trade rospecting applications to, and procosalnow of the Board of Irade under tho Blectrio Lifinting Aot.

Reports by the Board of Trede respecting Street and Rood Irammaye

Reports to the Board of Trade relating to rallways

Returns relating to all authorized gas undertakings in the Onited Ringlow

Returns of the Board of Irade relating to Blectrio Rallways

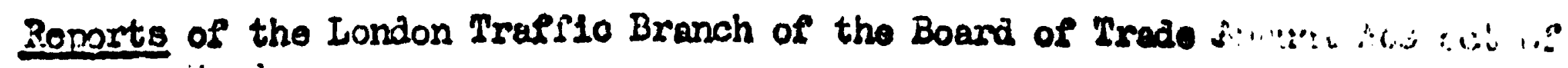
Annual Abstract of Trade

The pricing of electriolty

ILttIE, I.ULD. Tho Price of Fuel. Oxford 1953

Baker, C.A. 'The influence of tartsia on electriolty cupply', E, R. Vol, 50 FP $458-9,534-5$ 
Bowden, E.H. and Tait,F. 'Equitablo chareing for the supply of anergy by municipal electrical undertakings', E.R. Vol. 59, $P 323$

Chamen, Ti.A. 'Wothods of charging for elootricity supply', E.R. V01. 48, P 21288

Coopar, W.R. 'Domest10 Electricity sup.ly tariffs', E.R, Vol. 63, P 963

Gibbins, A.l. The varicus wetinois of charging the publio for electriolty from a central station', E.R. Vol. 35. PR 96-7, $125-7,257$ - 9.

Ifopisinion, J. 'The cost of electricity supply', Elect. Vol. 30, PP 29- 32 W. Lackie, 'Tariffs for eleotrical energy'. R.R. 701. 70, RP 522 - 5

Lang, Folf 'The cooking losd from the oupply point of view', E. R. Val. 70, PP $1034-6$

Perny, H.H. 'A two rate tariff system without timo operated control' E.R. Vol. $73, P 821$

Pringle, P.J. The restricted hour system of power supply, E.R. Pol. 67. P $354-6,305 \mathrm{fr}$.

Russoll, S.A. 'Eleotrio power supriy tariffs', B.R. Vol. 64, P 257

Seabrook, A.il. 'Reslience tarifis', E.Ke Vol. 70, IP $229-32$

Segundo, Ed. C.de 'The cost oi' private electrio 2ight', Ee.R Vol. 33. BP $613-4$

Toppin, WoA. 'The present tendency of charging for electrdolty', B.R. Vol, 60 IFP $945-7$

W12son, R.P. 'Hethods of charging for electricity supply', Eleot. Vol. 38, FP $695-7$

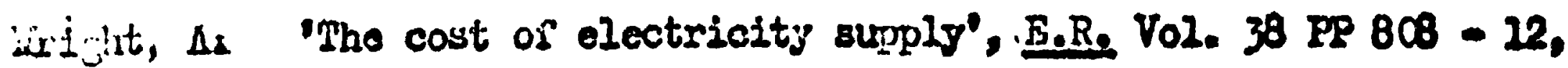

'The profitable extenstion of olectrio supply atation', B.R. Vol. 40 P 857.

Iosbury, A.E. 'Eqquitable charges for tramay supply', E.R. Vol, 66 PP 293 $6,240-3,325-6,423$ 


\section{Public Utilits Poller}

Ballin, H. H. Tho Orsanisation of Flectriclty Sumply in Great Britaln Landon 1946

Darwin, In Munteleal Ownorsh15, London 1907

Plncr, H. Municinal Trading, Iondon $194+1$

Gorion, I. The Public Cormoration in Great Britain, London 1938

James, F.J. The Rolation of the Modern Munteipality to the Gas Surply Nive York, 1836

Iaskd, H.J., Jennings, W.I. and Robson, H.A. (Eds) A Contury of Hundalpal Progress, London 2935

Robson, T.A. The Covernment and M1snovermment of London, London 1939

Sols, SLr II, and Fatson, E.M. Electricity Sunply in Great Britain, London 2952.

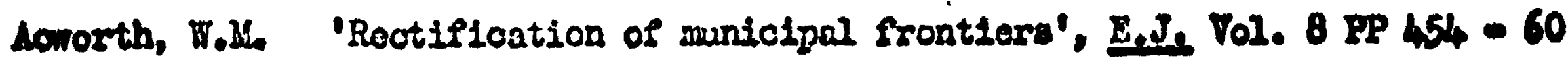

Blocrachles of people

Crompton, R.E.B. Reminisconecs; Inndon 1928

Johnsan, J.ll. and Randall, W.I. Colonel Crompton, (Solence in Britaln pamplet) Iondan 1945

Tournter a'Albe, E.E. Ilfe of Sir M. Crookes, Iondon 2923

Forrant1, G.z. de and Ince, R. The 23 fe and letters of S.Z. de Ferrenti Lasdan 1934

Balley, F. The Life and liork of S.Z. de Berrant1 2864 - 1930. Iinnahoutor 2931

Wather, I.B. (EU.) Str F. Mathar, Iondon 2925 ?

Kaxtm, Fi.S. liy Itfe Iondon, 1915

Herz, C.H. Privito liotas (unpablished)

Apployard, R. Charles Farsons. London 1933

Parsans, R.H. The Sieam Turbino and othor 1nventions of S1r Charlos Parson, $0.1_{0}$ (Science in Britain pamphlet) Iondon 2945 
Burstall, A. The nlace of Sir Charles Parsions in the history of mechanical engtneering", Ilention "iorlss Juurnal, Sumor 1954

Richardison, J. Wighem, llomolirs, Glasgow, 1911

Pole, 7. Llie of Sir T. Siemens, London 1888

Siomons, Fernor. (translated H. Coupland) Personal Recollectlons, Landan 2393

Swan, Ko. \& K.R. J.H. Syen - Q mgmolr, Landon 2929

Ening, A.C. An Fngingars Outlook, London 2933

Tho Electrical Trotes Directnyt contains blotraphical notos on a wlde range of important men in the incuetry

Blosraphice of flms

1. Bopks

XBoak, J.F. A brief history of the Electrical Poncr Storifo Co.

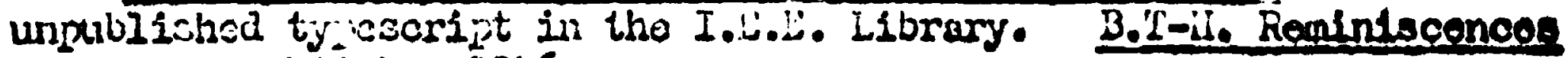
privatelin pubitioned 1946.

Broakos, C. Johnson and Phllilins, London 1950

Box, C.E. Liverpool Overhsar? Railiray 1893 - 1956, Londan 1959

CastnerwKoliner Alkall Co. 'Ififty years of procress, I.C.I. 2945.

Crompton Parkinson Ltd. The Pattern of Prosress

Dumolow, J. 1339 - 291,2, Nanchester 1949

Henderson, P.D. Tho Dovelorent of statutory porsers rolaiting to Blectriat ty supnly on the North East Coast. Unpubilshed dissertation at Carliol Housc, lictrcastlo-upon-Tyse.

Vather \& Platt Itd. 75 ycars of Electrical lingincering Kanohester 2957

Lascelles, T.S. The C1ty and South Londion Rntlagy, Lingolleld 1955

Iondon Transport, Ionden General The story of the London Bus, London 1956

Rowland, J. Progress in Power, London 1960

Scott, J.D. S1emens Brothers 2858 - 1958, Landon 2958 
2. Jounnals oto.

B.T-HI. yomphlets, London 1897 - 1905

Brit13h Wo:tinghouse Gazette

Brush Buàysot

Enylioh Floctric Journal

Eerront1 Journel

Henton Noxkes Journal

\section{ilistorleal archives consulted}

Brit1ah Thomson - Houston Co. Itd.

Brush Eleotrical ineoring Co.

Central Electriciuj Guisrating Board

Crompton Parkinson Itd. (for Crompton \& Co.)

Eleotrie Construction Co. Itd.

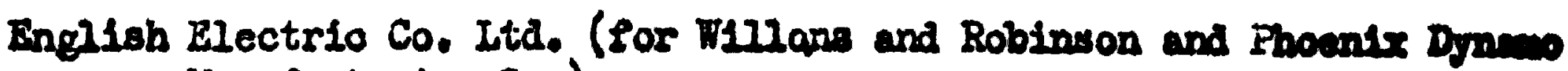
Lanufacturing $\mathrm{Co}_{0}$ )

Ferranti Ita.

Goneral Electric Co. Itd.

Biather \& Platt Ltd.

Londan Eloctrlcity Board

Letropolitan Vickers Electrical Co. (for British Veatinghouso)

North Eastern Eloctrioity Board (for N.E.S. Co.)

C.A. Parsons \& Co. Iti.

1. Royrollo \& 0 . Itd.

SIcmens Itras. \& Co. Itd. 